CARLOTA BOTO

\title{
Ler, escrever, contar e se comportar: a escola primária como rito do século XIX português (1820-1910)
}

\author{
VOLUME I
}

Tese apresentada ao Departamento de História da Faculdade de Filosofia, Letras e Ciências Humanas da Universidade de São Paulo, para a obtenção do título de Doutor em História Social.

Orientador: Prof. Dr. Carlos Guilherme Mota

Departamento de História

Faculdade de Filosofia, Letras e Ciências Humanas

Universidade de São Paulo

1997 
Pai, fiz esta tese para wacê.

2 


\title{
Agradecimentos
}

\author{
"O discurso destinado a dizer o outro \\ permanece sew discurso e o espelho de sua \\ operação. Inversamente, quando ele retorna às \\ suas práticas e thes examina os postulados para \\ renaová-las, $\sigma$ historiador descobre nelas \\ imposiçóes que se originaram bem antes do \\ presente e que remontam a organizaçóes \\ anteriores, das quais seu trabalho é o sintoma e \\ não a fonte. (Michel DE CERTEAU, A escrita da \\ história, p. 46)"
}

A finalização de um trabalho acadêmico causa sobre quem o escrevia um profundo efeito de reflexão sobre o percurso que lhe deu vida. $\mathrm{Na}$ verdade, é como se a própria objetividade do texto houvesse deixado de existir para que ele se transformasse em outro texto, um relato da história de sua produção; história que evidentemente engloba momentos criativos, instantes de profundo prazer e envolvimento, mas que traz também a dimensão da angústia, do medo, da insegurança e do cansaço. O trabalho que se conclui tornase, assim, para o autor, uma história; uma história com inúmeros cenários, variadas paisagens e um conjunto muito especial de personagens, cuja presença foi essencial para que se pudesse chegar ao fim.

Agradeço, primeiramente, às instituições que permitiram a finalização desta tese: à Faculdade de Ciências e Letras da UNESP - campus de Araraquara; à Universidade de São Paulo, particularmente ao Departamento de História da Faculdade de Filosofia, Letras e Ciências Humanas e à Faculdade de Educação. Seja como profissional, seja como aluna que fui, gostaria de prestar o devido tributo àquelas instituições às quais devo minha formação acadêmica. Agradeço também ao CNPq, pela bolsa de doutorado SWE que recebi durante os 16 meses que passei em Portugal; e à CAPES, pela bolsa auxílio-deslocamento oferecida entre 1991 e 1992. Agradeço ao Instituto de História e Teoria das Idéias da Faculdade de Letras da Universidade de Coimbra, à Biblioteca Geral da Universidade de Coimbra e ao Arquivo Nacional da Torre do Tombo, onde pude efetuar a maior parte da pesquisa que deu origem a este texto.

Ao Prof. Dr. Carlos Guilherme Mota, orientador deste trabalho, registro minha dívida de gratidão. O Prof. Mota, com sua peculiar destreza pedagógica, aliou, na difícil tarefa de orientação, estímulos, desafios, confiança e incentivo. Dotado de uma singular habilidade criativa, socializa o conhecimento, partilhando-o, debatendo e, sobretudo, apontando caminhos e alternativas, assinalando e corrigindo equívocos, atentando, enfim, para as coisas mais importantes. Da USP, agradeço também aos professores José Mário Pires Azanha, Marta Maria Chagas de Carvalho e Fernando Novais. Eles ofereceram suporte teórico e 
metodológico para que eu conseguisse encontrar o eixo deste trabalho, o que, há que se convir, é um dos momentos mais difíceis de uma tese. A duas grandes amigas - Ruth Maria Chittó Gauer e Denice Barbara Catani -, cuja presença, incentivo e ajuda foram determinantes no momento da defesa desta tese, "muito obrigada".

Da Faculdade de Ciências e Letras da UNESP - na pessoa do então Chefe do Departamento de Ciências da Educação, Prof. Dr. José Vaidergorn - agradeço a todos os demais colegas. O Prof. Dr. Jorge Nagle foi uma referência imprescindível. Sou grata também pelo apoio institucional que obtive de todos os funcionários da FCL, particularmente dos secretários Rosimar Aparecida Moreira e José Sebastião Soares. Agradeço também a Márcia Noguchi Potiens e a Valmir Dotta; e a James R. R. Motta.

Sou grata às turmas de formandos de Pedagogia/UNESP-FCL-C.Ar. de 1994, 1995, 1996. Agradeço às minhas alunas: Alessandra Aparecida de Souza, Adriana Silva Catelli, Cátia Regina Guidio de Oliveira, Luciana Cristina Batistini e Márcia Moreira.

Durante um ano e meio, permaneci vinculada à Faculdade de Letras da Universidade de Coimbra. Agradeço ao Prof. Dr. Fernando Catroga, pela orientação deste trabalho durante sua fase mais decisiva e pela cuidadosa leitura que fez do texto em todas as oportunidades que eu a ele recorri.

O Prof. Dr. Rogério Fernandes - com singular generosidade - levou-me diretamente aos arquivos dos Relatórios de Inspeção às escolas portuguesas, datados de 1867 e 1875. Além disso, ensinou-me valiosos procedimentos e etapas necessários para a realização da pesquisa estatística. Ajudou-me a montar e a organizar a análise estatística dos capítulos 5 e 6. Nesse sentido, agradeço também a Monica Domenech, por me auxiliar no tratamento estatístico das fontes.

O Prof. Dr. António Gomes Ferreira incentivou-me a pesquisar os compêndios didáticos, oferecendo-me métodos e pistas de investigação... Por ocasião do término de sua tese, entregou-me espontaneamente inúmeras obras que ele mesmo recolhera para seu trabalho; razão pela qual eu lhe agradeço, sensibilizada.

O Prof. António Nóvoa, referência teórica e inspiração metodológica deste trabalho, sempre manteve diálogo com ele, demonstrando, como é de seu costume, grandeza intelectual e didática exemplar. Prof. Dr. Joaquim Ferreira Gomes forneceu-me valiosas pistas de documentação e de bibliografia. Sou grata também à Prof ${ }^{a}$. Dra . Margarida Felgueiras.

O Prof. Dr. Justino Magalhães dirigiu minha atenção para as conferências e os congressos de professores do final do século passado. Entregou-me em mãos manuscritos que eram seus e autorizou-me a utilizá-los, demonstrando confiança e amizade.

Também o Prof. Dr. José de Oliveira Barata e a Prof ${ }^{a}$. Dr ${ }^{\mathrm{a}}$. Maria Manuela Bastos Tavares Ribeiro foram presenças intelectuais imprescindíveis, oferecendo preciosas indicações teóricas e metodológicas para o trato da documentação. Sou grata também ao Prof. Dr. Carlos Reis pelas sugestões sobre o encaminhamento desta tese, no período ainda de sua primeira elaboração, efetuadas por ocasião de seu curso sobre história da literatura.

Enfim, muitas palavras seriam inevitavelmente poucas para falar e descrever a generosidade dos intelectuais com que convivi em Portugal. Sinto que é com eles que aqui dialogo, como se este texto fosse dirigido a meia dúzia de pessoas que, ao fim e ao cabo, também me ajudaram a fazê-lo. Ficarei para sempre com esta dívida. Agradeceria ainda a alguns funcionários da Biblioteca Geral da Universidade de Coimbra, particularmente a bibliotecária Dra. Dulce, Sra. Dona Odete, e Sra. Dona Ana, responsáveis pelo setor de reservados daquela instituição.

Em Portugal, também sou grata a minha família, aos meus tios (Maria Amélia, Joaquim e Milu) e primos: Manuel Maria e Ana, Fátima, Didi e Chico, Teresa, Lena e Zé Manuel. Agradeço também - com ternura - a solidariedade e o carinho que recebi de Rui Martins, Eugenia Cunha - do menino Francisco e da menina Carolina. Pela mesma razão, serei sempre reconhecida ao embaixador Adriano de Carvalho e sua família. 
Agradeço às minhas irmãs Anita e Nenê, a meus cunhados Dudu e Renato; e muito especialmente, a meus sobrinhos - Luís Felipe e Luís Carlos - que me ajudaram a classificar o conjunto dos textos que compunham as fontes deste trabalho.

Meu pai acompanhou tão de perto esta tese que sinto como se ele a tivesse escrito junto comigo. De alguma maneira, Pai, nesta tese eu procurei um pouco a história de sua história. À minha mãe eu sempre sou profundamente grata pela formação intelectual e moral com que fui criada, sem a qual, tenho certeza, não teria sido capaz de suportar a disciplina que este percurso me exigiu. Agradeço sensibilizada pela compreensão que minha família sempre demonstrou para aceitar o tempo enorme em que eu os privei de minha companhia, quando a tese verdadeiramente me roubava das pessoas que, no fundo e apesar de tudo, são ainda as mais importantes e queridas.

Por fim, é inevitável recordar a solidão da escrita. No exato momento em que penetramos o território da palavra impressa, parece ocorrer um distanciamento do "mundo dos vivos" que, entretanto, persiste o sendo o nosso sempre interlocutor. Para diminuir o impacto dessa distância, algumas pessoas foram verdadeiramente essenciais. Foram grandes, enormes, maravilhosos amigos de todas as horas, companheiros de muitos anos, compreenderam a reclusão a que o presente trabalho inevitavelmente me levou: encorajaram-me a escrevê-la; incentivaram-me a terminá-la; sempre me oferecendo uma palavra de fraternidade. Recebam minha gratidão e minha eterna amizade: José Ênio Casalecchi, Milton Lahuerta, José Castilho Marques Neto, José Vaidergorn, Evaldo Sintoni, Raul Fiker, João Furtado, João Amorim, Marco Aurélio Nogueira, Mariana Cláudia Broens Stange, Jaime Francisco Parreira Cordeiro, Maria Aparecida Rodrigues de Lima Grande, Maria Lucia S. Hilsdorf, Vera T. Valdemarin, Dóris Accioly Silva, Ricardo Ribeiro, Angelo Del Vecchio, Mônica Guimarães Teixeira do Amaral e Márcia Teixeira de Souza. Finalmente, por esta que, das provas, é a última que a escola me reservou, expressaria minha gratidão à vida, que tantos amigos me deu para poder agradecer... 


\section{Resumo}

\section{Ler, escrever, contar e se comportar: a escola primária como rito do século XIX português (1820-1910)}

Tendo por objetivo o estudo da escola portuguesa no período compreendido entre 1820 e 1910, procuramos a identificação de aspectos concernentes à interface entre as práticas escolares e o debate social sobre as mesmas. Por essa trilha metodológica, propusemo-nos a historiar o cotidiano, pressupondo nele uma história dos atores que vivem a escola; que agenciam o dia-a-dia escolar. Além disso, tínhamos a intenção de entrelaçar esse ensaio da escola que passou com as representações postas no imaginário pedagógico da sociedade portuguesa na referida época. Por ser assim, pretendíamos verificar a intersecção entre os modos como a sociedade percebia o fenômeno da instrução e os procedimentos realmente adotados para o ensino, com a finalidade de reconstruir pela escrita alguns aspectos que pontuaram o universo simbólico acerca da educação em Portugal de um século atrás.

A escola primária era, em Portugal do século XIX (1820-1910), um ritual entre gerações. À infância, era suposto o reconhecimento escolar da tradição do povo e do passado do país. À infância seria também entregue o futuro. Cabia, portanto, à escola a projeção desse futuro, a exemplo do passado. Compreender a sociedade portuguesa do período exigiria então o reconhecimento desse intervalo entre passado e futuro; essa mudança de temporalidade representada pelos anos de escola. A escola era uma 'forma', um 'modelo' de criação e de irradiação de valores; valores que, muitas vezes 'reproduzindo', no mínimo, ela ajudou a criar. A escola primária era também a instituição que a comunidade reclamava para se fortalecer. A escola era o lugar de produção do cenário coletivo para a generalização do código da escrita. A escola era enfim o ambiente que paradoxalmente se opunha e complementava a ação familiar. O presente trabalho procurou então rastrear os sinais do discurso sobre a escola: quem era enfim essa escola que a modernidade criou, e no que supostamente ela se deveria tornar? Nesse diálogo entre o domínio da realidade do ensino e as prescrições - legais, intelectuais, institucionais, literárias - sobre o ideal educativo almejado, procurou-se interpretar a variação das fontes, estabelecendo sentidos, conexões, inferências, regularidades; enfim, compondo um relato. Na longa duração de quase um século, procurou-se perceber as rupturas e permanências de uma atmosfera escolar, cujos alicerces talvez tenham algo a dizer à nossa contemporaneidade pedagógica.

\section{Palavras-Chave}

história; século XIX; Portugal; educação; escola; cotidiano; história da educação; instrução; infância; currículo 


\section{Summary}

Read, write, count and behave: the primary school as a nineteenth century Portuguese rite (1820-1910)

The aim was to study Portuguese schools during the period between 1820 and 1910, we sought to identify aspects concerning the interface between school practices and the social debate about them. For this methodological path, we proposed to narrate daily life, presuming this is a story of actors who live in the school; who manage daily school life. Furthermore, we had the intention of intertwining this enacted school study with imaginary pedagogic representations put in Portuguese society in the referred to period. Accordingly, we intended to verify the meeting point between the way in which society perceived the educational phenomenon and the procedures really chosen in teaching, with the purpose of reconstituting in writing some of the aspects that marked the symbolic universe around education in Portugal in the last century.

In Portugal in the XIX century (1820-1910) the elementary school was a ritual between generations. The school was supposed to recognize the tradition of the people and the history of the country during childhood. The future would also be given in childhood. Therefore the school would fit this future projection to the example of the past. Therefore to understand Portuguese society of the period would require the recognition of this interval between past and future; this temporary change represented by the school years. The school was a 'mold', a 'model' of creation and the diffusion of values; values which, many times 'reproducing', at least, helped to create. The elementary school was also the institution that the community required to strengthen it. The school was the place for the production of the collective scenario for the generalization of the written code. Finally, the school was the environment that paradoxically opposed and complemented family activity. Therefore, this present work sought to track the signs of discourse about the school: which finally was the school modernity created, and which supposedly should become? In this dialog between the dominion of teaching reality and the requirements - legal, intellectual, institutional, literary - about the longed for educational ideal, we sought to interpret the variety of sources, establishing directions, connections, inferences, rules; finally, creating a report. In the long period of almost a century, we sought to understand breaks and permanent aspects of a school environment, whose foundation perhaps has something to say about our contemporary pedagogy.

\section{Keywords}

history; XIX century; Portugal; education; school; daily life; educational history; teaching; childhood; curriculum 


\section{Sumário}

$\begin{array}{ll}\text { INTRODUÇÃOO } & \mathbf{p . 1 2}\end{array}$

$\begin{array}{ll}\text { Para começo de conversa } & \text { p.12 }\end{array}$

$\begin{array}{ll}\text { Delimitação do objeto de estudo e estrutura dos capítulos } & \text { p.16 }\end{array}$

1. INTELECTUAIS E DISCURSOS PEDAGÓGICOS: A ARTE DA EDUCAÇÃO (1820-1870) p.26

$\begin{array}{ll}\text { A carência de escolas como problema nacional } & \text { p.26 }\end{array}$

$\begin{array}{ll}\text { A pedagogia sob o signo da política: alvorada do liberalismo } & \text { p.31 }\end{array}$

Carvalho e o papel da educação doméstica na codificação de regras morais uniformes $\quad$ p.37

$\begin{array}{ll}\text { A difusão escolar como chave para a regeneração e superação da decadência pátria } & \mathbf{p . 4 2}\end{array}$

$\begin{array}{ll}\text { Garrett e a educação intelectual na composição do futuro } & \text { p.48 }\end{array}$

$\begin{array}{ll}\text { Garrett e a pedagógica justiça da retribuição } & \text { p.54 }\end{array}$

$\begin{array}{ll}\text { O grande homem como exemplo do passado e profeta do futuro } & \text { p.62 }\end{array}$

$\begin{array}{ll}\text { A obra de Herculano e seu cariz pedagógico } & \text { p.67 }\end{array}$

A escola moderadora da avidez da leitura: António Feliciano de Castilho p.76

O poema educacional de António Feliciano de Castilho: fazer-se classe no coletivo $\quad$ p.90

Fascínio e medo das práticas espontâneas de leitura: a função reguladora da escola $\quad$ p.93

$\begin{array}{ll}\text { A disciplina escolar na formação de corpos dóceis } & \mathbf{p . 9 7}\end{array}$

O debate escolar no Conselho Superior de Instrução Pública e na Universidade de Coimbra p.105

D. António da Costa e o antecedente teórico da doutrina do capital humano 111

\section{INTELECTUAIS PERCURSOS PEDAGÓGICOS: A CIÊNCIA DA EDUCAÇÃO (1870-1910) p.115}

A Geração de 70: tradição e crítica na luta de representações $\quad$ p.115 Eça de Queirós, Ramalho Ortigão e As Farpas da leitura $\quad$ p.129

No caminho da ciência pedagógica, um futuro de incertezas: João de Deus e a Geração de $70 \quad$ p.137

A Cartilha Maternal e a forma analítico-global para o ensino da leitura $\quad$ p.141

João de Deus: do método de leitura à leitura do método $\quad$ p.148

João de Deus: a regeneração social pelo método de ensino $\quad$ p.156

$\begin{array}{ll}\text { Forma de escola, criminalidade e ciência } & \text { p.164 }\end{array}$

$\begin{array}{ll}\text { A pedagogia do exame } & \text { p.173 }\end{array}$

$\begin{array}{ll}\text { A escola que vê entrar a República } & \text { p.181 }\end{array}$ 
A escola e os ruídos da leitura

Reerguimento de Portugal pela generosa alternativa da cultura $\quad$ p.192

$\begin{array}{ll}\text { A ambiência educativa impressa por panorâmicas folhas periódicas } & \text { p.200 }\end{array}$

$\begin{array}{ll}\text { Rememorar, comemorar, reinaugurar um país } & \text { p.207 }\end{array}$

O modelo escolar e a persistência do arcaísmo no contexto da pretendida regeneração $\quad$ p.214

$\begin{array}{ll}\text { A escola que classifica, ordena, instrui } & \text { p.222 }\end{array}$

Lugar, formação e profissão de professor: tempo de escola, espaços de crianças...

$\begin{array}{ll}\text { Ciência e moralidade postas à prova da escola } & \text { p.239 }\end{array}$

$\begin{array}{ll}\text { Escola, disciplina, correção, castigo e ginástica } & \text { p.244 }\end{array}$

Segredos para o domínio da alquimia do magistério: vocação, criatividade, entusiasmo, conteúdo, disciplina p.248

$\begin{array}{ll}\mathrm{O} \text { associativismo docente e a crítica ao método João de Deus } & \text { p.257 }\end{array}$

\section{DAS REPRESENTAÇÕES ÀS PRÁTICAS, INTERFACE ENTRE LITERATURA E HISTÓRIA}

Sinais de leitura, vestígios de escola

A escola pela percepção do romantismo de Camilo Castelo Branco e Júlio Dinis $\quad$ p.265

$\begin{array}{ll}\text { Eça de Queirós e a crítica à educação tradicional } & \text { p.271 }\end{array}$

$\begin{array}{ll}\text { Literatura de cordel, cantigas populares e a tragicomédia da escola } & \text { p.277 }\end{array}$

$\begin{array}{ll}\text { Rotina e inovação: a geografia da escola passada } & \text { p.280 }\end{array}$

$\begin{array}{ll}\text { A vez dos professores pela voz de seus Congressos } & \text { p.285 }\end{array}$

A disciplina escolar como conteúdo programático das Conferências Pedagógicas $\quad$ p.289

$\begin{array}{lr}\text { A população luta por escola } & \mathbf{p . 2 9 2}\end{array}$

A escola como signo de poder local: rivalidade comunitária $\quad$ p.296

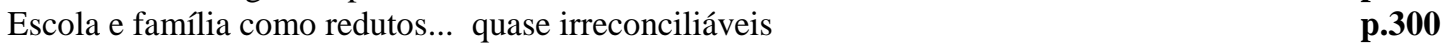

$\begin{array}{ll}\text { O público e o particular na disputa pela escola } & \text { p.304 }\end{array}$

$\begin{array}{ll}\text { A composição dos saberes escolares sob o signo da memória } & \text { p.308 }\end{array}$

$\begin{array}{ll}\text { O porteiro, o professor e o gaiato } & \text { p.314 }\end{array}$

Um professor de moral estragada: seu ofício, seus adversários, suas testemunhas, sua vida familiar $\quad$ p.324

$\begin{array}{ll}\text { O manuscrito da herança escolar: uma forma toda sua... } & \text { p.333 }\end{array}$

$\begin{array}{ll}\text { Escola e populações, por distritos e por regiões } & \text { p.335 }\end{array}$

\section{TEMPO E ESPAÇO DO ENSINO: O TRAÇADO DO CURRÍCULO (INSPEÇÃO ÀS ESCOLAS EM 1867)}

A inspeção estatística como fonte da História

Atraso português e demanda por escola (1844-1848) $\quad$ p.345

$\begin{array}{ll}\text { Rotina escolar e roteiros de leitura (1848-1857) } & \text { p.349 }\end{array}$

O Método Português-Castilho pelo olhar dos inspetores $\quad$ p.353

$\begin{array}{ll}\text { A face oculta da escola } & \text { p.356 }\end{array}$

Os relatórios de inspeção às escola públicas do ano letivo de 1866-67: abordagem preliminar $\quad$ p.358

$\begin{array}{ll}\text { Amostra utilizada e caracterização das escolas } & \text { p.359 }\end{array}$

Caracterização do zelo, da moral e da civilidade docente em suas intersecções

com o aproveitamento dos alunos

$\begin{array}{lr}\text { O espaço físico da escola e o funcionamento de sua estrutura administrativa } & \text { p.366 } \\ \text { O perfil do professor e suas condições físicas, morais e pedagógicas } & \text { p.371 }\end{array}$

Formação dos professores: estado civil, situação funcional e tempo de serviço $\quad$ p.376

$\begin{array}{ll}\text { A prática da sala de aula: o rotineiro, o repetitivo, o fugaz... } & \text { p.382 }\end{array}$ 
Freqüência, recompensas e castigos: dispositivos do poder escolar

Meninos e meninas de diferentes idades

Inspetor e professor avaliam Leitura, Escrita, Contas e Doutrina Cristã $\quad$ p.403

A origem social da comunidade escolar

Os compêndios mais utilizados e a realidade da leitura escolar

\section{O RITUAL ESCOLAR: ENTRE VOZES E VERSÕES (INSPEÇÃO ÀS ESCOLAS EM 1875)}

Livros mais utilizados nas escolas de Portugal em 1875

Modos e maneiras de inspecionar alunos e professores

Os alunos fogem da aula: o professor anda bêbado

A professora é velha e o método é facílimo

A escola não ensinava leitura por livro, por culpa do professor

Quando fábricas de cortiça se encontram com bancos de escola

Bom professor: criatividade, imaginação, habilidade...

Velhos e rústicos, professores que sequer sabiam escrever

Estímulo do professor e êxito do aluno: uma via de mão-dupla $\quad$ p.457

O método simultâneo e o maestro da orquestra escolar

A Câmara, a capela, a Ordem de São Francisco e a Junta de Paróquia: a quem pertence a escola? p.463

O bom professor dava abecedários de Monteverde aos alunos mais pobres $\quad$ p.465

$\begin{array}{ll}\text { O professor Moreira de Sá usava o compêndio Moreira de Sá } & \text { p.467 }\end{array}$

$\begin{array}{lr}\text { Jovem professora, já desanimada pelo ofício escolhido } & \text { p.469 }\end{array}$

Repetição em voz alta e Método Castilho $\quad$ p.471

$\begin{array}{ll}\text { O método rotineiro das mesmas cartilhas e catecismos } & \text { p.473 }\end{array}$

$\begin{array}{ll}\text { O ensino atraente e os bons resultados pedagógicos } & \text { p.475 }\end{array}$

$\begin{array}{ll}\text { O Método Legográfico: leitura e escrita simultaneamente } & \text { p.477 }\end{array}$

$\begin{array}{ll}\text { O poder local dentro da escola e o professor substituto } & \text { p.480 }\end{array}$

Concorrência do trabalho infantil com as letras da escola $\quad$ p.483

$\begin{array}{ll}\text { O professor foi atacado por alienação mental... } & \text { p.485 }\end{array}$

$\begin{array}{ll}\text { Mal estar e indiferentismo docentes como obstáculos ao bom aprendizado } & \mathbf{p . 4 8 7}\end{array}$

Fronte do mestre: pai, médico, sacerdote, juiz... a ciência pela virtude $\quad$ p.489

O compêndio escolar: uma ausência muito presente $\quad$ p.491

Sonhos de uniformidade, utopias de perfectibilidade e projetos de escola única $\quad$ p.495

A coleção dos saberes escolares na instrução dos professores: tempo de manuais enciclopédicos p.499

Dizia-se na minha meninice...

Eu ainda pertenço àquele tempo... tempo do Manual Encyclopedico

A escola como rito do futuro

O livro de infância contado pelos jornais

Método facílimo para aprender a ler no mais curto espaço de tempo possível p.532

Ler e escrever: ao mesmo tempo, todos juntos

Método Legográfico ou Cartilha Nacional de Caldas Aulete

p.548

Horário de uma escola primária dividida em duas classes

A escola que se queria tanto... O Expositor Portuguez, ou a cartilha de Midosi p.555

A política editorial do livro escolar: o mercado e a didática...

Os valores que a escola referendava e, na outra margem, instituía: programa para se dar bem com Deus $\quad$ p.562

Bordas de livros e indícios de leitura 
O ÚLTIMO DIA DE AULA

p.570

A dupla face da escrita

p.570

FONTES MANUSCRITAS

p.578

FONTES IMPRESSAS

p.581

BIBLIOGRAFIA

p.597 


\title{
Introdução
}

\author{
"Valeu a pena farejar-te na traça \\ dos livros e nos chamados instantes \\ inesquecíveis."
}

(Carlos Drummond de Andrade, Discurso)

\section{PARA COMEÇO DE CONVERSA...}

Tomando por pressuposto serem os vestígios que o tempo preservou o que permite a reconstituição histórica, o cruzamento dos testemunhos fará por recompor parte do trajeto passado. Esse quebra-cabeça, ao ser reconstruído, terá inevitavelmente por sujeito interlocutor aquele que manuseia, seleciona, classifica, une e distingue as várias peças passíveis de utilização. A leitura do passado ocorrerá, nessa medida, antes como um diálogo entre o tempo procurado e o tempo do investigador, do que como uma descoberta ou - no desejo de alguns - como um "resgate". Longe disso: certa perícia, o faro, e fundamentalmente a cautela metodológica do pensamento serão os alicerces que permitirão o rigor da pesquisa em história. ${ }^{1}$ A inteligibilidade do objeto existirá por existirem questões atuais postas por um determinado campo do conhecimento, em uma dada época sobre o passado: combinam-se portanto a curiosidade atual do investigador em face do tema com a identificação de categorias analíticas que permitam a indagação e a produção do relato sobre este mesmo tema. Há, nesse diapasão, o estabelecimento de sentidos e de conexões, posto pela interação entre o sujeito que relata o discurso e os atores que, no texto escrito, tornam-se seus protagonistas, suas personagens. Há um trabalho de enunciação do narrador do discurso; discurso que é sempre lacunar e que não corresponde ao desejo inicial daquele que o relata. Nessa medida, a própria ambição de colocar questões ao passado revela-se inelutavelmente frustrada, quando se compara o intento do princípio ao resultado final da pesquisa. ${ }^{2}$

\footnotetext{
${ }^{1}$ Sobre essa dimensão da historiografia, recorde-se o parecer de Paul Veyne a propósito dos dois princípios matriciais da investigação em História: "O primeiro, que data dos gregos, é que a história é conhecimento desinteressado, e não recordações nacionais ou dinásticas; o segundo, que acabou por se separar nos nossos dias, é que todo acontecimento é digno de história (...). Desde então, toda a espécie de fatos se torna caça para o historiador, desde que o historiador disponha de conceitos e categorias necessárias para o pensar: haverá um história econômica ou religiosa, desde que se detenham os meios de conceber fatos econômicos ou religiosos. " (Paul VEYNE, Como se escreve a história, p. 84 ) Por tal reflexão, Veyne sugere a necessidade da familiaridade, talvez empatia, do historiador para com o tema que elegeu como seu, como sua "intriga". Existiria então um enigma que o historiador pretende pois decifrar. Nesta intriga residiria a chave de compreensão da pesquisa historiográfica.

Ao pensar no arquivo acumulado da memória coletiva atado à singela capacidade que uma época teria de decifrar a outra, Marrou oferece pistas que são, a meu ver, remarcáveis: "na medida em que os documentos existem, cumpre-nos ainda, conseguir chegar até eles; aqui, de novo, intervirá a personalidade, as qualidades
} 
Ao discorrer sobre o que chamou "operação historiográfica", Michel de Certeau já dizia que a produção do conhecimento histórico teria como exigência um lugar social de produção, o estatuto de uma dada objetividade, que o autor caracteriza por "prática científica" e, finalmente, uma escrita. Essa escrita obedece a normas que são postas de maneira quase consuetudinária pelos pares ou colegas de ofício e pela instituição que organiza a produção do discurso historiográfico. ${ }^{3}$ Sabe-se que a organização, a classificação e a escrita dos fatos em história obedecem então a critérios que não são exatamente derivados de si próprios, mas que lhes são anteriores. Certeau comenta que a produção em História dirige-se fundamentalmente a um "nós" muito preciso. Esse "nós" é composto antes pelos parceiros e colegas de ofício do que pelo público não pertencente ao meio. Existem leis instituídas pela comunidade acadêmica, leis que ditam como este ou aquele resultado será bem ou mal recebido por seus pares. Leis, portanto, que se espera ver respeitadas... O texto histórico - continua Certeau não deve, pois, dialogar exclusivamente com os documentos, que, ao fim e ao cabo, sempre permanecem sendo sua razão de ser. Para além e na outra margem da documentação, o texto histórico deve debater com o estado da questão que aborda, com as tendências e com as orientações da pesquisa em sua época. Assim, evidentemente, poder-se-ia compreender porque a pesquisa em história vem inevitavelmente atada ao tempo dos documentos e simultaneamente ao tempo de sua própria escrita. ${ }^{4}$

Quanto ao lugar a que se prende, o investigador da História da Educação situa-se institucionalmente na confluência, nem sempre pacífica de duas áreas distintas - o estudo da história e o estudo da educação -, igualmente necessárias à guisa de referenciais teóricos e metodológicos. Tal constatação implica o reconhecimento de que os pilares norteadores da pesquisa em História da Educação exigem tanto as referências metodológicas e bibliográficas do campo da história quanto as do campo da educação. Teria de haver então um encontro interdisciplinar, a defesa dessa intersecção, dessa encruzilhada, no qual, afinal, poderá haver uma apropriação do objeto educativo do passado. Por tal razão é que julgamos que a Nouvelle Histoire francesa foi verdadeiramente uma saída temática e um encontro metodológico, posto

de espírito, a formação técnica, o talento e a cultura do historiador. Façamos alguns retoques com o objetivo de completá-lo no plano esboçado: o grande historiador não será aquele que souber formular os problemas da melhor maneira possível ( pois existem espíritos quiméricos hábeis em enfrentar questões insolúveis - o que é tempo perdido ), mas aquele que, ao mesmo tempo, souber elaborar um programa prático de pesquisas que permitam encontrar, fazer surgir os documentos mais numerosos, mais seguros, mais reveladores." (H. I. MARROU, Sobre o conhecimento histórico, p. 59).

3 "Essa análise das premissas, das quais o discurso não fala, permitirá dar contornos precisos às leis silenciosas que organizam o espaço produzido como texto. A escrita historiográfica se constrói em função de uma instituição cuja organização parece inverter: com efeito, obedece a regras próprias que exigem ser examinadas por elas mesmas. Toda a pesquisa historiográfica se articula com um lugar de produção socioeconômico, político e cultural. Implica um meio de elaboração que circunscrito por determinações próprias (...) Ela está pois submetida a imposições, ligada a privilégios, enraizada em uma particularidade. É em função deste lugar que se instauram os métodos, que se delineia uma topografia de interesses, que os documentos e as questões que lhe serão propostas se organizam." (Michel DE CERTEAU, A escrita da história, p. 66-7).

4 “Antes de saber o que a história diz de uma sociedade, é necessário saber como funciona dentro dela. Esta instituição se inscreve num complexo que lhe permite apenas um tipo de produção e lhe proíbe outros. Tal é a dupla função do lugar. Ele torna possíveis certas pesquisas em função de conjuntura e problemáticas comuns. Mas torna outras impossíveis; exclui do discurso aquilo que é sua condição num momento dado; representa o papel de uma censura com relação aos postulados presentes ( sociais, econômicos, políticos ) na análise. Sem dúvida, esta combinação entre permissão e interdição é o ponto cego da pesquisa histórica e a razão pela qual ela não é compatível com qualquer coisa. É igualmente sobre esta combinação que age o trabalho destinado a modificá-la. De toda a maneira, a pesquisa está circunscrita pelo lugar que define uma conexão do possível e do impossível. Encarando-a apenas como um “dizer”, acabar-se-ia por reintroduzir na história a lenda, quer dizer, a substituição de um não-lugar ou de um lugar imaginário pela articulação de um discurso com um lugar social. Pelo contrário, a história se define inteira por uma relação da linguagem com o corpo (social) e, portanto, também pela sua relação com os limites que o corpo impõe, seja à maneira do lugar particular de onde fala, seja à maneira do objeto outro (passado, morto) do qual se fala." (Michel De CERTEAU, A escrita da história, p. 76-7). 
que trouxe novos horizontes para o problema da investigação historiográfica e, com eles, a possibilidade de fornecer um estatuto que até então era incipiente quando se tratava de temáticas atinentes à problemas pedagógicos. Com a inegável ampliação do manancial de temas históricos, que, para além dos objetos exclusivamente políticos e econômicos, passam a partir disso a ser considerados também áreas nobres, os historiadores se debruçariam com maior frequiência sobre um objeto que até então estava praticamente restrito aos pedagogos: a história da escola e das instituições educativas. Assim como a história da escolarização, outros domínios ganharam força pela ação dos historiadores dos Annales: história da família, da infância e da vida privada; história do cotidiano e da cultura popular em suas distintas expressões.. No caso da história da escola, devem-se levar em consideração as intersecções e as distâncias entre o pensamento educacional de uma dada época e as práticas, os gestos, as rotinas corriqueiras do dia-a-dia escolar. A ressonância do debate teórico no domínio técnicopedagógico parece ser, entretanto, requisito analítico. ${ }^{5}$ Compreender o cotidiano da escola, por um lado, naquilo que ela representava para a comunidade que, bem ou mal, a ela recorria, e por outro lado nas práticas cotidianas desenvolvidas por seus atores maiores - os professores e os alunos - supõe o entrelaçar da intriga intelectual: deseja-se fundamentalmente compreender o que a escola dizia que fazia e o que ela de fato fazia. A história da escola exige, como pressuposto a apreensão desse contracanto...

Tendo em vista o estudo da escola portuguesa no período compreendido entre 1820 e 1910, procuraremos estabelecer critérios analíticos que possibilitem a identificação dos aspectos concernentes às práticas pedagógicas mediante o crivo de referência estrutural acenado pelo discurso sobre educação produzido em Portugal no período em pauta. Esse período coincide, até onde pudemos entender, com o século XIX português, ou seja, com a vigência mais plena de uma ampla etapa transitória, que não é mais marcada pelo absolutismo, mas que inicia em Portugal a vigência liberal, sem entretanto, romper as fronteiras fidalgas e aristocráticas da monarquia portuguesa. Um século é sempre uma fronteira simbólica que demarca, no artifício da cronologia, certas tendências de período longo. Por ser assim, permitimo-nos "atualizar" o século XIX, adaptando-o, no caso, à situação portuguesa, sob o exemplo do historiador francês René Rémond, que dirá que o século XIX foi para a França a etapa compreendida entre 1815 e $1914 .{ }^{6}$ Na verdade, o século é uma construção a posteriori, tendo em vista uma periodização inteligível do tempo.

\footnotetext{
${ }^{5}$ No trabalho que carateriza como uma introdução aos estudos em História da Educação, Antoine Léon rejeita a periodização rígida entre o movimento das idéias dominantes em uma dada época e as práticas educativas sobre as quais tais ideários se alicerçariam. O autor recorda a mediação das resistências mentais perante as mudanças preconizadas, as descontinuidades, as permanências das antigas tradições, os velhos costumes... Por essa trilha, Antoine Léon envereda para retomar o que ele próprio qualificara de problema das origens: "Se, como já se demonstrou, parece difícil indicar data precisa ao nascimento de uma idéia, de uma prática ou de uma instituição, é, pelo contrário, possível fixar, numa escala temporal, certos momentos privilegiados a partir dos quais essa idéia, essa prática ou essa instituição, que já foi objeto de antecipações pontuais ou de realizações parciais, tende a diferenciar-se, a sistematizar-se ou a generalizar-se." (Antoine LEON, Introdução à história da educação, p. 49). António Nóvoa recentemente ampliou essa classificação que León já fazia do contingente temático de seu objeto comum, demonstrando que a história da educação poderia ser construída sobre quatro eixos: “1) história das instituições escolares e do sistema educativo; 2) história das idéias pedagógicas sobre educação; 3) história das práticas escolares e da vida escolar; 4) história dos atores educativos da educação e do ensino." (António NÓVOA, A história do ensino primário em Portugal, In: $1^{\mathbf{0}}$ Encontro da história da educação em Portugal, p. 49-58).

6 "O século XIX, tal como os historiadores o delimitam, ou seja, o período compreendido entre o fim das guerras napoleônicas e o início do primeiro conflito mundial - uma centena de anos que se situam entre o Congresso de Viena e a crise do verão de 1914 - é um dos séculos mais complexos, mais cheios que existem. Cuidaremos para não atribuir-lhe retrospectivamente uma racionalidade que lhe seria estranha, mas um exame rápido permitirá a descoberta de algumas linhas mestras.” (René RÉMOND, O século XIX: 1815-1914, p. 13). Os grifos são nosso. Para o autor, o século XIX, tal como ele o periodiza, é dominado por múltiplas tentativas de domínio do globo, presenciando com frequência choques revolucionários. Nenhuma parte do continente europeu - no parecer de Rémond - teria sido poupada da imensa onda efervescente contra a ordem social instituída.
} 
Consideradas todas as características do período compreendido entre 1820 e 1910 na história portuguesa, entendemos que ele corresponde mais ao século XIX do que a etapa artificial e linear que vai de 1801 a 1900. Por essa trilha metodológica, propusemo-nos a historiar o cotidiano, pressupondo nele uma história dos atores que vivem a escola; perfazendo o relato da instituição que abriga sujeitos que agenciam o cotidiano escolar, para, finalmente entrelaçar esse ensaio da escola que passou com as representações configuradas no imaginário pedagógico. Sendo assim, pretendemos retomar os cruzamentos entre as "representações" e as "práticas" do ensino, considerando a reconstrução pela escrita de alguns aspectos que pontuaram o universo simbólico acerca da educação em Portugal de um século atrás. Acreditamos poder contribuir para o histórico da educação portuguesa, tendo em vista a atual produção historiográfica nessa matéria, nomeadamente pelo prisma do que julgamos ser a reconstituição da vida rotineira da escola, área pouco aprofundada para o caso português até o presente momento. Recompor o dia-a-dia em suas tarefas e rituais cotidianos significa buscar apreender o que a escola dizia sobre o mundo, sobre o homem, sobre a justiça, sobre a moral... Mais do que isso, significa rastrear os indícios do discurso sobre a escola, naquilo que ela era e no que supostamente deveria vir a se tornar. Nesse diapasão entre o domínio da realidade do ensino e as prescrições sobre o ideal almejado, o presente estudo procurará interrogar o testemunho das fontes, com a finalidade de, na longa duração de quase um século, perceber as rupturas e permanências de uma atmosfera educacional, cujos alicerces tenham talvez algo a dizer à nossa contemporaneidade pedagógica.

Acreditamos que, para o caso português, a história da escola primária do século XIX, herdeira de Pombal e precursora da escola de massas, estava por ser feita. Ora, se o nosso esboço objetivava a reconstituição das representações e práticas da escola primária no período que vai do liberalismo vintista aos primórdios da etapa republicana, partimos da hipótese de que haveria um diálogo, muitas vezes frustrado, entre o pensamento sobre a escola e as ações cotidianas engendradas na prática. Tal hipótese abarca, porém, a incursão por uma dinâmica de pesquisa pautada, talvez, pelo que Guinzburg qualifica de "paradigma indiciário" 8 . Os objetivos do trabalho efetuado situam-se, pois, no entrelaço de aspectos vários: as estratégias institucionais de conformação do estudante primário português; os relatos da dinâmica interna à escola, que nem sempre correspondem a tais prescrições legais e pedagogicamente intelectuais, dadas as especificidades regionais, as camadas sociais que no espaço escolar interagem e a própria formação do professor; o pensamento pedagógico e o eco de uma filosofia evolucionista da história como referencial para agenciar essa formação de um futuro por suposto passível de ser constantemente aperfeiçoado; a percepção das camadas populares acerca da utilidade social do conhecimento veiculado pela escola; e, finalmente, uma análise crítica dos conteúdos e saberes escolares como um dado de recriação da realidade, tal como se pretendia falar dela às crianças.

Pretendemos averiguar a via de mão dupla existente entre a sensibilidade popular e o rescaldo de cultura erudita no âmbito do repertório das práticas e dos saberes escolares. Compreendemos que a vida da escola tem uma dinâmica que entrelaça esses dois universos. Afinal, a escola projetada não será a mesma escola apropriada pelas crianças em sala de aula. Sem chegar ao ruído, ao buliço das classes de alunos, pouco se pode aferir sobre a realidade educacional de um dado país. Procurar a confluência entre pensamento e ação exige, no entanto, uma reorientação do olhar historiográfico. Além disso, pareceu-nos imprescindível readequar também boa parcela de nosso próprio imaginário pedagógico. No caminho de uma tese, trabalha-se invariavelmente com idas e vindas de certas cristalizações que são muitas

\footnotetext{
${ }^{7}$ Os conceitos de "representações" e de "práticas" são aqui tomados no sentido que lhes dá o trabalho de Roger Chartier: A história cultural: entre práticas e representações.

${ }^{8}$ Carlo GUINZBURG, Mitos, emblemas e sinais: morfologia e história, p. 143.
} 
vezes, nesse contexto, os principais óbices para que se possa rastrear, com propriedade, as "pistas, indícios e sinais" que o tempo da escola nos legou. Talvez por isso ou em nome disso tenhamos optado por dividir e classificar os diferentes momentos desta tese, não apenas em termos de seu conteúdo propriamente dito, mas também à luz de uma metodologia derivada da linguagem específica de fontes diferenciadas.

O século XIX foi para a Europa o tempo de redesenhar a nação. Pautado também pelo signo da reconstrução política, o caso de Portugal apresenta algumas especificidades no conjunto europeu. Seja como for, qual teria sido, nas representações e nos quadros mentais do cenário português, o ofício atribuído à escola primária? Qual a ressonância do debate pedagógico da Revolução Francesa e qual a apropriação portuguesa dos projetos ali gestados? Qual a interlocução dos pensadores da pedagogia em Portugal com as novas idéias educacionais debatidas já em outros países? Qual a interface entre esse ideário teórico e o diaa-dia da escola primária de aldeia? A intriga a ser reconstruída era composta por manuscritos relatando o cotidiano da escola, relatórios de inspeção, ditados e exercícios copiados pelos alunos, manuais, compêndios e cartilhas escolares, fragmentos de literatura erudita e popular, canções, adivinhas populares, jornais e revistas pedagógicos, almanaques, legislação, congressos e conferências de professores; enfim, tudo o que contribuísse como fonte de memória do cotidiano da escola. Entendíamos que entrelaçar as representações da infância escolar em meio a esse variado e profícuo conjunto documental possibilitaria uma aproximação do universo pedagógico do referido período, em suas continuidades e em suas inflexões.

\section{DELIMITAÇÃO DO OBJETO DE ESTUDO E ESTRUTURA DOS CAPÍTULOS}

Toda análise da escola portuguesa requererá a articulação entre os vários elementos que compõem a teia discursiva do ritual da escolarização. Julgamos ser metodologicamente apropriado esse olhar para trás, essa procura do século XVIII, também pela referência e herança que inegavelmente a atuação de Pombal representou para a escola portuguesa do período imediatamente posterior. Acreditamos ter havido em Portugal um caráter, até certo ponto, inédito da atuação pombalina, cujas reformas se orientam, entre outras coisas, para erradicação do monopólio religioso no âmbito da instrução; o que precede, inclusive, o projeto secularizante da revolução em França. Entretanto, toda a carga simbólica espraiada pelo efeito irradiador e internacionalista da Revolução Francesa terá, incontestavelmente, eco entre os intelectuais da primeira metade do século XIX português. Começa-se, a partir disso, a projetar, pelo discurso de vanguarda, a idéia de universalização do ensino como veículo institucional para capacitação de talentos. $\mathrm{O}$ universo de significados múltiplos inaugurado pela Revolução em França passa a ser apropriado nos países europeus como estratégia de reforma institucional nos marcos do Estado, até mesmo para protegê-lo contra os novos ventos de revolução. Por essa razão, entre outras, os países da Europa, no decorrer do XIX, apropriam-se do discurso revolucionário sobre a escola: o Estado passa a assumir para si a responsabilidade do ensino primário, como dispositivo privilegiado quer de consolidação, quer de ampliação das fronteiras nacionais. Já a partir de 1850, porém, o debate educativo deixa de se pautar por essa dimensão exclusivamente política, para centrar-se em alguns aspectos metodológicos, colocados como obstáculos a serem vencidos a fim de que o povo pudesse mesmo vir a se ilustrar. Essa discussão ganha ares de ciência nos anos 70 e o 
debate sobre a pedagogia assume como eixo primordial o tema das dimensões científicas que podem vir impressas no ato de educar.

De qualquer modo, ao propugnar o ensino universal e de boa qualidade como veículo de combate contra o atraso da nação portuguesa perante os demais países europeus, confere-se à escola o estatuto de regeneração. Reerguer Portugal decadente torna-se, no discurso, missão precípua da instrução pública. É como se o espraiar da cultura pudesse reconstruir a vocação de grandeza do povo português. Há também, nesse indício iluminista recorrente tonalidade econômica: fortalecida a rede de ensino, as novas gerações capacitar-seiam para impulsionar o progresso sem ferir a ordem. Posteriormente as idéias positivistas viriam a reforçar tal diagnóstico, alicerçadas pela, por vezes, eclética confluência entre a tradição pombalina, o exemplo francês e os novos autores e teóricos de uma pedagogia autodenominada nova. $\mathrm{O}$ debate intelectual sobre os rumos da pedagogia viria acompanhado por uma considerável produção editorial que buscava adaptar as novas idéias para o nível do senso comum. Nesse sentido, almanaques e enciclopédias dirigidos às famílias, compêndios de civilidade divulgados para as escolas, além de todo um conjunto de manuais escolares que se pretendiam apropriados aos novos modelos educativos, veiculavam procedimentos de análise da criança, métodos e estratégias de ensino, vendidos como a adequação prática da modernidade pedagógica. Elegiam-se, pelo encontro da produção editorial com o pensamento pedagógico, crivos de legitimidade para os saberes específicos e singulares da escola primária, que eram, por sua vez, eleitos como indispensáveis para a construção do futuro e, com isto, para a edificação do homem novo. Por essas características, o debate pedagógico só ganha significado mediante interlocução com os referenciais trazidos pelo cotidiano escolar. Pretendemos, por essa trilha, a reconstrução das interfaces dos testemunhos discursivos, enfim, aproximações e distâncias entre as variadas fontes e matrizes analíticas pelas quais se entremeava o tema da educação e da didática.

A investigação desses temas apontava para a necessidade de rastreamento de duas realidades: aquele determinado modelo de escola e, na outra margem, o que se desejava que ela viesse a ser. Era, também, imprescindível inferir - pelo estudo das representações e das práticas sobre a escolarização - o que se pretendia fazer da escola e o que ela teimava em fazer das realidades. Havia ainda que se proceder à escuta do diálogo entre pensamento e ação; entre o discurso e a vida da escola. Para tanto, paralelamente aos discursos, procuramos estudar os rituais cotidianos: aquilo que a escola fazia por rotina, o modo e o conteúdo do que ensinava, os valores e práticas disciplinares por que se pautava, as hierarquias e as demarcações de fronteiras de gênero, de classe, de região, que, naquele território da aula, se expressavam... É possível compreender, até certo ponto, a matriz pombalina da escola portuguesa presente e visível na realidade estudada. Afinal, uma das obras mais encontradas nas escolas de 1867 (segundo levantamento que fizemos a partir dos Relatórios dos Inspetores) era ainda o Cathecismo de Montpellier, o velho compêndio jansenista de ensino da leitura que Pombal indicara um século antes em substituição aos livros dos jesuítas. Houve tentativas de retirar o Cathecismo da orientação pedagógica das escolas do reino, porém todas elas pareceram falhas, posto que, ainda em 1867, o texto, cujo nome original é Cathecismos da diocese de Montpellier impressos por ordem do bispo Carlos Joaquim Colbert a traduzidos na lingua portugueza, para por elles se ensinar a doutrina chistã aos meninos nas escolas de Portugal e do Brasil apresentava uma média de utilização de $10,8 \%$ dentre todos os compêndios utilizados nas escolas primárias públicas portuguesas 9 .

\footnotetext{
${ }^{9}$ Optamos por simplificar o título do compêndio, pelo fato de ser uso corrente desde o século XVIII a expressão abreviada Cathecismo de Montpellier. Quanto à utilização constatada pelo relatório da inspeção de 1867, cabe lembrar que havia alguns distritos, particularmente para o norte de Portugal, que teriam feito um uso muito maior do que aquele indicado pela estatística geral. A média de utilização do Cathecismo em Viseu, por exemplo - segundo consta do mesmo levantamento feito a partir do relatório de 1867 - era de 25,6\%, chegando a haver algumas escolas que, recebendo doações de vários exemplares da referida cartilha, chegavam a adotá-la,
} 
Ainda em 1832, um ofício assinado pela rainha recomendava à Junta da Diretoria Geral dos Estudos que o uso, já bastante disseminado, do Cathecismo de Montpellier fosse substituído pela recorrência a outro catecismo, considerado mais apropriado em termos da linguagem ${ }^{10}$. Já em 1848, a Coroa pretendia nitidamente controlar a aprovação das obras de uso escolar; e o fazia por intermédio de sua presença no Conselho Superior da Instrução Pública ${ }^{11}$. Nem essa intercessão oficial conseguiu, entretanto, retirar de cena o Cathecismo de Pombal, dado que sua presença seria uma constante da escolarização portuguesa, mostrando-se sempre como o mais notório vestígio da herança e do legado que o século XVIII deixara para o XIX. Mas, em qualquer hipótese, poderíamos, quase paradoxalmente, afirmar que o colégio dos jesuítas, a escola religiosa, a educação dos padres deixaram também sua marca profundamente fincada no ensino primário português, tanto pelos conteúdos pedagógicos que veiculavam quanto por estratégias metodológicas de conformação da sala de aula. De todo modo, o próprio Cathecismo de Colbert era ele mesmo um indício da orientação profundamente religiosa que presidia a educação portuguesa. Tratava-se, de fato, de um catecismo, organizado por uma sequência de perguntas e respostas acerca da doutrina religiosa: sobre Deus, a origem e criação do mundo, a Santíssima Trindade, os anjos e demônios, Adão e Eva, o pecado original, o castigo, a promessa do messias redentor, o dilúvio, a formação do povo judaico, a vinda e a vida de Jesus Cristo, etc. Havia uma segunda parte do compêndio, dirigida aos meninos que ainda não estivessem confirmados, que era o Catecismo Pequeno, simplificado pela seguinte justificativa:

\begin{abstract}
"Deve principiar-se fazendo aprender de cor aos Meninos mais pequenos o Padre Nosso, a Ave Maria, o Credo e a Confissão, fazendo-os pronunciar distintamente todas as palavras e aprender estas orações em latim e em português. Acrescentar-se-á a isto os Mandamentos de Deus e da Igreja, e algumas perguntas escolhidas do Catecismo seguinte. Convém instruir aos Meninos pequenos nestas coisas, logo que souberem falar, sem esperar que saibam ler. Achar-se-ão estas
\end{abstract}

como veremos nos capítulos 5 e 6. Já a média de utilização do Cathecismo de Montpellier constatada pela inspeção que teria lugar em todas as escolas públicas do reino no ano letivo de 1874-5 era de 55\%. Levando em conta todo o território nacional, o Cathecismo de Montpellier ocuparia em 1867 o $4^{\circ}$ lugar; em 1875 ele teria já caído para o $7^{\circ}$ lugar. Seja como for, note-se que, em ambos os casos, era já passado praticamente um século desde aquele alvará de D. José, que prescrevia para uso escolar esse compêndio jansenista.

10 “(...) Hei por bem determinar que o Cathecismo chamado de Montpellier, o qual, assim no seu texto primitivo como nas suas traduções já por vezes tem sido condenado em Roma, seja interinamente substituído em todas as Escolas de Meus Reinos e Domínios pelo Cathecismo do Patriarcado de Lisboa, que foi adotado pelas duas Igrejas principais destes Reinos; e, por ser necessário, que pelas explicações deste Cathecismo tenham os professores alguns livros subsidiários em linguagem. Recomendo especialmente o Cathecismo Romano e as obras do mui douto e mui virtuoso Padre Frei Luís de Granada e nomeadamente o seu Cathecismo (...) a Junta da Diretoria Geral dos Estudos e Escolas do Reino assim o tenha entendido e faça executar sem embargo de quaisquer leis, decretos, ou outras disposições em contrário, que todas dei por derrogadas, por este efeito somente. Palácio de Cachias em 15 de Julho de 1832 = Com a rubrica de Sua Magestade; cumpra-se e registrese (...)" [OFFICIO ao Director da Imprensa para que faça impimir este Decreto e juntá-lo a todas e a cada hua das respectivas instrucções (Em junta de 10 de Dezembro de 1832), Coleção de Manuscritos da Biblioteca Geral da Universidade de Coimbra, Códice 2535, Caderno 9, Folha XXIII].

${ }^{11}$ Ofício assinado pelo Duque de Saldanha dizia em 31 de Maio de 1848 o seguinte: "Sua Magestade a Rainha, reconhecendo que os livros elementares constantes da relação junta, que se acham interinamente autorizados para uso das escolas primárias, não satisfazem as necessidades deste importante ramo da administração; e considerando quanto convém promover a composição definitiva dos compêndios que devam ser empregados no ensino público das disciplinas do primeiro e segundo grau das escolas de instrução primária: há por bem encarregar estes trabalhos a Luiz Augusto Rebello da Silva, Oficial da Secretaria do Conselho d'Estado Administrativo e Deputado da Nação Portuguesa, a fim de que, merecendo os compêndios por ele organizados a aprovação do Conselho Superior d'Instrução Pública, possam ser adotados para uso geral das escolas públicas; esperando a mesma Augusta Senhora que o dito Luiz Rebello da Silva se haverá nesta comissão com o seu costumado zelo e inteligência”.'(DUQUE DE SALDANHA, Coleção de Manuscritos da Biblioteca Geral da Universidade de Coimbra, Códice 3210, Decretos de D. Maria I e de D. Maria II: folha 3). 
Orações no fim do Catecismo, nas preces para de Manhã. É preciso também mandá-los fazer o sinal da Cruz todas as vezes que se começar a perguntá-los. O catecismo seguinte pode fazer-se aprender todo aos Meninos que têm cinco ou seis anos." 12

Na sequiência, o Cathecismo tornar-se-ia, segundo suas próprias palavras, um "compêndio breve de civilidade e urbanidade cristã para uso dos meninos", ensinando a seus virtuais leitores e ouvintes as regras básicas de comportamento, as prescrições gerais de urbanidade e cortesia; recomendando procedimentos pontuais a serem utilizados em encontros e em conversas, "sobre o modo de falar, advertir, repreender e gracejar" - do vestido, do andar, dos bons modos à mesa, etc. Verifica-se, portanto, que, a depender da orientação desse catecismo (que chegava muitas vezes a ser o livro com o qual o indivíduo travaria o maior contato, dentre todos os que manusearia durante toda sua vida), haveria um desdobramento da religiosidade para a vida civil, como a grande tarefa escolar, que, a esse respeito, ensinava, talvez antes mesmo do tradicional ler, escrever e contar, as maneiras de "se comportar". Em que medida, entretanto, as populações valorizariam ou não essa missão que a escola do catecismo se propunha a fazer? Qual era de fato o resultado prático desse modelo de ensino? A tese a que nos propusemos pretendia vistoriar essa intersecção entre projeto e realidade...

Passando, pois, à estrutura do trabalho que aqui apresentamos, procuramos recortar e dividir os capítulos fundamentalmente a partir da uma metodologia que seria interior a cada um deles. Tratam-se assim de sete vozes com que o objeto foi, ao fim e ao cabo, montado. Cada capítulo então pretende constituir uma unidade de sentido, dotada de divisão interior e de uma linguagem que lhe seria própria. Os diferentes capítulos, entretanto, cruzam-se uns com os outros e procuramos traçar essa confluência no próprio corpo do texto. Estabelecemos para isso feixes temáticos e metodológicos que, interagindo uns com os outros, pudessem, cada qual a seu modo, contribuir para a reconstituição da vida rotineira, das práticas sociais e do pensamento pedagógico da escola projetada.

No tocante ao percurso, partimos do debate intelectual e acadêmico sobre a questão da escola; optamos por vistoriar o registro que as revistas e jornais da época faziam sobre o tema da escolarização; enveredamos pelo recurso à literatura e pelo retrato que os autores de romances, de poesias, de literatura de cordel, faziam da educação, para, na seqüência, interpretarmos relatos manuscritos de alguns casos que a história deixou contado; a partir daí pudemos identificar vestígios das práticas escolares, tal como estas apareciam em diferentes relatórios de inspeção; e finalmente detivemo-nos no conteúdo dos compêndios de escola mais utilizados na sala de aula portuguesa do referido período. É evidente que a linha que demarca um capítulo do outro não será assim tão rígida. Será possível encontrar a descrição de uma obra didática no capítulo das revistas; ou uma idéia educativa no capítulo da inspeção... Entretanto, embora a busca da unidade epistemológica tenha trazido a procura da interação entre temas, capítulos e métodos de análise que se entrelaçam, procuramos diferenciar a linguagem. Carlos Guilherme Mota sempre nos adverte sobre o fato de o trabalho em história não exigir apenas a amplitude das fontes; ele requer sempre e de maneira crescente a pluralidade no modo de contar...

No primeiro e no segundo capítulos procuramos pontuar o movimento das idéias educacionais nas suas orientações teóricas e nas tendências que a reflexão pedagógica portuguesa expressa em seu conjunto para cada período estudado. $\mathrm{Na}$ verdade, detivemo-nos

\footnotetext{
12 CATECISMOS da Diocese de Montpellier impressos por ordem do Bispo Carlos Joaquim Colbert e traduzidos na lingua portugueza, para por elles se ensinar a Doutrina Christã aos meninos nas escolas de Portugal e do Brazil, p. 110. Na sequência, havia ainda o "Compendio da Fé que deve ler-se nas egrejas parochiais todos os domingos á estação”, seguido de Oração para de manhã e Orações para a noite.
} 
ali no discurso político e intelectual sobre a matéria educativa, considerando que os intelectuais são os homens que, de algum modo, formularam o conhecimento sobre a matéria, conhecimento esse que, a partir do debate de seu tempo, será apropriado, irradiado e divulgado, com diferentes estilos e ritmos, pelos veículos da imprensa, por revista e por jornais da época - cuja expressão cultural será caracterizada no terceiro capítulo. Pudemos observar que - tanto no debate dos intelectuais menos ou mais conhecidos, quanto nos órgãos da imprensa especializada encarregada da formação da opinião pública --, em linhas gerais, há uma trilha matriz do raciocínio sobre a educação, evidentemente pontuada por exceções, com cada período emprestando um pouco do outro que lhe antecede ou lhe sucede. Mas de maneira nítida, pudemos destacar que, entre 1820 e 1850, há a predominância da discussão sobre o problema político da educação como alicerce de formação de uma nova sociabilidade, de um sentimento claramente nacional, de uma preparação instrutiva para a cidadania e para a legitimação da ordem liberal. Portanto, a maioria dos intelectuais, seguidos que seriam pelos discursos da imprensa periódica, deter-se-ia na defesa de padrões iluministas de uma educação pública, gratuita, obrigatória, e universal. Acredita-se e proclama-se que a instrução primária traria um patamar superior para os padrões de cultura do povo, o que possibilitaria o reerguimento de Portugal em direção a um futuro mais promissor, consolidado já pela alternativa vitoriosa do liberalismo. Era quase como se a escola fosse o anteparo com o qual as sociedades contariam para não ter de pensar na possibilidade da democracia, que, desde os tempos da Revolução Francesa, tanto parecia ameaçar o mundo contemporâneo.

Já entre 1850 e 1870, diríamos que, para o caso português, sobretudo pela iniciativa demarcadora de Castilho, o debate seria substantivamente deslocado. O centro deixava de ser as razões últimas, as finalidades primeiras da escola, naquilo que os antigos estudantes teriam aproveitado da vida escolar para a tarefa da sua posterior identidade de cidadãos do país. Longe disso, a grande questão que inquietará os intelectuais e os homens da imprensa no referido período reside, fundamentalmente, no problema do método. Por que a escola que existia não dava certo? Entendia-se que os pais, mesmo desejando muitas vezes a instrução dos filhos, não enviavam as crianças à escola por não acreditarem na capacidade efetiva de a escola realmente ensinar as habilidades básicas da leitura, da escrita e do cálculo. A família não acreditava que aquela instituição, encarregada basicamente dessa transmissão da cultura institucionalizada, conseguisse de fato ensinar, porque ela de fato não demonstrava fazê-lo. Quando António Feliciano de Castilho, no início dos anos 50, apresenta seu método, é isso que ele fundamentalmente alega. Assim, o problema da metodologia, da didática, das técnicas e estratégias do aprendizado, bem como a discussão sobre os conteúdos culturais a serem veiculados pela escola seriam a grande prioridade nessa época, quando havia paralelamente, e não por acaso - uma notória e progressiva intensificação do número de compêndios produzidos e aprovados pelo Conselho Superior de Instrução Pública.

Finalmente, a partir de 1870, e até 1910, o debate pedagógico terá o predomínio da discussão sobre a pedagogia como uma sistematizada "ciência da educação". Mas havia, sobretudo, um novo universo de leituras que vinha até pelos trilhos dos caminhos de ferro, pelos novos meios de transporte e comunicações que, a cada dia, tornavam-se mais avançados, permitindo a apropriação pela leitura das obras que eram produzidas no estrangeiro. O progresso da técnica de tipografia e a agilidade que o mundo da impressão já possuía, no caso português e, particularmente, na Europa como um todo, eram, cada vez com maior intensidade, alavancas para propiciar a tradução de numerosas obras, que passavam a ser manuseadas, lidas e apropriadas por um público a cada dia mais numeroso. Desde aqueles polêmicos anos 70 , os teóricos da educação passariam a irradiar teorias que pontuavam a evolução do desenvolvimento infantil, em geral, trazendo a analogia entre esse processo individual e o percurso de evolução dos povos. Entendia-se, conseqüentemente, que alguns procedimentos educacionais deveriam ser urgentemente providenciados para que a 
desenvolução da criança ocorresse numa trilha cientificamente orientada, de acordo com o que - diziam eles - já estaria comprovado "lá fora".

Um novo universo de leituras vinha pelos trilhos dos caminhos de ferro, pelos novos meios de transporte e comunicações. O progresso da técnica de tipografia e a agilidade que o mundo da impressão já possuía, no caso português e, particularmente, na Europa como um todo, eram, cada vez com maior intensidade, alavancas para propiciar a tradução de numerosas obras, que passavam a ser manuseadas, lidas e incorporadas por um público a cada dia mais numeroso. Desde aqueles polêmicos anos 70 , os teóricos da educação apontavam para o estudo do desenvolvimento infantil, acreditando haver analogia entre esse processo individual e o percurso de evolução da espécie. Entendia-se, consequientemente, que alguns procedimentos educacionais deveriam ser urgentemente providenciados para que a desenvolução da criança ocorresse em uma trilha cientificamente orientada, de acordo com o que - diziam eles - já estaria comprovado no exterior. A educação seria uma forma de lutar contra os obstáculos do meio, mas também contra os limites da hereditariedade... Seja como for, há um progressivo deslocamento do discurso, que se torna ainda mais nítido na abordagem da matéria educativa por parte da imprensa, sobre a qual discorreremos no terceiro capítulo.

No período em pauta, era também muito grande o número de romances e relatos literários sobre a situação da escola, revelando pistas quanto à percepção comum e popular acerca do objeto da escolarização. Muito do que se diria sobre o estudante, sobre o aluno, sobre a precariedade das casas escolares viria através da leitura de autores que, pretendendo escrever ficção, deixaram, entretanto, depoimentos sobre a sua circunscrição histórica e social. Essas circunstâncias levaram-nos a pensar um quarto capítulo como mosaico multifacetado, capaz de contemplar a passagem e as representações mentais sobre a escolarização às práticas educativas da vida escolar. Partimos, portanto, em um primeiro momento, do retrato feito pelas fontes e registros literários sobre a questão da pedagogia e da escola no século XIX português. Para tanto, valemo-nos, por um lado, de obras mais conhecidas; romances eruditos de autores consagrados: Camilo Castelo Branco, Júlio Dinis, Eça de Queirós, etc. Por outro lado, procuramos também rastrear o veio popular da literatura; seja recorrendo a algumas peças de cordel, seja recordando algumas rimas e versos de cantigas populares. O tema da escola vinha apresentado, em ambos os casos, quer pelo signo da inadequação metodológica daquela escola que existia nas realidades das aldeias e dos centros urbanos, quer pela marca da relevância social representada pela própria existência da mesma escola. Na sequiência, trabalhamos a confluência do debate ocorrido em alguns congressos e conferências de educadores, que tiveram lugar nos anos 80. Ali eram bastante nítidas as preocupações educativas dos profissionais da instrução, no tocante ao funcionamento mais concreto e mais cotidiano da escola. Pensava-se, com muita ênfase, no problema do método. De fato, o que faltava àquela organização escolar portuguesa era, fundamentalmente, a organização do tempo, a demarcação dos horários, a melhor adequação do espaço e do mobiliário. Pensando nessas questões, de ordem mais prática, o debate dos professores complementava então o leque sobre o pensamento educativo alterando e ampliando o eixo das questões por ele abordadas. Finalmente, interpretamos alguns relatos que contam de ofícios encaminhados por populações em abaixo-assinados, seja pedindo escola, seja procurando interferir em decisões centrais como a contratação e a transferência de professores. Vistoriamos alguns processos de queixa das populações contra esse ou aquele professor, que tratava mal seus alunos ou que cobrava por aulas ministradas em escolas públicas. Procuramos narrar fatos presenciados pelo cotidiano das escolas e que colocam em questão a própria idéia da autoridade do professor como um dado inquestionável: visualizavase, muitas vezes, pelo contrário, o conflito entre o poder do mestre e a autoridade do porteiro e do Comissário dos Estudos, com ganho de causa para os dois últimos. Estudamos o discurso de alguns docentes sobre os regulamentos que teriam criado para suas escolas, tendo em vista 
uma preocupação reguladora dos acasos e dos imprevistos do cotidiano institucional. Nesse diálogo entre o pensamento pedagógico e a prática educativa, estaria contido talvez o segredo quanto à verdadeira compreensão do objeto que elegemos por tema desta tese. Com base nisso, procuramos então descortinar o outro lado da realidade escolar. Não se tratava mais de indagar o que se dizia sobre a escola; não se procurava mais apreender o que dela se falava; mas sim, lá dentro, o que essa escola dizia de si própria, quem eram seus atores dominantes e como as relações de poder e de disputas de representações ali se organizavam. Na verdade, aqueles processos movidos por ou contra professores, pais e alunos, revelavam, antes de tudo, a dinâmica da escola como organização complexa. Em cada momento, será possível, deste modo, ouvir a voz de diferentes atores, representando, cada qual a seu modo, o conjunto da instituição. Por essa razão, julgamos ter obtido nesse capítulo uma sinalização precisa do que seria o ritual da escola portuguesa do século XIX.

No quinto e sexto capítulos o eixo analítico se desloca. Voltados para o dia-a-dia da rotina escolar, estavam os relatórios de inspetores que, desde os anos 50, procuravam retratar o funcionamento das escolas, suas carências, suas dificuldades, seu potencial humano e material. Particularmente os Relatórios referentes aos anos letivos de 1866-1867 e 18741875 trazem dados extremamente precisos, que permitem ao investigador reconstituir a forma sob a qual a escola pública primária portuguesa se apresentava no período. O tratamento dado à amostragem pretendia trazer uma abordagem simultaneamente qualitativa e quantitativa da rotina escolar em seus usos e costumes. Tratava-se do parecer proferido pelos inspetores em suas visitas às escolas; parecer que trazia, até certo ponto, o vestígio de uma indeclinável subjetividade, mas que remarcava, também, aproximações, até certo ponto, objetivas e, de todo modo - pelo tratamento estatístico com que procuramos trabalhar o tema -, plausíveis, confiáveis, verossímeis. Através de tal registro, tanto o material escolar como a disposição física da sala de aula, incluindo o próprio mobiliário, seria vistoriado. $\mathrm{O}$ impresso padronizado do relatório de 1867 possibilitava uma abordagem mais detida em termos quantitativos, mediante a expectativa de que o inspetor transformasse em números tudo o que via. Procuramos seguir, pois, essa que parecia ser a orientação para o estudo do relatório. Transformamos, então, em números, os dados sobre o edifício escolar (a quem ele pertencia, quanto se pagava de renda pelo seu aluguel, etc.), as dimensões da sala de aula, a superfície interna do prédio, o número de janelas de que dispunham as classes, a ventilação, as condições higiênicas, as condições pedagógicas do local onde se situava a casa de escola; procuramos os números relativos à mobília e aos utensílios de sala de aula (mesas, bancos, cadeiras, tinteiros, quadros-negros, lousas pequenas, coleção de pesos e medidas, papel, livros, penas, tinta, etc.); sobre a situação do professor, sobre a disciplina e o "regime" escolar; sobre os métodos e modos de ensino utilizados para ensinar a primeira leitura; sobre as recompensas, os castigos, os registros de matrículas e de faltas, etc. Além disso, procuramos fazer um inventário (tanto para a inspeção de 1867 quanto para a de 1875) dos registros dos livros utilizados pela escola e pelos alunos: quais eram os compêndios de que a sala de aula portuguesa se valia naquela época determinada? Buscamos ainda mapear a idade dos estudantes, o tempo médio de frequiência à escola e a classificação dos alunos - pela avaliação do inspetor e do professor nas diferentes matérias. O relatório de 1875 - por ter um espaço maior para a palavra do inspetor no julgamento das condições gerais da escola, do mobiliário, do professor, da freqüência e do aproveitamento dos alunos - possibilitou-nos a reconstituição de alguns relatos de histórias de vida escolar, narrados a partir da experiência de inúmeros professores, que apareciam retratados pela voz da inspeção. Essa foi a voz que a história nos permitiu ecoar... Muito do que ali vinha registrado evidentemente teria a marca de sua produção; entretanto, foi o vestígio que restou, o depoimento que as fontes que pudemos encontrar nos desejaram oferecer. Partimos dessa recomposição das práticas escolares, para, em contracanto com os demais relatos do quarto capítulo e mesmo com as representações que os intelectuais, políticos, pedagogos e jornalistas faziam à época, obter um olhar sobre o 
conjunto, talvez mesmo sobre a intersecção sempre procurada entre a teoria e a realidade educativa...

Finalmente, no sétimo capítulo, rastreamos os compêndios didáticos que, segundo a pesquisa que pudemos efetuar, teriam sido os que maior utilização tiveram no século XIX. Os livros de escola eram todos eles acompanhados por um muito particular processo editorial, que passava por uma aprovação e uma recomendação do Conselho Superior da Instrução Pública ( ou órgão equivalente ). Existia, particularmente a partir dos anos 50 - em movimento que acompanha a fase de intensificação das preocupações com o método de ensino - uma estratégia muito acentuado no tocante à divulgação dos livros didáticos. Julgava-se até que a carência de preparação do pessoal docente poderia ser minorada com a confecção e utilização, em sala de aula, de obras, que, em geral, disporiam de um caráter enciclopédico, contendo tudo quanto se julgasse necessário para um professor primário ensinar a seus discípulos, em termos de conteúdo e de valores. Qual o segredo do livro didático que obtinha êxito? Seria exclusivamente a força editorial de alguns desses numerosos autores? Seria o conteúdo ou a disposição pedagógica dos compêndios o que levava legiões de educadores a optar por um conjunto relativamente restrito de obras? O que tais livros contavam às crianças sobre o seu país, sobre o homem, sobre o mundo? Quais eram os saberes escolares realmente valorizados e como eles se traduziriam na efetiva utilização dos compêndios em sala de aula?

Tendo em vista um diálogo combinado entre a área da pedagogia e o domínio da história, procuramos investigar, em termos metodológicos, a existência ou não de um ritual escolar, sobre o qual se estruturariam tanto os debates sobre a escolarização quanto as formas cotidianas de se tornar escola, todos os dias. Que tipo de mitologia escolar seria essa, que formava e conformava gerações de estudantes, atados essencialmente à mesma fôrma tradicional, no decorrer de séculos, no transcurso do mundo moderno? Até que ponto a escola foi e é uma instituição necessária para a construção da modernidade? Qual a relação entre a escolarização e a cultura do escrito, inventada em tempos de Reforma, mas universalizada apenas no XIX? Ao mesmo tempo em que a escola entende o texto como um poder de emancipação humana, verifica-se que há temor por parte da sociedade quanto a esse potencial de liberdade intrínseco ao saber ler. É assim que se pretendia, talvez, regrar, pela escola, o olhar da leitura... O território do livro, as perigosas mensagens do impresso, poderiam ser tanto destruidores de hábitos quanto criadores de novas necessidades sociais, que, por si, pareciam já ameaçar setores governantes. O caminho que iria conduzir à superação de uma vida pautada por territórios norteados exclusivamente pela tradição da oralidade passava inequivocamente pela escola... Cabia a essa instituição fazer a transição entre a família e a vida social: nisso lhe competia reproduzir uma demarcação de lugares que supostamente lhe seria anterior. Mas, exclusivamente para proceder a um ritual de reprodução, a tradição e a cultura familiar seriam por si suficientes. Era necessário avançar, inventar um futuro que parecesse aos olhos dos contemporâneos o aperfeiçoamento do presente. A ilusão quanto a um futuro de perfectibilidade parecia sempre acompanhar pensamento e prática educativa em Portugal do XIX. Estaria também nisso, por outro lado, o potencial criador, talvez transgressor da lógica da permanência, da conservação, da preservação da ordem... A escola produziria, pelo ritual com que organizava sua rotina, um mundo todo seu... Finalmente, diríamos que a escola primária portuguesa, entre 1820 e 1910, não é ainda a instituição incosteste do Estado-Nação. Não traz ainda a marca da homogeneidade, não é uniforme. Traz, entretanto, certas regularidades, certas constâncias, tanto na sua estrutura interna quanto nos métodos e procedimentos de ensino de que se valia.

Alerta Nóvoa sobre o perigo epistemológico de se acreditar ingenuamente em tudo aquilo que, à primeira vista, parece simples e evidente. Não se revela fácil, também, lidar com opiniões cristalizadas que surgem diante de nós. Costuma-se dizer, por exemplo, que a população portuguesa não valorizava o conhecimento escolar durante o decorrer do século 
XIX. Será isso verdade, ou tratar-se-á de um dos mitos da história da alfabetização, tal como aqueles que a análise de Graff apresenta como verdades presumidas? ${ }^{13}$ Dir-se-ia à partida que a escola veio para moralizar. Poderíamos ainda falar do papel disciplinar da vida escolar e da preparação nela suposta para a vida do trabalho, para a adequação do indivíduo à vida adulta. Ocorre que dizer isso e não dizer nada dá no mesmo. Cabe enveredar pela descoberta pontual, nos casos particulares que a história fez por retratar, que tipo de solicitação a família fazia da escola; por outro lado, como a escola se comportava perante os atores nela envolvidos e viceversa... Cabe indagar, portanto, o modo pelo qual a escolarização traça uma dinâmica toda sua, quais os ritos que no percurso parecem se repetir, quais os temas privilegiados, a quais valores a escola verdadeiramente irá "aderir"- para usar expressão de António Nóvoa -, de qual repertório ela se valerá.... O trabalho que nos propusemos a elaborar a título de tese de doutoramento partiu dessa inquietação. Centrar o objeto de estudo sobre o imaginário pedagógico e, na outra margem, sobre a vida rotineira da escola primária portuguesa pareceunos um grande desafio, ainda que trabalhássemos, de longe, com uma realidade distante. Corríamos o risco de banalizar esse cotidiano, transformando em obviedades muitas das evidências que pudemos, talvez, no caminho, descortinar. Julgamos que, por outro lado, havia a possibilidade de obtenção - mediante o diálogo entre as representações e as práticas pedagógicas - de elementos teóricos e informativos que qualificassem a interpretação do passado através da atualidade dos objetos nele compreendidos. Isso nos permitiria a sincronia do diálogo, que sempre procuramos, entre a história e a pedagogia.

Sob esse aspecto, identificar, por um lado, o que a escola falava da nação e, por outro lado, o que ela dizia à nação significaria apreender o lugar social dessa instituição no engendramento do futuro. Formar a mocidade é sempre uma aposta, um ofício ritualístico de projeção da utopia; talvez uma estratégia para o grupo social deliberadamente se iludir quanto a uma suposta programação da história, com a retirada então dos riscos postos pelo acaso e pela sempre indeterminação do futuro... Talvez por isso, os sinais da escola sejam tão reveladores. Historicamente a educação das novas gerações trabalha com a categoria da perpetuação de tradições e de códigos de conduta coletiva que se pretendem manter. Por outro lado, educar o menino - enquanto homem do dia seguinte - significa a prospecção de um dado conjunto de expectativas, esperanças e desejos projetados por grupos sociais historicamente circunscritos. Encarregam-se crianças e jovens, como portadores virtuais de um futuro embrionário, da tarefa de consolidação dos sonhos e projetos caros à geração adulta que lhes forma $^{14}$. Aí reside talvez o fascínio do domínio da educação. No caso de Portugal do século XIX, o retrato é claro: falar do futuro às crianças da escola supunha a valorização incondicional do tempo passado. A instrução portuguesa, por conteúdos e métodos, erigia o feito das navegações como a mais nítida prova de que Portugal, ao superar a decadência, reporia pela restauração, a vocação de grandeza perdida em um sítio qualquer do passado. $\mathrm{O}$ futuro de Portugal estaria, pois, atado aos ditos de pequenos compêndios de história. Por outro lado, havia que compreender o retrato do passado também para nortear o caminho do futuro. Para isso viria o ritual escolar.

Pareceu-nos, desde o princípio, necessário questionar a maneira pela qual a instituição escolar lidava com a dinâmica da leitura e com o universo valorativo metodologicamente contido nessa competência que, pouco a pouco, deveria vir a se irradiar, pelo caminho da vulgarização do impresso, cada vez mais acessível, cada vez em número maior. Qual a relação, enfim, entre escola e leitura? Por seu turno, o decorrer da pesquisa nos encaminharia para outra curiosidade: em que medida havia interlocução, concorrência, hostilidade entre a vida escolar e o universo familiar? A escola como agência de instrução e

\footnotetext{
${ }^{13}$ Harvey J. GRAFF, Os labirintos da alfabetização.

${ }^{14}$ A propósito deste tema, indicamos o trabalho de George Snyders, La pedagogie en France aux XVII ${ }^{\mathbf{e}}$ et XVIII ${ }^{\mathrm{e}}$ siècles.
} 
de moralização das camadas juvenis da sociedade evidentemente ocupava com a modernidade um espaço que até então pertencia inequivocamente à família. Portanto, talvez não fosse tão cooperativa essa relação entre pais e mestre...

A temporalidade do objeto justifica-se fundamentalmente em razão do movimento operatório de reconhecimento. Formas distintas de olhar comporiam cenários diversos na tela dessa memória produzida. Reencontrar a sala de aula do aluno do curso primário em Portugal do XIX era talvez uma ambição singela, por paradoxal que isso possa parecer aos olhos do leitor. Encontrar olhos para conseguir enxergar; aí sim estava o nosso grande desafio. De qualquer maneira, como alerta o coração de Pascal:

"Não ficamos nunca no tempo presente. Antecipamos o futuro, por chegar demasiado lentamente, como para apressar-lhe o curso; recordamos o passado, para detê-lo, por demasiado rápido: tão imprudentes que erramos nos tempos que não são nossos e só não pensamos no único que nos pertence; e tão vãos que sonhamos com os que já não existem e evitamos sem reflexão o único que subsiste. É que o presente de ordinário nos fere. Ocultamo-lo à vista porque nos aflige; e, se nos é desagradável, lamentamos vê-lo escapar. Tratamos de sustentá-lo pelo futuro e pensamos em dispor das coisas que não estão ao nosso alcance para um tempo que não temos nenhuma certeza de alcançar."

\footnotetext{
${ }^{15}$ PASCAL, Fragmento 172, Os pensadores, p. 80. A propósito do tema, indicamos a tese de doutoramento de Mariana Cláudia Broens Stange, defendida em 1996 no Departamento de Filosofia da FFLCH-USP, com o título de $\mathbf{O}$ problema da fundamentação do conhecimento na filosofia de Blaise Pascal.
} 


\title{
Intelectuais e discursos pedagógicos: a arte da educação (1820-1870)
}

\author{
"Pelas constelações é que esse espaço lemos..." \\ (Antero de Quental, No Templo, Odes modernas)
}

\section{A CARÊNCIA DE ESCOLAS COMO PROBLEMA NACIONAL}

Compreender a história da escola em suas dimensões subjetivas supõe perscrutar todo um imaginário por meio do qual podemos indagar quais eram, em cada época e em cada país, as representações mentais que acompanhavam a acepção mesma da escolarização; e, na outra margem, averiguar em que medida tais concepções teriam correspondência nas práticas escolares então desenvolvidas. Compreender o movimento da escola portuguesa nesse período que principia com a Revolução Liberal (1820) e termina com a República (1910), supõe o seguinte questionamento: o que era a escola para os portugueses desse século? Como era percebida a transferência de parcela da responsabilidade educativa da família para uma instituição que, em princípio, deveria contar com a tutela do Estado? Em que medida o ensino era ou não uma estratégia de setores da sociedade, no sentido de incutir valores burgueses, formar o consenso social, preparar o trabalhador? No presente capítulo, trabalharemos com os discursos entrecruzados, que permitirão uma breve incursão sobre aquilo que consideramos ser o olhar intelectual sobre o problema da instrução portuguesa nas diferentes etapas desses anos de monarquia constitucional. Transformando os referidos discursos quase numa constelação de idéias, com uma lógica própria e autônoma, procuraremos suspender - até onde isso é possível - os juízos e pareceres políticos desses protagonistas da política portuguesa. Optamos por sequestrar-lhes exclusivamente suas falas sobre educação. Com elas, buscamos observar, pela história da pedagogia, algumas das permanências e as descontinuidades do debate sobre escola. Em alguns casos, os diagnósticos e proposições se aproximam; em outros, a diferença vem à tona. Traçar esse movimento foi de fato o que pretendemos trazer à guisa de um introdutório panorama de idéias educativas que, sem dúvida, auxiliar-nos-á como um alicerce para a posterior compreensão da vida escolar em sua cotidianidade.

O problema pedagógico, entre o liberalismo do século XIX e os primeiros ventos do republicanismo português, colocava-se perante a indagação, que parecia fundamental aos olhos dos intelectuais contemporâneos. Quantas crianças efetivamente frequentavam a escola portuguesa e por que era tão grande o número daquelas que não iam à escola? Veremos que o 
tema da extensão da escolaridade para uma população acrescida e sempre em ampliação terá como contraponto a preocupação dos educadores com questões atinentes, ora ao tema da política liberal e da capacitação para a cidadania, ora ao problema da divisão social do trabalho e a formação do indivíduo para o mundo do mercado, ora para a própria eficácia técnica daquela escola. A escola como uma instituição socializadora de conhecimentos e de valores teria tido com a atuação do Marquês de Pombal um primeiro grande momento para o caso português. Tanto a Constituição Vintista quanto a Carta Constitucional e mesmo a Constituição de 1838 asseguravam a todos os cidadãos instrução primária e gratuita. Nessa medida, o tema da democratização do ensino público estaria já presente nessa alvorada do regime liberal. Ocorre que nem sempre as leis correspondem verdadeiramente aos fatos.

Manuel Francisco de Medeiros Botelho apontava, em 1969, (como, aliás, veremos adiante) o estado e as carências quantitativas da escolarização em Portugal. Segundo os dados daquele autor, o esforço por aumentar o número de escolas públicas era nítido particularmente desde meados daquele século. Entretanto não se poderia dizer que a situação portuguesa equacionara a dívida histórica para com a juventude que era a verdadeira beneficiária da expansão e democratização do ensino público.

\begin{abstract}
"Criaram-se, é verdade, no curto espaço de 11 anos (de 1854 a 1865) 2.006 escolas elementares, elevando o número desses estabelecimentos públicos de ambos os sexos a 3.206; têm-se criado muitas mais desde então, mas não são ainda em número suficiente. A Prússia contava, em 1865, 27.000 escolas para 18.500.000 habitantes; a França 60.000 escolas para 40.000.000; Portugal, 3.206 escolas para 4.350.917 habitantes, segundo o recenseamento do $1^{\circ}$ de janeiro de 1864 . $\mathrm{Na}$ França há uma escola para 666 habitantes; na Prússia, uma para 685; em Portugal, uma para 1.672. A desproporção é imensa ! O nosso país, não incluindo as colônias, deve contar pelo menos 5.400 escolas para o sexo masculino; toda a freguesia ou paróquia, cuja população orçar por 800 habitantes, deve possuir uma. Não é pretender muito. 4.350 .917 habitantes supõem 403.816 mancebos de 8 a 18 anos de idade, que, distribuídos por 5.400 escolas, ficará cada uma com 78 alunos, número maior que a maior parte delas não podem nem devem comportar."16
\end{abstract}

O século XIX é sem dúvida o momento privilegiado para o debate e a polêmica acerca de alguns dos grandes temas legados pelos princípios que de algum modo pautariam o sonho das democracias e das revoluções quanto à correlação entre os progressos da civilização, das indústrias e das artes e a socialização da parcela de saber acumulado pela humanidade, tendo em vista tanto a formação do cidadão quanto a preparação do trabalhador do novo mundo que então se anunciava. Entretanto, para isso, havia que se tomar como bandeira alguns princípios educacionais, que, derivados do campo da política mais do que de tratados de pedagogia, construiriam para legitimar a ordem liberal e desigual que vinha se anunciando. Defender a sociedade do mundo do liberalismo era defender a competição, a livre concorrência, o jogo do capital, o jugo do trabalho, o individualismo elevado à sua escala maior. Ocorre que se fazia fundamental justificar a dita competição e suas regras. Isso só poderia ser feito pela suposição da equalização das oportunidades. Tendo sido possível tornar igual as oportunidades de ascensão, só quem não aproveitasse sua chance fracassaria. A ideologia do progresso perfilharia por essa vereda o tema da instrução popular. A escolarização elementar pública, universal, gratuita, laica e obrigatória seria a primeira das chances igualmente distribuídas. Liberais reivindicavam esse direito, até para justificar perante o povo o que seria - digamos assim - a ordem natural das coisas. Democratas reivindicavam-na para expandir os direitos sociais. Socialistas reivindicavam-na como

\footnotetext{
${ }^{16}$ Manuel Francisco de Medeiros BOTELHO, Plano de Estudos Primários e Secundários, p. 17.
} 
possibilidade plena para tornar consciente o sonho da emancipação. O século XIX, seja como for, dialogou sempre - e Portugal não foi exceção a isso - com a expectativa de escolarização universal, laica, obrigatória, gratuita e pública. Das palavras de Catroga, podemos nos valer do esforço de síntese:

\begin{abstract}
"No entanto, é um fato indiscutível que existiu uma grande desadequação entre estas intenções e os seus efeitos práticos, apesar de terem sido inúmeras, e algumas bem significativas, as reformas apostadas em combater o analfabetismo através do alargamento da rede escolar primária e secundária do ensino público. Uma, a de Passos Manuel (15 de Novembro de 1836) apelava aos pais para aderirem ao princípio da obrigatoriedade, e o decreto de 20 de setembro de 1844 (Costa Cabral) impôs, explicitamente, a obrigatoriedade escolar desde os 7 até aos 15 anos de idade. Medidas sem grandes consequências (em 1870, Portugal Continental, com 4.200.000 habitantes, contava apenas com 2.300 escolas oficiais e, em 1868, o total de alunos das escolas oficiais e livres era de 132.000, o que significava que, das crianças de 7 a 15 anos, 600.000 não frequentavam qualquer escola). A lei de 16 de agosto de 1870, de autoria de D. António da Costa, procurou remar contra este estado de coisas e voltou a decretar a obrigatoriedade da instrução primária elementar ( $1^{\circ}$ grau), mas a precariedade governativa fez com que também este plano reformista não tivesse consequências. Em 1878, António Rodrigues Sampaio retomou-o, dando particular ênfase à obrigatoriedade. Debalde. A legislação posterior, promulgada ainda sob a Monarquia, manteve a exigência e, em1901, o governo presidido por Hintze Ribeiro seguiu uma via que julgava mais eficaz, estipulando que só a posse de diplomas do $1^{\circ}$ grau ou do $2^{\circ}$ grau permitiria o acesso a certos lugares na função pública. Apesar dos relativos progressos detectáveis no campo do ensino primário - o número de escolas públicas triplicou de 1860 a 1900, e a relação de escolas (públicas e privadas ) por habitante passou de 1 por 928 habitantes em 1875-6 para um por 890 em 1899-1900 -, o índice de analfabetização continuou a ser grande, pois somente decresceu de $82,4 \%$ em 1878 para 78,6\% em 1900." 17
\end{abstract}

No ano de 1909, um impresso de autoria de Carneiro de Moura publicava - pela Imprensa Nacional portuguesa, em nome da Direção Geral da Instrução Primária do Ministério dos Negócios do Reino - um Relatório intitulado A instrucção educativa e a organização geral do Estado, onde eram apresentados dados concernentes à situação geral da instrução pública portuguesa naquela época. O relator principiaria o trabalho, apontando a situação histórica da escolarização portuguesa, que, ao menos desde a Revolução Liberal segundo ele - permanecia relegada a um plano ínfimo das prioridades governamentais ${ }^{18}$. As

\footnotetext{
${ }^{17}$ Fernando CATROGA, O republicanismo em Portugal: da formação ao 5 de outubro de 1910, segunda parte, p. 379-380. Na sequência, o mesmo autor declara o seguinte: "Deste modo, não surpreende que a questão do ensino e, em particular, do ensino primário, se tenha transformado num dos temas maiores de doutrinação republicana, tanto mais que o eco da política educativa da III República francesa começou, desde os inícios da década de 80, a aparecer no seu discurso como prova de que a democratização do ensino seria impossível sem a solução da questão do regime e da questão religiosa. Daí que, também para os republicanos portugueses, o princípio da obrigatoriedade fosse irrealizável sem outros dois pressupostos correlatos, a saber: a gratuitidade, que só o Estado poderia garantir e a laicidade. E são estas ilações que, mais do que qualquer outra corrente, o republicanismo extraiu dos próprios pressupostos que reputava serem essenciais para se garantir a criação das condições culturais adequadas ao pleno cumprimento dos direitos naturais e, portanto, à completa consumação da essência do homem: - a perfectibilidade." (Id. Ibid., p. 380-1). Catroga destaca ainda neste seu trabalho que Passos Manuel havia introduzido em seu decreto de 15-11-1836 a civilidade, a moral e a doutrina cristã como matérias previstas no conteúdo programático obrigatório das escolas de instrução primária. Isso teria sido mantido pelas reformas seguintes, durante todo o século XIX, embora se pudesse constatar "uma tendência para retirar a formação cívica das alunas, saubstituindo-a por um ensino voltado para a formação das atividades domésticas." (Id. Ibid., p. 411).

18 "A revolução liberal, preocupada com a nova organização da propriedade, das Cortes e da realeza, mal cuidou da instrução popular. Continuou o mestre-escola a ser desconsiderado, e a servir apenas para ensinar a ler o catecismo, os devocionários e as Cartas de Sentenças. Como educação prática chegava-se, quando muito,
} 
escolas, em número insuficiente, de maneira alguma atendiam às necessidades postas pelos então atuais rumos da civilização, mantendo-se estreitamente presas ao ensino de leituras catequéticas, completamente inadequadas para a vida prática da criança após a instrução primária. Além disso, grande parcela da população portuguesa - segundo o relator - vivia nos campos, e a realidade rural era completamente desconhecida para aquela instrução modelada para a vida urbana. De acordo com os dados apresentados, das 5215 escolas primárias oficiais existentes em Portugal naquele ano de 1909, 1020 eram escolas mistas de povoados com população inferior a 500 habitantes. Havia 2511 escolas exclusivamente masculinas e 1684 escolas para o sexo feminino. Do total, 148 escolas estavam fechadas, " por falta de mobília, de casa para escola, ou por impossibilidade de professor". Havia em Portugal, naquele período - de acordo com os recenseamentos escolares - 650000 crianças entre 6 e 12 anos idade do ensino obrigatório - "o que quer dizer que corresponde uma escola para cada 105 alunos, ou seja para cada 955 habitantes". Os professores eram, por sua vez, em número de 5984 distribuídos que estavam, quase um por cada escola, perfazendo uma proporção de um professor primário para cada 90 alunos. De qualquer modo, a frequência escolar não correspondia, em hipótese alguma, a esses números, posto que particularmente as populações camponesas ainda retirassem os filhos da escola. Como destaca o mesmo Relatório, " a frequência real nas escolas primárias nos meses de verão não vai além de 220580 alunos, ou seja uma média de 40 alunos para cada escola”, faltando portanto à escola nesses meses mais de $60 \%$ da crianças constantes do recenseamento. Durante o inverno, faltava à escola uma média de $42 \%$ das crianças. Além de tudo, continua o texto:

\footnotetext{
“(...) das 5215 escolas apenas 978 estão instaladas em estabelecimento próprio, e cerca de 3000 existem em casas tristes, acanhadas, sem luz adequada, sem campos adjacentes para o recreio dos alunos (...) Criar mais escolas primárias a esmo não pode ser. As escolas primárias existentes, se fossem melhor distribuídas, seriam bem mais úteis. O norte do país é muito montanhoso e cortado de rios e ribeiros. Há freguesias com sete e mais povoações, que não têm cada uma mais de 100 habitantes, e estas povoações são separadas por montanhas ou rios que as crianças não podem atravessar pelo menos no inverno. Como ministrar o ensino às crianças de tais povoações?"19
}

O relatório frisa a necessidade da reorganização da instrução, expondo, para tanto, objetivos muito precisos. As escolas eram sim indispensáveis, não para a capacitação da cidadania, nem mesmo para conformação de valores. Aqui se tratava de proceder à transmissão de um conhecimento instrumental, técnico, utilitário, voltado - aí sim - para a prosperidade material do Reino. Nota-se então que o discurso pedagógico adquire uma tonalidade de provisão: vem para suprir diretamente carências sociais que não teriam sido de outro modo equacionadas. Para levantar o país que caíra decadente, havia que se formar um povo disciplinado, organizado e, sobretudo, trabalhador. O conhecimento da leitura e da escrita por si só de nada valeria, tornando-se absolutamente imprescindível a preparação educativa que capacitasse a curiosidade pela leitura de 'bons livros', capazes de conformar exemplos valorosos e hábitos sadios. Além disso, com certa obsessão, o Relatório destaca a relevância de a escola ensinar técnicas agrícolas, escrituração mercantil, contabilidade, de modo a efetivamente preparar as novas gerações de comerciantes e agricultores. Assim, acredita o relator:

a sopear uma criança, em caso de perigo de vida e na falta de sacerdote para o batismo solene." (Carneiro de MOURA, A instrucção educativa e a organização geral do Estado: relatório, p. 17).

${ }^{19}$ Carneiro de MOURA, A instrucção educativa e a organização geral do Estado: relatório, p.19-20. As demais citações, que, no parágrafo anterior, traziam também dados estatísticos, foram extraídas das páginas 18 e 19. 
“O professor provará como pelo desenvolvimento da indústria agrícola podem os trabalhadores dos campos ser felizes e ricos, se aproveitam a instrução como meio educativo, que lhes permita melhorar os processos de produção, aplicar com método os adubos, utilizar os pousios, comprar em tempo e lugar oportuno as sementes, adquirir alfaias agrícolas modernas, associar-se na paróquia como centro de ação cívica e econômica, em cooperativas de crédito, de produção e de consumo, em caixas econômicas, em sindicatos agrícolas. Fácil será ao professor provar e persuadir os filhos dos trabalhadores dos campos, a geração de amanhã, por meio de caixas escolares em que a gerência direta dos alunos lhes incuta hábitos de economia, de gerência, de iniciativa, de trabalho, e de ordem - provar que não é necessário que a emigração para o Brasil continue à procura de pão, nas terras inclementes, porque na pátria há lugar para todos poderem ganhar com abastança o pão de cada dia, se todos souberem e quiserem trabalhar, e impor a obrigação geral do trabalho aos parasitas de toda a ordem. O Brasil não é necessário que os portugueses o procurem fora da sua terra, porque nas nossas colônias e nos nossos campos da metrópole há território para se desenvolver um povo rico, depois que nele se desenvolvam as naturais qualidades de trabalho pela instrução educativa."20

O discurso da instrução, qualquer que seja ele, recordará o lugar de formação do caráter nessa alma coletiva da classe escolar. Entretanto, os propósitos declarados quanto à extensão dessa escola do ler-escrever-contar nem sempre seriam radicados nessa utilidade imediata do trabalho produtivo. Como a escola era percebida e sentida pela população portuguesa nesse século XIX? Quais eram as representações sobre o ofício da instrução mais em voga no período? O que diziam os mais renomados intelectuais sobre o moderno tema do ensino universal da leitura? Em que medida Portugal viria a construir um imaginário letrado que, a pouco e pouco, ganharia terreno sobre o universo da oralidade? Qual a dinâmica política que fazia por criar um discurso específico sobre a cidadania e a vida democrática, que, em certa medida, era um discurso escolar? Será pela interface que tais questões poderão no conjunto contribuir para desvendar o inextricável panorama da escola portuguesa, entre aquilo que dela se dizia e o que, de fato, se procurava nela engendrar.

Percebem-se nitidamente três etapas distintas nesse trajeto. Basicamente, poderse-ia dizer que a tônica do debate educativo no período compreendido entre 1820 e 1850 centra-se sobre tudo nos temas atinentes à questão política da educação e da escolarização. $\mathrm{O}$ setor progressista compreendia a instrução como uma fonte de esclarecimento, capaz de engendrar os dispositivos necessários para a preparação da cidadania liberal e, pelo desejo de alguns, democrática. Os conservadores, por seu turno - nesta primeira fase - alertam com veemência os contemporâneos sobre os perigos contidos nesse eventual esclarecimento suposto como intrínseco à aquisição de cultura. Eles julgavam - talvez com alguma razão que a ampliação das referências teóricas e intelectuais na compreensão da realidade tornaria o indivíduo mais crítico, socialmente mais propenso à transgressão. Por sua vez, na etapa compreendida entre 1850 e 1870, o objeto mais destacado dos estudiosos da educação foi explicitamente o tema do método de ensino. Acreditava-se que a escola para todos não se firmara em Portugal pelo simples fato de não se ter conhecimento algum dos mecanismos do

\footnotetext{
${ }^{20}$ Carneiro de MOURA, A instrucção educativa e a organização geral do estado: relatório, p. 58-59. Outro trecho pareceu-nos ilustrativo desse intento 'produtivo' com que se reveste o tema da instrução: "Há professores cheios de boa vontade; mas vivem constrangidos; não têm material de ensino e não podem ensinar, pela intuição dos fatos e das coisas, de modo a formarem o caráter forte, empreendedor e prático dos alunos. Isto torna muitas vezes inane o ensino da leitura e da escrita, que apenas fica sendo um instrumento inútil. É indispensável que todos saibam ler e escrever, mas para dirigirem pela contabilidade e pelo conhecimento dos preços e dos gêneros a economia doméstica; mas para lerem em livros de vulgarização as vantagens da química na valorização produtiva da terra; mas para compreenderem os modernos processos de produção, e, para porem em prática, pela educação cívica, o esforço individual que fez o grande povo inglês e que tem tornado ricos e prósperos os suíços, os alemães, os suecos, e todos os povos disciplinados, livres e trabalhadores.” (Id. Ibid., p. 22-23)
} 
aprendizado, particularmente do primeiro aprendizado: o ler, escrever e contar. Não sabendo ensinar, a escola que havia era então rejeitada e Portugal mantinha-se, de tal maneira, em sua tradicional carência de letras. Finalmente, a partir de 1870 - com a imensa contribuição dos episódios que envolviam o grupo-geração conhecido como Geração de 70 - passou-se a compreender o fenômeno educativo como se de uma ciência se tratasse. Sob tal clivagem, que perduraria até o final do período estudado (1910), a escolarização passou a ser entendida mediante referências teóricas e metodológicas que procuravam sinalizar o problema da escola como uma hipótese científica de desenvolvimento nacional. De qualquer maneira, existe uma crença comum, que os defensores da escola, qualquer que fosse o período, inarredavelmente partilharam: a educação se apresenta na história e no trajeto dos povos como uma atitude coletiva imprescindível para garantir a perfectibilidade entre as gerações. A esperança de que cada geração viesse a aperfeiçoar - mantendo e inovando, aprimorando e desenvolvendo - o tempo de seus antepassados pareceu-nos ser - no traçado do debate educativo em todo o século XIX português - pressuposto epistemológico para o pensamento sobre a escolarização.

\section{A PEDAGOGIA SOB O SIGNO DA POLÍTICA: ALVORADA DO LIBERALISMO}

António Nóvoa destaca que as bandeiras da Revolução Francesa ${ }^{21}$, ou - como prefere o autor - seus 'slogans educativos' seriam em Portugal plataformas discursivas posteriores à implementação efetiva do ensino secularizado por Pombal. Era como se, no caso português, curiosamente, a prática precedesse a instância da representação, dada a ambiguidade metodológica do próprio projeto pombalino. A Revolução Francesa, que pontua indubitavelmente uma forte referência simbólica, vem para Portugal com o liberalismo e o modo pelo qual irá se impor atenderia a algumas especificidades típicas da circunscrição histórica desse lastro de iberismo. Porém, para além dela, havia que se reconhecer a resistência da matriz de Estado legada por Pombal, naquilo que parecia ser o desejo de refundar ou reinventar a nação. A arquitetura escolar fazia parte integrante desse projeto. Nas palavras de Nóvoa:

\footnotetext{
“Antes de 1789, Portugal possuía já um sistema estatal de ensino, cuja estrutura tinha contornos semelhantes aos que foram delineados um pouco por toda a Europa durante o 'século da escola'. Mas os objetivos e os conteúdos desse sistema não estão todavia impregnados do ideário que a Revolução Francesa difundirá ao longo do século XIX. Isso não seria possível antes da instauração do Estado liberal (1820-1834), cunhado pela ideologia burguesa, tal como esta se havia definido na Europa ocidental dessa época."22
}

É assim que o tema da instrução pública inauguraria o século XIX em Portugal nos anos 20 - pela promessa de emancipação. Os ecos da Revolução Francesa e todo o lastro

\footnotetext{
21 No plano da pedagogia, a Revolução em França realmente inaugura um modelo de escola, que se torna referência de democracias que da Revolução se farão posteriormente herdeiras. Inegavelmente ali nasceria o ideário conjugado de uma escola pública, estatal, universal, única, gratuita obrigatória, laica e para ambos os sexos. Procuramos trabalhar o tema no livro publicado em 1996 pela Editora UNESP, sob o título A escola do homem novo.

${ }^{22}$ António NÓVOA, Notas sobre la influencia de la Revolución Francesa en la educación en Portugal, p. 190. Acerca do tema, o autor relativiza a influência francesa, destacando o desejo de a burguesia portuguesa construir um modelo que apresentasse um perfil nacional, consoante com a tradição do país. Além disso, Nóvoa salienta a dificuldade de implementação de muitos dos projetos democrático-liberais, dentre eles, a escola: "Vemo-nos obrigados a reconhecer que o século XIX português era predominantemente analfabeto e que persistem resistências profundas à imposição da lógica burguesa de escolarização, em suas diversas modalidades, pensada pelos liberais portugueses sobre a base da experiência revolucionária francesa." (Id. Ibid., p. 197).
} 
simbólico dela decorrente revelariam, por toda a Europa, o espraiar daquele imaginário, que apregoava, a um só tempo, liberdade, igualdade e fraternidade. No parecer de Nóvoa, havia declarado intento de integração nacional no percurso da revolução em França. Os projetos de escolarização pública fariam parte desse imaginário. Todo o desenvolvimento dos ideários e dos planos educativos do século XIX devem ser, portanto, vistos como "um grande intento de controle social e de legitimação da nova ordem política." ${ }^{23}$ Por um lado, a percepção de que as veias dessa nova nacionalidade que parecia nascer com o século traziam consigo o pulsar das Luzes; daí o tempo da nação ser também o tempo da escola. Na outra face, porém, o vulto sombrio da inscrição da violência na História. Se Portugal desejou fazer cumprir os preceitos de regeneração contidos no ato de declarar universais os direitos, os portugueses rechaçavam, com a mesma convicção, o prisma de fratura contido na acepção e prática do Terror.

Entre a reforma e a revolução, optava-se, pois, pela primeira alternativa. E, nesse diapasão, pedagogicamente, irrompe o liberalismo português.

O pombalismo enquanto projeto arquitetara já uma nova configuração da nacionalidade a partir da organização de um sistema de escolarização pública. Recorde-se que o próprio tema da nação seria deslocado a partir da transferência da Corte e da monarquia para o Rio de Janeiro em 1808. Seja no tocante aos investimentos culturais, seja no que diz respeito à centralização das políticas governamentais, a tônica passara a ser brasileira. Ora, até certo ponto, se teria cumprido o movimento previsto por Ribeiro Sanches naquilo que dizia respeito à identidade da nação decadente.

Compreender, pois, o modelo pedagógico que se segue ao vintismo supõe o contato com esse percurso anterior das idéias educacionais portuguesas de final dos setecentos. Acerca do que qualificam como "prática reformista e inércia", a saber, o tema da instrução no projeto vintista, Torgal e Vargues exaram o seguinte parecer:

\begin{abstract}
“Assim, não é de estranhar que em vários campos, e não apenas no do ensino, não se tomassem medidas revolucionárias. Não é de estranhar que, ao contrário do que sucedeu durante a Revolução Francesa, tivessem escasseado os projetos de transformação estrutural da política de instrução e que os poucos que surgiram tivessem sido atacados e reduzidos ao esquecimento. Poderá dizer-se que o movimento revolucionário francês, sobretudo na sua fase mais radical e mais laboriosa em matéria de ensino, a da Convenção, acabou por não produzir na prática grandes medidas, interessando-lhe muito mais destruir as estruturas existentes; mas, de qualquer forma, apontou claramente para um novo perfil de instrução pública. Em Portugal, ao contrário, permaneceu quase incólume a reforma pombalina, com todas as suas inflexões, que afinal só veio a ser posta verdadeiramente em causa - apesar de se terem operado no decorrer do século algumas reformas com a Primeira República."24
\end{abstract}

Julgamos que a apreensão das permanências e dos quadros mentais de longa duração pode ser, sim, procedimento operatório apropriado, desde que tal esforço surja devidamente acompanhado da procura de especificidades, das inflexões, enfim, de tudo o que pode ser distintivo. Qualquer tentativa de generalização na História perpassa certas cautelas metodológicas, naquilo que persiste sendo, em última instância, o reconhecimento da

\footnotetext{
23 António NÓVOA, Notas sobre a influencia..., p. 201. Para Nóvoa, "hoje sabemos que a tríade revolucionária - liberdade, igualdade, fraternidade - é muito mais complexa do que nos quiseram fazer crer: complementares entre si, esses três termos são ao mesmo tempo antagônicos. Mas é sob a luz da necessidade e a impossibilidade de realizar a trindade revolucionária que temos que pensar (e viver) hoje a Revolução francesa, concretamente em suas muitas repercussões educativas." (Idem Ibidem, p. 205) Fizemos esta tradução, assim como todas as que se seguirem, quando nos referimos a textos originalmente escritos em outras línguas.

${ }^{24}$ Luís Reis TORGAL e Isabel Nobre VARGUES, A Revolução de 1820 e a instrução pública, p.34-35.
} 
similitude na identificação de diferenças. Por ser assim, supomos apressado, ligeiro e, no mínimo, discutível o juízo acima exposto, segundo o qual, de Pombal à República, haveria uma uniformidade tanto nas representações simbólicas quanto na prática institucional em matéria de instrução pública.

A partir da hipótese de que teriam efetivamente ocorrido modificações substantivas no tocante ao pensamento educacional na trilha do XIX, procuraremos, no presente capítulo, reconhecer algumas vigas matriciais, passíveis de serem caracterizadas como tendências pedagógicas em desenvolução da intelectualidade portuguesa em um século que, ao acontecer, não permanece sendo já o que fôra. As idéias revelam-se tributárias de seu tempo, do discurso das Luzes, à moda portuguesa, até o foco cientista. Há similitudes, há contradições, há contrariedades. Resta saber, pelos discursos, quando e de onde falam os sujeitos que enunciam pareceres sobre educação.

Em termos de uma duração relativamente longa - 1820-1910 -, procuraremos apreender certas regularidades - e também algumas das variantes - mediante as quais o tema da instrução popular vinha povoar o imaginário discursivo. Para perscrutar esse olhar coletivo sobre a escolarização e seu significado social, buscaremos reconhecer a organização de racionalidades abrangentes, passíveis de se apresentarem como eixos discursivos por meio dos quais o problema posto tornava-se inteligível para aquela dada época. O que nos interessa efetivamente é depreender matrizes de pensamento que, de alguma forma, perfilhassem um modo de interpretação da questão educativa partilhado pelos contemporâneos.

Como sugere Rosanvallon, tal abordagem possibilitaria a identificação de 'nós históricos', ou sistemas de representações simbólicas capazes de revelar a cultura política (e especificamente o lugar tomado pelos projetos de escolarização nas práticas efetivadas por tal cultura política) do período estudado ${ }^{25}$. Estaríamos, a partir daqui, dando início a um estudo mais abrangente acerca das interfaces e mesmo intersecções entre tais representações e as práticas diretamente implementadas, no âmbito da história da educação portuguesa. Para isso, entretanto, deveremos posteriormente nos debruçar sobre a questão do cotidiano dessa escola.

Tendo em vista reconstituir tal panorama das idéias educativas expostas, quer pela intelectualidade, quer pelos atores da política, voltemo-nos mais uma vez ao olhar estrangeirado... Agora, com Mouzinho de Albuquerque, poder-se-á rastrear algo do legado deixado pelo século XVIII ao XIX no que diz respeito à apreciação do tema da escola. Em sua obra Educadores Portugueses, de fins do século passado, Ferreira Deusdado relata da seguinte maneira a obra póstuma de Mouzinho de Albuquerque:

\footnotetext{
${ }^{25}$ Pierre ROSANVALLON, em sua reflexão sobre o que intitula história conceitual do político_definirá seu objeto da seguinte maneira: "O objeto da história conceitual do político é a compreensão da formação $e$ evolução das racionalidades políticas, ou seja, dos sistemas de representações que comandam a maneira pela qual uma época, um país ou grupos sociais conduzem sua ação, encaram seu futuro. Partindo da idéia que estas representações não são uma globalização exterior à consciência dos atores - como o são por exemplo as mentalidades - mas que elas resultam, ao contrário, do trabalho permanente de reflexão da sociedade sobre ela mesma, tem por objetivo: 1) fazer a história da maneira pela qual uma época, um país ou grupos sociais procuram construir as respostas àquilo que percebem mais ou menos confusamente como um problema, e 2) fazer a história do trabalho realizado pela interação permanente entre a realidade e sua representação definindo os campos histórico-problemáticos." (Pierre ROSANVALLON, Para uma história conceitual do político, p. 16). Nosso ofício aqui não será evidentemente efetuar uma história do campo político, mas - por analogia - aproveitar a sugestão da abordagem para talvez proceder a uma história conceitual das idéias educativas, tendo em vista a apreensão de alguns campos de força do discurso pedagógico, a partir dessa perspectiva de inventariar o discurso pedagógico a partir do território da cultura, das mentalidades.
} 


\begin{abstract}
"Mouzinho de Albuquerque dirigia de Paris em 1828 uma carta de 46 páginas intitulada: Idéias sobre o estabelecimento da instrução pública, dedicadas à Nação portuguesa. Este opúsculo é inspirado no movimento pedagógico da Convenção francesa. Quer o ensino público gratuito, o professorado inamovível. É nos seus contornos um plano completo de organização pedagógica, dividindo o ensino em quatro categorias." 26
\end{abstract}

Luís da Silva Mousinho de Albuquerque era um bacharel em Medicina que, havendo estudado na França, fazia parte de uma agremiação intelectual de estudo e de reflexão acerca de Portugal. Em 1823, Albuquerque, ainda durante a fase miguelista, fôra nomeado como provedor da Casa da Moeda, que - como destaca Rômulo de Carvalho - era uma "instituição que possuía laboratórios de Física e de Química e cujo provedor tinha a obrigação, por lei, de reger aulas daquelas matérias. Mouzinho de Albuquerque, que de há muito se interessava pela ciência e estava habilitado para o desempenho daquele cargo, exerceu-o com proficiência excepcional. As suas aulas eram frequentadas não só por alunos matriculados mas por diversas pessoas que a elas queriam assistir."27

Em 1823, Mouzinho redigiria e publicaria aquele seu projeto de reforma da instrução pública - ao qual Ferreira-Deusdado acima fazia alusão - apresentando o direito dos povos ao ensino como alicerce diametralmente correspondente ao dever dos governos em assegurar ao mesmo povo a educação. Outros trabalhos posteriormente reiterariam o vínculo teórico - que era, como vimos, remarcado por Ferreira-Deusdado - entre os escritos de Mouzinho de Albuquerque e os debates da Convenção francesa.

É a obra de Luís Albuquerque que buscará apreender (aprofundando-se neste que considera "o primeiro plano completo que em Portugal conhecemos para o estabelecimento de um ensino liberal" ${ }^{28}$ ) a reforma preconizada, mediante uma certa filiação a todo um conjunto de referenciais históricos com os quais o próprio autor dialogava; e que certamente não se teriam reduzido ao trabalho da Convenção, mas lhe seriam anteriores, reportando-se à Constituinte francesa de $1791^{29}$.

O reformador português decerto conhecia as várias etapas da Revolução Francesa em relação à pedagogia. O já citado trabalho de Torgal e Vargues estabelece aproximações que ajudam a situar o plano de Mouzinho de Albuquerque em relação a seus antecessores franceses $^{30}$. Se inequivocamente o suporte teórico desdobrava-se da França revolucionária, acreditamos que, de fato, a matriz daquele plano teria sido fundamentalmente o Rapport de Condorcet, seja pela divisão dos quatro degraus de ensino, seja pela própria fundamentação teórica, subjacente ao discurso de Mouzinho de Albuquerque.

\footnotetext{
${ }^{26}$ M. A. FERREIRA-DEUSDADO, Educadores portugueses, p.405.

${ }^{27}$ Rómulo de CARVALHO, História do ensino em Portugal, p. 537.

${ }^{28}$ Luís ALBUQUERQUE, Notas para a História do ensino em Portugal, p.82.

29 "Não é difícil encontrar a fonte onde Mousinho de Albuquerque se inspirou para, com toda a segurança, propor aquela solução inteiramente em correspondência com as realidades, pelo menos teóricas, criadas pelo regime liberal. Quem percorrer os diplomas franceses respeitantes à instrução pública e subscritos pelos poderes legislativos saídos da Revolução de 1789, encontrará decretadas medidas análogas às do projeto de Mousinho para a resolução de problemas semelhantes àqueles que ele procurava solucionar. Essas medidas ofereciam até uma vantagem no plano do reformador português: o de se apresentarem neste com uma unidade que não podiam ter alcançado naquela legislação que foi construída ao longo de vários anos por diversos homens" (Luís ALBUQUERQUE, Notas para a história do ensino em Portugal, p. 82).

${ }^{30}$ Luís Reis TORGAL e Isabel Nobre VARGUES, op. cit., p. 335-336. No parecer desses comentaristas, “ $a$ organização francesa da instrução é extremamente complexa e sofreu transformações constantes. Mouzinho, embora baseando-se em algumas das suas realidades e apesar de seu caráter estrangeirado, não deixou de pensar (talvez) num plano original, mais adaptado à realidade portuguesa. Só, todavia, através de um estudo comparativo entre o seu plano e a realidade escolar francesa se poderá chegar a uma conclusão segura” (Id. Ibid., p. 336) .
} 
Aliás, acerca do impacto histórico e simbólico que o imaginário a propósito da Revolução Francesa traria para Portugal, Maria Manuela Bastos Tavares Ribeiro assinala os inúmeros semblantes que o motivo revolucionário passaria a adquirir:

\begin{abstract}
"Poderoso mito, sem dúvida o maior da primeira metade do século XIX, alimentado, naturalmente, pela visão romântica da história. De fato, o século XIX não cessou de refazer a Revolução Francesa. Não exatamente a Revolução dos fins do século XVIII, mas sim o movimento revolucionário iniciado em 1789 - promessa de igualdade - logo, uma empresa interminável, sem limites de tempo e de espaço."
\end{abstract}

Estavam postas na dimensão subjetiva da intelectualidade portuguesa todas as condições para que a apreciação do evento revolucionário em França fosse efetuada antes enquanto uma mitologia de fundação do Estado do que pela clivagem eminentemente histórica de sua ocorrência. Havia, nesse gesto da apropriação do que, ao fim e ao cabo, ocorrera lá fora, certo desejo de universalidade, desejo este que era pontuado como se de uma vocação se tratasse. Explicitamente tributário do movimento da Ilustração, Mouzinho de Albuquerque dirige-se aos deputados, apresentando-lhes o que acredita ser a reforma das instituições e consequente prosperidade nacional. No parecer do relator, a própria moral pública, entrelaçada à indústria e à agricultura, exigia com urgência o derramamento das "luzes", irradiadas à generalidade dos cidadãos. A instrução pública seria, pois, o dispositivo capaz de conferir legitimidade aos alicerces do liberalismo arquitetado. A pátria regenerada teria, no pilar da educação nacional, um tributo e uma promessa... Dívida do governo e direito dos povos, a universalização da escola derivaria da própria acepção de bem público, o qual, por sua vez, coincidiria, em última instância, com a felicidade e a plena realização dos talentos de que é composta a sociedade. Tal empreendimento, por si só, traria prosperidade à nação, regenerando-a dos vícios que eventualmente houvessem contribuído para certa decadência:

\begin{abstract}
"A aptidão que um cidadão adquire em um ramo qualquer de conhecimentos, se por uma parte é riqueza individual, é por outra uma riqueza pública que redunda em benefícios de todos os membros da sociedade. Com a parte do imposto destinada à instrução, cada cidadão paga o direito que adquire de procurar os conhecimentos nos estabelecimentos públicos e os bens que lhe resultam da existência de homens hábeis nos diversos ramos. Com as suas fadigas, aplicação e trabalho, o cidadão que se habilitou em um ramo paga a riqueza privada que adquiriu. Daqui concluímos que os estabelecimentos de instrução pública devem ser inteiramente gratuitos para todos os portugueses." 32
\end{abstract}

O pressuposto do autor, nitidamente tributário da Ilustração, reside na dimensão eminentemente pública das aptidões individuais. À sociedade caberia transformar em benefício coletivo quaisquer riquezas particulares. Ora, haveria, para tanto, uma via de mão dupla a ser trilhada no caso da instrução: o Estado despende os recursos necessários para a educação popular, tendo em vista, a seu tempo, obter o retorno de tal investimento, materializado na transfiguração do potencial de indivíduos bem formados em expectativa de melhoramento ou prosperidade do País, tanto sob o aspecto econômico quanto na dimensão política.

\footnotetext{
31 Maria Manuela Bastos Tavares RIBEIRO, A memória da Revolução Francesa nos movimentos revolucionários de 1848 em Portugal e no Brasil, In: Revista de história das idéias - volume 11, p. 357.

${ }^{32}$ Luís da Silva MOUZINHO DE ALBUQUERQUE, Ideas sobre o estabelecimento da instrucção publica, dedicadas á nação portugueza e offerecidas a seus representantes por..., p.11-12.
} 
Há no relato evidente preocupação com a profissionalização do magistério em termos de salários, de dedicação exclusiva a esse ofício e de liberdade de cátedra, dado que se acredita que os professores deveriam manter independência perante as diferentes autoridades políticas. Tal preocupação revelar-se-ia também no concernente aos critérios de seleção ou ingresso na carreira, mediante a priorização da notória e comprovada aptidão para a função docente. O professor público, no parecer de Mouzinho de Albuquerque, deveria ser inamovível, salvo casos de crime comprovado ou invalidez. ${ }^{33}$

Acerca da matriz francesa sobre a qual os estudiosos concordam estar assente esse projeto, caberá um aprofundamento no sentido de verificar comparativamente (como sugerem - recorde-se - Torgal e Vargues à pagina 336 do já citado ensaio) quais foram os planos ou autores que de fato embasaram a proposta de Mouzinho de Albuquerque, fornecendo suporte teórico às iniciativas pedagógicas por ele sinalizadas. Diante disso, tudo indica de fato que o texto de Albuquerque se remete à apropriação por parte do autor de inúmeras estratégias de ação preconizadas por Condorcet, no Rapport que enviara à Assembléia Legislativa francesa em 1792, como representante que era na Comissão de Instrução Pública. Indubitavelmente, pelas semelhanças textuais, poderíamos, desde logo, afirmar que Albuquerque leu Condorcet. Desde a proposta de quatro níveis de ensino - escolas primárias, secundárias, liceus e academias- até a sugestão de 'conselhos diretores da instrução', há alguma semelhança entre o texto de Mouzinho e os escritos de Condorcet. Para este, no topo da estrutura educativa, haveria uma 'Sociedade Nacional das Ciências e das Artes', que o reformador português denominaria 'Conselho de Aperfeiçoamento da Instrução Pública'. Abarcando também o tema dos compêndios escolares, a própria argumentação tecida parece dialogar com aquele referencial francês. Seja, portanto, pelos assuntos abordados, seja pela orientação analítica da abordagem, visualiza-se, neste projeto, o código das Luzes filtrado pelo cariz da Revolução de 1789.

Em seu trabalho sobre Intelectuais portugueses na primeira metade de oitocentos, Maria de Lourdes Costa Lima dos Santos ressalta o papel desempenhado pelo "exílio, lugar de aprendizagem", na ocasião. Fundamentalmente o período que se segue à reação conservadora miguelista (que a partir já de 1828 virá a empreender processo repressivo para com os partidários das idéias liberais) conviverá com a emigração e, através dela, por paradoxal que pareça, com a infiltração de idéias novas trazidas pelos portugueses radicados no estrangeiro ${ }^{34}$. Através da intensificação de práticas editoriais, de atividades de tradução e do exercício mais efetivo do jornalismo, as idéias ganhavam nova dinâmica, tanto no que tange à sua produção e/ou "apropriação" 35 quanto no que concerne à sua circulação. Por meio da comunicação que os dito estrangeirados mantinham entre si e do círculo que estabeleciam em termos de contatos internacionais, essa elite de pensadores do XIX português dá a ver aos

\footnotetext{
${ }^{33}$ Luís Albuquerque, ao discorrer sobre o tema, declara: "Mouzinho de Albuquerque procurava, deste modo, pôr termo ao 'certificado de informação moral', meio arbitrário de minimizar o mérito dos que, tendo embora prestado provas de bom nível sobre a sua capacidade intelectual e a sua preparação científica, tinham caído na desconfiança do conselho escolar por razões estranhas a esses merecimentos; mas o sistema, que fôra instituído no reinado de D. Maria I, pouco depois da queda de Pombal, havia ainda de ser aplicado legalmente durante mais alguns anos" (Luís ALBUQUERQUE, op. cit., p.89).

${ }^{34}$ Sobre isso ressalta a referida investigadora: "o acesso a obras de difícil aquisição e consulta em Portugal podia agora desempenhar um importante papel na formação dos intelectuais emigrados que passavam grande parte do tempo livre nas bibliotecas e gabinetes de leitura, estudando a história e a organização civil e política dos países de asilo. A economia política e a oratória parlamentar contar-se-iam entre os principais pólos de atração” (M. L. C. L. SANTOS, Intelectuais portugueses na primeira metade de oitocentos, p. 113).

35 A idéia de "apropriação" surge aqui na acepção que lhe fornecem os trabalhos recentes de De Certeau e fundamentalmente de Roger Chartier, que se valem do termo para designar as reinvenções de sentido e criação de novos significados por parte do leitor à obra lida. Chartier chega a dizer que existem três níveis de universos simbolicamente diferenciados: o mundo do texto, a materialidade do impresso e o território da leitura. Formarse-iam assim 'comunidades de leitores' de acordo com modalidades partilhadas do ato de ler. No caso em pauta, estamos diante de uma específica forma de encarar a pedagogia ilustrada. Mouzinho, pelas leituras de que dispôs, recriou a ilustração, a seu modo, pelos instrumentais teóricos e valorativos de que dispunha.
} 
conterrâneos as grandes questões intelectuais de seu tempo, permitindo, mediante a irradiação escrita dessas idéias inovadoras, certa publicização e mesmo vulgarização dos grandes quadros teóricos e conceituais que vinham com o novo século ${ }^{36}$. Como sugere Santos, ocorrerá um "alargamento do capital cultural e social dos emigrados que havia de ter importantes repercussões sobre o evoluir da intelligentsia liberal no segundo momento, quer no que respeita à sua estrutura (...) quer no que respeita ao seu papel na renovação da realidade nacional" 37 .

A propósito do espraiar das idéias pedagógicas no período do confronto entre liberais e miguelistas e fundamentalmente a partir do setembrismo, poder-se-á anotar a proeminência adquirida pelo tema da educação, até como dispositivo regenerador da nação e nacionalidade em crise, estratégia capaz de 'refundar' - para utilizar um termo caro a Fernando Catroga - o sentimento e a alma do país. Nessas novas representações acerca do tema da escola, destacam-se folhetos, impressos, brochuras e almanaques, de modo a que se pudesse dar a ver o tema da pedagogia para um público mais ampliado.

\title{
CARVALHO E O PAPEL DA EDUCAÇÃO DOMÉSTICA NA CODIFICAÇÃO DE REGRAS MORAIS UNIFORMES
}

Manoel Pedro Henrique de Carvalho põe a público, através de uma tipografia lisboeta, no ano de 1834, uma breve brochura intitulada Memória sobre a maneira de dirigir a educação nacional, segundo a forma de cada governo e sobre o modo de firmar a moral da nação. O próprio título já se revela elucidativo do intento. Naquele ano de expatriação de D. Miguel, o mesmo ano em que morre D. Pedro e principia o reinado de Maria II, Carvalho parte da suposição de que a existência de boas leis seria condição insuficiente para a pátria no caso de não haver instrumentos capazes de garantir seu efetivo cumprimento. A instrução liberal, como estratégia de âmbito público a ser implementada, deveria, no parecer do autor, transformar-se em bandeira a ser abraçada por todos os amigos da causa constitucional. A instrução popular, reconhecida aqui como ofício precípuo dos governos, faria por distinguir, inclusive, a forma de administração dos povos. Acerca disso, ressalta Carvalho:

\begin{abstract}
"Nós recebemos três ordens de educação: dos parentes, dos mestres e do mundo. Para poder ser úteis, devem dirigir-se todas no mesmo sentido; sendo muito diferentes em cada gênero de governo. Nos Governos Despóticos, logo habituam os filhos ao servilismo, à cega obediência, à resignação passiva às vontades dos Déspotas e dos seus Ministros. Nos Governos Monárquicos, pelo menos, os cortesãos têm uma educação sofrível, alguma delicadeza e bom gosto, sendo a
\end{abstract}

\footnotetext{
${ }^{36}$ Sobre os jornais do exílio, como estratégia privilegiada de difusão de informações, e sobre o intercâmbio cultural propiciado pela mesma prática, diz-nos aquela autora: "Redatores e leitores exilados estabeleciam um ativo vai-e-vem informativo, colaborando os últimos frequentemente através do envio de artigos, poemas, notícias e cartas. Esta colaboração fazia-se inclusivamente entre os exilados que se encontravam em países diferentes (...) Mas, já então, estes mesmos jornais eram também um espaço onde emergiam os aspectos conflituais que o relacionamento entre os exilados comportava e que as polêmicas entre jornais de diferentes orientações políticas documentavam (...) Através dos jornais do exílio estabeleciam-se também relações com os estrangeiros que não se traduziam apenas unilateralmente pela difusão de notícias sobre Portugal mas também por um considerável intercâmbio cultural. Os redatores portugueses publicavam escritos em jornais e revistas estrangeiras e extraíam delas artigos para os seus próprios jornais" (M.L.C.L. SANTOS, Intelectuais portugueses..., p. 109-110).

${ }^{37}$ Maria de Lourdes Costa Lima dos SANTOS , Intelectuais portugueses na primeira metade de oitocentos, p. 117 .
} 
vaidade a primeira mola de tudo. Nos Governos Republicanos, são as virtudes, o amor da pátria, quem lhe forma o principal caráter, segundo afirma Montesquieu." 38

Radicando, assim, a diversidade de modelos pedagógicos na distinção entre as diferentes formas de governo, o autor acentua a primazia do direito paterno sobre a formação das crianças, destacando com isso que não se deveria enviar ninguém à escola contra a vontade dos pais. Haveria que se nortear o ensino mediante a harmonia posta em uma aliança tríplice: pais, mestres, mundo. Para tanto, algumas medidas são sugeridas, tais como a qualificação dos mestres para o ofício que desempenharão, a seleção de livros elementares adequados para a formação das novas gerações de escolares e, fundamentalmente, o fortalecimento de um sistema de estabelecimentos públicos de educação, a serem custeados e mantidos pelo Estado.

A preocupação com a formulação doutrinária de um substrato teórico de educação liberal ancorava-se fundamentalmente na expectativa de engendrar mecanismos capazes de consolidar um regime representativo - ainda que monárquico - alicerçado sobre uma constituição. Nesse caso, haveria de se preencher a lacuna deixada naquele intervalo entre o regime despótico que se pretendia deposto e o universo da liberdade que, entretanto, não havia ainda conseguido ultrapassar a letra de uma cambaleante e formal legislação. Nos termos do texto:

\begin{abstract}
"Para que as leis possam ser amadas e respeitadas pelos cidadãos, é nacessário que eles as possam apreciar pelos bens que elas lhe procurem, devendo ao mesmo tempo ser educados no sentido e no gênio das instituições dominantes. Sem dúvida, sem a Nação ter uma instrução liberal, a mesma liberdade jamais sairá de uma apoucada infância, preste a expirar a cada momento, os homens continuarão a ser dengues de ridículos fantasmas enderçados por brilhantes teorias, que iludem os sentidos com a esperança de lisongeiros porvirs, ou então continuarão a pronunciar este nome augusto ( a liberdade ) para lhe servir de antimural às suas péssimas e depravadas inclinações." 39
\end{abstract}

$\mathrm{O}$ autor ressalta as marcas prioritárias do homem em convívio com estruturas de poder: por um lado, o medo seria o grande móvel; na outra margem, a esperança. O monarca absolutista lida fundamentalmente com a inculcação do medo, desejando, pela mesma lógica, a obediência passiva. O governo representativo, por seu turno, protege e objetiva o conhecimento verdadeiro, lutando contra possíveis obstáculos à racionalidade, expressos mediante atitudes amedrontadas, preconceituosas, supersticiosas. Politicamente, isso implicaria a formação e esclarecimento da opinião pública, que seria por si esperança e fonte iluminista de aperfeiçoamento do percurso civilizatório pela via da irradiação da cultura letrada. Além disso, desejava-se aqui, até certo ponto, direcionar instrução e forma de governo para proceder ao reerguimento da nação outrora gloriosa e naquela ocasião reconhecidamente decadente: à grandeza material e geográfica pela anexação dos territórios conquistados, havia que se acrescentar a força de domínio simbólico e espiritual, a ser adquirida fundamentalmente pela via da instrução:

"Ele [ governo representativo ] deve, pois, por todos os meios que estiverem à sua disposição, animar os progressos das luzes e muito principalmente sua difusão por todas as classes da Nação: porquanto ele ainda tem maior necessidade dela do que do seu muito grande aumento. Estando essencialmente ligado com a igualdade, com a sã justiça e com a boa moral, deve, sem nunca parar, trabalhar por aniquilar a mais fatal de todas as desigualdades, a qual encadeia todas as mais, vindo a ser a dos talentos e do saber, nas diferentes camadas da sociedade. Deverá ter o maior

\footnotetext{
${ }^{38}$ M. P. Henrique de CARVALHO, Memoria sobre a maneira de dirigir a educação nacional..., p.5.

${ }^{39}$ Id. Ibid., p.4.
} 
cuidado em garantir as classes inferiores da Nação dos vícios, da miséria e da ignorância, e as superiores da insolência e do falso saber das primeiras: devendo forcejar por nivelar estas com as classes médias, onde naturalmente domina o amor da ordem, da justiça, da razão, do trabalho, pois que elas pela sua posição e interesse se afastam de tudo quanto seja excessivo."40

No parecer do autor, a vontade do governo seria fator primordial para dar sustentação a uma política educacional capaz de reerguer o país da condição decadentista. Remarcando a vocação liberal de D. Pedro IV, que legitimamente outorgara a Carta Constitucional, considera-se que tal Constituição conteria os destinos do então qualificado "moribundo Portugal" ${ }^{41}$. O autor credita, pois, a D. Pedro a restituição da sã justiça, mediante o rompimento do tempo de tirania que tomara conta, no período miguelista, de seu "povo dócil e social" ${ }^{12}$. Não se pretende, pela trilha ilustrada, alterar tal docilidade. A ordenação e o equilíbrio social seriam, pelo contrário, mecanismos essenciais de retomada da rota do desenvolvimento português. Ao recolocar Portugal naquilo que se supunha ser o caminho de seu caráter nacional, reputa-se a D. Pedro a possibilidade de dar cabo dos males, afugentá-los, reconstruindo trilhas de ventura que já haviam caracterizado a nacionalidade. A pista da regeneração é nítida no esquadro da felicidade política projetada:

\begin{abstract}
"Sêde Legislador deste povo infeliz, sêde o restaurador de uma Nação outrora famosa e ilustre, sêde o reformador dos seus costumes e o promotor da sua felicidade. Reprimi a tirania da força e do crédito, a rapacidade dos empregados públicos, as cabalas e intrigas do fanatismo, os excessos da opulência, as loucuras do luxo consumidor, as impudências do deboche. Supri a licença à bementendida liberdade, tão necessária e útil aos governos como aos governados. Restitui a segurança a todo o cidadão, ponde os pobres a coberto das violências dos ricos. Os pobres são súditos igualmente, sendo quem trabalha para vós e para todos, tendo muito maior direito à vossa proteção; deste modo, ó Príncipe justo, não consintais que ninguém impunemente possa atropelar um súdito da Rainha. Que o vosso semblante indignado afugente o perverso cortesão, o lisongeiro odioso, o corrompido servidor, o interessado delator, o mal procedido desprezado, o gastador inconsiderado, o insensato que se arruina com loucas vaidades, finalmente os que retêm o salário do artista laborioso. Puni o crime com a lei, seja quem for que o pratique, mostrai desprezo aos vícios, recompensai as virtudes cívicas, o mérito, os talentos, por este modo sereis verdadeiramente grande e respeitado, Portugal venturoso, e vosso nome admirado até a mais remota posteridade. $" 43$
\end{abstract}

\footnotetext{
${ }^{40}$ M. P. Henrique de CARVALHO, Memoria sobre a maneira de dirigir a educação nacional..., p. 14-15. Era bastante comum, até mais ou menos meados do século, a aliança entre a ociosidade e o que os contemporâneos entendiam como "incontinência pública". Há alguns livretos - como o de Theolinda Amélia Christina Leça da Veiga, intitulado Elementos de instrucção moral para uzo da mocidade portugueza dedicados a sua alteza, a Senhora Infanta D. Maria Ana - que salientavam o papel do que compreendiam ser instrução moral para o equacionamento de tal problema. Dizia em 1857 a referida autora: "A ociosidade produz a incontinência; e estes dois males são sobejos para envenenar e destruir uma nação. Onde eles reinam, não há amor da pátria nem do soberano; porque este amor é a primeira virtude social, e aqueles dois vícios desconhecem toda a sorte de virtudes. Nós devemos à sociedade (...) o emprego de nossas faculdades e de nossos talentos: se os outros nada fizessem por nós, como poderíamos subsistir? Será justo que nos aproveitemos de seus serviços e lhes não façamos alguns? A ociosidade e a moleza, que tornam o homem inútil, e algumas vezes a cargo dos seus semelhantes, são um perene manancial de injustiça. $O$ mal é sensível a respeito do povo: a aversão para o trabalho, único meio de subsistência que resta àqueles cuja fortuna é limitada, bem depressa os reduz à necessidade, ou de mendigar vergonhosamente, ou de procurar no crime os recursos que poderiam encontrar em uma ocupação honesta. (...) Um pai de famílias pode, por sua indolência, ser a causa da desgraça a toda a sua posteridade: um cidadão, voluntariamente inútil à sua pátria, é um zangão que injustamente se aproveita do trabalho das abelhas. (...) A ociosidade se pune a si mesma, pelo fastio em que nos prolonga: quanto menos o homem se ocupa, mais a sua imaginação trabalha em inventar divertimentos e quimeras." (op. cit., p. 104-5)

${ }^{41}$ Id. Ibid., p. 15.

${ }^{42}$ M. P. Henrique de CARVALHO, op. cit., p. 16.

${ }^{43}$ Id. Ibid. ,p. 16-17.
} 
Convicto de que a ação de leis repressivas agiria enquanto obstáculo de práticas criminosas, o autor atenta para o impulso, quase instintivo, que muitas vezes o ser humano apresenta para cometer o mal. Tal alerta do autor desloca o eixo de sua análise acerca dos dispositivos de coerção para centrar-se sobre estratégias de obtenção de consenso social, de táticas persuasivas; em duas palavras: educação moral. Esta é caracterizada como atributo humano, capaz de ser aperfeiçoada em consonância com os trilhos da própria civilização. Pressupondo a acepção de cientificidade na ação moral, Carvalho entende que, composta enquanto tal, "do resultado das nossas experiências e dos nossos discursos e reflexões" "44, será aperfeiçoada pelo percurso da experiência de vida e, em outra dimensão, pelo caminho percorrido pela espécie. Foge-se, de qualquer modo, de definições correntes à época acerca do caráter inato das assertivas morais:

\begin{abstract}
“Ainda avançarei mais: a moral, não sendo outra coisa mais do que o conhecimento dos efeitos das nossas inclinações e dos nossos sentimentos sobre a nossa felicidade, não é senão da aplicação desta geração de sentimentos donde decorrem as idéias. Os seus progressos jamais deixarão de antecipar os da metafísica, e esta, como a razão e a experiência o tem mostrado, está sempre subordinada aos da física, de quem não é outra coisa mais do que uma fração. Segue-se que, de todas as ciências, a moral é a última que se aperfeiçoa, e que menos pode avançar, sendo aquela em que as opiniões são mais contrárias umas às outras. Também, se atendermos a isto, os nossos princípios morais estão muito distantes de ser uniformes, sendo muito diversas as maneiras de ver, de sentir e de pensar nos indivíduos; o que, sem o percebermos, dá a cada homem o seu sistema moral que lhes é próprio, ou sendo muito antes um confuso ajuntamento de idéias sem ligação, que hoje não pode merecer o nome de sistema, mas supre o lugar dele." 45
\end{abstract}

Daí surgia a necessidade social de obtenção de regras morais uniformes, válidas para todos, até como normatização da harmonia do conjunto da coletividade. A unificação dos referenciais de conduta ética apresentar-se-ia como exigência de regulação política. Aqui principia, na argumentação de Carvalho, a defesa da expansão e multiplicação dos preceitos pedagógicos, ou, em outras palavras, do "ensino direto", de modo a edificar, mediante esse empreendimento, uma sólida e adequada perspectiva moral. Reconhecendo a carência de "tempo e vontade" por parte dos conterrâneos quanto ao tema da instrução, o autor vê, ainda, outras limitações para o indivíduo comum enveredar pela trilha da ciência. Em seu parecer, apenas os legisladores efetivamente precisariam de conhecimentos mais aprofundados, posto que lidam com matéria que exige rigor e exatidão. A maior parte da sociedade, pelo contrário, orienta suas ações por combinação de observações e experiências. Daí talvez a força do exemplo a ser dado por governos e legisladores, caracterizados como mestres do gênero humano, responsáveis, enquanto tal, pela difusão da educação moral, que, neste discurso, não se confunde, em hipótese alguma, com a universalização das primeiras letras. Por tal raciocínio, dirá o autor:

“É preciso não perder de vista que nós só temos três ordens de necessidades a satisfazer: as físicas, as de cativar a benevolência dos outros e a nossa própria, sentindo-nos alegres e satisfeitos. Há três coisas a evitar para podermos ser felizes: a punição, a infâmia e os remorsos. Somente existem estes três motivos para conformar estas ações aos preceitos da moral quando é conhecida, para nos dirigirmos da maneira mais virtuosa e útil aos nossos semelhantes. Ora, destes três motivos, o último é o que o ensino direto pode dilatar e fortificar. Os dois primeiros, sendo incomparavelmente muito mais vigorosos para a maior parte dos homens, podem ser favorecidos ou anulados, ou mesmo contrariados por todas as instituições sociais, segundo elas estiverem

\footnotetext{
${ }^{44}$ Id. Ibid., p.35.

${ }^{45}$ M. P. H. CARVALHO,Memoria..., p.36-37.
} 
arranjadas em perfeitas, boas ou más. Então já vemos que o ensino direto, ainda o melhor, não pode dar outro resultado que não seja entrar em um diminuto número de cabeças as verdades abstratas da sã moral e que, por consequência, bem longe de ser o único ou o principal apoio, a sua utilidade limita-se a instigar o sucesso em tais averiguações deste gênero, aperfeiçoando a teoria desta ciência, mas nunca podendo levar-se até espalhar e propagar a sua prática. O ensino dado a homens já feitos constituirá em uma nação alguns moralistas especulativos e mesmo eruditos; mas nunca será isto quem deva imediatamente formar a massa mais interessante e virtuosa da nação."46

Se a instrução, por si só, poderia, aos olhos de Carvalho, trazer felicidade pessoal, ela, entretanto, não se mostraria capaz de satisfazer as necessidades moralizantes que já então eram colocadas como tarefa também da escola. A escola, organizada como estava no caso português desse princípio do XIX, não se revelara eficaz nem quanto à transmissão das suas competências específicas, nem quanto ao pretendido efeito de fortalecimento de algumas condutas e crenças desejadas pelos grupos sociais dominantes. Com essa impressão, ao defender a secularização do ensino, bem como a crítica velada à prioridade do ensino superior, Carvalho se distancia de qualquer projeto de generalização do ensino para camadas mais amplas da população. As habilidades da leitura e da escrita eram, em seu entender, perigosas enquanto não se houvesse realizado um verdadeiro ato de conversão coletiva. Por ser assim, à "profusão de lições", prefere-se sugerir a necessária orientação educacional a ser ministrada pelos pais, no ambiente doméstico familiar; como se os próprios mestres, frutos de um regime corrompido, ameaçassem a teia social, enquanto sujeitos naturalmente propensos à corrupção das gerações mais jovens. Parece haver o temor da ação combinada de uma pedagogia cívica que tornasse a infância refém da corporação dos professores. ${ }^{47} \mathrm{O}$ descrédito com que Carvalho visualiza a educação estendida a camadas majoritárias da população passa pelo silêncio com que aborda o tema do povo. Derivada do exemplo, a moral prescinde da escolarização e o que no título se lê como "educação nacional" reduz-se na verdade à pauta de diretrizes públicas para uma pedagogia política desenvolvida pelos governantes. Educação nacional, sim, para modelar formas e fôrmas de governo; escola... ainda não. Para justificar essa sua convicção dirá o autor sobre a educação de rapazes:

\begin{abstract}
"Ela será completamente perfeita quando seus pais tiverem bons hábitos e quando estes forem moldados por justas e sábias instituições. Ela será sempre má enquanto a Nação estiver entregue a erros, a vícios, a prejuízos, a superstições, etc.. Eu unicamente apelo para a experiência de cada indivíduo. Será porventura que ele tem ouvido nos sermões, nas escolas, nos teatros, onde se formaram os sentimentos e as inclinações de sua infância ? Não terá isto sido muito primeiro em tudo quanto o cingiu, em quanto viu, sentiu a todos os momentos, quando ainda não cogitavam de o doutrinar ? Se os pais estiverem ensopados em princípios errados, e os mestres os tiverem, o que ordinariamente sucede, eles dar-lhe-ão um novo vigor, ou os combaterão; neste caso não serão ouvidos, nem seguidos, tornando-se completamente inúteis. Eu tive muita razão quando avancei em dizer que a instrução moral da mocidade não podia ser senão a consequência imediata da dos pais, ou dos outros parentes que estivessem com ela em íntima relação, seja ela de que natureza
\end{abstract}

\footnotetext{
${ }^{46}$ Id. Ibid., p.38-39.

${ }^{47}$ Sobre a educação das classes menos favorecidas, que compreenderiam, segundo o autor, 9/10 da sociedade, declara o texto: “ O menor número de impostos possível à Nação dará maior quantidade de homens que saibam ler e escrever do que seriam capazes de dar legiões de mestres de primeiras letras (...) Não é porque eu pretenda duvidar do merecimento, dos esforços e dos muitos serviços que têm feito muitas sociedades científicas e de ensino (...) Mas eu investigo muito mais estes preciosos estabelecimentos como sendo consequências da boa ordem social e como sendo muito infrutuosos sem ela para poder criar a boa moral de uma nação” ( M. P. H. CARVALHO, Memorias sobre a maneira..., p. 49-50). Depreende-se do excerto acima transcrito a relutância do autor perante os desconhecidos efeitos da escola no concernente à moralização pública. Sem o esforço governamental no sentido de disciplinar a boa ordem da sociedade, poderia ser até perigoso estender as escolas para além do limite da vista vigilante...
} 
for, de repente será reformada ou destruída pelas circunstâncias que os cingir, e pelas instituições que sobre eles pesar, no lugar em que firmem na sociedade a sua representação." 48

Esta interpretação acerca do tema da escola não é, entretanto, partilhada por inúmeros outros sujeitos políticos da época, que, procurando ocupar o lugar progressista na vida pública, compreendiam a educação, no lastro de um iluminismo engajado, como alavanca prioritária para se erguer o futuro, através da concomitante superação das insígnias culturais da decadência portuguesa. Tal orientação supunha como alicerce a construção social de uma escola pública e dirigida pelo Estado; escola capaz de ser a alavanca da cidadania e da consolidação dos desejos e dos anseios por transformações. Indiscutivelmente o debate estava assim colocado entre os partidários e os opositores de uma escolarização de primeiras letras estendida a todos, assumida, enquanto tal, como questão do Estado no nível das políticas públicas; uma escola para preparar os homens para a vida civil.

\section{A DIFUSÃo ESCOLAR COMO CHAVE PARA REGENERAÇÃo E SUPERAÇÃO DA DECADÊNCIA PÁTRIA}

O texto Reflexões sobre educação pública, publicado em Lisboa, no ano de 1835, como brochura da tipografia de Filippe Nery, e assinado por alguém que se vale das abreviaturas J. A. B. (de modo a ocultar a própria identidade), apresentará parecer bastante distinto daquele exarado por Carvalho ${ }^{49}$. Ao contrário deste último, J. A. B. revelar-se-á convencido da capacidade que todo homem tem de aprender. $\mathrm{O}$ debate pedagógico de Portugal do princípio do século XIX retoma a discussão que os precursores desse olhar iluminista - no caso português Ribeiro Sanches e Verney - já haviam levantado no correr dos setecentos $^{50}$. Acreditar no poder social da educação corresponderia, sob esse ângulo, a efetuar uma aposta nas expectativas de aprimoramento humano pela desenvolução da espécie. Desde logo, J. A. B. traz, estampado na epígrafe, o tom de denúncia e de convicção: "ignorance is a vacuity, in which the soul sits motionless, \& torpid for want of attraction..."

$\mathrm{Na}$ verdade, professando sua irredutível crença no liberalismo, J. A. B. solicita na introdução de seu texto a indulgência de seus concidadãos para com esse seu atrevido gesto de refletir e comentar sobre a educação pública - em suas palavras, "matéria transcendente" ocupando com isso um lugar do escrito que se deveria preencher pela voz de mestres sábios; faria isso, porém, a partir de sua experiência no magistério, aliada ao amor pela pátria. No parecer do autor, a conquista política do liberalismo deveria ser, a qualquer custo, acompanhada do esforço para garantir, ampliar, e efetivar pelo coletivo as liberdades fixadas pela prescrição normativa da lei. $\mathrm{O}$ argumento do autor envereda por alguns caminhos da

\footnotetext{
${ }^{48}$ Id. Ibid., p. 48-49.

${ }^{49} \mathrm{O}$ texto de M. P. Henrique de Carvalho, ao qual já nos referimos acima, foi publicado também como brochura em Lisboa no ano de 1834, "como licença da Comissão de Censura", pela tipografia Santa Catharina. Recordese que o título completo daquela obra era Memoria sobre a maneira de dirigir a educação nacional segundo a forma de cada governo e sobre a maneira de firmar a moral da Nação.

${ }^{50}$ Recorde-se que nas Cartas sobre a educação da mocidade, datadas de 1760, Ribeiro Sanches chega a propor a supressão das escolas nas aldeias, sob o argumento segundo o qual as camadas populares deveriam conformar seus hábitos a partir da imitação de seus maiores. Por sua vez, o tratado pedagógico de Verney - Verdadeiro método de estudar - defende com veemência a universalização do ensino, alegando que a ética e a honra não são passíveis de transmissão hereditária, mas poderão e deverão ser formadas pela ação educativa. Por aí percebe-se que a controvérsia reporta-se aos próprios precursores - em solo português - da visão iluminista sobre a educação.

${ }^{51}$ J. A. B. Reflexões sobre educação publica, p.1.
} 
abordagem pedagógica; caminhos estes que julgam consentâneos os projetos de ensino público com a liberdade, a qual, por sua vez, viria assegurada e resguardada pelo contraponto do ensino particular:

\begin{abstract}
“(...) nenhum homem sensato procurará prolongar o estado de ignorância a que Portugal se acha reduzido. É necessário prover prontamente de remédio a esta calamidade. Não cogito, portanto, levado do amor das teorias, ou d'algum interesse particular, nem de entregar a educação da mocidade ao espírito de associação por ora tão fraco entre nós, ou a todas as Municipalidades do Reino, das quais algumas ainda são pouco zelosas; nem também de constituir a influência direta, geral e constante do Governo sobre o ensino público. A minha empresa é de achar um sistema eficaz para melhor promover a educação moral e científica dos portugueses. (...) Atendendo às circunstâncias do País, julgo que este resultado só poderá ser conseguido quando as Câmaras Legislativas e o Governo organizarem na extensão total do Reino o ensino público, consentindo e animando francamente a concorrência dos Estabelecimentos particulares. Nem as luzes estão por ora suficientemente espalhadas entre nós, nem o amor da Ciência, que só delas pode provir, bastante arraigado, para que o Governo se deva eximir de velar sobre o ensino público. Além de que, estabelecido o princípio da livre concorrência, podendo as Escolas particulares competir com as do Estado, abre-se a porta a todos os progressos e aperfeiçoamentos que o tempo for descobrindo, e fica temperada a natural tendência de todos os Governos para monopolizar." 52
\end{abstract}

$\mathrm{Na}$ perspectiva do mesmo autor, haveria em Portugal, naquela altura, uma preocupante carência de indivíduos instruídos, fator que ocasionaria, dentre outros efeitos, o atraso português perante a industrialização, agricultura, comércio e administração; enfim, coloca-se o obscurantismo popular como, a um só tempo, escudo e emblema da decadência. Além disso, critica-se a excessiva valorização em relação à formação superior de universitários pedantes e incapazes de se altearem como artesãos de seu país. ${ }^{53}$ Nessa medida, é a educação voltada para utilidades práticas o que J. A. B. defende, propugnando, também, o ensino livre, embora não deixado ao acaso; rejeita tanto os vícios de corporações quanto a excessiva ingerência governamental, ambos obstrutores dos progressos da instrução. Diante de tais considerações preliminares, J. A. B. divide o tema em três eixos: classificação das escolas e das matérias de ensino, sustentação das escolas, métodos de ensino.

Ao discorrer sobre os aspectos concernentes à classificação das escolas, J. A. B. destaca a necessidade de voltar as atenções para a escolarização primária, ainda que isso pudesse ocorrer sob o custo de uma correspondente diminuição de investimento em relação à instrução secundária a ao ensino superior. Fica claro, pelo movimento das idéias no texto, de que se trata de um projeto acerca da universalização da escola primária propriamente dita, incluindo nisso a escolarização das meninas, posto que esse seria o degrau de ilustração suficiente para indivíduos que no futuro se dedicariam a ofícios mecânicos. Para justificar seu projeto, o autor invoca a proposta pedagógica de Talleyrand, representante da Assembléia Constituinte Francesa, por ocasião da Revolução. Nessa medida, quando revela sua intenção de reduzir o número de escolas secundárias e superiores, J. A. B. elucida pela outra margem:

\footnotetext{
${ }^{52}$ J. A. B. Reflexões sobre educação pública, p.4.

53 A esse respeito, o autor profere crítica subliminar ao modelo universitário representado por Coimbra: " $E$ preferível o ignorante de boa fé ao pedante impostor. Deixará de existir o inconveniente daquelas universidades que se julgam omniscientes, organizados os estudos por métodos mais simples, banidas as formas inúteis e títulos aparatosos, promovida, sobretudo, a concorrência das escolas particulares. Na organização dos estudos, dever-se-á também considerar que o país não precisa maior número de sábios, mas que muito carece de homens instruídos, isto é, de homens que reúnam bastantes conhecimentos para praticarem vantajosamente a indústria a que se dedicam." (J.A.B., op. cit., p.4-5)
} 
“(...) mas não o das Primárias, porque como nelas se confira a instrução a que todas os Portugueses têm igual direito, não nos devemos satisfazer enquanto não houver uma destas escolas em cada Freguesia. Acresce também o motivo que elas são a primeira prova pela qual a sociedade conhece quais são as crianças de cuja educação é do seu dever e interesse encarregar-se."54

Revelando-se leitor dos revolucionários franceses, J. A. B. assume mesmo a própria orientação curricular expressa pelo Relatório de Talleyrand, cuja matéria de instrução primária seria fundamentalmente "o ensino e a prática da moral e da religião; a leitura; a escrita; os elementos de Língua Portuguesa; o cálculo e o desenho necessários a todas as classes; afinal, os exercícios ginásticos que forem praticáveis em cada localidade". 55

Na sequência, o ensino secundário torna-se alvo de severa crítica pelo fato de se restringir à condição de mero preparatório para os estudos de nível superior. $\mathrm{Na}$ verdade, havia nesse caso certa hesitação porque, embora efetivamente habilitasse o indivíduo para postular o acesso às carreiras superiores, o ensino secundário poderia, na outra margem, ser o responsável pela preparação da formação do comerciante, do agricultor, enfim, do homem voltado para profissões práticas e que desejasse, através dessa educação intermediária, capacitar-se para uma melhor atuação em seu próprio ofício. Ora, nesse caso, estudos como grego e latim seriam absolutamente inócuos e sugere-se, em função disso, uma completa reestruturação do conjunto das áreas de estudo, mediante introdução de disciplinas como direito e economia política, bem como a valorização das línguas estrangeiras, da história e da geografia. $^{56}$

Distinto desse modelo acima transcrito e que confluiria para um secundário profissionalizante, propõe-se a estruturação real da instrução verdadeiramente propedêutica, voltada para a preparação de jovens para o acesso aos cursos superiores. Para esse caso, aí sim, indica-se: "o Latim, o Português e Francês com acertados desenvolvimentos; os princípios de Grego e Inglês; o desenho; e que a estes estudos ande anexo o da lógica, Retórica, História e Geografia, e dos elementos de Matemática, Física, Química e História Natural" $" 57$.

Ao referir-se aos aspectos propriamente institucionais da vida rotineira das escolas, o autor destaca o silêncio e o medo como fatores proeminentes da ordenação pedagógica. Existiria, sob tal enfoque, rigoroso processo disciplinador, calcado antes pela normatividade e inspiração do temor do que pelo efeito da autoridade do mestre enquanto

\footnotetext{
${ }^{54}$ J. A. B. Reflexões sobre educação pública, p. 8.

${ }^{55}$ J. A. B. , op. cit. , p. 8.

56 "Qual é o homem que não precisa conhecer os direitos que deve defender e os deveres que tem de cumprir? E qual a transação, por mais simples que seja, a que não se apliquem as regras da economia política? Ensinar-seão, portanto, nas escolas complementares das primárias: o Português, o Francês e o Inglês; História e Geografia de Portugal; elementos de Matemática, Fásica, Química e História Natural; noções de direito e de economia política; desenho e exercícios ginásticos (...) Com estes conhecimentos, fica habilitada a mocidade para frequentar utilmente qualquer escola de aplicação, tanto de indústria, quanto de agricultura e de comércio (...)” ( J. A. B. Reflexões sobre educação pública, p. 11).

57 J. A. B. , Reflexões sobre educação pública, p. 12. Os estudos que o autor apresenta como anexos são considerados suplementares e deverão ser, portanto, trabalhados apenas em seu caráter introdutório, seja pela complexidade - como é o caso da Retórica - seja pelo conteúdo virtualmente perigoso. Acerca disso, o autor reflete sobre a composição da História: “(...) se a História se limitasse, na minha opiniã,o ao estudo de alguns factos e das suas datas, de barato eu concederia que ele fosse próprio de todas as idades; mas como o reputo o mais importante e difícil de todos porque os seus elementos são muitos numerosos, complicados e até incertos, e porque nas lições do passado encontramos o anúncio do porvir, estou persuadido que toda a nossa vida é curta para conhecer a História. Não é pois de uma criança que se pode esperar a penetração, o conhecimento dos homens, a universalidade de estudos precisos para ver o encadeamento dos factos, as suas causas secretas, para apreciar a influência dos homens superiores sobre as Nações, entender os planos do General, os atos do Legislador, as obras primas dos Poetas, dos Artistas de cada país, para conhecer os elementos de civilização e de prosperidade dos Povos, em uma palavra, para descobrir a natureza e os destinos do gênero humano" (J. A. B. Reflexões ..., p. 12-13).
} 
sujeito imbuído pelo segredo do conhecimento. A escola portuguesa, no conteúdo e na forma, é aqui veementemente questionada por configurar seu futuro a partir da lapidação de homens fracos no ânimo e parcos no espírito.

\begin{abstract}
"Quais as virtudes que se inculcam à mocidade? Quais os meios empregados para corrigir os seus defeitos? A única virtude que tenho visto recomendada no Colégio é o silêncio. Nas salas, nas casas de estudo, na Igreja, o que se exige é o silêncio. Neste ponto, manifesta-se ainda mais claramente a impostura dos atuais sistemas de educação. O silêncio, sendo a aparência do estudo e da aplicação, é quanto se requer, pois basta que os homens tenham a aparência de morais e instruídos. Enquanto para honrar as escolas também basta que um ou outro estudante privilegiado faça notáveis progressos. E por que meios procuram os Mestres emendar os defeitos da mocidade? Pelo medo! Numas partes, pelo medo da reclusão e da privação de alimentos, noutras até pelo medo das pancadas. Note-se esta contradição: a sociedade reprova e despreza o homem medroso; nas escolas procuram acostumar a mocidade a este vil sentimento. Facilmente eu perdoaria estas e outras anomalias se as consequências não fossem desastrosas; porque não me esmero em notar defeitos, mas sempre hei de procurar evitar males. E quais são maiores do que os resultados de um sistema tão imoral? Pelo medo, os ânimos fracos aviltam-se porque cedem, mas não se emendam, e as mais das vezes encobrem-se com hipocrisia e baixeza; os ânimos fortes pervertem-se porque, para resistirem aos ameaços que os revoltam, persistem nos seus erros, e até blasonam de os cometer" 58 .
\end{abstract}

Sob este argumento, considera-se que o homem, desde a infância, é incentivado a utilizar de modo errôneo os atributos da mente e do espírito com que a natureza o dotou. $\mathrm{O}$ autor destaca a corrupção dos costumes como um mal engendrado pela sociedade e reproduzido de maneira localizada pelas instituições do mesmo corpo social. Desse modo, com sociedade e governo imorais, as escolas refletiriam, como num espelho, os vícios que estariam para além dos seus muros. Reformar a escola seria, sob esse prisma, tarefa de largo alcance, dado que suporia a regeneração de outras instâncias da estrutura social. Tributário, assim, dos preceitos pedagógicos da Ilustração e da Revolução Francesa, o autor evoca o tema da perfectibilidade, quando se angustia perante o círculo vicioso do movimento pendular sob o qual se apresentava a matéria da instrução pública:

\begin{abstract}
“A reforma da educação depende da regeneração da Sociedade, e a Sociedade não se pode regenerar sem receber uma melhor educação. Mas dever-se-ia concluir, com os que não admitem a perfectibilidade humana, que todo progresso seja impossível? A história do passado serve de garantia para o futuro. São porventura poucas as conquistas do espírito filosófico, que não possamos confiar em outras maiores? Não há muito tempo ainda que existem Governos Representativos na Europa. Para a formação deste sistema, era forçoso que primeiro se espalhassem certas idéias, que os governos de então não promoveram, contra as quais até empregaram todos os meios, todo o poder do absolutismo." ${ }^{, 59}$
\end{abstract}

Supõe-se, pelo argumento do autor, que as idéias novas circulavam, firmando-se possivelmente como alicerces das transformações projetadas. É evidente que tudo isso não passava do plano das representações de uma dada intelectualidade em contato com o que se vinha produzindo nos demais países da Europa; mas inegavelmente, o eco do iluminismo pode ser já daqui decalcado. Entendendo que o movimento das idéias poderia e deveria preceder a dinâmica das práticas sociais, acredita-se que se está a tratar de uma pátria frágil e problemática por ser absoluta e reconhecidamente decadente. Ora, alterar tal realidade era empreitada que principiaria talvez com a reforma da instrução. Reconhecia-se a lentidão e as dificuldades desse processo, acreditando, porém, que o tempo seria ainda o fator decisivo:

${ }^{58}$ J. A. B., op. cit., p. 14-15. Os grifos são nossos.

${ }^{59}$ J. A. B. , Reflexões sobre educação pública, p. 15. 
“A regeneração social, de que está dependendo a completa reforma do ensino não pode ser nem imediata, nem repentina: virá pela ação vagarosa mas segura do tempo, a qual promoverá simultaneamente a introdução das idéias morais, o progressivo aperfeiçoamento do ensino e produzirá afinal uma sociedade mais morigerada, uma Representação Nacional menos imperfeita e melhores meios de governar.",60

Defende-se, sob tais pilares, a rigorosa intervenção governamental sobre a organização da instrução pública. Obtida a almejada regeneração, talvez, no futuro, as escolas pudessem ficar em mãos da iniciativa particular. Mas em tempos como aquele, de transição, o Estado era - como reconhece o autor - instrumento fundamental para a construção desse futuro. A propósito dos critérios adotados para a manutenção das escolas, sugere-se que se recorra às contribuições dos alunos, com subsídios do Estado. Referenciado - como vimos pelo modelo francês, o autor declara que as escolas primárias, devendo ser gratuitas, haviam de contar com um excedente de despesas, à guisa de incentivo e de efetivo investimento na instituição, até "para convidar os Pais a mandarem para ela as crianças; porque ainda não está chegada a época em que poderão ser castigados quando se recusarem e, muito menos, aquela em que o farão sem receio de castigos, nem esperanças de recompensa." ${ }^{\prime \prime 1}$ Acerca da alocação de recursos públicos, sugere-se a introdução de critérios municipalistas para o tratamento da questão relativa ao financiamento do ensino, nos moldes daquilo que, algumas décadas depois - como veremos adiante -, seria retomado por D. António da Costa, em sua apreciação acerca dos problemas da instrução em Portugal. De qualquer maneira, este que se esconde sob as iniciais J. A. B. preconiza a transferência de recursos para que os municípios custeassem a organização de um sistema público de ensino:

\begin{abstract}
"Convenho que as dificuldades da prática são muitas, que a civilização está atrasada, que o povo é ignorante; mas a civilização não está igualmente atrasada em todas as partes do Reino, nem todas as povoações de Portugal são igualmente ignorantes: proporcione-se portanto com a ilustração do povo a sua influência em cada localidade (...) Sobre uma adequada classificação das terras e cidades é que deve fundar-se o regime municipal e sobre esta base todos os mais ramos da administração interna."62
\end{abstract}

A instrução primária - nessa sugestão de ruptura com a matriz centralizadora herdada do pombalismo - recairia como atribuição das municipalidades. Em termos administrativos, são indicados os Procuradores de Escola, cuja tríplice função seria: advogar a causa da instrução nas instâncias das Juntas de Província, onde teriam voto; fiscalizar o funcionamento das escolas e a atuação dos professores e diretores; prestar contas do estado da instrução na localidade pela qual é responsável perante o Conselho Promotor da Instrução Pública, ao qual caberia todos os anos publicar relatório circunstanciado a respeito da situação geral das Escolas do Reino. Seria esse último, portanto, o órgão encarregado da inspeção.

Tendo exposto seus parâmetros administrativos quanto à organização e gestão das escolas, J. A. B. passa a referir-se aos métodos indicados para trazer exequibilidade ao processo do ensino. Antes de qualquer coisa, ressalta o efeito pernicioso de metologias

\footnotetext{
${ }^{60}$ J. A. B., Reflexões sobre educação pública, p. 16. Na sequência, o autor opina sobre a imprescindível, ainda que provisória, responsabilidade da ação governamental sobre a instrução da meninice: "Quando chegar essa época, que a fortuna de Portugal talvez não haja de demorar muito, poderá a educação da mocidade ser confiada exclusivamente ao zelo dos particulares e ao critério da opinião pública. Mas por ora julgo necessária a intervenção das Câmaras e do Governo. Conheço também que não é possível levar imediatamente a educação pública a uma grande perfeição, mas tanto maior é a dificuldade, tanto mais é de confiar que serão empregados todos os meios para promover aquele resultado." (Id. Ibid.,p. 16)

${ }^{61}$ J. A. B., Reflexões sobre educação pública, p. 21.

${ }^{62}$ J. A. B. , op. cit. , p. 22.
} 
usualmente adotadas, cujo único efeito residiria no cultivo e enaltecimento da memória, estilo perante o qual o aluno teria seu raciocínio travado pelo fato de habituar-se a esquecer no dia seguinte aquilo que, na véspera, aprendera. ${ }^{63} \mathrm{~A}$ idéia de um aprendizado contínuo passaria pela perspectiva de uma avaliação também cotidiana. O grande óbice para conferir êxito a tal modelo era exatamente o esquema de aulas livres, sem regulamentação legal quer quanto à duração dos cursos, quer quanto à própria estrutura dos mesmos. Acerca dos procedimentos e técnicas didático-pedagógicas, o autor adverte:

\begin{abstract}
"Costumam alguns Professores apresentar com muito talento as matérias das suas lições, expor com a a maior clareza tanto as causas como as consequências e as relações de todos os fatos, deixando pouco que fazer aos discípulos; pois que muito poderão eles acrescentar a uma obra tão perfeita? Mas esse mesmo talento, essa mesma excessiva clareza, é o que julgo pernicioso. $\mathrm{Na}$ minha fraca opinião, achava preferível que, antes de ouvir as explicações do Mestre, o discípulo fosse obrigado a procurá-las por si mesmo. Portanto aconselharia que, numa lição, o Lente indicasse os principais elementos de uma teoria e deixasse aos estudantes o cuidado de completar, de deduzir as consequências dos princípios e de fazer aplicações (...) A Ciência não se comunica com aparato: é por um trato familiar e contínuo com os discípulos que o Professor os animará ao estudo, suscitará as suas idéias e procurará mais formar-lhe o espírito do que gozar da fácil glória de ostentar sem discussão um saber pomposo." 64
\end{abstract}

Relata-se a preocupação quanto aos parâmetros norteadores da escolha dos mestres, os quais deveriam brilhar, não apenas por seu notório saber, mas fundamentalmente pela apresentação de padrões de conduta civil exemplares, bem como por sua moral irrepreensível. Na verdade, credita-se ao conhecimento esse preparo para o exercício consciente de imperativos morais. O mestre iniciaria o discípulo na vereda da árvore enciclopédica, desde esse balbucio da escolarização elementar; ali estariam supostamente contidos, de maneira traduzida, os saberes acumulados pela história da Humanidade no longo percurso percorrido pela civilização. Porém, havia algo para além disso: ao mestre caberia também indicar a senda da virtude, formando, acima da inteligência, o coração humano. Ora, tendo por premissa aquela idéia de que o conhecimento entrelaçado à virtude aproximaria o homem da própria acepção de humanidade, a escola portuguesa - constata o autor -, não cumprindo tais requisitos, deixava muito a desejar em direção àquela utopia. Por essa razão, declara na sequência o mesmo texto:

\begin{abstract}
“(...) ainda nos admiramos que a mocidade seja imoral, irreligiosa e ignorante! Quem há nas Escolas que lhe ensine já pela lição , já pelo exemplo, ou a religião ou a moral? Concedam-se grandes ordenados e maior consideração àqueles que se dedicarem não a manter a mocidade em silêncio, mas a educá-la: ou sejam obrigados os Professores por turno a preencher tão honroso cargo. Possam os homens que viverem com os estudantes ser respeitados pelo saber e pelas virtudes, sem que a lembrança dos castigos os faça temer: saibam eles assentar a educação pública
\end{abstract}

\footnotetext{
63 "De modo algum me posso conformar com a opinião de que os alunos não sejam em todas as épocas do ano obrigados a lições e sabatinas; d'outra forma é impossível evitar que enganem o Lente ou se iludam a si mesmos. Repito uma pergunta, que não devemos perder de vista: que se pretende do ensino público? Dar uma instrução sólida e positiva, e contanto que certa, embora seja limitada. Saiba cada um o que é que sabe; conheçam todos qual é o grau de instrução de cada um. Deixemo-nos, pois, uma vez de ilusões e de imposturas: o estudante, não sendo sempre obrigado a dar lição, cuidará muitas vezes de saber as matérias que só conhece imperfeitamente, isto é, que ignora; porque o saber incompleto não é saber: e, podendo-a dar quando quiser, escolherá ou as questões mais fáceis ou algumas que estudará com preferência às outras e com prejuízo delas. São inegáveis os males de um tal sistema; conhecimento incompleto dos cursos, costume de brilhar com impostura, falta de amor verdadeiro à ciência” (J. A.B., Reflexões sobre educação pública, p. 32).

${ }^{64}$ J. A. B., Reflexões sobre educação pública, p. 35-36.
} 
sobre a idéia de utilidade geral, que encerra a utilidade bem entendida de cada um em particular e constitui a verdadeira Justiça." 65

Este ainda era um período da história das idéias pedagógicas no qual a educação era tida sob um cariz eminentemente político, não se pretendendo atribuir à pedagogia qualquer estatuto de ciência, mas, antes, deixando transbordar tais pensamentos que caminhavam e circulavam pelas nações européias desde meados do século anterior, quando o iluminismo tornara-se quase uma era. Por isso, podemos estar certos de que havia um projeto de nação por detrás de cada intervenção pedagógica. As reflexões deste ou daquele sobre o prospecto da escolarização faziam ver, na entrelinha, a correspondente acepção do autor acerca de suas representações sobre o país, sobre a cidadania, sobre a prosperidade material, sobre as relações entre capital e trabalho, enfim, sobre o homem, sobre seu mundo... Instruir a mocidade era, na trilha do iluminismo, prestar contas com o passado glorioso e conduzir Portugal ao leme de uma vocação que parecia alhures perdida: a de conquistador de novos horizontes. Aqui, pela metáfora, superar a decadência correspondia ao máximo desafio do futuro, a projeção de um tempo por acontecer. As novas gerações significavam nesse plano, até pela carga simbólica que espontaneamente tendem a carregar, o embrião desses novos tempos que se pretendiam regenerados. O desafio de recriar a pátria era acompanhado pela arquitetura desse novo gesto de fundação. O século XIX português, desde o princípio, como podemos constatar, propõe-se a carregar consigo o reencontro de uma prosperidade algures perdida. Entre as chaves desse propósito, julgava-se estar a educação. Por ser assim, mesmo relegada ao esquecimento nas práticas e nas ações de investimento governamental, a escola perfilhava crenças, sonhos e expectativas de regeneração...

\section{GARRETT E A EDUCAÇÃO INTELECTUAL NA COMPOSIÇÃO DO FUTURO}

Será mediante a atuação de Almeida Garrett ${ }^{66}$ e de Alexandre Herculano que a educação portuguesa ganhará efetiva identidade teórica, enquanto projeto liberal. Produzir-seia, então, uma leitura inaudita do panorama social e político e a escola passaria, desde logo, a ser entendida como dispositivo de produção do consenso, de fortalecimento das raízes autênticas da nacionalidade em suas supostas tradições, e de estruturação de uma ordem de produção e reprodução de valores divulgados como códigos civilizatórios. A nacionalidade portuguesa, enquanto problema intelectual, viria a ter, sob novas representações simbólicas, um contorno bastante próprio. Garrett como Herculano, além de discorrer sobre a escola , desenvolvem táticas outras de pedagogia política, com o fito de espraiar suas visões e versões sobre o mundo e sobre a caminhada da civilização. Garrett fala a Portugal, escrevendo como pedagogo da rainha; ou, talvez pedagogo do futuro. Herculano assume O Panorama como a sua escola de propagação dos 'conhecimentos úteis ${ }^{67}$. Ambos, de qualquer modo, surgem

\footnotetext{
${ }^{65}$ J. A. B., Reflexões sobre educação pública, p. 37.

${ }^{66}$ Nascido no Porto em 1799, João Baptista da Silva Leitão de Almeida Garrett morre em Lisboa no ano de 1854. Escritor de inúmeros romances do romantismo português, é mais conhecido do grande público por suas obras literárias. Foi nomeado primeiro Visconde de Almeida Garrett por decreto de 25 de Junho de 1851. Fez parte do Conselho de Sua Magestade; foi Ministro de Estado honorário; Juiz do Tribunal Superior do Comércio; Comendador da Ordem de Cristo; baacharel em Direito pela Universidade de Coimbra; deputado às Cortes de 1837 e às subsequentes; sócio da Academia Real das Sciencias em Lisboa sócio do Instituto HistóricoGeográfico do Brasil. ( dados extraídos de: INNOCENCIO Francisco da Silva, Diccionario bibliographico portuguez). Como intelectual teve atuação intensa e ativa na vida pública da monarquia em seu tempo.

67 Alexandre Herculano de Carvalho Araújo (1810-1877) foi Comendador da Ordem de Torre e Espada; bibliotecário de Sua Magestade; deputado às cortes pela Legislatura de 1841; sócio da Academia Real das Sciencias de Lisboa; sócio da Academia de História de Madrid; sócio da Academia Real das Sciencias de Turim.
} 
como sujeitos de uma enunciação privilegiada. São agentes de novas representações, que antecedem em muito as novas práticas de escolarização, de um Portugal que vai sendo desenhado pelos ditames da própria repercussão que o Iluminismo adquire no desenrolar da primeira metade do século XIX.

Em um ensaio onde discorre sobre a memória histórica e a produção de uma memória mítica pelo culto cívico efetuado a propósito da imagem de D. Pedro IV em Portugal do XIX, Catroga nos traz suporte teórico e pretexto metodológico para abordarmos o tema do pensamento de Almeida Garrett e de Alexandre Herculano, que, de fato, teriam sido, a seu tempo, louvados e enaltecidos como só aos 'grandes homens' permite a história. Na construção da memória nacional, haveria, talvez, uma dimensão pedagógica para falar de pátria e de exemplaridade no mesmo acorde. O imaginário popular, ao se apropriar e passar a debater as idéias do suposto herói, cria uma memória apologética, uma saudação, quase mesmo uma saudade, mas - ao criar o personagem - evoca sua lembrança, por vezes, numa antecipada posteridade, de modo, antes de mais nada, a comemorá-lo. Investido , então, por "exemplaridade típica" e "capacidade profética" 68 , o grande homem fala do passado ao futuro. Pelo menos, seria essa sua única função. Para Catroga, construíam-se no século XIX - ainda que pela herança dos setecentos - memórias comprometidas com esse projeto de fabricação do homem incomum:

\begin{abstract}
“(...) contra os privilégios do nascimento, o triunfo das novas modalidades de imortalização anunciava uma carreira aberta aos méritos e aos talentos. Mas o direito à imortalidade também já não se confundia com a idéia estrita e comum do herói. Este, geralmente guerreiro, seria o homem do instante salvador, da ação individual miraculosa, enquanto no novo imaginário haveria também lugar para o filósofo, o legislador, o literato, o artista, o cientista, o político e, obviamente, para o militar. A personalidade do grande homem passa a ser apresentada como a resultante de um esforço de auto - aperfeiçoamento e o seu valor é medido à luz dos méritos da sua comparticipação na edificação de um tempo histórico acumulativo que, inexoravelmente, estaria a impelir a humanidade para uma crescente perfeição." 69
\end{abstract}

Foi autor de inúmeros romances, dispersos a princípio pelos periódicos nos quais era colaborador: O Panorama, Revista Universal, Mosaico, etc. Innocencio recorda que, sobre as sucessivas edições de sua História de Portugal, a partir de 1846, seu trabalho teria, já a princípio, grande aceitação, expressa nas inúmeras tiragens. Antes mesmo de se concluir a impressão do volume 1 (que constava já de 1800 exemplares), foi feita nova impressão com mais 1000 exemplares. Em 1853 repetiu-se outra impressão com mais 1200 exemplares; o que representa um total, no referido período - de 4000 exemplares. Como se sabe, Herculano abordava temas variados no estudo da história, com a ciência arábico-acadêmica, historiadores portugueses, existência ou não do feudalismo em Portugal, etc. Como intelectual, Innocencio recorda que Herculano discorreria também sobre os inúmeros temas candentes que agitavam sua contemporaneidade. Pronunciar-se-ia por escrito sobre teatros, arquivos eclesiásticos do Reino, supressão das Conferências do Casino, monumentos pátrios, propriedade literária, educação feminina, pena de morte, imprensa, instrução pública, etc. Diz o Diccionario sobre o perfil do homem: "Disse-se algures que Alexandre Herculano não era homem popular, não o fôra nunca; e todavia na minha sincera e singela opinião poucos escritores o igualariam na demonstração dos seus sentimentos populares, isto é, em favor do povo, em prol da instrução das classes populares, em defesa dos sagrados e legítimos direitos dos que trabalham e padecem. Quem se aproximasse dele e fitasse aquela fisionomia carregada e sombria e visse aquele aspecto de misantropo, julgá-lo-ia fora de todos os centros de convivência, fora da atração que traz comunidade de interesses e de idéias para o bem geral. E enganar-se-iam. Naquela aparente rudeza estavam ocultos os melhores e mais valiosos quilates de um coração nobre (...) Para os ignorantes ele tinha as palavras de ensino, para os fracos, frases de animação, para os pequenos, ditos de conforto, sem azedume, sem ofensas, sem recriminações, sem vexames (...)” (INNOCENCIO Francisco da Silva, Diccionario bibliographico portuguez, tomo XXI, p.65-6).

68 "Como na obra dos grandes homens é a história que se revela, a aferição da sua magnitude pertencerá à posteridade. Evocá-la será comemorá-la: o grande homem emerge investido de uma exemplaridade típica e de uma capacidade profética que se imporia seguir e escutar." (Fernando CATROGA, O culto cívico de D. Pedro IV e a construção da memória liberal, In: Revista de história das idéias / volume 12, 1990, p. 448)

${ }^{69}$ Fernando CATROGA, O culto cívico de D. Pedro IV e a construção da memória liberal, In: Revista de história das idéias / volume 12, 1990, p. 446. 
Grandes homens, tal como já os qualificavam os próprios contemporâneos, a diferença fundamental que Garrett e Herculano teriam em relação aos demais autores aqui abordados reside no fato de eles serem conhecidos, lidos, comentados, quer por teóricos da literatura, quer por profissionais da política, quer por especialistas desta ou daquela área acadêmica. Sem dúvida, passamos agora a tratar de autores que possuem notoriedade, que tiveram, portanto, seus escritos já conhecidos, já analisados, e já debatidos por parte da intelectualidade portuguesa, em inúmeros trabalhos. Pretendemos, então, contribuir com um outro olhar, voltado especificamente para o filtro mediante o qual Garret e Herculano julgavam a escola. Acreditamos que tal incursão pelo pensamento pedagógico português, pelas imagens da escola - fossem elas reais ou idealizadas - não poderia ser levada a cabo sem dialogar com inúmeros autores sobre os quais muito já se debruçou. Percorrer os escritos de Garrett, de Herculano, e até de Castilho representa talvez enveredar por um movimento do discurso educativo que deixou rastros, que fez escola, que teve enfim a repercussão dos clássicos. O imaginário pedagógico em Portugal do XIX exige pois que os retomemos, até para apreender as regularidades e confluências do discurso, até para verificar onde eles se particularizam: enfim, qual a grande marca deste ou daquele autor no debate educacional? Como era visto o tema da escola por parte dessa intelectualidade que completa a primeira etapa do século XIX português? Sendo o século XIX o século da escolarização em grande parte dos países europeus, qual a percepção que se tinha sobre a situação portuguesa? Quem forjaria o discurso da educação que naquela altura tomava forma? Para compreender, devemos recorrer às falas dos protagonistas do cenário intelectual português do período em foco. Procuraremos ouvi-los para compreendê-los...

No parecer de Teófilo Braga - que, aos olhos de Alberto Ferreira teria sido quem deu prosseguimento à obra de João Baptista da Silva Leitão de Almeida Garrett (1799-1854) 70 - a melancolia foi a musa dos trabalhos de Almeida Garret, tanto pelo fato de representar com nitidez alma e o espírito de um povo que carregava consigo esse traço da tristeza, quanto pela orientação impressa pelo efeito de um dado modelo de educação. Exilado pela mácula de liberal, partidário de D. Pedro, Garrett deveria sujeitar-se à condição de estrangeirado e refugiado do miguelismo em Inglaterra. Foi durante o exílio que, em 1829, escreveu o tratado Da educação, endereçado à futura rainha, Dona Maria da Glória, que contava então com apenas dez anos de idade. Como destaca Rómulo de Carvalho, antes de ser banido por D. Miguel, Garrett trabalhava no Ministério do Reino, órgão responsável pelos assuntos da instrução. Durante dois anos, chegou inclusive a ocupar o posto de chefe da Repartição do Ensino Público ${ }^{71}$. Talvez tenha vindo daí seu despertar para a reflexão acerca de temas relativos aos sistemas educacionais e sua organização técnica, administrativa e pedagógica. Além da redação do tratado Da educação, Garrett discorrera acerca da política escolar quando apresenta ao já então D. Pedro IV o projeto de reforma da instrução resultante dos trabalhos desenvolvidos por comissão nomeada pelo próprio rei. A carta que acompanha o texto revela a tonalidade política do discurso pedagógico de Almeida Garrett, sendo também bastante ilustrativa de um certo espírito de época:

“(...) o projecto da reforma geral dos estudos e da educação do Reino, que eu appresentei á
Commissão por Vossa Majestade nomeada para esse fim, já por ella approvada, vai subir á
Augusta Presença de Vossa Majestade Imperial. Eu tenho, Senhor, perdido n’este trabalho o resto
de saude que me deixaram doze annos de carceres e desterros. Mas somente rógo a Vossa
Majestade a mercê de ser ouvido sobre elle, e que antes de se resolver o mutilar ou alterar qualquer

70 Alberto Ferreira julga que Teófilo Braga, ao apresentar-se como discípulo de Garrrett, teria apreendido "alguns rasgos do seu gênio", que , segundo ele, estariam postos nos atributos de coragem cívica, curiosidade intelectual e espírito crítico quanto à interpretação do processo histórico ( Alberto FERREIRA, Perspectiva do romantismo português, p. 54 ).

${ }^{71}$ Rómulo de CARVALHO, História do ensino em Portugal, p. 545. 
parte d'elle, seja permittido expor, e desenvolver as suas razões, a quem há mais de dez anos, com improbo estudo, dispendiosas viagens e longas vigilias, medita n'este trabalho, e que há seis meses tem consagrado á sua redacção os dias todos e a maior parte das noites."72

Como destacam Isabel Nobre Vargues e Luís Reis Torgal, teria existido "frutuoso contato cultural, científico e também político"73 entre os intelectuais exilados de Portugal e os espanhóis e italianos. Certamente a presença desse intecâmbio de idéias produziu novos quadros mentais, que de algum modo traduziam as tendências da época. Portugal começava a viver um período de marcada divisão política entre liberais e miguelistas, e podemos, através dessa chave, compreender o tratado de Garrett sob o signo desse panorama político, no qual se desejava conferir lugar histórico àquela que se afirmaria como a herdeira de um trono liberal. Da educação é, portanto, antes de tudo, a sistematização de regras e preceitos norteadores da formação de uma rainha. Entretanto, como bem recorda Rogério Fernandes, apesar do subtítulo - "cartas dirigidas a uma senhora ilustre, encarregada da instituição de uma jovem princesa" - Da educação "não é um tratado de príncipes, mas um tratado de educação geral, que em sua generalidade até essa espécie compreende. Defendia como princípio basilar a nacionalização do ensino, isto é a apropriação de sistemas, programas e métodos de ensino a nossos costumes e circunstâncias." ${ }^{\text {"74 }}$ Embora se tratasse de uma obra que refletia sobre um modelo de educação a ser estendido e ampliado, não havia, como também anotou Rogério Fernandes, observância ou expectativa de equalização das oportunidades públicas no tocante à educação. Pelo contrário: tanto as distâncias sociais quanto a distinção de sexo deveriam se refletir nos níveis diferenciados do sistema educativo ${ }^{75}$.

Acerca, no caso específico, das hesitações de Garrett perante a opção entre o arcaísmo e a inovação, Maria de Lourdes C. L. dos Santos revela a ausência de familiaridade do autor Da educação para com as camadas economicamente inferiores. Pontuando a referência de Garrett como exemplar da tendência aristocratizante, a referida autora declara que ele, "negando embora o presente, não escolheria o futuro"76. Garrett, sob tal enfoque, identificar-se-ia com o povo enquanto princípio teórico instituinte na mesma proporção em que, na prática, dele se distanciaria. Com representações e estilos absolutamente distintos, não havia qualquer empatia natural entre as camadas excluídas do acesso à cultura e os intelectuais que dela falavam. Tomar a educação por bandeira significaria, pois, no caso de

\footnotetext{
${ }^{72}$ Carta de GARRETT dirigida ao Imperador D. Pedro IV, como vogal e secretário da Comissão da Reforma Geral dos Estudos, em 17 de Abril de 1834.

73 "O principal combate político dos exilados portugueses em Inglaterra e em França antes de 1820 foi o do estabelecimento do liberalismo e do constitucionalismo em Portugal, como depois de 1823 e de 1828 foi o do seu restabelecimento. Há, no entanto, a considerar orientações diferentes na sua luta, que foram determinadas tanto pela evolução da Europa entre 1815 e 1830, como, mais concretamente, pela existência de movimentos liberais e contra-revolucionários paralelos, sobretudo nos dois países ibéricos. Daí resultaram duas linhas de atuação relevantes: uma, que se assume como a da união política internacional dos liberais, e outra, que acompanhou a evolução da questão portuguesa, inicialmente centrada no combate ao usurpador D. Miguel e depois no papel político que os liberais pretendiam ver em D. Pedro ou em D. Maria." (Isabel Nobre Vargues e Luís Reis Torgal, Da revolução à contra-revolução: vintismo, cartismo, absolutismo..., In: José Mattoso, História de Portugal, quinto volume, p. 85)

${ }^{74}$ Rogério FERNANDES, O pensamento pedagógico português, p. 96.

${ }^{75}$ Rogério FERNANDES, O pensamento pedagógico português, p. 102.

76 Acerca do tema, Maria de Lourdes C. L. dos Santos busca justificar seu parecer: "Deter-se-ia um tanto perdido, no meio do desgosto que lhe inspirava uma sociedade dominada por barões que tinham reduzido a cifras o espírito, a inteligência, a moral e a religião, uma sociedade devassada por inovadores plebeus, às mãos dos quais, no seu dizer, ia morrendo tudo quanto havia de nobre e antigo em Portugal. A cultura, de que tanto esperava como arma a contrapor à estreiteza do utilitarismo e ao feroz individualismo a que via este conduzir, a cultura continuava inacessível à maioria. Não conseguia ver como e quando o propugnado ascenso das classes populares à classe média, através do acesso à instrução e do subsequente exercício do mérito individual, viria minorar os males sociais." (Maria de Lourdes Costa Lima dos SANTOS, Intelectuais portugueses na primeira metade dos oitocentos, p. 56)
} 
Garrett, a estruturação de um dado padrão civilizatório em sintonia com as nações avançadas da Europa naquele que se supunha a si próprio o século do progresso. A isso, viria somado um vago desejo de unificação, de demarcação de feições nacionais que, ao mesmo tempo em que civilizassem - por assim dizer -, demarcariam certa subjetividade especificamente nacional, reveladora de uma pertença às feições particulares de um país que, ao desejar competir no mundo europeu, sempre teve muita resistência em nivelar-se a ele. Era, até certo ponto, o sentimento de Portugal que viria a produzir o discurso sobre a escolarização. Se o grande tema era a superação da decadência, falar de educação era, por definição, contactar o futuro. Educar era, assim, em Garrett, como em Herculano, pressuposto para ser liberal, ser constitucionalista, no engendramento de um exercício pedagógico da cidadania projetada. $\mathrm{Na}$ trilha do iluminismo, recorde-se que havia a busca do ideal da perfectibilidade; e essa passava ainda pela utopia da instrução...

Garrett critica, como óbice ao desenvolvimento do povo português, o sentimento de miserabilidade que dele se apoderara. Em 1827, escrevia uma crônica onde, ressaltando a docilidade daquela gente, enfatiza o sentimento de insegurança coletiva que dela tomava conta. O povo português perdera a grandeza e a glória de outrora para permanecer no caminho lento que vinha sendo impulsionado por uma trajetória que não condizia com os próprios avanços da civilização. Sobre o tema, diz o cronista:

\begin{abstract}
"O maior empenho dos inimigos internos e externos de Portugal tem sido desacreditar e vilipendiar o caráter e sentimento do povo. Só podem dizer com verdade que é pouco ilustrado. Mas se a ilustração é condição indispensável para obter a liberdade (...) A ilustração é uma das consequências da liberdade e um dos meios necessários para a conservar. Uma nação muito ilustrada é má [, ] é madura demais para a liberdade, e do estado de maturidade, a inclinação natural e necessária é para a podridão - logo para a dissolução. A França deu um terrível exemplo ao mundo desta cruelíssima, porém, tão cruel como exata, verdade." ${ }^{, 77}$
\end{abstract}

Ao provocar temor e encantamento, a referência da Revolução Francesa é constantemente evocada pela marca da ruptura que esta supostamente traria consigo; mais do que isso, tratava-se, ao fim e ao cabo, de um exemplo, fosse para ser acatado, fosse para ser negado. A Revolução em França era o exemplo da idéia de nação levada a seu extremo: por um lado a libertação e por outro a inscrição da violência que fizera sangrar algumas das premissas éticas e políticas do movimento. É, portanto - como vimos - com olhar mesclado entre a curiosidade e o medo, que o século XIX português observa os efeitos e a referência do fenômeno francês ${ }^{78}$. Entende-se que a França representava um modelo a ser estudado: a revolução falhara por não ter sido capaz de alicerçar pela irradiação das luzes a cidadania que a órbita política pretendia conquistar. Assim, o tema da instrução popular acompanha o debate sobre a política, durante todo esse século XIX, herdeiro tanto do iluminismo quanto dos ventos da revolução. A ilustração do povo situar-se-á, nessa lógica, como o pressuposto para alicerçar instituições livres na plataforma de uma sociedade nova que se acreditava desenhar. O impulso civilizatório teria, sob tal enfoque, duas vias de acesso: a reforma institucional mediante instrução do povo capaz de capacitá-lo no sentido de seu aprimoramento subjetivo, ou a revolução, que, aí sim, derrocaria impiedosamente as balizas do antigo regime, para

\footnotetext{
${ }^{77}$ Almeida GARRETT, Obra política: doutrinação da sociedade liberal (1827), p. 240-241.

${ }^{78}$ A propósito do fascínio que se reconhece,à época, sobre a situação da França, o seguinte trecho é exemplar: "Ponde os olhos no povo francês, no grande povo, no povo modelo de outros povos, e vereis quanto pode a só, desajudada e desarmada força de uma nação que ousa querer, e fortemente sabe querer ser livre. Imitai-a nessa deliberada e resoluta vontade; imitai-a em seu valor na peleja, em sua constância quando vencida, na moderação quando vencedora. Em dois grandes escolhos se perde a liberdade; na tibieza com que se defende, ou na demasia com que dela se goza: evitemos um e outro. Somos poucos e pequenos; mas nem só para as grandes nações criou Deus a liberdade: antes, mais fácil vemos em toda a história manter-se ela nos menores do que nos maiores Estados" (Almeida GARRETT, Portugal na balança da Europa, p. 19).
} 
construir, sobre as ruínas, os pilares do que se acreditava ser o inteiramente outro. ${ }^{79}$ Aqui, estaria posta uma escolha, uma opção; e, para ilustrar o caso, a França deixa de ser apontada como irredutível modelo:

\begin{abstract}
“A Revolução Francesa no século passado abrasou toda a Europa. Onde é que não pegou esse fogo? Em Inglaterra, que já era liberal. Mataram-se milhões de homens por amor da Constituição em todos os países do continente; ninguém se matou em Inglaterra porque já lá a havia. Inglaterra contente de suas instituições monárquicas, fortes livres, não quis saber de inovações perigosas, nem fazer experiências para melhor: todos os outros países, que eram despóticos, não hesitaram a correr o risco... Se eles não tinham o que perder!... Um destes dois futuros espera Portugal: é escolher. Mas sobre este ponto, mais devagar e a seu tempo." 80
\end{abstract}

A propósito ainda da Inglaterra, Garrett recorda que, enquanto tivera o Brasil como sua colônia, Portugal mantinha o exclusivo comercial, interessando, no entanto, à Inglaterra a ausência e precariedade das indústrias da Península, pelo fato de os ingleses, diante de tal mercado potencial, ficarem com boa parcela da transação mercantil. Lembre-se que, na condição de metrópole, Portugal deveria importar produtos da Inglaterra, de modo a possibilitar o consumo no Brasil. No parecer de Garrett, diante da independência brasileira, era de interesse da Inglaterra que "Portugal produza e consuma para poder ser útil ao comércio inglês, e que saia da nulidade política absoluta para não ser um aliado só de peso sem proveito" ${ }^{\text {. A1 }}$ As novas condições econômicas acarretadas pela perda do Brasil exigiriam, pois, que Portugal fosse submetido a substantivas reformas, caracterizadas por Garrett como melhoramentos que só a condição política liberal poderia levar a cabo. As novas inflexões da política e da economia mundial são, por sua vez, tomadas pelo autor como dispositivos de desequilíbrios das tradicionais e já arcaicas oligarquias, originando distintas e inovadoras relações sociais em um sistema estruturado perante circunstâncias muitas vezes inspiradas por modelos transnacionais. Isso ocasionaria, segundo o antigo aristocrata, uma órbita planetária da civilização moderna. ${ }^{82}$ A alternativa da liberdade advinha, pois, através de caminhos sempre entrelaçados, e que compreenderiam desde o desenvolvimento da indústria nacional até um projeto de colonização eficaz, balizados todos eles pela atitude de irradiação das luzes, mediante a consecução de planos educativos delimitados e forjados como instrumento de consolidação e prosperidade nacional. ${ }^{83}$ Com tudo isso e por tudo isso, poderia ocorrer o desejado equilíbrio, tendo em vista o único objetivo efetivamente comum:

\footnotetext{
${ }^{79}$ No que diz respeito a essa disputa cujo fito seria a superação da decadência e a consequente retomada do desenvolvimento nacional, a instrução era tomada como estratégia e dispositivo extremamente poderosos: "Espanha e Portugal vão entrar na lice: ninguém o questiona ou duvida. Quando? Há-de ser breve. Como? Aqui vai o grande ponto, este é o objeto do terror e das esperanças de meio Universo. Se bem entrarmos em batalha, se bem combatermos, o trunfo é certo, infalível. Se soubermos usar da vitória, teremos longa, feliz e duradoura paz. - Mas se errarmos em uma ou outra coisa, se nos deixarmos seduzir pela perfídia estrangeira, atraiçoar da malevolência doméstica (...), podemos perder a maior parte, talvez tudo o que a justiça de nossa causa, e a oportunidade das circunstâncias, tanto nos promete. Em tal crise, é dever de todo o bom cidadão, de todo o homem verdadeiramente amigo de sua pátria, juntar quanto cabedal de luzes lhe deu Deus, quanto ganhou em estudo e experiência, e acender seu pequeno farol para o grande lumiar da instrução do povo. O povo há de erguer o braço; não o duvidemos; há de pelejar, e há de vencer. Façamos quanto em nós está para que bem o erga, bem peleje, bem vença, e bem saiba usar da vitória." (Almeida GARRETT, Portugal na balança da Europa, p. 28-29).

${ }^{80}$ Almeida GARRETT, Portugal na balança da Europa, p. 160.

${ }^{81}$ Almeida GARRETT, Portugal na balança da Europa, p. 165.

${ }^{82}$ Almeida GARRETT, Portugal na balança da Europa, p. 198

83 "A instrução pública, os melhoramentos das colônias, a proteção ao comércio, a emancipação da indústria, $e$ muitos outros melhoramentos necessários virão com o tempo, e como necessárias consequências que hão-de ser, das principais reformas, e essenciais garantias, sem as quais a Constituição não existirá senão de nome, a liberdade será nula, e a independência nacional, precária e arriscada, em vez de ser um bem, será o flagelo do povo” (Almeida GARRETT, Portugal na balança da Europa, p. 218).
} 
"Praza a Deus que todos, de um impulso, de um acordo, de simultâneo e unido esforço, todos os portugueses, sacrificadas opiniões, esquecidos ódios, perdoadas injúrias, ponhamos peito e metamos ombros à difícil, mas não impossível tarefa de salvar, de reconstituir, a nossa perdida e desconjuntada pátria -, de reequilibrar enfim Portugal na balança da Europa!"84

\section{GARRETT E A PEDAGÓGICA JUSTIÇA DA RETRIBUIÇÃo}

Convencido da necessidade do regime constitucional, é também mediante tal convicção política que Garrett abordará o tema da educação. Foi pensando na futura rainha, Dona Maria da Glória, que foi publicado em Inglaterra, ainda durante o período de seu exílio em Londres (1829), o tratado Da educação. Garrett aqui pretendia traçar diretrizes norteadoras da condução educativa daquela que, anos depois, deveria conduzir os destinos do reino. Imediatamente posto como marco na história das idéias pedagógicas de seu tempo e em seu país, o livro seria depois qualificado por Teófilo Braga como "pueril e sem ciência pedagógica" ${ }^{n 5}$.

Não apenas o título de seu tratado faz lembrar o Rousseau do Emílio; Da educação de Garrett parece ter nascido com a pretensão manifesta de ser a expressão portuguesa da feição iluminista de apostar na educação da criança para, através daí, regenerar o próprio gênero adulto ${ }^{86}$. Garrett principia seu trabalho destacando a metodológica oscilação de quem "antes propõe como quem duvida do que assevera como quem sabe" ${ }^{87}$. Revela-se, entretanto, convicto de que dos rumos pedagógicos da futura soberana dependeria o futuro da pátria. Credita a si próprio a missão de redigir aquele que seria o suporte teórico nacional para um modelo de educação portuguesa, modelo exemplar, a ser evidentemente implementado a partir da Corte. Acerca da prática de apropriação de referenciais estrangeiros - tão comum em Portugal, para análise dos assuntos educacionais do país - e de sua inadequação, Garrett argumentará pelas seguintes palavras:

"Pois educar por livros estrangeiros é o mesmo que mandar educar a países estrangeiros: não são
traduzíveis estes livros nem de seguir por estranhos: é preciso imitá-los, mas apropriando-os a
nossos costumes e circunstâncias. Por isto me não resolvi a traduzir nenhuma das excelentes obras
de educação que tenho lido; e apesar da íntima convicção em que estou de que o meu trabalho há
de sempre ficar muito aquém de todos esses, decidi-me a fazê-lo próprio. Estudei, aprendi, extraí
tudo o que me pareceu bom nesses outros: mas procurei digeri-lo e convertê-lo em substância

\footnotetext{
${ }^{84}$ Almeida GARRETT, Portugal na balança da Europa, p. 221.

85 “... a falta de filosofia, no critério do autor, é suprida por muita religião e muita moral em frases vagas e com citações autoritárias. Tratando da educação científica, Garrett apresenta também uma classificação das ciências, base de uma metodologia abaixo do que já então se conhecia de Bacon ou D’Alembert" (Teófilo Braga, História da literatura portuguesa - volume V / o Romantismo , p. 148).

${ }^{86}$ Acerca dos referenciais teóricos que alicerçaram a concepção pedagógica de Garrett, valemo-nos do livro de Fernando Augusto Machado, Almeida Garrett e a introdução do pensamento educacional de Rousseau em Portugal.

87 Visconde de Almeida GARRETT, Da educação; cartas dirigidas a uma senhora ilustre, encarregada da instituição de uma jovem princesa, p. V.
} 
minha (...) e procurei por este modo fazer, não um livro especulativo, não uma memória de gabinete, mas um tratado útil e praticável. Tratei, pois, de reunir nesta obra, como em um quadro, o melhor do que por tantos volumes anda disperso, juntei-lhe minhas próprias observações, e arranjei-o à portuguesa e para portugueses." $" 88$

Pelo conteúdo e pelo estilo, Garrett pretendia então produzir um tratado que, à portuguesa, abarcasse aspectos da educação física (higiene e ginástica), moral (ou do coração: deveres da família, sociedade, cidade, Estado e religião) e intelectual (matérias de ensino, tais como alfabeto, gramática, aritmética, geometria, história, geografia, etc...). Declara-se, em tal classificação, a tarefa de urbanidade a ser desempenhada pela instituição escolar, cuja baliza, antes de outra coisa, seria o estabelecimento de prescrições de ordem moral e regras de conduta civil que a elas se adequassem. O Estado inequivocamente deveria assumir um papel tutelar quanto ao oferecimento de uma educação pública, ainda que as acepções de tal formação não fossem por si equânimes. Há em Garrett a explicitação daquilo que o autor acreditava ser a necessidade de modelos educativos diferenciados, capazes de reger a formação das distintas camadas da sociedade. O território da escola se diferenciaria quanto ao encaminhamento pedagógico das crianças, na medida em que elas tivessem proveniência, quer de setores privilegiados, quer de setores economicamente desfavorecidos. Por outro lado, apesar da estipulação de um núcleo comum de matérias, mantinha-se, como era habitual à época, distinções entre a instrução oferecida aos meninos e aquela que se destinaria às meninas, abarcando algumas especificidades em termos de prendas domésticas, que de algum modo enclausuravam o papel social reservado para a mulher. Haveria finalmente um modelo pedagógico caritativo, voltado fundamentalmente para crianças órfãs ou indigentes. Por tais razões, detectamos, já à partida, a negação da escola única no projeto de Garrett; como já faziam, aliás, outros teóricos da educação portuguesa daquela altura. De qualquer modo, inscrever-se-ia ali toda a dimensão pedagógica que o julgamento acerca da decadência de Portugal viria então assumindo. É por essa chave que em sua obra, concebida para orientar as diretrizes pedagógicas de uma única menina, Garrett declara a crença de que disso “ dependerá a felicidade, talvez a existência, - os futuros todos de uma nação inteira, de uma nação até aqui tão infeliz." 89

Revelando sua pretensa identificação com o que qualifica de "arte de formar homens", Garrett aponta como objetivo de seu sistema a formação tríplice do corpo, do coração e do espírito. Convicto de que o ato de educar seria a necessária prevenção do ato de punir, Garrett aponta cuidados com a higiene e a robustez do físico como a medicina preventiva da orgânica social. Para a boa conformação do físico, os mestres deveriam atentar para as estratégias e a normatização de uma quase compostura moral. Por tal direção, Garrett adverte os austeros professores de escola:

\footnotetext{
${ }^{88}$ Visconde de Almeida GARRETT, Da educação..., p. XVI-XVII. A propósito do francesismo que já imperava na sociedade portuguesa naquela época, Garrett diria, ainda, o seguinte: "Abundam, é certo, nas línguas francesa $e$ inglesa,tratados destes; e aos portugueses, que tão familiares são hoje com esses idiomas, não é difícil consultá-los. Professo porém neste ponto uma opinião mui singular, que talvez não parecerá bastante filosófica, mas da qual todavia há de ser mui custoso mover-me. Eu tenho que nenhuma educação pode ser boa se não for eminentemente nacional. Nem o próprio 'cidadão de Genebra' era capaz de educar bem um cidadão estrangeiro. Devemos examinar as escolas, estudar os sistemas de educação dos países mais civilizados, não para mandar a elas nossos filhos, - que os não queremos para franceses, ingleses ou alemães, senão para portugueses, - mas para melhorarmos e aperfeiçoarmos nossas escolas por essas. ” (Id. Ibid. , p. XVI)

${ }^{89}$ Visconde de Almeida GARRETT, Da educação, p. 4. Confirmando o sentimento nostálgico de seu povo, imerso na saudade de um futuro nunca alcançado, continua o autor: "Eu tive a boa fortuna de receber uma educação 'portuguesa velha', sólida de bons princípios de religião, de moral, de sãos elementos de instrução, e, conquanto fosse mal aproveitada, das melhores que se dão, não direi em Portugal, mas pela Europa” (Id. Ibid., p.5)
} 


\begin{abstract}
“A alegria ou a tristeza, - a suavidade ou a rispidez dos mestres e educadores, as sensações morais de qualquer natureza demasiado fortes têm uma influência extraordinária nos órgãos tenros e por extremo sensíveis de uma criança. Geralmente se deve conservar o espírito do educando em um estado de alegria moderada e suave, que lhe distende brandamente os nervos, e mais que nenhuma outra coisa lhe conserva a saúde e avigora o corpo. A brandura dos mestres, a serenidade dos educadores deve ser constante: - se alguma vez ela relaxar a atenção ou diminuir a pontualidade do discípulo, há de por fim gerar aquela docilidade filha da convicção e do amor respeitoso, que só nasce da estima, e a qual não só forma o coração e retifica o entendimento, mas produz uma satisfação habitual e perene no ânimo do educando, que toda lhe expande a vida e lhe facilita as funções dela. Tenho visto sempre que a rigidez dos mestres e mentores intimida e tolhe as crianças, e acanhando-lhes o espírito e fechando-lhes o coração, gera um humor acre, que estimula e corrói as partes mais vitais do corpo, para o eterno tormento, amofinação e desconsolo do infeliz pupilo e de todos os que com ele têm de ter relação no decurso de sua triste vida." 90
\end{abstract}

Se a educação intelectual teria por princípio o reconhecimento das condições do educando perante critérios consoantes à posição que ele viria posteriormente a ocupar em sociedade, a educação moral alicerçar-se-ia sobre um único e inarredável preceito, apontado como formador do coração humano: a idéia de justiça; idéia esta apresentada como se fosse natural e necessária para a vida em sociedade. O senso de justiça que a educação deve desenvolver firmar-se-ia perante a disposição humana de acatar, respeitar e obedecer normas religiosas, civis ou sociais. A esfera privada e o âmbito público combinam-se aqui, quando, da premissa posta por uma ética engendrada no coletivo, derivariam padrões de conduta individuais que, calcados naqueles mesmos preceitos, produziriam no homem a acepção de honra. Até certo ponto, podemos encontrar aqui algum resquício do imaginário tipicamente feudal, seja no que concerne à ideia de honra, seja no que diz respeito a essa obsessão escolar pela obediência. ${ }^{91}$ Julgamos que o rito da vassalagem estaria subjetivamente impresso na gestação desse modelo escolar, determinando-o substantivamente. Na verdade, a escola projetada vê a criança como se fosse um vassalo dos mais velhos, ensinando fundamentalmente padrões de conteúdos e formas escolarizadas, que se interpretariam como uma preparação para a vida em sociedade. ${ }^{92}$

Tais saberes que a escola produz decorreriam de uma apropriação que a mesma escola faz dos valores e conhecimentos estipulados pelos grupos dominantes em cada sociedade. São tais grupos que orientam o que e como deve ser ensinado. Por sua vez, a escola recebe tal orientação, filtrando-a de acordo com procedimentos infinitamente sutis, até reinventá-los pela prática cotidiana. Descobrir esse movimento dos saberes da escola portuguesa é exatamente a grande intriga que aqui nos move. De qualquer modo, os conteúdos escolares, na proposta pedagógica de Garrett, seriam dispostos de maneira a que a

\footnotetext{
${ }^{90}$ Visconde de Almeida GARRETT, Da educação, p. 11-12.

${ }^{91}$ Para viajar um pouco no tempo, leia-se, sobre o tema, quanto à análise da ética feudal, o texto de Marc Bloch: "Esta ligação [ vassalagem ] era sentida como sendo tão poderosa que a sua imagem se projetava sobre todos os outros laços humanos, mais antigos do que ela e que teriam podido parecer mais veneráveis. A vassalagem, assim, impregnou a familia. 'Nos processos de pais contra filhos ou de filhos contra pais', decide a corte condal de Barcelona, "no julgamento, os pais deverão ser tratados como se fossem senhores e os filhos, como seus homens, entregues pelas mãos'." (Marc BLOCH, A sociedade feudal, p. 246) A nossa hipótese é que essa ética da vassalagem teria sido incorporada pelos códigos de dependência familiar da modernidade. De algum modo, a escola era aqui o escudo da família, impregnando a criança perante valores que eram, até certo ponto, necessários para a manutenção das relações de poder familiares.

92 O trabalho de Rogério FERNANDES, a propósito da escolarização elementar no Antigo Regime em Portugal, ressalta aquilo que caracteriza como uma "ética da obediência", concretizada fundamentalmente no estímulo escolar à adesão ou à "subordinação incondicional aos poderes hierarquizados. Na perspectiva das classes dominantes, neste princípio consistiria a regra áurea da conduta humana. Em vésperas da Revolução de 1820, os valores cuja transmissão se assinava à escola visavam a que, sem protestos, os dominados se vergassem à dominação.(...) Uma das concretizações do dever de obediência residiria na subordinação total dos filhos à vontade dos pais. O normativo social impunha a obediência incondicional à hierarquia familiar." (Rogério FERNANDES, Os caminhos do ABC: sociedade portuguesa e ensino de primeiras letras, p. 483)
} 
criança encare como natural, aceite e perpetue a ordem das coisas. A justiça aqui corresponde, não resta dúvida, à manutenção e valorização do existente como única possibilidade oferecida pela história, e, mesmo assim, a justiça é ainda posta como a mais nobre dentre todas as virtudes: a justiça que modela a honra, que estipula deveres naturalizados para com Deus, para com o Estado, para com o semelhante, para consigo próprio. A norma, a regra, a definição vem sempre de fora, devendo ser absorvida sem restrições pelos espíritos juvenis, tarefa essa que pertenceria à educação: orientadora dos eixos que conduziriam no futuro homem a sua sociabilidade. A criança desde cedo aprenderia o homem como se deve ser... ${ }^{93}$ Haveria, perante tal cartilha, uma incessante relação de dívida do indivíduo para com a Humanidade. Desde a nascença, se estaria em débito para com seres aos quais de algum modo se deve a sobrevivência: os pais são os primeiros credores de tal tributo a ser pago por dever da natureza.

Tomada como dever natural, a obediência se estende aos laços conjugais e à própria condição de cidadania: a pátria que origina o ser civil quer dele contributo, até por retribuição. Toda uma rede de constrições encadeia o indivíduo, enclausurando-o em seu lugar de súdito, sujeito a leis que ele não determinou; isso se aprende na infância. Garrett, com tudo isso, trará feição teórica a muito do que poderá ser compreendido como o território dos valores que seriam naquele século perfilhados pelos compêndios didáticos portugueses. No liberalismo pretendido, o âmbito civil desdobra-se dos parâmetros da moralidade prescrita; a ética pública deveria ser posta como um desdobramento das relações de família. Fazer da justiça o princípio da civilidade humana corresponde a assumi-la com base na idéia de retribuição: aos pais, à sociedade, ao Estado, ao cônjuge, a Deus. Ao supor a piedade e caridade como pilares da crença, o dever do cristão extrapola o âmbito da intimidade e aproxima-se de uma conduta generosa em termos da sua interface social. Nos termos do autor:

\begin{abstract}
"Piedade é amar a Deus sobre todas as coisas; - sublime justiça de amar sobre todas as coisas o que sobre todas as coisas mais nos ama e a quem mais devemos. Caridade é amar o próximo como a nós mesmos: - dever que, sendo mútuo e recíproco para todos os homens é, portanto, da mais escrupulosa e equilibradora justiça. Finalmente creio que, assim reduzida a educação moral ao único princípio de justiça, o educador achará mais facilidade, e menos tropeços em a dirigir sem desvio, e o educando em a receber." 94
\end{abstract}

Ao abarcar o tema da educação intelectual, Garrett explicita seu parecer: se todos carecem dessa necessidade de saber, fazem-no de maneira desigual, atendendo por um lado às disposições de espírito e por outro à projeção do futuro, o que evidentemente variará de acordo com a origem de classe de cada indivíduo. As propensões do educando, bem como sua índole, seriam também fatores relevantes, embora não descartassem o determinante econômico quase como uma última instância da vida e fundamentalmente do sucesso escolar. Tal condicionante revela o tom ambíguo desse liberalismo que a rigor deveria voltar-se à equalização das oportunidades sociais.

\footnotetext{
93 "Eu quisera que como base de toda a moral se estabelecesse e firmasse no coração do educando uma única virtude primordial e em que todas as outras se contivessem e da qual ele formasse uma noção perfeita e clara. Esta virtude não pode ser senão a Justiça. Justiça é tudo, justiça é as virtudes todas, justiça é religião, justiça é caridade, justiça é sociabilidade, é respeito às leis, é lealdade, é honra, - é tudo enfim. Acaso parecerá absurda esta proposição assim enunciada e seca? Meditemo-la, desenvolvamo-la e apliquemo-la; talvez o não pareça então. Para quê se educa um ente racional? Em relação à natureza, para filho, esposo e pai; - em relação à sociedade civil e ao Estado, para cidadão, súdito ou soberano; - em relação a Deus, religioso, determinadamente nós para cristão" (Visconde de Almeida GARRETT, Da educação, p.13-14)

${ }^{94}$ Visconde de Almeida GARRETT, Da educação, p. 19-20. Em nota de rodapé, Garrett destaca que, acerca do tema, certamente havia quem preferisse florear o objeto da justiça, apresentando questões de 'filosofismo', o que, segundo o autor, seria ‘tão intolerante quanto o fanatismo' (Id. Ibid., p. 19).
} 
Como ponto de partida da instrução, Garrett sugere o aprendizado prioritário do idioma nacional: “- Somos desgraçados nisto, os portugueses". ${ }^{95}$ Sobre as idades da vida, Garrett declara o papel repressor delegado à educação, que deveria - a sociedade o quer assim - agir sobre os instintos e sobre a conformação do caráter, em substituição à própria índole. A ação educativa deveria, nessa medida, transformar a vivacidade e espontaneidade da puerícia em hábitos de asseio, ordem, regularidade; enfim, um processo de domesticação das paixões para a estruturação de costumes e formas de conduta civil, de urbanidade, enfim. A civilidade, na composição escolar de Garrett, seria - pode-se dizer - meta superior à razão. É ela quem conduz um povo, oferecendo-lhe modos e formas que, no conjunto, criariam as tradições nacionais, tal como a pedagogia pretendia. ${ }^{96}$ Sendo por si educativa, a rotina recordava a própria progressão da vida, que, no conjunto, é também rotineira. Todo o engenho estaria na cronologia da vida e no aproveitamento daquilo que, estando já nela inscrito, poderá ser, pelo educador, potencializado:

\begin{abstract}
"Conta-se a infância desde o primeiro ai por que principia a vida até o crepúsculo da razão e suficiente uso dos membros, da voz, - até começar a semi-perfeita vida de relação. A puerícia desde essa época até despontarem os primeiros sinais aparentes da tendência do sexo, no arredondado ou musculoso das formas, na visível inclinação moral a certos hábitos e gostos, no maior desenvolvimento da razão e na agudeza do instinto. Nesse estado começa a adolescência, que dura até a sensível demonstração do sexo, manifesta alteração de formas, voz, - de todo o modo de ser, e já descobre propensões morais, caráter, engenho, índole. Neste ponto, a estrada comum acaba, os paralelos, mas distintos caminhos do dois sexos começam, e até a língua varia de termos para chamar a tal período da idade masculina 'puberdade' e ao da feminina 'nubilidade"., 97
\end{abstract}

Rotina sem fronteiras matematicamente demarcadas, porém plena em interdições e isolamento, controlada sempre pela incessante vigilância de um cioso educador... Assim, pelo olhar sobre a infância, seria constituído o lento caminhar da humanidade... A própria tarefa pedagógica aproximar-se-ia de um ritual de passagem, no qual elementos do espontâneo, do ato criador da razão infantil, seriam sistematicamente vedados e substituídos pela versão adulta, condição da verdade e da realidade. As fábulas mesmo são aqui tomadas como produtos da invenção e do fingimento; e, enquanto tal, deveriam ser - no parecer de Garrett - eliminadas do processo do ensino. Tudo o que incitasse à fantasia afastava do real e, assim o fazendo, seria antipedagógico. ${ }^{98}$ Como alternativa, o autor recomenda o contato da puerícia com histórias tidas por reais, exemplares e verdadeiras, elaboradas em Portugal e à portuguesa, ainda que sob a referência de modelos estrangeiros, já que - como desabafa Garrett - "a traduzir estamos nós, portugueses há século e meio e desde então ainda não temos um livro" "99

\footnotetext{
${ }^{95}$ Visconde de Almeida GARRETT, Da educação, p. 30.

${ }^{96}$ Sobre a necessária inculcação de hábitos, Garrett aconselhará às mães o seguinte: "Deitai o vosso pupilo, levantai-o à mesma hora; seja uma sempre e certa a hora do banho, do passeio, da comida, da oração; - e não temais que ele perca em anos feitos o costume da regularidade em tudo. Mães que educais vossos filhos, não os beijeis, não o acaricieis, quando por desmazelo e incúria vos aparecerem sujos e desemanhados; e sem ralhos nem asperezas nem outros castigos eles contrairão o hábito da limpeza” (Visconde de Almeida GARRETT, Da educação, p. 67-68)

${ }^{97}$ Visconde de Almeida GARRETT, Da educação, p. 40.

${ }^{98}$ De acordo com o pensamento de Garrett, a fábula leva a criança a "perder o horror à falsidade, ensina-lhes a contar contos e não olhar a verdade como uma coisa santa, com a qual não é lícito, não é possível brincar, - que nem se deve nem se pode saber dissimular, ou alterar no mínimo ponto. Deve ser pois um livro de história o primeiro que aos meninos se dê; não a história metódica e seguida, mas, conforme disse, uma coleção de fatos e ditos e de vidas de varões célebres, bem e singelamente contados em uma linguagem casta e fluente." (Visconde de Almeida GARRETT, Da educação, p. 101)

${ }^{99}$ Visconde de Almeida GARRETT, Da educação, p. 101.
} 
A mensagem frequentemente retomada por Garrett diz respeito à especificidade da própria genealogia nacional: herdeira, por um lado, da tradição clássica da Antiguidade ocidental, fundamentalmente romana; mas descendente também, na outra margem, de celtas, de judeus e de árabes que pela Península passaram... De tudo isso, a confluência de um Portugal arraigado por tradições diversas nas quais se imbricariam povos e histórias entrecruzados no percurso. Por tal razão, veicular o sentimento da nacionalidade exigiria da escola a sabedoria e o cuidado no filtro do olhar para trás. À meninice portuguesa, deveria ser fornecido o elenco de seus variados antepassados, mas com o firme propósito de formar o homem de sua época, capaz, se possível, de prover o país de um futuro de empreendimentos e grandeza. Não é por acaso que essa parte parecia a mais difícil:

\begin{abstract}
“É pois necessário que a educação forme homens de hoje; sirva-se embora de exemplos de outros tempos e costumes, porém não deixe de lhes dar, com esses, outros documentos, não menos ilustres e mais profícuos, os de nossa história e da dos povos com quem estamos em contato, e com cujas instituições se parecem as nossas. E quem empreender essa útil obra de formar um livrinho destes para os meninos portugueses, no que muito e bem merecerá da pátria, deverá nacionalizá-lo o mais possível, preferindo os exemplos domésticos aos alheios, ou pelo menos, comparando sempre uns com outros."100
\end{abstract}

A história é assim apresentada como uma coleção de virtudes eminentemente públicas ${ }^{101}$ a serem rememoradas e comemoradas na celebração de um passado que se ergue para servir de exemplo e referência ao presente. Espelho e monumento para o povo, a fabricação histórica serviria como um retrato, projetado sobre todos nós, trazendo-nos o consolo de folhearmos "a cena do mundo sem precisarmos ser atores nela". 102

De acordo com a leitura política de Garrett, em consonância com seu modo de ser liberal, não caberia ao sujeito histórico a alteração de dados objetivos de sua existência (classe social, posição posta pelo nascimento), mas, ao contrário, sob o influxo de quadros mentais arcaicos, aristocráticos e basicamente estamentais, não haveria - no parecer do autor qualquer liberdade para o movimento, para a mobilidade social. Ao indivíduo caberia, portanto, o reconhecimento de sua identidade individual e coletiva, a compreensão das forças que teriam delimitado tal situação e a aceitação dessa realidade supostamente intransponível. A vida individual e a vida dos povos seriam retratadas pela educação, de modo a conformar a fisionomia desse mesmo indivíduo, desse mesmo povo. Existiriam, sob tal ponto de vista, estados comuns à condição de qualquer homem - como esposo, filho e pai - e haveria, por outro lado, estados diferenciados pela proveniência de classe. ${ }^{103}$ Essa seria a ordem natural

\footnotetext{
${ }^{100}$ Visconde de Almeida GARRETT, Da educação, p. 112-113.

101 "De virtudes públicas, de virtudes privadas, de devoção filial, de amor paterno, de vícios, de crimes, de tudo há exemplos e documentos na história, que moralmente considerada é uma coleção de observações e experiências feitas pelo decurso dos séculos sobre a natureza do homem e o estado social, e das quais por simples análise se podem tirar as mais seguras regras da vida e os mais sólidos preceitos de moral" (Visconde de Almeida GARRETT, Da educação, p.115)

${ }^{102}$ Visconde de Almeida GARRETT, Da educação, p.121.

103 “(...) comparei a história ao espelho em que nos miramos e cuja posição está em nosso poder variar, - a moral que pela história estudamos, à luz que é constante e que em nossa mão não está alterar, - e a posição social em que nascemos ou temos de viver, à posição física em que nos achamos quando tomamos o espelho da qual mil circunstâncias nos podem impedir de nos movermos. Fixa pois de sua natureza a luz, a moral, - fixa pelo acaso e circunstâncias nessa posição, a classe social em que nascemos, - não nos resta liberdade de movimento senão para o espelho, a história: a esta moveremos e colocaremos de maneira que fique em justaposição para a luz e para o raio visual. Quererá dizer isto que em nosso poder esteja alterar a história? Mas ela deixaria de ser história desde que essa possibilidade existisse? - Quererá dizer que o devamos fazer tampouco? Mas ninguém tirará nenhuma destas conclusões; e é ocioso, se não ridículo refutá-las. Quer dizer que nem para todos os pupilos indistintamente devemos sempre abrir a mesma página da história; que em tal posição social estará um, que mais sobre este gênero histórico lhe cumpra demorar a atenção; em tal outro, que
} 
das coisas e à educação caberia apenas respeitá-la. Percebe-se então que - em Garrett - a igualdade do gênero humano é relativizada, mediante uma acepção de soberania tributária do absolutismo: soberano é o governante a quem os súditos devem obediência. A soberania, enquanto categoria intrínseca à própria nacionalidade, não consta pois da pedagogia liberal de Almeida Garrett. Consciente de seu controverso discurso, Garrett explicita que o soberano deverá ser, pela sua própria condição, moralmente irrepreensível. Ora, considerando-se que Portugal deveria ser governado por uma rainha, a futura soberana havia de ser preparada para exercer tal encargo que o Estado e a Constituição lhe conferiam. Para a educação da princesa, recomenda-se o estudo do coração humano ${ }^{104}$ :

\begin{abstract}
"O príncipe é tudo o que é o súdito; e como ele deve estudar o coração humano, ver em prática os efeitos da virtude para a amar e as consequências do vício para o aborrecer. Mas o príncipe é mais do que o súdito; e portanto é mais amplo e circunstanciado o quadro de experiêcias que tem de se lhe mostrar, e mais apropriado à sua posição."105
\end{abstract}

O ensino oferecido ao príncipe teria como eixo o estudo da História nacional, por cujos rudimentos se poderia extrair preceitos condutores da vida moral. Acontecimentos gloriosos, recordações de fatos notáveis, crônicas de heroísmo, todo esse conjunto revelaria virtualmente para o pupilo a própria vocação de Portugal. No princípio, para utilizar o enredo de Garrett, era a História: "Por este livro aprenderá a ler nosso pupilo. A ler digo: não a conhecer as letras, a soletrá-las em sílabas ou a ligar estas em palavras; mas a ler, isto é, a recitar orações e períodos, a graduar as inflexões da voz, as pausas, a entender, enfim, um discurso, um livro, - a ler na lata acepção do termo."106

Ao tomar Rousseau como constante referência de suas ideias pedagógicas, Garrett explicita seu intuito de traçar os contornos de um sistema educacional capaz de se colocar como alicerce para uma reforma social mais profunda, que, por sua vez, afastasse os ventos perigosos da sempre possível vinda da revolução... O espectro da Revolução Francesa rondava os argumentos desse liberalismo emergente de um Portugal que, entretanto, não despertara ainda de uma subjetividade típica do Antigo Regime. Acerca do tema, Garrett pondera:

\footnotetext{
"Viemos nós em tempos de vermos cumprir à letra a profecia de Rousseau; vimos as vítimas da revolução francesa, pessoas do mais nobre sangue, príncipes nascidos nos degraus do trono, ganhando com o suor do seu rosto o pão de cada dia. Vítimas de outras revoluções, não menos ilustres vítimas, já pela mesma causa da lealdade, já pela do patriotismo que não é somenos em nobreza, por aí os vemos exhules, foragidos, um sem número de indivíduos, de famílias que, por
}

por aquele ponto devamos passar rápidos para o fixarmos todo sobre este outro. Mas nem se cuide que tantas e tão variadas sejam estas diversas posições que demandam variedade de ensino histórico. As relações de família são iguais para todo homem: igual portanto é a posição natural ou social absoluta; todo homem é filho, há-de ser esposo e tem de ser pai. Idênticas são as relações religiosas; todo o homem está para com Deus da mesma posição. As relações sociais são pela máxima parte as mesmas também; mas nem todas: e aqui vai a principal distinção; todos os cidadãos estão na mesma posição para com a cidade, mas a respeito do Estado o grande número é súdito e um é soberano." (Visconde de Almeida GARRETT, Da educação, p. 122-124).

${ }^{104}$ Parece-nos aqui que tal idéia do conhecimento do coração humano como ponto de partida da educação da princesa revela-se notoriamente tributária do tratado pedagógico de Rousseau. Inequivocamente há outras passagens do texto de Garrett nas quais podemos escutar os ecos do Emílio: "não comecemos agora a ensinarlhe o que então seja preciso desaprender, não gravemos já em sua memória o que tenhamos de obliterar depois". (Visconde de Almeida GARRETT, Da educação, p. 105) A respeito da influência de Rousseau no pensamento de Garrett, já sugerimos o trabalho de Fernando Augusto Machado: Almeida Garrett e a introdução do pensamento educacional de Rousseau em Portugal.

${ }^{105}$ Visconde de Almeida GARRETT, Da educação, p. 126.

${ }^{106}$ Visconde de Almeida GARRETT, Da educação, p. 149-150. 
nascimentos, por riquezas ou talentos; ou, por todas essas qualidades, ocupavam em nossa pátria as eminências sociais. Vimos, vimos e vendo estamos com nossos próprios olhos o maior desengano das vaidades do mundo e da instabilidade de suas coisas. Não há portanto precauções que uma desvelada educação não deve tomar para premunir o seu pupilo contra tais golpes de fortuna."107

O espírito de reforma, expresso na pedagogia proposta, tem por finalidade última prevenir os excessos e, concomitantemente, modificar antigos e abusivos hábitos arraigados nas populações. Por tal motivo, a educação é pensada em Garrett por seus aspectos políticos, sim, mas fundamentalmente pela dinâmica técnico-pedagógica que lhes traz sustentação e método. Nessa direção, ele alude aos princípios intelectuais que norteiam a habilidade da escrita; para a caligrafia, sugere a utilização do tratado de Ventura. ${ }^{108}$ Propõe, também, estratégias para o ensino da tabuada, capazes de conduzir à memória, mediante um anterior processo de entendimento. Em suma, haveria necessidade de se ensinar pelo modo simultâneo, no qual o aprendizado da leitura a da escrita pudessem ser feitos concomitantemente. Além disso, a escrita caligráfica, sendo eminentemente mecânica, deveria tornar-se raciocinada, mediante a dedução de idéias, tal como orientava o estilo pedagógico já implementado nos novos métodos de se ensinar a tabuada. Nesse enlace entre o ler, o escrever e o contar, teríamos, por assim dizer, a súmula de um inusitado código para os saberes elementares da época:

\begin{abstract}
“As faculdades que por esta preparação queremos desenvolver são a memória e o entendimento. Aquela vem mais temporã que este; mas quase se cultivam ao mesmo tempo e por meios simultâneos. Já o nosso pupilo aprendeu a ler; quase ao mesmo tempo deve ter aprendido a escrever. Não falo da caligrafia, para a qual temos um excelente método em Portugal; e somos, talvez, geralmente falando, a nação que melhor escreve. Assim pudéramos nós dizer o mesmo de outras coisas. Não trato porém do mecânico da escrita, da formação e ligação dos caracteres; trato do intelectual dela. Comecemos a fazer transcrever e decorar pelo nosso educando alguns trechos escolhidos, fáceis, simples, dos melhores autores: e apenas virmos que chamada da memória, já vem acodindo a reflexão, tratemos de afazer o espírito à exação e reta dedução das idéias, que na verdade e mais um hábito que de tenros contraem os que o têm, do que fruto de longo estudo para os que mais duros o desejam adquirir, - o que rara vez conseguem. Para isto nada há como os rudimentos matemáticos. Chamemos pois já a aritmética em nosso auxílio: e sejam as primeiras noções que dela lhe dermos adquiridas pelo método que eu a tudo quisera aplicar, o de ser quem aprende o artífice de suas próprias idéias, o mestre de si mesmo. A tabuada é um dos martírios das crianças: pode-se-lhes fazer decorar mui suavemente indo pouco a pouco formando com eles o quadrado de Pitágoras. Eis aqui como cumpre fazer. Dar-se-lhes o quadrado descrito e repartido e enchem-se as casas só nos primeiros algarismos: no outro dia, sabidas estas, vão-se enchendo mais e assim por diante, de modo que numa semana aprenderá uma criança o que por qualquer outro método lhe levaria meses." 109
\end{abstract}

Percebe-se nitidamente que a preocupação de Garrett com essas questões de ordem metodológica derivavam do insucesso da educação e particularmente da escola em Portugal. Naquelas décadas que principiavam o século XIX, independentemente das possíveis inflexões políticas, o curso da educação persistia sendo o mesmo: moroso, lento e quantas vezes fracassado no ensino das primeiras letras. $\mathrm{O}$ analfabetismo em Portugal seria, durante todo o século XIX, uma realidade denunciada, não obstante não ter sido nesse período efetivamente enfrentada. Temos, portanto, o plano das idéias, das representações e dos

\footnotetext{
${ }^{107}$ Visconde de Almeida GARRETT, Da educação, p. 165-166.

108 Trata-se provavelmente do compêndio de Duarte Ventura, Arte de aprender a ler a letra manuscrita para uso das escolas em 10 lições progressivas do mais fácil ao mais difícil. Este texto é qualificado por Garrett como a mais perfeita e admirável obra para o ensino da caligrafia em língua portuguesa.

${ }^{109}$ Visconde de Almeida GARRETT, Da educação, p. 173-175.
} 
discursos antecipando-se sempre às práticas sociais, embora também ele fosse - em última instância - uma prática... ${ }^{110}$

A pedagogia portuguesa do século XIX, quando representa a mulher, coloca-a invariavelmente no seu lugar de esposa e de mãe. A tônica religiosa do discurso era, em geral, indisfarçável e o lugar do feminino, sublimado, passava a ser habitualmente encarado diante daquilo que, por si, ele viria a representar para um 'outro' masculino, fosse o marido, fosse o filho. Obediente, dócil, resignado e virtuoso, o rosto feminino é então indubitavelmente traçado pelo homem, - como sujeito da enunciação e como razão de ser da própria existência feminina. O estatuto da mulher portuguesa é, portanto, o ser duplo do homem, o seu olhar ao espelho, aquilo que, no máximo, lhe serviria de complemento. Receptáculo das vindouras gerações, a mulher é antes de tudo um ser biológico, devendo ser pois instruída fundamentalmente enquanto mãe que deverá, nesse encargo, encarregar-se dos anos iniciais da educação da criança. Garrett, ao dirigir-se fundamentalmente para a educação da futura soberana, e, dadas as configurações específicas e diferenciadas de ambos os sexos, enquadra o caso da rainha no que chama de "uma nova espécie, não participante de ambas, mas ela própria uma peculiar e de gênero seu" "111. Era como se a rainha deixasse de ser mulher ao se afirmar soberana... Se à mulher convém o recato, a soberana não pode agir com timidez; devendo, pelo contrário, ser enérgica. Se à mulher cabe obedecer, ocupar o trono equivale a mandar. A rainha deixa seu feminino para ocupar o lugar político reservado aos homens: mais do que ninguém, ela deve ser educada e preparada para esse seu ofício eminentemente masculino. Em tal transmutação, "a classe supre o sexo e a posição social a natureza: a educação intelectual de uma rainha é de varão e não de mulher."112 Sem dúvida alguma, teria sido antes por sua inquietação política que Garrett pensou a pedagogia. Talvez mais do que a preocupação com o povo, o que o intrigava era esse modo de gerir o feminino do Estado. Seja como for, seu tratado marcou época e hoje é um clássico na história do pensamento educacional português, legando-nos fundamentalmente a marca da apropriação de um Rousseau a seu modo...

\title{
O GRANDE HOMEM COMO EXEMPLO DO PASSADO E PROFETA DO FUTURO
}

\begin{abstract}
"Herculano é um homem estimável pelos seus dotes e, sobretudo, pela sua rara austeridade. Ocupando-se pouco das misérias do mundo, vive como segregado e independente dele, superior a tudo e a todos. Homem gasto em meditações e estudos profundos, com o espírito sempre sobrecarregado de cuidados, não é atributo seu o ser facilmente comunicativo; mas, quando o chega a ser, é um conselheiro e um mestre inestimável."
\end{abstract}

A descrição do Archivo Pittoresco demonstra a deferência prestada pelos contemporâneos por aquele que era já naquela altura tomado como um grande expoente intelectual - referência e exemplo para as gerações que viessem a seguir. Leitores de

\footnotetext{
110 Ramalho Ortigão, muitos anos depois, comentaria n’As Farpas sobre a inexistência de uma verdadeira instrução nas escolas portuguesas. O trecho abaixo transcrito pareceu-nos ilustrativo para evidenciar a preocupação do escritor e jornalista quanto ao tema do analfabetismo português: "A instrução pública da aldeia é uma ficção verdadeiramente irrisória. O censo de 1878 demonstrou pela estatística da instrução elementar que, no distrito de Braga, de mil indivíduos são inteiramente analfabetos oitocentos e onze! No distrito de Viana o número de analfabetos é de setecentos e noventa e nove por mil. Deduza-se da escassa porção dos que sabem ler e escrever, ou apenas ler, os habitantes das capitais dos distritos e dos concelhos, das cidades e das vilas, $e$ não será difícil concluir a priori que em regra geral nas aldeias minhotas ninguém sabe ler. E essa é a verdade. " (Ramalho ORTIGÃO, As Farpas I, p. 60)

${ }^{111}$ Visconde De Almeida GARRETT, Da educação, p.188.

${ }^{112}$ Visconde de Almeida GARRETT, Da educação, p. 193.

${ }^{113}$ ARCHIVO PITTORESCO; semanário ilustrado, $1^{\circ}$ anno, 1-7-1857, p. 7
} 
Alexandre Herculano de Carvalho Araújo (1810-1877) seriam, como veremos, os jovens da Questão Coimbrã, no coração daquela que se consagraria como a grande geração crítica, pretendendo pôr abaixo o tradicionalismo, o conservadorismo, enfim, tudo o que pudesse ser identificado como entrave ao caminho da evolução ou do socialismo; tudo o que fosse reacionário. ${ }^{114}$ Dos antigos, porém, mantinham, também eles, um valor: a personalidade de Herculano, a coerência de sua análise histórica, social e até existencial seria, então saudada como um modelo recomendado. A figura de Herculano deixou profundas marcas no tempo que se lhe seguiu, até porque a leitura que fez dele a Geração de 70 inscreveu-se na memória coletiva da nação portuguesa. Teófilo Braga - que se identificava como um representante da moderna geração - explicita seu tributo em nome dela àquele que, antes de qualquer outra coisa, soube observar e respeitar o futuro, contrariando, com isso, grande parte dos intelectuais do seu tempo. ${ }^{115}$ Acerca da proibição das Conferências do Casino e do sentido político que tal proibição trazia implícito, Teófilo Braga recorda o lugar de Herculano na contenda e o significado disso enquanto um emblema das novas idéias que vinham sendo expressas por uma também nova plêiade de intelectuais, dentre os quais Teófilo incluía a si próprio:

\footnotetext{
“Aqueles que pensavam que a circulação das idéias é o estímulo vital de todo o progresso em uma sociedade e que explicavam a decadência e o atraso da sua pátria como consequência da apatia mental protestaram, mas não foram ouvidos. O parlamento estava fechado e a imprensa jornalística, na expectativa de uma política de expedientes, deixou passar sem reparo esse ultraje à dignidade de um povo livre. Havia em Portugal um homem que era ouvido como um oráculo; Herculano era considerado como uma consciência inquebrantável e a sua voz, acostumada à energia do protesto, quando se pronunciava, fortalecia-se com o assentimento dos espíritos. Nunca ninguém exerceu um poder tão grande, na forma a mais espontaneamente reconhecida; as opiniões entregavam-se à sua afirmação, como um povo se entrega a um salvador. Tinha o poder espiritual sobre a Nação." 116
}

\footnotetext{
${ }^{114}$ Ocorre que, embora indiscutivelmente influenciados por Herculano, particularmente no plano dos valores, a Geração de 70 teria uma concepção histórica, profundamente marcada por outras referências. Pelas palavras de Catroga, sobre o tema da história, não era assim tão tranquila a relação da juventude portuguesa com o pensamento de Herculano: “(...) a chamada Geração de 70 irá definir como pedra de toque da sua compreensão do destino de Portugal a inserção da nossa história no horizonte de um devir da Humanidade metafisicamente fundamentado ( Antero de Quental, Oliveira Martins ), ou apreendido segundo uma tendência inexorável tida por científica ( Teófilo Braga). Tudo iso soava a abstrações ilusórias aos ouvidos de Herculano. Daí a sua posição crítica. De fato, estas interpretações, em que amiúde a idéia secularizada de providência aparece como sendo sinônima de necessidade histórica, não convenciam os que estavam apostados em imprimir aos estudos históricos um cunho mais objetivo e neutro. (...) De acordo com estes preceitos, que de certo modo, antecipam o que, mais tarde, se apelidará de 'historiografia metódica ou positivista', Herculano manifestou-se sem ambiguidades, a favor de uma clara destrinça entre a historiografia e a filosofia da história, convicto de que, tal como os seus mestres alemães, o conhecimento do passado só é verdadeiro se o historiador souber colocar-se numa posição de impassibilidade, imparcialidade e desnudamento das influências ideológicas, mesmo face a valores que lhe eram tão caros como o patriotismo.(...) Significava isto que o estudo da nossa história, segundo critérios modernos, requeria um levantamento aprofundado mais crítico das fontes e exigia o afastamento de preconceitos ( religiosos, políticos, etc.) que pudessem obstar à apreensão da verdade." (Fernando CATROGA, Alexandre Herculano e o historicismo romântico, In: A história através da história, p. 59-60) Em termos da crítica documental, Herculano atentava os contemporâneos para o cuidado em proceder à análise antes da preocupação com a síntese, dado que, no conhecimento histórico, a ânsia pela apressada generalização e universalização, exclusivamente por trilhas dedutivas, poderiam invariavelmente comprometer o resultado da pesquisa. ( Id. Ibid., p. 61-2 ).

${ }^{115}$ A dita geração moderna - nas palavras de Teófilo Braga - "procurou relacionar Portugal com o movimento estrangeiro, dando-lhe a conhecer as questões fundamentais do nosso século na ciência, na política, na literatura e na história" (TEÓFILO BRAGA, História da literatura portuguesa / volume V - O romantismo, p. 161)

${ }^{116}$ TEÓFILO BRAGA, História da literatura portuguesa / volume V - O romantismo, p. 161.
} 
Teófilo Braga entendia, porém, que era chegada a hora de o povo português deixar de reverenciar a autoridade espiritual deste ou daquele, criando códigos de um julgamento mais aprofundado e autônomo na população através de atos de democratização da vida pública, ou de mecanismos de divulgação de uma pedagogia da política e do debate acadêmico, histórico e filosófico, defendendo, por tais procedimentos, a substituição de homens legendários por dispositivos outros de compreensão intelectual. Cabia aqui a leitura, o contato com teóricos estrangeiros, as conferências... tudo o que fizesse por partilhar o acúmulo do conhecimento, tudo o que, em última instância, ensinasse.

Pinheiro Chagas ${ }^{117}$, por sua vez, também destacaria, como atributos inarredáveis de Herculano, a defesa da justiça e do direito contra qualquer manifestação de tirania. Inatacável por sua honradez, Herculano diferenciar-se-ia de Almeida Garrett por sua preocupação com o povo, um olhar entre distante e próximo que tinha como máxima finalidade a descoberta da verdadeira alma nacional. Herculano, enquanto narrador, não se reconhece partícipe do povo português, mas julga estar nele a essência da alma nacional; torna o povo sujeito e objeto de seu discurso e pensamento, sujeito e objeto de sua enunciação. Para Pinheiro Chagas, haveria nisso a tentativa de elucidação de leis históricas. A nosso ver, houve com Herculano um deslocamento quanto à interpretação da idéia de soberania, que talvez fosse, a partir de agora remetida à percepção dessa clivagem popular. Seja como for, com o relato de Herculano, o povo entraria na história que construíra:

\footnotetext{
"Herculano ia imergir-se no estudo do viver ignorado do povo, que ninguém conhecia quando a história era apenas o baixo-relevo em que figuravam no mesmo plano os personagens que a compunham. Garrett estudava na canção da camponesa que brotava nuns lábios risonhos a formação ingênua das lendas nacionais; Herculano decifrava pacientemente nos forais, escritos tantas vezes com sangue, a formação laboriosa do direito popular."118
}

\footnotetext{
${ }^{117}$ Manuel Joaquim Pinheiro Chagas cursou o Real Colégio Militar e foi lente no Curso Superior de Letras. Pertenceu ao Conselho de Sua Magestade; foi Ministro do Estado honorário, deputado às Cortes em várias legislaturas, foi sócio da Academia Real das Sciencias de Lisboa, da qual torna-se Secretário Geral quando morre em 1891 Latino Coelho. Escreveu como jornalista colaborador em inúmeras revistas, dentre as quais Innocencio destaca Archivo pittoresco, O Panorama, Revista Ilustrada, Illustração Portuguesa. Escreve ainda uma obra de cunho popular, dirigindo-se para as camadas menos ilustradas da população leitora. Innocencio diz que, dos 16 volumes desta referida coleção - publicada nos anos 70 - sob o título Educação popular: biblioteca instrutiva e amena, 12 seriam da autoria de Pinhiero Chagas. É protagonista da Questão Coimbrã, apresentando-se como partidário de Castilho, quando com veemência responde ao Bom-senso e bomgosto de Antero de Quental. Escrevendo Folhetim, a terceira peça da polêmica, Pinheiro Chagas dirá o seguinte sobre seu adversário: "Inovam o qu ? Inventam o quê? A filosofia de Hegel ? Os sistemas históricos de Vico ? A simbólica pagã de Creuzer ? O esclareciemtno da história pelo estudo da jurisprudência de Savigny? (...) Mas tudo isso já lá fora desceu das misteriosas alturas do saber de poucos para a erudição comezinha dos Dicionários de Conversação. Aplicaram pelo menos ao estudo das coisas pátrias os novos faróis acendidos pelos sábios estrangeiros, faróis que projetam a sua imensa luz nos mares tenebrosos do passado? Não; nem isso, a menos que os artigos do Sr. Teófilo Braga, que não dão um passo para além dos prólogos de Garrett, não sejam considerados como equivalentes aos trabalhos dos eruditos franceses e alemães! E por que não há de ser assim? (...) Mas o que tâm inventado então ? A forma talvez, o estilo, o fraseado, essa farraparia creio que ninguém lha reclama. Essas lantejoulas que tomam por estrelas, essa missanga que impingem por diamantes, essa baeta vermelha com que arramedam púrpura, tudo isso é seu, pertence-lhes... Que digo? Nem isso mesmo, nem na paródia foram originais (...)” [Manuel PINHEIRO CHAGAS, Folhetim, In: Alberto FERREIRA, Bom senso e bom gosto (a Questão Coimbrã), volume I, p. 254-5]. Há uma profusão de trabalhos estrangeiros que haviam sido traduzidos pelas mãos de Pinheiro Chagas. Innocencio referir-se-ia a Pinheiro Chagas como um dos mais laborosos e fecundos escritores de sua época, tanto pela qualidade do conteúdo de seus escritos quanto por seus dotes oratórios. Sua História de Portugal consta de 8 tomos e era muito citada no século XIX. Pinheiro Chagas foi ainda fundador do jornal Correio da manhã.

${ }^{118}$ Manuel Pinheiro Chagas, Elogio histórico do sócio de mérito Alexandre Herculano de Carvalho Araújo, p. 12.
} 
Na mesma direção, Antero de Quental ressalta a nobreza de caráter e a integridade impoluta de Herculano como a expressão mais acabada das idéias, do temperamento, da própria sensibilidade do homem português. Herculano tornara-se célebre pela análise política e pelo tom de profecia mediante o qual construía seu discurso histórico. ${ }^{119}$ Enquanto historiador - como anota Paulo Archer de Carvalho - Herculano procuraria o desenho da nação, os milhares de homens que se sobreporiam, na prática da história vivida, a duas ou três individualidades particularmente ilustres. A partir, como veremos, da constatação da decadência portuguesa, é que Herculano desenha o traçado possível da regeneração pretendida, traçado esse que passava, no conjunto, pelo contorno de uma escola voltada ao tempo e ao país do futuro. Muitas de suas teses seriam apropriadas por grande parte da intelectualidade portuguesa e, uma vez mais, nós nos perguntaríamos até que ponto seu modo de ver o tema do povo e da instrução na formação desse povo não teria deixado marcas profundas na atmosfera mental da sensibilidade coletiva portuguesa. ${ }^{120}$ Qualificando-o, em sua individualidade, como o representante singular da alma mais profunda da nação, disse Antero sobre seu predecessor:

"Na fisionomia moral de Alexandre Herculano, há certas linhas que fazem lembrar o perfil enérgico e simples dos heróis típicos da nacionalidade portuguesa. Pertence a essa grande linhagem, que acabou com ele - e o seu século, admirando-o, considerava-o todavia com um certo espanto ininteligente, como se sentisse vagamente que aquele homem pertencia a um mundo extinto, um mundo cujo altivo sentir ninguém já compreendia." 121

Olhando por outra direção, Oliveira Martins critica o individualismo de Herculano, individualismo esse calcado em todo um suporte teórico iluminista, kantiano. Martins julgava que Herculano - ao tomar a razão humana como fonte de todo desenvolvimento e o conhecimento como dispositivo natural para bem caracterizar a condição humana - teria seu pensamento estreitamente vinculado a uma ética liberal, calcada no individualismo em política e no livre-câmbio em economia. Para Oliveira Martins, deveria existir, pelo contrário, um princípio orgânico capaz de extrapolar o governo "das maiorias ignaras, dos números brutos" "22. Seduzido pelas doutrinas cientistas, combinadas a uma romântica vaga socialista, Oliveira Martins sugere a coesão social como oposição à fratura do todo no indivíduo liberal. Ao caracterizar a moral imperativa de Herculano, Oliveira Martins revela-se, entretanto, como os demais analistas, consciente da grandeza de propósitos do utópico Herculano:

"O livre-câmbio, proclamado como a melhor receita para criar a riqueza, era para Herculano, sobretudo, a melhor forma de a distribuir. Queria que as leis pulverizassem o solo, no qual não reconhecia outro valor senão o que o trabalho consolidara nele; e esperava que a concorrência, desembaraçada de todas as peias, criasse uma sociedade proudhoniana, em que todos fossem

\footnotetext{
119 Acerca do tema, indicamos o estudo de Paulo Archer de CARVALHO. Herculano: da história do poder ao poder da história, In: Revista de história das idéias 14/ Descobrimentos, expansão e identidade nacional, p. 513.

${ }^{120}$ Paulo Archer de Carvalho destaca também que Herculano, ao olhar a nação como um indivíduo moral estabelece a pedagogia como uma das chaves determinantes da regeneração pretendida; a instrução pública como condição primeira do progresso material. Nos termos daquele autor: "O referente educacional é de cariz iluminista: não há regeneração social sem regeneração das elites. E não há regeneração sem a reforma do estado, no sentido da descentralização, protagonizada pelas 'corporações' municipais, local de afirmação da cidadania ( o cidadão e não o súdito; o cidadão e não a sociedade) num quadro de conformação dos direitos constitucionais da pessoa humana e numa radical defesa dos direitos humanos atomisticamente conceptualizados" ( Paulo Archer de CARVALHO, Herculano: da história do poder ao poder da história, p. 504) ${ }^{121}$ Antero de QUENTAL, Alexandre Herculano, p. 12.

122 “(...) inconsequente, o individualismo não propõe, afinal, outra fórmula senão a do governo dos números brutos, das maiorias ignaras: que há-de propor, senão essa forma inexpressiva de uma força positiva indispensável à coesão social, desde que não há nas idéias um princípio orgânico?" (OLIVEIRA MARTINS,
} Alexandre Herculano, p. 80-81) 
capitalistas e proprietários. Como estóico, era um socialista; mas o seu socialismo realizar-se-ia pela liberdade, pela concorrência. E quando lhe contavam os casos repetidos, atuais, do sem número de monopólios de fato, nascidos, não das leis, mas sim da guerra natural econômica, ele parava, cismava e não respondia. Via-se que lá dentro lutavam a doutrina e a lucidez; e sem se convencer, sem mudar, aparecia o moralista invectivando os vencedores dessa luta donde ele esperava a justiça e donde apenas saía o dolo."123

Contrário à democracia, Herculano repele aquilo que julgava ser a conversão do homem em molécula. Temeroso dos possíveis efeitos da entrada do povo na história, o referencial da Revolução Francesa parecia-lhe emblemático. ${ }^{124}$ Suas reflexões sobre instrução pública derivariam certamente da premissa dessa irracionalidade popular como um perigo que sempre ameaça a democracia. Preparar o povo ordeiro, trabalhador, disciplinado, respeitoso, tornava-se, pois, tarefa precípua do educador das vontades coletivas, que, por definição, seria o intelectual. Por essa trilha, verificaremos, que o medo do povo, o reconhecimento de seu lugar histórico e a aposta na instrução popular seriam aspectos de um mesmo problema, no pensamento social de Herculano. Instruir multidões seria talvez o melhor antídoto contra a tentação revolucionária. E, seja como for - como recorda Adolpho Coelho - , Herculano reconhecia na Revolução Francesa o alicerce originário da proposta do ensino universal, o que o levaria, na prática, a defender a via das reformas institucionais como alicerce para o desenvolvimento e mesmo o progresso projetados. ${ }^{125}$ No parecer de Adolpho Coelho, Herculano haveria, talvez, se excedido ao conectar demasiadamente a instrução ao progresso industrial. Sob tal perspectiva, a crença de Herculano em um ensino de caráter politécnico decorreria fundamentalmente do diagnóstico acerca da decadência da sociedade portuguesa. ${ }^{126}$ A instrução, enquanto dispositivo contra o atraso, tomaria, pois, caráter instrumental, utilitário, já distante da proposta originária de Condorcet, que via na escola o caminho de preparação e capacitação das gerações jovens pela via da transmissão organizada e institucionalizada da cultura. Em Herculano, ao contrário, o conhecimento escolar não teria esse aspecto propedêutico, um valor em si e para si. A instrução escolar seria um veículo da prosperidade material e da superação da decadência através dessa prioridade dada à ordem da economia. Por tal razão, ao discorrer sobre a expressão pedagógica de Herculano, Adolpho Coelho repudiará aquilo que supõe ser instrumentalização política do ato educativo e dos anseios pedagógicos.

${ }^{123}$ Oliveira MARTINS, Alexandre Herculano, p. 83. Na correspondência que mantinha com Oliveira Martins, Herculano, já em Val-de-Lobos, buscaria defender sua perspectiva liberal, negando o socialismo e por vezes a democracia, para reafirmar sua crença na liberdade individual. Assim, em missiva datada de 10-12-1870, dizia o 'individualista': "As idéias democrático-republicanas tendem, pela sua índole, a apoucar o indivíduo e a engrandecer a sociedade, se é que eu as compreendo. É por isto que, nas trevas do seu pensar, a democracia estende constantemente os braços para o fantasma irrealizável da igualdade social entre os homens, blasfemando da natureza que, impassível, os vai eternamente gerando física e intelectualmente desiguais. É por isto que ela acreditou ter feito uma religião séria desse fantasma, quando o que realmente fez foi inventar a idolatria do algarismo; e, cobrindo com capa de púrpura a mais ruim das paixões, a inveja, enfeitou-a com um vago helenismo, cuja definição, seja qual for, nunca resistirá a uma severa análise" (Cartas de Herculano a Oliveira Martins, Oliveira Martins, op. cit., p. 115).

${ }^{124}$ A alusão implícita ao movimento perverso da irracionalidade democrática parece clara no prosseguimento da mesma carta, quando Herculano diz: "Nas democracias, a igualdade fabrica-se mergulhando-se as cabeças que se elevam e flutuam acima das vagas populares, na torrente das vontades irreflexivas e inconscientes que se precipitam para o imprevisto só porque as paixões as arrastam. E este mergulhar é eterno porque a realidade, a verdade natural, protesta eternamente contra ele” ( Id. Ibid., p. 116)

125 Adolpho COELHO, Alexandre Herculano e o ensino público, p. 62.

126 “(...) os imperativos da crítica documental coexistiram com uma ordenação teleológica do tempo: o presente seria mais pobre do que o passado paradigmático, mas ambos seriam uma espécie de períodos sacrificiais necessários ao advento de um futuro melhor. (...) Dentro desta lógica, o período decadentista surgia como uma espécie de experiência histórica transitória, mas fundamental, para se passar da variedade sem unidade, típica da vida medieva ( em que as nações somente existiam entre si ), para a variedade unificada, que as nações modernas teriam de cimentar a fim de conseguirem o equilíbrio superior das suas crises." (Fernando CATROGA, Alexandre Herculano e o historicismo romântico, In: A história através da história, p. 82). 
Maria de Lourdes Costa Lima dos Santos reconhece em Herculano um dado pendor para a causa do povo, embora destaque o fato de ele situar, como Garrett, no passado seu "tempo social de referência" 127 ; passado no qual a Idade Média é posta como o período de glória, ao qual necessariamente se seguiria o decadentismo. Joaquim Veríssimo Serrão comentará a esse respeito, indicando que: “A concepção histórica de Herculano era contrária à expansão ultramarina por entender que a nação vivera na Idade Média o seu período de glória, quando a ação dos reis anteriores ao absolutismo e a força regional dos municípios haviam fortalecido o organismo português." 128

Veríssimo Serrão destaca em seu estudo a liderança acadêmica que Herculano obteve em Portugal, a ponto de Ramalho Ortigão chegar a se referir ao isolamento a que voluntariamente ele se impusera no final da vida como "um fato social, e dos mais tristes fenômenos da decadência portuguesa" "129. Herculano foi, a seu tempo, um marco intelectual, um guia, cuja referência era, como vimos, por todos reconhecida. Como historiador, acreditava na existência de uma "índole nacional", mediante a qual se expressaria o espírito do povo e as próprias feições morais da alma de cada nação. Nessa medida, entendia o estudo da história como uma possibilidade viva de retirada de lições do passado, voltadas para o presente. ${ }^{130}$ Romântico em literatura, era iluminista quando abordava o problema da instrução. Seu liberalismo embaraçado negava a alternativa democrática. O substrato de seu parecer político visualizava-se no modo pelo qual discorria acerca do tema da instrução pública, onde surgirão - com bastante nitidez - os aspectos relativos ao povo, à nacionalidade; e, fundamentalmente, ao contrário de seus escritos históricos e literários, ali ele falava inquestionavelmente voltado para o futuro. O século XIX, que é por definição o século de desenhar esse futuro nacional, no caso português parece preso irremediavelmente ao passado. O discurso da educação, qualquer que seja ele, tem por sujeito e objeto enunciativo o caminho do futuro. Por ser assim, julgamos ser politicamente relevante essa vistoria nos temas através dos quais a intelectualidade portuguesa pensava o problema da pedagogia.

\section{A OBRA DE HERCULANO E SEU CARIZ PEDAGÓGICO}

Os especialistas ressaltam a relevância da edição dos Opúsculos, efetuada por Herculano, a pedido dos editores da Bertrand no último quartel de sua vida. ${ }^{131}$ Ao abordar no

\footnotetext{
${ }^{127}$ M. L. Costa Lima dos SANTOS, Intelectuais portugueses na primeira metade de oitocentos, p. 57. No parecer dessa autora, a opção popularizante de Herculano envolvia reforma de propriedade e reforma administrativa, aliadas a uma recusa do sufrágio universal. Veremos como se poderia nisso acrescentar seu projeto de reforma da instrução.

${ }_{128}$ Joaquim Veríssimo SERRÃ̃, Herculano e a consciência do liberalismo português, p. 61.

129 Ramalho ORTIGÃO, apud, Joaquim Veríssimo SERRÃO, Herculano e a consciência do liberalismo português, p. 61.

130 "'A luz da mediação presentista inerente a todo o estudo do passado, a definição da idiossincrasia da 'alma nacional' adequava-se otimamente à estratégia apostada em legitimar historicamente a refundação de uma nação, que, estando decadente, necessitava de se regenerar. E o argumento histórico, ao justificar os períodos de apogeu (e de queda) definia quadros paradigmáticos. Neste horizonte, a suposição dessa entidade metafísica chamada alma, espírito ou índole do povo, por mais cientista que fosse a sua caracterização, remetia para uma visão essencialista de história. Esta aparecia como a explicitação diacrônica, com avanços e recuos da índole da Nação, e os seus grandes ciclos são elevados a modelo, a reatualizar, por comparação e analogia, ou a evitar, quando é exemplo de desarmonia e de decadência. De certo modo, pode mesmo afirmar-se que a índole funciona como uma espécie de substância sempre onipresente à própria história, fundamento a-histórico da historicidade da Nação" (Fernando CATROGA, Alexandre Herculano e o historicismo romântico, In: A história através da história, p.69-70)

${ }^{131}$ Acerca dessa publicação, Herculano acreditava - como destaca Veríssimo Serrão - que "esses trabalhos talvez pudessem contribuir para esclarecer o seu itinerário mental, pois eram o espelho de uma época de rudes combates em prol das idéias que lhe haviam forjado o caráter (...) Fugindo ao plano cronológico, Herculano
} 
tomo VIII de seus Opúsculos, o tema da instrução popular como questão pública, Herculano advogaria a universalização do ensino como reforma necessária ao processo civilizatório, contraponto imprescindível da indesejada e nefasta revolução. A escola, fonte de prosperidade coletiva, agiria como alicerce da edificação do bem comum. Nos termos de Herculano, tal necessidade imperativa já se desenhara no continente europeu:

\begin{abstract}
"A revolução francesa do fïm do século passado, no meio de seus crimes, das suas vertigens, dos seus disparates, proclamou grandes verdades; e sobre a terra ensangüentada por ela, lançou as sementes dos mais profundos princípios sociais. Foi ela quem primeiro considerou a instrução à luz da nacionalidade; que primeiro a saudou como uma garantia individual; como uma dívida do estado para com os seus membros: foi ela quem primeiro disse - a república deve dar aos cidadãos uma instrução geral." 132
\end{abstract}

Conferindo à Revolução em França uma identidade de inauguração de uma nova era, é, entretanto, com receio que Herculano pontua sua referência, posto que, em nome da liberdade dos povos, ela teria acionado o recurso à violência e à tirania. O caminho de Portugal não deveria, por tal razão, confundir-se com esse percurso francês, embora fosse necessário apropriar-se de muitas de suas insígnias até para adequá-las a uma via diferenciada. Para superação do regime antigo, para regeneração do país decadente, a reforma intelectual surgia como uma estratégia prioritária de engendramento dos tempos novos, através do artefato das gerações que preencheriam o futuro - esse futuro que não se sabia dizer ao certo como seria, mas que certamente não se deveria confundir com os percalços franceses. Tendo em vista - aos olhos do intelectual - proporcionar a "felicidade futura", fortalecer o poder municipal contra as ingerências centralizadoras e "auxiliar a religião a moralizar o país", diminuindo a necessidade de "leis violentas", caberia à instrução pública a manifesta tarefa de prevenção dos desvios sociais, de conformação de corpos e mentes dóceis, ciosos da mais harmoniosa ordenação social.

Por outro lado, na trilha da tradição das luzes, a aquisição do conhecimento coincidiria, no plano individual, com o ato da libertação, da dignificação de si próprio e de cada um perante o juízo da vida social tomada como existência coletiva. ${ }^{133}$ Mas para que isso pudesse efetivamente ocorrer, não bastava o ensino escolar do 'ler, escrever e contar'. Era necessário um corpo de saberes elementares que se mostrasse capaz de efetivar uma preparação mais global, ou, pela reflexão de Herculano, havia de se estabelecer dois níveis de ensino complementares, embora não necessariamente dependentes. Analisando os diversos países que haviam já estruturado estratégias de escolarização, Herculano atenta para o fato de estes haverem obtido êxito, fundamentalmente, quando ofereciam dois níveis de escolarização: um, elementar, necessário à vida pública e à felicidade do país; outro, superior, necessário à felicidade individual... Dois modelos de instrução, o primeiro obrigatório e o segundo facultativo, embora também universal. Nas palavras de Herculano: “a primeira

preferiu dividir os Opúsculos em três grandes corpos, dedicados respectivamente às questões públicas, aos estudos históricos e à literatura. Cada tomo seria autônomo no que respeita ao conteúdo, solução que lhe agradava, na medida em que os estudos, uma vez corrigido o seu texto, podiam ser logo impressos para não atrasar a publicação gradual da obra." (J.V.SERRÃO, Herculano e a consciência do liberalismo português, p. 240-241)

${ }_{132}$ Alexandre HERCULANO, Opúsculos /Tomo VIII - Questões públicas, p. 108.

133 "Só ela [ a instruçao ] pode, enfim, desenvolvendo as faculdades dos cidadãos, habilitá-los para conhecerem os seus verdadeiros interesses, para desempenharem os seus deveres públicos e domésticos e, favorecendo o acréscimo da indústria, para aumentar a riqueza e promover o engrandecimento da nação. Considerada como garantia individual, a instrução primária realiza o direito que tem qualquer cidadão de aperfeiçoar o seu entendimento, não só para se ajudar desse aperfeiçoamento no gênero de indústria a que se destina e pela qual obtém o pão quotidiano, mas também para poder avaliar o estado das coisas públicas, os atos e as opiniões que governam e legislam, erguendo-se assim de feito à dignidade de homem livre" (Alexandre HERCULANO, Opúsculos / Tomo VIII - Questões públicas, p. 120-122). 
representará o direito da república, a segunda o de cada um de seus membros". ${ }^{134}$ No parecer do autor, entretanto, um projeto de instrução, qualquer que fosse ele, deveria, antes de mais nada, versar sobre temas variados capazes de percorrer toda a complexidade que o estudo aprofundado da questão exigia, em um país onde a escola era ainda apenas uma possibilidade futura. Nessa medida, "matéria da instrução; organização das escolas; métodos de ensino; (...) concorrência, a capacidade e ao mesmo tempo a sustentação dos professores; direção das

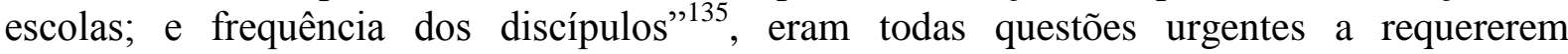
dispositivos legais imediatos. Em virtude disso, Herculano reconhece a necessidade de o analista identificar os principais problemas do Estado, tanto material, quanto política e moralmente falando. A ausência de organização e de projeto é sempre destacada por aquele que diz que "a chamada instrução primária é em Portugal mais uma palavra e uma verba de orçamento que outra coisa"136. Herculano vê a necessidade de a escola se adequar às novas condições necessárias ao país, com o desenvolvimento do trabalho e da indústria. Aqui essencialmente assumia o tom pragmático de quem diz ter problemas a resolver:

\begin{abstract}
"Vemos, pois, que no maior número de países onde as questões d'instrução nacional têm sido meditadas e acertadamente resolvidas, onde a ilustração tem produzido ao mesmo tempo o aumento da moralidade pública e o da indústria e riqueza, a autoridade não se tem limitado a propagar o ensino do ler e escrever, porque por si só não resolvia o problema. A necessidade de o completar sente-se por toda a parte, e o seu complemento está nas escolas superiores de ensino geral.",137
\end{abstract}

Desconfiado, como já expusemos, do percurso das democracias na Europa, Herculano desejava fortalecer o nível intelectual do povo português, o que se depreende de suas reflexões sobre as bases da instrução pública em seu país. Para Herculano, o intento da gratuidade escolar para todas as crianças parecia aspiração pueril, assim como os ditames estabelecidos acerca do tema da obrigatoriedade escolar. Reticente quanto à legislação, é com relutância que o intelectual aceita dados dos ministérios, quando estes, contrariando quaisquer evidências empíricas, revelavam aumento da demanda e da oferta do ensino. Para Herculano os números publicados a respeito da situação da escola naquele princípio da década de 40 não eram mais do que "prosperidades mentidas". Além disso, pondera o autor:

“É inegável que o número de cadeiras primárias foi aumentando (...) Mas cumpria antes de afirmar
que isto produzira um aumento d'instrução, um maior derramamento do ensino, examinar quantas
das antigas escolas têm deixado de ser providas; se o número de alunos aumentou em realidade e,
dado esse caso, se aumentou na proporção das novas cadeiras em exercício; se os mestres são mais
hábeis que d'antes; se os métodos de ensino têm sido melhorados; se a assiduidade dos que
ensinam principalmente nos distritos rurais, é maior; ou se, pelo contrário, a prolongação da
frequência dos alunos, em consequiência do desleixo dos mestres, não encobre a diminuição das
matrículas anuais. Era com o conhecimento de todas estas circunstâncias que se poderia assentar
um juízo seguro sobre tal matéria e, se as informações particulares que por nossas diligências

${ }^{134}$ Alexandre HERCULANO, Opúsculos / Tomo VIII - Questões públicas, p. 148. Rogério Fernandes procura as dimensões políticas e as implicações ideológicas do pensamento educacional de Alexandre Herculano, dizendo o seguinte: "As necessidades da economia nacional, concretamente do capitalismo industrial em agrário em ascensão, influíam-no com força pelo menos idêntica à sua consideração dos pequenos e médios proprietários rurais e dos artífices e operários, cujo diminuto grau de educação e instrução impedia ou dificultava a respectiva aculturação técnica. Relacionando o progresso econômico e social da Europa com os avanços da ciência e da técnica, Herculano antecipava-se, em certos aspectos das suas censuras, ao nosso tempo, quando condenava o mero adestramento profissional em detrimento de uma educação e instrução populares autênticas, firmadas em bases científicas e culturais e capazes de responder à mobilidade profissional." (Rogério FERNANDES, O pensamento pedagógico em Portugal, p. 106).

135 Alexandre HERCLANO, Opúsculos / Tomo VIII - Questões públicas, p. 141.

${ }^{136}$ Alexandre HERCULANO, Opúsculos / Tomo VIII - Questões públicas, p. 125

${ }^{137}$ Alexndre HERCULANO, Opúsculos / Tomo VIII - Questões públicas, p. 152. 
temos podido obter não são falsas, o exame de tais circunstâncias nos destruiria essas esperanças enganosas, essas prosperidades mentidas. Os inconvenientes de que é cercada a laboriosa vida do magistério elementar, vida de abnegação e estreiteza, espécie de sacerdócio que, semelhante ao das primeiras eras do cristianismo, requer a mais heróica resignação em uma existência de tédio, de obscuridade e de pobreza, têm aumentado com o prospecto de miséria que hoje apresenta essa humilde carreira. (...) Assim só a extrema miséria, a desesperação da fome pode arrastar um indivíduo que saiba ler e escrever a sepultar-se numa aldeia remota e pobríssima para aí morrer lentamente à míngua. Muitas vezes acontece estar aberto o concurso para uma cadeira primária durante meses e só no fim aparece algum raro concorrente, na maior parte dos casos completamente inábil, mas que é provido quase sempre porque as autoridades propostas a esse negócio entendem, e bem, que mais vale que o povo aprenda a ler pouco e mal que absolutamente nada. Então o desgraçado homem, desgraçado intelectual e materialmente, lá se encaminha para a escola rústica, onde não tarda a experimentar a um tempo a dificuldade de ensinar e a de subsistir. Obrigado a ganhar o pão por outro modo, abandona os seus alunos ou afugenta-os; e, como ninguém se interessa em que a escola floresça, porque o nosso povo ainda não crê nem levemente nos benefícios da instrução, o governo fica enganado, supondo que existe uma escola onde apenas há um indivíduo que goza o título honorífico de mestre. Nós sabemos de certa povoação onde o professor se converteu em ferreiro; e o mais é que andou avisado porque, assim, esquiva-se a morrer à fome." 138

Para Fernando Catroga, a concepção que Alexandre Herculano faria da decadência portuguesa seria o alicerce condutor de todos os seus escritos. Para o caso português, a decadência coincidiria fundamentalmente com a etapa renascentista, que teria conduzido Portugal do pico mais elevado da glória à ruína do império colonial. Além disso, teria sido o próprio absolutismo, com a destruição das municipalidades e das liberdades medievais em nome do perverso poder central, quem ocasionou o "desvio do percurso que a sociedade portuguesa devia ter percorrido para espontânea e naturalmente objetivar a sua índole." 139

Em certa medida, poder-se-ia dizer que a preocupação de Herculano com a instrução pública era derivada de suas intensas e incessantes preocupações com o destino coletivo de um país que perdera sua vocação. Aquilo que a aventura marítima deitara por terra, talvez a cultura pudesse então resgatar. Por acreditar que os povos mais desenvolvidos do continente europeu foram os que apostaram nos benefícios da instrução primária, Herculano enxerga o tema da escola com olhar de homem público, preocupado, por um lado, com a possibilidade de aperfeiçoamento do indivíduo e, por outro, com a capacitação coletiva para um consciente exercício da cidadania e da vida do trabalho. Entrar para o seleto mundo da cultura significaria uma pausa na dimensão do espontâneo travada fundamentalmente pela ruptura com a condição do popular; significaria, portanto, afastar-se da tendência das multidões ignorantes.

O edifício nacional deveria ser escrupulosamente erguido - como comenta Herculano em suas Composições várias - a partir dos cômodos que estivessem logo à entrada; em outras palavras, pelos aposentos reservados à escola. ${ }^{140}$ A carência de instrução poderia inclusive cristalizar-se como um elemento de perturbação e desequilíbrio da ordem

\footnotetext{
${ }^{138}$ Alexandre HERCULANO, Opúsculos / Tomo VIII - Questões públicas, p. 120-122.

${ }^{139}$ Fernando CATROGA, Alexandre Herculano e o historicismo romântico, In: A história através da história, p. 81. De acordo com Catroga, Herculano entendia como puramente negativo o valor real da dita glória dos descobrimentos e das conquistas marítimas. "Com esta tese, em que são responsabilizados a centralização política, a aventura colonial e o centralismo católico e inquisitorial ( com suas nocivas consequências econômicas, políticas e morais ), Herculano fixou um dos diagnósticos mais controversos sobre a história de Portugal que, daí para a frente, será um ponto de referência obrigatório nas interrogações sobre o nosso destino." (Id. Ibid., p. 81).

${ }^{140}$ Herculano coloca essa imagem nas seguintes palavras: "Tal erro consiste em edificarem sobre um terreno de vasa e em adornarem primorosamente as casas e os aposentos, sem abrirem no exterior entradas por onde haja acesso para o edifício. Este edifício é o da instrução pública”"(Alexandre HERCULANO, Composições várias, p. 33).
} 
social das demais instituições. Ao capacitar o indivíduo para a vida prática, a escola o induziria a aceitar sua condição de origem, ainda que, no âmbito individual, ele pudesse sonhar ultrapassá-la. Herculano desenha um retrato de sociedade, no qual, ainda que mantida a aristocracia, a elite governante deveria obter tal destaque e privilégio primordialmente mediante o crivo do talento. Há aqui o deslocamento burguês da noção de fidalguia e da própria acepção da nobreza:

\begin{abstract}
"Siga a charrua o que nasceu junto dela; as artes e a indústria, o filho do artista e do fabricante; cuide o proprietário dos bens que seus pais lhe herdaram; mas nenhum destes seja doutor, só porque teve meios de cursar a universidade ou as outras escolas superiores. Para isto só quereríamos a aristocracia... Mas de que aristocracia cuidais vós de que falamos? - Da do nascimento? - Miserável opinião fôra essa! - É a aristocracia do talento e do gênio, a aristocracia da natureza, aquela que nem tiranias da plebe poderão aniquilar e que, ainda que o não pareça, em todos os tempos e lugares dominará a sociedade.."
\end{abstract}

Cioso da necessidade da democratização da instrução particularmente em seu nível primário, Herculano critica os métodos habitualmente utilizados na escola portuguesa de primeiras letras, onde, após os primeiros elementos introdutórios no idioma pátrio, o aluno se defrontaria com complexos estudos de Latim, uma "língua de um povo que desapareceu há mais de um milheiro de anos" "142. A escola com que Herculano sonhava não era, porém, como vimos, a escola portuguesa. Essa pecava pela ausência de organização e o intelectual se perguntava em que medida adiantaria reformá-la... Havia que se projetar outro referencial para a instituição educativa, capaz de adequar-se aos padrões exigidos pela civilização européia. A escola portuguesa, sob esse aspecto, era absolutamente inadequada e em desacordo com aquilo que os tempos pareciam exigir. Preocupado também com os limites e as possibilidades da legislação perante o desafio de uma rede de escolas uniformemente estruturada pelo território nacional, Herculano pondera sobre a necessidade de se ter em conta diversidades regionais que perpassavam da geografia aos costumes. ${ }^{143}$ A boa lei seria - aos olhos do intelectual - não aquela efetuada por imitação e amálgama de outras experiências de povos alheios; mas antes a que se revelasse capaz de acomodar-se ao modo de ser nacional, em suas similitudes e em seus contrastes.

\footnotetext{
${ }^{141}$ Alexandre HERCULANO, Composições várias, p. 39.

142 Alexandre HERCULANO, Composições várias, p. 40. Na sequência, o autor diz o seguinte: "dez anos depois de a ter metido na cabeça, ninguém se lembra, salvo de traduzir gaguejando algum trecho de latim ou grego, traduzido e impresso em língua vulgares de há muito tempo” (Id. Ibid. , p. 42).

${ }_{143}$ "Se há país onde seja necessário atender constantemente às circunstâncias particulares do seu estado material, é este em que vivemos. O caráter industrial da nação é principalmente o da indústria agrícola: a povoação não é proporcional à extensão do território: os acidentes do nosso solo são variadíssimos, pode-se dizer que Portugal é um país de montanhas: carecemos absolutamente de meios de comunicação interna: eis as grandes dificuldades materiais com que uma lei de instrução geral tem de lutar. As dificuldades morais não são menores e porventura que a maior parte dela nasce da inércia da ignorância que ela tem de combater. Tudo o mais é comparativamente fácil de obviar: mas pelo que toca a esses embaraços, a lei não pode fazer mais do que aceitá-los, provendo em que as suas fatais consequências produzam o menor dano possível; e mais pode ainda fazer nesta parte a ação administrativa que as melhores providências legais. É por isso que se torna absoluta necessidade deixar ao arbítrio das autoridades encarregadas da direção das escolas o resolverem muitas coisas que pertenceriam à lei, se não fosse impossível uniformizar completamente o sistema de ensino num país onde acontece serem os costumes, a indústria, o caráter dos habitantes duma província tão diversos do gênero de vida, índole e hábitos dos doutra, quanto talvez o aspecto e natureza do solo de cada uma delas são diferentes e talvez opostos entre si. A exequibilidade é a primeira virtude de qualquer instituição e a exequibilidade de uma lei de instrução nacional só pode resultar de nunca deixar o legislador esquecer esse pensamento fundamental da variedade na unidade, que deve presidir à feitura da mesma lei" ( Alexandre HERCULANO, Opúsculos / Tomo VIII - Questões públicas, p. 141-142).
} 
A escola portuguesa, que - no parecer do legislador ${ }^{144}$ - nada ensinava quanto à religião, vida civil, mundo físico e moral, não contemplava as exigências de um século no qual o impulso vital seria justamente o aproveitamento das conquistas postas no campo da razão. Herculano vê no século XIX a urgência de se estruturar a reforma da escola até como estratégia de demarcação do território da nacionalidade. Ao pensar a História, falava na nação quase no passado; aqui seria talvez o contraponto... Crítico das reformas pedagógicas, que se haviam revelado sempre inócuas, era com preocupação que Herculano atribuía à instrução muitas das mazelas corruptoras do tecido social. As multidões, responsáveis em grande parte por mudanças, não teriam sido afinal contempladas pelo universo da ilustração. O mundo do conhecimento e a fruição que poderia nesse mundo obter o que soubesse desfrutar de suas aquisições intelectuais eram até então matéria reservada, como se a sociedade estivesse repartida em castas intransponíveis:

\begin{abstract}
"Antes de se haverem espalhado na Europa as luzes e os conhecimentos, o povo nada era, e servia, unicamente, para satisfazer as paixões torpíssimas daqueles que gozavam do exclusivo privilégio do mando. Foi a instrução quem enobreceu certas classes, que até aí eram abjetas e grosseiras, como ainda o continuaram a ser outras classes inferiores. Delas saíram os homens que hoje governam e os que plenamente gozam dos benefícios da civilização. Estas classes bem longe estão de quererem voltar ao seu primitivo aviltamento e miséria. Por que se recusaria, pois, às classes inferiores, a fruição das mesmas vantagens e a possibilidade de melhorar a sua situação? Não é isto menoscabar todos os sentimentos de humanidade e calcar aos pés a moral e a religião que fingimos professar?",145
\end{abstract}

A idéia de um bem estar social tributário do discurso iluminista, a uma dada altura, cola-se a essa defesa intransigente da instrução elementar, universalizada para o conjunto dos indivíduos. A perspectiva da multidão surge como ameaça desagregadora e é posta por Herculano como efeito provocado parcialmente por aquele já constatado descaso pela instrução. O povo-multidão aterroriza ao trazer consigo o potencial da revanche social, contrariando o processo civilizatório. O povo, embora havendo contribuído para a consolidação do mesmo processo, teria sido dele antes excluído do que incorporado.

Ao reportar-se a outros países (considerados mais adiantados) para falar de escola, Herculano recorda a lei francesa e prussiana quanto aos dispositivos concernentes à estruturação administrativa e curricular da escolarização tanto elementar quanto secundária e superior. O complemento do ler e escrever seria, como vimos, a propagação de um modelo escolar capaz de fazer prosperar a indústria e a riqueza nacional. Em função disso Herculano sugere a grade curricular apropriada àquela finalidade de uma política social a principiar pela população infantil. Pela sugestão, verifica-se a indução de quadros e julgamentos civis, morais e religiosos capazes de compor o mosaico desejado para o conjunto dos saberes recomendados por tal pedagogia:

"O ensino geral elementar deve abranger: $1^{\circ}$ ) A leitura de impressos e manuscritos; $2^{\circ}$ ) A escrita; $3^{\circ}$ ) Os princípios de aritmética até a regra de três, inclusive; $4^{\circ}$ ) $\mathrm{O}$ catecismo religioso; $\mathrm{O}$ ensino geral superior deve abranger: $1^{\circ}$ ) A gramática portuguesa e os exercícios de ler e escrever corretamente, servindo de textos para leitura e temas o Novo Testamento; $2^{\circ}$ ) Os elementos de história pátria e de geografia; $3^{\circ}$ ) A aritmética completa, os elementos de geometria e as suas aplicações usuais, especialmente o desenho linear e as noções mais necessárias de agrimensura;

\footnotetext{
${ }^{144}$ Publicada sob o título de Instrução pública, a reflexão aqui desenvolvida, que viria a ser incluída no tomo VIII dos Opúsculos, foi escrita sob a forma de artigos para a imprensa de setembro a novembro de 1841 - no periódico $\mathbf{O}$ constitucional - durante o período em que Herculano ocupava lugar na Câmara como deputado. ${ }^{145}$ Alexandre HERCULANO, Composições várias, p. 57.
} 
$4^{\circ}$ ) Os rudimentos de física e com especialidade os de mecânica, os princípios de química aplicada às artes, os elementos de botânica aplicada à agricultura e idéias gerais sobre higiene popular." 146

Percebe-se aqui o intuito de Herculano quanto à substituição de um sistema de escolarização propedêutico, herdeiro das humanidades clássicas, em prol de uma opção que privilegiaria o conhecimento de cunho prático. Este, por sua vez, objetivaria a utilidade social, fundamentalmente no que concerne à agricultura e ao aprimoramento das técnicas de plantio. Em Herculano, reconhece-se a suposição da vocação agrícola de Portugal, a ser respaldada por esse necessário conhecimento da agrimensura e da botânica. O ensino de caráter politécnico apresentava-se assim como a grande esperança de deter o longo e persistente período decadentista no qual o reino se enfronhara. Para Herculano, a estrutura que orientava a instrução secundária quase que exclusivamente como fonte de preparação para a carreira universitária revelaria o descompasso de um país que não se fizera capaz de acompanhar o ritmo dos tempos: ao formar um excessivo contingente de doutores em uma terra incapaz de lidar com os desafios postos por técnicas agrícolas renovadas, Portugal não soubera identificar, na inflexão da história, o domínio que a classe média, a pouco e pouco, passaria a exercer. Fortalecer a economia nacional seria, então, pressuposto para superar o domínio das arcaicas e desajustadas fidalguias, em um tempo no qual o reino perdera já sua grande fonte de sustentação, materializado nas riquezas extraídas do Brasil. Naquela época, recorda Herculano:

\begin{abstract}
"O tesouro do Estado substituía a ação dos homens. com agentes espertos para vender diamantes na Holanda e obreiros hábeis para cunhar ouro nos paços da moeda, estavam supridos trabalho, instrução popular, atividade, tudo. Era aquela uma época brilhante; mas passou. De quanto possuíam nossos avós, só resta uma tradição saudosa, o atraso industrial e a triste realidade da miséria pública. Cumpre-nos aceitar esta com hombridade, isto é, resignados e resolvidos a recuperar com o trabalho o que perdemos com o ócio. As conquistas não voltarão mais porque já não há novos mundos para devastar e as nossas esperanças devem dirigir-se para um solo fértil, visitado pela bênção de Deus; para a inteligência nacional, de que a providência não foi escassa conosco. Para converter aquela em manancial de riqueza e esta em instrumento de prosperidade, é mister acomodar às necessidades presentes o sistema de instrução pública; e do que fica dito me parece deduzir-se com evidência que o atual, nos seus caracteres essenciais, é inteiramente contrário a essas necessidades."147
\end{abstract}

Lembre-se que era também por seu anticlericalismo que Alexandre Herculano defendia com tanta veemência uma escola nacional. As ordens religiosas eram por ele percebidas como naturalmente contrárias a esse tipo de educação, radicada sobre bases intrinsecamente anticongregacionistas e anti-ultramontana. Reformar a escola era reformar a tradição herdada de tempos sombrios de jesuitismo e inquisição.

A urgência quanto à reforma da instrução secundária exigiria, à luz do exposto, contemplar os interesses das camadas laboriosas da sociedade. Tais escolas deveriam ser estruturadas mediante o exemplo profissional da escola politécnica, cujo projeto, ao ser

\footnotetext{
${ }^{146}$ Alexandre HERCULANO, Opúsculos / Tomo VIII - Questões públicas, p. 150-151.

147 Alexandre HERCULANO, Da escola politechnica e do collegio dos nobres, p. 10. Sobre o histórico da mentalidade de uma nobreza refratária à instrução, o autor recorda as idades da pátria: "A guerra era a idéia que representava a meia idade: ela gerou as cruzadas; as cruzadas geraram a navegação e a navegação produziu os descobrimentos e conquistas donde nasceram o comércio e a indústria da moderna Europa. Idéia progressiva era pois essa; e o nobre que se envergonhava de saber ler e escrever tinha nisso tanta razão relativamente à sua época, quanta hoje tem o mais obscuro cidadão em exigir da sociedade que dê gratuitamente a seus filhos a instrução primária, chave com que eles poderão abrir o vasto repositório do sustento do espírito”. (Id. Ibid. , p. 7)
} 
ampliado - democratizando o acesso a esse nível complementar de instrução - poderia contemplar a própria formação de mestres de escolas primárias superiores. Em virtude disso, julgava-se proceder à "regeneração intelectual e moral do povo português" ${ }^{148}$, lembrando que a consolidação das escolas primárias superiores se apresentava como "necessidade do século" - para utilizar a expressão de Herculano. Sob tal ponto de vista, "propriedade de todos; do nobre e do humilde; do abastado e do pobre"149 - dever e direito individual e social - , a escolarização assim constituída, só não era ainda exigida à força pelas multidões porque estas permaneciam envoltas na ignorância que lhes impedia de reconhecer a instrução como edifício por excelência da prosperidade e da "felicidade de seus filhos".

Herdeiro da tradição religiosa do iluminismo português, é com desconfiança que Herculano avalia a escola laica preconizada pela França revolucionária, preferindo adotar o enfoque da lei prussiana, onde o aprendizado da moral estaria profundamente vinculado a um catecismo religioso, posto como primeiro guia diretor da formação da meninice. É assim que, nisso, o católico assume a perspectiva luterana, resguardando por ela o lugar do Estado secular como o grande pastor da instrução:

\begin{abstract}
"Guardai as vossas doutrinas de sábios para o orgulho da ciência: para os pequenos e ignorantes, basta o catecismo. O evangelho é mais claro e preciso que os volumosos escritos de todos os moralistas e filósofos desde Platão até Kant: a moral que não desce do céu nunca fertilizará a terra. É nossa opinião que nesta parte do ensino geral, tanto elementar como superior, se não admita mais do que um bom catecismo e a Bíblia, para que logo na infância se não incuta aos homens a errada idéia de que é possível separar duas coisas que realmente são uma só: religião e bons costumes." 150
\end{abstract}

Ao insistir na necessidade de um ensino primário superior complementar à escola dos saberes elementares, Herculano argumenta explicitando que, nessa primeira etapa, a escolarização não traria qualquer proveito individual, revelando apenas a capacitação dos membros da coletividade para o exercício da cidadania, para ocupação de cargos gratuitos do município ou da paróquia, como jurados; enfim, "limitada assim a instrução, a lei que a propagar e tornar obrigatória será da parte da sociedade uma lei egoísta, uma lei de sacrifício sem compensação; e não admira que o espírito público reaja contra o que ela tem de tirania" 151. Seria por tal razão - continua Herculano - que os pais compreenderiam como um ônus a instrução elementar oferecida a seus filhos. Esta, posta como um "malaventurado presente", era identificada antes como um fardo que acarreta encargos sem qualquer compensação do que como fonte liberadora de proveitos individuais. $\mathrm{O}$ país deveria compensar essa habilitação necessária dos homens para o cumprimento dos deveres públicos (ensino elementar) com um outro nível de escolarização, de utilidade - este sim - individual e imediata. As escolas primárias superiores existiriam justamente para permitir a cada um colher os frutos da ilustração. ${ }^{152}$

\footnotetext{
${ }^{148}$ Alexandre HERCULANO, Da escola polythecnica e do collegio dos nobres, p. 11.

${ }^{149}$ Alexandre HERCULANO, Da eschola polythecnica e do collegio dos nobres, p. 11.

${ }^{150}$ Alexandre HERCULANO, Opúsculos / Tomo VIII - Questões públicas, p. 154.

151 Alexandre HERCULANO, Opúsculos / Tomo VIII - Questões públicas, p. 157.

152 "E como perceberá o povo que a ilustração é a fonte caudal de todo o bem, se os frutos imediatos que dela se colhe são só de trabalho e opressão? Os silogismos do vulgo raras vezes são falsos em si, mas o que o vulgo não sabe é juntar uma série deles para chegar à verdade. Por isso debalde lhe bradareis que enquanto se não instruir será desgraçado e opresso. Partindo dos fatos que vê e experimenta, responder-vos-á que mentis e esses fatos isolados põem evidentemente da sua parte a razão. Daqui a necessidade de compensar com o ensino de utilidade individual e imediata, o ensino cujo alvo principal é o habilitar os homens para o desempenho dos deveres públicos. $O$ que temos dito a este respeito prova que tal compensação é não só dever, mas um bom cálculo político”. (Alexandre HERCULANO, Opúsculos / Tomo VIII - Questões públicas, p. 160-161)
} 
Até certo ponto, a organização das escolas representaria uma medida de caráter público, como se fosse uma reforma da ordem institucional, voltada, entre outras coisas, para precaver a possibilidade da revolução. É assim que o tema da escolarização surge em Herculano tantas vezes acoplado às suas versões da Revolução Francesa. Havia que se ajudar o caminho da civilização para que este perfilasse de fato a rota da perfectibilidade, que, por sua vez, era - ela também - uma bandeira do iluminismo. Para Herculano, a desarmonia entre o discurso e as práticas sociais, entre o plano das intenções e a sociedade real poderia fazer triunfar a obstrutiva força da inércia, o que, em si, já comprometeria os caminhos do futuro. Tal alerta valeria também para o âmbito da instrução, entendido este como a necessária irradiação das conquistas, do conhecimento e do potencial da mente, da razão humana. Haveria, neste campo, um modo de compreender o problema que ultrapassaria o campo nacional:

\footnotetext{
“Quando o gênero humano, no seu caminhar contínuo para a perfectibilidade de que ainda está tão remoto, e a que nunca chegará porventura, é agitado por uma idéia profundamente progressiva; quando as nações peregrinas na estrada infinita da civilização se atiram rapidamente para o futuro, forçoso é que essa idéia se incarne em todos os modos de existir das sociedades, e que cada um deles sirva para a fazer triunfar: se em uma ou outra das formas sociais da atualidade há harmonia com a idéia que representa o futuro, esta a pule, melhora e completa: se, pelo contrário, entre o que existe e o que deve existir há desarmonia, o pensamento, que representa os fatos que hão-de ser, ou transforma ou destrói os fatos que são, porque o resultado da luta entre o passado e o porvir nunca é duvidoso, ainda quando a favor daqueles e contra este esteja casualmente a força material e ainda a moral - os interesses, os hábitos e a inércia natural do homem". ${ }^{153}$
}

Não obstante ser possível distinguir certo providencialismo histórico que age tendo em vista a adequação do país às novas instituições ou ao novo lugar a ser ocupado por velhas instituições, é com olhar militante que Herculano chama a si o compromisso de intelectual, engajado em seu tempo, procurando ver além dele e falando para tempos futuros. Com diversos estilos - da história à literatura ${ }^{154}$ - Herculano deixa mensagens os contemporâneos, erigindo-se, quer pelo discurso, quer pelos atos, como líder e exemplo de gerações portuguesas. O Panorama (revista fundada e dirigida por Herculano em 1837 e à qual retornaremos no capítulo 3) é reconhecidamente a primeira tentativa sistematizada e de largo alcance de um periódico de cariz enciclopédico, destinado à instrução das camadas médias da sociedade portuguesa. Herculano, ao dirigir aquele periódico voltado para propagação de "conhecimentos úteis", torna-se concomitantemente diretor, colaborador e redator de seu projeto jornalístico, que, por sua vez, representou iniciativa pioneira, copiada por inúmeros outros periódicos, que viriam logo a seguir. Cabe refletir desse modo para o papel de irradiador de idéias efetivamente desenhado na trajetória desse expoente do romantismo português. Entre a produção do conhecimento e o gesto de transmiti-lo, reconhece-se a vocação pedagoga de Herculano. Talvez por essa razão, sacralizado por seus herdeiros, Herculano - como já pudemos observar - apresentar-se-ia como o paradigma intelectual da mesma Geração de 70 que, com tanta veemência, se insurgiria contra convenções e tradicionalismos. ${ }^{155}$ A historiografia portuguesa estaria - já em Vale de Lobos -

\footnotetext{
${ }^{153}$ Alexandre HERCULANO, Da escola polytechnica e do collegio dos nobres, p. 6.

${ }^{154}$ Sobre os aspectos literários, Saraiva comenta que, mesmo em relação à poesia, "Herculano atribui uma função pública, doutrinária e intervencionista, e tenta dar através dela expressão à contemporaneidade, versando temas de interesse político, social e religioso." (A. J. SARAIVA e Óscar LOPES, História da literatura portuguesa, $\mathrm{p}$. 742).

${ }^{155}$ Sobre a criação do mito a propósito da figura de Herculano, indicamos o trabalho de Sérgio Campos Matos,
} História, mitologia, imaginário nacional , p. 161-173. 
irremediavelmente marcada por sua indelével referência. Seu modo de ver a escola e a instrução deixam-nos também preciosos rastros, tornando-se necessário, porém, percorrê-los pelos vestígios que o tempo de seus sucessores fez por revelar.

\section{A ESCOLA MODERADORA DA AVIDEZ DA LEITURA: ANTÓNIO FELICIANO DE CASTILHO}

De algum modo, o problema da instrução se colocava, para os homens da política portuguesa como uma hipótese de prosperidade. Instruir as populações rurais, que até então viviam na ignorância, significaria, sob tal perspectiva, retomar o caminho do desenvolvimento da agricultura, pela irradiação de hábitos, de conhecimentos e de técnicas e inovações quanto aos processos agrícolas. Supunha-se, pois, regenerar, a partir do desenvolvimento pedagógico da nação agrícola, a própria idéia nacional. Por outro lado, temia-se que a educação das camadas menos favorecidas, pela erradicação das superstições e das crendices populares, pudesse efetivamente ocasionar uma carência ética, um vazio de valores, uma ausência de parâmetros norteadores da conduta civil. A moralidade seria, sob essa outra hipótese, ameaçada. Os protagonistas da intelectualidade e da política na época hesitavam em relação a tal escolha. Na verdade a escola era uma aposta, que poderia ou não se tornar uma correta opção de futuro. De qualquer maneira reconhecia-se que o progresso, tal como ocorrera, teria acarretado consigo a degeneração dos costumes. Urgia, pois, adequar esse progresso a uma reconstrução dos comportamentos e das atitudes valorosas, ministrando às camadas populares os 'conhecimento úteis', que, no parecer de Herculano e Castilho, pudessem ilustrar sem corromper.

\footnotetext{
“(...) entre nós ensina-se à infância não o amor, mas o temor; não a fé, mas a superstição; não a virtude, mas a hipocrisia. Passa a infância: chega a puberdade. A indiferença, e muitas vezes o ódio, substitui o temor; a incredulidade, a superstição; e se alguma coisa fica é a hipocrisia - a virtude da praça pública, a virtude para o mundo, e não para a consciência. Em tempos de servidão, o poder absoluto dos reis e ministros era para o homem o que para a criança fôra o pai, o aio ou o mestre - o temor ficava sendo, ainda, o elemento da vida pública: então o clero continha o povo no aprisco da superstição; e a superstição também então se julgava elemento social. Quebradas as antigas formas de governo não por nós, mas pelo século, achamo-nos geração livre, com a educação e com todas as reminiscências do passado: corrompeu-se o povo, não porque sua índole fosse má; mas porque forçosamente se havia de corromper. Qual é o homem que, nascido em ferros e em ferros levado até a idade viril, se não torne licencioso, restituído de salto à liberdade natural?",156
}

O mundo do livro parecia querer assim ganhar vida própria e cada vez mais se faziam necessários atos e estratégias para regrar aquela leitura. Era preciso, por conseguinte, consolidar e regular a cultura letrada pelo auxílio moralizador reservado à escola; instituição que, ao mesmo tempo, disciplina, modela e normatiza a ação das letras. Tanto o gesto da leitura que se tornava extensivo a novos grupos sociais, quanto fundamentalmente o impacto do livro, criavam novas sociabilidades, reinventando espaços e criando estruturas mentais de apropriação dos textos, basicamente no sentido que Chartier daria a essa prática de leitura: "quer se considere o caráter todo-poderoso do texto e o seu poder de condicionamento sobre o

${ }^{156}$ O PANORAMA, volume 2, número 62, 7/7/1838. 
leitor - o que significa fazer desaparecer a leitura enquanto prática autônoma -; quer se considere como primordial a liberdade do leitor, produtor inventivo de sentidos não pretendidos e singulares - o que significa encarar os atos de leitura como uma coleção indefinida de experiências irredutíveis umas às outras." ${ }^{157}$ Perante o texto, o fato é que a leitura produz sentidos próprios, significados inusitados, absolutamente independentes de quaisquer injunções que vão das intenções do autor à ortodoxia do processo de editoração do impresso. Poder-se-ia, a partir daí, falar em pluralidade de competências, expectativas, disposições dos leitores e mesmo em comunidades de leitura: atos partilhados, seja em termos de repertório, seja no que diz respeito aos próprios significados que, por dispositivos de apropriação, vão se configurando. O século XVIII trouxera fôlego essa mentalidade substancialmente moderna, onde se valoriza o código impresso como alicerce da civilização, visão esta que apenas se irradia no decorrer do XIX, ainda que fosse tributária, no mínimo, dos tempos do Renascimento. $\mathrm{O}$ tema da leitura, do livro e das práticas sociais que, à volta dele se constituíam, parece-nos estratégico para a compreensão do pensamento educacional português durante todo o período dos 'oitocentos'.

Com António Feliciano de Castilho (1875-1800), o debate educativo português ganhará novas feições. A discussão, antes centrada quase exclusivamente sobre as implicações políticas da extensão da escola para as camadas majoritárias da população, agora passará a discutir a questão dos métodos e das técnicas mais adequadas ao ensino preconizado. Castilho era poeta, bacharel em direito por Coimbra e sócio da Academia Real das Sciencias de Lisboa. Foi membro do Conselho Superior de Instrução Pública e, em 1870, recebia o título de Visconde de Castilho. Sua passagem pela pedagogia consiste nas edições e na polêmica desenvolvida em torno de seu Methodo portuguez-Castilho para o ensino rapido e aprasivel do ler, escrever e bem falar, cujas cinco primeiras edições datam de 1850, 1853, 1857 e 1908. A preocupação de Castilho com assuntos educativos centrava-se substantivamente na questão da ineficiência e inoperância da escola, tal como esta se encontrava em Portugal, e na busca de uma reivenção metodológica que pudesse efetivamente tornar do ensino algo concorrido, algo atraente. Não queremos dizer com isso que, antes de Castilho, não tenha existido preocupações dos pensadores e teóricos da educação portuguesa quanto ao problema do método. Rogério Fernandes já se referia ao final do século XVIII como o período de "apoteose da Didática". Mesmo os "novos caminhos na arte penosa de iniciação à leitura" estariam já situados antes da virada para o XIX. ${ }^{158}$ Sucede que Castilho tinha como ninguém o domínio da irradiação da palavra e da formação da opinião pública pela via da imprensa. Castilho era um polemista; mas era também um poeta; e era finalmente um homem público de seu tempo, que, indubitavelmente, soube fazer uso de sua popularidade, tornando-a ainda maior. Parafraseando alguém, caberia mesmo dizer que se pode ser contra ou a favor de Castilho na educação portuguesa. Entretanto jamais se permitirá passar sem sua referência. Castilho traria visibilidade ao tema da metodologia do ensino, transformando-o irredutivelmente no epicentro de sua reflexão.

\footnotetext{
${ }^{157}$ Roger CHARTIER, A história cultural: entre práticas e representações, p. 121. Diz ainda Chartier sobre o tema: "Ler, olhar e escutar são, efetivamente, uma série de atitudes intelectuais que - longe de submeterem o consumidor à toda-poderosa mensagem ideológica elou estética que supostamente o deve modelar - permitem na verdade a reapropriação, o desvio, a desconfiança ou resistência. Esta constatação deve levar a repensar totalmente a relação entre um público designado como popular e os produtos historicamente diversos (...) propostos para o seu consumo." (Idem Ibidem, p. 60)

158 Acerca do tema, constata o especialista: “A atentar, porém, na literatura doutrinal da época, teremos de reconhecer que tais idéias obtiveram fraca ressonância. Os interesses dominantes encaminhavam-se, com efeito, muito mais para o conhecimento dos conteúdos e modos práticos do ensino do que para a fundamentação crítica das atividades pedagógicas. A ajuizar pela literatura e outra documentação disponível, os conteúdos e as práticas pedagógicas eram os pólos dominantes das atenções gerais. Sob certos aspectos, este período pode classificar-se como o da apoteose da Didática." (Rogério FERNANDES, Os caminhos do ABC: sociedade portuguesa e ensino das primeiras letras, p. 240).
} 
Pretendendo-se também representante do espírito das luzes, em um século que convive com o efeito irradiador do projeto iluminista, António Feliciano de Castilho tanto se aproxima quanto se distancia das proposições e dos pareceres emitidos por Herculano acerca do problema da instrução. Com efeito, fala-se muito do lugar ocupado por Castilho enquanto interlocutor da Geração de 70, como interlocutor, mais do que protagonista, da famosa polêmica que a História optou por intitular Questão Coimbrã. Conhece-se, na outra margem, o Castilho pedagogo, atento para os temas atinentes à instrução, debruçado sobre seu também polêmico método de alfabetização, sonhando talvez equacionar o problema educativo com que seu tempo lhe acenava. Há que se compreender a confluência entre ambos os cenários para reconstituir algo do que se poderia entender como a interface das perspectivas acerca das quais Castilho via o mundo. Em sua obra Felicidade pela Agricultura, o poeta pontua a ciência como fonte imprescindível para a prosperidade da instrução. Compreendidas como a grande conquista da modernidade e particularmente do legado da Ilustração, as verdades da ciência corriam à época expressas por folhas, textos, livros. O mundo do impresso teria alcançado profundo efeito irradiador, mediante formas inúmeras de apropriação dos temas novos que conquistavam passo a passo a cena cotidiana. Se tempos houve em que saber era privilégio e se tal imaginário permanecia como atmosfera mental partilhada, os tempos novos pareciam exigir do século XIX uma readequação de seu modo de compreender o problema da instrução popular. Na vereda do discurso, Castilho aqui aproximar-se-ia, guardados alguns matizes, da percepção de Herculano: acreditava viver num século em que o domínio da ciência surgia como fonte de civilização e desenvolvimento dos povos e que, na verdade, a instrução assumiria papel proeminente como contraponto desse desenvolvimento que ocorria no campo das ciências, das técnicas, da cultura. . Entretanto não é sem temor que se recebe esse brinde. No caso específico de Castilho, a própria construção do texto parece em si reveladora de práticas de leitura que - dizia-se - andavam por aí à solta...

\footnotetext{
"Esse frêmito, esse rumor sem estrondo e sem nome, quem o produz? São milhões de penas a escrever em milhões de retiros, por toda a face da terra; são milhões de espíritos a meditar; são milhões de mãos a folhear livros; são milhões de olhos a revolver a natureza (...); são as vozes infantis que soletram numa infinidade de escolas; são os colóquios familiares a alarem-se para não sei que altura; é a imprensa, árvore da ciência a chover de dia e noite frutos e flores (...); são os idiomas a permutarem entre si noções e descobrimentos; são os direitos e deveres a quererem passar de abstrações para princípios, de princípios para Leis, e de Leis para obras (...); é o Saber, a sede e a necessidade do Saber (...) Donde se segue que, mediata ou imediatamente, direta ou indiretamente, muito podemos; e se muito podemos, muitíssimo devemos a favor da pública instrução." 159
}

\footnotetext{
${ }^{159}$ António Feliciano de CASTILHO, Felicidade pela Agricultura, p.44-45. Em outro trecho do mesmo livro, o autor não hesita em fazer a irrestrita defesa da leitura e da hístória como atividades complementares e elucidativas para o conhecimento aprofundado dos homens e dos povos: "A leitura, meus amigos!...sabeis vós bem o que é a leitura?! É de todas as artes a que menos custa, e a que mais rende. Há livros que, semelhantes a barquinhas milagrosas, incorruptíveis e inaufragáveis, nos levam pelo oceano das idades a descobrir, visitar e conhecer todo o mundo que lá vai: os povos antigos revivem para nós com todos os seus usos, costumes, trajes, feições, crenças, idéias, vícios, virtudes, interesses e relações: a história é a mestra da vida e as suas lições ampliarão o complemento ao nosso juízo natural; no que foi aprendemos o que deve ser. Dizem que mente às vezes. Também na seara há joio e nem por isso deixais vós de ceifar com alegria. Mas apesar das suas mentiras, fica ainda sendo a história uma das mais verdadeiras coisas do mundo. Os contemporâneos de cada um dos homens notáveis, heróis ou monstros dos tempos antigos, talvez os não vissem tão ao natural como nós cá de longe: por quê? Por isso mesmo que eram vivos; cercavam-nos um estrondo confuso e vozes contraditórias que para nós emudeceram: o amor e o ódio, o terror e o entusiasmo tingiam nas sua cores os feitos e os ditos; o espectador muito de perto e distraído com os seus próprios negócios, não podia abranger a totalidade de uma cena às vezes imensa e complicada; não é nem ao pé em demasia, nem em demasia longe, que os objetos se julgam com isenção." (A. F. Castilho, Felicidade pela agricultura, In: O PANORAMA, vol.X, $2^{\circ}$ da $3^{\mathrm{a}}$ série, 1853, p. 104) Esse excerto vinha no jornal acompanhado do título "Vantagens do ler".
} 
Embora reconhecendo que "o ler, escrever e contar devem ser populares e plebeus; patrimônio geral e não privilégio; regra e não exceção, e tão rara exceção como é hoje" ${ }^{160}$, Castilho pretende efetuar procedimentos de controle sobre o que ler, como ler e quando ler... Compreendendo a habilidade da leitura como uma inestimável aquisição da humanidade, Castilho chega a caracterizar o acesso à decodificação do texto como uma tendência, uma propensão do século XIX. No prólogo de seu livro Felicidade pela Instrução, o autor refere-se ao que entende como "regeneração da Humanidade pelo Homem e regeneração do homem pelo Batismo da luz"161.

Os aspectos intervenientes na alfabetização estariam, no parecer de Castilho, mal estudados pelos portugueses, que, por ser assim, estariam atrasados em relação àquilo que o século anterior havia caracterizado como propagação das Luzes do conhecimento. $\mathrm{O}$ oferecimento da instrução elementar a todos corresponderia, sob tal perspectiva, à possibilidade de avanço do país em direção à sua prosperidade. Não é, porém, sem reticência que o poeta qualifica a universalização do acesso à leitura, como se pode depreender do texto abaixo :

\begin{abstract}
“O ler é um meio e não um fim. O saber ler pode conduzir ao bem, ao mal, ou a coisa alguma. Se o povo não tiver livros com que saciar a nova sede que na escola se lhe há de criar, deixar-se-á de mandar lá seus filhos. Se os livros que se lhe deparassem fossem só ociosos e corruptores, como o cardume das novelas, que até da formosa língua portuguesa nos têm dado cabo, valeria mais queimar escolas que fundá-las." 162
\end{abstract}

Para Castilho, sem dúvida alguma, a escola primária seria o meio socialmente controlado para regrar o efeito da leitura, trazendo equilíbrio, ponderação e bom-senso àquilo que, em princípio, seria atividade subversiva: as vozes e indagações da leitura. Em qualquer hipótese, alegre ou não, a escola deveria ser minuciosamente regrada mediante procedimentos disciplinadores e moderadores da avidez da leitura. A curiosidade para imersão no território do texto é assim veementemente combatida. Não se deve ler tudo; nem ao menos ler muito. Há que se ler bem as leituras moralmente proveitosas... Para isso, que viesse a escola.

Poder-se-ia desde já antecipar que, em larga medida, o discurso pedagógico português será, no século XIX, tributário desse imaginário crescente a respeito do impacto e do valor da leitura na sociabilidade e na conformação dos costumes. Ao que parece, a própria preocupação em relação à escola derivaria, essencialmente, da inquietação perante práticas de leitura que corriam sem quaisquer mecanismos de controle. A escola moderna surgiria, pois, como a instituição autorizada para o ensino da leitura. Evidentemente, estaria nela compreendida essa 'vocação para o ensino universal' - para usar as palavras de Jacques Ozouf e François Furet. Compreender a escola primária portuguesa do século XIX passa por essa avaliação a propósito desse modo de ser da escola moderna. Furet e Ozouf destacam procedimentos inequivocamente colados à mesma instituição; dispositivos esse que eram em si os próprios signos da civilidade moderna. Relatam-nos aqueles autores:

\footnotetext{
"A sociedade da Idade Média era uma sociedade de alfabetização restrita, onde a manipulação do escrito era de competência de um corpo de clérigos especializados. A sociedade da época moderna, que já principia por essa relação entre a tipografia e a Reforma, é uma sociedade onde a
}

\footnotetext{
${ }^{160}$ António feliciano de CASTILHO, Felicidade pela Instrução, p.16.

${ }^{161}$ António Feliciano de CASTILHO, Felicidade pela Instrução, p.9.

162 António Feliciano de CASTILHO, Methodo Portuguez-Castilho para o ensino rápido e aprazivel do ler escrever e bem falar, p. 83.
} 
alfabetização ganha vocação universal, posto que é ao mesmo tempo meio de segurança, aprendizagem da ordem social, pedagogia de boas maneiras, e instrumento da multiplicação das trocas. Não é de surpreender que, sob todos esses aspectos, ela tenha lentamente adquirido não apenas a consagração da utilidade, mas a do exemplo, e que sua extensão ao conjunto do corpo social se haja feito lentamente, de cima para baixo, segundo a força atribuída ao exemplo, a necessidade acordada ao útil, ou a resistência do hábito: quer dizer, segundo os tipos de representação e as práticas sociais dos grupos e das classes. Foram necessários inúmeros séculos para que a civilização do escrito, em sua forma mais elementar, passasse do notário das cidades para o assalariado dos campos."163

Ao caracterizar o estado da instrução em Portugal, Castilho salienta a precariedade das instalações escolares e as dificuldades vividas pelos mestres por elas responsáveis. No parecer do poeta, do equacionamento dessa situação, dependeria o progresso industrial e agrícola da terra portuguesa. Por tal orientação, ele sugere que sejam introduzidos e implementados métodos pedagógicos fáceis, claros e eficazes, possibilitando, a partir deles, o êxito do processo da alfabetização para todas as crianças. Por outro lado, era imprescindível a criação de escolas normais para irradiação dos referidos métodos enquanto procedimentos pedagógicos sugeridos, bem como o recebimento, por parte do professorado, de salário condigno, tendo em vista a utilidade social e o desgaste trazido pelo penoso ofício. As escolas deveriam ser, por fim, estendidas e repartidas por todas as povoações, de maneira a possibilitar o efetivo acesso das crianças ao caminho do conhecimento. Finalmente, Castilho propunha "que um centro diretor da instrução pública traga perenemente Comissários volantes, de grande ilustração e zelo, a visitar as escolas, a corrigi-las, a aperfeiçoá-las em todo o sentido e a tomar conta do mérito comparativo dos professores; para que os mais dignos, no fim de cada ano, recebam, não só o louvor público, mas ainda outros prêmios de sua diligência, e os ineptos, desleixados ou viciosos, sem misericórdia se despeçam e se substitua." ${ }^{164}$ Por tal orientação, Castilho sugere prêmios, distribuição de livros gratuitos, ordenados mais condizentes com a elevada tarefa social do professorado e construções de escolas como estratégia de consolidação de um sistema mais aperfeiçoado de instrução. Os gastos seriam cobertos mediante cobrança de tributos especiais, supondo, por custo de oportunidades, a supressão de outros gastos, por vezes mais vultuosos e sem dúvida mais supérfluos. O montante arrecadado por heranças vacantes, por exemplo, bem como os fundos de loterias, passariam a integrar essas verbas específicas destinadas à instrução. Além das escolas regulares, deveria haver "escolas ambulantes para os povoados pequenos; professores nômades, bem estipendiados, que vão de terrinha em terrinha dando o seu curso do mais indispensável das matérias primárias, por exemplo, o ler, escrever e contar (...); para o que, sendo eles bons e bons os métodos, três meses bastam e sobejam"; ${ }^{165}$

Castilho propõe - como complemento da enorme tarefa cultural que a escola, nessa sua nova acepção, cumpriria - a fundação, nas vilas e aldeias, de escolas só para adultos, de maneira a preencher instrutivamente as horas de serão dos dias de trabalho, bem como as manhãs e tardes de domingo e dias santificados. Os objetivos de tal iniciativa eram explicitamente catequizantes e moralizadores. Desse modo, "o camponês, depois de cultivar a terra, cultivará o seu espírito; depois de ter dado à sua pátria riquezas físicas, dar-se-lhe-á a si

\footnotetext{
${ }^{163}$ François FURET e Jacques OZOUF, Lire et écrire: l'alphabétisation des français de Calvin à Jules Ferry, p. 180.

${ }_{164}$ António Feliciano de CASTILHO, Felicidade pela Agricultura, p.48. Com uma inspeção regular, poderiam ser aferidos os progressos da instrução, de modo que "nos nove meses letivos, cada professor haverá dado, sob pena de grave multa em seus vencimentos, dois terços pelo menos dos seus alunos prontos no ler, escrever, contar, nos rudimentos religiosos, nos da civilidade, nos da gramática portuguesa, e nos da higiene.” (A. F. CASTILHO, Felicidade pela Instrução, p.21)

${ }^{165}$ António Feliciano de CASTILHO, Felicidade pela Agricultura, p.49.
} 
próprio, melhorado, que é riqueza moral muito maior" ${ }^{\text {"166 }}$. Nessa dimensão, atribuía-se à composição escolar a tarefa instrutiva, sim, de desenvolvimento de habilidades e de capacidades; porém, mais do que isso, a escola agiria como local de agregação, de coesão social, de transmissão de toda uma teia de valores e de significados morais, cuja preservação e reforço eram postos como necessários ao desenvolvimento da nação, compreendida esta como um coletivo dotado de certa identidade.

No parecer de Castilho, havia que se atentar, tendo em vista sua acepção de ensino público, para a idoneidade dos mestres, condição primeira para o exercício do magistério. A preocupação com a moralização do ofício da instrução suporia, por um lado, cursos especiais de moral, decência, direito político e jurisprudência usual e rural; por outro lado, visualizavase a urgência de consolidação de ensino feminino. A educação das mulheres é tomada aqui como dever de Estado, posto que,

\begin{abstract}
“a educação das mulheres (...) contém em si a dos homens. Elas são no princípio e por muito tempo as nossas mestras únicas; elas nos infiltram em todas as idades as suas idéias; no que temos de bom e benigno foram elas que nos modificaram à sua imagem; elas (sem o parecerem) nos educam e dirigem até o fim. A mulher convenientemente educada será melhor mãe, melhor esposa, melhor ecônoma, melhor amiga, mais proveitosa à casa, mais útil aos vizinhos, mais benemérita da Pátria, sem se lhe mostrar; mais querida de todos e de si mesma." 167
\end{abstract}

Percebe-se que o valor atribuído ao sexo feminino vem, no caso, condicionado às relações sociais: a mulher deve, pois, ser educada porque será esposa, mãe, educadora, vizinha, do homem... Não é, então por valor autônomo, mas por relação a 'outro' que se deverá instruir a mulher. Seja como for, Castilho deposita na escola o papel de regeneração dos vícios e corrupção do tecido social. Chega, em vista disso, a propor criação de escolas nas cadeias, com o fito de deter vícios e corrupções que nelas se concentrassem. O caráter sacralizado de que se reveste o lugar institucional da escola primária seria diametralmente contraposto a modelos de ensino morosos e imperfeitos. Castilho fala da instrução e de sua vocação para remediá-la. Ao criticar a situação das escolas, ele pretendeu criar o método; e, com ele equipada a instrução portuguesa caminharia, de maneira irrevogável, em direção à perfeição. Em seus escritos sobre a situação das escolas, Castilho se solidariza com o magistério português, de quem não se poderia nada exigir naquelas condições pouco alentadoras. Ora, na inexistência de uma inspeção regular, e considerados os baixos padrões salariais, bem como a carência de formação do professorado, nada poderia o poder público exigir enquanto não viabilizasse algum patamar de melhoramento material. Pelo texto do autor:

\footnotetext{
“'Quem quer os fins, quer os meios', é adágio trivial. Um dos meios indispensáveis para o ensino é a casa apropriada. Até agora as escolas, quase todas, têm sido nas residências dos respectivos professores. Não ponderarei a iniquidade de se compelir um pobre homem ou uma pobre senhora, que tão pouco recebe do tesouro, e em tão duras lidas se consomem, a alugarem maiores casas do que para si necessitariam, a fim de terem nelas uma sala para o serviço público. Rogo, porém, se considere, ou se examine com os próprios olhos, o como a pobreza, a penúria do mestre o força (quase em toda a parte) a tomar para escola uma enxovia, apertada, mal situada, mal distribuída, sem ventilação, sem luz, sem requisito algum dos que exigem a higiene, a humanidade e o interesse do ensino." 168
}

${ }^{166}$ Id.Ibid., p.50.
${ }^{167}$ Id. Ibid., p.51-52.
${ }^{168}$ António Feliciano de CASTILHO, Felicidade pela Instrução, p.27-28. 
Seria, pois, dever patriótico fornecer à Nação edifícios apropriados para a instrução primária, sem os quais não haveria qualquer progresso no ensino. Ao explicitar a crítica à escola de seu tempo, Castilho não se contenta, entretanto, com a denúncia dos aspectos materiais. Pelo contrário: adentrará e explorará largamente o problema da inadequação dos métodos como verdadeiros óbices aos progressos da instrução e consequentemente da própria civilização. Em um dos textos onde abarca o tema da escrita, Castilho buscará apresentar quase uma genealogia do ato de ler, explicitando sua concepção evolucionista perante o desenrolar das sociedades do século XIX. De fato a própria História, pela narração de Castilho, adquire conotação nitidamente teleológica, percorrendo estágios infantis e adolescentes, até finalmente adquirir o estatuto avançado que lhe confere a era da escrita... "escrita, que é para as palavras o que o falar é para as idéias". ${ }^{169}$ Essa percepção da escrita como a manifestação gráfica da fala será muito cara à pedagogia em Portugal, a partir daqueles meados de século.

Explicitamente rendido aos encantos da leitura, Castilho orientará seu fascínio em direção à busca de desvendamento dos mistérios do aprendizado deste código, do qual acredita ele - dependeria a marcha do gênero humano. A apreensão dos enigmas da leitura situava-se como o grande desafio que o poeta se propusera a enfrentar. Declarando objetivar a popularização do ler, escrever e contar, Castilho produzirá um método de alfabetização, introduzindo nele elementos que pretendiam ser, não apenas inovadores para o caso português, mas - mais do que isso - absolutamente contrários ao que corriqueiramente se vinha fazendo na escola. Para tanto, ao pretender fundar o novo absoluto, a própria acepção de escrita deveria ser substantivamente alterada. A competência da leitura é compreendida como posterior e derivada da habilidade da fala, posto que supõe a compreensão do valor da linguagem. Isso significava que o método Castilho supunha o aprendizado da escrita posteriormente à aquisição da leitura, tal como - diga-se de passagem - já prescrevia o cotidiano da escola em Portugal. Para Castilho, haveria inclusive uma anterioridade lógica da leitura sobre a escrita. ${ }^{170}$ Portanto logicamente a leitura seria tão mais racional, natural e fácil quanto fosse eficaz o processo de mnemonização dos valores sonoros contidos na própria figura das letras. Assim supunha Castilho:

\footnotetext{
"Graças a este feliz pensamento de decompor os vocábulos em elementos, de representar cada elemento por um sinal, e de por via desses sinais, recompor novamente o mesmo vocábulo para os olhos, e pelos olhos para o espírito; graças a este prodígio, o homem, limitado em lugar e em duração, o homem, a quem não é dado possuir mais que um só momento, se achou de repente com a faculdade de estar, intelectual e moralmente, em todas as partes e em todos os tempos: no futuro, pelo que ele escrevesse; no passado, pelo que ele mesmo e outros antes dele houvessem escrito. 'Eu não hei-de morrer de todo'-cantava há dois mil anos um Poeta romano. O seu corpo desfez-se; a sua urna desapareceu; mas dele duram ainda, mais que o nome, duram as flores e os frutos do seu talento; dura tudo quanto de mais brilhante produziu o seu espírito brilhantíssimo."171
}

\footnotetext{
${ }^{169}$ António Feliciano de CASTILHO, Noções rudimentares para uso das escolas, p.82.

${ }^{170}$ Acerca do dos aspectos propriamente metodológicos e técnicos da alfabetização de Castilho, eu indicaria o trabalho desenvolvido por minha orientanda de iniciação científica (bolsa PIBIC /CNPQ ), Cátia Regina Guidio de Oliveira.

${ }^{171}$ António Feliciano de Castilho, Noções rudimentares para uso das escolas, p.83. Em seu trabalho Felicidade pela instrução, Castilho efetivamente descreve aquilo que reputava como o cotidiano transformado da escola primária: "Os discípulos estão sentados nos seus lugares, cada um com a sua ardósia e lápis. O Mestre dita-lhes a palavra que hão-de escrever; os discípulos dizem em coro as figuras das letras com que a ortografia pede se escreva a palvra, com o que se fica de antemão certo de que, por essa parte, a não hão de viciar ao escrevê-la. Suponhamos que a palavra é Livro; o coro dirá: - leitura, pateta, regador, pandeiro, arquinho." (A. F. CASTILHO, Felicidade pela instrução, p. 115 ). Na sequência, o autor enumera o alfabeto, expondo a nomenclatura própria que criara para cada uma das letras, tendo em vista a apreensão mnemônica por parte das crianças. Cada letra vinha, ainda, acompanhada por uma gravura. Desse modo: "Os discípulos (...) vão procurando com os olhos no quadro grande,de que falei, a letra redonda correspondente a cada uma das figuras cujo nome proferiram e, copiando, cada um para a sua ardósia, a manuscrita que lá se vê à direita, e
} 
Ora, se na compreensão de Castilho o segredo da língua reside na sonoridade das letras, havia que ser por elas o princípio mesmo da alfabetização. Criticando os modos tradicionais de proceder à soletração, Castilho atribui à nomenclatura do alfabeto as dificuldades no aprendizado do ler. Seu trabalho, então, centrar-se-á no estudo do método. O pressuposto que norteia os escritos de Castilho é o da dependência entre os pares ler-escrever e escrever-falar, onde o ler se subordinaria ao escrever e a escrita estaria subordinada à fala; daí a suposição de todo o processo da leitura remeter-se à fala.

A primeira edição do método intitulado Leitura Repentina vem a público em 1850 , já recorrendo a certos artifícios editoriais para tornar-se célebre à partida ${ }^{172}$. Castilho, nesse começo, declarou ser o seu método uma adequação do método de Lemare, adaptado do francês para o português. Seria então de Lemare a ideia de memorização do som das letras através de imagens que a ele se ligassem, bem como a identificação em cada palavra das letras cuja união a compõe. Reconhecendo ser de Lemare a autoria e, portanto, a "glória da invenção", Castilho reivindicaria para si nessa primeira edição de seu método a adaptação, posto que, ao adotar a idéia fundamental, necessitara refazer a invenção, "criar quase tudo de novo (...) Para cada idioma tem de se assentar sobre a mesma base filosófica um edifício diverso" "173. Com tal alegação, Castilho pretende se tornar o arauto da causa da instrução em língua portuguesa, demarcando suas distinções e revelando inúmeras estratégias de ensino supostamente imprescindíveis para o êxito de seu método. Sem dúvida, quando pensa o tema da leitura, Castilho acredita ser a escola o local de produção dessa competência partilhada. Por outro lado, ao debruçar-se sobre questões de método, pretende institucionalizar sua descoberta. É assim que a segunda edição do método, datada de 1853, e dedicada a "Sua Alteza Imperial-O Príncipe D. Pedro" altera o título original, apresentando-se agora como Método Castilho para o ensino rápido e aprasível do ler impresso, manuscrito e numeração; e do escrever: obra tão própria para as escolas como para o uso das famílias. $\mathrm{O}$ então já conhecido Método de Leitura Repentina não obtivera àquela altura o sucesso pretendido pelo criador, que vinha a público através de sua obra conclamar os "snrs. Redatores de todas as folhas periódicas portuguesas":

\footnotetext{
"Se a imprensa é o eco da opinião, e se a opinião é também muitas vezes o eco da imprensa, entendo que o livro que vos apresento não pode deixar de ser por vós aceito, examinado e recomendado. Grande parte do público o adotou; tendes que falar por essa parte ilustrada. Uma porção do povo não lhe tomou ainda o gosto; está nas obrigações do vosso ministério o convencêla. Para todos há tarefa na obra da civilização. Eu cumpri a minha; vós haveis de cumprir a vossa; o Parlamento e o Governo hão-de cumprir também, segundo espero, a sua."174
}

principiando por onde a seta lho está dizendo." (Id. Ibid., p. 116 ) O mestre deveria circular por toda a sala, ensinando a cada um a posição correta para escrever, ensinando até a pegar corretamente na pena e apontando os erros do processo. Para Castilho, o ideal seria, entretanto, que o próprio aluno pudesse identificar como e por quê errou, sem o recurso da intervenção do professor. As outras palavras do ditado seriam também objeto do mesmo ritual.

172 De facto, a epígrafe da primeira edição do Método de Castilho buscará direcionar a leitura e o leitor, afirmando de maneira ortodoxa a eficácia do mesmo método, que não se assemelha a nenhum outro, que desde logo não é um, mas o método.Nos termos de seu criador, "os que houverem meditado, repetirão o que a experiência declarou: que, de todos os métodos conhecidos, é este o eficacíssimo.” (A. F. CASTILHO, Método Portuguez- Castilho para o ensino rapido e aprasivel do ler escrever e bem falar, p.13)

173 António Feliciano de CASTILHO, Methodo Portuguez-Castilho...,p.19. O autor principia essa primeira edição acenando com a ideia de rapidez como vantagem indiscutível de seu novo modelo de ensino. Acerca disso, garante ele: "O Método de leitura de Monsieur Lemare é engenhosamente fundado em bases naturais. É fácil de compreender e de ensinar; faz do trabalho um passatempo, assim para os mestres como para os discípulos; e, graças a todas estas cláusulas, reduz a um mês, a vinte dias, e às vezes a menos, este primário ensino que pelos métodos antigos devorava e devora anos."(Id. Ibid., p.17)

${ }^{174}$ António Feliciano de CASTILHO, Methodo Portuguez-Castilho...,p.33. 
Verifica-se que, ao travar interlocução com os homens de imprensa, Castilho revela a pretensão de se apropriar da opinião pública, apresentando ele mesmo sua obra como se de um ato civilizatório se tratasse. Sugerindo aos jornalistas que persuadam o povo a apreciar seu trabalho, Castilho demonstra seus interesses editoriais; mais do que isso, talvez sua própria consciência e sonho de posteridade antecipada ${ }^{175}$. É através de Castilho que o tema da educação portuguesa adquire, para o grande público, coloração metodológica. Não se tratava mais do discurso político a discorrer sobre os benefícios da instrução, como fazia Herculano. Não se tratava tampouco de conquistar a opinião pública para o reerguimento da escola desacreditada. Tratava-se, isso sim, de fazer repercutir um modelo alternativo e posto como infalível para edificar os alicerces de uma nova escola; ainda que para um velho país...

\begin{abstract}
"Cada escola deveria ser, quanto possível, espaçosa, clara, arejada, mobilada e abastecida de todo o necessário, tendo cômodos para a residência do Mestre e um terreiro ou pátio com suas sombras verdes para espairecimento dos alunos, e, nos dias formosos, até para ali se darem lições. Uma aula assim, humana e hospedeira por dentro, por fora risonha e convidativa, contribuiria admiravelmente, e melhor que raciocínios e exortações, para que o povo confluísse a se instruir. Não há vício que não empregue em seu favor as artes da sedução; por que não há-de uma nação seduzir-se a si mesma para se civilizar?"
\end{abstract}

Pela arte de uma escolarização sedutora, Castilho deseja garantir a eficácia da instrução. Seu método quer antes de tudo persuadir corações e corpos infantis, adquirindo credibilidade pela confiança das crianças a que se dirige. Tendo em vista ensinar pela sedução, Castilho desloca o tema da educação para o reduto da sala de aula, buscando encontrar leis capazes de reger o processo lógico do aprendizado da leitura. Preocupado com a escuta da linguagem das palavras faladas, Castilho parte da oralização, mediante a convicção de que este nível precede o ato da escrita. Acerca disso, dizia ele que a voz do homem, antes de expressar o pensamento, seria um desdobramento das afeições e do ânimo. Pelas palavras, poder-se-ia averiguar o corpo da frase, perscrutando nele as inflexões da alma. ${ }^{177}$ Ainda no prólogo da segunda edição de seu método, Castilho destaca como achado seu o gesto de ouvir a fala para desvelar as verdades mais simples de uma leitura natural. Ao buscar refazer a história do método e de seus postulados, o autor salienta à partida que "as verdades mais

\footnotetext{
$175 \mathrm{O}$ desejo de ser rememorado pelas gerações vindouras percorre toda a elaboração do método de leitura repentina. Em carta dirigida a Antonio de Bochart sobre o sucesso de seu drama Camões no Rio de Janeiro, bem como do êxito da aplicação de seu método em terras brasileiras, em 1855, Castilho fará o seguinte comentário: “(...)o Camões vingou, e, o que para mim vale dobradamente, vingou também e ao mesmo tempo o Método;(...) lá para o futuro, quando eu já for seiva de bem-me-queres no cemitério há-de avultar, a despeito de toda a sua aparente humildade, como a única indestrutivel e monumental dentre todas as minhas obras. Criei o Método Português depois de todas elas, como as boas das árvores dão os frutos que servem, depois das flores que recreiam.” (A.F. CASTILHO. Camões: estudo histórico-poético, p.14-15)

${ }^{176}$ António Feliciano de CASTILHO, Felicidade pela Instrução, p.31.

${ }^{177}$ Em suas Memórias de Conservatório, citadas por Teófilo Braga, Castilho teria feito alusão às motivações de ordem biográfica (sua congênita cegueira) para o empenho com que se devotara a questões de voz e ouvido. Pelas palavras do escritor: "Para compreender bem a fundo esta verdade, é mister haver feito por necessidade e por espaço de tão largos anos, como eu, um não interrompido nem distraído estudo sobre a expressão falada. Aqueles a quem sua desgraça houver iniciado nesta ciência adivinharão muitas virtudes e não menos vícios, muitas excelências e não menos vilanias pelo mero som e modulação da voz humana; para os habituados a ver pelos ouvidos, dificilmente se achará cortesão ou comediante, que, por mais que estude dissimulações, lhe possa dar trocados ou falsificados os sentimentos, que lhos ele não conheça; permite-me pois a triste vaidade de me julgar nesta matéria bom juiz” (A.F.CASTILHO, apud, Teófilo BRAGA, História da Literatura portuguesaV,p.301)
} 
óbvias são às vezes as últimas que se acham"178. Em sua perpesctiva, da arte da fala se haveria desmembrado a possibilidade da escrita, em torno da qual, posta a necessidade de comunicação do ser humano, cria-se o hábito da leitura. Por ser assim, todo o movimento do aprendizado do ler e escrever passaria, no entender do poeta, necessariamente pela fala, como consta da poesia de 1853:

\author{
"Os elementos da fala \\ Da nossa, entre as mais nações, \\ Dividem-se em duas CLASSES; \\ Que são: vozes e inflexões. \\ Nas vozes, duas FAMİLIAS \\ se distinguem bem marcadas: \\ A primeira, orais ou puras; \\ A segunda, nazaladas. \\ São vozes puras, á, $\hat{a}$, \\ É, $\hat{e}, e, i, o ́, \hat{o}, u$, \\ Nazaladas an, en, in, \\ On, un. Vai rol nu e cru. \\ Nas inflexões seis Famílias \\ Bem distintas encontrais: \\ É guturais a primeira; \\ É a segunda linguais. \\ Linguo-palatais terceira, \\ A quarta linguo-dentais; \\ Dento-labiais a quinta, \\ A sexta, enfim, labiais. \\ São guturais c e g; \\ São s, z, j, linguais; \\ São rr, r, l, lh, n, nh \\ As linguo-palatinais. \\ As línguo-dentais d, t; \\ F, v, dento-labiais; \\ Só b, p e m nos restam \\ Que se chamam labiais."179
}

Com Castilho a reflexão sobre a instrução em Portugal fôra, como se pode constatar, significativamente deslocada da esfera concernente ao lugar social e político a ser ocupado pela escola para uma dimensão de cunho técnico-pedagógico, onde o que está em jogo será a descoberta de instrumentos e estratégias de ensino diferenciadas e singulares em relação ao que corriqueiramente se costumava fazer. Ao vozear as letras, Castilho supõe alterar a própria acepção de método e, quem sabe, de leitura. A idéia de analfabetismo, bem como a confluência entre fala e escrita, ganhariam irredutivelmente novas dimensões nesse novo discurso da educação que com Castilho ganhava forma. ${ }^{180}$ Compreendendo pois que a

\footnotetext{
${ }^{178}$ António Feliciano de CASTILHO, Methodo Portuguez-Castilho, p.48.

${ }^{179}$ António Feliciano de CASTILHO, Elementos da palavra fallada na lingua portugueza; additamento ao Methodo-Portuguez-Castilho, pelo seu auctor.

${ }^{180}$ Acerca dessa dimensão do Método Repentino, já anotava Luís Albuquerque:

"Porém, naqueles seus fundamentos teóricos iniciais, o método Lemare-Castilho afastava-se, e apesar de tudo com notória melhoria, do que habitual e rotineiramente se praticava nas escolas portuguesas. E não era só isso: a par da racionalização que procurava introduzir no método de ensinar a ler e a escrever, Castilho defendia uma atualização no modo de o ministrar: condenava a imobilidade das crianças, amarradas às carteiras sob o domínio da palmatória; exigia a maleabilidade do professor na compreensão do seu cansaço inevitável, quando se lhes impunha atenção muito demorada sobre um mesmo ponto; e aconselhava as marchas, as palmas, os cantos e os jogos como meios de transformar a escola, da triste prisão que lhe parecia ser, na
} 
habilidade da leitura deriva da competência da fala, o método de Castilho, que se pretende explicitamente simples, eficaz e rápido, combina, analisa e disseca sons da palavra falada, decompondo-a em seus elementos fônicos e recompondo-a na sua totalidade de significado. É para tanto que Castilho sugere práticas entrelaçadas de decomposição das palavras em letras, atribuindo a estas a sonoridade que lhes seria original, para reconstituir, no final, a lógica da palavra inteira. ${ }^{181}$ Vale a pena recorrer à transcrição do pedagogo:

\footnotetext{
“A decomposição e a leitura auricular, que, em última análise, são uma e a mesma coisa; isto, que é para o ler e escrever o caminho de ferro; eis em que principalmente consiste o Método novo. É isto, pelo menos, o que nele há de mais filosófico, mais eficaz, mais sem precedente, antigo nem moderno, nacional nem estrangeiro que eu tenha conhecimento." 182
}

A bem dizer, em nada nos importa a polêmica a propósito da originalidade ou não de Castilho face ao método de ensino desenvolvido por Lemare. Importa salientar, isso sim, em que medida se cria em solo português um novo discurso pedagógico para situar o tema do ensino das primeiras letras. Além disso, caberia indagar às fontes qual o impacto e a repercussão desse novo olhar lançado para o problema. De certo modo, parece-nos inegável o fato de ter havido aqui a força persuasiva de um estilo obstinado pela criação do fato. Ao abordar a trajetória de Castilho, a historiografia da educação em Portugal por vezes assume o discurso da própria fonte. Em alguns casos, retoma-se o teor argumentativo da vertente crítica expressa na Geração de 70. Em ambas as situações, o historiador coloca-se como refém de sua documentação e só fala do passado aquilo que, por artimanha, os atores pretendiam já perpetuar. Com sede explícita de posteridade, Castilho é perigoso... Há sempre ardis na construção de seu texto tendentes à pontuá-lo e à sua biografia como o apóstolo da instrução renovada e renovadora. Porém parece-nos inegável o delineamento de questões que, embora pudessem afligir os entusiastas da escolarização, não costumavam ser expostas com tanta veemência, como é o caso do uso imoderado da palmatória, por exemplo. ${ }^{183}$ Sob tal aspecto, inegavelmente Castilho foi contundente, mesmo que, no engendramento de seu discurso, o método se tivesse caracterizado como dispositivo único e irrepreensível para remediar os males da instrução, colocando-a a postos, no caminho das multidões. É assim que Castilho atenta prioritariamente para aspectos concernentes à eficácia do método, naquilo que compreende ser a tarefa de reconstrução da escola, tendo em vista tornar do aluno um ser coletivo moral. A esse respeito - segue o autor - haveria que se principiar pelo aprendizado da pronúncia, dado que a arte da fala seria, dentre as três formas de comunicação verbal, a primeira e fundamental. A partir dela, alguns elementos deveriam passar a ser considerados,

alegre colmeia a que os rapazes concorriam felizes.” (Luís ALBUQUERQUE, Notas para a História do Ensino em Portugal, p.184)

181 "Era fácil notar, pelo ouvido e pela vista, escutando o falar de outrem, ou cada um pelas sensações do próprio órgão vocal, falando , era, digo, facílimo notar que as palavras se compunham de diversos elementos, os quais, sendo de si pouco numerosos, se prestavam todavia a combinações inumeráveis. Todo o trabalho então deveu ser analisar, dissecar (por que assim o digamos) a palavra falada, e estabelecer sinais convencionais visiveis correspondentes cada um a cada elemento dos vocábulos. Eis ai o alfabeto." (A.F.CASTILHO, Methodo Portuguez-Castilho...,p.49-50)

${ }^{182}$ Id.Ibid.,p.50-51.

183 "E são os partidários da palmatória, do murro, do bofetão, do pontapé, dos puxões de orelha, dos cabelos arrancados, dos narizes esmurrados, dos braços quebrados, das crianças estropiadas e bestificadas, são os Herodes tolerados, que ousam exprobar servicias aos que não pregam, não praticam senão o amor, aos que se fazem pequenos com os pequeninos, aos que ensinam brincando e cantando, aos que são na rua saudados $e$ abraçados pelos filhos descalços da plebe!!...Chove impropérios, desfaze-te em injúrias (...) arregala-me esse luzio, range-me essa dentuça quanto quiseres; a minha maior glória não m'a tiras.” (A.F.CASTILHO, Ou eu ou elles: tosquia de um camelo: carta a todos os mestres das aldeias e das cidades, p. 128) 
como o da índole particular da infância, a amenidade e clareza do método, a economia de tempo, o ritmo, a simultaneidade e a agilidade do aprendizado ${ }^{184}$.

Pelas palavras de Castilho, reconhecemos o perfil do professor, nesta talvez exaltação do modo de ensino simultâneo; o ensino simultâneo que, muito mais do que alternativa, seria já apreendido pelos contemporâneos como o fator decisivo para a obtenção do êxito daquela escolarização primária. Ensinar a todos como se eles fossem um só seria de fato o grande desafio pedagógico do século XIX, século de edificação das grandes redes públicas de escolarização. O modo simultâneo de ensino coletivo era posto como o segredo de uma pedagogia que pretendia encontrar cientificamente um "método universal de ensinar tudo a todos". Nesse encalço, havia que se adequar a busca do método com estratégias variadas capazes de adequar, de maneira ordenada e disciplinada, a distribuição ritmada e compassada do tempo e dos horários, do espaço e dos segredos de sua distribuição; e, nesse controle do tempo e do espaço - que só o modo simultâneo efetivamente possibilitaria - estaria contido o grande segredo da relação do ensino-aprendizado: o aluno, tido por único ser moral, sendo vários, era um só, apreendido pelo singular naquela atmosfera eminentemente coletiva. Nessa direção, as estratégias indicadas combinariam atividades de canto, de palmas, de marchas, com o objetivo precípuo de transformar o heterogêneo, variado e desagregado, em uma totalidade uniforme, normatizada, mecanicamente regulada por um único regente da orquestra escolar: o mestre...

\begin{abstract}
"O primeiro empenho do mestre sensato e humano é ser mestre ele próprio para todos os seus ouvintes, mestre querido e escutado. O seu primeiro trabalho é, portanto, fazer de toda a classe, confiada a seu afeto esclarecido, um só aluno moral, e sempre atento; que todo ele ouça o mesmo; que todo ele entenda e pense o mesmo; que todo ele diga e faça o mesmo; uma só percepção, um só discurso, uma só voz; de cem indivíduos um produto idêntico, uniforme, irrepreensível. Para a resolução deste problema, o compasso era condição imprescritível. (...) Para preparar às suas próximas lições o seu aluno coletivo com a destreza e o hábito rítmico, à falta de um compassador mecânico, recorre às vozes, regularizadas por acenos, às palmas, que podem acompanhar essas mesmas vozes, e aos passos de marcha, que podem com estas mesmas palmas coincidir. No emprego alternado ou simultâneo destes três meios naturais, há a vantagem higiênica do movimento, e a vantagem moral do gosto que afeiçoa à escola, ao guia e ao estudo." 185
\end{abstract}

Existiria assim uma forma escolar que mobilizaria por conhecimento e afeto a conduta disciplinada e organizada dos estudantes, tomados aqui como série, em uma acepção classificatória e orgânica. Haveria, no ritmo e na disposição do tempo e dos espaços rotineiros da vida escolar, toda uma arquitetura da "classe", pela projeção de um eficaz ensino coletivo. O ritmo compassado apresentar-se-ia como estratégia para conformação desse tão visado modo simultâneo de ensino. Este, por sua vez, cumpriria o papel de reinventar o método de ensinar a ler e, a partir dali, readequaria, até onde Castilho entendia, o estado das "letras" em Portugal. Por sua metodologia, a letra escrita deriva e desdobra-se da palavra falada que, por essa razão, deveria vir à frente do processo de ensino da leitura. Pelo fato de o objeto da leitura ser a palavra, esta deveria ser decomposta para que o aluno procedesse ao reconhecimento de seus elementos sonoros correspondentes aos valores da escuta das letras.

\footnotetext{
${ }^{184}$ Era muito comum naquela época o princípio da brevidade do método ser pontuado como um dos objetivos precípuos do modelo de aprendizado expresso em compêndios. A ideia de um ensino ágil evidencia-se, não apenas em prefácios, mas nos próprios títulos de alguns manuais escolares, como é o caso do Methodo facillimo para aprender a ler tanto a letra redonda como a manuscrita no mais curto espaço de tempo, de E. A. Monteverde. Castilho, como se percebe, não foge a essa orientação de seu tempo. Posteriormente, quem discordará dessa orientação será João de Deus, que, em seus escritos proferirá parecer contrário a esse tendência, quase generalizada na época, de valorização excessiva do tempo curto para o aprendizado, insistindo na idéia de que a rapidez não seria a única vantagem de um bom método de ensino.

${ }^{185}$ António Feliciano de CASTILHO, Methodo Portuguez-Castilho, p.96-97.
} 
A essa "biforme repetição do mesmo processo", Castilho deu o nome de "leitura auricular alternada" ${ }^{186}$. Na escola portuguesa era comum a sobrevivência de padrões individuais para o ensino da leitura, que pouco a pouco viriam a se substitídos pelo modo simultâneo. Poder-seia mesmo arriscar dizer que todo o século XIX português teria sido um grande ensaio no sentido da implementação dos alicerces do ensino simultâneo. Aliás, sabe-se que essa é uma das marcas da escola moderna: o ensino que regra temporalidade e espaço, tendo em vista a agilização e otimização do percurso do aprendizado das inúmeras crianças que constituiriam em uníssono o grupo-classe ${ }^{187}$. A própria diversidade de material manuscrito e impresso trazido pelos alunos para a sala de aula era reveladora dessa dificudade da estrutura escolar quanto à normatização de um padrão uniforme de ensino coletivo. Embora todo o século XIX português atentasse para a urgência de resolução desse problema, o ensino simultâneo só vigoraria com uma certa representatividade no último quartel do século. Aqui, sem dúvida, nós ainda estaríamos em um momento anterior, preso à individualização do aprendizado da leitura. Embora já se tenha anotado que a escrita é a língua da escola ao passo que a linguagem familiar pauta-se pela oralidade, o professor em Portugal valia-se de sinais que expressavam o valor utilitário da escrita no cotidiano das pessoas e dos ofícios. Para tanto, o mestre-escola mandava "cada discípulo trazer qualquer papel de letra de mão: uma folha de um processo, um rol da tenda, uma carta de uma cozinheira, quase sempre sem pontuação, sem ortografia de espécie alguma, sem o mínimo laivo de senso comum" ${ }^{\text {"188 }}$.O método de Castilho quer modernizar ao se pretender contraposto à formulação tradicional de uma escola que não mais atenderia às necessidades do tempo. Na escola que Castilho idealiza, verifica-se processo bastante distinto daquele acima descrito, o que fica evidenciado na seguinte passagem extraída do quarto prólogo de seu método:

\begin{abstract}
"Duas coisas são necessárias para bem escrever: ortografia e caligrafia. O Mestre, depois de ter armado os seus discípulos de ardósias e de lápis bem tomados entre os dedos como penas, dita uma palavra. Eles decompõem-na em elementos; no que não podem errar; e logo, em ato contínuo, dizem qual é a figura, isto é, a letra que naquela palavra corresponde a cada um daqueles elementos; no que já podem errar, e muitas vezes erram, a princípio. O Mestre emenda; eles repetem as figuras já corretamente. A ortografia do vocábulo que deve ser exarado na pedra está segura; resta desenhar os caracteres. Uma resenha alfabética de letra redonda e manuscrita está patente aos olhos de todos. Cada um vai dela trasladando a uma e uma as letras que tem de por. Não se trata ainda de escritura magnífica; e já, todavia, sob algumas daquelas mãozinhas vem a caligrafia alvorecendo. Correntes neste primeiro processo, passam a calcar bons originais caligráficos, sotopostos a papel transparente ou vidro fosco (papéis vidro.). Nestes originais caligráficos há, em cada um, um desenho simples que, sendo calcado assim como o é a letra, inicia para o desenho a mão bisonha, ao mesmo tempo que a aprimora no escrever (...) Expeditos e hábeis neste segundo trabalho, promovem-se a copiar para os mesmos vidros foscos ou para as ardósias, aqueles originais. O papel comum e a pena com tinta são a terceira fase; mas o trabalho ainda é de cópia. A quarta e última, é a escrita de período, acentuadamente ditado pelo Mestre.
\end{abstract}

\footnotetext{
${ }^{186}$ Id. Ibid., p. 98.

${ }^{187}$ Ao caracterizar a apropriação que os lassalistas fizeram de uma prática que já existia anteriormente nos Colégios, André PETITAT destaca o significado social desse modelo escolar referenciado pelo 'ensino simultâneo': "Se pensarmos sempre na escola elementar em termos de difusão da escrita, arriscamo-nos a deixar de lado uma de suas características essenciais. A alfabetização, tal como a entende a escola, é constantemente acompanhada por projetos anexos que chegam a colocar-se até mesmo em primeiro plano. Se entendermos as motivações de Démia e de La Salle, ensinar a ler e a escrever torna-se quase um pretexto para catequizar, para retirar as crianças da rua, para inculcar-lhes o respeito à ordem, hábitos de trabalho, etc. É verdade que essas eram as intenções. Não sabemos quais eram os resultados concretos. $O$ que restou por fim? O alfabeto? Os princípios e costumes morais? É sempre verdadeiro que a escola elementar deseja ser um agente de educação moral, tanto quando ela sobrecarrega de valores sociais a receptividade à alfabetização, como quando se soma a uma educação familiar considerada insuficiente, tanto no plano da difusão da escrita quanto no plano da integração em uma ordem política-religiosa." (André PETITAT, Produção da escola / produção da sociedade, p. 121)

${ }^{188}$ António Feliciano de CASTILHO, Methodo Portuguez - Castilho, p. 105.
} 
Aqui devem os alunos juntar, pela sua reflexão própria, a uma ortografia etimológica regular, e a um lançado de letras elegantes, bem dispostas em linhas horizontais e equidistantes, a pontuação exigida pelo tom do recitador. As qualidades da escrita dos adestrados pelo Método português, são as que unicamente se devem pedir (e direi até permitir) à escola primária popular: clareza, com facilidade; elegância, sem luxo; acerto de ortografia e de pontuação. Assim se perfazem a um tempo os dois ensinos: o da leitura, sem silabários sonolentos; o da escrita, sem regrados, pautas, riscos ou ligações; ambos, com perene variedade e constante satisfação."189

Se Herculano condicionava sua defesa da instrução à existência de uma escola primária superior e complementar àquela restrita ao ensino de primeiras letras, Castilho também atrela seu parecer político sobre o tema da escolarização. Havia que se defender, sim, a extensão do acesso às oportunidades educacionais, mas, concomitantemente, seria imprescindível idealizar a criação de um novo e diferente modo de ser escola. A forma escolar aqui propugnada não caberia nos antigos moldes e tradicionais modelos, os quais engessavam e perenizavam a instituição no que esta tinha de velho. A utopia do novo e da inovação fazia parte da obsessão do pedagogo reformador. As alterações previstas principiariam pela própria forma de olhar para a tarefa do professor... Mas, para além disso, como vimos, sugeria-se um modo alternativo de se perceber a dinâmica do aprendizado da leitura. Finalmente a reinvenção do que Anne Marie Chartier denominou de "fazeres ordinários da classe", mediante o entrecruzar-se do trabalho do aprendizado com atividades ritmadas $\mathrm{e}$ compassadas, capazes de reorganizar o habitus, a rotina, o próprio cotidiano do trabalho escolar. ${ }^{190}$ A dimensão emancipadora tributária do discurso das Luzes quando fala de educação subordina-se, com Castilho, à adoção de seu projeto escolar. Isso significa dizer que Castilho não quer aquilo que denominava escola antiga; Castilho defende única e exclusivamente a escola que nasceu de sua pena. Aliás, segundo ele, essa seria a única instituição pedagógica assente em bases naturais ${ }^{191}$. Sob tal convicção, o autor sente-se à vontade inclusive para propor modificações quanto ao mobiliário escolar, tendo em vista alterações na dimensão física da sala de aula, conforme veremos adiante.

\footnotetext{
${ }^{189}$ António Feliciano de CASTILHO, Methodo Portuguez-Castilho, p.105-107. Abaixo, no canto esquerdo da página 106, há uma nota de rodapé onde se lê o seguinte comentário:

"Resenha alfabética, grande quadro parietal. Preço 240 réis. Papéis-vidros vendem-se nas lojas de livros e objetos de desenho, preço240 réis; e com uma coleção de doze traslados caligráficos, 480 réis.”

${ }^{190}$ Nas palavras da educadora: “(...) esse fazer ordinário da classe não possui estatuto algum no discurso de transmissão do saber profissional efetuado pela instituição escolar. Com efeito, ele é largamente ignorado nas instituições de formação que, durante toda a sua história, parecem menos preocupadas em transmitir tais práticas elementares do que preconizar a renovação das condutas pedagógicas ou didáticas, Deverá isso ser abandonado ao 'ver fazer e ouvir dizer', às transmissões invisíveis que se fazem nesse terreno (...)? Seria essa efetivamente a parte oculta do iceberg?" (Anne Marie CHARTIER, Les faire ordinaires de la classe: un enjeu pour la recherche et pour la formation, Faculdade de Educação da USP, manuscrito, p. 12)

${ }^{191}$ Há, nos escritos de Castilho a tentativa de naturalização do processo pedagógico. Sendo assim, caberia ao mestre apresentar, logo à entrada da sala de aula, uma nova concepção da matéria escolar, dado que, pelas palavras de seu criador: "O Método Português assenta em bases naturais; é eminentemente analítico; acessível a todos os entendimentos; convidativo para todas as vontades; insinua-se nas memórias mais rebeldes, e se grava nas mais inconsistentes. Reúne ao proveito das primeiras noções literárias o higiênico uso dos braços, das pernas e dos pulmões: dos braços, pelas palmas; das pernas, pelas marchas; e dos pulmões, pelo canto. Afeiçoa os ânimos dos analfabetos a um trabalho que se lhes apresenta com todas as seduções de uma continuada festa.” (António Feliciano de CASTILHO, Felicidade pela instrução, p. 120)
} 

COLETIVO

Cabe notar que a atividade da escrita deveria vir acompanhada por um dado conjunto de atitudes que desenhassem a si mesmas como esboços dos comportamentos agendados pela escola para os futuros adultos, em que se transformaria a presente infância. Por tal razão, par e passo com o aprendizado da leitura e da escrita, estipulam-se ensinamentos de toda uma moralidade de cariz religioso, que, embora seja, por definição, incompatível com o conhecimento, estrutura-se como protagonista dos saberes elementares da escola. Desse modo, os conteúdos internos à alfabetização serão expressos, usualmente, mediante preceitos de Doutrina Cristã, Civilidade, Higiene, componentes substantivos do feitio típico dessa primeira escolarização. O método de Castilho, prevendo situações antepostas à realidade, conjectura, inclusive, abolir "malquerenças" entre mestres e discípulos, favorecendo nestes últimos a aceitação do ambiente escolar, além da orientação das atividades de leitura através das quais pudesse haver a interiorização de hábitos de mnemônica, acentuação e pronúncia, necessários ao desenvolvimento cognitivo. Da leitura auricular às figuras que recordam letras, das "inflexões da pontuação", aos cantos e palmas, obter-se-ia o "contentamento de quem aprende..."

A partir do conjunto de conhecimentos iniciais básicos, a escolarização caminharia tendo em vista a idéia de um aprofundamento quase enciclopédico a partir do estudo de outras áreas, tomadas como necessárias para a formação das gerações novas. $\mathrm{O}$ conhecimento escolar, que parece ser em cada época o modo como a escola se apropria dos níveis de cultura de seu tempo, surge na história como se de uma opção se tratasse. No caso da escolha de Castilho teremos o seguinte elenco: Física, Geometria, História Natural, Química, Economia Doméstica, Jurisprudência, História Universal, História Sagrada, História de Portugal, Música, Desenho. Evidentemente esse conjunto disciplinar representava, na estrutura do currículo planeado por Castilho, uma continuidade do estudo aprofundado da Aritmética e fundamentalmente da língua materna, em sua normatividade gramatical. $\mathrm{O}$ estudo da Gramática, por seu turno, vem proposto como instrumento para facultar o bom uso do bom português; o que Castilho dirá da seguinte maneira:

\footnotetext{
"Discípulos e mestres sabem gramáticas, e não sabem Gramática. Gramática não é um livro mais ou menos gordo, mais ou menos autorizado, mais ou menos entenebrecido de mistérios. Gramática é o senso comum da linguagem(...) Um mestre, como os há de haver em se querendo, ensinará analiticamente a Gramática de aplicação e préstimo sem aparato de livros, sem tediosas tecnologias supérfluas, sem trambolhos de definições textuais. Não dará sequer a esta disciplina uma porção designada do tempo letivo; analisará ao acaso, e quando lhe parecer, um período que serviu para a leitura ou para a escrita: o Padre Nosso, uma máxima, uma regra de saúde. Fará compreender a significação de cada palavra, a diferença de índole gramatical de umas e outras.",193
}

Verifica-se aí o modo pelo qual Castilho concebe a interface das matérias, ainda que não propusesse grandes novidades à guisa de conteúdos programáticos. $\mathrm{O}$ diálogo do pedagogo com o que acreditava ser a escola velha aparece de maneira recorrente em seus escritos. Acerca disso, julgava Castilho que o seu modo de ensinar era original desde o processo de decifração das letras, posto que, ao contrário dos procedimentos tradicionais, cada letra seria aqui nomeada pelo som que teria no vocábulo, em um modelo de soletração

\footnotetext{
192 António Feliciano de CASTILHO, Felicidade pela instrução..., p.124.

${ }^{193}$ Id. Ibid., p. 63.
} 
moderna, cuja originalidade Castilho parecia querer reivindicar. ${ }^{194}$ Cada letra foi então associada a uma história, vindo acompanhada pela figura geradora, a qual, por sua vez, ficaria, pela mnemonização, gravada na mente do aprendiz. ${ }^{195}$ Cabe recordar que o método dito "português" foi bastante criticado a seu tempo, particularmente por professores presos ao tradicional modelo de ensino, ao qual Castilho passaria a designar como "adversário". O método inventado pelo poeta era muitas vezes taxado de pueril, de dispendioso, de trabalhoso, não factível, portanto, para escolas de um único professor. Castilho, de modo recorrente, compra a polêmica, tentando persuadir os professores no reconhecimento das virtudes postas inclusive naqueles que eram, à partida, os aparentes defeitos do Método. A premissa básica, nesse assunto, pautava-se na necessidade de o mestre fazer-se menino para se recordar...

"O Mestre, que já foi menino, que lida com eles e os deve conhecer, pode (sem se desautorizar) nivelar-se até certo ponto com a infância; enquanto a infância, que nunca passou, nem pela austeridade da velhice, nem pela circunspecção da virilidade, não pode deixar de ser aquilo que Deus a fez." 196

Em sua trajetória pedagógica, Castilho soube identificar e contrapor-se aos argumentos de seus adversários. Costumava, em suas polêmicas apropriar-se das premissas do interlocutor, tomando-as para si em um ato de inversão, para, a partir delas, alcançar o argumento capaz de calar a oposição. Essas peças de retórica podem ser constatadas nos escritos reunidos sob os títulos de Ajuste de contas com os adversários do Método Português e Resposta aos novíssimos impugnadores do Método Português. A primeira trata-se de um discurso de Castilho em novembro de 1854, na sala da Philarmónica de Coimbra. O público a quem ele se dirigia era constituído fundamentalmente por professores régios e particulares, por estudantes e, segundo consta, por lentes da Universidade. Referenciando-se por essa mocidade acadêmica, o poeta apresenta seu método como a "carta de alforria da puerícia", a alavanca de obtenção da emancipação intelectual do povo, através de seu aprimoramento moral, civil, religioso, intelectual e político. Tais seriam os objetivos manifestos para o âmbito da escolarização primária. O segundo texto - datado de 1855 consiste na argumentação de Castilho contrariando a resposta que a Comissão de professores ao acatar o desafio do poeta - teria encaminhado sobre a comparação entre o Método Português e o antigo procedimento pedagógico em vigor nas escolas primárias. Sempre pronto para o debate e decidido a desmascarar os senões dos adversários, Castilho, aceitando e já respondendo aos "provocadores", apresenta, a dada altura, um "inventário de tudo quanto até hoje tem constado haver-se dito, escrito ou impresso contra o Método Português". Já com fama de ditador em matéria de educação - "crê ou morre" era sua tácita insígnia - Castilho era criticado por haver - no parecer de seus opositores - transformado a escola em um território de experimentações pedagógicas, negando com isso, não apenas as tradições da Pedagogia, mas também as próprias tradições nacionais, posto que teria pretendido inclusive alterar os padrões ortográficos da língua portuguesa. Dizia-se mal também da busca da rapidez no processo de alfabetização, sob a alegação de que "se se aprende depressa, também se há de esquecer

\footnotetext{
194 "Tanto as vogais como as consoantes se ensinavam antes do Método Português com duas lamentáveis deficiências; de que resultava o desbaratarem-se, em tormentos, largos meses para se saber o alfabeto, e, ainda depois do alfabeto sabido, não se poderem logo decifrar as palavras escritas, uma vez que as letras nelas empregadas aparecessem ali com valor diverso daquele com que originariamente se haviam nomeado. A ambas as faltas acudiu o previdente Método.” (A.F.CASTILHO, Methodo Portuguez-Castilho, p.99-100)

195 "É da natureza do espírito humano menosprezar e aborrecer as coisas em que não descobre préstimo. O aluno da escola velha odiava o estudo das letras, cujo uso na composição das sílabas não podia adivinhar; assim como depois abominava o estudo das sílabas, cujo uso na composição dos vocábulos era para ele outro mistério. O Método, pelo seu horror a arcanos insensatos, quis que as letras se entrassem a conhecer, se entrassem sem mais demora a ler palavras.” (A.F.CASTILHO, Methodo Portuguez-Castilho, p.100-101)
}

${ }^{196}$ Id. Ibid., p. 110. 
depressa" ${ }^{197}$ Apresentava-se como outro inconveniente do Método a priorização do canto, das palmas, do ritmo, já que isso, a despeito de aliviar o enfado da infância em relação à escola, não a predisporia - pela mesma razão - para as "durezas da vida", além de não prepará-la para estudos posteriores. Outras críticas que Castilho procurará refutar são as que se pautam pela recusa do ensino simultâneo. Castilho - como já pudemos anteriormente comentar - em toda a estrutura de seu projeto pedagógico, tem de fato por suposto o modo simultâneo do processo de ensino. A leitura era feita em coro, as atividades ritmadas possuíam nítida conotação disciplinadora, as próprias atividades previstas parecem estar falando para um grupo-classe. A indagação que se colocava, a esse respeito, provinha da situação de muitas escolas, que, a cada dia, recebiam novos estudantes, não permitindo, até por carência de pessoal docente, a estruturação de turmas uniformes de alunos de mesma idade e nível de aprendizado similar. A essa questão, quando se contrapôs às respostas que os professores deram aos quesitos por ele apresentados à quisa de comparação de seu método com o da escola antiga, Castilho teria comentado pela ilustração: trata-se, no caso, do cenário que assiste uma mãe quando, pela primeira vez, leva os dois filhos à escola antiga...

\begin{abstract}
"À porta da escola antiga, pára, limpando o suor, e espera para entrar, que se conclua uma execução estrondosa, que lá dentro se está fazendo. Ressoam promiscuamente os estalidos dos golpes, os ais e implorações do paciente, os impropérios, e ainda as ameaças, do juiz-algoz. Aperta as mãos dos seus dois pobrezitos, e mais ternamente a do que lhe há-de ficar ali. Entram enfim. De quanta virtude não há mister o nosso assisado analfabeto, para levar a cabo o seu propósito! Tudo o que vê, lhe repugna; de toda parte assombra a sujeição servil, a desconfiança mútua, o desamor e a aversão. Os da mesma idade, que fora dali brincaram como irmãos, espancam-se e acusam-se, depõem como testemunhas falsas, desculpam-se mentindo, denunciando e caluniando. Uns, arvorados em mestres, fingem ensinar o que não sabem; vendem a este por um registo, àquele por um figo passado, a outro por cinco alfinetes ou um botão de chumbo, a conta que hão-de apresentar de lição sabida, fazendo muitas vezes recair as penas sobre o triste que estudou, mas que não teve com que peitar. O Professor, a quem os cuidados domésticos e a penúria azedaram o gênio, e que o hábito de maltratar, covarde e impunemente fez desabido, grosseiro, desumano, sente uma espécie de regalo feroz em poder desafogar o seu mal humor. Nenhuma palavra sua revela, no tom, que reste ainda lá dentro um átomo de coração. Eis aqui, sem ficções nem exageração, a escola de bons costumes, tal como a tem, e pretende conservá-la, o sistema antigo." 198
\end{abstract}

A função moralizadora da escola de primeiras letras, tão ressaltada pela recente historiografia da educação, parece constituir-se como finalidade explícita da instituição, de acordo com autores do século XIX. No caso português, esse será um século que caminha em busca de uma escola unificada e unificadora, capaz de forjar hábitos de religiosidade, urbanidade e, consequentemente, disciplina social. Porém, a todo o momento, deparamo-nos com o depoimento dos contemporâneos, queixosos do estado da instrução, descrevendo e relatando uma escola que não se mostrava capaz de cumprir tal tarefa que lhe fôra, à guisa de projeto, designada. Castilho procura situar-se sempre como o arauto de uma nova era, na qual a escola transformada possibilitaria maneiras renovadas de olhar para a etapa da infância. Insistindo em sua argumentação pedagógica, o autor do Método Português irá apresentar a causa da escola como uma obra de arte a ser edificada; de todos os seus poemas, o que ele mais intensamente teria amado. ${ }^{199}$ De fato, Castilho parece pretender, na entrelinha, o

\footnotetext{
${ }^{197}$ António Feliciano de CASTILHO, Ajuste de contas com os adversários do Método Português, p. 20.

198 António Feliciano de CASTILHO, Resposta aos novíssimos impugnadores do Método Português, vol. I, p.81-82. Castilho usa de modo recorrente em sua argumentação a descrição das palmatoadas, que, sem dúvida alguma, perturbariam mais o compasso do ensino do que o canto ou as palmas previstos por seu método. Tencionava tornar mais humana a escola, reestruturando seu interior pedagógico. Era, pelo menos, o que dizia...

199 "Estranham-me ter renunciado à poesia pelo ensino primário. Este ensino primário com afabilidade e sem dureza, esta carta de alforria das crianças, é o único dos meus poemas que eu amo, e não perdôo à crítica me
} 
reconhecimento como pedagogo de um talento que, enquanto poeta, não teria sido, a seus olhos, suficientemente reverenciado.

Em sua tarefa de reflexão sobre o método, Castilho crê atribuir racionalidade àquilo que anteriormente se fazia sem regras, "ao acaso e à toa". ${ }^{200}$ Contrapõe a estrutura lógica de seu projeto à dinâmica anteriormente ultrapassada e desconexa da "escola velha", na qual professores sem orientação agiriam por sucessivos ensaios e erros, na atividade pautada exclusivamente pelo critério da rotina e da imitação de modelos que, com o correr dos tempos, vinham se tornando cada vez mais antigos. Por ser assim, julgamos que Castilho tem realmente uma coloração precursora no sentido de pretender conferir regras e padrões de eficácia a uma escola portuguesa que, até então, caminhava pautada pelo acaso, pela indeterminação, pela inconstância de um cotidiano pouco sistemático e quase alheio às prescrições normativas; em última instância, Castilho pretendeu transformar o corriqueiro savoir faire de uma escola que sequer sabia dizer porque fazia isso e não aquilo em um corpo de conhecimentos, dotado de uma estrutura e de uma normatividade que lhe seriam próprias, capaz de se apresentar como conhecimento especificamente escolar. De fato, Castilho atribui à escola finalidades mais amplas do que ela própria: o conhecimento escolar deveria ter, pois, função civilizatória. Também sob esse aspecto, o antigo método deixava a desejar. Nas palavras do interlocutor, o juízo sobre a escola:

\begin{abstract}
"Há em Portugal poucos homens instruídos; pouquíssimos sábios; pode-se mesmo dizer que o máximo da população é por ora analfabeto. E d'onde provém isto? De um complexo de causas desgraçadas, que todos conhecem, mas entre as quais não avulta pouco a insuficiência da escola primária, a morosidade e a imperfeição de seu ensino. Reconstruam-na, civilizem-na, como é fácil; provejam-na em mestres idôneos, o que é difícil, mas não impossível se à obra se proporcionar o salário; façam-na superintender e vigiar de perto, como convém e é indispensável; obriguem à matrícula e à frequência exata os carecentes das primeiras noções, para o que não faltam meios seguríssimos; e só então nos poderemos jactar de possuirmos instrução geral."201
\end{abstract}

\title{
FASCÍNIO E MEDO DAS PRÁTICAS ESPONTÂNEAS DE LEITURA: A FUNÇÃO REGULADORA DA ESCOLA
}

Confiante no sucesso de seu método, que se constituía, a seus olhos, como o grande empreendimento de transformação da escola naquilo que ela sempre deveria ter sido, Castilho chega a declarar que uma das críticas possíveis ao método português decorreria do alcance de seu êxito, com a consequente diminuição do tempo escolar: "se aprenderem depressa - diz-se - como se hão-de depois as famílias livrar das crianças, que até agora se mandavam para as escolas?" 202 Sob esse aspecto, Castilho compara o efeito da boa escola ao da vacinação, que, fazendo com que as crianças vivam, certamente possibilitará o acréscimo

atassalhe. Que me importam meia dúzia de louvores mesclados, suspeitos, inúteis, que poderiam dar os homens a mais algumas páginas minhas de poesia vã, se eu tenho, em vez dessa, a poesia das bençãos de tantas mães, os abraços e beijos de tantos filhos, que ainda não aprenderam a ser ingratos?" (A.F. CASTILHO, Ajuste de contas com os adversários do Methodo Portuguez, p. 54-55).

200 "É intuitivo para qualquer espírito pensador, que o ensino antigo não tem regras; não as tem; faz-se ao acaso,à toa, pelos meios mais grosseiros e materiais. Se há engenho tão divinamente criador, que possa aspirar a sistematizar com vantagem o abecedário incompleto e anti-lógico, a leitura das palavras incompleta e antilógica, uma pontuação sem valor marcado, um estudo do ler sem conhecimento do falar, o estudo da escrita sem os seus fundamentos essenciais, a simultaneidade com a individualidade, o desgosto com a atenção, a ininteligibilidade com a clareza, e a desenvolução de todas as faculdades com a compreensão de todas elas, esse engenho, esse Apolo magno, que empreenda no caos da escola velha uma criação, que nós (confessamos a nossa fraqueza) reputamos impossivel." (A. F. CASTILHO, Resposta aos novíssimos impugnadores do Methodo Portuguez, vol. II, p.145)

${ }^{201}$ A. F. CASTILHO, Resposta aos novísssimos impugnadores do Methodo Portuguez, vol. II, p. $130-131$. ${ }^{202}$ António Feliciano de CASTILHO, Ajuste de contas com os adversários do Méthodo Portuguez, p.55. 
de trabalho dos pais e da sociedade para com elas. Para o criador do método, essa escolarização que conduz à vida convive, ainda, com uma última indagação: "não convém derramar prodigamente a instrução pelo povo. Para que é este empenho de pôr todo o povo a ler, se ele não tem quê, nem com que o compre?"203 A época parecia compactuar com um 'fascínio pânico' pelas práticas de leitura, e a mesma escola que é propalada como a regeneradora da nação é temida como foco de subversão do tecido social. A idéia de uma instrução que desorganiza os espaços, engendrando a negação de quaisquer trabalhos manuais e trazendo confusão à estabilidade dos ofícios e dos lugares pré - determinados, permeia esse imaginário. Enfim, o conhecimento, enquanto poder subjetivo, ao ser irradiado pela via da escolarização, poderia ser uma arma ameaçadora das próprias instituições. Castilho procura fugir do impasse, respondendo às possíveis nefastas consequências da leitura de livros impróprios com a prescrição de outras leituras, de outros textos, adequados à tarefa formadora da escolarização. O livro era já um suporte acessível, que circulava pelas aldeias, vilarejos e cidades. Enquanto artefato, objeto que era, não estava sob controle desta ou daquela autoridade. Não conviria concorrer, pois, com o efeito dos progressos da ciência e da técnica. Havia de se adequar os tempos e as novas necessidades sociais a essa situação que, no decorrer do XIX, parecia cada vez mais irreversível. O parecer de Castilho é tributário, como podemos constatar, desse ponto de vista:

\footnotetext{
"Supõe-se que a ilustração perverte! É o mesmo que dizer que a luz pode extraviar. Quando Deus fez a luz, 'reconheceu que era boa'- diz o texto sagrado. Logo que as nações houverem também feito a luz, hão-de reconhecer a sua bondade. A maior parte dos males provém da ignorância. Alguns são efeito de idéias falsas e princípios ruins; esses princípios e essas idéias, que os livros podem até certo ponto fomentar, outros livros mais sisudos, e para logo preferidos pelo senso comum das turbas, hão-de (com o auxílio da Providência, que não dorme nunca) ir substituindo a esses erros, acertos; e a esses princípios perigosos, princípios seguros. Deixe trabalhar para as multidões a Imprensa, que é a charrua dos baldios intelectuais e das charnecas morais: e deixai trabalhar o Mestre-Escola, que é o escolhedor e semeador do bom grão. Tendes boas leis; tende ótimos fiscais zeladores da instrução pública, e não vos arrecearei de que o povo saiba." ${ }^{\text {,204 }}$
}

$\mathrm{Na}$ verdade, a chave de Castilho consistia em sua preocupação quanto ao aprimoramento das leituras populares, apresentando-se assim como o arauto de uma nova literatura prescrita e recomendada para o homem comum. Dizia ele que 'os livros convenientes ao Povo estão ainda por escrever', acreditando que tal situação poderia ser contornada mediante a aprovação de leis que garantissem a publicação barata de boas obras. $^{205}$ Castilho sempre procurou tornar seu método oficial nas escolas portuguesas. Podemos dizer que essa sua preocupação com os mecanismos de publicação tinham interesse de cunho pessoal, posto que facilitassem sua situação confortável de escritor de boas obras. Seja como for, nos textos do escritor, o tema da leitura aparece, invariavelmente, sob dupla chave: por um lado, sem dúvida, a emancipação, após se ter devidamente precavido contra a tentativa da corrupção, ameaçadora por trazer o descontrole aos canais da comunicação. Em relação à uma estética da recepção, podemos dizer que Castilho, como muitos de seus contemporâneos, prenunciava já as transformações que o ato da leitura imprime no texto, embora não reconhecesse a possibilidade de o ato da leitura criar significados novos, sentidos inusitados, reinventando, nessa façanha, até a mensagem do autor. O papel do leitor seria, de

\footnotetext{
${ }^{203}$ Id. Ibid., p. 24.

${ }^{204}$ Id. Ibid., p. 107-108

${ }^{205}$ Id.Ibid., p.108. Sobre essa questão das leis, o autor diz o seguinte: "Uma Lei, que proporcione a publicação barata de obras prestadias! Uma Lei que as proteja de todos os modos! Uma Lei, que obrigue a assinar para ela todas as Câmaras municipais e todas as paróquias! Uma Lei, que force os curas de almas a recomendá-las à estação da Missa! Uma Lei, que obrigue as escolas a ensinar por elas! Uma lei, que assegure prêmios pecuniários e honoríficos aos homens de bem, que vierem, com esses escritos civilizadores, lavar alguma parte da vergonha, de que a nossa imprensa, por culpa de sicophantes, de bárbaros, e de antropófagos, se tem coberto e se está cobrindo." ( A.F. CASTILHO, Ajuste de Contas..., p.108-109)
} 
acordo com o que julgava Castilho, o de submissão às estratégias do autor, que, enquanto tal, era produtor de mundos... mundos por escrito. $\mathrm{O}$ fascínio e o temor pela leitura andavam, por essa razão, sempre juntos:

\begin{abstract}
"O tempo da novela, veneno suave e sutil, que tantas mortes d'alma e de coração tem já causado, o reinado da novela vai passando. Um bem fez ela, todavia, e foi criar o gosto e o costume pela leitura; resta aproveitá-los, encaminhá-los, desenvolvê-los ainda mais. Nos domínios mesmos da ficção há para traduzir; e obras de natureza didática de grande proveito. As ciências, quase todas, têm sido postas ao alcance e temperadas ao sabor até do vulgo; e a moral não é menos suscetível de enfeites e encantos que a imoralidade." ${ }^{206}$
\end{abstract}

A civilização fazia-se, no discurso, por obras; urgia providenciar leitura para que se procedesse à tarefa redentora da escola primária: a escola que moraliza, civiliza, ensina a ler e a ser... A leitura escolar, prefixando a própria forma escolar, dever-se-ia mostrar reveladora de um universo valorativo que, até certo ponto, estaria agendado, antecipando-se, pela pauta da escola, à realidade. Em qualquer hipótese, Castilho oferecia a possibilidade de instrução também para os adultos; e pela sua cara Revista Universal Lisbonense:

"Curso público e gratuito de leitura e escrita repentina pelo método de A. F. de Castilho e de caligrafia pelo sr. D. Pedro Sebastiá e Vila.- Este curso já anda anunciado em todos os periódicos de Lisboa e para o qual se continuavam a receber matrículas no palácio do Sarmento, rua dos Navegantes á Estrela, há de se abrir infalivelmente no dia 15 do corrente julho ao escurecer. São admitidas a frequentá-lo pessoas de qualquer sexo e idade, tendo por isso de se dividir a totalidade dos discípulos em três turmas para polícia moral e boa ordem no ensino, a saber homens, mulheres e crianças. Admitem-se igualmente a presenciar os trabalhos quaisquer senhoras e cavalheiros. Aos senhores e senhoras professores da instrução primária, bem como aos senhores diretores e senhoras diretoras de colégios se oferece e pede para comparecerem aos exercícios, a fim não só de poderem julgar estes novos métodos com conhecimento de causa, mas também de ajudarem com as suas luzes e conselhos o autor, quando assim julguem conveniente. Aos senhores chefes de estabelecimentos públicos ou particulares, tais como arsenais, cordoaria, alfândegas, obras públicas, oficinas, fábricas etc., assim como aos senhores comandantes de corpos militares e de navios do governo ou do comércio, roga-se concorram com a sua valiosa persuasão para que se aproveitem do oferecido benefício todos aqueles dos seus subalternos que dele se possam aproveitar. Finalmente se espera que todos os reverendos párocos das freguesias circunvizinhas ao lugar da escola, principalmente, se dignem de empregar a ungida persuasão da palavra de Deus para moverem as ovelhas que a Providência lhes confiou e acudirem -precisandoa este pasto abundante, agradável e também espiritual, como já com admirável e edificativa eficácia o estão fazendo os reverendos senhores priores de Santa Isabel e da Lapa. N.B. Este curso durará até que a maioria saiba ler e escrever; concluído ele não será repetido. Os alunos que não forem assíduos na frequência e os que perturbarem a seriedade e a atenção das lições serão inevitavelmente excluídos."207

Sobre o mesmo curso de 'leitura popular', oferecido na casa em que Castilho residia, anuncia-se posteriormente que o acesso teria sido restrito aos 'alunos dóceis' e às pessoas que vieram munidos de senhas. Estas só seriam entregue com a condição de a pessoa assinar o nome e morada em livro próprio para esse registro, devendo, ainda, portar-se com 'decência e urbanidade'. ${ }^{208}$ Com esses cursos de Leitura Repentina, Castilho conseguia certamente boa divulgação, por periódicos da época, de seu novo método, conquistando

\footnotetext{
${ }^{206}$ A.F.CASTILHO, Ajuste de contas..., p. 109.

${ }^{207}$ REVISTA Universal Lisbonense, 2 série - tomo 5,1852-1853, p.11.

${ }^{208}$ Id. Ibid., p.33-34.
} 
efetiva notoriedade através desse concreto efeito irradiador de suas idéias. O curso certamente não era tão aberto assim, posto que, como assegura a Revista, Castilho teria pleno controle do acesso, à entrada. ${ }^{209}$.

A polêmica que foi detonada acerca do Método Castilho de Leitura Repentina parece-nos bastante tributária do parecer político de seu artífice quanto aos assuntos educacionais. Castilho, ao falar de educação, tocava nas grandes feridas da escola portuguesa. Ao contrário da maioria dos intelectuais que lhe eram contemporâneos ou antecessores, Castilho desejava remeter o problema para além das questões correntes no discurso de defesa da escola. Por que a escola propugnada não existia na realidade? Quem era a verdadeira escola sobre a qual pouco se dizia? Por que as populações não procuravam devidamente os benefícios da instrução para os seus filhos? Que tipo de castigos eram empregados usualmente por essa instituição? A facilitação do aprendizado produziria como efeito imediato o desejo pela instrução. Para isso, havia que se alterar o método; tornar a escola um local de prazer. Tendo em vista consolidar sua tese, Castilho falava a jornais e a revistas, apontando impiedosamente muitas feridas de uma escola que ainda carecia de organização, que era notoriamente autoritária e que, por ser assim, não se apresentava, aos olhos de seus usuários, como o templo de edificação da prosperidade futura. De fato, a escola desenhada pelo iluminismo não chegara ainda a Portugal. Castilho inova, pois, quando ousa afirmar a necessidade de transformação do espaço escolar. Aqui a defesa da escola estava efetivamente condicionada à sua transformação. Por sua vez, a transformação exigiria a adoção do novo método. Em carta publicada, em 1864, no periódico Archivo Pittoresco, e dirigida ao redator daquela revista, Castilho dizia o seguinte:

\begin{abstract}
"Bom é, não há dúvida, que as povoações carecentes de escolas se lembrem já de as pedir; que as respectivas autoridades abonem e apadrinhem o requerimento; que este seja favoravelmente consultado pelo Conselho de Instrução Pública, e pelo governo deferido. (...) Mas, na verdade, verdade, a multiplicação das escolas materiais só per si bem pouco vale, se porventura vale alguma coisa. São capelinhas de almas fundadas em charnecas por beatos mendicantes, mas onde não há festa, nem lâmpada, nem ermitão zeloso, nem sineta que chame. (...) Que são escolas sem ensino? Que é ensino sem mestre? Que é mestre sem método (...)? Quanto mais não valeria do que dez ou vinte escolas nominais, fingidas, antipáticas aos pais, odiosas aos filhos, imorais por muitos modos, e que em anos e anos quase nada ensinam, uma só escola bem frequentada, bem regida, bem contente, bem fecunda! São as desta espécie que hão de convencer o vulgo de que o aprender é útil, agradável e facílimo; enquanto aquelas outras, as de que nós inçamos as províncias, só valem para confirmar cada vez mais a plebe na sua aversão hereditária para com o que nós lhe chamamos, no nosso estilo artificioso, fontes do saber, mas em que eles com o seu pingue bom senso natural não descobrem, por mais que abram os olhos, senão poços, ou secos ou salobros, que não prestam para beber nem para regar, e onde pelo peso dos baldes e emperrado nas roldanas, é menos a água que se tira que a que se sua. Enfim esperemos. Atrás de tempos tempos vêm. Já se gosta de ir instituindo umas coisas que têm o nome de escolas. Daqui a alguns anos poderá ser que se criem escolas verdadeiras. E não sejamos pessimistas: para lá caminhamos nós. Por bastantes sinais e bem claros se reconhece." 210
\end{abstract}

\footnotetext{
${ }^{209}$ Em número posterior da Revista Universal Lisbonense consta o seguinte aviso: "Em consequência da indispensável necessidade de evitar nos sermões deste curso a confusão e o sussurro, e que necessariamente resultam da excessiva concorrência de visitadores, assim como a estes e, mormente, às damas o incômodo que têm sofrido com o apinhamento da turba, declara-se positivamente: 1. Que nenhuma pessoa de um e outro sexo será admitida sem bilhete previamente obtido; 2. Que os bilhetes só serão dados a pessoas perfeitamente conhecidas do sr. Castilho ou às que por estas lhes forem recomendadas; 3. Que um bilhete não serve por mais de uma vez, pelo que logo à entrada da porta deverão ser restituídos ao recebedor." (Revista Universal Lisbonense, 2 série - tomo 5, 1852-1853, p.60)

${ }^{210}$ António Feliciano de CASTILHO, Escola Casal Ribeiro; Carta do sr. A.F. de Castilho ao redactor do Archivo Pittoresco, In: Archivo Pittoresco, 1864, p. 53.
} 


\section{A DISCIPLINA ESCOLAR NA FABRICAÇÃO DE CORPOS DÓCEIS}

Como já observava Luís Albuquerque, ao criar seu método de alfabetização, Castilho efetuou intensa campanha junto à imprensa e autoridades da época, tendo em vista a consagração da sua Leitura Repentina como método oficial e único do ensino das primeiras letras em escolas portuguesas. ${ }^{211}$ Pode-se mesmo dizer que Castilho intitula de velho tudo aquilo que não corresponde à metodologia que criara e que supunha ser única. Contrapondose ao que entendia ser o ensino catequético da escola então existente, é com os saberes dessa escola, com o conteúdo da cultura escolar, que o poeta irá dialogar. Para Castilho a prática do ensino da caligrafia consistia em atividade vã e nociva, na medida em que, ao contrário do que se poderia supor à época, esse escrever primoroso nada teria a ver com a necessária legibilidade de uma escrita clara e corrente. Assim o campo da caligrafia não faria parte - no entender do poeta - da índole da escola primária. ${ }^{212} \mathrm{O}$ povo, da escola primária esperava "o ler claro e fácil, o escrever fácil e claro, o calcular exato e pronto" ${ }^{213}$. Nada de outras superfluidades.

Já nos aspectos concernentes à ortografia, como vimos, Castilho era bastante mais rigoroso. O poeta apresenta como dificuldade maior da alfabetização em língua portuguesa a pequena correlação entre a escrita das letras e sua leitura, chegando a propor sugestões quanto a uma modificação ortográfica da língua, de modo a facilitar a alfabetização pelo método que criara. Talvez nisso residisse parte do intenso fervilhar de debates sobre o mesmo. Castilho entendia que, se as letras não possuírem alguma "relação perceptível" com o som, elas fugirão da memória; daí a criação de imagens que fossem geradoras de histórias relacionadas a cada letra. No parecer do criador, "a letra, sombra daquela pintura historiada, ficou, portanto, e para logo, e para sempre, estampada no cérebro com o som que lhe pertencia. É porque, onde só reinavam trevas, contradições e repugnâncias, se acendeu a luz, e se introduziu a harmonia" "214. Além desse recurso mnemônico, Castilho pretende substituir a ortografia etimológica por aquilo que supunha ser a "ortografia racional" 215 . A preocupação do educador com as gerações de portugueses que se mostravam incapazes de decifrar o enigma da leitura convida-o a procurar desvendar os nódulos que obscureciam o processo da alfabetização. Sob tal aspecto, Castilho chega à conclusão de que é a acepção mesma do ensino que deverá ser alterada, tendo em vista a melhoria da escola e o êxito da instrução das ditas primeiras letras. Para tanto havia que se recorrer ao ensino simultâneo como modo escolar mais apropriado;

211 “(...) ei-lo lançado na maior e mais árdua das suas campanhas. Dirige requerimentos a ministros, cartas a governadores civis e a professores, escreve artigos para jornais, conversa com pessoas de influência, pede e intima, tudo a favor do método. O que Castilho pretende é um despacho do Conselho Superior, um decreto do ministro do Reino, uma intervenção da Rainha, qualquer coisa que imponha a leitura repentina como o único método adotável nas escolas primárias do país. Mas o Conselho alega faltarem-lhe poderes para tanto,o ministro, se o chegou a prometer, adia eternamente o decreto, e a Rainha, apesar da segunda edição da cartilha (...) ser oferecida ao futuro D. Pedro V, mostra ignorar as pretensões do poeta" (Luís ALBUQUERQUE, Notas para a história do ensino em Portugal, p.189-190).

212 "É nociva para o povo a caligrafia porque lhe devora muito tempo, e conseguintemente desfalca-o por mais de um modo.É nociva porque o acostuma em idade tenra a preferir ao sólido o brilhante, e ao indispensável o escusado. É nociva porque o escrever minucioso e lambido, sendo na prática muito mais moroso, só se pode conservar, sacrificando a essas vanidades de formas a brevidade e expedição dos negócios. E é finalmente vã (além de nociva) a caligrafia porque nada prova, nada, senão ociosidade, futilidade, e pouco juízo em quem a exerce, não sendo como profissão porque ai militam outras razões.” (A. F. CASTILHO, Resposta aos novíssimos impugnadores do Methodo Portuguez, vol.I, p.156-157).

${ }^{213}$ Id. Ibid., p. 156

${ }^{214}$ A. F. CASTILHO, Resposta aos novíssimos impugnadores do Methodo Portuguez, volume II, p.115.

215 “(...) segundo a qual cada elemento da palavra falada só por um sinal gráfico se represente, e cada elemento da palavra escrita só num elemento fônico se traduza. Desejamo-lo e temos fé viva em que, depois das abreviações que o gênio do homem vai aplicando a todas as coisas, o escrever uniforme e inequívoco há-de vir; $e$, vindo ele, o ensino do ler e do escrever (...) se há-de reduzir a duas ou três semanas.” (A. F. CASTILHO, Resposta aos novíssimos impugnadores...vol. I, p.160) 
nele, a procedimentos que facultassem a boa memorização do traçado e entrelaçado das letras. Com isso, entretanto, havia um entendimento prévio sobre a escola a ser frontalmente contrariado. Aos métodos tradicionais, Castilho pretendia opor o princípio do prazer, que o êxito do aprendizado poderia efetivamente fornecer. Ainda que criticasse o uso de regrados e pautas, o autor pretende reinventar a tradição, mediante a apropriação de alguns de seus componentes:

\begin{abstract}
"O decorar natural, liberal, e proveitoso, é o que assenta na inteligência e no gosto, e não o que se opera servilmente, às escuras, esbofeteado, raivando contra os livros como cadafalsos, contra os mestres como algozes. Ignoramos (...) se o que se aprende barbaramente fica mais impresso na memória. O que sabemos, e o que importa saber é que das noções assim adquiridas se há-de sempre se fugir com aversão; que o que só se aprendeu textualmente, e por mero efeito mecânico da repetição, não é mais ciência do que são linguagem as frases do corvo, da pêga, ou do papagaio; que habituar tão irracionalmente um espírito móvel, logo na escola primária, é contribuir para que ele no futuro não saiba estudar, não saiba dirigir quando for pai, e não saiba ensinar quando for mestre; é concorrer para que se não interrompa jamais a tradição secular e milenária de pseudomestres, que tão pouco produzem, e tanto devastam como praga em toda a parte."216
\end{abstract}

Também a propósito da forma do ensino, Castilho é veemente em sua condenação do uso da palmatória, apresentada como meio irracional de se obter do aluno a atenção. Exemplo da 'anti-lógica', os castigos escolares revelariam a tenebrosa face oculta da escola portuguesa, que, não podendo ou não querendo fazer ver seus percalços, culpabiliza o aluno pela desatenção ou pelo próprio fracasso. De fato, pelo que pudemos depreender, a recorrência a estilos de punição diversos era uma característica essencial dessa geometria escolar que se vinha aos poucos traçando. Encontramos registros variados sobre o uso de castigos físicos e morais, embora nem sempre o discurso pedagógico explicitasse tal dimensão. A crítica de Castilho a esse respeito é contundente e impiedosa para os partidários da antiga escola. $\mathrm{O}$ retrato que aqui vamos ver não parece, em hipótese alguma, dos mais favoráveis:

\footnotetext{
"Por que é para uma criança a mais tremebunda de todas as ameaças o falar-se-lhe em a mandar para o mestre? D’onde vem a mútua e manifesta aversão, já proverbial, dos instituidores para com os discípulos e dos discípulos para com os instituidores? Se podeis empregar esses muitíssimos meios de atrair a atenção, para que é a carranca oficial, a voz grossa, o tom enfático de tirano de comédia, e a vossa razão das razões, a palmatória, a palmatória que sobrevive às varas supliciais do Exército, o escândalo da palmatória, não atenuado mas agravado ainda pelo irracional sistema, que alguns de vós têm formulado em códigos de perdões, contados e descontados, compráveis, vendíveis, agiotáveis por todos os modos? Qual é o homem feito, qual é o velho, que recorda sem horror da tempestuosa quadra da sua escola primária? Qual de vós mesmos se lembra com prazer e afeto desses dias remotos, em que tanta e tão boa primavera da vida se lhe desbaratou?"217
}

Nesse universo de mútua aversão, discípulos e mestres às voltas com a contrariedade, muitos dos castigos aplicados pareciam ser comuns e usuais nas escolas de maneira geral. No parecer de Castilho, a própria imobilidade das crianças em sala de aula era por si só um castigo. Sentados ou em pé para que lhes fosse tomada a lição, a verdade é que os alunos se mantinham imóveis sempre; e quando a isso se acrescia a dura realidade do castigo, mantinha-se a situação, já agora perpetuada:

\footnotetext{
${ }^{216}$ Id. Ibid., p. 67.

${ }^{217}$ A. F .de CASTILHO, Reposta aos novíssimos impugnadores do Methodo Portuguez, vol. II, p.8.
} 
“(...) de joelhos, talvez em cima de um pau anguloso; ou de pé, e como em pelourinho de afronta, sobre o pedestal de um banco, e cingido de insígnias estúpidas, vis e desmoralizantes para o paciente e para os circunstantes; ou saltando, gemendo, e bramindo sob o peso da férula ou da vara; espetáculo de circo, onde com tempo se vai ensinando insensibilidade e crueza aos que encetam a vida." 218

É assim que a palmatória e a prática autoritária da escola portuguesa são caracterizadas como efeito da falta de lógica e de projeto da mesma escola, que, não sabendo agir mediante o crivo da racionalidade, recorre impunemente aos castigos, mesmo que estes não tivessem exata correspondência em relação aos delitos cometidos. Até porque a idéia de delito pressuporia liberdade de opção. Acerca disso, mais uma vez citaríamos Castilho:

\begin{abstract}
"O que não depende da vontade não se castiga; e ninguém pode, por milagre da sua vontade, ver o que está às escuras, abraçar o que se lhe não apresenta, reter o que não escolheu, fixar-se no que é vago, nem afeiçoar-se ao que repulsa as afeições. A anti-lógica do suplício do corpo pelos crimes (como se o fossem) do entendimento procuraram talvez obviar inventando penas de outra ordem: ao que não soube a lição, ao que não entendeu a lição, acrescente-se a lição; e tanto mais se lhe acrescente, quanto menos a entendeu. Aqui a anti-lógica é talvez ainda mais flagrante. Pois não se vê que fazer castigo com o estudo é reconhecer tacitamente que o estudo é um tormento? Se o estudo é um tormento, como querem que uma criança o não desame? E se ela, pela natureza mesma das coisas, e da sua alma, o desama, com que direito a castigam por isso? As contradições e as contraproducências correm neste caso parelhas com a tirania., 219
\end{abstract}

Ao evidenciar as vicissitudes da escola portuguesa, e talvez por causa disso, Castilho engendrará um novo estilo de discurso a propósito da escolarização. O que estará em jogo, a partir daqui, não será mais o valor intrínseco da instrução, mas antes o lugar social ocupado pela instituição da escola. Em função disso, o tema do método ganharia forma, perpassando, desde então, o discurso pedagógico português. Castilho sugeria procedimentos inclusive quanto à organização da sala de aula e disposição do mobiliário a ela pertencente. Era um novo rosto que se desejava para a situação escolar. A modificação pretendida visava sobretudo a institucionalização do modo simultâneo, até então praticamente inexistente. Os bancos estariam dispostos dois a dois, todos voltados para o quadro-negro que ficaria em frente da mesa do professor. A disposição dos banquinhos dos alunos deveria formar um ângulo obtuso, como o que vem reproduzido em ilustrações de livros com que o educador ensina seu método. Na frente da sala, existiria um estrado e sobre ele um assento para o professor. Haveria, ainda, como vimos, "um quadro preto de madeira, em que se possa escrever com giz, e que se monta, ou adapta, quando é preciso, em maior ou menor altura, segundo convém" 220 .A sala de aula de uma classe de leitura repentina contaria ainda para ficar completa com giz, esponja (ou pano para apagar), vara para apontar, coleção completa dos quadros em grande das figuras das letras, estantes armadas com os quadros do alfabeto, um exemplar do livro do método para o professor, "uma ardósia para cada discípulo, com a competente pena de pedra, lápis ou gesseto" ${ }^{221}$.Em termos de procedimentos práticos:

\footnotetext{
${ }^{218}$ Id. Ibid., p.34. Castilho, na seqüencia, acrescenta que “ dai principalmente procede a notória repugnância que a maior parte dos instituidores pela antiga barbárie teve, tem e há de sempre ter, a que olhos estranhos vão devassar os mistérios do seu ensino." ( Idem Ibidem )

${ }^{219}$ Id. Ibid., p.111-112.

${ }^{220}$ António Feliciano de CASTILHO, Methodo Portuguez-Castilho..., p.121.

${ }^{221}$ Id. Ibid., p. 123.
} 
“O professor ocupa o estrado, tendo de estar sempre à vista a vigiar e quase sempre em ação. Os matriculados, que já começaram a ler, estão rigorosamente separados e ocupam os bancos últimos. Os que não conheciam as letras sentam-se nos primeiros. Os que só as conheciam, ou pouco mais, formam o centro. Havendo discípulos dos dois sexos na mesma aula, completa separação dos rapazes e das raparigas. (...) No meio de cada banco, estará um dos discípulos, escolhido pelas suas boas qualidades, para vigiar os seus vizinhos da direita e da esquerda, e fazê-los estar em ordem. Este cargo dos discípulos-vigias pode-se ganhar e perder, segundo o mérito e demérito do aluno.",222

Percebe-se nisso nítido incentivo a práticas de delação. Se remetermos a análise para uma perspectiva foucaultiana, diríamos que essas "pequenas coisas" poderiam ser mais sugestivas e reveladoras da inconfessável economia da escola do que quaisquer prescrições discursivas. Na compreensão do autor de Vigiar e punir, estaria contido, na própria organização interna da instituição, um minucioso processo de fabricação da disciplina, mediante práticas de ininterrupta coerção e vigilância. Verificamos que a escola proposta por Castilho é sub-repticiamente sujeita a relações de interação entre utilidade e docilidade, distribuindo de maneira privilegiada os indivíduos no espaço e buscando atribuir-lhes nova relação com o tempo: o tempo de um aprendizado por palmas, cantos e marchas, onde o ritmo deve ser sempre dado pelo coletivo; onde o preço do simultâneo seria o custo de cada ser individual. Castilho aponta a necessidade que o século XIX tem de fabricar, pela via da escola, o ambiente regrado, conformado, disciplinado. Para tanto, a escola que propõe ganharia em eficácia pelo simples fato de ser aquela capaz de disciplinar a contento. Como ilustra Foucault:

\footnotetext{
"Cada indivíduo no seu lugar; em cada lugar, um indivíduo. Evitar as distribuições por grupos; decompor as implantações coletivas; analisar as pluralidades confusas, maciças ou fugidias. $\mathrm{O}$ espaço disciplinar tende a se dividir em tantas parcelas quanto corpos ou elementos há a repartir. É preciso anular os efeitos das repartições indecisas, o desaparecimento descontrolado dos indivíduos, sua circulação difusa, sua coagulação inutilizável e perigosa; tática de antideserção, de antivadiagem, de antiaglomeração. Importa estabelecer as presenças e as ausências, saber onde e como encontrar os indivíduos, instaurar as comunicações úteis, interromper as outras, poder a cada instante vigiar o comportamento de cada um, apreciá-lo, sancioná-lo, medir as qualidades ou os méritos. Procedimento, portanto, para conhecer, dominar e utilizar. A disciplina organiza um espaço analítico."223
}

Vemos em Castilho a prospecção dessa disciplina de que fala Foucault: "arte das distribuições", fabrica-se com ela corpos dóceis, submissos, exercitados. Se, por um lado, a disciplina subtrai, por outro ela acrescenta. ${ }^{224}$ Sua pedra de toque é o controle, sendo que este opera por rarefações, por deslocamentos, por intercâmbios e intervalos. Arranjos variados se formam e se transformam, na circulação dos poderes assim distribuídos. A escolarização caminha para a uniformização. Havia que se recompor toda uma arquitetura dos espaços, pelo encontro de séries que aos poucos tornassem homogêneo o que era até então disperso. O jogo da escola foi assim montado nesse percurso que acompanha o século XIX português.

\footnotetext{
${ }^{222}$ A. F. CASTILHO, Methodo Portuguez-Castilho, p.125-126.

${ }^{223}$ Michel FOUCAULT, Vigiar e punir, p. 131.

224 "A disciplina fabrica assim corpos submissos e exercitados, corpos dóceis. A disciplina aumenta as forças do corpo ( em termos econômicos de utilidade) e diminui essas mesmas forças (em termos políticos de obediência ). Em uma palavra: ela dissocia o poder do corpo; faz dele, por um lado, uma aptidão, uma capacidade que ela procura aumentar; e inverte, por outro lado, a energia, a potência que poderia resultar disso e faz dela uma relação de sujeição estrita. Se a exploração econômica separa a força e o produto do trabalho, digamos que a coerção disciplinar estabelece no corpo o elo coercitivo entre uma aptidão aumentada e uma dominação acentuada" ( Michel FOUCAULT, Vigiar e punir, p.127).
} 
Entende-se que a escolarização só se transformaria em efetiva demanda das populações no momento em que se houvesse de fato atingido esse ideal da uniformidade: classes homogêneas, lugares demarcados na fila, alunos repartidos em fileiras e classificados por colunas, atividades como cantos, palmas, marchas... Tudo por uma só sonoridade. A escola era então percebida como um mundo a ser construído. O mestre, como não poderia deixar de ser, ocupa, nessa constelação, lugar de destaque. Pelas palavras de Castilho, procuremos seu retrato:

\begin{abstract}
"Afabilidade grave; uma paciência quase inesgotável; suma abnegação; vigilância contínua; severidade inexorável nos casos que a requererem; renunciação a todo o desejo de brilhar perante os ignorantes com termos escolhidos e pomposos; clareza máxima, e suma ordem no encadear as idéias; atenção escrupulosíssima a tudo o que tem de ensinar, e a tudo quanto os discípulos lhe respondem; familiaridade e humildade no estilo, nas comparações, nos exemplos, em tudo que se emprega com vantagem para a doutrinação; perseverança para multiplicar e variar explicações sobre os pontos que logo à primeira se não compreendem; eis aqui muitas raras qualidades, porém muito importantes num preceptor por este Método. (...) Das qualidade físicas, desejáveis para um professor das nossas escolas, as principais são: um peito forte, uma voz sonora, um ouvido sutilíssimo e uma cabeça que não canse facilmente com o estrondo nem com a atenção continuada. A isto ajuntaremos: uma pronúncia clara e distinta, um falar e um ler devidamente pausado e acentuado."225
\end{abstract}

O perfil projetado para o mestre de primeiras letras ultrapassava, na perspectiva do autor do Método Português, caracterizações de ordem psicológica ou mesmo moral, que compunham, por assim dizer o senso comum acerca dos deveres do professor naquela sagrada missão que lhe era confiada pela família e que se assemelharia à do pároco em termos de responsabilidade ética. $\mathrm{O}$ professor de instrução primária era também isso; mas - no parecer de Castilho - deveria ser mais do que isso. A ele caberia todo um treinamento no sentido de adestrar todos os órgãos de seu corpo - desde a postura física, a ereção da espinha dorsal até a potência e volume da voz - como dispositivos a serem usados na composição de seu papel, para a tarefa de liderança, à qual ele estaria inevitavelmente vinculado, na direção firme daquele corpo coletivo e disciplinado constituído por seu grupo-classe. Ao docente caberia então compor e regular a arquitetura social que a vida escolar, enquanto tal, intrinsecamente já constituía.

Podemos mesmo dizer que, em última instância, a escola propugnada por Castilho, em termos do discurso pedagógico português, constitui um efetivo deslocamento. Passa-se a pensar na configuração interna da instituição para buscar compreendê-la. $\mathrm{O}$ universo da educação ganha com isso coloração didática, sem para tanto perder o lustre da iluminação política. A fala iluminista é substituída pela preocupação com o método; e, por método, leia-se caminho. Acerca da repercussão atingida pelo Método Português, D. António da Costa declararia que os ataques se teriam dirigido aos acessórios e não às bases, posto que estas se teriam mostrado superiores à discussão. ${ }^{226}$ Para seus partidários, as

\footnotetext{
225 António Feliciano de CASTILHO, Methodo Portuguez-Castilho..., p.129-130. Na sequência, o educador declara que seriam impedimentos para o magistério quaisquer vícios de pronúncia, trocas ou adulterações de consoantes, o comer ou não articular bem as sílabas; assim como evidentemente o balbuciar e gaguejar. O professor, ao contrário dos alunos, teria seu trabalho acrescido por este método. Acerca do lugar do mestre, destaca Castilho: “ O professor está sempre em cena, quase sempre em pé, gritando, palmeando, acionando, atentíssimo a tudo e para toda a parte, ao que diz, ao que deve dizer, ao que executa, ao que ouve, ao que deixa de ouvir, ao que se faz ao que se omite." (Id. Ibid., p.131)

226 “Mas, no nosso entender, a razão por que a obra de Castilho se tornou mais relevante (e é neste sentido que a história da instrução nacional deve receber o complexo daquela obra ), foi, $1^{\circ}$ ) porque além de levantar o pendão para a facilitação do ler, levantou-o implicitamente para a facilitação de todo o ensinamento primário; não foi só um método de leitura, mas a lei fundamental da pedagogia; $2^{\circ}$ ) e mais importante ainda pela espécie de revolução que ele ocasionou na matéria da instrução popular, pelo movimento que produziu. No espírito da
} 
reformas no ensino propostas por Castilho só poderiam encontrar oposição e adversários nas pessoas enraizadas por hábitos e convenções cristalizadas e consagradas pelo tempo, "porque as trevas são inimigas da luz e a rotina reage às inovações"227. Os partidários do Método agiam pois como se suas bases fossem absolutamente inatacáveis. No julgamento desses adeptos incondicionais, teria sido a resistência à mudança da escola e da mentalidade corrente em Portugal quem dificultou o êxito dos processos de Leitura Repentina. Verificamos nos Relatórios do Conselho Superior de Instrução Pública, entre os anos 1844 e 1859, compilados por Joaquim Ferreira Gomes, a presença desse fervilhar do debate sobre a alfabetização de Castilho, e mesmo a simpatia de alguns dos inspetores para com o novo método. Ocorre que mesmo os mais empenhados reconheciam a dificuldade de sua efetiva implementação e o Conselho Superior de Instrução Pública vinha, na ocasião, disposto a estudar o método para melhor pronunciar um juízo sobre o mesmo. Acerca do assunto, consta do relatório correspondente ao ano letivo de 1852-1853:

\begin{abstract}
"E, para remate do que se oferece a dizer na instrução primária, resta falar dos métodos de ensino. $\mathrm{O}$ individual, que deve haver-se pelo método natural, nem é admissível em escolas públicas de número superior a dez alunos, nem isento de outros inconvenientes. O mútuo tem sido quase geralmente abandonado pelo maior consumo de tempo de aprendizado e deficiência na educação moral. Se em algum país se segue ainda só a economia o pode justificar. O simultâneo puro é impossível em escolas com grande número de alunos. O simultâneo-mútuo é o que satisfaz melhor às indicações do ensino e o que é geralmente seguido entre nós. O método de leitura dita repentina, fora, de princípio, abraçado com o entusiasmo da novidade, alentado pelo prestígio do nome e amenizado pela harmonia musical, de que ordinariamente era acompanhado o seu exercício. Hoje, terminada a impressão primeira da novidade e desacompanhado da recriação da música, é pouco frequentado. Talvez a força do hábito e a imperícia dos instrutores lhe tenham também embargado o passo.,"228
\end{abstract}

No mesmo relatório, o Conselho pronunciava-se sobre a questão da adoção legal do método, declarando preferir não proscrever nem tampouco recomendá-lo, a partir dos resultados obtidos nos ensaios que com ele se efetuaram em escolas públicas e particulares. Reconhecendo a pequena aceitação de seu método e desafiando para a contenda seus adversários, na mesma ocasião, Castilho provocava:

\footnotetext{
"Não querem o modo simultâneo absoluto? Dispam-lho.

Não querem palmas para o ritmo? Vedem-lhas.

Não querem canto para as regras e para as orações? Emudeçam-no.

Não querem marchas? Parem-nas.

Não querem movimentos? Paralisem-nos.

Não querem alegria? Aterrem.

Não querem amor? Odeiem.
}

obra, no movimento geral, no pensamento da doutrinação consistiu tudo" ( D. António da COSTA, História da instrução popular em Portugal, p. 212 ).

${ }^{227}$ Braz Tisana - em artigo publicado no número 580 do ano 1857 no periódico intitulado O Conimbricense discorre sobre o método Português-Castilho que teria então atingido a quarta edição de 2000 exemplares. Segundo o analista, "apesar, porém, desta guerra acintosa, o público esgotou-lhe a primeira edição de mil exemplares; a segunda de dois mil; a terceira de quatro mil; e por isso aparece agora a quarta de 2000 mil (...) As repetidas edições desta obra constituem o crédito de seu autor, e contra um argumento tão forte são impotentes os tiros da maledicência e os recursos do sarcasmo" ( Braz Tisana, O Conimbricense, número 580, 1857, p.1-2).

228 Joaquim FERREIRA GOMES (organizador), Relatórios do Conselho Superior de Instrução Pública (1844-1859), p.158-159. 
Mas a essência do método, provado eficacíssimo, não a neguem, que o não permite o bom senso. Não o injuriem, que é dura ingratidão; e menos ainda o repulsem, que é servicia não só para com a infância, que a não merece, mas até contra a Pátria, que a todos nós devemos, e devemos tudo."229

Há que se compreender que o Castilho-pedagogo que procuramos aqui retratar possuía uma especificidade toda sua, que lhe traz para a posteridade inclusive uma certa autonomia, diferenciando-o talvez do caráter eminentemente reacionário que caracteriza o conservadorismo registrado em sua atuação contra os jovens da Geração de 70. Acreditamos que o preconceito analítico que pontua sempre o pensamento educativo de Castilho à luz de um tradicionalismo intrínseco e pressuposto, bem como a coloração laudatória dos que avaliam o método a partir de uma apologia prévia sobre seu autor, têm sido obstáculos que dificultam a reconstituição historiográfica do intelectual e de sua obra pedagógica. De algum modo poder-se-ia dizer que, se virtude houve no método Castilho, esta estava posta exatamente nesse desencadear do debate metodológico sobre o ensino da leitura, nessa crítica veemente ao tradicionalismo, arcaísmo e inoperância da escola de então; em mais nada, posto que se tratava de uma idéia com pequenina adesão efetiva no que tange às práticas escolares. A escola portuguesa, entretanto, estaria aqui posta sob suspeita. Ilustrar o país suporia concordavam todos - recriar o caminho da educação. Daí a necessidade de serem repensados os alicerces daquela instituição que - no caso português - falhara, não levando a contento sua tarefa civilizatória. De algum modo, Castilho - justiça seja feita - acordou e reanimou um debate que, entretanto, não primava exatamente pela originalidade. A coloração didática do problema educativo estaria, de qualquer modo, posta ao crivo dos usos da prática. Pensar a pedagogia correspondia, a partir de então, inventar uma forma alternativa de se fazer escola. O desenrolar da história encarregar-se-ia de confirmar tal tendência.

Por seus acertos e desacertos e fundamentalmente pela capacidade que revelou no sentido de deslocar o problema da pedagogia do universo estritamente político para a dimensão técnico-pedagógica, Castilho demarcou um ponto de inflexão na história das idéias educacionais em Portugal do XIX. A questão pedagógica em Portugal ganhava relevância no debate do século XIX exatamente por ser esse o século de firmamento cultural dos estados nacionais. O tema da nação é ainda dimensão prioritária para compreensão da escola moderna. Era sempre em nome de sua orientação social que os políticos e intelectuais julgavam compreender a escola. De certa maneira - no imaginário da intelectualidade portuguesa da época - falar a respeito da escola seria falar ao povo no futuro e construir, por assim dizer, uma nacionalidade aprimorada. A propósito, já recordava Nóvoa do descompasso

\footnotetext{
${ }^{229}$ António Feliciano de CASTILHO, Methodo Portuguez-Castilho para o ensino rápido e aprazivel do ler, escrever e bem falar, p.113-114. Quando da célebre Questão Coimbrã, que é um marco na história portuguesa do século passado, e sobre a qual posteriormente nos referiremos, houve muita ridicularização dos adeptos da dita escola repentina. Pudemos, a esse respeito ter acesso a um texto intitulado Folhetim da voz acadêmica: Delenda Thibur; primeira aos homens da cigarra e do ermo dedicada a todos os ramalhudos Ortigões da escola do ABC repentino, cujo conteúdo reportava-se ao debate entre Castilho e a Geração de 70. A escola de Castilho é, antes de mais nada, apresentada como um reduto de bajulação servil, que se compõe enquanto "crítica de camarilha": admiração mútua de amigos que, entre si, interagem no sentido da autopromoção: “(...)mundo criado pelos hábitos da conveniência ou pelos laços da amizade, que não escuta, que não distingue sequer um eco simpático ou uma nota harmoniosa fora dessa orquestra de amigos e prediletos que executam alternativamente a música uns dos outros e se aplaudem reciprocamente dentro das eminências que ergue a sua imaginação" (FOLHETIM da voz acadêmica: Dellenda Thibur, p.2). Por seu turno, Antero de Quental é apontado como um fedelho que contava com "robusta inteligência e independência honrosa e honrada” ( Id. Ibid., p. 4), revoltado contra tal escola pedante, de intelectualidade atrasada e prepotente, que, em seu mútuo elogio, fimava uma partilha medíocre de tácitas alianças e ilusões: "Iludidos sim, porque é mister dizê-lo,- nessa cousa - a que chamam escola de Castilho, e que é a entronização do elogio parvo e da verrina injusta, que é a substituição ridiculamente monstruosa da boa crítica, do bom senso, do bom gosto e da boa fé, pelo ipse dixit, há também pobres homens dotados de inteligência, de estudo e de grande vontade que se deixam iludir pelos aplausos do vulgo boçal e não os discutem, ou fingem deixar-se iludir porque vêem que desgraçadamente é aquele o meio mais fácil e pronto de angariarem reputação" (Id. Ibid., p.5).
} 
existente entre as idéias pedagógicas expressas pelos discursos dos especialistas e das autoridades e a realidade cotidiana das escolas portuguesas. Mesmo assim, o autor qualifica a dimensão heterogênea dessa escola primária que vinha sendo construída nas realidades do dia-a-dia e, na outra margem, no intelecto de alguns expoentes do cenário acadêmico e político nacional. A escola de que tratamos não era, como se poderia, à primeira vista, supor, um território reservado a parcelas diminutas da população. Mais do que isso, recorramos às palavras de António Nóvoa:

\begin{abstract}
“A escola primária portuguesa no século XIX não era uma instituição homogênea, frequentada essencialmente por crianças pertencentes a classes sociais médias e superiores. Pelo contrário, ela se afirma como um espaço onde diferentes classes sociais coabitam, interagem e se confrontam. A função social e ideológica da escola adquire, nesse quadro, uma amplitude que não existiria em presença de um público homogêneo de crianças pertencentes a classes médias e superiores."230
\end{abstract}

No decorrer dos anos que percorrem 1850-1870, o debate pedagógico em Portugal seguirá pontuado pelas grandes e clássicas questões que estão postas no próprio imaginário da escolarização moderna: obrigatoriedade escolar como antídoto ao problema do absenteísmo; universalização do ensino de primeiras letras; escolas particulares e ensino oficial; métodos e práticas de sala de aula; etc.. Seja como for, a pouco e pouco, o debate toma feição mais institucionalizada e o tema da pedagogia entraria de fato na lógica do debate político. Poderíamos inclusive indagar até que ponto a discussão da matéria pedagógica não teria sido, ao menos em parte, estimulada pelo fervilhar jornalístico e pelo papel pedagógico que a imprensa - fundamentalmente a partir d' O Panorama - pretendeu tomar, quando supunha conduzir o país ao aprendizado de 'conhecimento úteis', proporcionados espontaneamente aos cidadãos, pela via de proveitosas leituras. ${ }^{231}$ Por outro lado, havia ainda aqueles que tomavam a leitura como fonte segura de corrupção dos costumes. Particularmente no tocante ao papel

\footnotetext{
${ }^{230}$ António Nóvoa, Le temps des professeurs/ volume I, p. 358.

231 Artigo de Andrade-Ferreira, intitulado 'Jornalismo literário em Portugal', para o periódico Archivo pittoresco, dizia o seguinte, a propósito dessa matéria: "O aparecimento e a difusão dos periódicos ilustrados constituem por certo um sintoma de ilustração em todo e qualquer país. Neste caso, as publicações literárias operam de duas sortes: são um meio indireto, mas eficaz, mas perseverante e progressivo de conquista intelectual, que abrilhanta e alarga todos os dias e todas as horas as suas vitórias por entre as classes mais rudes e populares; e são um resultado desses mesmos conhecimentos implantados aqui e ali, dessas luzes derramadas pelo seio de tantas trevas. Em Portugal a progressão das publicações periódicas, cujo fim haja sido $o$ derramamento da instrução popular, tem sido sujeita a alternativas, como tudo neste país, onde o convencimento das coisas úteis ainda não é um sentimento comum e frutificado nos seus efeitos para todas as circunstâncias ativas da sociedade." ( ANDRADE - FERREIRA, Jornalismo literário em Portugal, In: Archivo pittoresco, $1^{\circ}$ anno / 1-7-1857, p. 93-4 ). O panorama teria inaugurado o gênero e permaneceria modelando os sucessores pelo eco do que soubera ser: radicou e difundiu o gosto pela leitura, multiplicando, através dela, o repertório e as competências intelectuais das classes populares. Posteriormente, representantes de camadas menos eruditas teriam tido, em sua esteira e como continuidade de sua obra civilizatória, a oportunidade de redigir em periódicos desse estilo. O Archivo pittoresco apresenta a si próprio como artífice de uma "ilustração amena e recreativa em todas as camadas da nossa sociedade. É um jornal de instrução, como o precisam as nossas classes, que, menos lidas e ilustradas, conservam, contudo, em si o desejo instintivo da ilustração. É destes jornais que mais necessita Portugal, porque é assim que, sem assustar as compreensões populares, é possível e agradável encaminhar estas às fontes da nossa história e às noções mais elementares das ciências morais, tornando-se-lhes fácil e apetecível o que lhes fôra inacessível apresentado em difusos compêndios” ( Id. Ibid., p. 95 ). O jornal aqui revela e explicita sua concorrência com a escola e com o conhecimento dela proveniente, ao criticar o veículo precípuo desse conhecimento escolar: a cultura do compêndio. Procura-se radicar no adulto a sedução da leitura, que a escola não teria sido capaz de apresentar às crianças. A instrução pelo jornal, ao contrário do que ocorria com a instrução, era factível: "O Archivo pittoresco não se vangloria de ser já o mais eloquente misssionário, o catecista mais persuasivo e escutado desta propaganda, cujos resultados devem tanto refletir na purificação e educação dos costumes, como no desenvolvimento das qualidades do entendimento; mas confia nos esforços da sua empresa e esses dirigidos e ilustrados pelas principais forças intelectuais do país.” ( Id. Ibid., p. 96 ).
} 
da imprensa na obra da civilização, os pareceres dos contemporâneos nem sempre eram favoráveis. ${ }^{232}$ De qualquer maneira, considerando já a inevitabilidade da cultura letrada, em sua maioria, os teóricos da educação, os intelectuais, os políticos, advogavam a escola, até para regrar e controlar a dinâmica que poderia, talvez, no futuro, conformar uma cultura do impresso: criadora de juízos, destruidora de tradições, transformadora de hábitos...

\section{O DEBATE ESCOLAR NO CONSELHO SUPERIOR DE INSTRUÇÃO PÚBLICA E NA UNIVERSIDADE DE COIMBRA}

Em discurso lido à sessão de 20 de Janeiro de 1852 do Conselho Superior de Instrução Pública, Manoel dos Santos Pereira Jardim apresentava proposta alternativa a outra anteriormente exposta ao mesmo Conselho por Bernardo de Serpa Pimentel. Na verdade, o autor explicita seu tema, ao diferenciar-se de seu antecessor que não estaria, segundo ele, empenhado em espraiar o conhecimento pelas "classes desvalidas". Para Jardim, a utilidade pública da escolarização estaria justamente em propiciar instrução "ao maior número possível de crianças, e com especial cuidado às que vivem na miséria"233, objetivo esse que seria perseguido tanto pela iniciativa governamental no campo da educação quanto pelos esforços dos particulares. A partir disso, o orador teceria réplicas discriminadas artigo por artigo à proposta anteriormente apresentada por Bernardo Serpa. Já a princípio, Jardim discorda do artigo $1^{\circ}$ que sugeria a criação de pelo menos uma escola de $1^{\circ}$ grau em cada paróquia do Continente. Ao rejeitar a tão apregoada obrigatoriedade, Jardim recordava que: “(...) há freguesias tão pobres que os habitantes delas, em virtude de sua extrema pobreza,

\footnotetext{
232 O mesmo Archivo pittoresco traria nos anos 50 - como veremos particulamente no capítulo 3 - inúmeros artigos que apontavam para essa polêmica. Verifique-se o tom dos argumentos proferidos por Luiz Filipe Leite, em seu artigo intitulado 'Estudos literários: a imprensa política e a imprensa literária'. Naquela oportunidade, o educador explicitava sua convicção de que o jornal seria uma das expressões mais típicas do mundo moderno. Tal feição que o jornalismo adquirira foi tomada, entretanto, à custa do declínio do mundo do livro. Tal situação provocara, antes de qualquer coisa, uma alteração na vida cotidiana dos povos, posto que, no caso português, a própria língua sofreu inúmeras inflexões para se adequar às necessidades técnicas do linguajar jornalístico. A irradiação do escrito pela intermediação do jornal alterara dinâmicas corriqueiras e triviais em coletividades, desde há muito tempo, habituadas ao uso praticamente exclusivo do registro oral. Nos termos do também articulista: "A necessidade de escrever, necessidade que a si mesma se criou, foi a perpetradora de tais atentados contra o pobre do senso comum. Como irrefregável dedução da grafomania deste tempo, veio a inundação jornalística invadir os mais pacíficos tegurios. Atam-se hoje em Portugal as terras da província que não têm o seu, ou antes os seus periódicos. A população, que ainda há bem poucos anos vivia em santa paz, apenas perturbada de longe em longe por alguma intriguinha palreira de senhoras vizinhas; o distrito que só falava em política lá de tempos a tempos, quando a metrópole lhe pedia os seus representantes, e que, se tinha alguma queixa a fazer valer perante os poderes públicos, só a vinha desafogar na imprensa da capital, para ser ouvida de quem cumpria atendê-la; foi afinal mais uma vítima expiatória da loquaz profusão dos neo-políticos." ( Luiz Filipe LEITE, Estudos literários: a imprensa política e a imprensa literária, In: Archivo pittoresco, $1^{\circ}$ anno / 1857, p. 102-103 ). À crítica a esse império que a imprensa vinha criando alia-se a denúncia da usurpação política à condenação quanto ao estilo mediante o qual os jornalistas costumavam escrever: pouco rigorosos, eles deturpariam - no parecer do articulista - os parâmetros do rigor normativo que caracterizaria a língua portuguesa. Além disso, a imprensa seria, aos olhos de Luís Filipe Leite, destituída de princípios e a apreciação dos redatores sobre cada assunto pode ser alterada a cada manhã. Um objeto exótico - o folhetim - teria sido derivado da cultura jornalística. O folhetim, enquanto gênero, seria meramente aplicação da política à arte, não tendo qualquer valor algum para a literatura. Nos termos do autor: "Como de três milhões de habitantes não é possível fazer três milhões de escrevedores, e a literatura é ainda uma palavra, posto que já quase oca de todo pela falsa interpretação que se lhe vai dando, é necessário que haja quem cultive as letras; mas comodamente, sem mudar de pena, nem de tinteiro, nem de secretária, nem de disposição mental... nem de papel.” (Id. Ibid., p. 103)

${ }^{233}$ Manoel dos Santos Pereira JARDIM, Discurso lido em a sessão do Conselho Superior de Instrução Pública de 20 de Janeiro e projecto de lei apresentado, p. 3.
} 
carecem do auxílio dos filhos para ajudarem a viver a família. Em tais paróquias seria uma barbaridade obrigar as crianças a irem às escolas.",234

Do mesmo modo, Jardim não concordava com o parágrafo $1^{\circ}$ do artigo 1 que excetuava a criação de escolas em cidades ou vilas que já contassem com outras cadeiras de instrução primária. Tal proposição seria - no parecer desse comentarista - um atestado da inutilidade da escola pública perante a concorrência das particulares. Além disso, o Conselho deveria preocupar-se e, de fato, comprometer-se com aquelas famílias que não poderiam pagar a instrução de seus filhos. A propósito do tema da pobreza, indagava Jardim acerca da liberdade do ensino e da frequência, mesmo na hipótese de haver uma escola em cada paróquia:

\begin{abstract}
"Se a frequência das escolas for livre, ficarão desertas, ou a sua concorrência será muito diminuta, como já hoje sucede à maior parte delas. E não pense, como geralmente se acredita, que os povos rurais dificultam as letras aos filhos para estes no futuro não serem incomodados com os cargos públicos de jurados, juízes eleitos, etc., etc. (...) O motivo, senhores, da geral ignorância, é principalmente a extrema miséria a que se vêem condenadas as classes laboriosas. Nós vivemos, é verdade, em um país que se diz livre; em uma sociedade que, bem ou mal constituída, é o resultado de muitas idéias falsas, de tristes prejuízos, e de uma série de iniquidades tradicionais que têm muitos séculos de duração. Mas neste século de ilustração e liberdade; no nosso país civilizado e livre, perguntarei eu: será livre o pai que desvia o filho da escola para o mandar à fábrica, às obras públicas e a mil outros trabalhos, unicamente com a mira no mesquinho jornal, que este lhe ganha? Será livre o filho do pobre, que desviado pela fome, corre do caminho da escola a vender o corpo e a alma à oficina? A liberdade, senhores, é para quem tem o que comer. O pobre de hoje é tão escravo como o que vivia há um ou mais séculos. Se os grilhões lhe não pesam nos pulsos, pesalhe a miséria na alma e no corpo. Registemos uma verdade, senhores, e é que o pobre decide-se sempre pelo jornal e esquece a escola, que o deixaria morrer de fome."235
\end{abstract}

No parecer de Jardim, seria, então, desumano obrigar os pais de baixa renda a enviarem seus filhos à escola. Mesmo a escola noturna é aqui desaconselhada, dado que não lhe parecia razoável remeter o menino a qualquer sala de aula quando ele regressasse à casa, fatigado pelo trabalho diário. Vemos, com isso, a persistência da hesitação das populações e dos homens da política perante o tema da obrigatoriedade da escola primária. Mesmo os caminhos da escola eram desestimulantes quando perfilhavam por vezes árduas geografias...

“(...) E haveria um pai que expusesse seu filho a atravessar torrentes e despenhadeiros durante a noite, para este ir à escola? De tudo isto, senhores, eu infiro que para levar a instrução às últimas classes do povo, não deveríamos procurar o meio de aumentar o número de escolas, mas antes, como uma questão prévia, perscrutar o modo de tirar da miséria tantos infelizes (...) Eu estou convencido de que, se os filhos do povo tiverem o que comer, vão à escola, se não, não."236

A proposta de Jardim perpassava, entretanto, uma clivagem ideológica bastante clara: havia que se ilustrar o povo para levá-lo a aceitar como natural a desigualdade das riquezas. Os ricos arcariam com a instrução de seus filhos, pagando-lhes a escola pública primária. Contrariando Serpa Pimentel - que declarara no artigo 2 de seu projeto que os padres eram os "mestres natos da escola" - Jardim argumenta que muitos párocos, pelo contrário, não apresentavam à época os três requisitos por ele postos como imprescindíveis para proceder à tarefa do ensino: suficiente instrução, moral e consonância com a ordem política. Além desses párocos, portanto, não possuírem suficiente proficiência para o ensino

\footnotetext{
${ }^{234}$ Id. Ibid., p. 5.

${ }^{235}$ Manoel dos Santos Pereira JARDIM, op. cit., p. 5-7.

${ }^{236}$ Manoel dos Santos Pereira JARDIM, Discurso lido em a sessão do Conselho Superior de Instrução Pública de 20 de Janeiro e projeto de lei apresentado, p. 7.
} 
da leitura e da escrita, seus compromissos com padrões de conduta civil e patriótica seriam também questionáveis, dado que compunham verdadeira corporação espalhada por todo o mundo, cujo compromisso com o país parecia-lhes inferior a suas obrigações diante da Corte de Roma. Além disso, muitas vezes o sacerdócio era menos um instrumento da religião do que esta um instrumento das paixões. ${ }^{237}$

No decorrer daqueles tempos, cada vez mais passa-se de um entusiasmo inicial para nítida hesitação em relação à escola. Os autores não se limitam apenas a atentar para a carência da escolarização, centrando-se mais e mais sobre críticas a supostas maneiras incorretas de ser escola em Portugal. Da esperança ao medo, o tema da instrução - seja como for - continua na pauta do discurso sobre a feitura da nação. José Leite Monteiro - estudante do quarto ano de Direito - publica em Coimbra, no ano de 1863, uma brochura de 90 páginas intitulada $O$ ultramontanismo na instrução pública de Portugal. Tratava-se efetivamente de um conjunto de ensaios onde o autor buscava cercar e desvendar as diversas faces que permeavam o problema da escola na sociedade portuguesa. A ausência de uma forma escolar apropriada, fosse em termos dos métodos e modos de ensino, fosse no que dizia respeito à própria conduta moral e civil dos professores responsáveis, o fato é que Portugal ainda não contava com uma instrução pública digna desse título, o que, a seus olhos, era fator determinante do atraso nacional:

\begin{abstract}
"O progresso, que por toda a parte se denuncia, o desenvolvimento vivo e universal da civilização também teve a sua vez de entrar nesse país; mas parou às portas da escola! Esse augusto recinto, por uma aberração da ordem das coisas, repeliu a visita magestosa do progresso, e em vez de se constituir a estância luminosa da verdadeira pedagogia, o Delphos cristão da doutrina, o sancta sanctorum da casa da sabedoria, mantém-se o prostíbulo repugnante e ingrato, das orgias do ensino! Lá dentro, em vez de sacerdotes, temos algozes da luz; no lugar dos querubins, opressores, que flagelam a infância, que corrompem a mocidade; por oblação o holocausto, a hecatombe! (...) Com efeito, quem entra nessas mansões lúgubres, e presenceia a severidade desse carrasco que em nome da sua comissão social dita leis orientais do seu tribunal implacável a um bando de avezinhas aterradas, abominando as letras no mestre, detestando o saber na dureza do ensino, figura-se-nos assistir à decapitação do futuro!"238
\end{abstract}

Entre algozes da luz e revelações do flagelo da infância, o que se diz sobre a escola principia talvez pelos umbrais da porta de entrada, na tentativa de descrição, não de uma escola idealizada como templo da cidadania, mas de uma instituição arcaica e dissonante dos caminhos da modernidade. Nela, os artífices da instrução, longe de derramar as luzes, apagariam-nas para aquelas crianças cujo primeiro contato com o conhecimento seria suficiente para que elas nunca mais o procurassem. Seria essa a verdadeira face da escola? A instrução, que assim contribuiria para degenerar o futuro, não poderia, na outra margem, regenerar. No confronto entre o relato iluminista e as práticas que alicerçam tais representações, não haveria o consolo do termo médio. Os jesuítas seriam, no parecer de Monteiro, os grandes responsáveis pela ruína da dinâmica educativa e as próprias aulas régias se qualificariam como estrutura reacionária herdada da organização jesuítica, mantendo, por tal razão, o princípio primeiro da escolástica, contrário a quaisquer parâmetros de racionalidade cartesiana. Daí viria o atraso de Portugal perante a lógica da modernidade. ${ }^{239} \mathrm{E}$, na órbita da des-razão escolar, continua o autor:

\footnotetext{
237 “Em todas as épocas, em todos os países, o clero ambicionou sempre a direção das escolas. Sou de parecer que não se lhe oponham obstáculos, contanto que ele se habilite, em harmonia com a lei da instrução, com exames públicos, e dê, além disso, garantias de moralidade. Nisto lucraria toda a classe a que pertence, e a sociedade que é destinado a dirigir. Mas fazê-lo mestre nato; dar-lhe mais um meio de predomínio no espírito do povo, uma arma poderosa para com ela guerrear talvez as instituições políticas, não me parece prudente." (M. S. P. JARDIM, op. cit., p. 11-12)

${ }^{238}$ José Leite MONTEIRO, O ultramontanismo na instrucção publica de Portugal, p. 40-41.

239 "Ao passo que ao último abalo de Descartes as nações cultas se abrem ao grande dia da razão, se sentem energicamente impelidas para o reinado livre do pensamento; aqui, nesta terra tão vaidosa, aliás, das suas
} 
"O compêndio representa nesta conformidade a sentença passada a escritura, a sentença impertinente, recalcitrante, inflexível, das aspirações científicas, razão permanente da esterilidade do ensino, alimento obstinado de antipatia, de enfado no estudo das doutrinas, que nele se fossilizam. A novidade e a expansão, que tanto lisonjeiam os afetos da juventude, quebram-se, desfazem-se contra esse rochedo imóvel e infecundo. O mais forte e ardente zelo das letras apagase à primeira rajada dessa intolerância legalizada no método compendiário."240

Dizendo isso, o autor qualifica de burlados os conhecimentos transmitidos pelos compêndios, independentemente da disciplina sobre a qual os mesmos compêndios versassem. Impregnados da intolerância que presidira a tradição do jesuitismo em Portugal, os compêndios representariam, por definição, a cristalização esterilizada de preceitos e juízos de valor postos como imutáveis, irredutíveis, e impermeáveis ao crivo do tempo e da história. Ora, o próprio espírito científico seria sacrificado por essa cultura do compêndio, posto que a dinâmica da descoberta e dos progressos do conhecimento ficariam absolutamente perdidos, assim como a razão e o julgamento crítico. O compêndio escolar se dispõe para a escola como se o sujeito da enunciação fosse um ser universal e inquestionável, como se fosse o próprio Deus quem falava às crianças. E a cultura compendiária extrapolava já os muros da escola primária para ser encontrada, em sua mais sofrível versão, na Universidade ${ }^{241}$, mediante o império da sebenta. Nessa medida, qualquer que fosse o nível do ensino, a tradição, o legado, a herança jesuitíca eram ainda um fardo a ser ultrapassado. Acerca do tema, veremos nos capítulos seguintes como o manual escolar conformava as práticas rotineiras de sala de aula. A esse respeito, mais do que por outros documentos, será pelo livro escolar que se estruturarão mecanismos diretores de uma dada ordenação de mundo a ser inculcada nas gerações mais jovens. A reprodução da ordem social efetuada pela escola passa por essa pregação de alguns valores postulados como verdades imperativas inquestionáveis. O futuro estaria já ali; e, do aprendizado de tais versões de mundo, teríamos sujeitos menos ou mais rebeldes... À escola cabia, preventivamente, dar nota para tal rebeldia.

Manuel Francisco de Medeiros Botelho publicaria no ano de 1869, pela Imprensa da Universidade de Coimbra, seu auto-intitulado Plano Geral de Estudos Primários e Secundários. Naquele opúsculo, o autor tratava exatamente da idéia de reforma quando aplicada ao problema da instrução pública, destacando que qualquer prescrição legislativa deveria ser derivada dos usos, dos costumes e da índole nacional. Fundamentalmente, tratavase de polemizar com a tendência do povo português no sentido de imitar regulamentos e reformas de outros países. Isso - no parecer de Botelho - desqualificaria o próprio sentido reformador $^{242}$. Botelho entendia que o problema da escolarização portuguesa devia-se

instituições e tradições liberais, a aula pública jaz, por força de sua constituição e índole legal, sobre o predomínio degradante do despotismo escolástico. As tendências da força viva da mocidade são abafadas pela força mortal da autoridade, os vôos da inteligência cortados pela tesoura implacável dum dogmatismo inoportuno, dum ipse dixit deslocado" ( José Leite MONTEIRO, O ultramontanismo na instrucção publica de Portugal, p. 51 ).

240 J. L. MONTEIRO, op. cit. , p. 51-52.

241 “Assim, com elementos tão acanhados, como os que é possivel colher neste agro indigente de ciência velha, abandona o aluno fatigado, aborrecido, cinco anos, continuado de desgostos, cinco anos de aborrecidos bancos, que envolvem a época mais preciosa da existência, aquela em que as próprias ilusões sustentam o amor do saber, em que a vida ao desabrochar para o pensamento é vigorosa e aventureira. Em vez de se aproveitarem estas predisposições tão favoráveis, em vez de se favonearem estes afetos filosóficos com uma direção mais feliz da liberdade de pensar, de esquadrinhar, de inquirir por si, por seus esforços e pelo auxílio das indicações profissionais, escravizam-se os moços estudiosos à gleba estéril do compêndio(...)” (J. L. MONTEIRO, O ultramontanismo...,p. 64-65).

${ }_{242}$ "Pretender, repito, aplicar em Portugal as reformas e regulamentos da França, de qualquer outro país estrangeiro, e mui principalmente da Alemanha, é levantar um grave conflito contra os regulamentos e leis do 
sobretudo à carência quantitativa de escolas, ao medíocre desenvolvimento que os professores davam às poucas matérias sobre as quais a escola primária se detinha, à inadequação dos programas perante das exigências do campo da indústria, do comércio e das artes, à não habilitação dos professores que, por sua vez, não se mostravam capazes de habilitar os alunos para o ingresso na instrução secundária. A propósito da reforma da instrução primária, o autor salientava a necessidade de propagar a arte do desenho para a classe operária, como um grau de "desenvolvimento de estudos intelectuais e científicos". O desenho seria importante por se constituir - como argumenta o referido folheto - como a "língua da indústria"; ou

\begin{abstract}
“(...) um instrumento mecânico posto nas mãos do homem, a base fundamental de todas belasartes: sem ela não existiriam a escultura, a pintura, a arquitetura, a mecânica, a estatutária, a perspectiva, etc., etc. A elegância das formas, a harmônica proporção das partes, as qualidades engenhosas que revelam gosto e arte em todas as produções de um povo, estão sempre em harmonia com o grau de instrução das classes artísticas, com os progressos que fazem os conhecimentos relativos às artes nas escolas desse povo. A ignorância da arte do desenho imprime um caráter de inferioridade a quase todas as obras do homem; mas onde ela é cultivada com desvelo e indústria faz prodigiosos progressos: a superioridade dos produtos de um país sobre os de um outro país não provêm de outra causa. É por este meio que a Inglaterra se esforça por levar a palma à França, e esta se empenha em sustentar seu posto. Nesse dois teatros da arte, da ciência, do comércio, da grandeza, as crianças, os adultos, os já homens, aprendem todos com avidez a arte do desenho; e as cidades mais importantes e industriosas tomam a frente do movimento. Todos os outros estados mais ou menos civilizados do mundo fazem os mesmos esforços, reconhecem a mesma necessidade."243
\end{abstract}

Assim, de algum modo, a autor volta atrás; sendo que dissera anteriormente não querer, em hipótese alguma, imitar povos estrangeiros com o medo de se afastar da própria identidade, já agora ele deseja pautar a tônica da ação educativa pela referência exterior, posto que as técnicas alhures desenvolvidas poderiam ser incorporadas e revitalizadas para colocar Portugal na direção de sua específica identidade. Esta é vista como perdida em tradições e no culto de um passado grandioso, cheio de glórias, mas que era - de qualquer maneira - passado. "A cruzada do saber" seria fundamentalmente a chave da conquista do presente. A rivalidade entre as potências mundiais naquela época eram outras, não perfilhando mais o antigo sonho colonial. Tratava-se - os tempos pediam isso - de aprimorar o campo dos preparativos militares, e, ao lado disso, militar no campo da instrução e do desenvolvimento industrial. A cultura intelectual dos cidadãos seria em um futuro próximo - profetiza o autor - a grande variável diferenciadora entre as primeiras e as últimas das nações. Ocorre que os países deveriam privilegiar ou o gasto com a preparação da guerra e o custo das armas, ou com o aprimoramento das condições de existência de todos os artistas e pessoas voltadas para o mundo da cultura. A perspectiva de Botelho é extremamente original pelo fato de revelar o

Estado a índole nacional, os usos e costumes, as tendências e necessidades dos povos, a liberdade de ensino iludida; é negar a possibilidade de organizar eficazmente a instrução portuguesa, lutar contra a natureza das coisas, oferecer um triste espetáculo aos olhos das pessoas sensatas, espalhar a descrença em coisas da instrução por todos os ângulos do país, apagar o último raio de esperança acerca do melhoramento das nossas letras! Podemos receber em matéria de reforma da instrução lições profícuas da França e da Alemanha, podemos e devemos estudar detidamente a organização dos corpos científicos, a distribuição das disciplinas, os métodos de ensino e a fixação dos cursos naqueles dois países ilustrados; mas tudo o que nos vier dali deve assimilar-se em corpo de reforma em harmonia com as coisas de nosso país, deve tomar a feição portuguesa, passar por nacional. Muitas coisas há, que são de todos os tempos e lugares, comuns a todos os povos; essas, podemo-las tomar como próprias. A organização da instrução de um povo e talvez o fato mais grave da vida de um governo; digo mais grave porque dele depende a educação física e moral desse povo, e desta o seu futuro destino. Em negócio de tal magnitude não deve proceder-se com culpável precipitação mas com muita reflexão e acerto; além dos ditames da razão, escutem-se as lições da experiência." (Manuel Francisco de Medeiros BOTELHO, Plano Geral de Estudos Primários e Secundários, p. 4).

${ }^{243}$ Manuel Francisco de Medeiros BOTELHO, Plano Geral de Estudos Primários e Secundários, p. 6-7. 
explícito desejo de desejar pautar o ensino pelo reconhecimento da "noção do belo": educar, pois, pela formação continuada do golpe de vista, que possibilitaria ao ser humano o reconhecimento das distâncias das dimensões e das formas dos diferentes objetos. Por outro lado, havia que se exercitar ao máximo a criança para proceder por imitação do belo, de maneira a lhe "despertar a atenção, a dar mais firmeza e destreza, a inspirar a reflexão, a desenvolver e fortificar o amor da ordem, e a entreter o gosto pela elegância e asseio." "244

Indubitavelmente, reconhece-se e proclama-se a desenvolução do indivíduo a partir de estágios do processo de formação, que seriam análogos para todos, e que poderiam ser apreendidos cientificamente pelo estudo da teoria de educação. Entretanto, julga-se que numa primeira etapa, particularmente dos 6 aos 10 anos, a criança tem realmente a memória como faculdade predominante, cedendo logo seu lugar à razão, que entre os 10 e os 15 anos, aliar-se-á à primeira, que posteriormente, entre 15 e 18 anos, ocupará um espaço cada vez menor. A razão e a inteligência teriam, a partir dos 19 anos até os 25 uma grande recorrência à faculdade da imaginação. É evidente - acredita Botelho - que se deveria considerar tais fases do desenvolvimento da juventude como pressupostos para a composição de plataformas curriculares. Havia que se dividir o tempo na escola primária, havia que se classificar as crianças por grupos etários, havia que se distribuir até o espaço físico, tendo em vista esse requisito. Conhecer como a criança pensa era indispensável inclusive para distribuir convenientemente as disciplinas. Nisso estaria o segredo do sucesso de qualquer reforma da escolarização. A instrução primária deveria ser, portanto, bem organizada e dar lugar à possibilidade de controle das localidades sobre a educação, de maneira a que a escola se pudesse verdadeiramente tornar o lugar concorrido e sedutor que apregoavam todos os tratados pedagógicos. Pensa-se, sobretudo, o panorama político que requisitaria as habilidades que somente a escola poderia oferecer:

\footnotetext{
"Num estado livre, como este a que temos a felicidade de pertencer, onde a discussão é socialmente livre, e a opinião pública e o interesse geral são a suprema lei do estado; onde todos os cidadãos são iguais perante a lei, e a soberania está nas mãos do povo; é urgente organizar a sociedade, de modo que a instrução se torne um patrimônio comum a todos, e de todos; e por conseguinte, que seja distribuída gratuitamente, de maneira que todos os membros daquela sociedade gozem igualmente dos meios indispensáveis para a adquirir. Um sistema de instrução pública bem organizado será sempre o meio mais eficaz de fazer prosperar um povo, de formar os costumes e os sentimentos da mocidade, de elevar as gerações que vêm vindo ao mais alto grau de civilização, de corrigir e melhor apreciar o sistema governamental que nos rege, de aumentar o número de cidadãos capazes de gerir os negócios locais, tornando possível esse sistema de descentralização tão desejado, de conservar as nossas liberdades contra os hábitos e prejuízos da antiga feudalidade e despotismo, de manter a nossa autonomia em presença do poderio dos povos inimigos. Quando falo da instrução universal, da instrução para todos, reporto-me principalmente à instrução elementar, que não consiste simplesmente (...) em noções mecânicas da leitura e escrita; ela tem por objeto a educação: é o conjunto de verdades morais e religiosas, que, constituindo a vida íntima do indivíduo, perpetuam a vida tradicional dos povos. É instrumento de conquista para a religião e moral, para a riqueza e prosperidade das massas populares." 245
}

\footnotetext{
${ }^{244}$ Manuel Francisco de Medeiros BOTELHO, Plano Geral de Estudos Primários e Secundários, p. 7-8.

245 Manuel Francisco de Medeiros BOTELHO, Plano Geral de Estudos Primários e Secundários, p. 13. Na sequência, Botelho atenta para o facto de, embora tendo sido decretada em 20 de setembro de 1844 a obrigatoriedade do ensino dos 7 aos 15 anos, não havia em Portugal o cumprimento desse excessivamente exigente - e inegavelmente avançado - preceito legal. A situação de pobreza e até de miséria das famílias atestava o insucesso das letras, das indústrias e das artes naquele país. Por outro lado, era a mesma pobreza quem, requisitando o trabalho infantil, impediria as crianças de frequentarem o período de instrução obrigatória. Diz o texto sobre o tema: "A instrução primária, por motivos diversos e bem conhecidos, está entre nós em um estado deplorável; as povoações rurais principalmente jazem numa profunda ignorância, e muitas há em que não começou ainda a brilhar a luz da instrução mais elementar! Não é isso à míngua de aptidão; o nosso povo tem boas disposições naturais para as ciências, letras e artes, falta-lhe sim o hábito de estudo, o gosto pelo saber, e, levado pelo espírito de rotina, tem um certo horror contra toda a mudança, todo o melhoramento, todo
} 
Ocorre - continua o autor - que instrução universal supõe, já no ponto de partida, tanto a gratuidade quanto a obrigatoriedade. $\mathrm{O}$ autor reporta-se também à necessidade de criação das escolas profissionais para as crianças de origem popular cujos pais estivessem apenas interessados em lhes proporcionar uma instrução elementar. Na verdade, o plano do autor delimita nitidamente a divisão entre as camadas tradicionalmente mais abastadas e aquelas que, em sua perspectiva, não teriam maiores ambições. $\mathrm{O}$ discurso pedagógico português, mais uma vez, oscilava entre a crença e a descrença no potencial transformador de uma escolarização única. Temia-se que a escola única pudesse subverter os lugares economicamente demarcados. Um meio de se prevenir contra tal hipótese era justamente preconizar uma escolar dividida entre os diferentes meios e classes sociais.

\section{ANTÓNIO DA COSTA E O ANTECEDENTE TEÓRICO DA DOUTRINA DO CAPITAL HUMANO}

Os anos 70, por sua vez, viveriam, como nunca, a crença na cultura escolarizada como estratégia privilegiada para redesenhar os parâmetros da nacionalidade e alçar o país na lógica de uma competitividade européia. Os protagonistas do debate pedagógico depositavam na instrução toda a esperança de regenerar os tempos e o discurso tende a aliar cada vez mais o tema da democracia e o objeto da ilustração popular. A instrução, como destaca D. António da Costa, representante inegável do espírito de sua época, revelar-se-ia como a semente da ordem, da virtude, a fonte de moralização das camadas populares, mediante o discernimento que a escola proporcionaria às crianças do povo em relação às noções do bem e do mal. D. António da Costa foi membro da Direção Geral Da Instrução Pública, desde 1859, quando esse órgão foi instituído. Depois, chegou a ser Ministro da Instrução Pública, quando, em 1870 , esse ministério foi finalmente criado $^{246}$. Era, portanto, um homem em sintonia com as grandes questões pedagógicas de Portugal. Entretanto, debatia alguns temas com uma originalidade própria, sem se deixar seduzir pelas plataformas mais comuns do discurso político sobre a escolarização. Era, por exemplo, um partidário da descentralização do ensino, particularmente no concernente ao nível primário ${ }^{247}$. Era em termos políticos que analisava a escola; mas, para ele, a configuração tomada pelo perfil de uma escola que se desejava, desde os tempos de Pombal, uniforme e centralizadora impedia o próprio desenvolvimento da

o progresso, por não the poder compreender as vantagens. Por quase todo o país, o camponês repete obstinadamente que ele tem vivido bem sem saber ler nem escrever; que tem lavrado o seu campo e colhido produtos; que tem cumprido com os deveres de filho e de cidadão sem possuir alguma instrução, e que seus filhos hão de fazer o mesmo. Mas nem ele tem sido tão útil a si e à pátria como deveria, nem o solo entregue nas suas mãos tem produzido o que poderia produzir; nem ele tem cumprido talvez cabalmente com os deveres de filho e de cidadão, porque se observa que onde reina a ignorância decai a autoridade paternal, entibia-se o sentimento religioso, e prevalece muitas vezes o egoísmo muitas vezes implacável e execrado.” ( Id. Ibid., p. 14) ${ }^{246}$ Aliás, sobre isso, diz Rómulo de Carvalho que "o combatente mais pertinaz pela criação de um Ministério da Instrução foi António da Costa de Sousa de Macedo, personalidade que avulta entre os escritores portugueses de assuntos pedagógicos com trabalhos de natureza histórica e de crítica construtiva sobre a instrução nacional que tiveram grande aceitação entre os contemporâneos" (Rómulo de CARVALHO, História do ensino em Portugal, p. 600).

247 "Outra questão de fundo que D. António da Costa sempre debateu nas obras que publicou foi a da descentralização do ensino, em particular do ensino primário, ao qual dedicou a maior parte da sua atenção. 'A situação atual do ensino, fundada na ação direta do Estado' (...), afirma num dos seus livros, 'não poderá por forma alguma resolver o problema da instrução primária em Portugal' (...) 'O sistema que propomos é este: a escola primária será dotada pela paróquia, auxiliada pelo município na míngua de meios paroquiais, e pelo Estado na insuficiência do município'(...)” (Rómulo de CARVALHO, História do ensino em Portugal, p. 603). 
instrução popular, e, nisso, haveria problemas para o desenvolvimento estatal. O lugar disciplinador e homogeneizante de um caráter nacional, configurado pela mãos da escola primária, ficaria assim nitidamente caracterizado em termos da projeção do ideal escolar aqui preconizado: "Dentre as instituições que a idéia moderna, o novo atleta, está disputando ao seu contendor, é a instrução primária uma das principais (...) Concebe-se o absolutismo ignorante e só ignorante se concebe. A liberdade, essa não se pode conceber senão inteligente. $" 248$

Assim como o enfraquecimento do crime dependeria desse conhecimento do bem que a escola pode trazer, para D. António da Costa, no "vagaroso caminhar da Humanidade", as próprias instituições políticas viriam na dependência da formação de modelos de homem em consonância com as referências sociais que se pretendiam consolidar. Sob tal enfoque,o autor supõe que, para a própria existência da liberdade coletiva, a instrução estaria colocada como imperativo categórico, dado que seria ela o dispositivo social de formação para o sentimento da cidadania, para o sentimento de pátria, para o sentimento do gênero humano, enfim. Recorde-se que naquele princípio da década de 70 , a Suécia contava com uma taxa de $10 \%$ de analfabetismo adulto, a Prússia tinha $20 \%$ de analfabetos entre as pessoas com mais de dez anos, a Inglaterra e o País de Gales não ultrapassavam os 30\%, enquanto a França e a Bélgica tinham praticamente $50 \%$ do povo já alfabetizado ${ }^{249}$. Era, pois, sob tal aspecto, visivel o atraso de Portugal, que chegaria ao final do século XIX com um índice de analfabetismo na casa dos quase $80 \%$. Ora, preocupado com a situação de seu país, que não parecia querer acompanhar os tempos, D António da Costa alertava os contemporâneos:

\begin{abstract}
"Em tão verdes anos povo nenhum mereceu tanto a liberdade como o povo português. Deve-o à branda índole do seu caráter e à bondade do seu coração. Podemos ser livres porque sabemos ser homens. Mas não basta só o amor da liberdade. Nos governos livres o povo é chamado a realizar por si próprio a vida política. É-lhe portanto indispensável conhecê-la e realizá-la. Sem a instrução do povo, não pode haver cidadãos que a executem, e sem cidadãos cônscios dos seus direitos e deveres a liberdade será apenas a estátua da formosa deusa." 250
\end{abstract}

Assim, firma-se no discurso esse estreito laço entre a instrução escolar e a capacitação para a cidadania: se ontem a eleição era indireta, hoje ela já era direta; havia de se preparar, inclusive, para a possibilidade do sufrágio universal amanhã... Do contrário, corriase o risco de o povo continuar a ser arrebanhado, pela persistência do que o autor qualificava como "escravidão da ignorância". Percebe-se a preocupação com o sufrágio como a baliza que sustenta o discurso sobre a escola; uma escola que deve preparar, sim, para o esclarecimento, mas para um esclarecimento contido e comportado, nos parâmetros de um tecido social que não pretende romper com quaisquer estruturas de classe. É, até certo ponto,

\footnotetext{
${ }^{248}$ D. António da COSTA, A instrução nacional , p. 5.

${ }^{249}$ Tomamos esses dados da referência feita por André Petitat, em seu livro Produção da escola/ produção da sociedade, p. 150.

${ }^{250}$ D. António da COSTA, A instrução nacional, p. 9. Em outra obra - Auroras da instrução pela iniciativa particular - António da Costa qualificaria o problema da crise portuguesa pelas seguintes palavras: "O velho Portugal, que jaz amortalhado nas suas tradições gloriosas, guerreiro que libertou da meia lua as terras que fizeram recuar as fronteiras lusitanas, conquistador que foi arrancado às vastidões do além-mar (...) esse velho Portugal representou um mundo novo, para exemplo de que opera prodígios a vontade do fraco, sempre que a robustece a virtude do trabalho. Mas o Portugal heróico morrera, o Portugal dos ricos homens e infanções, dos galeões fabulosos e dos assombros titânicos, restando para lhe entoar o ave derradeiro o gênio da poesia, como perecem as nações todas pela grande lei da transformação social, depois de preencherem o mandato da sua missão civilizadora." (D. António da COSTA, Auroras da instrução pela iniciativa particular, p. 365) A glória terminada seria assim sucedida pela imortalidade de Camões. O país entretanto reduzir-se-ia, nos tempos que então corriam, a um país de imitação, sem originalidade, sem criações de vulto: "como todo aventureiro propenso à inércia quando descansa”. (Id. Ibid., p. 368)
} 
o medo da democracia política quem apregoa a escola. A instrução serviria assim como o anteparo da escolha. De qualquer modo, a construção discursiva de D. António da Costa recorre a metáfora da luz que, pela instrução, alumia:

\begin{abstract}
"A república ignorante proclama-se num dia e morre no dia seguinte. Não é uma aurora, mas uma noite (...) Quereis a liberdade consubstanciada no sangue nacional? a liberdade que não depende de fórmulas para viver, nem receia fórmulas que a matem? Universalizai a instrução. Ponde por pedestal das instituições, não a escola mentirosamente prometida, mas a escola verdadeiramente realizada, e só esta virá a alumiar o horizonte da nação e da Humanidade."251
\end{abstract}

O autor afirma, ainda, que a objeção passível de ser apresentada contra a instrução universal residiria fundamentalmente nas elevadas dotações necessárias ao ensino primário se este efetivamente viesse a atender todas as crianças; refutando tal argumento, o educador destacava que, pelo contrário, o ensino apresentar-se-ia, para os que o quisessem, como "fonte do trabalho nacional e da riqueza pública" ${ }^{252}$. Prossegue afirmando a possibilidade de obtenção de capital financeiro, mediante o desenvolvimento dos espíritos. Praticamente antecipa a teoria do capital humano quando se revela convicto de que o conhecimento do operário faria crescer a produção industrial, aumentando, com isso, o lucro dos capitalistas. A universalização da instrução é posta, por tal vereda, como estratégia sutil e privilegiada de multiplicação da riqueza nacional, tendo em vista o próprio interesse das camadas economicamente favorecidas, particularmente de uma burguesia mercantil que enriquecia e desejava preservar e fazer crescer seu patrimônio. À luz de tal constatação, o autor modifica substancialmente o território da abordagem, para evocar o caráter sacralizado da tarefa da instrução, quando julgada a partir de sua tarefa precípua de formação da Humanidade. Nesse sentido, ele declara: "A instrução primária seria já uma altíssima questão se tivesse unicamente por objetos o homem, a família, o cidadão e a sociedade, como temos estudado até aqui, mas é ainda mais: é a grande questão do gênero humano."253

$\mathrm{O}$ tema da necessidade do ensino estaria atrelado à percepção explicitada pelo autor quanto ao aperfeiçoamento que a instrução proporciona em termos individuais e que, integradas as individualidades, resultaria em um bem universal, considerados os esforços de cada povo. Haveria, no parecer do educador, uma desigualdade efetiva de talentos e aptidões individuais, em cuja essência estaria contida a harmonia universal. Para António da Costa, mais uma vez, a escola é tida por fator de civilização, para a construção dessa mesma harmonia a que ele tanto se referia; mesmo que a escola fosse apenas a velha instituição do ler, escrever e contar...

\footnotetext{
“A escola do século XIX inaugurou a idéia nova. Herdamos a escola ridicularizada. O menoscabo e o riso acompanhavam o professor, que os velhos de hoje não conhecem ainda senão pelo 'mestre de primeiras letras'. Não percamos o epíteto, que é significativo. A questão cifrava-se nas primeiras letras, como prólogo exclusivo das segundas e das superiores. Ler, mas ler mal, era a missão da escola. A educação, à luz de todas as suas especialidades, não cunhava ainda na escola o verdadeiro caráter que a filosofia do século lhe não dispensa." 254
}

A escola primária teria o objetivo de formar e conformar almas para o ato da moralização. E com isso os povos apostavam nesse investimento que, podendo ensinar regras de vida e de conduta às populações carentes de orientação na vida e no trabalho, permitiria ser

\footnotetext{
${ }^{251}$ D. António da COSTA, A instrução nacional, p. 11.

${ }^{252}$ D. António da COSTA, A instrução nacional, p. 11.

${ }^{253}$ D. António da COSTA, A instrução nacional , p. 12.

${ }^{254}$ D. António da COSTA, A instrução nacional, p. 21-22. Os grifos são nossos.
} 
qualificado como fonte de prosperidade. A partir de então, passa a discorrer sobre a organização da instrução primária nas ditas 'nações civilizadas'. Nessa direção, D. António da Costa recorda que a organização do ensino inglês seria fundamentalmente assentada na iniciativa particular, ocorrendo fundações de escolas inclusive mediante testamentos e legados familiares. Já nos Estados Unidos, o Estado interviria indiretamente, dado que, havendo o direito subjetivo à instrução, seria obrigação do município oferecer ensino elementar. A Prússia, por sua vez, teria uma organização estatal, na qual as responsabilidades pela instrução seriam partilhadas entre Estado (para o caso do ensino superior), províncias (que cuidariam do ensino secundário) e municípios (responsáveis pelo ensino primário). Com tal exposição, Costa pretende revelar a impropriedade do caso português que, a partir de Pombal, teria focalizado o tema da educação sob a exclusiva centralização do Estado. $\mathrm{Na}$ verdade, a hipótese do autor é a de que talvez por isso Portugal se atrasara em relação aos demais países no que dizia respeito à erradicação do analfabetismo.

\footnotetext{
“(...) uma que não há nação alguma onde a organização do ensino primário se baseie diretamente na intervenção do Estado, senão em Portugal; a outra é que a instrução primária de todos os povos está fundada numa combinação dos diversos elementos, associação, iniciativa individual, localidade, retribuição dos alunos e, como último reforço, o Estado, não como simples tentativas, mas como forças vivas e poderosas da instrução popular, o que também se não dá entre nós, como veremos.",255
}

Sobre a organização do ensino primário em Portugal, Costa destaca que, ao passo que o número de alunos quadriplicou nos últimos vinte anos, a parcela do orçamento do Estado dirigida à educação apenas dobrou. $\mathrm{O}$ autor contrapõe assim as causas aparentes às causas reais para que a instrução portuguesa estivesse - como se sabia - tão atrasada. Aparentemente - prossegue ele - os fatores determinantes consistiriam na falta de frequência da escola pelos alunos; na ausência de escolas normais; na inabilidade do magistério para o ofício desempenhado; no fracasso da obrigatoriedade prevista pela lei. Na realidade, porém como explicitamos anteriormente - o educador acreditava que havia desorganização nos assuntos da instrução, fundamentalmente devido ao fato de se concentrarem todos eles na ação quase exclusiva e centralizadora do governo. Faltava, por conseguinte, o fomento a iniciativas locais e particulares, fossem elas individuais ou oficiais. A opinião pública, por sua vez, parecia ficar completamente alheia e indiferente ao debate, até porque não estaria ainda convencida - segundo António da Costa - sobre a relevância do papel da instrução primária para os destinos da nação. Repare-se que a orientação deste discurso revela a hesitação de alguns teóricos portugueses quanto à própria uniformização de uma escola única sob o signo do controle estatal. Não havia consenso acerca da estrutura que balizaria a nova instrução proposta; nem, aliás, sobre qual era essa escola proposta... Pouco se falava disso. Mas, dado que se entendia ser necessário aproveitar iniciativas particulares que se mostrassem capazes de estender e aprimorar o ensino existente, sugere-se como imprescindível a organização de inspeção, regular e eficaz, em funcionamento em cada concelho ou freguesia, centralizada sob o comando do "diretor geral da instrução pública". Assim, as preocupações sobre o papel da escola na conformação de uma dada mentalidade nacional poderiam ser atendidas, sem prejuízo. Por outro lado, pontuando a questão escolar a partir de sua crença no progresso dos povos, António da Costa sustenta que seria esse mesmo caminho do progresso quem traria os contornos para uma nova escola, dotada concomitantemente de uma organização física, política e científica em sua base curricular, capaz de, por si só, agenciar os impulsos para uma educação efetivamente regeneradora.

${ }^{255}$ D. António da COSTA, A instrução nacional, p. 54. 


\title{
Intelectuais e percursos pedagógicos: a ciência
}

\author{
da educação (1870-1910)
}

"O povo, esse, reza. É a única coisa que faz além de pagar." (Eça de Queirós. Uma campanha alegre 1, p. 22)

\section{A GERAÇÃO DE 70: TRADIÇÃO E CRÍTICA NA LUTA DE REPRESENTAÇÕES}

Como bem observa António José Saraiva, o movimento de idéias efetuado pela designada Geração de 70 aconteceu exatamente no decurso dos anos em que ocorria a plena consolidação do capitalismo português. Coimbra - nas palavras de Saraiva - "fica ligada, em 1864, à rede européia de caminho-de-ferro. Por outro lado, as gerações que ascendiam não tinham já que preocupar-se com o problema fundamental que mobilizara a energia dos primeiros Românticos, que era a substituição de uma cultura clérico-aristocrática por uma cultura laica, burguesa e dirigida a um mais numeroso público alfabetizado". ${ }^{256}$ Ocorre que a prosperidade material objetiva não fôra acompanhada por alterações correlatas no plano das consciências, da subjetividade e da própria situação cultural do país. Por essa razão talvez tenha sido mais veemente o descontentamento daquele grupo-geração que, por sua vez, se diferenciaria também da tradição dos românticos que lhe antecederam, fundamentalmente pela leitura que faria da obra de autores até então desconhecidos, e que naqueles tempos adentravam Portugal pelos trilhos do caminho-de-ferro.

\footnotetext{
"A consciência da Geração de $\mathbf{7 0}$ desperta dentro destas condições, e no seu despertar tem papel decisivo certa visão imaginária da Europa em conjuntura de crise, sobre a qual os moços de Coimbra fixam avidamente os olhos. Antero, Eça, Teófilo e outros deixaram-nos largos depoimentos sobre as suas leituras, sobre os acontecimentos europeus, a que assistiram de longe mas apaixonadamente. Toda a sua atenção parece atraída por uma cultura antes mal conhecida que lhes chegava agora, como diz Eça, aos pacotes de livros, pelo caminho-de-ferro. Importa por isso
}

${ }^{256}$ A. J. SARAIVA e Óscar LOPES, História da literatura portuguesa, p. 833. 
atentar um pouco nos acontecimentos europeus e nas leituras estrangeiras que parecem ter dado a esta geração o sentimento de se chocar frontalmente com a sociedade dentro da qual vivia." 257

Toda uma mundividência - estruturada fundamentalmente a partir das leituras de Comte, de Hegel, de Proudhon - configuraria, para a intelectualidade portuguesa, a referência positivista, a matriz da reflexão dialética e a utopia do socialismo. A Geração de 70 seria, pois, profundamente tributária dessa tríplice tradição. Por outro lado, embora pareça nítido que a geração nova só existiu porque seus protagonistas haviam feito leituras novas, parece também nítido que aqueles jovens intelectuais eram acompanhados por toda uma camada ampliada de leitores que os novos tempos haviam, por sua vez, preparado.

A Questão Coimbrã (1865), que faz despontar aquele grupo, e que - nas palavras de Catroga - "daria início a uma das controvérsias que maiores repercussões teve na vida cultural portuguesa" ${ }^{, 58}$, principia como uma polêmica da juventude contra o tradicionalismo de Castilho e os discípulos e protegidos que eram partidários da escola ultra-romântica liderada pelo velho mestre. Naquela altura, o eixo da contenda teria sido um elogio que Castilho fizera ao trabalho de Pinheiro Chagas, de quem o poeta se dizia padrinho. Ao redigir o posfácio do Poema da mocidade de Pinheiro Chagas, Castilho, ao mesmo tempo em que elogiava seu jovem poeta, censurava outro grupo de "jovens de Coimbra, acusando-os de exibicionismo livresco, de obscuridade propositada e de tratarem de temas que nada tinham a ver com a poesia." ${ }^{259}$ Antero de Quental, em carta aberta intitulada Bom senso e bom gosto, responde às acusações de Castilho e, a partir de então, estaria ali criada a disputa, que seria polarizada pelos aliados de ambos os lados. O grupo-geração de 70 estaria desde então constituído como referência e símbolo da inovação portuguesa contra o arcaísmo e o tradicionalismo. Em 1871, Antero teria a iniciativa de organizar as chamadas Conferências Democráticas do Casino Lisbonense, onde deveriam ser tratadas as diferentes idéias que vinham sendo recentemente produzidas nas distintas formas de expressão do conhecimento, da cultura e das artes. Como bem nos recorda Saraiva:

\begin{abstract}
"Para compreender todo o alcance das Conferências, convém notar que se estava então num ano de grandes acontecimentos - 1871, remate da unificação da Itália, queda do II Império francês, guerra franco-prussiano, Comuna de Paris, que dois membros do Cenáculo ( Antero e Guilherme de Azevedo ) aplaudiram publicamente. No plano interno é o ano em que a Associação Internacional dos Trabalhadores, fundada em 1864, se estende a Portugal, com a cooperação de Antero. O principal promotor em Portugal desta organização, um empregado da Livraria Bertrand, José Fontana, tem contatos com o Cenáculo, e participa, como organizador administrativos, nas Conferências. É fácil, desta maneira, compreender a importância que lhe dedicaram as autoridades, até ao seu encerramento compulsivo por ordem do ministro do Reino, António José de Ávila, após os ataques de jornais conservadores, que acusavam os conferencistas de intenções subversivas e de serem adeptos da Comuna. A motivação próxima da ordem de encerramento parece ter sido a de impedir a realização de uma conferência que ia pôr em causa a religião católica, constitucionalmente ligada ao Estado."260
\end{abstract}

Acerca do movimento da nova geração, Catroga observa que, desde a Questão Coimbrã, a despeito da orientação estética que qualquer um dos lados perfilhasse, havia sem dúvida uma "estratégia de ataque mais global aos valores em que assentavam o regime monárquico-constitucional e os padrões morais dos seus grupos dirigentes." ${ }^{261}$ Era como se, fundamentalmente pela percepção de Antero, houvesse um sentido evolutivo inerente ao

\footnotetext{
${ }^{257}$ A. J. SARAIVA e Óscar LOPES, História da literatura portuguesa, p. 834.

${ }^{258}$ Fernando CATROGA, Positivistas e republicanos, In: A história através da história, p. 87.

${ }^{259}$ A. J. SARAIVA e Óscar LOPES, História da literatura portuguesa, p. 837.

${ }^{260}$ A. J. SARAIVA e Óscar LOPES, História da literatura portuguesa, p. 839.

${ }^{261}$ Fernando CATROGA, Positivistas e republicanos, In: A história através da história, p. 87.
} 
cosmos e, nele, como ideal, a realização mais plena da acepção de justiça. Por outro lado, o aperfeiçoamento dos tempos pela ciência parecia compor essa nova orquestração do tecido social. $^{262}$

António Nóvoa, ao analisar um manuscrito inédito de Antero de Quental, destaca aquela tão celebrada Geração de $\mathbf{7 0}$ no que seus partícipes entendiam ser sua procura pelo século novo. Para Nóvoa, haveria uma dimensão pedagógica a partir da qual se poderia olhar o problema das preocupações levantadas por Antero, tanto na Questão Coimbrã quanto nas Causas da decadência dos povos peninsulares - conferência que Antero faria nas reuniões do Casino. A idéia de uma reforma nos procedimentos de ensino é apresentada como bandeira norteadora da primeira intervenção política de Antero, quando este elegia a polêmica com Castilho como a oportunidade de criação de um fato que proporcionasse o debate sobre a intelectualidade da época. ${ }^{263}$ Para Antonio Machado Pires, era o sentimento de Humanidade que caracterizava aquele grupo-geração. Para ele também, a Questão Coimbrã (1865), enquanto conflito que contrapunha dois universos mentais distintos, estabeleceu-se fundamentalmente pela crítica da geração mais jovem à tradição e ao argumento de autoridade dos antigos, que eram, no caso, personificados pela figura de Castilho. Por seu turno, as Conferências do Casino Lisbonense (1871) seriam uma iniciativa liderada por um Antero de 29 anos, com o objetivo de fazer um balanço da história peninsular e portuguesa naquele quase final do século XIX. Para discorrer sobre a acepção pedagógica da combativa Geração de 70, tomamos por empréstimo as palavras de Machado Pires, à guisa de introdução do tema:

\begin{abstract}
“A Geração de 70 foi, pois, um grupo de homens, em vários momentos diversamente reunidos, para contestarem e discutirem valores culturais mais ou menos assentes (teses históricas, correntes literárias, estados de mentalidade, padrões de educação), mas foi também uma problemática, uma atitude mental, uma interrogação sobre a identidade nacional; falar desta geração é também abstrair dos homens e das obras e encarar uma temática comum, uma enunciação de problemas, uma definição do pensamento nacional." 264
\end{abstract}

Para Catroga, por sua vez, eram os próprios integrantes da chamada Geração de 70 que reivindicavam para si a originalidade firmada perante a radical distinção que a si mesmos atribuíam em relação às gerações precedentes. Eles julgavam trazer consigo, pela primeira vez, algum sentimento de mundo, aquilo que os contemporâneos entendiam por "novo culto da Humanidade"; no caminho para a desejada realização da justiça, da liberdade, nessa missão quase profética que teriam eles mesmos delegado aos intelectuais. $\mathrm{O}$ mundo da

\footnotetext{
${ }^{262}$ Como anota o trabalho de Catroga, tributária da entrada do positivismo em Portugal, havia uma ilação entre os contemporâneos, no sentido de acreditarem que existiria uma irreversível progressão do espírito, que caminhava no sentido de conferir cada vez mais cientificidade a todos os fenômenos, incluindo os fenômenos sociais. Consagrava-se na intelectualidade portuguesa, naqueles anos 70, a idéia de evolução, que subordina umbilicalmente homem e natureza. Para utilizar os argumentos de Catroga a propósito deste cientismo e da visão de história que a ele vem correlata, teremos o seguinte: "A definitiva regeneração social só aconteceria quando a práxis política fosse mediada pela sociologia e pelo conhecimento científico do passado (diaronia); a realização de tal desiderato passava, por sua vez, pela concretização de um plano educativo inspirado, em última análise, no espírito positivo e na ordenação sistematizada dos saberes. Só assim a cultura poderia vencer a natureza e a evolução poderia objetivar-se como verdadeiro progresso." (Fernando CATROGA, Positivistas e republicanos, In: A história através da história, p. 92).

263 "A incongruência que Antero de Quental denuncia nos tempos de Coimbra é a mesma que ele questiona no texto de 1871. Porque se é verdade que não há liberdade sem instrução, é preciso reconhecer que também não há educação sem liberdade. O século novo reclama uma nova educação." (António Nóvoa, Em nome da liberdade, da fraternidade e da emancipação da Academia, In:Antero de Quental, p. 264)

${ }^{264}$ António Machado PIRES, A idéia de decadência na Geracão de 70, p. 53. Para o autor, "foi esta, sem dúvida, uma geração que marcou profundamente na consciência cívica nacional. Foi uma geração por excelência - a grande geração do século XIX em Portugal - (...) pelo que suscitou e pelo que realizou na grande obra coletiva e na obra de cada um dos seus representantes (...)” (Id. Ibid., p. 52)
} 
cultura adquiriria, sob tal perspectiva, uma nova luminosidade, dado que ao intelectual caberia apontar os caminhos do tempo novo, após criteriosa interpretação do presente, tendo por objetivo o traçado do futuro. Reformar a sociedade era, para essa geração, levar à radicalidade o território da cultura. Havia nisso todo um imaginário intrinsecamente pedagógico. ${ }^{265}$ Como também sublinha Catroga, Antero de Quental encarava o presente a partir da idéia de queda e de decadência, a serem ultrapassadas mediante uma "forte vontade de reconversão espiritual". O futuro seria - pelas palavras de Catroga - uma "promessa de consumação plena do sentido do tempo" 266 , e a regeneração das consciências poderia produzir um novo consenso social, estabelecido, substancialmente, por uma vontade coletiva, por um ato de voluntária adesão, que, por sua vez, seria estruturada por efeito de uma conversão intelectual: daí a revolução em Antero ser caracterizada simultaneamente como evolução e revelação. É assim que, ao estudar o pensamento e a filosofia de Antero, Catroga chega à acepção de Humanidade:

\begin{abstract}
“(...) não admira que, nele, tal como no historicismo moderno,a assunção da história como o palco em que a natureza humana se objetiva, ou melhor, como uma antropofania, seja correlata da problemática das filosofias da 'morte de Deus' e, como estas, enalteça a auto-suficiência do universo e do homem. Por isso a verdadeira filosofia, mais do que um sistema abstrato e acabado, devia resumir-se à própria 'idéia histórica de Humanidade, perseguida, entrevista, esquivada, pressentida, através de todos os sistemas, de todas as religiões, de todas as revoluções'. Esta concepção de um tempo histórico movido pela espontaneidade imanente do universo - a espontaneidade é uma idéia-chave do pensamento de Antero - e visto como a objetivação civilizacional do dinamismo cósmico apontava para a colocação da Humanidade no vértice da pirâmide construída pela escalada ascendente do Ser porque só no homem este poderá assumir consciência de si. No fundo, Antero dava expressão metafísica ao enaltecimento da Humanidade que tanto empolgou sua geração."267
\end{abstract}

As Conferências do Casino tinham como objetivo irradiar e impulsionar o debate sobre as questões que seus artífices julgavam ser prementes: filosofia, ciência moderna, situação de Portugal na Europa e no mundo. Os protagonistas daquele cenário tinham, por um lado, a marca da secularização e da racionalidade. Por outro, sensibilizavam-se e aderiam à causa dos trabalhadores reunidos na Internacional. Havia o chamado da revolução socialista; havia a atração representada pelo convite que a Europa parecia fazer a Portugal. ${ }^{268}$ Tratava-se,

265 "Cabia ao intelectual, e particularmente ao poeta - pensavam nesta altura -, a missão profética de tornar visível a opacidade, para os não eleitos, do sentido da história, a fim de lhes anunciar a proximidade da realização da 'idéia nova', isto é, a iminente entrada no reino da libertação de todas as opressões (políticas, econômicas, religiosas). A degenerescência romântica, ao contrário, e sob o beneplácito de Castilho, ter-se-ia transformado num fontismo literário. Como se vê, prosseguiam um objetivo mais radical e totalizante: o escritor tinha por missão semear a 'seara nova', a fim de educar os educadores e de elevar a cultura a instrumento reformador da sociedade." (Fernando CATROGA, Os caminhos polémicos da 'geração nova', In: José MATTOSO, História de Portugal / quinto volume, p. 569)

${ }^{266}$ Fernando CATROGA, Política, história e revolução em Antero de Quental, In: Antero de Quental, p. 30. Acerca dessa propensão do gênero humano para a justiça, Antero veria o individualismo como uma etapa importante, mas a ser ultrapassada, no desenvolvimento da humanidade. Como destaca Catroga, a história seria para Antero, o território onde o espírito universal vem a se objetivar, sendo que indivíduos, classes e povos seriam, nesse 'palco', episódios e momentos fortuitos e que se sucedem uns aos outros como as espirais. Nas palavras de Catroga: “(...) a história, exigindo a contradição, se desenvolve, não segundo um ritmo linear ou sob o signo da épica, mas como a objetivação, num tempo elíptico, do drama essencial do próprio ser, pelo que 'a única idéia segura da história' é a de demonstrar que todas as contradições, dores, injustiças, guerras (...), são momentos necessários do devir". (Id. Ibid. , p. 29)

${ }^{267}$ Fernando CATROGA, Política, história e revolução em Antero de Quental, In: Antero de Quental, p. 36.

268 "Ora, entre as várias opções que então eram invocadas como paradigmas de modernidade, foi a que reivindicava o valor exclusivo da ciência que ganhou maior número de adeptos. Acreditando na validade da lei dos três estados de A. Comte ou da lei da evolução ( Herbert Spencer ), defendiam que a Humanidade teria 
no caso, de uma geração que apostava quase irrestritamente na ciência. Começava a haver a sacralização do conhecimento científico, como se de seus progressos dependesse a própria evolução da Humanidade. Antero de Quental, nisso, pontuava certa distinção dos contemporâneos, posto que via a necessidade de o âmbito da ciência ser sempre matizado pelo fundamento da filosofia, da vontade e da "apropriação prognóstica do futuro" ${ }^{\text {"269. }}$. E esta como ressalta Catroga - pautava-se na suposição de que "a idéia de justiça seria, em última análise, a verdadeira matriz da história, cuja evolução, midiatizada pela ciência social, conduziria à liquidação da opressão do homem pelo homem" ${ }^{\text {270 }}$. Seja como for, a liderança de Antero de Quental perante os companheiros de sua tão polêmica geração, parece, aos olhos dos especialistas, indiscutível. Há-de se interpretar sob essa chave o conflito com Castilho e a oportunidade histórica das Conferências do Casino. Há ali, em tudo isso, um efeito pedagógico que nos parece pouco trabalhado pelos estudiosos do tema. Não será nosso propósito aqui determo-nos em uma análise mais minuciosa daquele grupo-geração. Desejamos, apenas, na constelação de ideais educativos que nos propusemos a apresentar, enfocar o parecer pedagógico do grupo de 70 e o legado que teria sido deixado por ele às gerações posteriores. Isso poderá, a nosso ver, iluminar a reflexão sobre o pensamento a intelectualidade portuguesa acerca do tema da instrução e da escola.

A Geração de 70, indubitavelmente, tem histórias para contar... Não são, pois, apenas os estudiosos, mas os próprios contemporâneos já afirmavam a liderança de Antero

chegado à sua definitiva fase de maturação intelectual, isto é, a um período em que seria desnecessário recorrer a explicações religiosas e metafísicas acerca do mundo e da vida. No entanto, uma outra corrente, sem jamais pôr em causa o valor da ciência, continuará a reivindicar a necessidade de a filosofia ( entendida na velha acepção da ciência dos primeiros princípios ) fundamental todo o saber humano. Foi este o caso, entre outros, de Antero de Quental e de Oliveira Martins." (Fernando CATROGA, Os caminhos polémicos da 'geração nova', In: José MATTOSO, História de Portugal - quinto volume, p.571).

269 "O necessitarismo histórico transmuta-se, assim, num determinismo evolucionista, cientificamente explicado pela lei dos três estados. A humanidade teria percorrido dois períodos sucessivos e necessários (teológico, metafísico) e estaria a entrar na sua fase definitiva (o período positivo ou científico). Ora, mesmo os que, dentro do movimento, punham em causa a validade da lei de Comte, não deixavam de estar convictos de que as novas ciências sociais, tal como as ciências naturais, iriam municiar o homem com uma capacidade de previsão do futuro que anularia a emergência do inesperado, isto é, daquilo que a ignorância humana chama acaso. É certo que, para os positivistas, a maior complexidade dos fenômenos sociais, quando comparada com a da natureza e a sua irrepetibilidade, debilitavam um pouco a clareza das previsões, tornando-os, de certo modo, mais fortuitos, embora essa mesma característica permitisse que a ação dentro de certos limites pudesse condicionar, positiva ou negativamente, a evolução da sociedade. Daí que o acesso à previsão científica não convidasse ao quietismo. A apropriação prognóstica do futuro incitava à ação, tendo em vista antecipar o que teoreticamente se sabia ser inevitável. Só assim o determinismo não seria sinônimo de fatalismo e a potencialidade perfectível da humanidade deixaria de ser um mero ideal utópico. E, com esta promessa, contestava-se tanto o conservadorismo como as ilusões do revolucionarismo voluntarista: a mediação subjetiva só seria profícua se fosse síntona com as leis objetivas da diacronia social." (Fernando CATROGA, Positivistas e republicanos, In: A história através da história, p. 93).

270 Fernando CATROGA, Os caminhos polémicos da 'geração nova', In: José MATTOSO, História de Portugal / quinto volume, p. 571. Mesmo sobre os caminhos do positivismo no caso português, Fernando Catroga ressaltará a feição progressista que essa corrente teria vinda a assumir em Portugal: "Significa isto que o ideário de Comte e de alguns filósofos por ele influenciados foi conhecido entre nós nos finais da década de 60 , tendo então sido interpretado essencialmente como uma filosofia das ciências e da história. Porém, a agudização da crise política e social - e as suas incidências ao nível das elites intelectuais - acentuar-se-á entre 1868 ( ano da revolução liberal espanhola) e 1871 (Comuna de Paris) e conduzirá ao aumento da militância política e social ( surto grevista dos inícios da década de 70) e à consequente busca de alternativas teóricas que pudessem fundamentar a contestação do status quo. Deste modo, se é unilateral afirmar que só o positivismo se casou com a emergência da aspiração republicana e democrática - como parece sugerir Teófilo Braga -, é, contudo, verdade que as razões que levaram à valorização da sua componente sociológica se prendem diretamente com a adequação da nova filosofia, ou, pelo menos, de alguns dos seus aspectos, às necessidades ideológicas das aspirações políticas, que nesse mesmo momento buscavam uma legitimação teórica escudada no prestígio que o saber científico-experimental tinha alcançado. Não surpreende, assim, que a esmagadora maioria dos intelectuais que se declaravam como positivistas se situasse politicamente à esquerda, quase todos próximos da então influente ala radical-federalista do republicanismo português.” (Idem Ibidem, p. 574) 
perante o grupo que mais tarde se revelaria histórico. No princípio dos anos 60 , Antero era reconhecido líder e dirigente no âmbito da Academia. Havendo já publicado conhecidas poesias, firmava-se na intelectualidade pelo teor da sua crítica política e social. Lia, e lia muito; mais do que isso, incitava seus colegas à leitura. Talvez o tema da leitura tenha sido a pedra de toque da Questão Coimbrã, já que o que se falava então era sobre um novo modo de olhar o mundo e retratá-lo. Os partidários da contenda que, contra Castilho, tomaram o partido de Antero de Quental (e mesmo outros - como Ramalho Ortigão - que se identificavam com a literatura de Antero, desaprovando porém o estilo pessoal da polêmica), todos eles sentiam essa pertença a um grupo, que não se colocava apenas pela idade, mas fundamentalmente pela comunhão de idéias, idéias essas que evidentemente se supunham renovadas. Eram inúmeros os autores que passavam a ser assim conhecidos: Hegel, Michelet, Hugo, Proudhon etc. ${ }^{271} \mathrm{O}$ socialismo utópico e o pensamento dialético tomavam forma na própria poesia anteriana. $\mathrm{O}$ despertar daquela geração para a leitura vinha ao encontro de novas formas de olhar também para o problema social, para a dinâmica política, enfim, para a própria vida democrática. Basicamente o contato inicial com essa circulação das idéias literárias, políticas ou mesmo pedagógicas, os intérpretes e historiadores têm atribuído, em grande parte, à liderança de Antero de Quental, que reconhecidamente vivificou o debate acadêmico de então. Aliás, os próprios contemporâneos - na voz de Eça de Queirós, transcrita abaixo - pareciam reivindicar tal referência:

\begin{abstract}
"Nesse tempo ele era em Coimbra, e nos domínios da inteligência, o Príncipe da Mocidade. E, com razão - porque ninguém resumia com mais brilho os defeitos e as qualidades daquela geração, rebelde a todo o ensino tradicional, e que penetrava no mundo do pensamento com audácia, inventividade, fumegante imaginação, amorosa fé, impaciência de todo o método, e uma energia arquejante que a cada encruzilhada cansava. Coimbra vivia então numa grande atividade, ou antes num grande tumulto mental. Pelos caminhos-de-ferro, que tinham aberto a Península, rompiam cada dia, descendo da França e Alemanha ( através da França ), torrentes de coisas novas, idéias, sistemas, estéticas, formas, sentimentos, interesses humanitários... Cada manhã trazia a sua revelação, como um sol que fosse novo. Era Michelet que surgia, e Hegel, e Vico, e Proudhon; e Hugo, tornado profeta e justiceiro dos reis; e Balzac, com o seu mundo perverso e lânguido; e Goethe, vasto como o universo; e Poe, e Heine, e creio que já Darwin, e quantos outros! Naquela geração nervosa, sensível e pálida (...), todas estas maravilhas caíam à maneira de achas numa fogueira, fazendo uma vasta crepitação e uma vasta fumaça! E ao mesmo tempo nos chegavam, por cima dos Pireneus moralmente arrasados, largos entusiasmos europeus que logo adotávamos como nossos e próprios (...) Nesse mundo novo que o Norte nos arremessava aos pacotes, fazíamos por vezes achados bem singulares: (...) Mas a nossa descoberta suprema foi a da Humanidade. Coimbra de repente teve a visão e a consciência adorável da Humanidade. Que encanto e que orgulho. Começamos logo a amar a Humanidade..."272
\end{abstract}

\footnotetext{
${ }^{271}$ Catroga diz que a introdução do positivismo em Portugal ocorre quando o Lente de Matemática em Coimbra, José Falcão, em 1865, incitou Manuel Emídio Garcia, professor da Faculdade de Direito a ler a obra de Comte. O desenvolvimento do positivismo estaria dado - também segundo Catroga - mediante a interpretação sociológica que Manuel Ermídio Garcia, Teófilo Braga e Júlio de Matos confeririam, respectivamente em Coimbra, Lisboa e Porto, ao trabalho teórico e doutrinário de Comte e seus seguidores.

${ }^{272}$ EÇA DE QUEIRÓS, Obras ..., volume II, p. 1542-1543. Teria havido, porém, algum balanço crítico acerca da inquestionável proeminência de Antero e seus efeitos para a produção intelectual daquele grupo-geração do qual ele fazia parte. Para alguns, ao contrário do que afirmava Eça, a liderança de Antero pode não ter sido alguma coisa tão louvável, como também por vezes nos querem fazer acreditar alguns estudiosos do tema.. O relato de Teófilo Braga, abaixo transcrito, não deixa de ser um lamento e uma manifestação solitária e vencida do desaponto em relação ao líder. Nos termos deste outro companheiro de Antero: "Antero de Quental foi sempre julgado pelo que prometia; mas o tempo decorreu, e deixando a crítica numa generosa expectativa, nada produziu, como estes frutos pecos em que se não acha suco apesar do seu aspecto apetecível. Não obstante, sem criar nem produzir, nem dirigir o espírito dos outros, consideravam-no vidente, o maior espírito da geração moderna portuguesa, e o que mais é, um extraordinário filósofo. Estas afirmações gratuitas dos amigos serviram para esterilizá-lo; para que era preciso trabalhar? Quem punha em dúvida a sua capacidade, o seu gênio, a sua influência sobre o século? Foi assim que caiu num misticismo metafísico, que o tornou para
} 
Nas entrelinhas do texto, podemos supor também que teria havido, por aquela altura, uma maior e mais facilitada difusão daquele 'bardo de idéias novas', a que tanto se referiam os protagonistas de cenário intelectual. Uma sólida estratégia comercial, editorial, em termos da circulação e do acesso ao livro, fazia-se bastante nítida à época. Daí suspeitarmos que, talvez, o mercado editorial tivesse algo a ver com o brilho dos jovens de 70... A análise dos textos da época revela, ainda, um perfil contestatório passível de ser interpretado como uma crítica às estruturas e instituições educacionais, guardiãs da tradição e da autoridade. Quando, por exemplo, em Bom senso e bom gosto, Antero cria a polêmica com Castilho, ele imediatamente se refere ao seu interlocutor como partidário do que qualificaria como "escola do elogio mútuo", na qual o debate acadêmico e intelectual teria sido sacrificado em prol de espírito de confraria sectária; ali, obras e autores passavam a ser apenas reverenciados, mesmo que o custo disso fosse o próprio espírito crítico. Antero desqualifica o grupo de Castilho, afirmando que lhe faltaria idéias; e o estilo sozinho não sustentava essa falta.

Além disso, o culto da autoridade, tão apreciado por alguma intelectualidade portuguesa à época, foi o grande inimigo que, em nome de sua geração, Antero pretendeu pôr abaixo. ${ }^{273}$ Ao renegar o 'culto dos dez', do alto de seus vinte e cinco anos, Antero naquele momento encetava briga com alguns outros companheiros de sua geração - como é o caso de Ramalho Ortigão - que julgavam que o colega exagerara na dose, em relação aos termos com que se dirigira ao velho Castilho. ${ }^{274}$ Antero costumava alegar - para provocar o oponente - que o crime imperdoável cometido pela dita escola de Coimbra seria a pretensa inovação. Em nome da tradição, seus adversários encontravam falsas questões para deixar em silêncio aquilo que, de fato, seria o essencial: nas palavras de Antero - "essa falta de querer caminhar por si, de dizer e não repetir, de inventar e não copiar" ${ }^{275}$. Mais do que um ataque a idéias, na

alguns poucos amigos o sacerdote de um culto (...) Dos novos, ninguém foi recebido na literatura com melhor vontade do que Antero de Quental; um dia será acusado de não ter cumprido." (Teófilo BRAGA, História das idéias republicanas em Portugal, p. 90-91)

273 "Cuido mesmo que já me escapou uma ou outra frase não tão reverente e tão lisonjeira como eu desejara. Mas é que realmente, não sei como hei-de dizer, sem parecer ensinar, certas coisas elementares a um homem de sessenta anos; dizê-lo eu, com os meus vinte e cinco! V. Ex a aturou-me em tempo no seu colégio do Pórtico, tinha eu dez anos, e confesso que devo à sua muita paciência o pouco francês que ainda hoje sei. Lembra-se, pois, da minha docilidade e adivinha quanto eu desejaria agora podê-lo seguir humildemente nos seus preceitos e nos seus exemplos, em poesia e filosofia, como outrora em gramática francesa, na compreensão das verdades eternas como em outro tempo no entendimento das fábulas de La Fontaine. Vejo, porém, com desgosto, que temos muitas vezes de renegar aos vinte e cinco anos do culto da autoridade dos dez; e que saber explicar bem Telêmaco a crianças não é precisamente quanto basta para dar o direito de ensinar a homens o que sejam razão e gosto. Concluo daqui que a idade não a fazem os cabelos brancos, mas a madureza das idéias, o tino, a seriedade: e, neste ponto, os meus vinte e cinco anos têm-me as verduras de V. Ex. ${ }^{a}$ convencido valerem-me pelo menos os seus sessenta. Posso pois falar sem desacato. Levanto-me quando os cabelos brancos de V. Exa. passam diante de mim. Mas o travesso cérebro que está debaixo e as garridas e pequeninas coisas, que saem dele, confesso não me merecerem nem admiração nem respeito, nem ainda estima.. A futilidade num velho desgosta-me tanto quanto a gravidade numa criança. V. Ex . precisa menos cinquenta anos de idade, ou então mais cinquenta de reflexão." (Antero de QUENTAL, Bom-senso e bom-gosto, In: Bom senso e bom gosto ( a questão coimbrã ), volume I, p. 246-247)

${ }^{274}$ Ramalho Ortigão, no texto que escreve para a polêmica Questão Coimbrã consegue contrariar tanto Castilho quanto Antero de Quental, ridicularizando, até certo ponto, ambos os lados: "Estão-se dilacerando rancorosamente em Portugal duas seitas literárias a que chamam a coimbrã e a olissiponense. Dizem os de Lisboa que não percebem o palavroso e abstruso mistifório dos literatos de Coimbra. Gritam os de Coimbra que se lhes não dá com o paladar acadêmico o palavrório delambido dos literatos de Lisboa. De modo que, aí temos o Mondego engalfinhado no Tejo." (J. D. RAMALHO ORTIGÃO, Literatura de hoje, In: Bom senso e bom gosto ( a questão coimbrã ), volume II, p. 117)

${ }^{275}$ Antero de Quental, Bom-senso e bom-gosto, In: Bom senso e bom gosto (a questão coimbrã ), volume I, p. 236. Na sequência, o poeta provoca o adversário: “(...) todos os outros crimes eram contra as idéias: haveria sempre um perdão para eles. Mas esta falta era contra as pessoas: e essas tais são imperdoáveis. Inovar é dizer 
verdade o que se fez foi atentar contra pessoas que se apresentavam, aos olhos dos contemporâneos, como verdadeiros profetas do pensamento. Tratando-se de Castilho, vimos já o quanto um método de alfabetização que não teve a menor ressonância prática fez em termos da polarização do debate pedagógico português no decorrer de decênios. Era, em parte, isso que Antero injuriava:

\begin{abstract}
"Mas se eu, como homem, desprezo e esqueço, como escritor é que não posso calar-me; porque atacar a independência do pensamento, a liberdade dos espíritos, é não só ofender o que há de mais santo nos indivíduos, mas é ainda levantar mão roubada contra o patrimônio sagrado da Humanidade - o futuro. É secar as nascentes da fonte onde as gerações futuras têm de beber. É cortar a raiz da árvore a que os vindouros tinham de pedir sombra e sossego. É atrofiar as idéias e os sentimentos das cabeças e dos corações que têm de vir. O contrário disso tudo é a bela, a imensa missão do escritor. É um sacerdócio, um ofício público e religioso de guarda incorruptível da idéias, dos sentimentos, dos costumes, das obras e das palavras. Para isso toda a altura, toda a nobreza interior são pouco ainda. Para isso, toda a independência de espírito, toda a despreocupação de vaidades, toda a liberdade de jugos impostos, de mestres, de autoridades, nunca será demais." 276
\end{abstract}

Repare-se aqui como o jovem poeta engrandece, dignifica e sacraliza a missão social do escritor que, ao que parece, pretende apresentar aos olhos do seu tempo quase como um incorruptível juiz moral, pleno em idealismo e em sabedoria. A vocação do escritor para a interpretação das questões sociais é muito apontada por essa geração, constituindo talvez a própria marca que os unia e que os diferenciava dos antecessores em termos do discurso, posto que, na vida prática, tanto Herculano quanto Garrett, ou mesmo o próprio Castilho, já teriam tido essa iniciativa de aproximação das camadas leitoras, para, apregoando 'ensinamentos úteis', formar e preparar o espírito público, as opiniões intelectualmente transformadas. O lugar do escritor era, entretanto, utilizado, sob a perspectiva dos jovens de 70, como alguma coisa que deve estar, por definição, no campo do insuspeito, do incorruptível, quase para além do bem e do mal. Essa pertença da virtude ao escritor engajado faz por, na esteira da ilustração, mas já sob os ventos do positivismo, dignificar notoriamente o campo do conhecimento, fundamentalmente em se recordando o fato de ser esse um território de poder; um poder que tenderia a ser, inclusive, potencializado, pela palavra do escritor, às populações leitoras. Para os jovens da Geração de 70, o tema da leitura viria codificado pela suposição de um aprendizado posto nesse pacto entre escritor e leitor; pacto esse, que se supunha, acima de tudo, desprovido de receios, desprendido, despojado, generoso, de ambas as partes. ${ }^{277}$

aos profetas, aos reveladores encartados: 'Há alguma coisa que vós ignorais; alguma coisa que nunca pensastes nem dissestes; há mundo além do círculo que se vê com os vossos óculos de teatro; há mundo maior do que os vossos sistemas, mais profundo do que os vossos folhetins; há universo um pouco mais extenso e mais agradável sobretudo do que os vossos livros e os vossos discursos'. Isto sim que é intolerável! Isto, sim, que é infame e revoltante e ímpio e subversivo! Contra isto, sim, às armas, ergamo-nos na nossa força, mostremos o que somos e o que podemos...Escrevamos três folhetins e um prólogo “(Id. Ibid., p. 236)

${ }^{276}$ Antero de QUENTAL, Bom-senso e bom-gosto, In: Bom senso e bom gosto (a questão coimbrã), volume I, p. 236-237.

${ }^{277}$ A idéia de um pacto de generosidade entre autor e leitor foi formulada nesses termos por Jean Paul SARTRE, em Que é a literatura?: "cada um confia no outro, exige do outro quanto exige de si mesmo. Essa confiança já é, em si mesma, generosidade: ninguém pode obrigar o autor a crer que o leitor fará uso da sua liberdade; ninguém pode obrigar o leitor a crer que o autor fez uso da sua. É uma decisão livre que cada um deles toma independentemente. Estabelece-se então um vaivém dialético; quando leio, exijo; o que leio então desde que minhas exigências sejam satisfeitas, me incita a exigir mais do autor, o que significa: exigir do autor que ele exija mais de mim mesmo. Reciprocamente, a exigência do autor é que eu leve ao mais alto grau as minhas exigências. Assim a minha liberdade, ao se manifestar, desvenda a liberdade do outro." (Jean Paul SARTRE, Que é literatura?, p. 46) 
Um novo imaginário da leitura - como temos visto - percorreria todo o século XIX, chegando a esse último quartel, já com contornos bem definidos. A torrente de leitores precisaria ser sim dirigida e orientada pelo campo do ideal, mas nada poderia ser feito a não ser ilustrar o raciocínio pela aquisição e habilidade do escrito. Ocorre que o lugar ocupado por esse estilo de discurso 'libertário' não pode ser minimizado, já que ele em si é um instrumento da nova feição que a intelectualidade portuguesa vinha tomando, fundamentalmente no que que diz respeito a essa pedagogia da leitura. A escrita e o escritor, aos olhos dos protagonistas da época, roubariam o lugar da oralidade do poder. É como se o mundo do impresso se revelasse capaz de estruturar novos alicerces para referenciar o ato da política. Pouco a pouco, intelectuais gestavam o sonho do domínio pela força das letras. Na Questão Coimbrã, a anotação para a posteridade parecia atitude deliberada pelos próprios atores. Seria uma república dos sábios que eles no fundo desejavam contrapor à monarquia? Esses escritores, que mais tarde se apresentariam nitidamente tributários dos ideários de matrizes positivista e socialista, nessa ocasião eram fundamentalmente leitores de Hegel e entendiam especialmente Antero - que a revolução viria pelo movimento da idéia em um tipo de passeio do espírito universal. Deslocar o foco do poder era, em sendo assim, assumir-se eles próprios como arautos do campo da idéia; isso corresponderia a uma realocação dos centros decisórios e das estratégias da política. O tema da leitura passa a ser, agora, uma prioridade, um dispositivo, quase uma arma, na órbita desse inusitado olhar sobre a matéria da cultura.

Nessas andanças dirigidas pela preocupação com o campo letrado, destacam-se as considerações de Antero por ocasião das Conferências do Casino, em 1871, tanto em seu discurso de apresentação do programa daquela iniciativa quanto, fundamentalmente, no texto lido a 27 de maio de 1871, na sala do Casino Lisbonense, sob o título Causas da decadência dos povos peninsulares nos últimos três séculos. No discurso de apresentação, o intuito daquelas conferências era assim resumido por Antero de Quental: "mais forte que nunca, a questão de saber como deve regenerar-se a organização social" ${ }^{278}$. Com tal objetivo, tratavase de investigar em que medida a sociedade vinha se estruturando e o que poderia ser feito para alterar o rumo que havia sido tomado a dada altura do percurso histórico. Urgia descobrir onde estaria posta a causa da decadência, até como estratégia para poder agir contra ela. Já nessa primeira declaração de princípios, destaca-se a urgência de:

\footnotetext{
"Abrir uma tribuna, onde tenham voz as idéias e os trabalhos que caracterizam este momento do século, preocupando-nos, sobretudo, com a transformação social, moral e política dos povos; ligar Portugal com o movimento moderno, fazendo-o assim nutrir-se dos elementos vitais de que vive a Humanidade civilizada; procurar adquirir a consciência dos fatos que nos rodeiam na Europa; agitar na opinião pública as grandes questões da Filosofia e da Ciência moderna; estudar as condições da transformação política, econômica e religiosa da sociedade portuguesa; tal é o fim das Conferências democráticas.",279
}

Formando as idéias, de acordo com esse espírito, a consciência pública viria a ser preparada para presidir a revolução antevista pelo orador, revolução nos costumes e na subjetividade social. É como se Antero apresentasse ali o preâmbulo do que se preparava para declarar depois, quando trataria especificamente de analisar as razões da decadência dos povos peninsulares, uma "desalentadora evidência", a ser reconhecida e superada de modo a que o tecido social fosse emendado e regenerado. Para o expositor, havia algo, nos passados três séculos, que provocara a decadência daquela que foi um dia uma das mais fortes nações

\footnotetext{
278 Antero de QUENTAL, Programa das conferências democráticas, In: Causas da decadência dos povos peninsulares, p. 7.

279 Antero de QUENTAL, Programa das conferências democráticas, In: Causas da decadência dos povos peninsulares, p. 8.
} 
européias. A partir do cumprimento da vocação marítima, os povos ibéricos perderam a liderança na Europa e o eixo decisório transferiu-se para o Norte. ${ }^{280}$ De caráter eminentemente cristão, os peninsulares teriam sido vitimados pelo seu próprio espírito de conquista, não demonstrando habilidade de consolidar pela colonização a aventura que presidira as navegações. De fato - declara Antero - "nunca povo algum absorveu tantos tesouros, ficando ao mesmo tempo tão pobre!" 281 E, resgatando a trilha do que dissera já na Questão Coimbrã:

\begin{abstract}
"No meio dessa pobreza e dessa atonia, o espírito nacional, desanimado e sem estímulos, devia cair naturalmente num estado de torpor e de indiferença. É o que nos mostra claramente esse salto mortal dado pela inteligência dos povos peninsulares, passando da Renascença para os séculos XVII e XVIII. A uma geração de filósofos, de sábios e de artistas criadores sucede a tribo vulgar dos eruditos sem crítica, dos acadêmicos, dos imitadores. Saímos de uma sociedade de homens vivos, movendo-se ao ar livre: entramos num recinto acanhado e quase sepulcral, com uma atmosfera turva pelo pó dos livros velhos e habitado por espectros de doutores. (...) Traduzir é o ideal: inventar, considera-se um perigo e uma inferioridade"282
\end{abstract}

De fato, a crítica ao francesismo era já acentuada entre os autores mais destacados da época. Havia - e isso já preocupava o próprio Eça de Queirós - uma política de imposição dos valores culturais franceses, não apenas através da tradução de textos, mas da incorporação dos conteúdos culturais do romance francês, em seu modo de olhar para a civilização, além naquilo que nos interessa mais diretamente - da elaboração de compêndios que imitavam o feitio (quando não eram a mera tradução quase copiada) dos livros escolares franceses, fossem esses dirigidos ao público da escola primária, secundária ou até superior. Assim, eram os suportes da cultura escolar que viriam a ser absorvidos nessa obsessão mimética. O Estado português, com isso, no parecer dos expoentes dessa Geração de 70, impunha a referência francesa, perdendo consequentemente os parâmetros da alma nacional e a identidade dessa alma, a pouco e pouco, perecia. ${ }^{283}$ Antero diz que há séculos Portugal não produzia um só

\footnotetext{
${ }^{280}$ Como observa Catroga, Antero entendia - em nítida contraposição ao universo liberal - que os valores que conduziram à crise foram individualismo, jesuitismo e espírito de conquista. Nos termos do historiador: “(...) se esse período foi o momento de apogeu da Península, foi, igualmente, o início de sua decadência, ilação que fundamentava a visão trágica que ele tinha da história ibérica. Cumprida a sua missão universal nos alvores da modernidade, os povos ibéricos entraram num processo de esgotamento e de queda, pois o facho da vanguarda passou para os povos arianos do Norte, cuja mentalidade, mais pragmática, menos heróica e menos suscetível de entusiasmo religioso do que a dos peninsulares, se adequava melhor às necessidades sociais e mercantis nascidas dos próprios descobrimentos, enquanto na Península, ao invés, medraram os valores que conduziram à crise: o individualismo, o jesuitismo, o mero espírito de conquista. Não erraremos muito se sustentarmos que estas idéias seduziram Antero, tanto mais elas vinham ao encontro de uma das preocupações essenciais de seu ideário: diagnosticar as razões da decadência e da crise não só dos povos peninsulares, mas também da própria civilização ocidental." (Fernando CATROGA, Política, história e revolução, In: Antero de Quental, p. 21) António José Saraiva acentua a vinculação herculaniana da tese de Antero, que no fundo seria - nos termos do crítico literário - "a estrutura antidemocrática das nações ibéricas desde meados do século XV com vista à conquista e exploração de terras no além-mar. Esta filosofia da história peninsular já, porém, aponta como remédio, não a proposta municipalista pequeno-burguesa e basicamente agrária de Herculano, mas a utopia proudhoniana de um princípio federalista, que se estenderia desde um largo campo político (federação livre de repúblicas peninsulares) até a organização econômica (federações de associações dos produtores).” (A. J. SARAIVA e Óscar LOPES, História da literatura portuguesa, p. 856-7).

${ }^{281}$ Antero de QUENTAL, Causas da decadência dos povos peninsulares, p. 24.

${ }^{282}$ Antero de QUENTAL, Causas da decadência dos povos peninsulares, p. 24-25.

283 Acerca do tema, encontramos nos escritos de Eça de Queirós inúmeras menções ao problema do francesismo. A trascrição abaixo, tratando do problema escolar, pareceu-nos ilustrativa: "A minha cartilha, traduzida também do francês, com a aprovação de um bispo francês, ensinava-me, por outro lado, que Deus é absoluto, de ilimitado poder, e que as suas vastas mãos, que o Universo fizeram, podem o Universo desfazer." (EÇA DE QUEIRÓS, O Francesismo, In : Obras...- volume II, p. 815) Acerca dessa apropriação que os intelectuais da
} 
homem de brilho, capaz de ser posto ao lado dos artífices dessa modernidade que, desde a Renascença, vinha sendo gestada. Além disso, pelo efeito de uma religiosidade marcada pelo selo da Inquisição, os costumes morais e mesmo a energia da vontade e da determinação haviam sido "esmagados, destruídos pelo medo"; e, como resultado, via-se uma sociedade paralisada pela inércia de três séculos decadentistas. A compreensão dessa decadência, para ser efetuada, exigiria, entretanto, o entendimento dos variados componentes que, aliados uns aos outros, formariam a índole ou o temperamento próprios da nação. Assim como Herculano, Antero procurava fugir das interpretações que apresentavam o elemento étnico como fator prioritário na consolidação da "alma nacional"284. Isto posto, Antero irá deter-se especificamente nos motivos de tal ruína, a saber, um de ordem moral, outro de caráter político e um último de origem econômica. Mais uma vez, recorreremos às palavras do expositor em seu discurso:

"O primeiro é a transformação do catolicismo, pelo Concílio de Trento. O segundo, o estabelecimento do absolutismo, pela ruína das liberdades locais. O terceiro, o desenvolvimento das conquistas longínquas. Estes fenômenos, assim agrupados, compreendendo os três grandes aspectos da vida social, o pensamento, a política e o trabalho, indicam-nos claramente que uma profunda e universal revolução se operou, durante o século XVI, nas sociedades peninsulares. Essa revolução foi funesta, funestíssima. Se fosse necessária uma contraprova, bastava considerarmos o fato contemporâneo muito simples: esses três fenômenos eram exatamente o oposto dos três fatos capitais, que se davam nas nações que lá fora cresciam, se moralizavam, se faziam inteligentes, ricas, poderosas, e tomavam a dianteira da civilização. Aqueles três fatos civilizadores foram a liberdade moral, conquistada pela Reforma ou pela filosofia: a elevação da classe média, instrumento do progresso nas sociedades modernas, e diretoras dos reis, até ao dia em que os destronou: a indústria, finalmente, verdadeiro fundamento do mundo atual, que veio a dar às nações uma concepção nova do Direito, substituindo o trabalho à força e o comércio à guerra de conquista. (...) Assim, enquanto as outras nações subiam, nós baixávamos. Subiam elas pelas virtudes modernas; nós descíamos pelos vícios antigos, concentrados, levados ao sumo grau de desenvolvimento e aplicação. Baixávamos pela indústria, pela política. Baixávamos, sobretudo, pela religião."285

Para Antero, a liberdade moral era o contrário da dogmática expressa pelo Concílio de Trento e perpetuada pelo catolicismo português; a classe média seria oposta do absolutismo e do primado aristocrático da sociedade portuguesa; e, por fim, a indústria era o espírito burguês, mercantil, por excelência, antítese do espírito medieval que estava dado na aventura das conquistas longínquas - "o oposto do espírito de conquista, antipático ao trabalho e ao comércio". Como bem observa António Machado Pires, Antero - no discurso pronunciado no Casino Lisbonense - efetua severo julgamento da história portuguesa. ${ }^{286} \mathrm{Sem}$

época faziam da cultura francesa, indicamos o estudo de António Machado Pires - A idéia de decadência na Geração de 70 - particularmente o capítulo intitulado 'A perda do caráter nacional: o francesismo'.

284 “Deste modo, para Antero, pelo menos neste periodo, reduzir a compreensão do gênio nacional ou da alma nacional a um princípio único é querer de propósito acanhar a história. Tal método, se era válido quando aplicado a povos etnicamente mais homogêneos, seria desapropriado à explicação de uma nação sem base rácica definida, como a portuguesa. É que a formação dos povos modernos europeus não foi fruto de uma raiz fisiológica exclusiva, mas de elementos complexos, uns fatais, outros livres, uns criados, outros herdados, cuja síntese constitui a idéia da sua nacionalidade - raça, instituições, religião, tradição histórica, e vocação política e econômica no meio dos outros povos. Assim sendo, defendia que foi a idéia nacional, na sua evolução histórica, a definir gradualmente o chamado temperamento da nação; o elemento étnico só tinha sido determinante da história das chamadas raças originárias, como a ariana, logo, das raças primordiais que não foram o produto de complexas misturas." (Fernando CATROGA, Positivistas e republicanos, In: A história através da história, p. 105).

${ }^{285}$ Antero de QUENTAL, Causas da decadência dos povos peninsulares, p. 30-31.

${ }^{286}$ Caracterizando Antero como historiador-filósofo, António Machado Pires destaca que “Antero está a julgar a história, isto é, traz os Povos, como agentes, e a História, como entidade, a juízo moral, social e político. Daqui 
sombra de dúvida, a leitura de Antero a respeito das trilhas e das desventuras do povo português marcaria época, influenciando inúmeras gerações que nela se inspirariam. O texto de Antero seria um marco na história da cultura portuguesa, tanto no sentido de expressar as novas tendências que despontavam naquele período, quanto no sentido de revelar a apropriação que a Geração de $\mathbf{7 0}$ fizera das leituras de Herculano, sobre - por exemplo - o municipalismo que tanto entusiasmara o redator do Panorama. A história das idéias em Portugal revela, de fato, com muita nitidez, esse entrelaçamento de teorias e de gerações do pensamento. Na verdade, a marcante Geração de $\mathbf{7 0}$ bebera já nos escritos de Garrett, de Herculano, ainda que tivesse explícito o desejo de avançar, em um século que tinha talvez por principal característica essa ilusão do progresso intermitente na reforma intelectual da evolução humana.

A idéia de decadência contrapor-se-ia ao caminho da perfectibilidade histórica, rejeitando a herança iluminista e ameaçando o lugar de Portugal na nova Europa que se pretendia desenhar. Por outro lado, se a decadência viera e se apresentava aos olhos dos conterrâneos como uma realidade inquestionável, havia que superá-la e, para isso, se conferia sentido de urgência em compreendê-la. Até certo ponto, o pensamento pedagógico português é tributário, no que diz respeito ao período aqui estudado, do sonho de redenção pelo ato da pedagogia. Educar e instruir eram tidos por instrumentos para reeerguer; ou, para usar os termos de Antero, regenerar. Não se tratava do mesmo estilo de regeneração que queriam os franceses quando, durante a revolução, recorriam à palavra. ${ }^{287}$ No caso português, regenerar significava recuperar a grandeza que a história perdera: a educação, de qualquer modo, era apenas, talvez, o veículo.

Para Antero, inconfundivelmente, o atraso seria devido, entre outras coisas, ao arcaísmo de uma religião que estava também em decadência desde que, no século XVI, fôra reformada. ${ }^{288}$ Assim, os povos prósperos e íntegros não eram os da tradição católica, mas os protestantes, até porque os dogmas e os procedimentos ritualísticos da religiosidade católica eram impeditivos do espírito crítico e criativo, posto que havia sempre um Deus escondido, no confessionário, ou na perseguição dos pecadores; aquele Deus a quem nada escapa, que vê tudo, tudo ouve e irá julgar os transgressores, fundamentalmente pelo que eles tentaram esconder. Os parâmetros da religiosidade portuguesa, aliás, mereceriam, por si, um estudo à parte, até porque todas as instituições da vida social estavam parcialmente determinadas por essa variável. Há que se descobrir como as práticas sociais traduziam as representações simbólicas e até que ponto essas correspondem ao que entendemos delas. A equação parecenos, assim, profundamente complexa, em uma cadeia de significados, onde falsas certezas substituem simbolicamente realidades nas quais dificilmente se consegue adentrar. A vida religiosa, que de tão relevante aparece-nos como uma caixa preta, persiste sendo, nessa medida, um enigma. De qualquer modo, em Portugal do século XIX, toda uma cultura do

decorre o apontar e discutir as causas de decadência." Mais do que isso, para o comentarista, na análise anteriana estaria presente "uma aceitação de que os povos obedecem a um estatuto anímico coletivo, estrutural, isto é, a crença no gênio de um povo, nos caracteres de uma raça. Assim o 'mundo brilhante' criado pelo gênio peninsular: assim ainda o apontar os 'caracteres essenciais da raça peninsular': o 'espírito de independência local' e a 'originalidade do gênio inventivo." (António Machado Pires, A ideia de decadência na Geração de 70 , p. 65)

287 Acerca do tema da regeneração enquanto projeto de pedagogia político-social, os trabalhos de Mona Ozouf foram, sem dúvida, nossa grande referência. Para essa autora, o caso francês teria sido exemplar no sentido de edificação de um imaginário que supunha fundamentalmente a formação de um homem novo pela erradicação de quaisquer vestígios do regime deposto. (Mona OZOUF, L'homme régénéré).

288 "Quem pode hoje negar que é, em grande parte, à Reforma que os povos reformados devem os progressos morais que os colocaram naturalmente à frente da civilização? Contraste significativo, que nos apresenta hoje o mundo! As nações mais inteligentes, mais moralizadas, mais pacíficas e mais industriosas são exatamente aquelas que seguiram a revolução religiosa do século XVI: Alemanha, Holanda, Inglaterra, Estados Unidos, Suíça. As mais decadentes são exatamente as mais católicas! Com a Reforma, estaríamos hoje talvez à altura dessas nações; estaríamos livres, prósperos, inteligentes, morais... mas Roma teria caído!" (Antero de QUENTAL, Causas da decadência dos povos peninsulares, p. 37) 
confessionário parecia, aos olhos dos contemporâneos, absolutamente estruturada, atingindo todos os setores da vida social, a começar, evidentemente, pela educação. Pelas palavras de Antero:

\begin{abstract}
"Com esse catecismo, imposto por toda a parte e por todos os modos aos espíritos moços e simples, tratou-se de matar a liberdade no seu gérmen, de absorver as gerações nascentes, de as deformar e as torturar, comprimindo-as nos moldes estreitos duma doutrina seca, formal, escolástica e sutilmente ininteligível. Se se conseguiu ou não esse resultado funesto, respondam umas poucas de nações moribundas, enfermas da pior das enfermidades, a atrofia moral!"289
\end{abstract}

Mais adiante, o autor analisará aquilo que supõe ser a essência do catolicismo ibérico, uma religião que pesava por todos os lados por onde fosse abordada; uma religião que incentivava práticas de delação, apresentando-as como se de virtudes se tratassem; uma religião persecutória, onde havia sempre um 'terror invisível' a pairar sobre a vida social; uma religião que alçou a hipocrisia como vício necessário e expulsou, em nome de Cristo, judeus e mouros. Enfim, uma religião que restringiria por si só a condição de Humanidade apenas àqueles que se mantivessem nas fileiras do seu catolicismo intolerante. Foi essa religião que, no parecer de Antero, atrasou Portugal. A religião era, então, um princípio em nome do qual todos os demais princípios seriam solapados. A escolarização, por sua vez, tinha por tarefa primeira a consolidação desse universo mental. A tradição jesuítica não deixava dúvida alguma sobre isso:

\begin{abstract}
“(...) métodos de ensino, ao mesmo tempo brutais e requintados, esterilizam as inteligências, dirigindo-se à memória, com o fim de matarem o pensamento inventivo, e alcançam alhear o espírito peninsular do grande movimento da ciência moderna, essencialmente livre e criadora: a educação jesuítica faz das classes elevadas máquinas ininteligentes e passivas; do povo, fanáticos corruptos e cruéis: a funesta moral jesuítica, explicada (e praticada) pelos seus casuístas, com as suas restrições mentais, as suas sutilezas, os seus equívocos, as suas condescendências, infiltra-se por toda a parte, como um veneno lento, desorganiza moralmente a sociedade, desfaz o espírito de família, corrompe as consciências com a oscilação contínua da noção do dever, e aniquila os caracteres, sofismando-os, amolecendo-os: o ideal da educação jesuítica é um povo de crianças mudas, obedientes e imbecis (...) ${ }^{, 290}$
\end{abstract}

A segunda razão da decadência seria - diz Antero - o absolutismo, que, gerando em terras portuguesas uma cultura centralista, em termos políticos seria frontalmente contrário à tradição localista anterior a ele. Não haveria, a partir de então, equilíbrio de poderes, em virtude da excessiva centralização e da consequente diminuição do papel das paróquias e municípios. Além disso, em franca dissonância com a maior parte dos países

\footnotetext{
${ }^{289}$ Antero de QUENTAL, Causas da decadência..., p. 42.

290 Antero de QUENTAL, Causas da decadência..., p. 46-47. Antero continua e chega à conclusão que o jesuitismo deixara consequências terrivelmente funestas para a vida nacional, mesmo depois de sua expulsão. $\mathrm{Na}$ verdade, eram hábitos que se haviam formado no decorrer de muitos séculos e que produziam efeitos os mais perversos de incorporação espontânea. O jesuitismo é assim o passado, mas um passado que vive, pesa sobre a vida presente e chega mesmo a paralisar o contemporâneo. Sobre os fatores envolvidos na decadência do povo, Antero vê na ação jesuítica o que havia, talvez, de pior: "Das influências deletérias nenhuma foi tão universal, nenhuma lançou tão fundas raízes. Feriu o homem no que há de mais íntimo, nos pontos mais essenciais da vida moral, no crer, no sentir - no ser: envenenou a vida nas suas fontes mais secretas. Essa transformação da alma peninsular fez-se em tão íntimas profundidades, que tem escapado às maiores revoluções; passam por cima dessa região quase inacessível, superficialmente, e deixam-na na sua inércia secular. Há em todos nós, por mais modernos que queiramos ser, há lá oculto, dissimulado, mas não inteiramente morto, um beato, um fanático ou um jesuíta. Esse moribundo que se ergue dentro de nós é o inimigo, é o passado. É preciso enterrá-lo por uma vez, e com ele o espírito sinistro do catolicismo de Trento.” (Id. Ibid., p. 49)
} 
europeus, as monarquias ibéricas impediram o desenvolvimento da burguesia, impondo a manutenção de uma mentalidade aristocrática que viria a se tornar cada vez mais ultrapassada e obsoleta. ${ }^{291}$ Foi a monarquia absoluta que habituou o povo a esperar por soluções prontas, vindas, se possível, pelo alto e sem iniciativa ou impulso para a luta pela liberdade. E, por fim, quando supostamente a liberdade política era alcançada, o povo, inerte, não foi capaz de fazer uso dela. ${ }^{292}$ Foi também a obsessão centralista que impediu o país de rumar para a forma republicana e democrática de governo. Como observa Catroga, Antero entende que a inquisição e o jesuitismo mataram o poder local, atrofiando consequentemente a democracia e gerando o absolutismo. Por sua vez, clericalismo e absolutismo liquidaram juntos o "momento de apogeu - os Descobrimentos -, bloqueando a modernização econômica, política e cultural do país que estes podiam ter propiciado."293 Finalmente, o último fator de decadência era de ordem econômica: as conquistas. Vale a pena recorrer diretamente à argumentação de Antero:

\begin{abstract}
"Há dois séculos que os livros, as tradições e a memória dos homens, andam cheios dessa epopéia guerreira, que os povos peninsulares, atravessando oceanos desconhecidos, deixaram escrita por todas as partes do mundo. Embalaram-nos com essas histórias: atacá-las é quase um sacrilégio. E, todavia, esse brilhante poema em ação foi uma das maiores causas da nossa decadência. É necessário dizê-lo, em que pese aos nossos sentimentos mais caros de patriotismo tradicional. Tanto mais que um erro econômico não é necessariamente uma vergonha nacional. No ponto de vista heróico, quem pode negá-lo? Foi esse movimento das conquistas espanholas e portuguesas um relâmpago brilhante, e por certos lados, sublime, da alma intrépida peninsular. A moralidade subjetiva desse movimento é indiscutível perante a história: são do domínio da poesia, e se-lo-ão sempre acontecimentos que puderam inspirar a grande alma de Camões. A desgraça é que esse espírito guerreiro estava deslocado nos tempos modernos: as nações modernas estão condenadas a não fazerem poesia, mas ciência. Quem domina não é já a musa heróica da epopéia; é a economia política, Calíope dum mundo novo, senão tão belo, pelo menos mais justo e lógico do que o antigo. Ora, é à luz da economia política que eu condeno as conquistas e o espírito guerreiro. Quisemos refazer os tempos heróicos da idade moderna: enganamo-nos; não era possível; caímos."294
\end{abstract}

Na sequiência, Antero destaca que o espírito da era moderna correspondia às idéias de trabalho e de indústria, distanciando-se e não mais se identificando com o espírito de aventura que comandara a empresa das navegações. A lei econômica da produção teria passado a dominar a vida das nações que acompanhavam a tendência de seu tempo. Ao deixar de fazer isso, Portugal ficara para trás. ${ }^{295}$ Seja como for, a decadência portuguesa estaria

\footnotetext{
${ }^{291}$ Acerca do tema, Antero justifica: “A burguesia, a quem estava destinado o futuro, erguia-se, começava a ter voz. As nossas monarquias, porém, tiveram um caráter exclusivamente aristocrático; eram-no pelo princípio, e eram-no pelos resultados. Governava-se então pela nobreza e para a nobreza. As consequências sabemo-las nós todos. Pelos morgados, vinculou-se a terra, criaram-se imensas propriedades. Com isto, anulou-se a classe dos pequenos proprietários; a grande cultura sendo então impossível, e desaparecendo gradualmente a pequena, a agricultura caiu; metade da Península transformou-se numa charneca: a população decresceu, sem que por isso se aliviasse a miséria. Por outro lado, o espírito aristocrático da monarquia, opondo-se naturalmente aos progressos da classe média, impediu o desenvolvimento da burguesia, a classe moderna por excelência, civilizadora e iniciadora, já na indústria, já nas ciências, já no comércio. Sem ela, o que podíamos nós ser nos grandes trabalhos com que o espírito moderno tem transformado a sociedade, a inteligência e a natureza?" (Antero de QUENTAL, Causas da decadência dos povos peninsulares, p. 53)

${ }^{292}$ Nos termos de Antero: "Essa monarquia, acostumando o povo a servir, habituando-o à inércia de quem espera tudo de cima, obliterou o sentimento instintivo de liberdade, quebrou a energia das vontades, adormeceu a iniciativa; quando mais tarde lhe deram a liberdade, não a compreendeu; ainda hoje a não compreende, nem sabe usar dela. As revoluções podem chamar por ele, sacudi-lo com força: continua dormindo sempre o seu sono secular!" (Antero de QUENTAL, Causas da decadência dos povos peninsulares, p. 54)

${ }^{293}$ Fernando CATROGA, Positivistas e republicanos, In: A história atrvés da história, p. 108.

${ }^{294}$ Antero de QUENTAL, Causas da decadência dos povos peninsulares, p. 54-55.

295 "Qual é com efeito, o espírito da Idade Moderna? é o espírito de trabalho e de indústria.: a riqueza e a vida das nações têm de se tirar da atividade produtora, e não da guerra esterilizadora. O que sai da guerra não só
} 
expressa nesse constante olhar para trás, nessa saudade de um passado que se foi, nessa dificuldade secular de projeção do futuro. O parecer de Antero seria, sem dúvida, uma das grandes marcas daquela sua geração, e revelar-se-ia como matriz de grande parte do pensamento político imediatamente posterior. No plano da história da cultura, acreditamos que muito do que se passaria a dizer sobre o tema da escolarização e da pedagogia, a partir dali, teria a ver com essa crença vincada em uma lei da evolução histórica, ' inflexível e impassível', que presidiria os destinos e o movimento das nações. Pensar a educação, como veremos, passará a ser, desde então, estratégia para interferir nesse caminho anteriormente traçado. Há pretensão de ciência na pedagogia daqui para frente. Para Antero, o instrumento da regeneração seria a revolução; havia que se descobrir, entretanto, qual o papel que a educação poderia vir a ter para alterar uma ordem social que teria sido, em parte, também criada por um modelo pedagógico. A escolarização era assim referência para o diálogo com a perversa tradição jesuítica. Antero não chega a especificar o antídoto da decadência; mas muitos de seus contemporâneos ou leitores o fariam. A história do pensamento pedagógico português no século XIX parece-nos, pois, bastante tributária dessa dimensão analítica dos tempos passados, dimensão construída pelo discurso intelectual de algumas gerações entrecruzadas e que toma sua forma mais acabada na percepção de Antero de Quental. ${ }^{296}$ Veremos que esse olhar sobre a história de Portugal no mundo ganhará adeptos dentre aqueles que se debruçam sobre o tema da pedagogia, logo a seguir.

\section{EÇA DE QUEIRÓS, RAMALHO ORTIGÃO E AS FARPAS DA LEITURA}

As Conferências do Casino haviam sido saudadas por Eça de Queirós como a palavra da revolução, em sua forma científica, revolução essa que principiaria por esse ato de relatar ao povo suas misérias. Falar de Portugal era, aos olhos do escritor, o primeiro passo para o enfrentamento do rol de problemas e dificuldades que assolavam o país, particularmente nos aspectos concernentes ao mundo da cultura. As conferências eram esperadas, então, como a voz da lógica e do bom-senso. Havia que se habituar a escutar o que ali poderia vir a surgir como caracterização da pátria que - por aquilo que esses protagonistas chamavam de revolução - se pretendia remendar. ${ }^{297}$ Com a proibição e o encerramento das

acaba cedo, mas é além disso um capital morto, consumido sem resultado. É necessário que o trabalho sobretudo a indústria agrícola o fecunde, lhe dê vida. Domina todo este assunto uma lei econômica, formulada por Adão Smith, um dos pais da ciência, nas seguintes palavras: 'o capital adquirido pelo comércio e pela guerra só se torna real e produtivo quando se fixa na cultura da terra e nas outras indústrias." (Antero de Quental, Causas da decadência dos povos peninsulares, p. 55)

${ }^{296}$ Sobre a avaliação feita pelo autor acerca dos efeitos da decadência, caberia transcrever o seguinte trecho: " $E$ o abatimento, a prostração do espírito nacional, pervertido e atrofiado por uns poucos de séculos da mais nociva educação. As causas, que indiquei, cessaram em grande parte: mas os efeitos morais que persistem, e é a eles que devemos atribuir a incerteza, o desânimo, o mal-estar da nossa sociedade contemporânea.. À influência do espírito católico, no seu pesado dogmatismo, deve ser atribuída esta indiferença universal pela filosofia, pela ciência, pelo movimento moral e social moderno, este adormecimento sonambulesco em face da revolução do século XIX, que é quase a nossa feição característica e nacional entre os povos da Europa. Já não cremos certamente com o ardor apaixonado e cego de nossos avós, nos dogmas católicos: mas continuamos a fechar os olhos às verdades descobertas pelo pensamento livre. Se a Igreja nos incomoda com as suas exigências, não deixa por isso também de nos incomodar a Revolução com as lutas. Fomos os portugueses intolerantes e fanáticos dos séculos XVI, XVII e XVIII: somos agora os portugueses indiferentes do século XIX." (Antero de Quental, Causas da decadência dos povos peninsulares, p. 65-66)

297 "As conferências hão-de encontrar resistências. Em primeiro lugar o nosso público inteligente e literário, ama sobretudo o bel - esprit, a oratória, a frase. Moda peninsular. Ora as conferências pela sua natureza científica e experimental - exigem justamente o contrário dos aparatos retóricos. São a demonstração, não são a 
Conferências do Casino, o tema das idéias se conflui com a zona perigosa da fala, das versões e da leitura; ou, pelas palavras de Eça de Queirós n’As Farpas de Julho de 1871:

\begin{abstract}
"Sejamos lógicos; fechemos as Conferências do Casino onde se ouvem doutrinas livres, mas expulsemos os livros onde se lêem doutrinas livres. Ouvir ou ler dá os mesmos resultados para a inteligência, para a memória, e para a ação: é a mesma entrada para a consciência de duas portas paralelas. Façamos calar o sr. Antero de Quental, mas proibamos na alfândega a entrada dos livros de Vítor Hugo, Proudhon, Langlois, Feuerbach, Quinet, Littré, toda a crítica francesa, todo o pensamento alemão, toda a idéia, toda a história. Dobremos a cabeça sobre a nossa ignorância e sobre a nossa inércia, e deixemo-nos apodrecer, mudos, vis, inertes, na torpeza moral e no tédio." ${ }^{, 98}$
\end{abstract}

Como recorda Saraiva, "no mesmo ano em que decorrem as Conferências do Casino, e orientadas no mesmo sentido de crítica geral da sociedade portuguesa"299, As Farpas seriam um conjunto de publicações mensais, sob a autoria de Ramalho Ortigão e Eça de Queirós, satirizando os debates socio-políticos mais candentes na época e procurando ironizar e caricaturar as instituições vigentes. Os redatores destacavam, frequentemente, em suas crônicas a carência de leitura da sociedade portuguesa de então. Descreviam um país onde ninguém comprava livros e a leitura nem de longe se colocava como uma forma concorrida de distração. Com espírito preguiçoso, Portugal perdera o sentimento de cidade e fundamentalmente o sentimento de pátria, transformando-se no país das sempre passadas conquistas e da inatividade enfastiada do presente. ${ }^{300}$ Ora, a reflexão acerca do problema da leitura evoca quase imediatamente a questão da escola enquanto um projeto de Estado, na talvez reconstrução da nacionalidade. É por aí que o pensamento político português, particularmente a partir da dita Geração de 70, passará a abordar o tema da escolarização como uma necessidade posta para a superação da constatada decadência e, ao mesmo tempo, como veículo da feitura de uma inusitada cidadania, direcionada rumo a uma nova modernidade. Nessa dimensão, pode-se compreender a proeminência que o objeto da leitura passará a adquirir nos últimos decênios do século XIX. Na verdade, grande parte da intelectualidade portuguesa da época virá a se preocupar com o problema da preparação de novos leitores, a partir do exercício da leitura escolar. Livros didáticos existiam já e, pelo menos desde a década de 50, em grande escala, disputavam, uns com os outros, os lugares restritos da vida escolar. Ora, se o compêndio escolar passa a ser aqui no discurso encarado como a via de ingresso ao mundo do livro e do escrito, evidentemente isso pertence a um movimento mais amplo que deslocaria a pauta do debate educativo das questões de ordem política para a dinâmica de cunho técnico-pedagógico. O campo da discussão assumiria,

apóstrofe; são a ciência, não são a eloquência. As declamações têm tirado à democracia o seu caráter privativo de realidade e de ciência. Temos ouvido cantar a democracia, berrá-la, soluçá-la: é tempo de a vermos demonstrar. Deixemos no bengaleiro a nossa perpétua inclinação nacional de escutar odes - e entremos só com a tendência humana de resolver problemas." (EÇA DE QUEIRÓS, Uma campanha alegre / volume I, p. 37)

${ }^{298}$ EÇA DE QUEIRÓS, Uma campanha alegre / volume I, p. 61.

299 A. J. SARAIVA e Óscar LOPES, História da literatura portuguesa, p. 840. De acordo com estes comentaristas, "cada número constituía um comentário crítico e satírico aos acontecimentos e instituições, orientado segundo um ideário cuja principal fonte era, nos primeiros tempos, a obra de Proudhon. " (Id. Ibid. , p. 841).

${ }^{300}$ Tal apreciação também constava dos textos publicados n’As Farpas, particularmente em Junho de 1871. Destacando esse fastio da sociedade portuguesa daquele último quartel do XIX, Eça pontua o cenário que apresenta: “Os cafés são soturnos. Meio deitados para cima das mesas, os homens tomam o café a pequenos goles, ou fumam calados. A conversação extinguiu-se. Ninguém possui idéias originais e próprias. Há quatro ou cinco frases, feitas de há muito, que se repetem. Depois boceja-se. Quatro pessoas reúnem-se: passados cinco minutos, murmuradas as trivialidades, o pensamento de cada um dos conversadores é poder-se livrar dos outros três. " (EÇA DE QUEIRÓS, Uma campanha alegre / volume I, p. 34) 
assim, novas feições, ganhando terreno as polêmicas metodológicas e o discurso sobre a pauta especificamente escolar, os saberes pedagógicos escolarizados e, em tudo isso, a leitura ocupando lugar de destaque. Com isso projeta-se o caminho de uma organização de rede educativa uniforme, homogênea e única, capaz de efetivar de modo conveniente a transmissão desses conhecimentos das primeiras letras. A realidade, entretanto, ainda não acompanhava o tom de proficiência com que se pretendia construir as representações mentais sobre a vida escolar. Sobre o lugar de Portugal em uma exposição que ocorreria em Viena de Áustria, em dezembro de 1872, Ramalho Ortigão recorda aos portugueses que pouco havia para ser mostrado em termos dos produtos didáticos nacionais. Compêndios aprovados de todas as áreas do conhecimento traziam noções errôneas, a despeito de haverem sido todos eles submetidos e aprovados pelos órgãos pedagógicos competentes. Assim, encontravam-se, com muita freqüência, obras que traziam inúmeras definições incorretas, envergonhando o país e o ensino. Em tom jocoso, o jornalista arremata:

\begin{abstract}
"Quando os austríacos virem esses assombrosos prodígios da grande fertilidade intelectual portuguesa terão tristezas, como famintos hebreus do deserto perante as grossas cebolas do Egito. (...) Pedimos sobretudo, que não esqueça de mandar, dentro de uma gaiola, para a seção de história natural, um dos nossos professores de instrução primária, que o Estado consegue sustentar com noventa mil réis por ano. Que se faça notar a todos os visitantes que a gaiola não tem comedouro e que o professor se alimenta exclusivamente com a leitura do Manual Enciclopédico que tem debaixo do braço. Que principalmente não esqueça - a fim de podermos continuar a aproveitar no serviço público o professor que expusermos - afixar no recinto da exposição um rótulo em que se leia: 'Pede-se ao público o obséquio de não comer nem mostrar comestíveis diante da gaiola do Sr. Professor português, para não despertar no objeto exposto idéias que o Governo de sua Majestade Fidelíssima julga incompatíveis com o exercício do magistério no território nacional. $" 301$
\end{abstract}

Poder-se-ia mesmo dizer que a leitura é reconhecidamente o sujeito e a razão de ser da escola primária. A partir da irradiação da palavra escrita - e Ramalho Ortigão parece obcecado por essa idéia - os julgamento e a reflexão foram postos a público, de modo profundamente ameaçador. A tipografia teria sido - aos olhos do intelectual - o instrumento que possibilitou a irradiação efetiva das idéias, a circulação do pensamento, a partilha das reflexões e das intervenções no mundo e na história ${ }^{302^{3}}$. Tal progresso, que, de técnico,

\footnotetext{
${ }^{301}$ Ramalho ORTIGÃO, As Farpas / XIII: crónica mensal da política, das letras e dos costumes (1872), p. 174. Ramalho Ortigão, em vários artigos d'As Farpas, destaca o problema dos maus compêndios como um dos grandes óbices ao aprendizado das crianças na escola. No excerto acima transcrito, a alusão feita ao Manual enciclopédico coincide, como veremos nos capítulos seguintes, com o depoimento de muitos outros protagonistas da época, que retratam esse livro de Monteverde como o grande livro da escola portuguesa na segunda metade do século XIX. Por aqui, somos tentados a indagar até que ponto muitas das obras aprovadas pela Junta Consultiva da Instrução Pública e adotadas nas escolas não eram dirigidas exatamente aos alunos, constituindo-se antes em guias e roteiros para que os professores, que andavam com esses livros "debaixo do braço" preparassem adequadamente a aula, que, na maior parte das vezes, não saberiam dar de outro modo. Estamos convencidos de que, no caso específico, o Manual enciclopédico cumpria essa função, como explicitaremos adiante, quando da análise específica dos textos escolares.

302 "Muito antes de se ter descoberto a imprensa, existia já a instituição oficial da censura. Nesse tempo compreendia-se a intervenção fiscalizante do Governo na circulação das idéias. Os livros e os panfletos em manuscrito passavam secretamente de mão em mão. Os que governavam não podiam mais ter uma vaga e bem incompleta noção do que se lia. As idéias viviam e procriavam invisivelmente, lentamente, surdamente, minando quase que por baixo da terra os poderes estabelecidos, e roendo devastadoramente as construções de aparência mais sólida e mais rija, como os escalrachos ou como os formigueiros. Mas no tempo de hoje! Quando o descobrimento da tipografia tresdobrou muitos milhares de vezes a sua primitiva força de expansão na publicidade e na luz; quando quase toda a gente sabe ler; quando há o prelo Marinoni, movido a vapor, e há o grande jornal a 10 réis, tirado a milhares de exemplares por hora, redigido por milhares de repórteres aos
} 
tornava-se político, exigia evolução paralela e concomitante no território da instrução, dado que a escola deveria ser a instituição de conformação do universo leitor . Ocorre que , naquela altura, a escola não cumpria ainda a tarefa que a história das técnicas e processos de leitura lhe houvera conferido. Havia, portanto, que reformar a escola, fosse para regrar, fosse para estender o âmbito da leitura. A população portuguesa era, ainda, presa de um imaginário que identificava pretensas virtudes em se permanecer ignorante. Habitualmente, o povo sequer reconhecia os benefícios da instrução, desconfiado da "mística terra da promissão [prometida] pelos homens que o governam e pelos homens que o instruem. De todo o tempo esteve na tendência popular esta profunda fé na simplicidade ignorante" ${ }^{, 303}$.

De qualquer maneira, a instrução oferecida em Portugal, completamente inadequada e ineficaz, levava a supor que a educação popular era, na realidade, uma mentira alegada por um Estado que não teria sequer intenção de erradicar a ignorância. $\mathrm{O}$ mesmo Estado que em termos concretos investia em caminhos-de-ferro deixava a instrução ao relento. Falava-se, pois, de uma escola que se sabia não existir sequer nas mentes daqueles que proferiam laudatários discursos. Assim o que se fazia era apenas fingir que se educava... ${ }^{304}$ Assim como em Antero, também o discurso de Ramalho Ortigão tende a apontar a escola como um dos possíveis antídotos da decadência que assolava o país há alguns séculos. Para que isso viesse a ocorrer, tornava-se, entretanto, imprescindível modernizar e reestruturar o arcaico modelo de escola, que não atendia nem às exigências da época nem à urgência da crise.

Ramalho Ortigão recorre a uma carta - escrita ainda por D. Pedro IV ao Marquês de Resende - quando o rei, tempos atrás, já identificava, em seu país, algo próximo dessa miséria intelectual de que há pouco se falava. Dizia D. Pedro: "A criação portuguesa é e tem sido sempre para a vida servil, Este povo está inteiramente apático. Eu vou constitucionalizálo contra a sua vontade". ${ }^{305}$ O que o jornalista lamenta é que, passado meio século, a educação portuguesa permanecesse voltada ainda para essa vida servil. Mais do que isso: se o sentimento de pátria supunha uma relativa comunhão de idéias, o autor chega a dizer que essa mesma acepção de pátria estaria ausente do universo simbólico do homem português que reconheceria apenas manifestações localizadas e regionais, dado que até a tradição popular

guichets de todos os telégrafos do mundo; quando já não há idéia concebida em qualquer parte que seja, que em vinte e quatro horas não tenha dado a volta ao globo, e não apareça ao mesmo tempo formulada, redigida, impressa, afixada, apregoada, vendida, dada de graça aos milhões e milhões de exemplares, por toda a superfície do orbe, agora digo, o perigo que poderia ter tido a idéia desapareceu inteiramente. Não há já segredos. " (Ramalho ORTIGÃO, As farpas / IX, p. 25-26)

${ }^{303}$ Ramalho ORTIGÃO, As farpas / VII, p. 225. Acerca dessa fé na simplicidade da cultura oralizada, leia-se o princípio do conto tradicional que, no relato de Adolfo Coelho, trazia por título O criado do estrujeitante: "Era uma vez um rapaz que foi procurar amo. Chegou a uma casa onde lhe perguntaram se ele sabia ler e, tendo ele respondido que sim, disseram-lhe que o não queriam. Foi a outra casa e, tendo-lhe feito a mesma pergunta, respondeu que não e lá aceitaram-no. O amo dele era um estrujeitante; de noite escrevia e o rapaz ia vendo o que ele escrevia sem que ele o suspeitasse." (Adolfo COELHO, Contos populares portugueses, p. 121).

${ }^{304}$ Sobre a questão da ausência de investimento estatal, Ramalho Ortigão diz o seguinte: "Os dinheiros do Estado não chegam para o grande aumento de despesa que este serviço demanda. É verdade isso - mas quanto tempo não chega o dinheiro do Estado para os gastos que ele empreende? Não se está cobrindo o país todo de caminhos de ferro? Não será chegado ainda o momento de olharmos um pouco para essa segunda viação: - a viação do espírito? O Estado em Portugal tira-nos da ignorância abecedária, para nos lançar em seguida numa ignorância ainda mais perniciosa que a ignorância dos analfabetos: a ignorância resultante da falsa instrução e da falsa ciência. Se não há dinheiro para nos educar inteiramente, poupe-se então o dinheiro despendido em fingir que nos educam, e acabem para sempre com os liceus! Quando não, coloque-se a instrução na estrada que ela deve percorrer, contraia-se para isso um grande empréstimo e lance-se para o amortizar um novo tributo! Nenhum cidadão deixará de concorrer voluntariamente para que seus filhos deixem de ser no futuro o que nós atualmente somos: - uma geração de inúteis, incapazes de trabalho, de perseverança, de ordem, de economia, inábeis para tudo quanto não sejam as carreiras públicas ou as carreiras literárias, fora das quais uma numerosa mocidade desempregada estaciona, devorada pelos vícios do ócio e pelas explorações da usura" (Ramalho ORTIGÃO, As farpas / II, p. 164-165).

${ }^{305}$ D. Pedro IV de Portugal e I do Brasil, apud, Ramalho ORTIGÃO, As farpas / XV, p. 34. 
fôra deturpada no solo ibérico. Por isso - continua ele - "a coisa a que figuradamente se continua a chamar a pátria nos instrumentos oficiais é uma pura agregação territorial em que nós nos achamos uns defronte dos outros, ao acaso (...)." ${ }^{306}$ Em qualquer hipótese, pública ou particular, falar de escola no caso português seria compactuar com a farsa:

\begin{abstract}
“(...) os mestres não dirigem os trabalhos. Os exercícios escolares não são suficientemente entremeados com os trabalhos mecânicos ou com a ginástica. De modo que às cinco horas da tarde o estudante aparece em casa, desabotoado, sujo, pálido, cheirando a cigarro, tendo apenas assistido às lições. É preciso em casa dirigir-lhe o estudo, obrigá-lo a aplicar-se de noite. Assim, desde os oito anos até os dezessete, na idade mais crítica da vida, quando o sistema muscular se desenvolve, quando se fixa a constituição física, quando se forma o caráter, o aluno vive inteiramente amarrado, de dia e de noite, a uma série de compêndios absurdos, em que apenas aprende a ser um pedante ou um imbecil. O método dogmático do ensino faz-lhe perder os hábitos mentais de investigação, de análise, de reflexão; converte-se em um mecanismo de decorar definições, dá-lhe o tédio do trabalho, a desconsideração de si mesmo. A convivência dos seus companheiros de escola, tão pervertidos como ele, ajuda o rápido desenvolvimento de todas as más qualidades que contrai. Torna-se indolente, grosseiro, vicioso."307
\end{abstract}

A escola que não instrui, não educa, não faz nada, é - de acordo com o redator d'As farpas - a escola do compêndio, a escola da repetição e da memorização vazia; a escola, enfim, que o século XIX português conseguira produzir. E os compêndios seriam, por sua vez, o comércio produtivo do Estado. Tanto isso seria verdade que nem as mais ásperas críticas eram capazes de sequer alterar a publicação, a distribuição ou mesmo a venda desses produtos do comércio que a escolarização criou - pelo menos, é o que diz Ramalho Ortigão. ${ }^{308}$ Assim o tema da leitura escolar entra com a Geração de 70 na pauta da discussão sobre a escola, que, por coincidência, tomaria a partir dali outro rumo...

Eça de Queirós, por sua vez, procuraria revelar o retrato numérico do estado da instrução, também n’ As farpas. Para ele também, o estado das escolas era por si elucidativo de uma situação extremamente crítica de hostilidade dos governantes e da população para com a escola. No primeiro caso, sabidamente não se investia; no segundo, o povo realmente optava por mandar as crianças ao trabalho, mesmo que isso lhes fosse custar a oportunidade de instrução. De fato, das intenções aos atos, a escola não dava certo... ${ }^{309}$ Cursos eram, a todo

\footnotetext{
${ }^{306}$ Ramalho ORTIGÃO, As farpas / XV, p. 34-35.

307 Ramalho ORTIGÃO, As farpas / XV, p. 32. A defesa da ginástica e da educação física como modelo alternativo será acentuada nos romances de Eça, como veremos no capítulo 4.

308 "Por muitas vezes nos temos referido às facécias venenosas que os autores encartados de compêndios publicam e vendem para as escolas sob a aprovação da junta consultiva. $O$ único resultado que até hoje pudemos conseguir à civilização por efeito da análise de tais livros foi que os autores deles, nomeados informadores do grêmio dos escritores públicos, elevassem a importância do imposto industrial do autor destas linhas à soma de de trinta e seis mil réis anuais. Também a única coisa verdadeiramente espirituosa que temos visto fazer a estes senhores é esta de não darem licença que os achemos fenomenais por menos de trinta e seis mil réis! " (Ramalho ORTIGÃO, As farpas / VIII, p. 57).

309 “A escola por si oferece igual desorganização. Os edificios ( a não ser os legados pelo Conde de Ferreira, que ainda quase não funcionam ) são na maior parte uma variante torpe entre o celeiro e o curral. Nem espaço, nem asseio, nem arranjo, nem luz, nem ar. Nada torna o estudo tão penoso como a fealdade da aula. (...) Sobretudo nas aldeias é quase impossível atrair ao estudo, numa saleta tenebrosa e abafada, crianças inquietas que vêm do vasto ar, da luz alegre dos prados e dos montes. A escola não deve ter a melancolia de uma cadeia. Pestallozi, Froebel, os grandes educadores, ensinavam em pátios, ao ar livre, entre árvores. Froebel fazia alterar o estudo do á-bê-cê e o trabalho manual; a criança soletrava e cavava. A educação deve ser dada com higiene. A escola entre nós é uma grilheta do abecedário, escura e suja; as crianças, enfastiadas, repetem a lição sem vontade, sem inteligência, sem estímulo: o professor domina pela palmatória, e põe todo o tédio da sua vida na rotina do seu ensino." (EÇA DE QUEIRÓS, Uma campanha alegre II, p. 79). Sobre os edifícios que haviam sido legados pelo sobredito Conde de Ferreira, podemos efetivamente observar que eles teriam expressão à época, posto que tanto as revistas (capítulo 2) quanto os inspetores (capítulo 4) comentavam a existência de escolas que só funcionariam graças àquele referido bemfeitor.
} 
o momento, abertos e fechados. O professor primário não tinha carreira e ganhava um salário miserável. Para aceitar essa remuneração, quem efetivamente concorria para as cadeiras de instrução primária eram indivíduos absolutamente desprovidos de habilitações literárias. Não havia inspeção organizada e, com esse abandono generalizado, o professor abandonava-se tambem, rendido ao seu entediante cotidiano, indolente perante a desesperança que pautava sua vida. Eça de Queirós, assim como seus companheiros, reclamava agressivamente do Estado a alteração nos padrões educativos do povo português. O quadro era dos mais desanimadores; como ilustram, destarte, os números com que o escritor evidenciava aquilo que ele caracterizava por "canalhice pública":

"Eis resumidamente o estado da instrução. 2.300 escolas num país de 4 milhões de habitantes! De 700.000 crianças a educar, apenas se encontram 97.000 nas escolas. Destas 97.000 apenas se apuram 1.940. Portanto de 700.000 crianças a educar - educa o país 1.940! Sendo indispensáveis cursos noturnos - criaram-se 545. Hoje restam 100! Os professores têm em 1.872 o ordenado de réis $120 \$ 000$ - que já em 1.813 era julgado absolutamente insuficiente! Só com boas escolas normais se podem criar bons professores. Havia uma em 68. Foi extinta! (Tenta-se agora criar 5 ). Dos 1.867 professores, foram julgados com habilitações literárias 263 - e zelosos 172! As escolas são currais de ensino! Inspeção, não há. Já em 1854 se queixava disso o ministro do Reino! Estamos em 1.872! Eis aqui o estados da instrução pública em Portugal, nos fins do século XIX. A instrução em Portugal é uma canalhice pública! Que o atual Governo volte os seus olhos, um momento para este grande desastre da civilização!"310

O grupo-geração do qual Eça de Queirós era um dos maiores protagonistas polemizava com a tese já corrente em Portugal segundo a qual, por parte das próprias famílias, não haveria interesse na escolarização das crianças. Haveria, ao contrário, rivalidade entre escola e família. Acreditar nisso seria mais confortável - observa o literato - embora não houvesse correspondência entre o mito que se criara e o plano das realidades materiais. O país como um todo e particularmente o Estado português não apostavam na instrução como uma estratégia de fortalecimento social. Aí residiria fundamentalmente o problema. Se não se pensasse em remediar o óbice da pobreza do camponês, havia ao menos que se pensar na adoção da alternativa de cursos noturnos, aos quais os mesmos homens do campo sem dúvida recorreriam.

\footnotetext{
"Nos campos a família é hostil à escola, diz-se. Erro. A família não nega o filho à escola, requer o filho para o trabalho. A criança aí, de sete a dez anos, já conduz os bois, guarda o gado, apanha a lenha, acarreta, sacha, colabora na cultura. Tem a altura de uma enxada e a utilidade de um homem. Sai de madrugada, recolhe às trindades, com o seu dia rudemente trabalhado. Mandá-lo à escola, de manhã e de tarde, umas poucas de horas, é diminuir a força produtora do casal. Um aluno de mais na escola é assim um braço de menos na lavoura. Ora uma família de lavradores não pode luxuosamente diminuir as suas forças vivas. Não é por o filho saber soletrar a cartilha que a terra lhe dará mais pão. Portanto tiram a criança à escola para a empregar na terra. $\mathrm{O}$ remédio a isso seria a criação de cursos noturnos. À noite, o campo restituiria a criança à escola. Os cursos noturnos eram outrora exclusivamente para os adultos que tinham o seu dia tomado pela lavoura
}

${ }^{310}$ EÇA DE QUEIRÓS, Uma campanha alegre II, p. 80-81. A concepção que Eça possuía do ensino em Portugal articulava-se ao desânimo que o escritor também evidenciava perante outros aspectos da vida pública portuguesa. Acerca da desorganização com que andavam os negócios do reino, diz o seguinte: “(...) sabe a coroa o que logicamente devia dizer? - Isto: 'Meus senhores: - É com o maior desprazer que me acho no meio de vós, pois que estou fatigado da vossa imbecilidade, da vossa intriga e do vosso desleixo. A situação exterior é esta: somos o que somos, porque nos deixam sê-lo por misericórdia. A interior é esta: finanças em ruína; colônias exploradas pelo estrangeiro; marinha nula; indústria entorpecida; clero ignorante e imoral; ensino caótico; vida municipal extinta; funcionalismo desbragado, pensamento emudecido, caráter corrompido; serviços públicos desorganizados; leis em confusão; agiotagem em triunfo; proletariado em miséria; etc., etc. Vão, e que o Diabo os carregue, para os seus lugares. Disse.' Assim devia falar a coroa." (EÇA DE QUEIRÓS, Uma campanha alegre I, p. 71). 
ou pelo ofício. No entanto num país pobre, como o nosso, de pequena cultura e de pequena indústria, a criança trabalha quase tanto como o homem. O filho tem o seu dia tomado pelo mesmo labor do pai. Os cursos noturnos deveriam ser sobretudo para ele - senão para ambos."311

Sendo assim, julgava-se que Portugal viveria, dentre os países civilizados, uma situação anômala, particularmente pelos perversos efeitos acarretados pelo trabalho infantil, que era, segundo consta, adotado em larga escala. Eça de Queirós, em outra oportunidade, relataria ainda o drama de um pescador que fôra preso, juntamente com os seus filhos crianças ainda, que o ajudavam - por ter usado redes de arrastar que haviam sido proibidas por alguma portaria, publicada no Diário de Governo, e que provavelmente o referido pescador desconhecia. Eça ridicuriza o fato de a punição estar calcada justamente no fato de o pescador não haver tomado conhecimento de uma lei que exigiria, para ser compreendida, o domínio da leitura e dos códigos escritos da informação. Nessa medida, o redator destaca que o crime daquele homem teria sido o de não se ter feito capaz de ler as prescrições do Diário de Governo; condenado, por conseguinte, "por ousar ser pescador antes de ser bacharel formado" 312 . Porém o que mais irritava o destacado articulista era o fato de as crianças, não tendo sequer idade para estar presas ao trabalho, serem também punidas com o pai.

\begin{abstract}
"E, além disso, foram presas três crianças de 10 anos ! Ah ! Estes criminosos vão decerto ser tratados com as penas mais severas ! Lá estão na enxovia, as mães choram às grades ! É justo ! Estes indignos entezinhos também pescavam ! Aos 10 anos, quando todas as crianças brincam, até as dos lavradores miseráveis, que guiam bois, trepam aos ninhos, se rolam nas altas ervas - estes bandidos que já trabalham, que já vão ao mar, que já aprendem a morrer na idade em que os outros ainda sequer aprenderam a viver, que já ajudam os pais, que já são um braço ao remo, uma mão à escota, às vezes uma criança ao mar, estes celerados tinham ido nos barcos com as redes, ganhar o seu pedaço de pão, enquanto as mães, inquietas, esperavam na praia, ousando também eles, os facínoras, ignorar as portarias do senhor ministro do Reino ! Por isso agora choram na cadeia ! E são vinte pescadores ! Vinte famílias, dez pelo menos, sem pão, sem lume ! Os pais, os maridos, os irmãos presos, têm ao menos o rancho da cadeia: as mulheres pedem pelas esquinas ! E estamos em pleno inverno, e vêm os temporais, e começa aquele mar violento, varrido pelos ventos, que as pobres mães olham dias e dias da praia, com os seus mantéus pela cabeça, sem o verem jamais condescendente, sem o verem jamais piedoso!"313
\end{abstract}

${ }^{311}$ EÇA DE QUEIRÓS, Uma campanha alegre II, p. 77. Sobre as estatísticas do ensino em Portugal, mais uma vez, o escritor advertia: "O Estado, portanto, tem a instrução inteiramente a seu cargo e sob sua responsabilidade. Ora, tendo um país a educar, eis o que o Estado tem feito: Sabeis, amigos, quantas escolas há de Norte a Sul, neste país onde floresce a vinha e Melício pensa? 2.300! Existindo no país, segundo as últimas estatísticas, 700.000 crianças, e não sendo justo que se apertem na estreiteza abafada de uma escola mais de 50 alunos ( e já é fazer transpirar de mais tenros cidadãos imberbes ) segue-se que deveríamos ter 14.000 escolas... Temos 2.300 ! Devendo, pois, fundar uma escola para cada 50 crianças, possuímos apenas uma escola para cada 300 crianças! Há uma escola para cada 2.600 habitantes! Das 700.000 crianças que existem em Portugal o Estado, nessas 2.300 escolas - ensina 97.000. Isto é, de 700.000 crianças, estão fora da escola mais de 600.000 ! Destas 97.000 crianças que frequentam as escolas, sabeis, amigos, quantas se apuram prontas, por ano ? Segundo as últimas inspeções - em cada 50 alunos apura-se um aluno ! Portanto Portugal, de 97.000 crianças que traz nas suas escolas - tira por ano, sabendo os rudimentos, 1.940 ! Mordei-vos de ciúmes, ó cafres !’ (Id. Ibid., p. 76)

312 "Um pobre homem passa o seu dia remando, quebrado pela luta com o mar, para comer à noite, na promiscuidade da mesma gamela, com uns poucos de filhos, uma pouca de sardinha. Levou para isso a sua rede de arrastar com que trabalha há muito, que ele vê no barco de seu amigo, do seu vizinho, do seu patrão. Desembarca ao pôr do Sol, esfomeado, encharcado de água - e encontra pela frente o Senhor Regedor! - E como existe a portaria de tantos de tal, revogada por uma portaria posterior, posta em vigor por outra, caída depois em desleixo, novamente revogada, alterada por uma diferente legislação, ultimamente anulada, e agora rediviva e ativa - ele, por ignorar completamente essa jurisprudência trapalhona, vai ser levado por aqueles soldados ao Porto e aferrolhado numa enxovia! O crime deste homem, portanto, é não ler o Diário do Governo ! Esse homem está preso por não ser um jurisconsulto ! Esse homem será condenado por ousar ser pescador antes de ser bacharel formado!" (EÇA DE QUEIRÓS, Uma campanha alegre I, p. 137)

${ }^{313}$ EÇA DE QUEIRÓS, Uma campanha alegre I, p. 138. 
Explícito o tom de crítica social expresso em sua crônica, Eça de Queirós também iria ser um crítico do modelo que norteava o tradicionalismo daquela educação, personificada, segundo ele, na referência do ensino dos colégios. Haveria que se repensar, portanto, o tema da educação, tanto em sua variável política - discutindo o papel do Estado e a responsabilidade dos familiares em fazer cumprir a prescrição da obrigatoriedade - quanto nos aspectos atinentes ao método de que a escolarização se valia para proceder à desejada transmissão de conteúdos culturais. Em função da carência de escola para a maioria das crianças portuguesas, mas também em função do fato de as escolas existentes não se mostrarem capazes de tornar o aluno pronto no final do ano - já que em cada 50 alunos apenas 1 era considerado preparado para a etapa seguinte - a escolarização primária portuguesa era falha e em completo desacordo com todas as tendências contemporâneas. Havia, pois, que se atentar para o problema do método e da superação dos entediantes processos que ainda obstaculizavam o sucesso e a eficácia da vida escolar. Além de provocar o tédio particularmente no caso das raparigas, com uma intensidade preocupante -, a instrução desenvolveria fundamentalmente uma perigosa imaginação que resultaria, grande parte das vezes, em uma vida sentimental precoce e astuciosa.

\footnotetext{
"Será necessário que penetremos nos colégios ? - Espreitemos só pela porta. - Um dos grandes males do colégio é o tédio. O tédio enfraquece, anula o espírito, a vontade, e só deixa viva e exigente a curiosidade. De quê ? de tudo, do imprevisto, do que se não tem, do que está na rua quando nós estamos em casa, do que está no vício quando nós estamos no dever. (...) Os cólégios, pelos seus métodos fatigantes, repelem o espírito das mulheres dos livros e das coisas da ciência. É o que nos acontece a nós os homens, também, com o Telêmaco e com o Virgílio. Passamos sobre eles as compridas e sonolentas noites de estudo, tiramos-lhes, palavra a palavra, o significado duro, choramos sobre as suas páginas a dor das palmatoadas (...),314
}

Seja como for, a profundidade crítica dos artífices da Geração de $\mathbf{7 0}$ tinha a ver com o estado de Portugal em uma época onde a crise cultural somava-se a problemas de ordem material. Quanto à escola, os comentários sobre ela revelam sem dúvida certas imprecisões, algumas vezes até contradições. Mas inegavelmente a tônica já estaria, entre aqueles intelectuais, sobre o temário do método; um método que, agora, se pretendia científico. Eles procuravam descrever a escola existente a partir da compreensão que a própria experiência e a posterior análise haviam permitido. Mas visivelmente pairava a indagação acerca das alternativas; alternativas essas que, se passavam indubitavelmente por determinadas opções políticas, deveriam, na outra margem, configurar uma nova delimitação da intervenção educativa do espaço escolar. Em outras palavras, passa-se a conferir prioridade para o tema do método, já enunciando a nova feição escolar como um agregado de procedimentos extraídos das recentes conquistas das ciências. Estava-se, sem dúvida, se não a inaugurar, pela menos a irradiar, para significativas parcelas da população, uma nova versão da decadência portuguesa que, a partir de então, passaria a ser a chave do debate intelectual, qualquer que fosse a área de enunciação do discurso. Finalmente parece-nos inquestionável o fato de os homens que protagonizaram as Conferências do Casino haverem deixado profundas marcas nos quadros mentais de seus contemporâneos e naqueles que a eles se seguiriam.

\footnotetext{
${ }^{314}$ EÇA DE QUEIRÓS, Uma campanha alegre II, p. 91-2.
} 

DEUS E A GERAÇÃO DE 70

De algum modo, os intelectuais que ficaram caracterizados como integrantes da chamada Geração de 70 pretenderam - como já expusemos - demarcar a diferença entre sua geração e todas as outras que lhe precederam. Procurando em tudo sinais de inovação, eles se pretendiam transformadores. Fosse pelo estilo ou pelo conteúdo e vigor da crítica e dos juízos que proferiam, os protagonistas pareciam desejar demarcar os parâmetros da distinção. Julgavam-se à frente de seu tempo, por dialogar com o que este trazia de mais atual. Acreditavam romper com as tênues fronteiras de uma arte descompromissada, com o álibi de que a realidade social solicitava ser substantivamente alterada. Ao criarem eixos de interpretação social, pelo signo da criação artística que os envolvia, aqueles jovens desejavam intervir nesse cenário. Eram, pois, acima de tudo, militantes do que Antero qualificaria como 'ideal'... Porém, nesse caminho, "onde cada um desses mundos tem mil vidas" ${ }^{315}$, os jovens de 70 não estariam em absoluto sozinhos. A história não costuma apresentar questões que os contemporâneos não se disponham a ouvir. A recusa da tradição atingia naquela altura outros personagens, outros territórios; dentre eles, mais especificamente, havia quem buscasse modificar o roteiro da pedagogia. Sobre João de Deus, mais especificamente, ouçamos o comentário de Catroga:

\begin{abstract}
"Num outro registro filosófico, e numa base mais intuitiva do que teorizada, João de Deus procurou responder aos problemas pedagógicos suscitados pelas dificuldades do combate ao analfabetismo recorrendo a uma via de aprendizagem que seria mais fácil do que a dos métodos anteriores - incluindo o de Castilho. A Cartilha Maternal (1876) deve ser vista, por isso, como uma das obras culturais mais importantes das que foram produzidas por intelectuais ligados à chamada 'Geração de 70', e não deve espantar que tenha suscitado entusiasmos imediatos, sobretudo nos setores empenhados na luta pela democratização do ensino."
\end{abstract}

A Geração de 70 - como já pudemos observar anteriormente - de alguma forma deslocaria o problema pedagógico em Portugal, particularmente pelas críticas efetuadas à questão da autoridade e da tradição. Dessacralizando o universo do conhecimento e de sua produção, aqueles jovens teriam - como vimos - questionado profundamente a tônica dominante da história portuguesa. No que tange à esfera educativa, muitos eram os problemas levantados por Antero e tantas vezes repetidos por seus companheiros, naquilo que poderíamos entender como os desdobramentos didáticos da compreensão educacional dos jesuítas. Na verdade, julgava-se que os portugueses cultivavam a ignorância por não terem efetivamente lutado contra aqueles séculos de atraso, em função dos quais se haveria criado uma mentalidade de intolerância e de dogmatismo intelectual. Para os jovens de 70, lutar contra tal força da inércia histórica tornava-se tarefa urgente. Mais do que nunca, a questão pedagógica adquiria nítida coloração política, histórica e mesmo filosófica. Se o problema português era identificado na ignorância das populações, havia que se ilustrar o povo e transformar a leitura, de atividade restrita e sacralizada, em atitude rotineira, trivial, dessacralizada, e, nessa medida, emancipadora. Ora, a expressão prática desse objetivo estaria dada nas esperanças depositadas no método de ensino da leitura e da escrita desenvolvido pelo poeta João de Deus ${ }^{317}$.

\footnotetext{
315 Antero de QUENTAL, Vida, In: Odes modernas, p. 66.

${ }^{316}$ Fernando CATROGA, Os caminhos polémicos da 'geração nova', In: História de Portugal / quinto volume, p. 581 .

${ }^{317}$ O Diccionario bibliographico portuguez compara João de Deus a Castilho, pela polêmica com que ambos os métodos teriam marcado a história do pensamento pedagógico em Portugal. Nascido em 1831, João de Deus
} 
O último quartel do século XIX veria o desenvolvimento das correntes cientificistas, evolucionistas - dentre as quais se destacariam o marxismo e o positivismo - na sempre obsessiva tarefa de edificação de uma ciência da sociedade. ${ }^{318}$ Os sonhos e projetos deixados pela inconclusão dos revolucionários franceses adquiririam nova feição, na medida em que a acepção de perfectibilidade - tão cara aos homens do final do século XVIII e aos que a eles sucederam - deixaria de ser tomada no território da utopia, para ser apreendida enquanto modo efetivo de progresso e de ordenação evolutiva do tecido social. Consolidar o âmbito público era, portanto, evitar - pela via da ordem e do progresso - novas revoluções que abalassem o futuro. A capacidade científica dos povos estaria ligada a seu potencial de prosperidade material e humano e, portanto, seria fruto do desenvolvimento industrial. Era necessário e urgente, pois, encaminhar Portugal para esse avanço que a lei da evolução teria já traçado. Destaca Saraiva a respeito daqueles tempos:

\begin{abstract}
"As novas instituições inseriam-se numa sociedade que, sob o ponto de vista tecnológico, econômico e mesmo social, estagnava, comparativamente. Há uma certa prosperidade passageira da grande burguesia rural, mas as condições de vida, de cultura e o nível de consciência da massa campesina não se alteram muito. A enorme emigração para o Brasil é um sintoma das dificuldades no campo. Quanto à chamada população industrial, a situação não cessa de se agravar, porque o modo de produção artesanal não pode deixar de perecer em face da produção mecânica que
\end{abstract}

teria - aos 30 anos - se formado bascharel em Direito pela Universidade de Coimbra. A primeira edição da Cartilha maternal ou arte da leitura data de 1876, tendo sido essa publicação organizada e providenciada pelo rev. Madureira, abade d' Arcozello. Em 1881, a cartilha já estava em sua $5^{a}$ edição. A força do debate que em torno desse método de leitura se travaria em Portugal teria sido estampada em jornais, que publicavam a polêmica entre os partidários do autor e seus adversários, no parlamento e nas revistas especializadas. Sobre o reconhecimento oficial quando à eficácia daquele modelo alternativo de ensino das letras, Innocencio dirá o seguinte: "Apontarei algumas particularidades a respeito deste livrinho. Na sessão de 20 de março de 1878, na Câmara dos Deputados, o Sr. Osório de Vasconcellos, hoje falecido, chamou a atenção do ministro do reino para o método do Sr. João de Deus, encarecendo os frutos que a instrução primária tirava desse método; e pediu ao ministro que o mandasse estudar. Outro deputado, Sr. Pires de Lima, reforçou as instâncias do orador antecedente, dizendo que também lhe parecia que o método podia ser protegido pelos poderes públicos, mandando-se o autor em peregrinação pelo reino para o divulgar. Respondeu o ministro [António Rodrigues Sampaio] que, embora não tivesse tanta fé como os Srs. Deputados citados, nos milagres do método, não se descuidaria em examinar o parecer da repartição da instrução pública, para a qual o próprio autor já tinha concorrido, e cumpriria o seu dever." (INNOCENCIO Francisco da Silva, Diccionario bibliographico portuguez, tomo 10, p.23 ).

${ }^{318}$ A propósito desse tema, já havia vestígios dessa atmosfera evolucionista desde, no mínimo meados do século XIX. De acordo com texto publicado no número 30 do jornal A península, publicado a 15 de agosto de 1852 , existiria um trajeto pré-fixado na história do espírito humano, mediante o qual cada fato, cada período, representariam apenas páginas de um livro que, enquanto obra, havia sido escrita de véspera. As reformas e as transformações teriam lugar no "quadrante da providência"; o triunfo da democracia seria um dado garantido; havia que se ter sabedoria para ser capaz de, com tolerância, esperar por ele. Os parâmetros de tal visão historicista fundamentavam-se em uma apropriação muito particular da leitura que, à época, se fazia de Hegel, citado aqui da seguinte maneira: "O espirito do homem - diz Hegel - realiza-se pela história do mundo...; a idéia e o fato, a filosofia e a história não diferem senão na forma. O filósofo, pois, diz tudo o que pensa; ao estadista cumpre atender as circunstâncias e expiar a oportunidade para realização do pensamento. O filósofo diz tudo o que deve fazer-se, o estadista faz tudo o que é possivel. Mas tudo neste mundo é progressivo; a verdade é progressiva, é progressiva a história, é progressiva a filosofia e progressiva também a ciência do governo." (A PENÍNSULA, número 30,15/8/1852, p. 555). Por não ser ele próprio um filósofo, caberia ao estadista continua o texto - tomar o filósofo como guia. Nessa tentaiva de prever o futuro pelo conhecimento que se poderia dele extrair, postulava-se a bandeira da instrução pública como uma das estratégias primordiais para erguer a nação. Fonte de correção do vício e dispositivo de moralidade pública, a universalização do direito à instrução seria oportunidade privilegiada para prover de talentos o futuro. Até porque: "como sabeis vós que o artista, o lavrador e o guerreiro não podiam ser um Leibnitz, um Newton ou um Descartes se tivessem sido instruídos como eles? Mas conquanto o direito à instrução seja igual para todos, nem todos têm igual direito à igual instrução porque nem as propensões são iguais em todos, nem é igual também a suscetibilidade de desenvolvimento das faculdades intelectuais, porque essas faculdades são, como já disse, as mesmas, mas não são iguais." (A PENÍNSULA, nº 30, 15/8/1852, p. 554). 
dominava cada vez mais o mercado mundial, mas que em Portugal só conhecia pequenos surtos sem continuidade. Por mais liberais que se mostrassem, as novas instituições não podiam deixar de atestar tal estagnação. A sua tendência oligárquica torna-se patente, bem como a sua evolução no sentido de consolidar uma nova hierarquia conservadora, à medida que se esgotava o efeito dos melhoramentos materiais fontistas em curso." 319

Teóphilo Braga, ao discorrer sobre a personalidade de João de Deus, aponta o poeta como representante do 'gênio nacional' naquilo que havia de emotividade lírica e espiritual do povo. Porém, mais do que a sua poesia, aquela Geração de 70 valorizaria a atuação do poeta na polêmica que este teria travado com Castilho a propósito do valor estético dos Lusíadas. Este, segundo a apreciação que, naqueles anos 50, fizera Castilho, seria inferior ao seu D. Jayme, por pedagogicamente não ser recomendável como leitura escolar. Nos termos de Teóphilo Braga, isso teria proporcionado a visibilidade da intransigência intelectual de Castilho, particularmente diante do desprendimento da resposta dada por João de Deus: “Condenar os Lusíadas porque não servem para Cartilha do Padre Ignácio, é o mesmo que condenar a Cartilha do Padre Ignácio porque não serve para epopéia nacional."320 Os antigos membros da geração nova desejavam ver em João de Deus um aliado, talvez um cúmplice, indubitavelmente um precursor. É assim que Teófilo Braga se refere ao poeta:

\footnotetext{
"Este fenômeno da chamada Questão de Coimbra, que significou simplesmente a dissolução final do romantismo (...) não será bem compreendido, sobretudo na transformação da poesia lírica moderna em Portugal, se se não estudar João de Deus como o seu precursor. Precedeu no movimento filosófico e crítico os Dissidentes de Coimbra, e, sem conhecer a renovação das doutrinas metafísicas nem as teorias sociais, nem a síntese monística das ciências físicas ou naturais, nem a indisciplina revolucionária; sem ter em vista romper com o passado nem proclamar novas afirmações, como é que ele fecundou duplamente a poesia portuguesa, pela sua obra e por uma influência imediata?"321
}

Em termos da história das idéias pedagógicas, João de Deus destaca-se por ter sido o autor de um método para o ensino das primeiras letras que traz notoriedade à polêmica acerca do tema, assim como o Método de Leitura Repentina fizera tempos atrás. Na verdade o método João de Deus e o método Castilho são apresentados por parte da bibliografia ainda recente na história da educação portuguesa como as grandes demarcações educacionais que pontuaram o século XIX. Não se trata, no presente capítulo, de averiguar o impacto que tais metodologias trouxeram à efetiva prática pedagógica - o que pretendemos fazer a seguir -, mas fundamentalmente delimitar o papel de ambas no percurso das idéias e dos grupos acadêmicos que em torno delas se iam formando.

Estudar a proposta pedagógica de João de Deus representa muito mais do que a busca de compreensão de um método. Trata-se, como em Castilho, da tentativa de apreensão do fenômeno da aquisição da habilidade da leitura como um componente de um imaginário,

\footnotetext{
319 A. J. SARAIVA e Oscar LOPES, História da literatura portuguesa, p. 833.

320 Teóphilo BRAGA, João de Deus: esforço biographico por..., p. 20. Teóphilo Braga encadeia do seguinte modo a questão: "Depois da morte de Garrett, em 1854, e do silêncio sistemático de Herculano, por 1859, Castilho arrogou-se um pontificado literário, concedendo bulas de talento, ou revogando os juízos da imortalidade; foi por este abuso de uma autoridade ainda então não discutida, que soltou a blasfêmia de os Lusíadas serem inferiores ao D. Jayme, por que não serviam para se ler por eles nas escolas. João de Deus insurgiu-se na sua bondade e protestou com um dito da mais fina ironia. (...) E rebateu dignamente essa outra heresia de Castilho, de que entre a geração moderna não havia quem assinasse sem vergonha uma estrofe dos Lusíadas. A literatura oficial não queria reconhecer a superioridade de João de Deus, e fez-se o silêncio sobre o seu protesto. Sem rompimento de escola, ainda assim cabe a João de Deus a glória do primeiro passo para a dissolução do ultra-romantismo." (Teóphilo BRAGA, João de Deus: esforço biographico por..., p. 20-21).

321 Teóphilo BRAGA, João de Deus: um esforço biográphico por..., p. 21.
} 
de um universo simbólico mais amplo. Questionaremos adiante o significado da leitura para os intelectuais dessa geração e suas proximidades e distâncias perante aquela que imediatamente lhe antecedeu. Rômulo de Carvalho avalia, em seu trabalho, a Cartilha Maternal de João de Deus como "uma das obras mais notáveis da pedagogia portuguesa". Para esse estudioso, João de Deus teria alcançado um dos "maiores êxitos na luta contra os processos tradicionais do aprendizado da leitura" ${ }^{322}$. Os teóricos da educação portuguesa tendem, portanto, a acreditar que o debate gerado pelo método teria sido traduzido por uma real implementação da Cartilha Maternal nas práticas escolares portuguesas.

Segundo nos relata Teóphilo Braga, ainda em 1870, João de Deus fôra convidado pelo gerente da casa Rolland para elaboração de uma cartilha para o ensino das primeiras letras. A referida livraria posteriormente iria à falência, mas João de Deus se teria sentido desafiado e, em 1876, seria publicada pela primeira vez aquela que se chamaria Cartilha Maternal ou Arte da Leitura. O título é já por si revelador do desejo subliminar do autor quanto à proposição de uma aliança entre escola e família, em nome da instrução. Havia oposição entre o modelo educativo familiar e a tarefa civilizatória que, em tese, era fundamentalmente a escola quem se propunha cumprir. João de Deus pretendia, pois, cativar a confiança dos lares, pela homenagem prestada às mães. Partia do pressuposto segundo o qual a fala é a língua da família; quem se aparta do ambiente doméstico exerce simbolicamente a atividade da escrita, que - em si própria - prometia ser a língua social ${ }^{323}$. Daí a relevância da escolarização, como o passaporte autorizado para o ingresso no sinuoso mundo da cultura letrada. O formato da Cartilha Maternal, inclusive na dinâmica da apresentação, parecia à primeira vista inovador. Todo o conteúdo do texto vinha impresso "em letras gordas, umas a negro, outras preenchidas a traço fino, com o fim de distinguir as sílabas entre si, imediatamente, pelo aspecto dos caracteres tipográficos". ${ }^{324}$ Trazendo, já à partida, textos explicativos para servirem de orientação ao professor, dirigindo-o em sua atividade cotidiana, João de Deus divide a obra em vinte e cinco lições, a partir das quais o aluno estaria habilitado, em termos de competência cognitiva e de repertório linguístico, ao domínio e ao manejo da palavra escrita. Em termos de método, João de Deus recusa a antecedência do trabalho com a identificação das letras e das sílabas, cujo reconhecimento, a seu ver, seria, na margem oposta, decorrente da leitura da palavra. Provavelmente pela primeira vez, em Portugal, desafiava-se o primado da soletração e propunham-se, em seu lugar, procedimentos analíticos para o ensino da leitura, mediante aquilo que os teóricos da escola nova chamariam de método global. A justificativa do autor, nesse sentido, aproximava-se do discurso de Castilho: pretendia-se alcançar o êxito e a brevidade do aprendizado da leitura, bem como tornar a escola atraente...

\footnotetext{
322 Rômulo de CARVALHO, História do ensino em Portugal, p. 607.

${ }^{323}$ João de Deus RAMOS, filho do poeta e educador João de Deus escreveria, pela colagem de alguns escritos de seus pais, o que resolveu chamar de Guia Prático e Theórico da cartilha Maternal ou Arte da Leitura. Consta do título da Cartilha, a seguinte observação: "O título da Cartilha Maternal revela que compete o delicado ensino primário à mulher, às mães, porque, em princípio, nos ensinam a falar, e nos deviam ensinar a ler. Se ainda n'algumas nações, de cem mães, uma sabe ler, e de mil uma ensina os seus filhos, hão de vir outros tempos e outros costumes. A fala é a língua da família: quem se aparta do lar doméstico deve já saber a língua social. Por isso as mães, que do coração professam a religião da adorável inocência, e até por instinto sabem que em cérebros tão tenros e mimosos todo o cansaço e violência pode deixar vestígios indeléveis, oferecemos no nosso sistema profundamente prático o meio de evitar a seus filhos o flagelo da cartilha tradicional, que, ainda assim, fundada e deduzida sistematicamente sobre a base da simples memória do aluno, tem decididas vantagens a essas afetações de método onde se estabelece, por exemplo, que c vale ce e que; e isto suposto, é impossivel ler! Onde se acorda a inteligência e a reflexão do aluno com princípios, dos quais lhe não é permitido tirar as consequências." (João de Deus RAMOS, Guia prático e teórico da Cartilha Maternal ou arte da leitura de João de Deus, 1901, p. 94-5).

${ }^{324}$ Rômulo de CARVALHO, História do ensino em Portugal, p. 608.
} 
"Este sistema funda-se na língua viva. Não apresenta os seis ou oito abecedários do costume, senão um, do tipo mais frequente, e não todo, mas por partes, indo logo combinando esses elementos conhecidos em palavras que se digam, que se ouçam, que se entendam, que se expliquem; de modo que, em vez do principiante apurar a paciência numa repetição néscia, se familiarizasse com as letras e os seus valores na leitura animada de palavras inteligíveis. Assim ficamos também livres do silabário, em cuja interminável série de combinações mecânicas não há penetrar uma idéia! Esses longos exercícios de pura intuição visual constituem uma violência, uma amputação moral contrária à natureza. Seis meses, um ano, e mais, de vozes sem sentido, basta para imprimir num espírito nascente o selo do idiotismo. Por que razão observamos nós, a cada passo, nos filhos da indigência, meramente abandonados à escola da vida, uma irradiação moral, uma viveza rara nos mártires do ensino primário? Às mães que do coração professam a religião da adorável inocência, e até por instinto sabem que em cérebros tão tenros e mimosos todo o cansaço e violência pode deixar vestígios indeléveis, oferecemos, neste sistema profundamente prático, o meio de evitar a seus filhos o flagelo da cartilha tradicional., 325

\section{A CARTILHA MATERNAL E A FORMA ANALÍTICO-GLOBAL PARA O ENSINO DA LEITURA}

O princípio da competência da leitura era o estudo das vogais, sem as quais - diz João de Deus - não poderia haver palavra escrita. As vogais consistiriam nessa medida em verdadeiras vozes, por meio das quais surgirão os valores sonoros das palavras. Mas não se partia das vogais soltas em seus sons. Principiava-se, antes, pelo significado que se extraía da

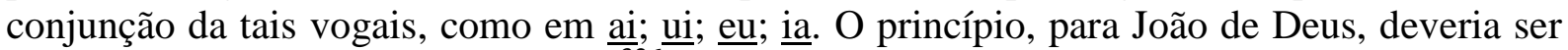
sempre a inteligibilidade da palavra. ${ }^{326}$ Como antes dele já apontara Castilho, João de Deus dirá que a palavra falada está para a família tanto quanto a palavra escrita para a escola. Porém, enquanto o aprendizado da fala acontecia de maneira espontânea, natural, no ambiente familiar, o domínio progressivo da leitura abarcava um percurso extremamente doloroso, atormentando, de maneira insuportável, mestres e discípulos. João de Deus, confiante quanto à existência de um modelo alternativo de ensino da leitura, enfatiza a necessidade de se suprimir a etapa da soletração e da silabação como habilidades prévias e imprescindíveis à alfabetização. O alfabeto, por ser assim, não seria apresentado logo à partida. Só se voltaria a falar nele, aliás, na vigésima quinta lição, quando - chegada a página 106 de sua cartilha - o aluno já dominasse efetivamente o processo da língua, reconhecendo todo tipo de palavra, e podendo inclusive ler textos. ${ }^{327}$ Ao retirar o alfabeto do princípio do percurso do ensino, João

325 JOÃO DE DEUS, Cartilha Maternal ou arte da leitura por..., p. VII-VIII. Pelo próprio título e pela orientação das lições, percebe-se que explicitamente o autor desejava, para além da escola, atingir as mães e monitorá-las para o ensino da leitura.

${ }^{326}$ Nota-se que, de certa maneira, todos os métodos que foram debatidos pela imprensa especializada, no período que estudamos, de alguma maneira pretenderam inovar. Castilho - lembre-se - discorria sobre a necessidade de se vozear a leitura, prendendo seu método à pronúncia, ao ritmo, à fala e talvez a uma nova disposição da própria idéia de sala de aula. João de Deus procurava ensinar pelo valor semântico, pelo significado e não pela fonética constitutiva das palavras da língua. Para João de Deus, a sonorização de letra ou sílabas soltas em nada contribuiria para a aquisição da habilidade da leitura, pelo fato de ser o conteúdo lido (e nunca o valor sonoro) que, de um modo ou de outro, será fixado pelo leitor. Ainda nos anos 50, a cartilha de Monteverde (a quem daremos destaque nos três últimos capítulos) pretendia ensinar ao ao mesmo tempo a leitura e a escrita, assim como fazia também o compêndio de Caldas Aulete. Esse dois autores talvez tenham inovado pelo fato de apresentarem, com suas lições, a possibilidade de ensino concomitante da leitura e da escrita, o que, por sua vez, facilitaria o desejado ensino simultâneo e coletivo, aspiração da maioria dos teóricos da educação portuguesa e dos professores naquela época.

${ }^{327}$ Diz, portanto, nosso autor - em um verdadeiro exercício de lingüística aplicada - naquela referida página 106 da Cartilha Maternal: "Mas uma cartilha sem alfabeto seria coisa estranha. O alfabeto é um caos: principalmente disposto em linha, na tal chamada carreira do abc, mal se descobre o motivo porque dois caracteres se acham próximos. A velha divisão de vogais e consoantes não tem melhor fundamento. Consoantes são as que se lêem só com soantes? Nesse caso a divisão natural seria soantes e consoantes. Mas nem as vogais 
de Deus pretendia, pelo encanto intrínseco à leitura, revigorar o aprendizado, que estaria desde então pautado fundamentalmente sobre esse fascínio exercido pela palavra escrita:

\begin{abstract}
"Ora a verdadeira palavra do homem é a palavra escrita, porque só ela é imortal. Mas enquanto o ensino da palavra falada é o encanto de mães e filhos, o ensino da palavra escrita é o tormento de mestres e discípulos. Estranha diversidade entre coisas tão irmãs! Deus, na sua providência, não o podia determinar assim. Há de haver meio facílimo, grato, universalmente acessível, de espalhar essa arte, ou antes faculdade, sem a qual o homem não passa de um selvagem. Esse meio ou método não pode ser essencialmente diferente do método encantador, pelo qual as mães nos ensinam a falar, que é falando, ensinando-nos palavras vivas, que entretêm o espírito, e não letras e sílabas mortas, como fazem os mestres. Pois apressemo-nos também nós a ensinar palavras, e acharemos a mesma amenidade. Com aquelas cinco letras já se escrevem quatro palavras usuais, e que, por uma feliz coincidência, se lêm do mesmo modo, isto é, acentuando a primeira voz. Lêdeas, e nunca soletreis; que mal sabeis como a soletração confunde o principiante, e lhe deprava o raciocínio com somas falsas. Lêde-as acompanhando fielmente com o ponteiro a letra que estais lendo; e vereis a facilidade, o gosto e a admiração com que o aluno vos segue e vos imita, reconhecendo em sua consciência a palavra retratada no papel.",328
\end{abstract}

O aluno deveria ser, durante todo o processo da leitura, estimulado pelo professor, que lhe entusiasmaria, mostrando-lhe tudo aquilo que ele já aprendera, quanto à junção das vogais, em livros e impressos comuns. Assim, tornar-se-ia claro que a leitura é atividade sempre superior ao universo do compêndio ou da própria escola. Ora, não sendo as letras, mas a junção delas quem desenvolveria o raciocínio analítico do estudante, recomenda-se - nessa primeira lição - o reconhecimento das vozes e dos sons correspondentes - como vimos - às seguintes expressões: ai, ui, eu, ia. $\mathrm{O}$ aluno percebe, ao reconhecer os sons pelos sinais e, com os sinais, os significados a eles correlatos, a invenção da palavra escrita, que se traduz, enquanto tal, como uma sinalização da voz e da mensagem da comunicação entre os homens. ${ }^{329}$

são unicamente soantes, nem são unicamente as soantes. A articulação $f \ldots$ soa. Os caracteres que a representam podiam-se, por figura, chamar soantes. Ainda soa mais a articulação rr...; e nessa há mais do que som, há tom, voz. Prolongai-a, ou melhor, parai com a língua, continuando no mesmo esforço, ouvireis uma voz apreciável na escala, que até se pode tomar por tônica de uma oitava: é a voz que o repique da língua está recortando. Porque toda a voz é essencialmente musical: a mais frouxamente proferida, em se prolongando, afina ou desafina com a nota dum instrumento. Não há diferença essencial entre a palavra e o canto; e com razão chamaram vogais (ou vocais) as letras que representam as vozes. Mas, por isso, chamar consoantes a todas as outras envolve impropriedade. Todos os sons soam; dizer que as vozes soam, não é bastante: as vozes cantam. É uma síntese exagerada. Porque na palavra há vozes, há tons, há sons, e há simples modificações, sem tom nem som, que se percebem na palavra como se percebe na nota da rabeca a unha ou o arco. Nem a unha nem as sedas do arco são elementos fônicos: fazem ouvir de certo modo, sem que por si se ouçam. Ora a estas quatro espécies de elementos, e a estes simples acidentes, que formam como uma escola - 1) vozes: todas as simples vozes; 2) tons: $r r, j, z, v ; 3)$ sons: $x, c, f ; 4)$ modos: $b d q$, gl, lh, etc. - correspondem naturalmente quatro espécies de letras suscetíveis das mesmas denominações, se se quiser. Assim teremos letras soantes e mudas, toantes e mudas; etc. $X$ toante (z), soante $(c, x)$ e simultaneamente modal e soante ( $k c ̧)$. Estas denominações $e$ classificações têm utilidade porque envolvem análise, dão um conhecimento mais perfeito da palavra e da escrita e proporcionam em muitos casos à doutrina do mestre uma precisão e clareza que a distinção geral de vogais e consoantes não admite. Mas, pela nossa parte, reprovamos uma nomenclatura figurada." (JOÃO DE DEUS, Cartilha Maternal ou arte da leitura..., p. 106-7).

${ }^{328}$ JO ̃̃O DE DEUS, Cartilha Maternal ou arte da leitura por..., p. 2.

329 "Iniciamos no mecanismo da escrita o principiante, com grande e justa maravilha sua. Ele recebeu, sentiu, mais ou menos lucidamente, o engenho dos homens que, estudando as vozes, de que as palavras se compõem, inventou, para cada voz, um sinal, e depois, conforme a palavra consta de tais ou tais vozes, assim na escrita põe tais e tais sinais! Mas aqui vem a propósito admirar como esta arte fundada numa base tão singela tem sido o martírio de tantos inocentes, e passe ainda, na opinião das multidões, por uma ciência árdua! É verdade que tal correspondência não é perfeita, mas essa imperfeição pouco embaraça os nacionais, sendo bem dirigidos. Aonde não chegam as regras, vem em auxílio do principiante a prática e o estilo da língua. O aluno, 
Aprofundando a tônica da crítica que iniciara aos modelos de ensino da leitura comumente usados em Portugal, João de Deus não poupa recriminações àqueles que pretendiam começar o processo de ensino da leitura pela prática da silabação. No que concerne à leitura por sílabas, o escritor, logo, demonstra particular reticência quanto a um modelo de ensino que privilegiava o som, em detrimento do valor analítico dos caracteres, o que seria - segundo ele - "tão mal ou pior que soletrar, e esse valor analítico não era conhecido" $" 330$. A cartilha de João de Deus - ao grafar as diferentes sílabas com tonalidades que destacam umas das outras - detém-se em problemas trazidos pelos falares regionais, pelos diferentes sotaques que não contemplam, em sua transcrição escrita, nenhum nível de variação. A escola e a língua seriam nessa medida tecidas pela tecla da uniformidade, não tendo, entretanto, correspondência falada dessa unidade, o que indubitavelmente dificultava o processo de aquisição da linguagem escrita. Isso seria, para o autor, a dinâmica fundada na melodia, em um tipo de ouvir-falar, aceitável para a linguagem oral e passível de ser superada mediante o estilo único do ler-escrever. Percebe-se, nessas lições, o quanto João de Deus está voltado para erradicar as variantes linguísticas regionais, mediante a unívoca e inconfundível norma da língua culta, a língua do impresso. O lugar da escola e da instrução passaria, então, por indisfarçável crítica dos falares das populações. Pretende-se, além do mais, trazer à tona uma "forma escolar" inteiramente outra. ${ }^{331} \mathrm{Na}$ Décima Lição da Cartilha o poeta declara que só pudera experimentá-la até então, mediante a aplicação do ensino individual. O relato dessa sua experiência traduz-se no que vem a seguir:

\begin{abstract}
“(...) costumamo-nos colocar a um canto da mesa, mais o aluno, ele dum lado à esquerda, e nós do outro; pomo-lhes a lição diante convenientemente; e enquanto nas primeiras quatro lições percorremos com o ponteiro pela parte de cima as letras da palavra, imo-las simultaneamente lendo. Ora, como do intervalo da letra naturalmente se abstrai, nem esse intervalo é apreciável na marcha do ponteiro, a sílaba e a palavra afigura-se, aos olhos do principiante, como uma pequena escala cujas notas se vibram na sua ordem natural. E o que é a leitura senão a interpretação sucessiva das letras simples e compostas, certas ou incertas da palavra escrita? Por isso é que a leitura é a verdadeira soletração; porque só na leitura se dá aos caracteres seu justo valor."332
\end{abstract}

acostumado a ler palavras, não lê, por exemplo, tódo nem môdo; lê tôdo e módo como tem ouvido dizer." (JOÃO DE DEUS, Cartilha Maternal ou arte da leitura por..., p. 4)

${ }^{330}$ JOÃO DE DEUS, Cartilha Maternal ou arte da leitura por..., p. 8. Na sequência, o educador prepara o leitor: "Adiante exporemos claramente os elementos e condições da linguagem, base de toda a arte de leitura. Se a letra representa um fato da linguagem, e o mestre não discrimina esse fato, como há de ensinar a ler ?" (Id. Ibid., p. 8)

331 "O magistério é de sua natureza ofício de abnegação e de paciência. O mestre que se ira corrompe o coração do aluno. E se o aluno, pela sua tenra idade, é incapaz de aprender as regras e de as aplicar, então a sua presença na escola apenas atesta a ignorância dos pais e a incúria da autoridade. Até aos sete anos de idade todos andamos numa fervorosa elaboração física, que só reclama alimento, movimento e sono; assim como andamos nesse profundo e imenso estudo da língua, e nessa insaciável investigação do mundo exterior, que absorve totalmente a faísca mais brilhante que possa alumiar uma cabeça infantil. Complicar esse duplo movimento quase vertiginoso com o ensino primário - leitura, escrita e contas - passa de absurdo a cruel." (JOÃO DE DEUS, Cartilha Maternal ou arte da leitura por..., p. 67).

332 JOÃO DE DEUS, Cartilha Maternal ou arte da leitura por..., p. 28. Um dos problemas da alfabetização popular, a que o autor se detém bastante - como, aliás, já pudemos comentar acima, é a questão dos falares regionais, que se compunham por variações quanto à pronúncia para as quais o professor deveria estar sempre atento. Entretanto, ao referir-se a isso, João de Deus desliza e deixa-nos visualizar o recorte da classe pela qual pretende falar: "Este é o fato, e, por consequência, a lei fundada, não diremos na melodia, que é relativa, porém no uso mais autorizado e aliás mais vasto. Com isto não queremos dizer que em tal ou tal lugar, onde reine sem contradição aquela variante, o professor se empenhe em arrancar aos seus discípulos talvez um hábito invencível. A toada é singularmente ingrata a ouvidos estranhos, e ilegítima; porém não é essencial que os filhos do povo falem classicamente; o essencial é fazê-los quebrar o círculo da animalidade, dando-lhes, por meio da leitura e da escrita, o horizonte infinito do homem." (Id. Idid., p. 33). 
João de Deus polemiza também com o método de Castilho, no concernente à criação que seu adversário fizera de palavras e sinais sonoros, remarcando que a invenção de novos caracteres em nada contribuiria para tal ortografia exata. O autor da Cartilha Maternal questiona a própria existência de uma ortografia exata posto que existam tantos modos de ler quantas forem as variações de ênfase na força relativa dos diferentes sons que compõem a palavra. Não haveria método algum passível de ser eficaz enquanto não se reconhecesse que não há correspondência direta entre ler e dizer o que se leu. ${ }^{333}$ Diante disso, João de Deus contrapõe-se aos críticos que argumentavam que de qualquer maneira se aprende a ler. De fato, em alguns casos - explicita o polemista - é possível aprender com qualquer método. Ocorre que, talvez na grande maioria das vezes, o indivíduo desiste, quer pelo excessivo tempo gasto para a operação da leitura, quer pelo tormento causado pelos rígidos, arcaicos e incorretos procedimentos escolares. ${ }^{334}$ João de Deus pretende, diante disso, tornar seu método nitidamente português e as instruções da própria cartilha são visivelmente um recado para os mestres de primeiras letras, ou para qualquer um que se pretende aventurar pelo universo do ensino da leitura. Os procedimentos indicados são também dicas para permitir ao professor conhecer melhor sua língua maternal. ${ }^{335}$

João de Deus qualifica o valor de cada letra, dando-lhe a entonação da leitura, a partir do modo pelo qual ela deveria ser pronunciada. Tal preocupação fica exposta na seqüência de seu texto, quando classifica a fala em função não mais do critério binário das vogais e consoantes, mas pelo parâmetro quaternário que supunha vozes ( as vogais puras e nasaladas ), tons ( $v, z, j, r)$, sons ( $f, c ̧, x)$ e modos [ labiais ( $\mathrm{m}, \mathrm{b}, \mathrm{p}$ ) - e linguais; divididos, por sua vez, em dentais $(\mathrm{d}, \mathrm{t})$, palatais $(\mathrm{r}, \mathrm{l}, \mathrm{lh})$ e guturais $(\mathrm{g}, \mathrm{q})]$.

A obra A Cartilha Maternal e a imprensa, publicada em Lisboa no ano de 1877, consistia numa coletânea de artigos laudatórios. Tratava-se de um conjunto selecionado de textos publicados pela imprensa portuguesa dos últimos anos. O método era assim elogiado, na maioria dos casos, pelo fato de consistir em um procedimento diferente para o ensino da habilidade da leitura. $\mathrm{Na}$ verdade, entendiam esses partidários da Cartilha Maternal que João de Deus se pautara por inovações que reconhecidamente mereceriam o louvor da crítica. Os méritos do método consistiam, em poucas palavras, na simplicidade, nos excelentes

333 Đeve já ser claro para o leitor que as invogais (...) designam fatos absolutamente silenciosos. Ler não é dizer. Dessa confusão, dessa suposição falsíssima resultou não haver método de leitura até hoje. Ler é dizer, ou fazer o que a letra vale. Esta pode valer alguma coisa que se diga; mas pode unicamente valer alguma coisa que se faça." (JOÃO DE DEUS, Cartilha Maternal ou arte da leitura..., p. 135). Acreditamos que uma das inquietações do autor, ao sinalizar tal referência, era quanto às inflexões da leitura oralizada até a leitura silenciosa.

334 "Os quadros alfabéticos assim talhados, pelas cinco vogais, em tantas regras ou linhas, estão indicando as porções em que se há de estudar o alfabeto. O alfabeto é uma ordem puramente histórica; o seu estudo, aborrecido; e não há necessidade de molestar o aluno. Quantos terão renunciado à glória de saber ler, pelo fastio invencível dessa enfiada de nomes bárbaros e desconexos? É verdade que no princípio, que é quando o costumam ensinar, a essa desconexão ajunta-se a absoluta ausência de sentido; mas em todo o tempo a memória se esquiva a encadear semelhante salsada." (JOÃO DE DEUS, Cartilha Maternal ou arte da leitura..., p. 108)

${ }^{335}$ Veja, a propósito alguns exemplos: "É estilo português nasalarmos na palavra as vozes dominantes antes das articulações que se escrevem com $m, n$ nh. Nós dizemos penar com a primeira voz pura ( pe ); mas já dizemos pena, com a primeira voz nasalada ( $p \sim e)$. É uma regra com poucas exceções (...) Ao Norte de Portugal em muitos pontos se diz cáma, mána. Se pudéssemos escolher, preferiríamos esse estilo, porque é mais claro e musical: mas em linguagem não podemos adotar o mais sonoro, e sim o mais usual e autorizado. Daqui vem que $m, n$ sejam frequentemente letras e ao mesmo tempo sinais de nasalidade. A vogal dominante, seguida de $n$,

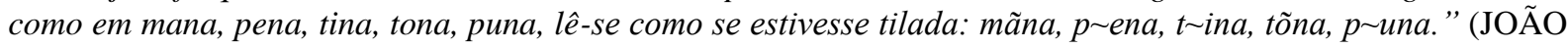
DE DEUS, Cartilha Maternal ou arte da leitura por..., p. 92-3) Podemos aliás dizer que nada na Cartilha de João de Deus vem por acaso. Observe-se o primeiro texto completo que acompanha a lista de palavras da décima sétima lição. Não é mais do que um explícito astímulo à leitura. Seria sua mensagem dirigida apenas ao aluno, ou talvez, fundamentalmente a quem a o ensina? "- Ó Pedro, que é do livro de capa verde, que te deu o avô? Já o dei ao Jorge a guardar. - Vai lá pedi-lo. - Para quê? - Para a tia Carlota ver a gravura do caçador.” (Id. Ibid., p. 62-3) 
resultados práticos que já demonstrara acarretar, na rapidez do processo do ensino, e no maior alcance social que essa suposta eficácia traria. Por sua vez, o que havia de radicalmente distinto naquele novo modelo de ensinar a ler? Fundamentalmente a inversão quanto ao trajeto da aprendizagem do aluno. O ponto de partida deixava de ser o entediante processo da soletração, ou a soletração carente de significado. Enfim, não se partia exclusivamente do som, mas buscava-se alçar fundamentalmente o significado das palavras; e por essa razão o ponto de partida da alfabetização era a palavra. Poderíamos mesmo dizer que João de Deus inventou para o caso português a alfabetização analítica. As palavras da Cartilha, grafadas com diferentes tonalidades, faziam dessa distinção tipográfica a chave para a posterior compreensão das partes sonoras de que se compõem os vocábulos. Finalmente, a uniformidade dos exercícios era apreciada pelos entusiastas do método como uma fonte de clareza lógica. Diante disso, havia quem classificasse o método como uma derivação pedagógica da corrente positivista; seja como for, o método procurava ser radicalmente moderno:

\begin{abstract}
"Fundado na análise e na crítica dos elementos da palavra e dos sinais que a representam, filia-se na escola positivista, sendo portanto revolucionário e democrático; mas habilmente revolucionário, pois que aceitando os absurdos admitidos por convencionais tradições, a maior parte delas sem clareza lógica, habilita todavia as crianças à leitura do que está escrito e se vai escrevendo; e ao mesmo tempo, pela profunda análise e estudo consciencioso dos elementos fônicos e gráficos, pelas engenhosas e aceitáveis inovações que apresenta, e que na sua maioria vingarão, prepara e apressa a simplificação da palavra escrita, principal desideratum de todos quanto se emprenham pelo sincero derramamento da instrução elementar.",336
\end{abstract}

João de Deus na verdade inova, por não acoplar seu método a questões fonéticas ou de sons, dado que, fazendo principiar o processo da leitura pela palavra, realmente torna a lógica do aprendizado da leitura semelhante à lógica da fala; em ambos os casos, o ponto de partida seria o significado. Diante disso, poder-se-ia realmente entender que há uma lógica distinta no método de João de Deus; e que provavelmente a brevidade deixara de ser, como em Castilho e em Monteverde, uma meta, para se tornar um efeito do próprio percurso e da dinâmica da leitura. João de Deus, nessa medida, pode mesmo ser considerado como um antecedente ou até como um precursor do método global ou analítico desenvolvido por Decroly no princípio do século XX, particularmente desde 1906. Havia clareza em João de Deus, no sentido de pontuar que o verdadeiro interesse da criança pela leitura seria determinante no processo do aprendizado. Por sua vez, no tocante à alfabetização, o interesse não ocorreria pelo sinal sonoro, ou pela mecânica reprodução do sinal gráfico. O interesse seria despertado fundamentalmente pelo sentido da palavra.; por aquilo que ela designa e pela

\footnotetext{
${ }^{336}$ DEMOCRACIA, In: A Cartilha Maternal e a imprensa, p. 7. Outro artigo no mesmo periódico viria a caracterizar o método de João de Deus como excitante do instinto lógico das crianças. Nos termos de José Jacintho Nunes, temos o seguinte: “Podemos afiançar que o método de leitura do distinto poeta João de Deus é racional e duma extrema simplicidade. Os métodos geralmente adotados nas escolas confundem e fatigam as crianças, com abstrações que nada dizem ao seu espírito: o de João de Deus, pelo contrário, esclarece-as e inspira-lhes o amor do estudo com combinações e exemplos vivos, que despertam a curiosidade e se gravam fielmente na memória. Enquanto que uns são bárbaros e absurdos nos seus processos de pronúncia e soletração, excita o outro o instinto lógico das crianças, e encaminha-as para a verdade e para a justiça. Eis porque o novo trabalho de João de Deus é eminentemente democrático e deve conquistar os aplausos de todos os que trabalham seriamente para a emancipação dos oprimidos. Os membros da Câmara Municipal deste concelho não se limitaram a admirá-lo. Na sua penúltima sessão resolveram mandar à sua custa uma criança fazer a experiência da prontidão do método. Cremos que não serão desmentidas as nossas previsões, e que João de Deus terá mais uma ocasião de demonstrar praticamente as excelências de sua obra." (José Jacintho NUNES, Democracia, In: A Cartilha Maternal e a imprensa, p. 9).
} 
correspondência escrita entre os nomes e os objetos. ${ }^{337}$ Seria então a correspondência entre os objetos da realidade e os nomes que a linguagem humana dá para eles que despertaria a curiosidade da infância para com a fala e posteriormente para com a transposição escrita dessa mesma fala. O ponto de partida, não sendo, em hipótese alguma o som, era, isso sim, a representação do real.

Carvalho Junior atesta para o Jornal das Senhoras a eficácia do método, quando relata a prova pública a que a Cartilha Maternal fôra submetida. O teste ocorreu em um teatro de Lisboa e foi presenciado por pais e professores - além das autoridades do distrito muitos deles descrentes quanto aos possíveis resultados positivos. O Abade de Arcozello seria o responsável pelo convite que fôra feito às pessoas que compunham o auditório. Diante daquele público, seriam entrevistadas crianças entre 5 e 8 anos, as quais haviam aprendido a ler pela Cartilha Maternal, cada uma com um número específico de lições: algumas tinham tido 12 aulas, outras 20, outras 30, ou mesmo cem. O resultado comprovava que o ensino pelo método inventado por João de Deus se destacava de maneira singular particularmente porque às crianças eram apresentados textos extraídos de diversos livros, com os quais elas não teriam familiaridade, e em cuja leitura apresentavam notável fluência e desenvoltura. Salientava-se ainda a brevidade com que a maioria dos discípulos havia decifrado os enigmas da leitura. Contava-se sobre um menino - esse mais velho, de 12 ou 13 anos - que, tendo passado 4 anos na escola, chegara a aprender apenas algumas letras. Quando foi introduzido na Cartilha Maternal, passou finalmente, em pouquíssimas lições dadas no decorrer de dois meses, a ser capaz de ler. O pai da criança e o mestre asseguravam o fato. ${ }^{338}$ Outros relatos publicados na mesma obra - A Cartilha Maternal e a imprensa - destacavam que João de Deus costumava tomar como um desafio todas as crianças que lhe chegavam às mãos, rotuladas pelos pais e mães como incapazes de aprender o bê-á-bá. Nesses casos - contava-se - João de Deus procurava convencer o discípulo e seus pais de que o culpado não era o menino, mas o martírio e o trauma que a escola, os castigos, as palmatoadas e fundamentalmente a irracionalidade do método - ou mesmo a ausência de método provocavam. ${ }^{339}$ Com isso João de Deus costumava mesmo granjear inúmeros adeptos e

\footnotetext{
${ }^{337}$ O clássico livro de Berta BRASLAVSKY - Problemas e métodos no ensino da leitura - que na tradução brasileira foi prefaciado por Lorenço Filho, aborda o que a autora intitula de " precursores do método global antes do século XX". Porém a autora refere-se apenas a trabalhos desenvolvidos na França, Estados Unidos e Rio da Prata ( Argentina ); provavelmente por desconhecer o caso de João de Deus em Portugal, que - como vimos, atendia ao requisito de "unir o conceito, a significação, ao ensino da leitura", fazendo com que pudesse ocorrer o que Braslavsky intitula de "predomínio da percepção visual na aprendizagem da leitura” (Berta P. De BRASLAVSKY, Problemas e métodos no ensino da leitura, p. 65). Sobre Decroly, diz a especialista: "Decroly foi, talvez, quem proclamou com maior veemência o princípio do interesse para refutar o manejo dos símbolos abstratos, vazios de sentido, e propôs que a visão dos símbolos se transformasse de modo imediato em representação de idéias, já que somente a representação concreta das idéias mediante as coisas ou as figuras poderia despertar o interesse que, segundo ele, não suscitam nunca a letra morta nem a linguagem por si só." (Id. Ibid., p. 69)

338 "E se acrescentarmos que, como disse o professor, o desenvolvimento do rapaz datava de apenas dois meses, umas cinquenta lições, parece-nos desculpável o pasmo e a admiração de que ficamos possuídos, nós os incrédulos, que os havia lá, como dissemos, ao começar esta notícia. Não somos daqueles que se deixam arrastar pelas primeiras impressões; mas se não estivemos sonhando, se o que relatamos era uma realidade, não podemos deixar de confessar que o novo sistema de ensino, apresentado pelo Sr. João de Deus, tem mais um sectário que se esforçará quanto puder para que ele seja adotado em todas as escolas do país, pois que os resultados a colher são do maior alcance. (...) maior interesse devemos ter pelo desenvolvimento do ensino nas escolas inferiores, que se não têm progredido como era para desejar, a culpa não é dos professores, mas, acabamos de ver, da falta de bom método". (CARVALHO JUNIOR, Jornal de Senhoras, In: A Cartilha Maternal e a imprensa, p. 11-2) O autor termina o texto recomendando às mães de família a cartilha de João de Deus. Provavelmente a ênfase posta na leitura ensinada pelas mães indicava que essa prática deveria ser frequente em Portugal da segunda metade do XIX.

${ }^{339}$ Fernando LEAL, no número 183 do periódico intitulado Progresso narrava a visibilidade do estímulo com que João de Deus incitava em seus alunos a predisposição para o aprendizado. Dizia sobre o caso da mãe que entregara o filho aos cuidados do educador: "Mas enquanto durou a conversa da mãe com o poeta, percebia-se
} 
incontáveis admiradores, entre os mestres que orientava e a população que o acompanhava. Acreditando piamente naquilo que fazia, o poeta demonstrava realmente haver se tornado o detentor dos segredos da didática da leitura. Em suas mãos, ensinava-se bem e em pouco tempo. Os incontáveis registros sobre o tema levam-nos realmente a acreditar na eficiência do método quanto àquilo que propunha. Mesmo assim, João de Deus defendia-se contra os que o acusavam de priorizar a brevidade:

\begin{abstract}
“A brevidade no ensino não é virtude, mas simples prenda. A brevidade não é essencial, nem prefere a outras condições. Se me ensinam mal e violentamente, antes me ensinassem melhor e mais devagar. Para uma ou outra pessoa já ocupada e cheia de cuidados pode ser a brevidade um grande mérito. Todos os que pela sua idade chegaram a julgar já passado o tempo de aprenderem a ler, acham na brevidade grande recomendação e até, talvez, condição necessária. Sem isso não se resolvem ou não persistem. E desses o número é ainda infinito! Mas a leitura é a confirmação da fala; e, portanto, o primeiro dos estudos. Em princípio não há homem que não saiba ler: o fato atual é ainda um legado dos séculos de barbárie. Assim, pois, as cartilhas escrevem-se para a infância; e a infância tem muito tempo a perder. Por isso a brevidade não pode prevalecer sobre nenhuma outra condição de um método. O que importa, principalmente e essencialmente é levar o principiante de degrau em degrau pelas dificuldades da arte; é não contrariar a natureza humana com processos e afirmações absurdas; é lisonjear, favorecer, desenvolver as nossas faculdades, em vez de as torcer e atrofiar. A brevidade pouco importa. Mas a quem pode ela prejudicar ? Que mal faz à criança ou ao adulto, aprender num mês aquilo que havia de aprender em dois, se o não molestam, se o não cansam, se o não enfastiam, antes o entretêm e deleitam ?" 340
\end{abstract}

na ligeira contração dos músculos superciliares do analfabeto, não sei que vaga expressão de rebeldia refletida. Guardadas as devidas proporções, devia ser aquela expressão da fisionomia de Galileu obrigado a aceitar os princípios cuja falsidade repugnava ao seu espírito. E quando João de Deus falava nas sem-razões do bê-á-bá, o rapaz fez um movimento maquinal, um relâmpago de inteligência coruscou em seus olhos, iluminando-os. Duas ou três semanas mais tarde o discípulo, que já lia quase correntemente, dava uma das suas últimas lições em casa do mestre. Estavam presentes algumas pessoas. João de Deus fez não sei que pergunta sobre a lição ao estudante, que respondeu atiladamente. Transparecia-lhe no semblante a satisfação de não ter sido emendado. Houve um intervalo de silêncio, fumava-se. De repente, o rapaz dá com o indicador da mão direita, suja de cerol, no meio da testa e muito sério, com uma expressão pensativa, como se falasse consigo mesmo, diz estas palavras inesperadas:

- Eu sinto que tenho mais tino!” (Fernando LEAL, Progresso - $\mathrm{n}^{\circ} 183$, In: A Cartilha Maternal e a imprensa, p. 22)

340 JOÃO DE DEUS, Carta lida pelo Abade de Arcozello - Cândido José Ayres de Madureira - no teatro Baquet em Lisboa, quando da reunião de avaliação do método de João de Deus, In: A Cartilha Maternal e a imprensa, p. 15-6. Na mesma missiva - datada de 20-3-1877 - João de Deus expunha que não pudera assistir àquela sessão, mas que esperava a devida atenção do público e dos especialistas ali presentes. Repare-se que, embora sendo por vezes qualificado de positivista, João de Deus sempre se refere ao ensino da leitura como uma arte. De qualquer maneira, havia na época, pelos seus "apóstolos" a nítida preocupação em salientar a modernidade da Cartilha Maternal: “(...) é a eletricidade no ensino, é o vapor na ilustração de todas as classes! É a imprensa multiplicada cem vezes, é o gaz iluminando os caminhos grandiosos da civilização, aos que mal sabem aventurar uns passos nos escolhos da vida. (...) É o nivelamento das classes, é a nobilitação do trabalho pela ilustração da inteligência do obreiro. É a charrua arrotedora abrindo à meteorização dos meios civilizadores a inteligência inculta das classes fecundas e mais vastas da humanidade. (...) O seu método há de ter uma generalização. Hoje está apenas aplicado à língua portuguesa, mas ele é de todas as línguas. O método não rouba tempo ao trabalho, não afugenta as crianças desses longos dias fastidiosos e horrendos das escolas onde se gastam na saúde e na privação dos carinhos e cuidados das mães. O método é insinuante, dá gosto ao professor e estímulo ao aprendiz. As mães que o souberem têm meio fácil de não abdicar n'outrem este encargo que elas devem fazer melhor do que ninguém. A escola passará para o santuário da família e não será uma tutela dos governos, nem o suplício das crianças. O pobre não precisará roubar o tempo do estudo às horas do trabalho, conciliará a alimentação do espírito com a do corpo, e, pela ilustração daquele, conquistará a alforria deste. As crianças serão homens cedo pelo estudo e pela reflexão.” (CORREIO do meio dia, In: A Cartilha Maternal e a imprensa, p. 18-9) 


\title{
JOÃO DE DEUS: DO MÉTODO DE LEITURA À LEITURA DO MÉTODO
}

Em muitos de seus escritos, João de Deus alude à sua preocupação quanto aos efeitos da leitura, quanto à necessidade da leitura, quanto às intersecções entre cultura, civilização e leitura; essa leitura que vinha pelos trilhos do caminho de ferro... Havia, naquele último quartel do século XIX reconhecida relação entre a prosperidade material e o âmbito do desenvolvimento das letras. Era como se a nova civilização que estava por vir exigisse a forma escolar como seu modelo básico. Por ser assim, o ler e escrever passam a ser apreendidos como armas competitivas, instrumentos de cuja posse dependeria o progresso das nações. A humanidade, no atual estágio por que passava, exigia o signo da escrita como condição imprescindível para seu desenvolvimento. O saber ler era, pois, condição de dignificação humana; aquilo que metodologicamente atribuía a distinção do homem cultivado. $\mathrm{Na}$ trilha da herança dos revolucionários franceses - fossem os homens de 1789, fossem os homens da Comuna - havia uma necessidade de formação da opinião esclarecida, de consolidação de um espírito público, capaz de trazer dividendos ao país instruído. ${ }^{341} \mathrm{E}$ esse projeto de formatação de uma subjetividade coletiva esclarecida e autônoma passava pela escola. No percurso da espécie, teria há muito findado o tempo da oralidade:

\begin{abstract}
"Como condição de dignidade humana, diremos que o homem que não sabe ler é um bárbaro. Ele fala aos que o ouvem, e ouve os que lhe falam; mas aí se fecham as atribuições de sua inteligência. É o selvagem da horda; o membro primitivo da família errante ou solitária - não o membro de uma sociedade muitas vezes cortada por mares e continentes; não o membro da humanidade, em comunhão moral com ela, progredindo e desenvolvendo-se pela circulação das idéias; mas girando sobre si mesmo no círculo vicioso das espécies estacionárias, como um ente sem fala, um ente mudo, sem o divino caráter da palavra. Porque a palavra é não só o característico da espécie humana, mas a sua essência: sem ela todos morreríamos com as nossas próprias observações e experiências, ninguém poderia acumular conhecimentos alheios e o último homem saberia tanto como o primeiro: a espécie humana não existiria: porque não existiria a espécie que acumula e progride. Mas a palavra falada é como a iniciação da humanidade; a palavra que se apaga à flor dos lábios não tem ainda o caráter de divindade; é só, fixando-a pela escrita e multiplicando-a pela imprensa, que ela assume os foros da universalidade e da imortalidade. $O$ ente que fala essa linguagem é realmente feito à imagem e semelhança de Deus." ${ }^{342}$
\end{abstract}

A sacralização da atividade da leitura vem acoplada a uma percepção evolutiva da humanidade: a leitura decorre da palavra divina, aproxima o homem de seu Criador e favorece a partilha, a socialização e a circulação das idéias. Na acepção evolutiva desse modelo interpretativo, prosperariam os povos que melhor se fizessem capazes de aproveitar dos benefícios trazidos pela distribuição da palavra escrita. A civilização, por tal dispositivo,

\footnotetext{
341 Nessa medida, os próprios ventos progressistas que teriam caracterizado Portugal dos anos 70 solicitavam, como requisito para o desenvolvimento nacional, a preparação cuidadosa de uma opinião pública verdadeiramente esclarecida. Só assim seria possível efetuar as desejadas mudanças, prescindindo da dolorosa via da revolução. Fomar para a democracia era o que afirmavam desejar os arautos da nova pedagogia, particularmente João de Deus: "Há uma necessidade primitiva, fundamental, essencial nas sociedades políticas, que é a de saberem ler todos os cidadãos, sob pena de que, seja qual for a forma de governo, esse não terá por base, falando rigorosamente, a opinião, nem, por consequência, o direito. Só há opinião pública quando há povo que opine: ora, quando sabe ler, de cada mil, um, a opinião pública é frase vazia de sentido. Os nossos jornais correm um estreito círculo; o conhecimento dos negócios públicos é privilégio de alguns poucos milhares de indivíduos; e entre quatro milhões de habitantes, quando apenas quatro mil, isto é, a milésima parte, dá razão aos negócios comuns, confessemos que falar em maiorias e em opinião pública, é para sorrir-se o homem reflexivo”( JOÃO DE DEUS, ,Cartas sobre o método de leitura, In: Prosas, p. 249-250).

342 JOÃO DE DEUS, Cartas sobre o método de leitura, Prosas, p. 250-251.
} 
acumula memória e sai vitoriosa do embate contra o obscurantismo popular. Transformar o povo era tarefa urgente... O ensino da leitura seria visto, por tal dimensão, como um projeto civilizatório, passível de se colocar ao alcance das camadas majoritárias da população. Espraiar a atitude leitora era o objetivo maior de João de Deus. Na verdade, tratava-se do empreendimento de esforço no sentido de trazer eficácia à instrução portuguesa, naquela escola que era, entretanto, rejeitada por seus usuários, como uma instituição incapaz de fazer cumprir o que promete.

Sucede que abordar analítica e historicamente o método de João de Deus é uma atitude intelectual que deve ser acompanhada da observação sobre o modo mediante o qual o poeta orientava os educadores da época para lidarem com as predisposições mentais e emocionais dos estudantes. Em virtude da maneira dogmática e constritiva mediante a qual a escola estivera, desde remotas épocas, estruturada, o aluno que não era capaz de aprender, de modo geral, era um estudante espiritualmente bloqueado para o aprendizado. $\mathrm{O}$ aluno deveria ser, portanto, estimulado, motivado, a partir do entusiasmo com que o mestre lhe devolveria a auto-estima que ficara alhures perdida. $O$ processo de aprendizado suporia pois, como condição primordial que o estudante acreditasse nele mesmo. Talvez nem o próprio João de Deus tivesse consciência dessa sua estratégia, mas indubitavelmente ela agia como uma profecia auto-realizadora. Convencia-se o aluno de que sua dificuldade de aprender não era ocasionada por sua incapacidade, mas pela ineficácia da ação escolar; dizia-se a ele que, em função disso, tentar-se-ia usar método diferenciado dos procedimentos tradicionais já experimentados pelo mesmo aluno; este passaria então a acreditar na possibilidade da mudança e na ocorrência efetiva do aprendizado; aberto para aprender, o jovem aprenderia... E assim, criava-se um ciclo de estímulo, autoconfiança e sucesso escolar. João de Deus parecia firmemente acreditar na possibilidade de transformação da escola. Talvez por isso tenha sido bem-sucedido com seu método. Talvez por isso, tenha sido tão cultuado a seu tempo...Ora, ocorre que o mestre deveria, acima de tudo, ser capaz de apreender os mecanismos lógicos utilizados pelo aluno no percurso da aprendizagem. A arte da educação supunha, antes de qualquer coisa, uma linguagem comum. Cabia ao mestre decodificar a linguagem do estudante e ser capaz de torná-la mais complexa, aproximando-a da outra linguagem, a linguagem culta, a linguagem da escola, a linguagem socialmente recomendada. A arte do magistério exigiria ser pois estudada, como se de uma ciência se tratasse:

\footnotetext{
"A arte da leitura é hoje uma ciência culta, um sistema, uma unidade lógica: todas as suas partes jogam entre si, e têm uma filosofia. O mestre deixou de ser um autômato que repetia ba, be, bi, bó, bu, a ser um intérprete, um explicador. Não conta com o grande auxiliar do tempo, que até gasta os mármores, nem ainda com o empenho do aluno. Conta consigo, com a arte, com a natural e irresistível simpatia da racionalidade do aluno, com a racionalidade do Método. Pode o discípulo não estudar, mas se prestou atenção, se ouviu, aprendeu a ler. Não há cabeças de burro. As cabeças de burro passaram das crianças para os homens, dos discípulos para os mestres. Ler é essencial a todos. Onde há um analfabeto, não há civilização. Mas se ler é essencial a todos, está ao alcance de todos. O gênio e o idiotismo são duas monstruosidades, raras de sua natureza. Pelo nosso método não se ensina o idiota; mas em paga o gênio aprenderia no tempo necessário para percorrer a cartilha. $\mathrm{Na}$ imensa distância do gênio ao idiota está a humanidade, está o povo português: este, se dentro em pouco ainda for analfabeto, é porque quer.",343
}

\footnotetext{
343 JOÃO DE DEUS, Cartas sobre o método de leitura, In: Prosas, p. 261-2. João de Deus pretende ter encontrado o segredo da didática do ensino da leitura. Declara-se sempre convencido de que todos os seres humanos são capazes de aprender a ler; como se estivesse polemizando com pessoas que naquela altura entendiam como natural que determinadas pessoas, ou mesmo determinadas camadas da população, não se julgassem aptas para almejar a aprendizado dos códigos escritos.
} 
João de Deus, preocupado em ensinar os professores sobre sua arte, partia do pressuposto de que eles em geral não sabiam o que faziam, agindo por aproximações, por induções, mas sem um método claramente definido. António Gomes Ferreira relata a carência de método como uma concreta característica do ensino português no século XVIII. ${ }^{344}$ Os professores, também no XIX, praticamente desconheciam as matérias que ensinavam. Tampouco compreendiam a fisiologia e a psicologia de seus alunos. O magistério era ainda um fazer profissional, que se praticava, sem qualquer dimensão teórica. O trabalho de João de Deus evidentemente sofreu essa dificuldade. Nem sempre os professores compreendiam o que lhes era proposto. À luz dessa realidade é que a Cartilha Maternal passará a ser julgada, e muitas vezes criticada.

Ao procurar se contrapor ao método de João de Deus, Francisco do Amaral Cirne Jr., tanto no relatório apresentado ao Comissário de Estudos do Distrito do Porto, sob o título Exame da Cartilha Maternal (1879), quanto em sua obra Resumo da História da Pedagogia (1881), atenta para o fato de seu autor não haver conseguido e nem haver sequer acreditado no ensino da leitura e da escrita simultaneamente, como processos concomitantes. Esta seria, no parecer daquele crítico, uma das maiores falhas do método. Embora condenando, como vimos, as práticas escolares presas por práticas arcaicas de soletração e de silabação, João de Deus - mesmo assim - entendia que a leitura era processo cognitivo do qual dependia a posterior prontidão para a escrita. ${ }^{345}$ Anteriormente, porém, entre as décadas de 40 e 50, Caldas Aulete publicava sua Cartilha Nacional, que se teria constituído na primeira tentativa em língua portuguesa de articular de maneira simultânea o ensino da leitura e da escrita sem haver precedência de um sobre o outro. Embora Cirne Jr. julgasse que até mesmo a cartilha de Caldas Aulete apresentasse problemas metodológicos, a despeito da larga utilização que teria conseguido nas escolas, o crítico reconhece que seu autor soubera decifrar o nó górdio do ensino português, ao propugnar um modelo simultâneo para o aprendizado dos saberes da escola primária. ${ }^{346}$ Em seu parecer, a cartilha de João de Deus provocara, em certo

\footnotetext{
344 "Em geral, os mestres de ler, escrever e contar sabiam pouco sobre o que ensinavam e menos ainda sobre como o deviam fazer. Sem método, alguns terão perdido o controlo da aula ou permitido uma relação demasiado permissiva, situação que não podia deixar de desagradar às populações e às autoridades, mas a maioria parece ter assumido ar grave e austero que ajudava a impor o respeito e manter a disciplina, o que estava mais de acordo com a mentalidade da época. Todavia, manter todos os alunos em silêncio e a trabalhar entregues a si mesmos ou a outros mais adiantados, enquanto se atendia uma criança de cada vez, dificilmente seria conseguido sem se recorrer a castigos. Então, se o grupo dos meninos que o mestre tinha sob a sua responsabilidade era não só muito numeroso como muito diversificado, tanto quanto a idades como a saberes e, ainda por cima, dados a travessuras ou a desmandos, que os mais velhos ardilosamente provocariam, o mais provável seria que ele se exasperasse com alguma frequência, punindo sem critério e com violência desmesurada todos aqueles que lhe pareciam estar envolvidos nas perturbações." (António Gomes FERREIRA, A criança no Portugal do setecentos: contributo para o estudo da evolução dos cuidados e das atitudes para com a infância, p. 381-2).

${ }^{345}$ Leia-se o que o autor publica em suas Cartas sobre o método de Leitura: "O caminho mais curto e agradável para dois pontos diversos não pode ser o mesmo. Pode a arte de ler ser a arte de falar: mas a arte de ler ser a arte de escrever, ou a arte de escrever ser a arte de ler, arte verdadeira, método, não pode ser. Nesse paralelismo a razão há de ser sacrificada alternativamente." (JOÃO DE DEUS, Cartas sobre o método de leitura, In: Prosas, p. 293).

346 "Caldas Aulete não se contenta em associar a escrita à leitura; junta-lhe também o cálculo e o desenho. Não padece dúvida que os exercícios de desenho se ligam com grande proveito ao ensino de ler. Não são, porém, exercícios especiais o que agora se requer, mas tão somente alguns exercícios, embora grosseiros, sobre o desenho dos objetos significados pelas palavras que servem à leitura. Quanto à pretensão a associar o contar com a leitura, diremos sem tergiversações que temos por quimérico o intento. Isto não quer dizer que não há-de ensinar-se o cálculo enquanto se ensina a ler, o que seria absurdo, pois é indispensável promover o desenvolvimento harmônico de todas as faculdades do espírito. Apesar dos defeitos apontados, a Cartilha Nacional, introduzindo o ensino simultâneo da leitura e escrita, prestou à pedagogia portuguesa serviços meritórios, que ninguém contestará razoavelmente" (F. A do Amaral CIRNE JR.., Resumo da história da pedagogia, p. 147-148). Percebe-se, por esse excerto, o quanto o crítico parecia cioso quanto à necessidade de conformação de um modelo escolar, criteriosamente dividido por espaços e por temporalidades curriculares, que, simultânea e reciprocamente, fossem capazes de entre si se complementar.
} 
sentido, uma volta atrás, apesar de toda a louvação que lhe era feita, e que Cirne Jr. atribui à completa ausência em Portugal de uma ciência pedagógica à altura do século. ${ }^{347}$

No texto em que examina a cartilha de João de Deus, Cirne Jr. conclama os leitores à prudência diante de novidades, declarando que o entusiasmo nunca deverá ser o primeiro alicerce da atitude de investigação e de crítica. Todo o debate posto em torno do método Castilho não teria sido suficiente - argumenta Cirne Jr. - para impedi-lo de cair por terra e ser submetido ao mais completo esquecimento. De maneira análoga, o crítico previa a redução gradativa do entusiasmo gerado pela Cartilha Maternal, e explica: na verdade, os métodos só se fariam capazes de resistir ao crivo do tempo quando se mostrassem capazes de ser manuseados pelo professor no cotidiano da sala de aula.

\begin{abstract}
"E por um desses saltos mortais que não são tão raros como poderia parecer, declarou-se para logo regenerada a instrução popular, como se nas escolas tudo se cifrasse em ler e como se, aplanadas as escabrosidades do ensino do ler, pudessem ser aplicados aos outros ramos da instrução primária - instrumental e real - os processos empregados no aprendizado da leitura! (...) Desde que os homens do mister se calam, é natural que surjam as opiniões mais aventurosas, as quais, não encontrando periódicos da especialidade que lhe corrijam as demasias, passam a ser aceites de todos os que, por negligência ou falta de instrução na matéria, aderem à primeira opinião que apareça. Mas é bem de ver que tais opiniões, sem base sólida em que se fundem, não conseguem granjear amigos perduráveis, não conseguem radicar-se; a agitação é tão só superficial, aparente, e passado o momento crítico do entusiasmo, voltam as coisas quase ao estado anterior, ficando, por assim dizer, apagados os vestígios dum movimento assaz ruidoso. Na história contemporânea do ensino primário em Portugal, avultam e destacam-se principalmente dois fatos característicos que confirmam plenamente este modo de ver. Refiro-me ao Ensino Mútuo e ao Método Português do Snr. Castilho. Que resta d'um e d'outro ?" 348
\end{abstract}

Haveria, nesse sentido, uma tendência, por assim dizer, compreensível e quase natural, de se empregar a metodologia já conhecida, sobre cujo domínio e eficácia não pairassem quaisquer dúvidas; enfim aquilo que, posto à prova do tempo, deu certo. O método novo, descrito apenas nos livros, era, em geral, visto com reticência e desconfiança por parte dos protagonistas da educação: os professores, que hesitavam para pô-lo em prática. Pelas palavras de Cirne Jr., explicita-se a relutância quanto àquilo que é apenas projeto impresso nas teoria : "Com efeito, um método só será eficazmente implantado numa escola quando teórica e praticamente for bem familiar ao professor. Prefere-se o método que melhor se conhece porque é aquele com que melhor nos ajeitamos." 349 A lógica que presidia a aceitação e o otimismo para com o método de João de Deus estaria posta na carência de reformas efetivas capazes de aprimorar o ensino português. Mesmo a imprensa periódica, em função da proverbial pobreza de idéias e de notícias sobre educação, cobrira o tema de modo superficial, até porque havia reconhecida incapacidade técnica de avaliação da matéria. Nessa trilha,

\footnotetext{
347 “A importância realmente injustificável atribuída à Cartilha Maternal, em que muitos viam a regeneração da instrução primária, a carta de alforria do povo português e talvez uma panacéia para os mais variados males de nosso país, só pode explicar-se pela ignorância, entre nós, quase geral da ciência pedagógica. A carência de habilitações no magistério primário é proverbial, a imprensa pedagógica falece totalmente, o país ainda está reduzido no ano corrente a duas escolas normais com uma organização mesquinha e absurda: em tamanha miséria não admira que a opinião se desnorteasse sobre o alcance do novo método. O Sr. João de Deus não encarou a educação e instrução debaixo de um ponto de vista geral e superior, como fizeram Comenius, Pestalozzi e Froebel, mas apresentou-se apenas como reformador do ensino da leitura (...)” ( F. A. do Amaral CIRNE JR. , Resumo da história da pedagogia, p. 151).

${ }^{348}$ Francisco do Amaral CIRNE JR., Exame da Cartilha Maternal: relatório apresentado ao Exmo Snr Comissário d'Estudos do Distrito do Porto, p. 6.

349 Francisco do Amaral CIRNE JR. , Exame da Cartilha Maternal: relatório apresentados ao Exmo snr Comisário d'Estudos do distrito do Porto, p. 7.
} 
afirma-se que, de tudo o que se teria escrito à época acerca da Cartilha Maternal de João de Deus, a grande ênfase e realce eram colocados na dimensão da suposta brevidade do método, o que por si contrastaria com a lentidão e a inoperância da escola primária portuguesa naqueles tempos. Cirne Jr, desqualificando completamente os entusiastas do método de João de Deus, refere-se a eles como "pedagogos improvisados": "Publicam-se anúncios pomposos, promete-se aos pais rapidez assombrosa, chegando a afiançar-se que bastam quinze lições para uma criança aprender a ler corretamente." ${ }^{350}$ A Cartilha Maternal, no parecer do crítico, havia apenas reordenado o modo com que se dispunha o alfabeto, mas não representava - no parecer daquele opositor - um avanço significativo, até porque se mantinha, disfarçado, o aprendizado tradicional e os procedimentos sintéticos de alfabetização. Acerca da polêmica pedagógica que há alguns anos assolava o país, Cirne Jr. procura desvendar a prática efetivamente instituída nas escolas primárias:

\begin{abstract}
"Com efeito, o método de leitura que predominava (e porventura ainda predomina na maioria das escolas rurais portuguesas) era o método alfabético ou de soletração antiga, caracterizado pelo estudo simultâneo de todas as letras. Este método foi gradualmente caindo em descrédito e surgiram novos métodos de leitura, mirando a remediar os defeitos dele. Vieram os métodos de soletração moderna e de silabação que, pela rejeição da velha nomenclatura das letras e por uma graduação mais ou menos racional, levaram este ramo de ensino ao estado em que presentemente se encontra. Foi o Sr. Castilho quem rompeu o combate contra os velhos processos de leitura e por tal forma se houve que conquistou ilustre nome da história do ensino popular. O Método Português não só ensinava o alfabeto por partes mas enjeitava a ordem alfabética (...) O método do $\mathrm{Sr}$. Castilho, apesar do período áureo a que logrou chegar bem depressa, caiu no esquecimento dos literatos que tanta bulha fizeram ao princípio e fugiu das escolas corrido pela inépcia, pela preguiça e pela malvadez que preferiam, ao novo método, a cartilha velha e a palmatória, leal amiga e companheira de tantos anos. A desorganização administrativa e pedagógica do ensino primário favoreceram muito particularmente essa regressão do professorado ao estado anterior. Nem tudo, porém, foi perdido no meio deste esfacelamento. O desprezo da ordem do alfabeto e o princípio da fragmentação do mesmo não foram esquecidos; ficaram com muita outra coisa do método, fato adquirido para a pedagogia, não sendo jamais posto de lado pela parte culta dos mestres." 351
\end{abstract}

O que parecia estar em jogo, pelas premissas de F. A. Cirne Jr., era a própria capacidade de resistência à inovação por parte da escola e do professorado. Essa aversão ao desconhecido e à mudança verificar-se-ia, como diz ele, no indisfarçável apego da escola a práticas e técnicas ultrapassadas. Com tal propensão à conservação do existente, dificilmente a escola mudaria, e, a despeito das tentativas reformadoras, veremos que todo o embate do século XIX português será por um lado o discurso da inovação e por outro as representações da permanência secular daquilo que se criticava. A estrutura da escola em gestação passava também por inúmeras contradições... Cada vez mais, a pedagogia do discurso parecia buscar soluções. Esse era um tempo em que o grande desafio aparecia posto em um imaginário evolucionista, onde o desenvolvimento da criança é apreendido apenas como uma revelação do anterior percurso da espécie. Desse modo, havia que se caminhar - na trilha aberta pelo positivismo - do simples para o complexo, da parte para o todo, do conhecido para o desconhecido, do concreto para o abstrato, do exemplo para a regra, dos fatos para a lei... A identidade entre o indivíduo e dos povos progressivamente se firmava como pressuposto, e por tal razão a cartilha de João de Deus deixaria de obedecer à racionalidade pedagógica quando produzia uma redistribuição e combinação aleatória entre letras, sílabas e palavras.

\footnotetext{
${ }^{350}$ Francisco do Amaral CIRNE JR., Exame da Cartilha Maternal..., p. 9.

351 Francisco do Amaral CIRNE JR., Exame da Cartilha Maternal..., p. 12-13.
} 
Para Cirne Jr.: “(...) no ensino da leitura o conhecido é a palavra falada ou a frase. Da adoção da palavra ou da frase para ponto de partida resultam duas variantes do mesmo método,"352, a saber: decomposição das palavras em sílabas e depois em sons elementares e irredutíveis. A partir do contato com esses elementos fonéticos da palavra é que seriam estudadas as letras (sinais) que os representam:

\begin{abstract}
"Depois o aluno reconstrói a palavra (síntese reflexa) e fica completa, com este primeiro ensaio de leitura, a operação do método. Tomando a frase para ponto de partida, procede-se, ainda, da mesma forma: decomposição da frase em palavras, das palavras em sílabas, da sílaba nos elementos que a formam e assim sucessivamente como na outra variante. É este o único método racional de ensinar a ler, é o caminho que seguiu a raça na invenção da escrita. Ora, o Snr. João de Deus segue exatamente o caminho oposto porque toma, para ponto de partida, o ensino das letras que nada significam para uma criança, parte do desconhecido para o desconhecido." 353
\end{abstract}

Destacando que o método de João de Deus estaria em desacordo com o desenvolvimento histórico da espécie e do indivíduo, por não se ter mostrado capaz de descobrir o segredo do ensino simultâneo da leitura e da escrita, Cirne Jr. resume a contribuição da Cartilha Maternal. à idéia de apresentação do texto por caracteres com tons de preto diferenciados para as sílabas. Era - segundo ele - fundamentalmente a parte formal, quando compunha a cartilha em letras distintas da cor preta, mais clara ou mais escura, a única coisa que teria valido a pena, computando-se todo o esforço que João de Deus efetuara... Por outro lado, a excessiva preocupação com a brevidade levaria a um retrocesso nos estudos sobre alfabetização, dado que o projeto de João de Deus, naquilo que representava o encalço do modelo analítico para o ensino da leitura, em tese ficaria aquém do de Caldas Aulete, de Ramos Paz e de Brito Aranha.

Ao rebater essa crítica, João de Deus enfatiza que ele estaria preocupado com o progresso civilizatório e com o papel da leitura no mesmo processo. E, enfaticamente, destaca que o saber ler seria, sob tal enfoque, muito mais premente do que o saber escrever. Era preciso ler, e, mais do que isso, ler o texto impresso. Parece-nos emblemático o embate dessa intelectualidade portuguesa sobre a estratégia e o segredo da alfabetização. Disso - supunham eles - dependeria o futuro da escolarização primária, e, aqui estaria também contido o próprio futuro do país. O imaginário da leitura, mais do que nunca, permeava a acepção simbólica da escola:

"A grande letra, a letra eminentemente civilizadora e indispensável é a letra de forma. Todos têm mais idéias a receber que a transmitir; e, portanto, mais necessidade de saber ler, que de saber escrever. Pode-se saber ler sem se saber escrever, mas não se pode saber escrever sem se saber ler;

\footnotetext{
${ }^{352}$ Id. Ibid., p. 19.

${ }^{353}$ Francisco do Amaral CIRNE JR., Exame da Cartilha Maternal..., p. 20. Cirne Jr., diante do exposto, passa a discorrer sobre quais seriam os procedimentos adequados para o ensino da leitura, mediante o respeito ao desenvolvimento natural da fala e de suas gradações. A escrita e a leitura subordinar-se-iam, por analogia com o desenvolvimento da espécie, à palavra falada. Na concepção do crítico, mesmo as descobertas da ciência da educação deveriam ser compreendidas como uma cadeia evolutiva e em constante aprimoramento, onde haveria acúmulo, empréstimo, mais do que contraposições. É por tal razão que mesmo as técnicas mais criticadas poderiam efetivamente ter real eficácia prática. Acreditando nisso, Cirne Jr. complementa: “Parece-nos porém que o Snr. João de Deus se deixou levar do ódio que vota ao velho método e soltou frases de combate, frases de efeito em livro didático, quando nos diz que a soletração antiga embrutece, leva atá ao idiotismo. Se as coisas se dessem daquela forma, todos acompanhariam o poeta no seu grito de dor e na sua preferência (...) Se a soletração antiga levasse ao idiotismo, estaríamos, ipso fato, necessariamente privados de todos os homens notáveis que assinalaram a sua passagem pela humanidade e e cujo rastro ainda hoje nos enche de assombro e luz. O próprio Snr. João de Deus não seria por modo nenhum o grande poeta que todos admiramos, não seria João de Deus; e a sua querida Cartilha Maternal não existiria tampouco.” (Id .Ibid, p. 25)
} 
a leitura é portanto o alicerce da escrita. A escrita auxilia e confirma a leitura, entretém a atividade e lisonjeia talvez mais o amor próprio do aluno; mas todas essas condições são contempladas na marcha paralela, melhor que na acumulação de duas rates que, embora irmãs, não deixam de ser diversas." 354

A obra A Cartilha Maternal e a crítica, publicada em Lisboa, pela Antiga Casa Bertrand - José Bastos, no ano de 1897, reunia artigos que compunham as inúmeras polêmicas às quais o método de João de Deus foi submetido, seus opositores, de um lado, e os defensores do outro. Foi Trindade Coelho quem em 1896 escreveu o prefácio, onde procurava evidenciar os paradoxos da leitura e de seu ensino, que aparentemente interpretados pelo signo da trivialidade, eram verdadeiramente atitudes intelectuais dotadas da mais profunda complexidade. Tratava-se de um trabalho póstumo, embora João de Deus, no final da vida, tenha participado da seleção no princípio. Foram escolhidos artigos e trechos variados, de João de Deus, de seus partidários e de seus críticos. João de Deus confiara o trabalho a Trindade Coelho. O objetivo subliminar de Trindade Coelho era defender João de Deus particularmente daqueles críticos que o teriam acusado de plágio. Remarcava, para tanto, que o trabalho do poeta não pretendia originalidade; o que não queria, entretanto, dizer que se tratava de um plágio. Trindade Coelho recorda que "uma obra é original, desde que não é modelada por outra, embora seja semelhante ou até igual" ${ }^{355}$. João de Deus - garantia o discípulo - teria na sua cartilha um fruto espontâneo de sua criação. Se tinha ou não afinidade com outros métodos, isso talvez fosse questão secundária, até pelo fato de não ser João de Deus um grande leitor. O que a Cartilha Maternal trazia de novo era fundamentalmente sua pretensão à simplicidade e ao favorecimento da intuição do aluno. Com isso ela de fato se fizera revolucionária quanto ao atraso português na prática da leitura. No referido prefácio com que apresentava a obra, Trindade Coelho emprestava as palavras de alguns notórios pedagogistas da época e de outros grandes polemistas de João de Deus (como, por exemplo, Simões Raposo), que demonstravam que o ensino elementar fracassava em Portugal fundamentalmente porque não se sabia ensinar a ler. ${ }^{356} \mathrm{Na}$ verdade, o intuito de Trindade

\footnotetext{
${ }^{354}$ JOÃO DE DEUS, Pedagogia: A Cartilha Maternal e a crítica, p. 231.

${ }^{355}$ Trindade COELHO, Ao leitor, In: João de Deus, A Cartilha Maternal e a crítica, p. XI. Pode-se reparar que um primeiro artigo da coletânea era de autoria do próprio João de Deus, defendendo-se da acusação segundo a qual teria plagiado o método REGIMBAU. Em 26-9-1878, João de Deus afirmava, portanto, para o Partido do povo: "Por amor da verdade, e agradecendo este louvor, direi que não li absolutamente nada, e que nem o método por que aprendi, há quarenta anos, me lembra, como é natural. Foi provavelmente essa ignorância o que me valeu”. (JOÃO DE DEUS, A Cartilha Maternal e a crítica, p. 1).

356 "No meio desta desordem, perde-se a lógica do ensino elementar, e o professor desespera de encontrar método racional; e as crianças cansam-se, aborrecem-se e martirizam-se, consumindo improdutivamente um preciosíssimo tempo que lhes podia servir para desenvolver a inteligência e educar o coração. Deste modo, a aprendizagem da leitura, que devera ser facílima, tornou-se, por tantos absurdos e por tantas anomalias a disciplina mais custosa da escola primária! Basta dizer que são poucas as crianças que chegam a ler bem, e que ainda assim a leitura lhes rouba duas ou três horas no dia durante a sua longa frequência de muitos anos, isto é, aleitura consome tanto tempo, ela só, como todas as outras disciplinas do programa: falo só da leitura mecânica e corrente, porque a leitura inteligente, sustentada, artística, ainda não chegou a penetrar nas nossas escolas.” ( Simões Raposo, 1877, apud., Trindade COELHO, Ao Leitor, In: João de Deus, A Cartilha Maternal e a crítica, p. VII ) Na sequência, o prefácio de Trindade Coelho alude ao papel que João de Deus tivera no equacionamento das dificuldades do ensino da leitura. Diz o educador: "Eu não pretendo enaltecer aqui a obra pedagógica de João de Deus. Nem eu saberia, nem é preciso para o meu propósito, - modesto como eu. Mas o estado da aprendizagem da leitura era o que se patenteia do depoimento do Sr. Simóes Raposo - que sobre ser um pedagogista, era o professor oficial encarregado de ministrar o ensino das primeiras letras num estabelecimento escolar da importância da Casa Pia - depreendo quanto devo a João de Deus, (e, como eu, quantas mães e quantos pais!) ao lembrar-me ao fim de 18 lições, o meu pequeno que eu levava ao colégio todas as manhãs, leu de caminho, sem errar, a tabuleta de um estabelecimento. E foi ele que, definindo-me uma vez, a seu modo, o método de João de Deus, empregou as seguintes palavras, que o próprio mestre sabia de cor:- $O$ método João de Deus não se aprende. No método de João de Deus as palavras é que vêm ter com a gente:
} 
Coelho parecia ser, com aquela publicação, a adoção em todas as escolas portuguesa do método de leitura desenvolvido por João de Deus. ${ }^{357}$ Desse modo, procura-se realçar a defesa que João de Deus recebera por parte de alguns pedagogos que eram críticos da Cartilha Maternal ( como é o caso de Graça Affreixo ), quando das acusações de que teria plagiado o método Regimbau ( aplicado em França e em Inglaterra ). Quando um dia lhe foi apresentada a cartilha escrita pelo poeta, Affreixo dissera que ela não prestava para as escolas, por ser excessivamente volumosa para o trabalho com crianças, por trazer poucos exercícios e por ser muito cara para os pobres. Graça Afreixo era, pois, o sujeito ideal para aparecer como defensor de João de Deus. Quanto à acusação de plágio, ele a desqualifica logo, demonstrando que "é coisa ignóbil, a propósito das discussões dos predicados de uma obra, imputar ao seu autor um crime de furto antes do ministério público ou o roubado o acusar de tal crime; e mais ignóbil ainda devassar as íntimas intenções dum homem, se ele as tem, porque as íntimas intenções são propriedade sagrada e indiscutível de cada um." Quanto às acusações de alguns críticos - entre eles, como vimos, Amaral Cirne Jr. - de que a Cartilha Maternal, ao principiar o processo de ensino da leitura pelo reconhecimento visual da palavra, trairia a bandeira da nova pedagogia, segundo a qual se deveria caminhar do simples para o composto, Graça Affreixo destaca que, ao prescindir da soletração, "é um método rigorosamente ordenado do fácil para o difícil.” ${ }^{358}$ Em conversa com João de Deus, Graça Affreixo, que havia criticado a questão da acentuação na Cartilha Maternal - até certo ponto por ser partidário do que defendera Castilho - volta atrás e, em 4-1-1879, reconhece:

\begin{abstract}
"Não me prendem vãs preocupações de orgulho quando discuto; daí vem que tendo eu discutido com o autor da Cartilha Maternal o seu método de leitura, discussão terminada por mútuas explicações particulares, me tornei admirador e propagandista do mesmo método. Poucas dúvidas me distanciavam da doutrina de João de Deus e essas desapareceram; venho pois explicar-me sobre este ponto. O Visconde de Castilho arvorara em Portugal a grande reforma dos métodos de leitura. O Método Português procurava tirar das nossas escolas os anteriores processos de soletração, mas não conseguia libertar-se inteiramente dos defeitos que pretendia corrigir, donde proveio conservarem-se os exercícios mnemônicos nos asilos da infância desvalida de Lisboa, e procurarem excelentes professores, em várias cartilhas, organizar uma silabação sintética, ensinando, não os elementos da sílaba, mas a própria sílaba. Por este caminho me guiava eu e guiava alguns professores que recebem inspirações minhas; à luz destas opiniões critiquei a Cartilha Maternal. Ouvi o dr. João de Deus e fiquei extasiado perante a imensa simplicidade com que me resolveu muitos problemas do ensino da leitura e até da ortografia. Eu vira o método a uma luz inconveniente; procurava-o no caminho da síntese, e ele ia no da análise; supunha eu que ele queria realizar a silabação pura, e o que ele tende a realizar e fatalmente realizará, é a adoção de uma silabação analítica, correta, lógica. Alguns professores e pedagogistas procuraram em
\end{abstract}

assim, zás, do papel 'pros' olhos!' (Trindade COELHO, Ao leitor, In: João de Deus, A Cartilha Maternal e a crática, p. VII).

357 "Ensine como ensinar, o professor há de adotar um método, ou próprio ou alheio. Se próprio, por que não há de proibir-se-lhe se for mau; ou por que se não há de fazer dele o método geral, se tem, com efeito, valor que sobreleve o de todos mais? Se alheio, por que não há de ser preferido o que obtiver a consagração do maior número? O problema da leitura não é insolúvel; - e, portanto, preferível é dar-lhe a solução que se apurou ser a melhor, a deixar de pé, indistintamente e irracionalmente, o arbitrio. Deixar a cada professor a liberdade de ensinar pelo método que quiser, condescendendo, por esta forma, com a expectativa de que o seu trabalho dará assim melhores resultados, é não só cair numa expectativa falaz, e que, de resto, apenas poderá ter aplicação a um outro professor, mas é também abrir a meia porta, pelo menos ao absurdo, aliás mais simpático, de se experimentar um método para cada discípulo, consoante o seu grau de capacidade! Isto pode ser ? Não. Pois, ainda menos, deve ser aquilo. E tão atrasada estará a pedagogia nacional, pergunto eu, que não possa, por um lado, proferir a condenação irremissível de certos métodos, e, por outro, graduar os restantes e preferir um ? E por que não será esse o caso de João de Deus? Ou se há outro melhor, declaradamente melhor, por que não será esse ? Não estará aqui um princípio de disciplina, essencial no mecanismo e no governo de todas as instituições e essencialíssimo, note-se, na do ensino de todas as outras?" (Trindade COELHO, Ao leitor, In: João de Deus, A Cartilha Maternal e a crítica, p. XVII-XVIII )

${ }^{358}$ GRAÇA AFFREIXO, Jornal do povo, In: JO ÃO DE DEUS, A Cartilha Maternal e a crítica. As duas últimas transcrições vêm nas páginas 6 e 9 da referida obra. 
analogias mais ou menos frisantes, em mnemônicas mais ou menos agradáveis, a resolução dum problema julgado impossível: o valor verdadeiro das letras não vogais. Outros partindo da impossibilidade de resolver o problema faziam um método, aliás, verdadeiro, começando da sílaba. O Dr. João de Deus nem seguiu analogias nem tomou a verdade a meio caminho, tirou o problema da classe dos impossíveis e achou o valor da incógnita." 359

O trecho acima evidencia aquela nossa hipótese anteriormente explicitada segundo a qual a polêmica sobre o método Castilho deslocara substantivamente o debate sobre a escolarização em Portugal, colocando, a partir dos anos 50, o problema do método como o grande impasse a ser equacionado para dar eficácia à escola portuguesa. Mesmo a discussão política sobre a razão de ser da escola primária passaria, desde então, a ser subordinada às questões do método de ensino da leitura.

\section{JOÃO DE DEUS: A REGENERAÇÃO SOCIAL PELO MÉTODO DE ENSINO}

O sucesso de João de Deus parecia, para alguns, matéria inquestionável. ${ }^{360}$ Era o caso de Samuel Tito que entretece seu relato de maneira a apontar o poeta como o apogeu de um longo e árduo processo histórico, no qual inúmeras tentativas pregressas teriam tido seu ápice nos resultados dos estudos do poeta e em suas técnicas para ensinar a ler e a escrever. ${ }^{361}$ Outros destacavam a singeleza de sua concepção, muitos ainda apontam que seus exercícios de intuição visual seriam o caminho para interromper, de uma vez por todas, o interminável império da soletração. De qualquer modo, o próprio João de Deus - assim como Castilho já fizera há vinte e poucos anos atrás - não poupava elogios a si mesmo: acreditava de fato ter tomado posse do segredo da didática da leitura. Julgava que a racionalidade do processo da leitura vinha por analogia à racionalidade da fala e era imprescindível para orientar o

\footnotetext{
${ }^{359}$ GRAÇA AFFREIXO, Jornal do povo, In: JOÃO DE DEUS, A Cartilha Maternal e a crítica, p. 25-6.

${ }^{360}$ Rómulo de Carvalho atenta para o sucesso rápido que o método de João de Deus teria obtido a seu tempo. Sobre o tema, comenta o investigador: "Em 1879 o governo, indeciso na opinião que deveria tomar oficialmente a respeito da Cartilha, decide proceder a uma rigorosa e imparcial confrontação mandando comparar o método de João de Deus com o método usual. Certamente que a conclusão foi favorável ao poeta atendendo à utilização crescente da Cartilha nas escolas primárias do país.” (Rómulo de CARVALHO, História do ensino em Portugal, p. 611). Também acerca da organização das Escolas Móveis, por parte de um dos fundadores do primeiro Centro Republicano do país, Rómulo de Carvalho irá se deter, preocupado em evidenciar a apropriação política daquele método, a princípio exclusivamente pedagógico, que marcará o percurso do criador da Cartilha Maternal.

361 “(...) fez grande arruído o poeta Castilho com seu Método Português, suplantando os absurdos meios de ensino em que havíamos caído. Caiu por sua vez completamente em desuso, condenado pela prática porque estava muito longe da perfeição. A mesma sorte sofreram ainda os métodos ou sistemas de Ramos Paz, Brito e Aranha, Caldas Aulete, etc.(...) O poeta João de Deus presenteou a nação, a sua pátria, com o melhor produto do seu gênio. Sem me deixar arrastar pelas apologias exageradas que mais desmerecem que encarecem o seu método, creio contudo que ele é preferivel a todos quantos tem havido e há em Portugal." (Samuel TITO, Transmontano, 9-7-1880, In: JOÃO DE DEUS, A Cartilha Maternal e a crítica, p. 28-9). Samuel Tito dizia que, por sua experiência, a Cartilha Maternal seria ideal para ensinar adultos, aconselhando, por essa razão, que seu uso fosse adotado nas escolas regimentais. João de Deus logo se contraporia a essa semi-objeção, posto que, como ele mesmo diz, as crianças também devem ser instigadas ao raciocínio. Por suas palavras: "Aquela opinião resulta dessa preocupação geral de que as crianças não precisam nem alcançam a razão das coisas ao mesmo tempo, princípio falso e na prática prejudicalíssimo. Se as crianças não precisassem de razão das coisas, precisávamos nós de lh'a dar, para as desenvolver no raciocínio e as habituar a proceder racionalmente. $O$ método é racional e raciocinado? Tanto mais adequado e grato aos inocentes, que já nos podem entender porque falam, e nos querem entender porque podem. Na explicação das coisas não fazemos senão corresponder a uma exigência íntima dessas inteligências eminentemente indagadoras. Mostram os facots e devia prever a razão que o método não é melhor para adultos." (JOÃO DE DEUS, transmontano, 6-8-1880, In: A Cartilha
} Maternal e a crítica, p. 32) 
aprendizado. A leitura escolar tornara-se algo repugnante pelo fato de não respeitar esse processo, mas antes contrariá-lo, opondo-se ao modo racional, e que seria por isso natural. Desse modo, instaurar-se-ia a irracionalidade, a falsidade, a contradição. A leitura correta exigiria, por sua vez, princípios adequados, corretos, deduzidos gradual e metodicamente. Referindo-se aos concorrentes, diz então João de Deus:

\begin{abstract}
“Os Britos, os Simões Lopes, quejandos não tinham princípios, e isto bastava para que se achassem na impossibilidade de compor um método; mas ainda que tivessem princípios, saberiam eles coordenar a escala do ensino, traçar o itinerário conveniente? O método é um dom que se não supre com o estudo e a ciência, quanto mais com uma boçal ignorância. Em todo o tempo se tem sabido aonde se quer levar o aluno, que é a leitura. Mas para se ir a qualquer parte é necessário saber donde: e não se sabendo donde, como se há de saber por onde? Se não havia princípios, como podia haver processo, marcha ordenada, itinerário racional? No desespero de um problema insolúvel chegaram a arremessar a criança à leitura, num jato, a uma vez, sem mais prelúdios, o que seria ridículo se não fosse cruel. Mestre Lopes põe nas cartilhas - 'para aprender a ler sem soletração'. Na escola dele soletra-se; mas se não se soletrasse, como ensinava ele a ler? Silabando, sem mais análise: isto é, ensinando a ler letras como os chineses ensinam a decifrar símbolos! Que lhe parece ao meu amigo este método de ensinar a ler ?"362
\end{abstract}

A leitura era para João de Deus pretendia ser a confirmação da fala - nisso ele concordava com Castilho. A grande polêmica, aliás, que marcaria seu trajeto de debatedor foi com um seguidor de Castilho: Simões Raposo, vereador e professor oficial na chamada Casa Pia em Lisboa. No ano de 1879, Simões Raposo já havia publicado sua cartilha que seria adotada para o uso dos alunos da Real Casa Pia de Lisboa (O primeiro livro da escola: cartilha de leitura preliminar e elementar - aprovada pelo Conselho Superior de Instrução Pública para ser usada em escolas primárias de $1^{\circ}$ grau). Tendo sido inspetor de instrução primária no Porto, Raposo tinha formação pela Escola Normal primária de Lisboa, e se destacava como um especialista no assunto da educação. ${ }^{363} \mathrm{~A}$ verdade é que sairia já em 7 de janeiro de 1879 uma carta de Simões Raposo dirigida ao redator do jornal Comércio de Lisboa - um tal Luciano Cordeiro. Nessa polêmica pública (porque noticiada logo naquele mesmo veículo de imprensa), Raposo visivelmente provocava João de Deus declarando que a Cartilha Maternal não era maternal, não tinha originalidade alguma, e, sobretudo, não trouxera qualquer melhoramento à escola portuguesa. $\mathrm{O}$ crítico ainda acrescenta, dizendo que seu sucesso derivava, além de tudo, de uma mera exploração mercantil. Para Raposo, o que de mais ridículo havia nos apóstolos de João de Deus era o fato de entenderem a Cartilha Maternal como a única alternativa - que não tivera nem precedente e nem sucessor - como se

\footnotetext{
362 JOÃO DE DEUS, Comércio de Lisboa, 7-2-1879, In: A Cartilha Maternal e a crítica, p. 42-3. Para concluir João de Deus arremata dizendo que só quando se analisasse verdadeiramente a fala e a pusesse em correspondência com a escrita é que se teria o verdadeiro método. Sobre isso, acrescenta: "Fizemo-lo nós; é imodesto, mas é verdade." (Id. Ibid., p. 44)

${ }^{363}$ Encontramos vários artigos de revistas e jornais que apontam Simões Raposo como uma das autoridades em pedagogia na época. Há particularmente um, no qual o conhecimento do autor sobre a dita ciência da educação pareceu-nos notório. A intitulada "seção pedagógica", do periódico a instrucção portuguesa; revista semanal, datada de 1-1-1886 discorria brevemente sobre a evolução do que se considerava já "ciência pedagógica". A reflexão ressalta o caráter de "fílosofia abstrata e metafísica" que a pedagogia tinha "antigamente", em contraste com o cunho moderno e multifacetado em termos de conexão entre os saberes das várias ordens que ela adquiriu após profundíssimas revoluções literárias e científicas da Renascença até aos fins do século XVIII. Tomando Comenius, Rousseau e Locke como pais das "concepções científicos experimentais" de educação, haveria surgido, enfim, o período positivo no concernente aos estudos pedagógicos. Diz ele sobre o tema: “(...) é então que começa a fundar-se em bases sólidas a verdadeira ciência do ensino, que imortalizou os nomes sempre autorizados de Pestalozzi e de Froebel, de Comte e de Spencer, verdadeiros fundadores da Pedagogia moderna, ao mesmo tempo natural e científica, racional, metódica e experimental.” (José António Simões RAPOSO, Secção Pedagogica, In: A instrucção portuguesa; revista semanal, 1-1-1886, p. 5).
} 
a história da educação pudesse assim ser resumida a um discurso de inauguração e encerramento. João de Deus era na época cultuado e sua obra apontada como a grande descoberta de toda a história da pedagogia. Por ser isso - em sua opinião - uma inverdade, o crítico pretendia evidenciar a improcedência da tese. ${ }^{364}$ João de Deus, diante do ataque se enfurece a parecem faltar-lhe argumentos. ${ }^{365}$ No primeiro semestre de 1879, Simões Raposo seria o único vereador da câmara de Lisboa a votar contra um projeto segundo o qual os professores deveriam ser, pela mesma Câmara, convidados para receber os conhecimentos teóricos do referido método João de Deus pelo próprio autor da Cartilha Maternal. A Câmara forneceria aos docentes os meios de transportes e lhes custearia as despesas. Raposo justifica sua rejeição a tal projeto, pelo fato de haver nele uma cláusula que dizia que esse estudo ocorreria a fim de que posteriormente o método fosse adotado nas escolas de Lisboa. Além disso, o projeto conteria juízo de valor antecipado ao crivo da investigação e da prática, expondo que o método por João de Deus desenvolvido era o que mais satisfazia às necessidades de aprendizado de crianças e adultos. ${ }^{366}$ Ocorre que naquela altura o método de João de Deus não teria ainda conseguido aprovação da junta consultiva de instrução pública e a objeção de Simões Raposo teria nesse obstáculo o amparo legal de que precisava. João de Deus, no calor daquela contenda, enfurece-se:

\begin{abstract}
“(...) proponha o Sr. Raposo aos seus colegas que sustem o convite aos professores, e me enviem antes algum ou alguns analfabetos, crianças ou macróbios, e formarão o seu juízo antes de proceder a despesas mais importantes. Não querer que os professores venham cá ouvir explicações do método, quando mesmo o Sr. Raposo está muito longe de o compreender, como prova sempre que se refere a ele mais particularmente, é um voto que mal se explica. (...) Para desenganar o Sr. Raposo e acabar de convencer os seus colegas peço oito dias, isto é, oito horas. A respeito do nosso método, o dia não pode ter mais que sessenta minutos. Mas seriamente será ainda necessário provas? Pois à vista do que vai no país com o método, qual será a pessoa sensata que duvide se há ali alguma coisa de extraordinário, uma nova luz, uma verdade desconhecida e utilíssima?’367
\end{abstract}

A não aprovação imediata da Cartilha Maternal se deveu - segundo seu autor - a algumas frases que foram interpretadas como republicanas, como é o caso da expressão: "sombra espessa da monarquia". Isso não impediu, entretanto, João de Deus de se sentir

364 "Já lhe chamaram o novo Colombo da escola, o Cristo duma nova religião, de que ele por modéstia se declarou papa infalível. Nem no país nem fora do país, jamais houve métodos de leitura racionais, humanos; e só a Cartilha Maternal possui esses atributos. Pela minha parte, juro-te, meu Luciano, que hei de lutar e protestar contra estas imposições autoritárias, indiscutíveis; e hei de fazer todo o possível para que a ciência e a experiência respondam categoricamente as afirmações gratuitas do autor da Cartilha Maternal. (...) e, com ela na mão, tentarei demonstrar que nem é maternal, nem tem originalidade alguma, nem é racionalmente metódica em face da ciência da linguagem, nem trouxe à escola portuguesa melhoramento algum (...)” (José António Simões RAPOSO, Commércio de Lisboa, 7-1-1879, In: João de Deus, A Cartilha Maternal e a crítica, p. 445)

365 "Raposo e os idiotas como Alfredo de Brito que presumiram entender a Cartilha, e até se encarregaram de lhe fazer a crítica, dizem que a leitura da palavra por inteiro está atrasada cinquenta anos nos fastos da pedagogia normal da Europa civilizada. Querem dizer que eu ensino a palavra por inteiro!" (JOÃO DE DEUS, Novidades, In: A Cartilha Maternal e a crítica, p. 57). Ora, é claro, que ele ensinava a palavra por inteiro. Talvez quisesse disfarçar isso por não ser bem compreendido em sua época. Mas aí estava justamente a grande inovação do método!

366 "Ponderando que não estava provado que assim fosse, pois o seu autor e os seus defensores tinham fugido ao repto de provas públicas e práticas que alguns professores lhe propuseram, e que, sendo lícito a qualquer veredor ter (particularmente) sobre a Cartilha Maternal as opiniões favoráveis ou desfavoráveis que melhor lhe aprouvesse, me parecia menos lícito por parte de um corpo coletivo municipal, deprimir, por uma afirmativa gratuita, o mérito de muitos métodos aprovados pelo governo e bem aceitos pela imprensa e pela opinião pública, como se demonstra pelas suas numerosas e repetidas edições.” (José António Simões RAPOSO, Commércio de Lisboa, 26-4-1879, In: João de Deus, A Cartilha Maternal e a crítica, p. 61)

${ }^{367}$ JOÃO DE DEUS, Novidades, In: A Cartilha Maternal e a crítica, p. 65-6. 
lesado quando outras obras - segundo eles menores e que constituíam apenas plagiato ou contrabando literário - foram aprovadas pela mesma junta consultiva, que tanto relutava no caso da unanimemente reconhecida Cartilha Maternal. ${ }^{368}$ Verificaremos particularmente no último capítulo desta tese que o mercado editorial do livro didático e a aprovação dos mesmos livros pelo órgão governamental competente eram peças de um jogo de poder e dinheiro bastante destacado em Portugal de meados do século XIX. Os critérios pedagógicos evidentemente subordinar-se-iam à questão do mercado e das relações com a corte monárquica.

Foram muitas as polêmicas e inquietações que João de Deus teria com a apropriação que outros fariam de seu método. Entretanto, talvez a que mais lhe tenha incomodado foi a que relataremos a seguir. Ao tomar contato com o método de um dito Felizardo Lima, de Vila Meã, no concelho de Amarante, João de Deus se surpreenderia com a disputa que, desde o princípio, o autor da chamada Cartilha Infantil parecia desejar travar com a Cartilha Maternal.

O método de Felizardo Lima, embora não fosse novo, dado que o autor tinha grande experiência anterior, parecia agora renovado, a partir de uma suposta metodologia sincrética, da qual o autor também se vangloriava, e que se dizia basear na fusão dos princípios de Castilho com os de João de Deus, na pretensão de, evidentemente, superar a ambos A nova cartilha no prelo era anunciada por vários jornais do Norte e prometia ser enviada pelo correio, além de dizer que ensinava a ler em 20 dias. Outro anúncio no jornal Penafidelense garantia que desde o ano de 1863 - há quinze anos, portanto, daquela publicação - o dito educador costumava ensinar a ler e a escrever em três meses. Nos últimos tempos, fazia até provas públicas para certificar que era capaz de levar trabalhadores do concelho de Torres Vedras, de Amarante, de Penafiel, a aprenderem a ler e escrever em 47 lições. Dizendo possuir significativa vantagem sobre os procedimentos de ensino desenvolvidos por João de Deus, Lima oferecia seus préstimos às Câmaras Municipais, "sem outra remuneração que o abono da despesa em jornadas, que só receberá depois de obtidos os resultados que promete" ${ }^{369}$. João de Deus, que, como realça Theóphilo Braga ${ }^{370}$, era - nos

\footnotetext{
${ }^{368}$ Quando João de Deus se referia à sua Cartilha e à hesitação da Junta Consultiva da Instrução Pública em aprová-la, sempre manifestava seu otimismo e confiança em relação aos méritos da cartilha que fizera. Além disso, costumava dizer que "a Junta não peca pelo rigor, mas pela extrema benevolência.(...) Tais juntas partem do princípio de estimular o trabalho no gênero didático. Se a obra não ofende à religião nem ao estado é aprovada." ( JOÃO DE DEUS, Diário Popular, 16-11-1878, In: A Cartilha Maternal e a crítica, p. 77 ) Mas quando outras obras notoriamente menores passaram a ser aprovadas, a própria imprensa reagiu em prol de João de Deus. No mesmo dia daquela observação do poeta, outro jornal trazia o seguinte: "A junta consultiva de instrução pública tem em seu poder, há perto de um ano, um requerimento em que se lhe pediu parecer acerca da Cartilha Maternal do sr. João de Deus. A junta nada deliberou até o presente; medita sobre o caso; e talvez no ano de dois mil se resolva a apresentar o fruto das suas profundas meditações. Enquanto a junta medita, lembra-se um curioso de imitar e contrafazer a Cartilha Maternal; e sujeitando a contrafação à aprovação de mesma junta, consegue em poucos dias parecer favorável e aprovação do contrabando literário para uso das escolas!? Dá-se porém a circunstância de ter o sr. Dr. João de Deus requerido a apreensão do contrabando, e de ter o poder judicial ordenado um arresto da tal cartilha, que a estas horas se acha lacrada e selada com os selos da justiça. Parece-nos inútil qualquer comentário. A junta não aprova o original; mas aprova a contrafacção!!! É curioso." (DIÁRIO POPULAR, 16-11-1878, In: João de Deus, A Cartilha Maternal e a crítica , p. 75-6 ). Verificaremos, particularmente no último capítulo desta tese, o quanto o mercado editorial do livro didático passara a ser no século XIX português um mundo à parte, sendo, por seu turno, o problema das aprovações pelos pelos órgãos competentes parte de uma trama intrincada que envolve poder e dinheiro, bem mais do que pedagogia.

${ }^{369}$ PENAFIDELENSE, In: João de Deus, A Cartilha Maternal e a crítica, p. 82.

370 "O método de leitura propagou-se por todos os municípios e fundaram-se Escolas Móveis, que o ensinaram com vantagem em toda a parte. Mas o poeta teve de lutar para arrancar a Cartilha Maternal da exploração de ávidos livreiros, das imitações sofísticas, e, por último, de uma cruzada de descrédito sustentada pelos professores normalistas de Lisboa. Nas polêmicas diárias da imprensa, João de Deus revelou-se um prosador de primeira ordem e um polemista cuja força era a noção do bom senso realçado pela fina ironia. Nenhum dos
} 
debates diários que a imprensa lhe reservava - um polemista de extrema grandeza, destacado pela fina ironia, rebate imediatamente, distanciando-se inclusive dos determinantes ideológicos que colocavam à esquerda seu recente opositor. Assim a 3 de janeiro de 1879, dizia no mesmo jornal Penafidelense - dirigindo-se em carta a seu redator - o seguinte:

"Há anos ouvi falar muito dum Felizardo Lima embaraçado pela polícia de Guimarães numa missão, não fiquei sabendo bem se republicana se socialista; e ouvi falar tanto, que me ficou o nome na memória. Há meses li no seu acreditado jornal que um Sr. Felizardo Lima, professor em Villa-Meã, colhera não sei que notáveis resultados do meu método de leitura misturado com o de Castilho. Duas coisas concluí logo: que o Felizardo de Guimarães não podia ser o professor de Villa-Meã; e que o professor de Villa-Meã não entendia nada do meu método."371

O poeta complementava dizendo que, muito embora sua Cartilha Maternal não fosse ainda o método oficial da escola portuguesa, ela era indubitavelmente o método nacional, por ser já reconhecida e utilizada por todo o território. Seria ela um dia o método europeu e quem sabe o método universal. Seu autor, ao dizer, reafirmava sua crença na própria glória. Felizardo Lima, por sua vez, principia sua resposta - dirigida à mesma redação do periódico Penafidelense com data de 15-1-1879 - justamente com excertos de jornais trocados anos antes pelos dois educadores - ele e João de Deus. O poeta teria citado seu nome e o ensino que oferecera naqueles estados do Norte como uma das mais cabais comprovações de que o aprendizado pela Cartilha Maternal era eficaz, honrando fundamentalmente ao setor mais progressistas dentre os que - liberais e democratas - dedicavam-se à causa da instrução. Na seqüência, Lima dá sua identidade e procura tornar evidente sua hipótese de que João de Deus não era assim tão único como ele próprio se pretendia:

\footnotetext{
"Tomando sempre a responsabilidade e conseqüências de maus atos, francamente declaro ao Sr. Dr. João de Deus que sou esse mesmo Felizardo Lima que em companhia de três amigos estive, há talvez três anos, para ser vítima, mais da ignorância que da selvageria do povo de Guimarães, porque alguma gente de 'tino' ( pode ser que fosse a polícia com s. diz ) espalhou que estávamos ali para proclamar a República e deitar as igrejas abaixo. Porém perdôo a esses pobres, como o Sr. também perdoa ao Conselho Superior de Instrução Pública não aprovar a sua Cartilha Maternal por lhe descobrir idéias republicanas; igualmente perdôo como cristão ao Sr. Dr. João de Deus abrir sua carta com este episódio de minha vida, e creio que tal denúncia muito influirá para decidir a sorte dos dois métodos de ensino, e talvez por isso o Sr. doutor entrasse por esse modo no assunto. (...) Os estados do Norte a que me refiro são Dinamarca, a Suécia e a Noruega (...) Nestes países se ensina em seis semanas a ler corretamente. E não seria necessário ir fora do país buscar o método chamado de João de Deus, porque, à parte sua teoria, o Sr. Júlio Caldas Aulete ensinou pelo mesmo método e com muito maior resultado, antes de aparecer a Cartilha Maternal." 372
}

ministros que dispunham do poder, e que tinham sido seus condiscípulos, souberam pagar uma dívida nacional. ” (THEÓPHILO BRAGA, João de Deus:escorço biobráphico, p. 26)

${ }^{371} \mathrm{Na}$ sequência da carta ao redator do jornal Penafidelense, João de Deus tornar-se-ia agressivo: "Depois comecei a ver uns anúncios do sr. Felizardo Lima, de Villa-Meã, em como do princípio do mês próximo futuro em diante enviaria uma Cartilha Infantil por onde se aprende a ler e escrever em 20 lições, a quem lhe remetesse 55 réis. Aqui a minha tentação e curiosidade foi reprimida pelas sguinte considerações: Tendo Portugal quatro milhões de habitantes, e havendo cinquenta mil pessoas ( na modesta proporção duma para cada oitenta) que enviassem, às atenças dos cinquenta mil exemplares correpondentes, os seus sessenta e dois mil e quinhentos cruzados (salvo o erro), achar-se-ia o sr. Felizardo Lima de Villa-Meã depositário duma soma evidentemente superior aos créditos bancários dum pobre professor de quaquer vila. Assim pois encostei-me aos ditames da prudência, e tenho esperado a obra se imprima e ponha à venda nas lojas e na forma de costume." (JOÃO DE DEUS, Penafidelense, 3-1-1879, In: A Cartilha Maternal e a crítica, p. 82-3)

${ }^{372}$ Felizardo LIMA, Penafidelense, 15-1-1879, In: João de Deus, A Cartilha Maternal e a crítica, p. 87-8. 
Demonstrando então que, nas diferentes etapas de sua longa trajetória, toda ela dedicada ao estudo e à prática da alfabetização, ele tentara e obtivera sucesso com variados métodos, Felizardo Lima diz haver constatado que o método que teve a oportunidade de formular levava vantagem sobre o de João de Deus. Pretendia provar isso. Desafia então os brios do poeta. Sugere que fossem reunidos alguns analfabetos de qualquer freguesia do país, metade para serem ensinados por João de Deus e a outra metade por ele, Lima; cada qual evidentemente com seu respectivo método. No final de 20 dias, os discípulos de ambos seriam apresentados em reunião pública para que o público decidisse qual dos dois dera o melhor resultado. Logo nos meses seguintes, Felizardo Lima tomaria contato com as críticas efetuadas por Francisco do Amaral Cirne Jr. No mês de Setembro de 1879, afirmava-se partidáriodo que dissera o mais veemente dos críticos de João de Deus.

Durante todo aquele ano de 1879, houve grande número de debates e requerimentos dirigidos à Câmara dos Deputados solicitando do governo os investimentos de recursos, quer com o estudo e o ensino do método de João de Deus, quer com sua adoção. Havia, como contraponto, também uma representação de professores primários de Lisboa, solicitando do legislativo que, "no caso de ser votada a proposta com relação ao método de João de Deus, se estabeleçam cursos paralelos em que se pratiquem os outros métodos em uso, a fim de conhecer-se o que dá mais vantagens no ensino." ${ }^{373}$ Este sim seria aquele que se deveria uniformemente utilizar por todo o território nacional. Naquela ocasião e a propósito disso, é João de Deus quem propõe um desafio a um daqueles professores que assinavam a carta, a quem ele nesse momento elege como crítico dileto; ele, que sempre se recusara a aceitar desafios de outros opositores, aqui, provavelmente privilegiava o interlocutor. A 21-51879, João de Deus sugeria a M. J. Martins Contreiras que fosse feita uma disputa no ensino: um dos lados com seu método; o outro com um método qualquer. Cada facção teria um padrinho, e Theóphilo Braga, que a princípio deveria ser o padrinho de João de Deus, acaba por ser escolhido como árbitro da contenda. Contreiras opta por valer-se do método legográfico que, na ocasião era verdadeiramente o que mais ameaçava João de Deus, pela promessa que fazia do ensino simultâneo da leitura com a escrita. Na verdade, Contreiras, naquele momento, não desejava a adoção oficial deste ou daquele método, mas defendia a liberdade de escolha do professor de acordo com o que ele mais se familiarizasse. Acreditava inclusive que seria tarefa da escola normal ensinar a seus alunos-mestres diferentes métodos, diferentes procedimentos educativos, diferentes técnicas de ensino, de modo a verdadeiramente habilitá-los pelo conhecimento polivalente de seu ofício. Dizia então Contreiras que "desviar pois alunos mestres para o estudo especial dum método e para a prática do mesmo, seria expô-los a ficarem ignorando todos os outros, obstar a que adquirissem conhecimentos que lhe são igualmente necessários" ${ }^{\text {374 }}$. Quando escolhe para o debate com João de Deus o método legográfico, provavelmente Contreiras desejasse, portanto, apenas provocar o oponente, por saber que a cartilha de Caldas Aulete assustava o poeta, como nenhuma outra o fazia. João de Deus, no calor da polêmica, procurava descaracterizar aquela preocupação do seu crítico com assuntos de pedagogia, dizendo-lhe o seguinte:

\footnotetext{
"Diz o professor: eu não conheço, nem quero conhecer a Cartilha Maternal; eu normalista, eu lente de pedagogia e metodologia incomparável (...), eu que conheço todos os métodos nacionais e estrangeiros; que sei que b p são explosivas; $r$, rebolante; e 1, tremulante; que sei a análise da fala como o Padre Nosso ; como hei de eu descer da minha dignidade a ouvir um profano, um curioso que nunca assomou às portas de Marvilla, ou antes Maravilha como lhe chamam lá fora na Suíssa
}

\footnotetext{
${ }^{373}$ DIÁRIO DE NOTÍCIAS, 10-5-1879, In: João de Deus, A Cartilha Maternal e a crítica, p. 122.

${ }^{374}$ M. J. Martins CONTREIRAS, Democracia, 1-6-1879, In: João de Deus, A Cartilha Maternal e a crítica, p. 139.
} 
e na Suécia ? Todo o inspetor sensato dirá: o Sr. Professor discorre como um Demóstenes: mas a sua dignidade é tal, que mal lhe fica a humilde cadeira dum mestre-escola! O governo fundado na opinião pública, e ainda no voto de homens competentíssimos a quem incumbiu de estudar teórica e praticamente os vários métodos, quer que todos os professores conheçam a Cartilha Maternal, deixando-lhes a liberdade de a não seguir; mas não lhe deixa a liberdade de a não conhecer, de a substituir pela inépcia. O governo, o tesouro não paga as vaidades nem insânias, principalmente das que complicam com os mais sagrados interesses sociais. O governo vai dispensar ao sr. Professor os seus serviços; e eu da minha parte recomendo-lhe que funde por sua conta um ateneu de eloquência...."375

Com o fito de convencer a opinião pública e particularmente a categoria dos professores, João de Deus - hábil e retoricamente - pretendia aproximar-se dela, pela simplicidade e pela excessiva valorização da prática de sala de aula em detrimento das teorias educacionais, às quais tantas vezes seus debatedores recorriam. Sobre o tema do método, dizia que o parecer de Contreiras defendia antes a liberdade da ignorância do que a liberdade de escolha, o que - convenhamos - não deixa de ser verdade. Com isso o propósito do autor era o de angariar a simpatia dos leitores que, pela própria história de vida enquanto professores, estariam distanciados dos contatos com o exterior e das vastas experiências teóricas de Contreiras, identificando-se mais com o estilo dito por João de Deus. A estratégia do poeta assim como ele fizera anteriormente com crianças que com os métodos habituais da escola portuguesa não teriam sido capazes de aprender a ler - pautava-se no esforço de devolver ao leitor e professor comum a confiança em seu trabalho e a auto-estima; o que serviria - para além de encontrar partidários - também para propagar, divulgar e impulsionar o uso escolar da Cartilha Maternal. Todo o argumento de Contreiras leva a crer que realmente havia um projeto embutido naquela movimentação parlamentar sobre a causa da instrução, cujo vértice seria a provável adoção do método de João de Deus nas escolas, o que seria injustificável, dado que nem Castilho, nem a Gramática Nacional de Caldas Aulete conseguiram tal favoritismo. Além disso, qualquer imposição oficial dogmaticamente determinada consistia na transmutação do saber humano em dogma e a negação do prospecto de aperfeiçoamento intermitente do homem. Sobre sua história de vida como professor, Contreiras relata:

\footnotetext{
"Pratiquei o método legográfico na aula anexa à normal, quando o meu falecido professor Caldas Aulete andava organizando a Cartilha Nacional, sob o plano de J. Halben. Estou convencido que embora a arte de ler e a de traçar caracteres sejam diferentes, a leitura e a escrita completam-se e auxiliam-se, porque têm a mesma base e o mesmo fim: a idéia. Um curso noturno, de 90 alunos, que lecionei em Oeiras, determinou pelos resultados práticos, a minha predileção pelo método legográfico, que usarei ao efetuar-se o nosso certamen. E aumenta a força da minha convicção, quando leio os jornais pedagógicos da Bélgica, e vejo que presentemente há uma luta entre os partidários deste método a que chamam o método do futuro e os seus adversários que não apresentam um argumento sério para o combater.!"376
}

\footnotetext{
${ }^{375}$ JOÃO DE DEUS, Democracia, 17-6-1879, In: A Cartilha Maternal e a crítica, p. 143-4. É de se notar que, no index de seu Resumo da história da pedagogia, Francisco do Amaral Cirne Jr. coloca Caldas Aulete como um dos grandes pedagogos portugueses do século XIX, junto com Garrett, Castilho e João de Deus. (op. cit., p. 209)

${ }^{376}$ M. J. Martins CONTREIRAS, Democracia, 18-6-1879, In: João de Deus, a Cartilha Maternal e a crítica, p. 152. "Frequentava eu a escola normal de Marvilla, em 1869, quando o ilustre professor Caldas Aulete (...) apresentou a seus discípulos o manuscrito da Cartilha Nacional, fazendo na presença do curso alguns exercícios práticos. Nas conferências pedagógicas que, por esse tempo, se realizaram entre os alunos, presididos pelo distinto diretor da escola, discutiu-se e apreciou-se em todos os sentidos a cartilha, que vinha iniciar entre nós o método legográfico, os exercícios simultâneos de leitura e escrita. Pouco depois ela foi praticada na escola acadêmica, e muitos dos discípulos de Caldas Aulete, em cujo número me encontro, não deixaram de procurar praticamente também em suas escolas a confirmação das teorias que o ensino normal lhes apresentara. Provam-no as diversas edições tiradas, apesar do elevado preço por que se vende a Cartilha
} 
Contreiras costumava também fazer a apologia da imprensa e a necessidade da educação para a leitura no sentido de capacitar as gerações mais jovens a fazerem melhor uso do jornal, como um agente transmissor das forças intelectuais da nação. Recorda que Caldas Aulete, inclusive para fazer sua obra, costumava consultar e referenciar-se por diferentes jornais e compêndios estrangeiros, o que teria evidentemente contribuído para o bom resultado que obtivera. Contreiras por fim desafia João de Deus quanto ao próprio mérito de sua cartilha, dizendo que não parece natural ensinar a ligação das vogais antes mesmo de se haver explicado às crianças quais eram as vogais. Acrescenta que, em termos dos princípios positivos da linguística, mesmo a cartilha tradicional, por mais caluniada que houvesse sido, tinha mais razão de ser que a dita maternal. Sucede que em um daqueles textos e cartas enviadas à imprensa, Contreiras remetera para o redator do jornal Democracia o método de leitura que acabara de concluir: Cartilha da Escola. Diante de tal oportunismo, João de Deus desfaz o desafio, acusando a cartilha de Contreiras de plágio da de Caldas Aulete e declarando que o único interesse daquele seu opositor seria o de promover seu método à custa da polêmica. $^{377}$

Seja como for, todos pareciam concordar no seguinte: era necessário aprimorar a escola para capacitar o povo para esse diálogo escrito. Realmente, a despeito ou mesmo sob o auxílio de todas aquelas polêmicas, o método de leitura preconizado por João de Deus teve um alcance ímpar na opiniao pública portuguesa, que - verdade seja dita - o recebeu com simpatia. Chegou-se a destacar o fato de a Cartilha Maternal adequar-se inclusive àquelas famílias que não desejavam para seus filhos a perda do tempo de trabalho com o estudo. $\mathrm{O}$ ensino rápido da leitura permitiria a conciliação entre o tempo do plantio e da colheita e o tempo da escola. E com isso, quem sabe, o país poderia mudar seu modo de olhar tão indiferente para a escola e para os benefícios da instrução. Pelo relato do autor, decalcava-se o retrato de uma instituição que clamava por mudanças urgentes:

\begin{abstract}
“É verdade que o professor tinha antigamente o desabafo na palmatória, e ainda hoje lhe resta o puxão de orelhas; mas a experiência prova que tal desabafo ou alívio é insuficiente. O professor zeloso, que ensina ele mesmo os seus discípulos, chega de ordinário a atra-bilis. Ver-se-á rir o trabalhador de enchada; mas ele, nunca. Não é a tristeza da anemia orçamental; é o fel que lhe inquina as veias. D'um se conta, chegado a tais hábitos de ferocidade, que perguntando a um discípulo: quem fez o mundo? A criança caiu de joelhos e de mãos postas a gritar: eu não fui, senhor mestre! Estavam todos desorientados, mestres e discípulos. E com certeza; ensino absurdo, a entes essencialmente racionais - desesperação comum! Porque a criança é lógica. Perguntava eu um dia a um menino: por que não vais tu à escola? - Eu não sei ler! E com razão: ele passava pela escola, via todos a ler, o que ia ele lá fazer? Mas acrescentei: por isso mesmo, deves ir aprender. Mas o meu António não sabe e não vai?...Resposta profundamente lógica e moral. O António era o irmão mais velho. Por isto se vê que os meses e os anos levados na escola inutilmente, não é incapacidade do discípulo, mas insuficiência do mestre ou vício do sistema. Como há de a criança compreender que cê á faz ká, se é impossível? O que pode é decorar a fórmula; mas primeiro que fixe uma infinidade de absurdos semelhantes, tem ralado o mestre e minado a própria existência. Deus livre principalmente as crianças mais inteligentes, d'um ensino irracional; as menos alumiadas aceitam melhor aquelas imposições brutais." 378
\end{abstract}

\footnotetext{
Nacional.” (M. J. Martins CONTREIRAS, Democracia, 8-12-1879, In: João de Deus, A Cartilha Maternal e a crítica, p. 201).

377 "Como se explica isto? O Sr. Contreiras já disse, que se faz uma cartilha foi porque não achou à venda a terceira edicação da Cartilha de Caldas Aulete. Naturalmente aquela edição de 1870 é a terceira que o sr. Contreiras buscava e não achou. E como não achou, o meio de se efetuar o nosso desafio era fazer uma semelhante." (João de Deus, Commércio de Portugal, 20-2-1880, In: A Cartilha Maternal e a crítica, p. 230) 378 JOÃO DE DEUS, Cartilha Maternal e a imprensa, p. 29.
} 
João de Deus, naqueles últimos decênios da monarquia, realmente teria seu método apropriado por inúmeros dos arautos republicanos em Portugal. Passa a haver naqueles anos intenso debate sobre o problema da instrução pública, e, talvez pela aproximação do final do século, talvez pelo rearranjo econômico e o rápido desenvolvimento de alguns países europeus, o atraso português parecia cada vez mais evidente. Em Coimbra de 1880, a Câmara Municipal fazia sessão solene para examinar alguns alunos da escola municipal regida pelo método João de Deus. O final de século tornava a educação um rito cada vez mais visível, destacado pelo acompanhamento incansável dos jornais. ${ }^{379}$ Por sua vez, os congressos e conferências pedagógicas que se intensificariam a partir dos anos 80, coordenados em geral por integrantes da Liga Nacional de Instrução, impulsionariam a Associação das Escolas Móveis pelo método João de Deus, que, fundada em 1882, teria promovido - segundo dados de Catroga - "149 missões escolares, o que representava uma média de 7 missões anuais; em 1908, esse número foi de 18, que envolveram 1.153 alunos, o que perfez um total de 9.664, isto é, 420 alunos por ano; e, em 1909, a associação contava com 1.705 sócios. ${ }^{" 380}$ Em 1890, a Revista de Educação e Ensino trazia com freqüência comentários sobre a boa repercussão social ocasionada pelo Método João de Deus quando aplicado às escolas primárias e particularmente se ressaltava o valor social representado pela iniciativa das Escolas Móveis. Naquele ano, já havia 50 missões da Associação das Escolas Móveis João de Deus. O projeto de lei das Escolas Móveis supunha - como constava da mesma revista - o seguinte: 1) ensino da leitura, escrita e quatro operações pelo método João de Deus; 2) as Escolas Móveis seriam enviadas para os distritos que mais carecessem de instrução e deveriam funcionar durante cinco meses; 3) o ministro de Estado dos negócios da instrução pública e belas-artes era o responsável para o envio das escolas; 4) o local, dia e horário dos cursos seriam estabelecidos pelo Presidente da Câmara, conforme as conveniências locais; 5) a duração do curso seria inicialmente de três horas, podendo prolongar-se até quatro, no caso de haver um só; 6) após os 5 meses previstos para duração dos cursos seria realizado, em dia de feriado ou domingo, o exame dos alunos, cerimônia que contaria com a presença de todas as autoridades civis, eclesiásticas e militares da região, o que

\footnotetext{
379 Perante o público, perante os vereadores e perante os examinadores convidados, os alunos da escola municipal regida pela Cartilha Maternal reuniram-se em uma das salas do novo paço do Concelho de Coimbra e - segundo consta do noticiário jornalístico - deram provas de efetivo adiantamento. Nas palavras da imprensa: "Estando presentes a vereação, o Sr. Comissário dos Estudos, o Sr. Administrador do Concelho, bastantes professores e muitos cavalheiros de diversas classes, o digno representante da Câmara expôs o fim daquela reunião e convidou o ilustrado professor da escola municipal, o Sr. Gonçalves da Cunha, a fazer uma breve exposição do método, ao que o mesmo professor satisfez explicando as tabelas, clara, mas resumidamente." (CORRESPONDÊNCIA DE COIMBRA, 16-3-1880, In: João de Deus, A Cartilha Maternal e a crítica, p. 255).

${ }^{380}$ Fernando CATROGA, O republicanismo em Portugal..., segunda parte, p. 397. Continua Catroga: "Dir-seá que os resultados foram escassos. Porém, aqui importa sublinhar que o entusiasmo pelo método de João de Deus tinha muito a ver com a crença na superioridade pedagógica em relação aos concorrentes e, em particular, ao de Castilho, e por se pensar que iria ser um grande instrumento de democratização do ensino elementar. Neste contexto são explicáveis as propostas republicanas para que o método fosse apoiado e aprovado oficialmente, e torna-se lógico o louvor público que, em 24 de janeiro de 1911, o Governo Provisório da jovem República se apressou a dar à Associação das Escolas Móveis e a seu fundador. O decreto de 29 de maio de 1911 (artigo $8^{\circ}$ ) criava Escolas Móveis oficiais nas freguesias em que não pudessem ser imediatamente fundadas escolas fixas, que ficaram a coexistir com as da Associação até 1920. E os adeptos do método de João de Deus entendiam que este proselitismo a bem da educação popular constituía uma gesta de verdadeira missionação." ( Id. Ibid., p. 398).
} 
faria por supor uma solenidade festiva para se proceder ao encerramento do processo. $\mathrm{O}$ artigo terceiro do projeto previa, entretanto que:

\begin{abstract}
"Se o número de alunos matriculados exceder a quarenta, haverá um curso diurno, outro noturno, sendo o primeiro para crianças d'ambos os sexos e mulheres, e o noturno para adultos do sexo masculino. Num e noutro curso, se receberão homens, mulheres e crianças se alegarem que não podem pela distância da sua residência, trabalho ou outro motivo justo, frequentar o curso que, em regra, lhes pertencia." 381
\end{abstract}

Dizia João de Sousa Tavares na sala de sessões da Câmara dos Deputados em Lisboa, no ano de 1908, quando finalmente se daria o reconhecimento oficial das Escolas Móveis, que, dos 13.115 analfabetos matriculados nelas, as Escolas Móveis teriam conseguido apenas 36,2\% ( ou 4.748 alunos ) de aproveitamento. Mesmo assim, a partir daquela data, as Escolas Móveis ficariam isentas de tributos pelas doações que recebessem e o governo mandaria imprimir seu Boletim Anual. ${ }^{382}$ Nessa medida, o objetivo declarado das Escolas Móveis seria, desde o princípio, o de "tornar todos os portugueses iguais perante a palavra escrita. E pur si muove. Todo aquele que soubesse ler, escrever e contar, tendo massa cinzenta suficiente, saberia abrir novos horizontes à sua atividade." Com tais palavras Casimiro Freire - o fundador das Escolas Móveis - definia o objetivo daquela agremiação que militava pela causa da instrução em nome da memória de João de Deus. ${ }^{383}$ Os cursos ambulantes, que preparariam para os rudimentos da leitura, da escrita e do cálculo, habilitariam , no decorrer de 4 ou de 6 meses, o indivíduo para que, no trabalho, ele pudesse depois adquirir os indispensáveis conhecimentos profissionais.

Os professores das Escolas Móveis chegariam às localidades e durante alguns dias encarregar-se-iam da matrícula dos alunos - crianças e adultos dos dois sexos- que pretendiam ser inscritos. Verificariam na ocasião se os alunos eram completamente analfabetos ou se teriam algum reconhecimento da escrita. O programa das atividades estaria contido no programa de leitura da Cartilha Maternal seguida pela leitura da tradução que João de Deus fizera da obra Deveres dos filhos. Além disso, os alunos deveriam ser avaliados com ditados e cópias feitas no quadro, no reconhecimento e desenvoltura nas quatro operações. Deveria haver inspeção sobre as atividades das Escolas Móveis por parte de reconhecidas autoridades locais na área da pedagogia.

Com o intenso debate travado em torno de seu método, João de Deus terá com Castilho o lugar de destaque assegurado pela memória pedagógica em Portugal. A discussão

\footnotetext{
${ }^{381}$ INSTRUCÇÃO popular: Escolas Móveis, In: Revista de Educação e Ensino, volume V, 1890, p. 315. No volume 3 daquela mesma revista, havia outro artigo intitulado “João de Deus e a Cartilha Maternal”, escrito por Ferreira Deusdado, onde se destacava a dívida do país para com aquele educador, cuja obra pedagógica evidentemente sinalizava para a diminuição progressiva das vergonhosas taxas de analfabetismo. Dizia ainda o artigo que João de Deus tinha compreendido a necessidade de se efetuar a obra que Castilho já houvera anteriormente projetado no sentido de civilizar o povo português até como maneira de aprimorar-lhe o potencial de sua alma. A eficácia e o êxito do reconhecimento público que obtivera colocavam a Cartilha Maternal como o verdadeiro Método Português. Naquela ocasião, Augusto Ribeiro, presidente da comissão encarregada dos assuntos educacionais na Câmara dos Deputados, fazia um projeto de lei que autorizava o governo a criar o cargo de um Comissário especial para cuidar do acompanhamento do método João de Deus. A comissão da Câmara foi, no entanto, contrária à aprovação daquele projeto, assim como não aprovaria a implementação oficial do método, entendendo que o professor não deveria ser tomado como correia de transmissão de idéias dos outros, mas antes como um elemento ativo no processo do aprendizado, o que suporia, por definição, a liberdade de ensino.

382 José de Sousa TAVARES, O reconhecimento official das Escolas Móveis pelo Methodo João de Deus no Parlamento, In: João de Deus RAMOS, A intrucção do povo; boletim das Escolas Móveis pelo Methodo João de Deus, III anno, $2^{\text {a }}$ série, $\mathrm{n}^{\text {o }}$ 1, 1908, p. 9-10.

383 Casimiro FREIRE, Por que se instituíram as Escolas Móveis, In: João de Deus RAMOS, A instrucção do povo..., III tomo, $2^{\mathrm{a}}$ série, $\mathrm{n}^{\mathrm{o}} 1$, p. 3-4.
} 
das idéias, seja como for, não se confunde com a implementação de práticas a elas irredutivelmente acopladas. Tomar a história do ideário pedagógico, no nível de suas representações, como se de práticas se tratasse, tem sido inequivocamente uma das mais sedutoras ilusões da história da educação. Veremos, em capítulos seguintes, que o cotidiano da sala de aula em Portugal tinha àquela altura uma autonomia própria e o que lá se fazia não coincidia exatamente com o teor caloroso do debate. A escolarização - como já se atentou inúmeras vezes - tem uma lógica própria, que compreende certos ritos, certos saberes, certos valores, tomados talvez por apropriação do leque mais extenso da cultura social, mas apresentando inequivocamente uma fisionomia particular, muito específica, e que precisa ser estudada se pretendermos de fato obter dados sobre a escola em sua brutalidade. O campo das idéias deverá ser, pois, acompanhado da procura dessa singularidade escolar, em seu movimento, naquilo que se apresentava como dinâmica e funcionamento interno à instituição, muitas vezes alheia ao que sobre ela se dizia. ${ }^{384}$

Poderíamos, aliás, a propósito do tema, recordar que são inúmeros os autores atuais que exploram essa vertente do que designam por modelo (António Nóvoa), forma (Guy Vincent), ou gramática escolar (David Tyach). Seria - dizem os especialistas da História da Educação - uma relação pedagógica inédita essa que, com a modernidade, se estruturará nos países europeus. A escola, ao se apropriar da tarefa educativa que anteriormente era reservada a outros setores sociais, particularmente à família, institui práticas inusitadas de formação do comportamento religioso e da conduta civil, de conformação de hábitos de obediência e de disciplina, de treino para submissão às autoridades e táticas visando o controle do corpo e dos impulsos. Haveria, sob tal perspectiva, regras impessoais que determinariam a dinâmica da instituição; sob tais regras, deveriam ser normatizadas as atitudes dos mestres e dos discípulos. Essa configuração da escola tende, por definição, ao ensino simultâneo, embora não haja inequivocamente se confundido com ele, posto que, durante muito tempo, sobreviveram práticas de ensino individualizadas. Mas tratava-se fundamentalmente da transmissão e aquisição de competências e habilidades, que, de modo algum, reduziam-se ao domínio cognitivo, abarcando - por assim dizer - aspectos afetivos, motores, corporais e emocionais. O objetivo talvez não declarado da escola era, sim, alcançar um patamar onde o professor pudesse falar a todos os alunos como se eles constituíssem um só corpo moral Recorde-se aqui o projeto tantas vezes assinalado por Castilho. $\mathrm{O}$ interlocutor do professor da escola primária é um só: o conjunto homogeneizado de seus discípulos enfileirados. A escola, que transmite supostamente o saber, veicularia também o código das classificações e as teias de poder, tal como estas se dispõem na organização social. Faz isso - a escola - por palavras e por gestos, demarcando por sinais e por algum arbitrário conceitual e valorativo, aquilo que revestido sob o signo da cultura - procuraria preparar para a vida social, tal como esta estaria já constituída: com seus desajustes, suas distribuições, suas hierarquias, as intenções prescritas e os resultados permitidos, suas interdições, suas desigualdades; enfim, com suas injustiças... Acerca do tema, dirá Vincent: "A emergência da forma escolar, forma que se caracteriza por um conjunto coerente de atributos,
onde os primeiros que se devem citar são a constituição de um universo separado para a infância, a

\footnotetext{
${ }^{384}$ O trabalho de Silvina GVIRTZ, acerca dos cadernos escolares da Argentina entre 1930 e 1990 destaca que uma das características do discurso escolar consistiria exatamente em sua capacidade de administrar outros discursos, estabelecidos, por sua vez, em inúmeros universos de linguagem: “(...) o discurso escolar é diferente e irredutível a outros discursos, e torna-se no mínimo difícil aproximar-se de sua estrutura a partir da ideía de uma redução ou transposição de outros discursos." (Silvina GVIRTZ, El discurso escolar a traves de los cuadernos de clase: Argentina 1930-1990, p. 213). Os saberes disciplinares na escola organizar-se-iam de modo muito particular, estabelecendo, entretanto, de maneira entrelaçada, competências e habilidades fundamentalmente eficazes para a inserção do homem adulto da sociedade massificada: "homogeneização, compartimentalização, classificação e hierarquização”(Id. Ibid. , p. 193-194). A escola, apropriando-se a seu modo do mundo do poder e da cultura, agiria, então, até certo ponto, por conta própria.
} 
importância das regras no aprendizado, a organização racional do tempo, a multiplicação e a repetição de exercícios cuja única função é proporcionar o aprendizado e o aprendizado de acordo com regras, ou, dito de outro modo, tendo por fim seu próprio fim, que corresponde a um novo modo de socialização, o modo escolar de socialização. Este não cessa de se estender e de se generalizar para se tornar o modo de socialização dominante de nossas formações sociais." 385

Verificamos que o tempo de João de Deus era povoado por um imaginário absolutamente aficcionado pela idéia da perfectibilidade pela via da instrução. A escola era assim tomada como instituição regeneradora capaz de contribuir até para alterar a rota inscrita no destino das nações. Era preciso, dessa maneira, alcançar o segredo da alfabetização eficaz; era preciso desvendar os enigmas do aprendizado da leitura e da escrita. A intelectualidade portuguesa demonstrava ainda aquela simpatia pela instituição escolar, empatia ancorada na crença de que pela instrução se poderia retomar parte da glória perdida por séculos de decadência contínua. Havia que elevar Portugal à senda do progresso obtido pelas nações tidas por mais civilizadas do planeta; a escola cumpriria, nessa empreitada, uma função estratégica. Para que esse ideal pudesse, no entanto, ocorrer, era imprescindível que os alicerces básicos da instituição fossem diametralmente alterados, com o fito de ancorar em Portugal a escola da modernidade: uma escola capaz de trabalhar com uma população mais ampla; capaz de reproduzir e mesmo reordenar as margens classificatórias que trazem clivagens entre os homens na vida social. O discurso sobre a escola, para aqueles homens da Geração de 70 , era ao mesmo tempo um discurso de exaltação e de crítica. Havia que se empreender esforços pela educação escolar, mas junto disso tornava-se absolutamente urgente a transformação daquela escola de onde fugiam crianças e famílias...

Segundo Joaquim Ferreira Gomes, mesmo antes da impressão da Cartilha Maternal, havia já quem ensinasse pelo método de João de Deus. O próprio poeta dava lições a cianças e a adultos e, pouco a pouco, iria se formando uma rede de professores que eram enviados por todo o país para divulgar o método. A Cartilha Maternal teria tido, nessa medida, ressonância prática, tanto em Portugal como no Brasil. Nos termos do mesmo historiador, teria sido efetivamente esse êxito precoce quem proporcionou, ou, no mínimo, alimentou o debate:

\footnotetext{
"À medida que o novo método ia sendo experimentado, um pouco por toda a parte, em todo o País, os jornais de Lisboa, do Porto e da Província fazem-se eco das críticas que iam surgindo: umas calmas, serenas e objetivas; outras talvez exageradamente laudatórias; e outras ainda apaixonadas e virulentas em demasia. Pedagogos e políticos sentem que têm uma palavra a dizer. Este contraste de reações, tantas vezes contraditórias, faz da polêmica em torno da Cartilha Maternal um capítulo apaixonante da nossa História da Educação.”386
}

Na verdade, a polêmica travada em torno do método João de Deus traz de volta a ambiguidade do discurso pedagógico português: efetivamente, aqui a questão metodológica

\footnotetext{
385 Guy VINCENT (org.), L'éducation prisonnière de la forme scolaire?, p. 39. No trabalho intitulado Tinkering toward utopia, David Tyack e Larry Cuban destacariam também a existência daquilo que eles qualificam como uma gramática própria que regula a vida da escola enquanto instituição. Para esses autores, essa gramática normativa e não redutível a quaisquer outras ordenações exteriores, tenderia a modelar esquemas muito particulares para a dinâmica da escolarização. De alguma forma, essa gramática possibilitaria o cumprimento do ritual cotidiano, tal como prevê o imaginário escolar em sua perspectiva histórica. Por tal razão, também no parecer desses dois autores, a escola tende a modificar intrinsecamente inclusive as reformas que são para ela projetadas.

386 Joaquim FERREIRA GOMES, A educação infantil em Portugal, p. 169.
} 
assume notória primazia, e a escola projetada não mais corresponderá ao modelo escolar vigente no período. Cumpre lembrar que desde Pombal, havia em Portugal a explícita preocupação quanto aos conteúdos curriculares organizadores dessa, que seria - antes de qualquer coisa - a escola do ler, escrever e contar. O debate ao redor do método de João de Deus, a exemplo do que acontecera anteriormente com Castilho, iria adquirir aspecto institucionalizado, pelo fato de seus partidários desejarem e defenderem sua adoção uniforme como método oficial das escolas do país. Assim como no caso de Castilho, o culto ao redor da personagem João de Deus contribuiria para obscurecer a objetividade quanto ao tratamento da questão. Ainda no final do século, em muitas sessões do parlamento, seria proposta a adoção oficial do método de João de Deus, que, no confronto com outras cartilhas - dizia-se - teria tido maior eficácia. ${ }^{387}$

A Reforma de 1836 estabelecia o seguinte quadro de matérias para a instrução primária: "ler, escrever e contar; civilidade, moral e doutrina cristã; gramática portuguesa; breves noções de história, geografia e constituição; desenho linear; exercícios ginásticos. A reforma concede a todo cidadão a liberdade de estabelecer escolas contanto que participe ao administrador do concelho qual o local da escola." ${ }^{388}$ Por sua vez, em 1844 a instrução obrigatória foi estabelecida para as crianças e jovens entre 7 e 15 anos de idade. A lei previa inclusive punição aos pais e tutores que não enviassem seus filhos à escola, prescrição essa que durante todo o transcorrer da monarquia constitucional ficou apenas como letra morta no papel, posto que não havia escolas em número e condições suficientes, não havia quaisquer mecanismos de formação dos mestres, não havia interesse por parte da família pela instrução oferecida, não havia vontade política dos poderes públicos no sentido de dar prioridade efetiva às práticas de educação popular. A escola portuguesa, pensada e posta em lei como uma necessidade, não existia como realidade necessária para o cotidiano das populações. Talvez porque, presos aos segredos das soluções de gabinete, os homens que pensavam a pedagogia pouco conhecessem acerca da realidade onde se inscrevia o aprendizado escolar.

Os anos 70, como vimos, transformaram a educação em ciência e, nessa medida, o tema da pedagogia teria como eixo a questão dos métodos e procedimentos de um ensino eminentemente racional, eficaz, científico. Na recorrente comparação feita entre os destinos dos povos e os percursos individuais, a preocupação educativa será tomada como estratégia privilegiada para superação do atraso, da constatada decadência. A tônica predominante nos autores do último quartel do século XIX será a de explicitar a aplicação educativa das doutrinas derivadas do evolucionismo, do darwinismo social, do positivismo. A preocupação com o método cada vez mais ocupará o lugar anteriormente reservado à circunscrição política do objeto educativo. Tal inflexão, sem dúvida alguma, deixou sua marca, na medida em que tornar-se letrado deixa de ser escolha cultural, para passar a se constituir como destino inexorável dos povos na caminhada da civilização. Sendo assim, o problema pedagógico principiaria a ser visto pela denúncia dos equívocos de uma prática restrita às tentativas inócuas da memorização. A carência quanto a dispositivos educacionais adequados é compreendida cada vez mais como a grande responsável pelo malogro da escolarização primária. Considera-se que a metodologia utilizada pelas escolas portuguesas estaria em completo desacordo com as tendências reveladas pela trajetória do espírito do século. A espécie humana é comparada aos sujeitos:

"Portanto, como a experiência o tem provado e a razão o está mostrando, qualquer criança aproveitará muito mais achando por si mesma as conclusões, que decorando-as já formuladas e impostas à sua fé pela autoridade do mestre ou do livro. As definições devem pois sair das

\footnotetext{
387 A INSTRUCÇÃO DO POVO e o methodo de João de Deus: representação á camara dos sns. deputados, publicada no Diario do Governo n 163 de 26 de Julho de 1897, p.10-11.

${ }^{388}$ F. A. do Amaral CIRNE JR., Resumo da história da pedagogia, p. 170.
} 
disciplinas, e não as disciplinas das definições. Semelhantemente o estudo da gramática há de ser posterior e não anterior ao estudo da língua. Assim somente se observará a lei geral do desenvolvimento do espírito humano, que manda seguir do simples para o composto, do indefinido para o definido, do concreto para o abstrato." 389

A racionalidade do processo educativo, ao contrário do que se vinha fazendo até então, derivaria dessa sensibilidade pedagógica para a compreensão do raciocínio infantil, que, por sua vez, não se sujeitaria às orientações do pensamento adulto. Caminhar por etapas era a tônica desse discurso em prol de uma educação nova, radicalmente diferenciada do que até então se fazia. O discurso pedagógico passa a advogar as "lições de cousas", como proposta alternativa à dogmática tradicional. De acordo com o que vem assinalado nas edições e nos periódicos com que à época o tema seria abordado, a finalidade desse modelo de ensino intuitivo seria primordialmente a condução das crianças para que, no processo de aprendizado, elas pudessem efetivamente observar as coisas, nomeá-las e compará-las com outras. O intuito das "lições de coisas" seria, portanto, permitir um aprendizado decorrente do exercício dos sentidos e do amadurecimento das capacidades de observação. ${ }^{390}$ Com isso, pretendia-se inovar as orientações usuais e os métodos já corriqueiros na escola tradicional. Começava, aliás, o discurso contra o tradicional em educação, tradição essa que é comumente confundida com as técnicas das definições decoradas. São sugeridos nos tratados pedagógicos dessa época procedimentos intuitivos para o ensino e, com freqüência, apresentava-se a articulação entre educação física, moral e intelectual. A esse respeito, os autores referenciarse-iam pela obra de Spencer, que tem justamente por título - na tradução portuguesa efetuada por Ricardo Jorge, exatamente Educação intelectual, moral e física. No Directorio de sua Cartilha Nacional, pela qual pretendia ensinar simultaneamente a "ler, escrever, ortografar e desenhar”, Júlio Caldas Aulete parte dessa tríplice classificação - sugerida por Spencer acerca do percurso educativo. Os escritos, com isso, pretendiam ser contrapostos às rotinas da instrução e, com isso, contribuir para erradicar algumas das práticas autoritárias e opressoras da escola portuguesa a seu tempo, fosse o uso imoderado da palmatória, fosse a excessiva imobilidade a que eram obrigados os estudantes. Pelo contrário, sugere Caldas Aulete:

\footnotetext{
"Quem há que não sinta apertar-se-lhe o coração ao ver as escolas povoadas de crianças de aspecto mórbido, raquíticas e tristes, parecendo mais filhos de algum condenado saídos de infesta enxovia, que filhos de pais livres e pela maior parte amimados dos dons da fortuna. E, se sondais a origem dessa degeneração, encontra-la-eis na vaidade, na ostentação de certos pais loucos, que, para se mostrarem homens do progresso, procuram apresentar seus filhos como prodígios da natureza, de
}

\footnotetext{
${ }^{389}$ Augusto Filippe SIMÕES, Educação physica, p.296.

${ }^{390} \mathrm{O}$ periódico $\mathbf{O}$ ensino publicava nos anos 80 inúmeros pareceres explicativos, defensores e contrários à introdução do modelo das "lições de coisas" nas escolas portuguesas. Referenciando-se por alguns dentre os mais destacados teóricos estrangeiros - Hippeau, Buisson, etc. - o periódico recordava que fôra nas escolas da Alemanha e da França que essa inovação produzira já seus melhores resultados. Mas havia quem, no mesmo jornal, não concordasse com a orientação tomada por seus apologistas. O artigo publicado a 31/7/1885 destaca que a pretensão de infalibilidade apresentada pelos partidários dessa técnica de 'lições de coisas' seria extremamente prejudicial para o debate acerca de sua adequação, tendo em vista a extrema carência a que ainda se sujeitava o ensino português. Escolas e professores não contariam, portanto, com os recursos necessários para adquirirem a vasta gama de manuais e de compêndios que os permitiria atualizarem-se, tendo em vista a aplicação da nova metodologia. Desconfiava-se, pelo contraponto com a realidade de todas e quaisquer inovações. Na sequência desse debate - vale a pena anotar - o mesmo periódico trazia exercícios de análise sintática do seguinte período: “A qual coisa, que depois que o Hidalcão caiu nela, assim o atormentou, além da perda de tamanho estado e de tanta injúria como nela recebeu por duas vezes, que partido ele capitão-mor para Málaca, mandou cercar aquela cidade, cujos lares ainda estavam quentes da habitação que nela fizeram alguns do que ali vinham." (O ENSINO, $1^{\circ}$ anno, $2^{\mathrm{a}}$ série, 31/7/1885, volume 1, n⿳⺈, p. 105) Efetivamente, não haveria nada menos intuitivo do que o conteúdo de um trecho como esse!
} 
descomunal talento. Quanto melhor não fôra que se gloriassem de exibir crianças vigorosas, risonhas como a primavera, vivazes e radiantes como a aurora. (...) Tratai sempre as crianças com benignidade. $O$ terror atrofia a inteligência e não melhora o coração. Os castigos corporais são um crime e um grave atentado contra a moral (...) $\mathrm{Na}$ escola onde presidir a justiça não haverá necessidade nunca de recorrer a esses meios criminosos e imorais. Na escola onde houver injustiça existirá sempre a indisciplina e a confusão. $\mathrm{O}$ homem habituado na juventude a ser tratado com prepotência e força, mais tarde empregará os mesmos meios brutais para com os seus inferiores. E ei-los entrados no caminho do crime. E se é crime entre homens o praticar sevícias contra alguém, por que o não há de ser no recinto da escola, exercidas contra crianças? Pois não é juntar a covardia ao crime?"391

O discurso pedagógico passa a se defender à época ao explicitar que a escola, enquanto agência moralizadora, teria por função precípua desviar a criança do caminho do mal, mediante atitudes disciplinadoras, preventivas desse contato. Ocorre que o caminho do mal precisava ser mostrado, até para que ele viesse a ser temido. Reconhecia-se o mundo como território regido por leis, cuja transgressão exigiria por si a severidade da punição. $\mathrm{O}$ imaginário escolar apresentar-se-ia, em última instância, como microcosmos dessa órbita maniqueísta; e a escola justificava com isso sua sinistra austeridade. ${ }^{392}$ De certo modo, utilizase crescentemente o recurso a práticas soi disant naturais para demonstrar a necessidade de firmar o domínio de uma normatividade social indeclinável e inquestionável, como se sua ordenação derivasse mesmo de fatores naturais. Além disso, a educação era vista como antídoto natural da desordem e da agitação social. Na organicidade do tecido social, a má educação seria, pois, ruína corruptora dos costumes, da ordem, das hierarquias pretensamente naturais.

O tema da educação, que indubitavelmente assumirá nova coloração a partir de meados do século, será abraçado pela Geração de 70 - como vimos - como uma alternativa para a decadência nacional. $O$ problema da decadência contrapunha-se por sua vez a um dado imaginário prospectivo, cuja tendência era basicamente a de rascunhar um Portugal do futuro, por meio do enfrentamento real dos problemas do presente. De qualquer maneira, eram distintas mundividências que, a pouco e pouco, iriam se impondo em Portugal. Como ressalta o trabalho de Catroga, o século XIX pautava-se pela ilusão de equacionar os dilemas sociais da humanidade a partir dos progressos efetuados no âmbito daquilo que supunha ser a Ciência:

"Com efeito, a história das idéias tem dado o devido relevo à influência que os avanços das
ciências da natureza exerceram na organização do espaço epistêmico dominante a partir de meados
do século XIX. Os sucessos da física, da química e da biologia deram ênfase à crença segundo a
qual a evolução da humanidade estaria a atingir o estádio em que toda a ordem de fenômenos,
incluindo a realidade social, receberia uma explicação pautada pelos cânones da teoria do
conhecimento subjacente às grandes descobertas científicas modernas. Como Michel Foucault

391 Júlio CALDAS AULETE, Directorio, In: Cartilha nacional ou methodo legographico para aprender simultaneamente a ler, escrever, ortographar e desenhar, sem página. Sobre o método legográfico, pudemos constatar, como já indicamos anteriormente, que ele teve um papel bem mais destacado na história da educação portuguesa do século XIX do que faz crer a literatura pedagógica posterior. Eram inúmeros os tratados teóricos sobre o ensino, até o princípio deste nosso século XX - ainda que algumas vezes fosse para criticar - que dialogavam com essa referência (vide, por exemplo, João de Deus RAMOS, Guia prático e teórico da Cartilha Maternal ou arte da leitura de João de Deus, 1901, p. 75). A Cartilha Nacional: methodo legographico para aprender simultaneamente a ler, escrever, ortographar e desenhar - de Caldas Aulete - será analisada no último capítulo desta tese.

392 "Assim aprende a criança a conhecer a gravidade das suas faltas pela grandeza das penas que elas têm por naturais consequências. Finalmente os resultados das transgressões são certos, diretos e inevitáveis. Das leis que regem o mundo orgânico em suas relações com o mundo inorgânico, não há apelação nem agravo. A criança vendo a natureza bemfazeja, mas inexorável e fatal, adquirirá o hábito profícuo de não transgredir a lei." (Augusto Filippe SIMÕES, Educação physica, p. 315) 
escreveu, o homem é uma invenção recente, isto é, só no século XIX surgiu como objeto de ciência. E não deixa de ser interessante notar que a sobrevalorização do conhecimento científico só emergiu, com força, no momento em que se acreditou na sua aplicabilidade à explicação dos fenômenos sociais. Em conseqüência, inteligir as razões últimas que ditaram a valorização das ciências exige que se compreenda, simultaneamente, quais as bases em que radicou o novo otimismo epistemológico, atitude esta que, apesar das diferenças de seus pontos de partida e de seus objetivos, encontramos a animar o trabalho teórico de pensadores como Saint-Simon, Comte, Proudhon, Marx e de todos os que estavam convictos de que, finalmente, seria possível cientificar a realidade mais contraditória, complexa e heterogênea: a realidade social. Sintomaticamente, estes projetos emergiram num contexto polêmico face aos saberes de vocação totalizante, fosse a economia política clássica, fosse, sobretudo, a religião e as filosofias metafísicas." ${ }^{393}$

No caso da pedagogia, era necessário que a cultura letrada passasse a ser considerada um valor. A sociedade portuguesa - dizia-se - não via na ignorância uma vergonha para o indivíduo, o que obviamente contribuía ainda mais para atrasar o estado das letras e das ciências em Portugal. E, mesmo assim, a superação da decadência - até onde entendia a maior parte da intelectualidade do final do século - passava fundamentalmente pela reorganização da cultura:

\begin{abstract}
"A anarquia na política, a desordem dos partidos, a falta de organização, correspondem exatamente ao estado da educação. Desta anarquia, ou há de sair a ordem por meio de uma reorganização, ou a decadência e a ruína por meio da dissolução de elementos sociais. Empenhem-se pois todos em evitar este mal, e convençam-se de que a má educação será a maior das forças dissolventes, e a boa educação, pelo contrário, a maior das forças reorganizadoras. Enquanto durar a anarquia da educação, a sociedade não poderá progredir senão no caminho da anarquia." 394
\end{abstract}

Augusto Fillipe Simões, preocupado em 1879 com os efeitos da educação na conformação do caráter coletivo do povo, destaca que a seriedade e a austeridade exigidas da infância por seus também severos e austeros educadores eram fatores que propiciariam o enfraquecimento do povo, a timidez do feitio. ${ }^{395}$ Além disso a atividade escolar, ao contrário de fortalecer as disposições físicas naturais da criança, prejudicaria o desenvolvimento corporal pela perigosa exigência de uma constante imobilidade, que fatiga a coluna vertebral e pode, por essa razão, produzir inclusive deformidades orgânicas. ${ }^{396}$ Preocupado com a completa ausência de quaisquer exercícios físicos na escola, o autor faz a seguinte observação: "Quem estudar bem o estado da instrução primária em Portugal ficará em dúvida

\footnotetext{
${ }^{393}$ Fernando José de Almeida CATROGA, A militância laica e a descristianização da morte em Portugal (1865-1911), p. 35-36.

${ }^{394}$ Augusto Filippe SIMÕES, Educação physica, p. 320.

395 “Queixamo-nos muitas vezes de que somos um dos povos mais tristes da terra. O fato é verdadeiro e uma das suas causas está evidentemente neste comum sistema de constranger as expansões da infância, de obrigar as crianças a fingir de homens na seriedade, na compostura, no andar, no falar e até no vestuário. O caráter é um dos elementos que a educação forma. Ora o caráter assim formado há-de ser tímido, embiocado ou menos verdadeiro. É, portanto, de absoluta necessidade destruir a opinião vulgar de que, sem quietação ou sem repouso, não há gravidade nem bom procedimento. Importa que todos se convençam de que para os homens viverem como homens é indispensável que os rapazes vivam vida de rapazes. Embora nas ruas das cidades caminhem com ordem para não incomodar os transeuntes, deixem-se livres logo que cessar este impedimento. No campo acabe o enfileirado do passeio. Brinquem e saltem quanto queiram. A variedade do movimento é uma condição de saúde." (Augusto Filippe SIMÕES, Educação physica, p. 352)

396 "A quem entrar alguma vez numa aula à hora em que as crianças estão sentadas nos bancos, impressionarão com certeza os esforços que a maior parte delas fazem para se conservar direitas e imóveis, e até para espantar o sono que o sistema adotado em muitas escolas lhes concilia." (Augusto Filippe SIMÕES, op. cit., p. 356).
} 
- se a escola será um instrumento de civilização, ou antes um elemento de degeneração e ruína da espécie humana., 397

Naquela época, Luiz Jardim - vereador do pelouro da instrução em Lisboa assinala a possível correspondência entre a precariedade da instrução pública e o aumento nos índices de criminalidade e de prostituição nas sociedades contemporâneas, particularmente nos grandes aglomerados urbanos. Com matrículas escassas, não haveria instrumento social de controle daquela juventude que, imersa na multidão da cidade grande, facilmente adquiria outros contatos, outras influências, menos saudáveis que a escola que, em última instância, o Estado lhe teria sonegado. Acredita o político que "a instrução restringe a miséria, educa moralmente e dá ao educando elementos de trabalho; é por isso duplamente produtiva e evitará, de futuro, que aumente o dispêndio feito com as cadeias civis e com os funcionários, que policiam os homens, regulam os costumes e reprimem os delitos." 398 Comparando as verbas aplicadas para com a segurança pública (incluindo cadeias, casas de correção, guarda municipal e polícia civil) - de 268:704\$250 - com a verba reservada à educação (escolas) - de apenas 6:944\$500 - o autor conclui que a insignificância dos recursos evidenciava descaso tanto em relação à necessária formação moral que só a escolarização poderia efetuar quanto no tocante a "outra doença terrível da sociedade em que vivemos: o suicídio" "399. Apontado como um mal sombrio, que atinge particularmente as camadas mais jovens da população, o suicídio seria provocado, acima de tudo, por aspirações românticas e por fantasias inatingíveis; mas exigiria, para ser equacionado, a existência de firme ação governamental, em termos de orientação daqueles jovens que teriam optado pela mais drástica das alternativas. Outro problema a ser debelado pelo desenvolvimento da instrução pública seria no parecer de Jardim - a emigração. O vereador contava com dados que informavam que, apenas no ano de 1876, teriam emigrado para o Brasil 8.623 portugueses (sendo, desses, 7.471 homens e 1.152 mulheres):

\footnotetext{
397 Augusto Filippe SIMÕES, Educação physica, p. 357.

${ }^{398}$ Luiz JARDIM, A instrucção primaria no municipio de Lisboa, p. 14. Depois de salientar a precariedade do estado em que se encontravam as escolas lisboetas naqueles anos 70, sem luz, sem ventilação, com parcas condições higiênicas, constituindo verdadeiros focos de infecção para as crianças, o vereador destaca aquilo que reputava ser consequência imediata: "Ao passo que não existem escolas no município, sucedem-se os crimes (...) A prostituição, terrivel cancro, mata a família e depaupera a sociedade; mas, em parte, consequência fatal da miséria e da ignorância, só pode ser combatida com uma grande instituição: a escola. Desgraçadamente escasseiam os alunos na matrícula das escolas e engrossa a matrícula das meretrizes no livro negro da política." (Id. Ibid., p. 13)

${ }^{399}$ Luiz JARDIM, A instrucção primaria no município de Lisboa, p. 14. Ao descrever, porém, o estado em que se encontravam as escolas, Jardim não poupa a Câmara de Lisboa; nos seguintes termos: “As (...) escolas públicas que a Câmara subsidia, funcionando em casas de renda, são úmidas, mal resguardadas, e em condições tais, que enchem de tristeza o espírito do visitante que lá entra. Às vezes, a escola funciona em duas e três casas pequenas, pouco asseadas, com velhos móveis e, se algumas são forradas de papel, esse pende tristemente em frangalhos. As carteiras, destinadas para três crianças, servem para seis. Quando algum aluno tem de sair, levantam-se todos para lhe dar passagem. As cartas parietais têm a cor amarelada dos velhos pergaminhos; o pó e as moscas habitam por toda a parte. As escadas destas escolas são velhas $e$ íngremes, $e$ por vezes nas paredes deparam-se letreiros obscenos. Algumas escolas vi, que parecem lojas de ferros-velhos. Têm fotografias de famílias pelas paredes, e várias gravuras de ilustração pregadas com alfinetes. Os mapas corográficos, encarquilhados pelos anos, desbotam as paredes em manchas amarelo-verdoengo; e sobre a mesa do professor, há, em muitas, a terrífica palmatória. Tábuas suspensas do teto alojam alguns livros, de que pendem folhas rasgadas ao lado de rolos de papéis poentos.” (Id. Ibid., p. 28 ) Ressaltando que escolas assim apresentadas não poderiam mesmo ser bem recebidas pelas famílias, o autor destaca que havia que se tornar atraente aquela escola que não parecia sequer destinada ao elevado ofício para o qual se voltava. Em termos de propostas, após tão drástico diagnóstico, o vereador sugere a descentralização como um caminho de obtenção de uma autonomia em termos de dotação orçamentária, o que permitiria melhor utilização dos recursos. Além disso, postula a necessidade de que efetivamente fosse efetuada uma política de seriação nas escolas, posto que um único professor não seria capaz de lidar com diferentes níveis de aprendizagem e de idade na mesma sala. A especialização do trabalho requereria esse tipo de organização das classes que, no parecer do relator, poderia também, mediante a nova organização por ele defendida, vir a estimular os alunos para o aprendizado.
} 
"Assim grande parte dos nossos emigrantes, abandonando a família, aventurando-se aos rigores da sorte, foram em terra estranha encontrar aberta a sepultura! Estes fatos são tristes e provêm do abandono completo em que se acha a instrução do nosso povo. Os humildes de entendimento, desejando melhorar de fortuna e fantasinado venturas, onde a realidade muitas vezes é triste e desgraçada, facilmente acreditam nos conselhos dos aliciadores e enganadores, que se valem da sua boa fé, para conseguir fins reprovados por todos os princípios. Sem dúvida concorre igualmente a situação geográfica do país e a índole deste povo influído do espírito aventureiro, que dele fez o primeiro navegante do mundo; mas a ignorância popular é a causa (...) da nossa emigração. Umas vezes emigram os menores de 14 anos entregues pelos seus aos exploradores; outras abandonam a terra as raparigas, que têm mocidade e beleza fiadas nas grandes promessas das engajadoras; outras, ainda, saem de Portugal os próprios pais de famílias inteiras, despovoando campos e cidades! Todos emigram iludidos! Há, pois, em todos um grande defeito - pobreza intelectual, falta de escola! (...) Combater os preconceitos e superstições populares; debelar o espírito aventureiro, substituindo-o pelo senso prático; educar, finalmente, a opinião pública, para erguer em base segura a prosperidade da nação, - tal é, em vista dos fatos referidos, o dever dos poderes públicos que têm a honra de representar o povo." 400

\section{A PEDAgOgia do EXAME}

Note-se que, como já pudemos observar noutra ocasião, a crítica à organização escolar torna-se bastante comum entre os pedagogos desse final de século, até porque eles constatavam a dissonância entre o descaso português e o êxito já europeu do modelo escolar. Em Portugal a escola falhara. Urgia encontrar as razões que, no conjunto, explicassem isso. Muitas vezes se recorria à ausência de atrativos da vida escolar, tendo em vista a necessidade prática de as famílias recorrerem ao trabalho infantil. Além disso, como observam algumas obras pedagógicas da época, os professores muitas vezes não sabiam dar aulas e confundiam seu ofício com a memorização do compêndio. Era como se o livro escolar dirigisse a aula, como guia para o professor, não apenas em termos da abordagem dos conteúdos trabalhados, mas talvez fundamentalmente pela própria seleção do conteúdo. $\mathrm{O}$ abuso do compêndio levava a que houvesse casos em que a aula não existia: era substituída pela mera cópia do texto, a partir da qual os alunos estudavam, e o mestre viria depois para 'tomar a lição'; professores e alunos ignorando o modo coletivo de ensinar e aprender...

\footnotetext{
"Note-se de passagem que o saber estudar não é coisa fácil; é talvez a mais difícil e os alunos ressentem-se muito do sistema de ensino do professor, e estudam, na acepção material do termo, conforme o caráter das lições. A prática do ensino não deixa dúvidas a este respeito. Honra pois aos professores que, emancipando-se dos empíricos moldes convencionais, levantam o seu ensino a uma altura que os distingue. (...) Há três pontos negros que se destacam d'entre os que prostituem a missão do professor: $1^{\circ}$ ) $\mathrm{O}$ confundir-se o estudar com o decorar; $2^{\circ}$ ) Uso e abuso do compêndio e dos livros em geral; $3^{\circ}$ ) Uma severidade mal cabida como meio de disciplina e de domínio aparente. Enquanto ao primeiro ponto temos já dito bastante (...); a afixação inconsciente de palavras pode produzir resultados bem funestos, verdadeiros casos de patologia cerebral; esse sistema jesuítico é um tóxico psicológico dos mais enérgicos: não seria difícil demonstrá-lo. (...) Acentue-se bem que o professor que obriga a decorar nada ensina (...) é apenas matar o tempo e fazer cretinos. Relaciona-se muito este primeiro ponto com o segundo que apontamos: uso e abuso do compêndio; com efeito nada mais cômodo nem mais estúpido do que dizer: a lição é de páginas
}

${ }^{400}$ Luiz JARDIM, op cit, p. 15. 
tantas a tantas e no dia conveniente 'tomar a lição'; este sistema de rotina ainda é tão vulgar quão pernicioso." 401

Ocorre que muitas vezes a crítica ao compêndio vinha presa à crítica sobre o livro de modo geral, como se fosse a própria existência do impresso quem desviou a prática do professor. A desconfiança acerca do tema da leitura é ainda muito ilustrativa para se compreender os paradoxos do debate sobre a instrução naquele Portugal de final de século. Supomos que, de alguma maneira, à escola caberia regrar, vigiar, delimitar e circunscrever o território de uma leitura que, leiga, tornava-se cada vez mais profana e ameaçadora dos valores dominantes. A circulação do texto conformava práticas leitoras que, se fossem deixadas por si, contribuiriam para a indesejada e temida transformação dos costumes. Cabia à escola - porque o grupo social assim a escolheu - domesticar o rebelde gesto da leitura, que, através dessa operação, deveria deixar o campo da fruição, do prazer, para penetrar no 'científico' terreno da Pedagogia: conhecimentos úteis, morais... pedagógicos, enfim. Assim, na sequiência do que acabara de dizer, o mesmo autor José de Sousa complementa e sugere:

\begin{abstract}
"O professor não deve adotar compêndio, o compêndio é ele; o único ensino em harmonia com a dignidade profissional é o ensino oral; o aluno aprende assim a ouvir, o que é difícil, a refletir e a investigar. Escreve Ramalho Ortigão: 'os livros são lentes através das quais se observa o mundo; são necessários aos olhos fracos, cuja vista conservam e frutificam; mas será melhor poder passarse sem eles.' A autoridade de Spencer sanciona isto mesmo: 'a função dos livros é uma função suplementar; os livros constituem um meio indireto de adquirir conhecimentos para quando faltam os meios diretos; um meio para ver, segundo a opinião dos outros homens, aquilo que não podemos ver pelos nossos próprios olhos."
\end{abstract}

\footnotetext{
${ }^{401}$ José de SOUSA, Notas de pedagogia philosophica, p. 61-62. Nessa obra, o autor recorre inúmeras vezes a longas transcrições de trabalhos pedagógicos desenvolvidos por autores estrangeiros. Sobre o capítulo referente à "educação dos sentidos", José de Sousa refere-se a um artigo que em 1887 havia traduzido e publicado. Era um texto escrito por Sir Philip Magnus e publicado originalmente na Contemporary Review. Aqui Sousa procurava firmar sobre um argumento de autoridade a denúncia que fazia sobre o excessivo apelo escolar ao recurso dos livros, na ilusão de que eles poderiam se constituir na grande alavanca da instrução. O trecho transcrito por José de Sousa e que copiamos abaixo fala um pouco sobre esse assunto: "Ter por demonstrado que o melhor ensino é aquele que se bebe nos livros, é estar manietado a um preconceito medieval contra o qual protestam todos os mestres da pedagogia moderna. Mas no fundo da aludida objeção, há ainda um outro erro mais flagrante. Geralmente considera-se a instrução primária como destinada a ensinar à criança o que ela de futuro não virá provavelmente a aprender, enquanto que o verdadeiro objeto do ensino primário deve ser inspirar o desejo de completar por si próprio os conhecimentos adquiridos na escola. Por outras palavras, a escola primária deve ser tanto quanto possível o noviciado da vida ativa, e os mestres devem, acima de tudo, esforçar-se em fazer que a transição de uma para outra seja fácil e natural. Para isso, é indispensável que os métodos com que procuramos a informação e a experiência sejam na escola os mesmos que na luta pela existência." (José de SOUSA, Notas de pedagogia philosophica, p. 93) É explícito nesse excerto a preocupação do autor quanto aos possíveis e nefastos efeitos transgressores que a prática escolar, aliada à prática da leitura poderiam trazer para o mundo onde a luta pela existência não dá a todos o mesmo espaço para competir.

${ }^{402}$ José de SOUSA, Notas de pedagogia philosophica, p. 63. Os grifos são de nossa autoria. Sobre os efeitos perniciosos da leitura enquanto prática, se a mesma não fosse acompanhada de uma orientação extremamente rigorosa, o autor comenta em um outro trecho o seguinte: "O saber ler é apenas um meio e muitas vezes de resultados terríveis; a questão não é saber ler, mas sim saber escolher o que se deve ler (...) O que adiantamos é que a leitura pode produzir efeitos negativos; parte das pessoas não analfabetas aplicam essa prenda - a leitura - nas maiores banalidades e os editores exploram o mercado. Para tudo isto não vale a pena saber ler; julgamos que era melhor o ser-se analfabeto. A leitura pode mesmo produzir grandes comoções em cérebros fracos e impressionáveis (...) Não seria melhor uma sólida instrução ministrada sem livros? Parece que sim, neste caso. Quando o espírito estiver mais fortalecido e educado, haja então a leitura e só muito mais tarde se consultem livros.” (Id. Ibid., p. 54-55). Percebe-se pelo tom do texto extrema hesitação no autor quanto ao princípio do processo do ensino da leitura.
} 
O conhecimento por meio de livros deveria ser, sob tal aspecto, substituído pelo aprendizado que prescinde do livro, já que esse instrumento da cultura ameaçava, a todo momento, se autonomizar e colocar em risco todo o tipo de palavra de mestre. Era como se o próprio princípio da autoridade tivesse vindo abaixo pelo primado do impresso vulgarizado e acessível, que dessacralizara, enquanto veículo material, todos os pensamentos secretos e as idéias perigosas. ${ }^{403}$ É o medo da força simbólica do livro, na concorrência com a disciplina das instituições familiar e escolar, quem move determinados setores da intelectualidade a fazer a quase apologia da tranquila ignorância.

A crítica àquela pedagogia do compêndio não deixava de ser também a proposição de um olhar de denúncia sobre algumas das sabidas mazelas da escola portuguesa. Uma das dificuldades levantadas diz respeito à questão dos exames de instrução primária, necessários para o ingresso nos liceus, e que se apresentavam como o tenebroso resultado da ausência de cuidados metodológicos e didáticos no âmbito da instrução. Na imensa maioria das vezes os alunos não eram sequer submetidos a exames e, quando o eram, falhavam. Os exames eram feitos nas próprias salas dos liceus e o júri era composto por um inspetor ou um professor que tivesse sido por ele designado, por um membro da junta escolar e por um professor de escola complementar. O professor dos alunos examinados também deveria estar presente, "sem voto, mas com a faculdade de os interrogar, dirigir, elucidar e fornecer as notas do seu aproveitamento." ${ }^{404} \mathrm{O}$ espaço da sala era reduzido e não comportava nada além de meia dúzia de cadeiras, onde se sentavam em geral as pessoas convidadas dos examinadores. Não eram admitidas pessoas em pé e, na maioria das vezes, os familiares dos alunos não obtinham assento, ficando no corredor, do lado de fora, muitas vezes sob os vigilantes olhares de um policial. A descrição feita por Domingos Tarrozo parece-nos bastante ilustrativa da representação dos exames de instrução primária, naquele contexto de final de século. Era medo, insegurança e recordação do compêndio:

\begin{abstract}
“É que lá está no garrote, entre as garras da hidra, um filho, um sobrinho, um irmão,- um rapazito encolhido, trêmulo, titubeante, desvairado, sem voz, sem palavras, sem idéias, quase chorando como um pintainho levado por um milhafre. E as pobres criancitas têm razão para estarem assim. As decisões daquele horrível tribunal são infalíveis, são irrevogáveis como a sentença do juízo final de que falam as santas escrituras. Também dali não há apelação nem agravo possível. A criança não pode dizer o que aprendeu e o que sabe. Não tem licença de falar. Há de responder unicamente e em poucas palavras às perguntas que o examinador lhe faz. $\mathrm{O}$ pedagogo interroga pelo seu compêndio ou pelo dum amigo que lhe dá uma boa parte dos ganhos sobre as vendas feitas. Se o examinando estudou por outro livro e não repete mecanicamente as definições e as
\end{abstract}

\footnotetext{
${ }^{403}$ Sobre o tema do impacto da leitura sobre a vida escolar - para o caso francês - o trabalho Discursos sobre a leitura - produzido por uma equipe coordenada por Anne-Marie CHARTIER e Jean HEBRARD - forneceu-nos inúmeras pistas metodológicas. Sobre o tema, e preocupados com as intersecções e variantes entre os discursos escolares sobre leitura e aqueles produzidos por outros meios, particularmente ligados à Igreja e aos bibliotecários, os organizadores destacam o seguinte: "Em contraponto aos discursos da escola, matizados pelas questões que há mais de um século vêm sendo submetidas a essa máquina da qual esperamos tudo, ouvimos a resposta incessante de outros discursos, outras palavras, como um eco indefinido ao qual a escola responde sempre. De alguns deles ela faz seu mel, esquecendo a origem; de outros, o obstáculo contra o qual se choca para encontrar novas razões, novos argumentos, outros fins. Pode-se contudo levantar a hipótese de que muitos deles se inscrevem confusamente na tradição de uma concepção religiosa da leitura ou, ao contrário, na modernidade da transgressão da arte de ler, sustentada por esses atores, novos no campo da leitura mas orgulhosos de sua segura competência: os bibliotecários. Assim, enquanto os discursos das igrejas e dos profissionais da leitura pública se mantinham em relativa autonomia, garantida pelo caráter específico e pela autoridade dos seus enunciadores, os discursos da escola sobre a leitura se revelam permeáveis a todas as influências, aptos a transfomar em prescrições muitas das representações do ler que lhe são opostas ou apenas estranhas.” (Anne-Marie CHARTIER e Jean HEBRARD, Discursos sobre a leitura - 1880-1980 , p. 248)

${ }^{404}$ ENSINO obrigatório ou collecção completa da legislação sobre instrucção primaria, p. 13.
} 
asneiras do volume que dá interesse ao professor do liceu proprietário da respectiva cadeira, está, desde logo, perdido. O examinador, para se mostrar sabichão, quase nunca pergunta as coisas simples, úteis, importantes, as coisas mais notáveis que vêm em todos os livros e que sabem todos os rapazes. Busca sutilezas, investiga hipóteses difíceis, argúcias embaraçosas, faz apenas interrogações enigmáticas, bifrontes para poder aprovar ou reprovar o aluno conforme está interessado em aprová-lo ou não."405

A denúncia abarcaria inclusive - como fica exposto - aspectos concernentes ao mercado editorial e à sua interferência na escolha do compêndio adotado pelos examinadores; compêndio esse que, em tese, sequer era exigido, posto que apenas havia orientações explícitas quanto ao programa de estudos e não existia nenhuma prescrição de literatura didática obrigatória. Era como se toda a estrutura da escolarização primária estivesse voltada para aquela ocasião, à espera do momento em que o aprendiz fosse submetido a exame. Ali eram concentradas todas as manifestações do poder disciplinar e coercitivo exercido pela escolarização. Os examinadores deveriam pronunciar-se sobre uma prova escrita que constaria de um ditado de vinte linhas extraído de algum dos livros aprovados para as escolas, de operações aritméticas, de resolução de um problema para aplicação das operações simples, e de um desenho a lápis. Depois é que seria feita a prova oral. Aqui, o examinando poderia ser solicitado para classificação gramatical, conjugação oral de verbos regulares e irregulares, escrita e leitura de números no quadro, "leitura em voz alta e acentuada de uma página de livro de prosa aprovada para as escolas de ensino complementar e de duas ou três estâncias do poema Os Lusíadas." 406 Insurgindo-se contra a pedagogia do exame, Domingos Tarrozo declara que os examinadores, bem como os compêndios, conheciam mal a língua em nome da qual pretendiam avaliar. A língua - no parecer de Tarrozo - seria algo substancialmente distinto do conhecimento fragmentário e memorativo do compêndio. Como vimos, pelo fato de não saberem recitar o compêndio decorado, os examinandos - que eventualmente poderiam ter até estudado por outros livros - seriam sumariamente reprovados; e nisso consistia a liturgia da escola. Acresce-se a isso que os professores, presos ao suposto conhecimento obtido com a leitura do livro escolar, distanciar-se-iam da leitura das grandes obras que haviam de fato coroado a língua portuguesa:

\footnotetext{
"Os examinadores, por via de regra, não conhecem praticamente, profundamente as línguas sobre que examinam. Não são capazes de as escrever nem de as falar. Conhecem-lhes a gramática, o ‘compêndio para uso dos portugueses aprovado pelo governo'. Ora, como o discípulo (...) não sabe o tal compêndio nem responde as mesmas coisas que esse triste livro expõe e afirma, o examinador, para quem o compêndio é a língua, é a sabedoria, convicto, desde a primeira palavra de que o examinando não sabe nada, reprova-o solenemente; e o pobre público, ignorante destas coisas, pensa que a reprovação foi legítima e que o aluno é um estúpido que não sabe nem é capaz de saber!" 407
}

Por tais procedimentos constritivos, a escola, longe de sua declarada missão de irradiadora do conhecimento, da ciência produzida, teria como resultado a conformação de espíritos dóceis, modelados pelo diapasão restritivo de maus compêndios que encerram por completo qualquer manifestação de criatividade por parte do postulante ao saber. A escola, nessa medida, rejeitaria, a princípio, seus frutos mais valorosos e os bons estudantes, na maior parte das vezes, traduzir-se-iam em maus alunos. Sob tais restrições, o problema da escolarização adquiria, no caso português, tonalidade sombria, dado que parecia impossível o êxito de uma instituição enredada em certas mazelas que, por sua vez, estariam na origem de

\footnotetext{
${ }^{405}$ Domingos TARROZO, O monopólio da sciencia official: discussão d'um problema politico, p. 95-96.

${ }^{406}$ ENSINO obrigatório ou collecção completa da legislação sobre instrucção primaria, p. 66.

${ }^{407}$ Domingos TARROZO, O monopolio da sciencia official: discussão d'um problema politico, p. 132-133.
} 
sua lógica. Reconhecer-se-ia, portanto, o aspecto dogmático da instituição que se apropria, põe e dispõe a seu modo de saberes produzidos no campo da ciência e da técnica. Ocorre que, contraditoriamente a essa feição escolar do conhecimento, o que há de específico no campo do saber é exatamente a oposição irredutível ao pressuposto dogmático. A escola, em sua atividade costumeira, trabalharia talvez com o oposto de seus objetivos declarados - fechada que estava a qualquer inovação. ${ }^{408}$

Ocorre que a instituição escolar, tal como esta se põe em nossa contemporaneidade, aparece como um dispositivo de mediação entre as iniciativas conservadoras do existente e os projetos de mudança social. A escola moderna, nem sempre adequada aparentemente à sociedade que a acolhe, é de fato agenciada como um centro de irradiação cultural, cuja tarefa seria eminentemente a de transmissão dos valores, dos costumes, da tradição, por um lado; na outra margem, situar-se-ia a projeção da mudança. Desse modo, institucionalmente, procede-se ao binômio tradição-inovação como a própria razão de ser da tarefa da escolarização; daí, talvez, seus aparentes paradoxos, que teimam em resistir ao tempo... ${ }^{409}$ Como destacam os estudos acerca do tema, a educação escolar portuguesa, no decorrer de todo o século XIX, não chegara exatamente a ser uma aquisição, um bem, um valor efetivamente procurado pelas famílias, que, na maior parte das vezes, requisitavam precocemente o trabalho dos seus filhos, retirando-os da escola. ${ }^{410}$

\footnotetext{
${ }^{408}$ Domingos Tarrozo chega a trazer ênfase de universalidade para a crítica veemente a que submete o espaço da escolarização: "Percorra-se a história da instrução pública moderna, observe-se o que se passa, estude-se a vida dos mais notáveis espíritos do nosso tempo e ver-se-á que um estudante paciente e humilde às indicações e à ciência do professor, isto é, um bom estudante, - oficialmente considerado,- com distinções e prêmios, é quase sempre um nulo ou um parvo; ao passo que um estudante rebelde, insubmisso, adverso ao professor, à disciplina e às doutrinas que lhe ensinaram, é sempre, com raras excecões, um cérebro de grande força, um espírito superior ou uma notabilidade. Dadas as circunstâncias atuais, os fatos autorizam-nos a formular a seguinte lei que tem toda a força de uma lei histórica: um grande espírito está na razão inversa da sua submissão aos dogmatismos oficiais; quanto maior é, menos se submete. Contrariamente: um espírito medíocre está na razão direta da sua submissão aos dogmatismos oficiais; quanto é mais nulo, mais se submete." (Domingos TARROZO, $O$ monopolio da sciencia official: discussão d'um problema politico, p. 80-1)

${ }^{409}$ Cambi define a escola como instituição central da vida social exatamente por essa sua capacidade de adequarse simultaneamente ao ofício de filtrar, selecionar e irradiar os conteúdos culturais de que se apropria, como se de fato procedesse à mediação entre passado e futuro, entre permanência e mudança. (Franco CAMBI, Storia della pedagogia, p. 327)

${ }^{410}$ Acerca do problema, Jaime Reis constata: "A aquisição de uma educação elementar implicava, de fato, um investimento - o custo da freqüência da escola em si mais a perda do rendimento do aluno impedido de trabalhar - que era excessivamente alto para uma grande parte da população portuguesa. Os respectivos benefícios materiais, representados por rendimentos posteriores mais elevados, não compensavam esse custo, no entender das famílias. Era isto um reflexo não só da fragilidade das economias familiares traduzidas pelo baixo nível de rendimento real per capita do País, mas também das oportunidades de emprego que se ofereciam numa economia dominada por uma agricultura tecnicamente rudimentar e de reduzida produtividade. Ao mesmo tempo e pelas mesmas razões, ainda menos seria de esperar uma procura 'espontânea' forte pela educação como 'bem cultural' ou como 'ornamento social', não havendo nada, por outro lado, nos costumes sociais ou religiosos portugueses que estimulasse o grosso da população nessa direção, como sucedeu em vários países da Europa, neste e em séculos anteriores. Podendo-se assim constatar que não haveria na sociedade portuguesa de Oitocentos um número elevado de familias com a vontade ou a capacidade para 'comprar' para os seus filhos uma educação elementar privada, entende-se por que a única via para uma maior alfabetização tinha de passar por um esforço estatal acrescido, como sucedeu nos países de alfabetização tardia com os quais temos vindo a comparar Portugal. Para elevar significativamente a percentagem da população a saber ler $e$ escrever, era necessário que o Estado providenciasse estabelecimentos de ensino e professores em muito maior quantidade e criasse, simultaneamente, mecanismos de pressão sobre os pais para que os seus filhos fossem à escola." (Jaime REIS, O analfabetismo em Portugal no século XIX: uma interpretação, In: Colóquio educação e sociedade, p. 23-4). Na sequência, o autor recorda que não teria havido,em todo o século XIX, a despeito de insuficientes tentativas, vontade política suficiente para concretizar o desejo por vezes manifestado pelos intelectuais portugueses no sentido de escolarizar as novas gerações. Em termos numéricos, valeria a pena recorrermos novamente ao texto de Jaime Reis: "Dado o fato de a alfabetização de uma população ser um processo caracteristicamente prolongado, a segunda conclusão é que foi nas décadas já de 1850, 1860 e 1870 que em Portugal se começou a perder a oportunidade para sair da situação de ignorância abissal em que se
} 
Custódio Dias Guerreiro ${ }^{411}$ declara em texto dedicado a comentar os Congressos Pedagógicos ocorridos em Lisboa e no Porto em 1898 - sob o título Aspirações e protestos do professorado primário - que um dos maiores males da sociedade portuguesa de modo geral, e que se refletia intensamente na condição do magistério, era o indiferentismo. Ele, que era professor, membro e defensor da Associação do Professorado Primário Português, destacava que a própria vida associativa sofria desse mal da descrença e da indiferença de seus associados para com os debates que, em última instância, diziam respeito à sua vida enquanto profissionais do ensino.

\begin{abstract}
"Para que serve a Associação? A quantos professores tenho ouvido dizer: 'Ora! vamos a ver no que é que isto pára; quem sabe? a mensalidade é carita: e depois, tenho fé que nunca precisarei de socorros da Associação e os mais que se arranjem... Não te rales...' Conseguida a realização do último Congresso Pedagógico com grande custo dos delegados que a ele assistiram e também dos que concorreram para as despesas, quantos professores diziam: 'Ora! Congresso! de que serve? Temos passado sem isso perfeitamente, e depois... os delegados é que vão por lá gozar as belezas da capital e nós aqui...Não te rales...",412
\end{abstract}

Essa imagem de conformismo poderia também traduzir-se na pequena valorização que as famílias, de maneira geral, atribuíam ao aprendizado das letras. A indiferença com que era visto o tempo da escola por parte da população é, como temos visto, salientada por inúmeros autores. No entanto, mesmo entre os intelectuais do final do século, em alguns casos, não era nítida a defesa da escola como um valor irredutível. Havia quem desconfiasse da trilha tomada pela cultura das letras. A propósito, Francisco Adolpho Coelho, curiosamente, chegou um dia a argumentar que a crença irrestrita nos poderes civilizatórios da alfabetização conduziria inevitavelmente a apreciação de caráter discricionário assumido relativamente a povos e sujeitos ignorantes, que passavam, sob essa ótica, a ser encarados como inferiores ou incompletos. ${ }^{413}$ Ele, que era considerado por alguns, como um dos maiores especialistas nas origens da língua portuguesa, foi quem proferiu a quarta e última

encontrava mergulhada a população. De fato, ao ritmo de escolarização que estava então a ter lugar - entre 200 e 300 alunos por 10000 de população - apenas se poderia reduzir a taxa de analfabetismo inicial de 80\% em cerca de 0,3\% pontos por ano, o que equivalia a levar aproximadamente 100 anos para atingir o estágio dos 50 $\%$ de analfabetos na população. O mesmo cálculo aplicado ao fim do período, já com a escolarização em 500 600/10000, aponta para melhores resultados, embora ainda muito inferiores aos padrões europeus contemporâneos. Por volta de 1900, a taxa de analfabetismo de 78\% estaria a sofrer uma contração de 0,6\% pontos ao ano. A este ritmo, levaria até 1944 para se atingir a metade da população alfabetizada a que a Espanha e a Itália já tinham chegado no princípio do século.” ( Id. Ibid., p. 17)

${ }^{411}$ António NÓVOA define o professor e dirigente associativo Custódio Dias Guerreiro como um entusiasta do movimento de associação dos docentes em Portugal. Defensor das Conferências Pedagógicas, Guerreiro supunha que elas agiriam no sentido de desenvolver um espírito de classe e de solidariedade corporativa no professorado português. (vide António NÓVOA, Le temps des professeurs / volume I, p. 494-5)

${ }_{412}$ Custódio Dias GUERREIRO, Aspirações e protestos do professorado primario , p. 88.

${ }^{413}$ Nascido em 1846, Franciso Adolpho Coelho ingressa aos 23 anos (1869) no $1^{\circ}$ ano do curso de Letras da Universidade de Coimbra. Posteriormente, ficaria imortalizado tanto por seus escrito, quanto pela participação que tivera junto à chamada Geração de 70. Fora encarregado por Antero de proferir uma palestra sobre as questões do ensino em Portugal nas célebres Conferências do Casino Lisbonense. Em 1868, havia lançado A língua portuguesa, fonologia, etmologia, morfologia e sintaxe. Este trabalho foi muito debatido em seu tempo; aplaudido por alguns, criticado por outros. A imprensa periódica qualificava este texto como oscilante entre o máximo rigor e a falta de clareza, não havendo, em hipótese alguma, consenso sobre seu mérito. De qualquer maneira - como destaca o Diccionario de Innocencio - tratava-se de uma obra que compreendia desde os elementos gramaticais da língua até seus componentes etimológicos. Especialista no estudo do pensamento e da prática desse autor, Rogério Fernandes dirá o seguinte: “O capítulo sobre o século XIX não poderia deixar de referir Francisco Adolfo Coelho, filólogo e pedagogo, que, partindo de um quase total auto-didatismo por inadaptação justificada, trouxe ao nosso país a honra de um doutoramento honoris causa por Goettingen." (Rogério FERNANDES, O pensamento pedagógico em Portugal, p. 121). 
Conferência do Casino Lisbonense. Intitulou sua intervenção Questões de Ensino e - como nos atesta Rogério Fernandes - "no decorrer de uma sessão memorável motivou a indignação do mandarinato universitário e que a polícia denunciou ao Governo. Essa conferência e as de Antero motivaram explicitamente a tão célebre quanto escandalosa portaria de supressão assinada pelo duque d'Ávila e Bolama." 414

Em um momento de menor otimismo cultural, Adolpho Coelho destacava o perigo de os meios de se conhecer confundirem-se com o próprio conhecimento e, nesse esquadro, a leitura e a escrita seriam antes estratégias, que, por isso mesmo, deveriam ser analisadas sem tanta paixão. O domínio dos relatos tradicionais, bem como a capacidade de memorização da história pátria, seriam, no parecer do autor, propriedades mais frequentemente encontradas entre pessoas analfabetas, posto que a habilidade escrita traria consigo a propensão para o esquecimento. Desse modo, Adolpho Coelho questiona algumas das certezas já estabelecidas naquele último quartel do XIX acerca das supostas propriedades benéficas intrínsecas à alfabetização. ${ }^{415}$ Mesmo assim, o autor não nega a interface entre escolarização e desenvolvimento industrial, destacando, porém, a ineficácia da organização escolar em tal sentido. Acerca do tema, diz em seu trabalho sobre Cultura e analfabetismo:

\begin{abstract}
“A decadência das nossas indústrias domésticas é um fato e a previsão da sua quase total ruína não exige notáveis faculdades proféticas, a não ser que mãos superiores, que no momento não parecem existir aqui, as venham fazer entrar em nova fase de vida. Os progressos da ciência e de suas aplicações à técnica impunham ou a morte ou a transformação dessas indústrias. Essa transformação só podia operar-se pela influência da escola e d'outros meios de propaganda dos
\end{abstract}

414 Rogério FERNANDES, O pensamento pedagógico em Portugal, p. 121-2. Ainda sobre o filólogo e educador, Fernandes diz o seguinte: "Adolfo Coelho ocupou-se largamente do sistema de ensino em numerosos escritos, interveio em algumas de suas reformas, designadamente na de 1894-1895, fundou e dirigiu até ao fim de sua vida a Escola Primária Superior de Rodrigues Sampaio (...) em que, de certo modo, concretiza, pela primeira vez na nossa história, um ensino pós-primário de elevada qualidade, exterior aos dos liceus, tal como queria Herculano. Preconizava a ligação entre o trabalho manual e o trabalho intelectual, salientava a importância da educação física, punha em relevo o valor da educação infantil." (Id. Ibid., p. 122).

${ }^{415}$ Harvey J. Graff destaca em seu trabalho a necessidade de se averiguar a procedência ou não de algumas teses que têm acompanhado os estudos sobre história da alfabetização nas sociedades ocidentais. Existiria - afirma ele - uma idéia generalizada de que o avanço das habilidades da leitura e da escrita nas sociedades corresponderia a seu progresso social e econômico. Além da importância em si mesma, a alfabetização traria ainda uma associação com a "modernização atitudinal, industrialização, urbanismo, radicalismo político e revolução" (Harvey GRAFF, Os labirintos da alfabetização, p. 195 ). Na verdade, mesmo quando os historiadores saem a campo, muitas vezes o fazem já com esses pressupostos equivocados, que, na verdade ocultariam - no parecer de Graff - a verdade última da instituição escolar: "No passado, como no presente, a estrutura institucional da escola promoveu a inculcação de padrões comportamentais corretos. Por meios que excediam seus objetivos declarados e o plano curricular, a escola foi, e aparentemente continua a ser, um ambiente efetivo para o treinamento em padrões aprovados de conduta - isto é, na inculcação de comportamentos normativos. A organização racional da escola atua como um 'sedutor escondido' que contribui com regras aprendidas para a ação pessoal. Consciente e inconscientemente, formal e informalmente, a organização das relações trabalhistas e sociais está implicitamente encerrada no microcosmo da escola a ser compreendido e assimilado. De fato, este é um mecanismo da socialização inicial frequentemente ignorado, o qual os estudiosos da alfabetização (...) comumente ignoram. Assim, as bases morais e sociais da alfabetização ganham reforço diretamente do ambiente construído para transmiti-las. O propósito da alfabetização, no passado e também no presente, era integrar a sociedade e fomentar o progresso pela ligação de homens e mulheres em sua malha, neles introjetando as diretrizes do comportamento correto. A importância da imprensa e a habilidade concomitante de ler e escrever foram captadas pelos mais interessados na ordem social. Eles viram, por um lado, que cada vez mais homens e mulheres estavam tornando-se alfabetizados, capazes de usar sua alfabetização sem restrições. Viram, por outro lado, indivíduos desprovidos de alfabetização - em especial os jovens, mas algumas vezes os adultos também. Os dois elementos representavam uma ameaça e um obstáculo, uma barreira à disseminação de valores de classe média, considerados essenciais à ordem social e ao progresso econômico. O resultado, é claro, foi a administração da imprensa e da alfabetização em ambientes cuidadosamente estruturados para esse fim específico e a instrução conforme o código normativo e os usos socialmente aprovados da alfabetização." (Id. Ibid., p. 69-70) 
conhecimentos científicos e das práticas tecnológicas modernas. Supôs-se que o ler e escrever e decorar em compêndios o que lá se lia era tudo: a educação que vem do passado está-se aniquilando e a educação própria do presente e do futuro ainda não surgiu." 416

O livro de leitura era, como pudemos observar, o grande alvo revelador do atraso da instrução portuguesa. Adolpho Coelho toma sua referência também para revelar a evidência da necessidade de se adequar e inovar o conjunto de procedimentos pedagógicos de sala de aula. Para esse estudioso dos assuntos educacionais, a excessiva ênfase dada aos aspectos moralizadores da educação primária fazia por perder o atrativo do aprendizado enquanto percurso intelectual do espírito. Textos moralizantes e inadequados para a perspectiva infantil ocasionavam até a repugnância pela prática da leitura e fundamentalmente não conduziam as crianças a seu aprendizado. Supondo como os contemporâneos que o desenvolvimento individual teria analogia com o desenvolvimento da espécie, Adolpho Coelho condena os compêndios que, além de não estimularem em nada a intuição e imaginação das crianças, exigiriam delas uma capacidade de raciocínio que pressuporia maturidade maior do que a sua idade permite. Para além disso, haveria as obviedades e os disparates que, ao serem postos como saber de escola, traziam funestas consequiências em termos do desenvolvimento do raciocínio lógico de todos os que a isto fossem submetidos:

\begin{abstract}
"O livro citado continua: 'a oliveira dá azeitonas, a figueira dá figos, o castanheiro dá castanhas', etc. Tais coisas não são objeto de ensino: desgraçada da criança que é incapaz de aprender espontaneamente isso e muito mais do que constitui o vulgar ensino das coisas. Condenamos, pois, completamente as leituras de principiantes tendo por objeto o ensino das coisas ou os elementos das ciências naturais; já porque uma parte daquele ensino, como se faz vulgarmente, é inútil, já porque os elementos das ciências devem ser ensinados intuitivamente, pela observação, tanto quanto for possível, das coisas a que se referem. Os livros escolares que examinamos revelam uma curiosa contradição. Enquanto d'um lado mostram que seus autores duvidam tanto das forças nativas da criança que julgam necessário que constituam objeto de leituras as mais vulgares noções, d'outro supõem-na tão forte que possa compreender d'um salto coisas inteiramente abstratas, ou reconstruir pela imaginação pura, suscitada por descrições verbais, objetos e fenômenos de que não teve a mínima intuição.",417
\end{abstract}

Em virtude da reorientação metodológica da escola primária, era comum sugerirse a introdução de matérias alternativas (como canto coral, desenho, ginástica e trabalhos manuais), as quais são por vezes advogadas como elementos formadores de habilidades importantes para a efetiva formação humana. Supõe a nova pedagogia que a escolarização deveria adequar-se aos progressos da civilização e a preparação do indivíduo para sua futura vida profissional faria parte desse novo caminho. Mas havia, desde logo, quem denunciasse os abusos dessa dita pedagogia nova, no sentido da perda dos reais e primeiros objetivos da escolarização: os saberes elementares da escola primária. Supunham alguns dos pedagogos portugueses que teria sido a 'inflação' do currículo quem conduziu à perda da função precípua do ensino elementar. Na verdade - perguntava-se - o que teria rebaixado o padrão de um modelo escolar que não conseguia mais dar conta da sua tarefa essencial - que era o ensino da leitura, da escrita e das quatro operações? F. Adolpho Coelho, em 1882, a propósito do tema fazia o seguinte comentário:

\footnotetext{
${ }^{416}$ F. Adolfo COELHO, Cultura e analfabetismo, p. p. 43.

${ }^{417}$ F. Adolpho COELHO, Os elementos tradicionais da educação, p. 16-7.
} 
"A escola primária era a escola das primeiras letras; nela aprendia-se a ler, a escrever e a contar; a leitura reduzia-se à reprodução mecânica vocal da escrita, geralmente sem inteligência do que se lia; a escrita à caligrafia e a uma tal ou qual ortografia; o contar às quatro operações fundamentais, indo-se às vezes até as regras de três; acrescia o catecismo católico; depois juntou-se o trabalho de decorar regras de gramática, conjugar verbos e a análise gramatical, um catálogo de reis de Portugal com os fatos pretendidos mais notáveis de seus reinados, e uma seca nomenclatura corográfica. É nisto que está a instrução primária entre nós em regra, e em diversos países as condições não são geralmente melhores."

\section{A ESCOLA QUE VÊ ENTRAR A REPÚBLICA}

A escola que vê entrar a República em Portugal é ainda uma instituição primária que não logrou obter a desejada homogeneidade, a desejada unificação por todo o território do continente. É, muito aquém disso, uma instituição pobre, fragmentária, que atende populações as mais diversificadas e que não dispõe dos necessários recursos para seu papel educativo. Essa escola é responsável por uma prática desacreditada pelas populações, incapaz que se revela de atender seus próprios objetivos declarados: as crianças não aprendem, em sua maioria, nem a ler, nem a escrever, nem a contar. O professor, na única sala de que em geral se compõe a mesma escola, recebe 20 ou 30 crianças, número este que, entretanto, pode variar de acordo com a localidade do país, chegando a haver casos de 60 ou de 6 crianças compondo as classes. A mobília era composta, habitualmente por cinco ou seis banquinhos, às vezes bancos-mesas, onde as crianças, sujeitas a deformações físicas, "passam horas e horas com o corpito feito num arco, mirando e remirando alguma gravura mais interessante dos seus livrinhos de estudo" ${ }^{419}$ Embora de variada superfície, o pé direito de algumas escolas mais precárias chegava a ser de dois metros e, à guisa de recursos didáticos, o professor contava, quando muito, com um quadro-negro em más condições e, por vezes, com um mapa de Portugal. O ensino, absolutamente teórico e árido, afastava a criança de qualquer contato com seu cotidiano, como se esse - como queriam os jesuítas - fosse por princípio fonte potencial de corruptibilidade. Alheios à experiência e mesmo à observação, os fenômenos naturais eram alguma coisa profundamente estranha à prática educativa das escolas primárias portuguesas no princípio do século. Falava-se de inovação; mas a prática voltava-se para a mais entediante tradição. Alguma coisa na escola resistia ao novo; e a população, de algum modo, resistia à escola $^{420}$ :

\footnotetext{
"Efetivamente, para fazer compreender a crianças de seis anos o que são e o que valem as letras e os algarismos, sem outro auxiliar que não seja o seu desenho no papel; para fazer compreender a crianças de oito ou doze anos o que é um cubo, como se constrói um termômetro, que a Terra é redonda, que a Terra gira, qual a situação de Portugal continental e suas colônias, e qual a situação e forma dos diferentes ossos do esqueleto humano sem outros auxiliares que os próprios livros de ensino, é estiolar-se com tanta explicação, é obrigar os alunos a uma atenção e um estudo
}

\footnotetext{
${ }^{418}$ F. Adolpho COELHO, O trabalho manual na eschola primaria, p. 34-5.

${ }^{419}$ Alfredo Filippe MATTOS, O passado, o presente e o futuro da escola primaria portugueza, p. 278.

420 "E o pior de tudo é que os pais, únicos agentes atuais capazes de tornarem eficazes os esforços dos professores, não tendo geralmente meios de comprar os livros escolares e prover os pupilos do indispensável para lhes assegurar uma regular frequência e precisando, além disso, deles para os trabalhos agrícolas onde fazem enorme falta durante as cinco horas de escola, acrescentadas por vezes quase outras cinco para o caminho, acabam por os retirar semi-analfabetos." (A. F. MATTOS, O passado, o presente e o futuro da escola primaria portugueza, $\mathrm{p}$. 279).
} 
superiores à sua mentalidade, é obrigá-los a aborrecerem os livros e desviarem-se do caminho da escola, gazeteando." 421

Mesmo assim, a escola enquanto agência de moralização e socialização será profundamente valorizada por todo o movimento republicano, que, por sua vez, via na instrução uma estratégia privilegiada para elaboração do novo consenso nacional, de índole laica, secular e cívica. Criar a escola efetivamente nacional significaria para os republicanos dar vida e conteúdo à possibilidade de superar pela via da cultura os tempos de abatimento e de declínio nacional; significava dar suporte institucional e viabilidade ao propósito da regeneração; significava enfim caminhar, pela superação do passado, rumo à prospecção do futuro. Recriar-se-ia assim, com a escola e com a República, a nacionalidade em sua acepção mais plena.

Aliás, Catroga já acenava para o intuito que se afigurou no último quartel do século XIX no sentido de formação e consolidação de um novo espírito pedagogicamente formador de uma esclarecida 'opinião pública', capaz de, pela mediação da cultura, erradicar o obscurantismo e trazer um sopro de renovação ao arcaísmo da tradicional mentalidade portuguesa. Os intelectuais da geração nova - que abraça as doutrinas cientistas, evolucionistas e dialéticas - teriam visto a si próprios como fundadores de um novo começo, de uma pátria regenerada, encarando a solução do problema educativo como uma prioridade para esse privilegiado olhar sobre a verdade e sua interpretação. ${ }^{422}$ A sociedade era há tempos vista como um organismo, com uma constituição e funcionamento próprios, sua evolução obedecia a um ritmo, que precisava ser cientificamente controlado, tendo em vista o não esquecido ideal de perfectibilidade que remontava ainda do imaginário herdado das Luzes e de tempos de revolução. Pensar a República passará a ser, nesse esquadro, pensar a gestação de um novo ideal de pedagogia. Novamente a escola, na tessitura de uma nova sociabilidade político-social, viria a assumir um conteúdo de redenção e de profecia.

Mesmo assim, há que se lembrar que Portugal continuava a ser particularmente um país de analfabetos, muito embora o número de escolas houvesse aumentado significativamente. A tese de António Nóvoa revela, nesse sentido, que, entre os anos letivos de 1852/3 e 1899/90, o número de escolas primárias públicas no território português havia praticamente quadriplicado, o que não se verificou nos índices de alfabetização, que não conseguiam sequer alcançar a casa dos $30 \%$ nos primórdios do século. Nóvoa já destacava que as elevadíssimas taxas de analfabetismo em Portugal eram então representativas do descompasso entre os textos das autoridades e dos intelectuais e as reais necessidades percebidas pela população como um todo. ${ }^{423}$

\footnotetext{
${ }^{421}$ Alfredo Filippe MATTOS, 0 passado, o presente e o futuro da escola primaria portugueza, p. 278-9.

422 "Seja como for, o certo é que, fosse para ser colocada como o motor decisivo da 'revolução', ou fosse para garantir a capacidade racional para o bom uso do sufrágio, toda a 'questão política', para a esmagadora maioria dos intelectuais que se interessaram pela 'coisa pública' desde os primórdios do liberalismo, se reduzia, em última instância a um 'problema educativo' e à formação de uma nova 'opinião pública'. Esta conclusão é particularmente visível na primeira geração romântica, no romantismo social dos anos 50, e a 'geração nova' só se distingue pela pretensão de conferir uma dimensão científica à questão. Sabe-se como os intelectuais, particularmente a partir do século XVIII, começaram a afirmar-se como participantes de uma 'república das letras', que os vocacionava, pelo seu próprio oficio, a reivindicarem um comércio mais íntimo com a verdade. Daí o seu estatuto não só crítico, mas também de grupo de pressão face ao poder político, e a atitude ambígua que, em relação a este, manifestaram: atração, repulsa e, muitas vezes, sentimentos de fracasso e de incompreensão. É que, como aconteceu no liberalismo português, o escol sentia que não conseguia levar 'os que detêm as alavancas a tomar as decisões inovadoras', enquanto 'debaixo não surdem os movimentos capazes de as impor'(...) De qualquer modo, continuaram a almejar exercer um papel, se não de detentores do poder político, pelo menos de guias espirituais da nova sociedade." (Fernando CATROGA, Cientismo, política e anticlericalismo, In: José Mattoso, História de Portugal / quinto volume, p. 587)

423 " $O$ esforço quanto ao desenvolvimento escolar é efetivamente apreciável; todavia, os resultados concretos não são compatíveis com seus esforços. Um indicador clássico, a taxa de analfabetismo, nos ajudará a
} 


\begin{abstract}
“A burguesia portuguesa não soube reagir à independência do Brasil e desenvolver as condições socio-econômicas criadas a partir da Revolução Liberal e, em seguida, com a Regeneração; ela não foi capaz de dirigir energicamente o processo de industrialização do país. Assim, apesar da instauração de uma nova ordem social, Portugal não foi capaz de ajustar seu ritmo de desenvolvimento econômico àqueles dos demais países europeus (...) Nesse quadro, não é de admirar que o tema da decadência nacional tomasse a dianteira no final do século. (...) Falta de ciência, falta de instrução. E, no entanto, nós vimos que a rede escolar havia sido consideravelmente estendida no decorrer do século XIX e que o sistema de ensino se havia organizado de acordo com as bases que ainda serão atualmente as suas. Mas a eficácia social da escola permanecia ainda muito aquém do que se poderia esperar. (...) No fim do século XIX a ideologia do progresso é mais forte do que nunca; o principal instrumento desse progresso é a instrução; daí a crença nas virtudes da escola e no papel central assegurado a um personagem relativamente apagado até então: o professor de instrução primária" ${ }^{2} 4$
\end{abstract}

Supunha-se que uma das tarefas prioritárias da distinção com que a ordem republicana deveria operar em relação aos tempos da monarquia era a instrução popular. Mais uma vez, aparece a crença do discurso quanto ao potencial presumidamente transformador posto no ofício da educação escolar. A república desenharia o homem do dia seguinte. E isso, para os políticos da época, parecia ser estratégia essencial. Havia uma nova realidade a ser desenhada. Na verdade, aquela República que começara pela política, havia que firmá-la pela formação das subjetividades e das consciências. Daí, mais uma vez, a confiança irrestrita que parece ser, por alguns dos atores do cenário político, depositada na instrução; instrução essa formadora de uma nova pátria, de um novo pacto social, de uma nova moral coletiva. Essa moral, por sua vez, como destaca João de Barros, é a "moral do esforço, da energia, da vontade, do trabalho"; aquela que efetivamente forma e conforma o corpo e o espírito do estudante para a disciplina da vida do trabalhador. Desejava-se explicitamente substituir o lugar da religiosidade da escola que viera com a Monarquia pelo espírito da constância, da tenacidade, da perseverança, da disciplina, necessário ao trabalhador do futuro.

\begin{abstract}
"Querem que a educação se torne numa aprendizagem para homem - que faça a energia mais flexível, o corpo mais robusto, a inteligência apta para aceitar e compreender o meio em que terá de expandir-se. E abandonando todos os seus ideais que não sejam estes, todos os seus ideais de sectários ou partidaristas - querem unicamente criar almas que tenham outros ideais, e outros desejos e outras ambições. Querem auxiliar o movimento perene, sempre inconstante, sempre variável da vida; querem desenvolver, diferenciar consciências, não criar uma consciência unânime e submissa. Desejariam ser como alguém que, tendo plantado uma semente desconhecida, a trate carinhosamente e devotamente, sem poder adivinhar com que magníficas e imprevistas florações ela deslumbrará um dia os seus olhos maravilhados. Pretendem ser homens de ação, não
\end{abstract}

demonstrar: indica-nos o descompasso existente entre o discurso das autoridadas, os textos teóricos e a realidade cotidiana de Portugal no século XIX. É verdade que o país contava com uma rede de escolas primárias à sua disposição, ainda que de dimensões reduzidas; mas ela não era plenamente utilizada porque " ter à disposição' não significa 'ter necessidade de' e uma análise das taxas de analfabetismo mostra que parcela considrável da população não sentia a necessidade (ou não possuía os meios) de aprender a ler e a escrever." (António NÓVOA, Le temps des professeurs / volume I, p. 350 ) Na sequência, o autor mostra a tabela que transcrevemos abaixo:

\begin{tabular}{llll}
\hline anos & homens & mulheres & total \\
\hline 1878 & $75 \%$ & $89,3 \%$ & $82,4 \%$ \\
1890 & $72,5 \%$ & $85,4 \%$ & $79,2 \%$ \\
1900 & $71,6 \%$ & $85 \%$ & $78,6 \%$ \\
\hline
\end{tabular}

${ }^{424}$ António NÓVOA, Le temps des professeurs / volume I, p. 362-3. 
ideólogos teimosos, estúpidos ou ingênuos, emoldurando a irrequieta expansividade da criança nas suas concepções arqueológicas." ${ }^{425}$

E, assim, indiferente a prescrições dos que desejariam dominá-la para o melhor controle do futuro, a história segue a sua serena trajetória, retratando o traçado de uma escola, que prossegue em hesitar continuamente entre o que se queria alterar e o que teimou em persistir: tradição e inovação, como notas distintas de um mesmo acorde. Sobre a escola, então, passemos a ela...

${ }^{425}$ JOÃO DE BARROS, A escola e o futuro, p. 17-8. 


\title{
Sociedade portuguesa em revista: método da escola e a escola como método
}

\begin{abstract}
"A história tem a propriedade de nos confundir; ela confronta-nos sem cessar com coisas estranhas diante das quais a nossa reação mais natural é não ver; longe de constatar que não temos a boa chave, não nos apercebemos mesmo que há uma fechadura para abrir",
\end{abstract}

(Paul VEYNE, Como se escreve a história, p.259).

\section{A ESCOLA E OS RUÍDOS DA LEITURA}

A situação da escola portuguesa desde o princípio do século XIX e particularmente desde o início do período liberal e constitucional não era exatamente das melhores, se comparada ao restante dos países europeus. Como destacava no ano de 1842 a Revista Universal Lisbonense, o quadro era o seguinte:

\begin{abstract}
"A povoação de Portugal, no continente do Reino, pode-se arbitrar hoje sem erro em 3.300 .000 almas. A perfeição da instrução manda que, de cada 5 indivíduos masculinos e femininos em uma nação, 1 ande na escola. Assim sucede em Inglaterra atualmente. Para este termo se encaminha também rápidamente a América do Norte, pois, pelo seu recenseamento de 1841, trazia em todas as escolas primárias, secundárias e superiores, tanto públicas como particulares, e de um sexo como de outro, 2.493.900 discípulos, os quais, repartidos por 17.062.566 habitantes, dão 1 estudante por 6,8 indivíduos. A França andava nesta parte aquém de sua civilização; mas a nova dinastia tem zelado pela generalização da instrução, principalmente da primária. Contavam-se já ali em 1840, segundo um relatório do ministro competente publicado o ano passado, 2.881.679 crianças nas escolas primárias; (...) pouco mais ou menos 1 aluno entre 8 e 9 habitantes. (...) Deixando de encorpar portanto esta lista com mais nomes e cifras, o que seria fácil, venhamos a Portugal, que para ele é o que nos propomos a tratar com a extensão compatível com os limites e a índole de um jornal semanal, matéria tão transcendente; e vejamos qual é a nossa partilha em confrontação com as mais nações."
\end{abstract}

${ }^{426}$ Cláudio Adriano da COSTA, Revista Universal Lisbonense, tomo II, anno de 1842-1843, volume II série !, $13-10-1842$, p. 37. Como poderemos verificar posterirmente, durante a primeira metade dos anos 40 , o 
A situação de Portugal era já apreendida, portanto, à guisa de comparação com aqueles outros países que, entretanto, pareciam extremamente favorecidos e à frente da situação precária em que se encontrava a península ibérica. Na verdade havia em Portugal na mesma ocasião, segundo dados do mesmo artigo assinado por Cláudio Adriano da Costa, 34.869 alunos de instrução primária e 1.872 de instrução secundária. Isso significava, para os 3.300.000 indivíduos que compunham a população portuguesa de então uma correspondência equivalente a 1 estudante por 54 pessoas. O último recenseamento que dera então esse quadro havia sido efetuado no ano de 1838. De acordo com a situação verificada, a composição média de uma família portuguesa era na ocasião de 3,89 indivíduos; o que significava na prática que, em cada 14 famílias, apenas uma delas teria um indivíduo educado ${ }^{427}$; entendendo -se aqui por educação - diga-se de passagem - o cumprimento de alguns anos de escola, que nem sempre podiam ser caracterizados como profícuos em termos da aquisição das habilidades básicas da leitura e da escrita.

Ocorre que, no decorrer dos primeiros anos do século XX, particularmente no período que imediatamente antecedeu a queda da monarquia, a situação do ensino persistia sendo denunciada pela imprensa periódica, que julgava o caso português sempre à luz de sua já sabida defasagem em relação a países mais desenvolvidos da Europa. A tabela abaixo, publicada pelo semanário A Escola, que circulava em Coimbra no ano de 1905, vinha a propósito do debate que então se travava acerca do recenseamento escolar. Os números por si pareciam já revelar a urgência de se atentar para a gravidade da situação das escolas em Portugal, tendo em vista o próprio desenvolvimento cultural e econômico do país, à luz da comparação com a Europa. ${ }^{428}$ :

\begin{tabular}{|c|c|c|c|}
\hline CONCELHO & ESCOLAS & POPULAÇÃO & $\begin{array}{l}\text { NÚMERO DE ESCOLAS EM } \\
\text { RELAÇÃO Ã POPULAÇÃO }\end{array}$ \\
\hline 1. Condeixa & 12 & 11.597 habitantes & 1 escola para 966 hab. \\
\hline 2. Figueira da Foz & 30 & 43.035 habitantes & 1 escola para 1434 hab. \\
\hline 3.Montemor-o-Velho & 22 & 22.050 habitantes & 1 escola para 1002 hab. \\
\hline 4.Penela & 10 & 10.354 habitantes & 1 escola para 1035 hab \\
\hline 5.Pombal & 14 & 34.516 habitantes & 1 escola para 2465 hab. \\
\hline 6.Soure & 14 & 20.380 habitantes & 1 escola para 1455 hab. \\
\hline 7.Total do Círculo & 102 & 141.932 habitantes & 1 escola para 1391 hab. \\
\hline 8. Total do Reino & 4886 & 5.000 .000 habitantes & 1 escola para 1023 hab. \\
\hline 9. Suissa & 7000 & 2.934.075 habitantes & 1 escola para 419 hab. \\
\hline 10. Noruega & 6490 & 2.000.000 habitantes & 1 escola para 308 hab. \\
\hline 11. Suécia & 9794 & 4.579.115 habitantes & 1 escola para 467 hab. \\
\hline 12. Dinamarca & 2940 & 1.969.039 habitantes & 1 escola para 669 hab. \\
\hline
\end{tabular}

articulista Cláudio Adriano da Costa seria um dos principais redatores do temário pedagógico da referida revista, comumente trazendo inúmeras informações e correlações estatísticas a partir de dados do recenseamento e de outros levantamentos quantitativos, que, por sua vez, contribuiriam para elucidar a carência de referenciais 'numéricos' da época.

427 “(...) e as outras 13, por conseguinte, não se poderão dedicar senão às mais humildes ocupações do trato doméstico ou trabalho braçal; ficando as mulheres condenadas a fazerem as vezes de animais de carga, como se está vendo por essas estradas de província, e os homens a cavarem com uma enxada." (C. A. Da COSTA, Revista Universal Lisbonense, tomo II, volumeII, série I, 13-10-1842, p. 38)

${ }^{428}$ A ESCOLA; bi-semanário dedicado aos interesses da instrucção e do magistério, no 204, 23-9-1905. 
$\mathrm{Na}$ verdade, o debate pedagógico português durante todo esse período compreendido entre 1820-1910 perpassa o objeto sobre o qual discorre a partir de variadas matrizes analíticas. Como já pudemos introduzir no capítulo anterior, houve três etapas que delinearam e marcaram as tendências do discurso sobre a educação em Portugal do período que caminhava do liberalismo monárquico (1820) à República (1910). Em um primeiro momento, compreendido genericamente entre 1820 e 1850, a tônica seria colocada fundamentalmente sobre os critérios e as condições para a extensão por parte do Estado da escolarização às camadas populares. No período compreendido entre 1850 e 1870, passa-se a enfatizar o modelo de escola de Estado que se pretendia desde o princípio engendrar: qual seria o método indicado, como se processaria o ensino, quais os requisitos para a formação de um bom professor, etc. Acreditava-se já que discutir apenas a referência da escola, sem pontuar as estratégias pelas quais se daria seu funcionamento, seria tarefa inócua, dado que a vida escolar, tal como se encontrava à época, não cumpria sequer aquilo a que se propunha. Finalmente, a educação passaria - particularmente entre 1870 e 1910 - a ser apreendida como se de uma ciência se tratasse. Deseja-se conjugar o máximo de eficácia ao máximo de precisão na atividade do ensino, como se esta pudesse ser prevista, controlada, direcionada e fundamentalmente descortinada em função de regras e de toda uma normatização científica que dissertavam sobre o assunto da formação do homem. A pedagogia passaria, desde então, a ser entendida como o conjunto das ciências do homem que, ainda que emprestadas de outras áreas, mapeariam, de maneira inequívoca, o objeto da educação.

O tema da escola persistia, entretanto, tendo alguma imbricação com a dinâmica política, posto que a grande questão intelectual para os teóricos do XIX português era acima de tudo a reflexão sobre a identidade de Portugal. Compreendido quer como destino, quer como vocação, quer como vontade, havia um contorno para a identificação do país. O tema da escola era apresentado como estratégia para dinamizar e consolidar a própria acepção da nacionalidade. Ocorre que, durante o período em pauta, não houve a priorização da política educativa no contexto das políticas públicas. Isso não quer dizer, entretanto, que não houvesse debate acumulado e refletido nos próprios discursos políticos ou mesmo nos jornais da época sobre o referido tema. A instrução pública era apresentada, pelo menos desde os anos trinta, como o motor privilegiado para a regeneração nacional, para a efetivação do progresso social e político e para possibilitar a prosperidade econômica. Na verdade, por essa época, ainda eram muito frequentes as reticências à instrução das camadas populares, que periódicos como O Panorama viriam com veemência defender.

Os preconceitos relativos à instrução popular colocavam-se perante a perspectiva de que o povo, ilustrado, passasse a se recusar a exercer ofícios braçais, o que inevitavelmente ocasionaria uma convulsão social, possivelmente similar àquela ocorrida em França no final do século XVIII. Além desse obstáculo, supõe-se que a instrução e o aprendizado da leitura teriam um efeito nefasto sobre a moral e a religião populares, proporcionando ao homem contato com idéias perigosas, subversivas, transgressoras. Para o caso das meninas, o receio era ainda maior, dado que o conhecimento da escrita permitiria a correspondência livre com namorados e pretendentes, facilitando dessa maneira a fuga do controle paterno. Inquestionavelmente, reconhece-se que a ordem pública seria mais facilmente mantida com a manutenção da ignorância popular. Como a isso se somava o descrédito que, na maior parte das vezes, as famílias depositavam na escola, não havia grandes esforços quanto à promoção da escolarização. Sucede que, de algum modo, o tema da instrução permeava a própria acepção da política liberal, supondo a necessária correspondência entre a cidadania proclamada e a preparação do juízo crítico daqueles que deveriam exercitar a soberania nacional pelo sufrágio. Compreendendo a vida liberal e democrática como um processo em constante e progressivo aperfeiçoamento, destacava-se a urgência de se superar o estágio de "bestialidade" intrínseco à ignorância, de maneira a potencializar os talentos, aperfeiçoar o percurso civilizatório. Oferecer instrução era, para homens como Herculano, acima de tudo, 
capacitar as camadas populares ao apego à ordem instituída, até para que o clamor pela democracia não fosse mais longe:

\begin{abstract}
"Crê-se porventura que a ordem e a tranquilidade pública se mantêm mais facilmente no meio de um vulgo ignorante e grosseiro do que entre homens laboriosos, que, além dos conhecimentos próprios de seus ofícios e misteres, saibam quais são os seus direitos e obrigações, e conheçam alguma coisa do mundo das suas leis e sucessos? Quem assim pensa vai bater contra a história de todos os séculos. Um povo empregado na ignorância e bruteza, será mais fácil oprimi-lo do que governá-lo; ou antes diremos que é mais necessário regê-lo com vara de ferro, para que não se converta em uma besta-fera; ao passo que o povo ilustrado facilmente se governa, sendo ao mesmo tempo impossível oprimi-lo. Entendemos por educação e instrução popular a cultivação do espírito, e não o ensino das artes fabris ou mecânicas, a que muita gente dá aquele nome. Negar o aperfeiçoamento intelectual aos homens; deixá-los na bruteza e na ignorância é um ato imoral, um menoscabo de deveres sagrados, e por consequência um crime. Está assentado que, sendo em toda a parte o homem escravo do hábito, o seu procedimento, quer na vida privada, quer no trato com os outros homens, há de ser dirigido por preceitos constantes e forçosos, e guiado principalmente pelo exemplo. Será regular esse proceder, se ele vir que reina a justiça; religioso, se a santidade de sua religião não for profanada. Mas, apesar disso, o homem não passará de máquina, se carecer de instrução e raciocínio. É, portanto, preciso cultivar-lhe o espírito." 429
\end{abstract}

Oferecer a instrução significava o Estado assumir verdadeiramente parcela da responsabilidade familiar e amparar a nação portuguesa para situá-la no rumo onde já estariam os demais países europeus; como diziam à época, a par de seu tempo. Na verdade, compreendia-se por educação mais do que o componente de desenvolvimento intelectual. A educação abrangeria uma dimensão de valores que não seria redutível a quaisquer saberes de cunho propriamente científico. Através do gesto educativo, se estaria fortalecendo, por um lado a inteligência, e por outro, o caráter moral do indivíduo, para que seus bons atributos pudessem ser potencializados e desenvolvidos ao máximo e para que seus vícios ou suas perturbações fossem sanadas. Trabalhar com a categoria da educabilidade humana era, para aqueles portugueses da primeira metade do século XIX, enfrentar a prevenção do crime. A educação era assim tanto domesticação quanto moralização: o curioso é que, de alguma maneira, a sociedade e particularmente as suas elites viam no potencial educativo a ameaça da

${ }^{429}$ DA EDUCAÇÃO e instrucção das classes laboriosas, O Panorama, volume 2, n ${ }^{\text {o }} 75$, 6-10-1838. Era um tema muito recorrente em $\mathbf{O}$ panorama: "De ordinário confundimos estas duas palavras: educação-instrução; mas cada uma tem sua acepção diversa. A educação é mais ampla que a instrução porque abrange todos os meios de desenvolver e cultivar todas as faculdades do homem, segundo os fins para que as recebemos da natureza; a instrução porém é um desses meios, destina-se a exercitar só uma espécie dessas faculdades, isto é, as intelectuais. Ainda que vulgarmente chamemos educação ao desenvolvimento das faculdades morais, é mui lato o sentido desta palavra porque o homem tem qualidades físicas e intelectuais que todas precisam de cultura e conveniente exercício. Mas não sabemos por que razão, ou se fale de educação ou simplesmente de instrução, o pensamento encaminha-se logo para a mocidade, como se esta idade fosse a única susceptível de exercitar as suas faculdades, de adquirir conhecimentos úteis e bons hábitos e de fazer cotidianos progressos. Este erro é grande apesar de ser geral; porque, qualquer que seja a idade do homem, cumpre-lhe instruir-se e aperfeiçoarse sempre: até o último dia da vida tem esta obrigação e não lhe faltam os meios de a preencher, se a vontade for eficaz. (...) A razão e a consciência são de todas as condições e as virtudes nunca foram privilégio de uma classe da sociedade. Às classes inferiores oferecem-se menos meios de instrução, mas esta circunstância deve ser uma razão fortíssima para não desperdiçarem os que puderem aproveitar.” (O panorama, volume 3, 1839, p. 278) Era muito comum que artigos como esse de vários jornais e revistas da época discorressem sobre o tema da educação, preocupados fundamentalmente com o fundo de cultura, de padrões de moralidade e regras de cortesia com os quais as famílias deveriam orientar a ação educativa de seus filhos. A educação enquanto objeto entraria antes como uma problemática atinente ao âmbito familiar, ganhando entretanto invitavelmente a conotação pública desde logo imbuída no ato da instrução. 
mudança e da revolta. Assim, os mesmos argumentos que eram usados para a defesa da causa da instrução eram utilizados para criticá-la. Para alguns, a escola contribuiria para a dissolução dos vícios, dos crimes, da desordem da rebelião, enfim, de todos os espectros da transgressão do tecido social. ${ }^{430}$ Para outros, ela poderia, perigosamente, fazer o oposto, incentivando as revoltas e potencializando as inquietações que ameaçavam o tecido social. Os partidários da causa educativa - e cabe recordar que a grande maioria da imprensa estaria deste lado progressista - consideravam imprescindível o espraiar da instrução popular em função do fato de o homem ser apresentado como um ser moral, moralidade que, por si, era julgada como atributo distintivo do gênero humano. A escola seria entendida, sob tal perspectiva, antes como uma agência de socialização e de moralização - capaz de trazer ao estudante a compreensão da lógica e das hierarquias da sociedade adulta - por cuja experiência, o indivíduo adquiriria os conteúdos e as atitudes socialmente prescritos e valorizados. A escola era então um rito. Envolvia todo um aprendizado com o manusear do impresso, cuja apreensão ou não também delimitaria lugares sociais, também insinuaria fronteiras de posição.

\begin{abstract}
"Quando desejamos, por exemplo, que os homens destinados para o serviço da lavoura, para as artes fabris, para os vários misteres da sociedade, saibam ler, não queremos que eles se habilitem para ler muitos livros, para gastar nisto a vida, para serem grandes letrados: não pretendemos encher o mundo de sábios e eruditos (...) Os meninos pobres, que frequentam as escolas elementares, tiram desde logo a utilidade de livrar-se da ociosidade, da distração e dissipação do espírito (...) Ao mesmo tempo vão contraindo o hábito da aplicação, da ordem, da obediência, do amor do trabalho, da piedade, da recíproca afeição de uns para com os outros, etc."431
\end{abstract}

Haveria supostamente uma correlação entre os níveis de cultura intelectual do povo e sua moralidade. Era, pelo menos, o que garantiam os jornais que à época circulavam... Propugnando enfaticamente a "multiplicação das escolas, a escolha dos mestres, a boa eleição dos livros e a obrigação de educar a infância", recomendava-se ao povo português a superação do atraso pela erradicação do obscurantismo, dos preconceitos, enfim, de tudo o que tornava arcaica aquela cultura, de tudo o que embaraçava a desenvolução do aperfeiçoamento para o qual a vocação originária portuguesa em sua própria imanência já tenderia. Por ser assim, assumindo interlocução com o leitor do periódico através de onde falavam, os autores costumavam apontar os benefícios individuais da instrução e a contribuição da cultura letrada para o aprimoramento dos talentos individuais. $\mathrm{O}$ indivíduo, por sua vez apresentado como a célula matricial da sociedade, tornar-se-ia imperativo categórico da própria época, sendo, destarte, o investimento no indivíduo uma exigência intrínseca ao liberalismo que se desejava propugnar enquanto doutrina e regime político-social. Há um tempo coletivo, no qual o desenvolvimento individual era pressuposto:

\footnotetext{
"A instrução da mocidade é um grande dever, uma grande responsabilidade adstrita a nós, os homens desta época. O ensino primário, porta de todos os outros, é o que primeiro fere a vista, a quem medita remédio aos grandes males da ignorância pública. A este fim conversaremos com o leitor; e se por fim conseguirmos ficar de acordo já muito haveremos obtido. Teremos levado ao fundo de mais uma alma a convicção de certas verdades, que circunstâncias adversas, império dos
}

\footnotetext{
${ }^{430}$ O PANORAMA, volume IV, 1840, página 391.

${ }^{431}$ O PANORAMA, 3-6-1837, n ${ }^{\circ}$, página 37.
} 
tempos e influência de certos astros, capricham muitas vezes ofuscar ou tornar dúbias.(...). A instrução pública, principalmente a primária, ainda está por organizar entre nós."432

O corpo legislativo era aqui percebido como "depositário das liberdades pátrias"; teria, por ser assim, destacado lugar na organização dos distintos ramos da administração do Estado. Caberia então a ele, sob tal aspecto, a promulgação de leis renovadoras, que permitissem um efetivo aprimoramento do sistema de ensino do país, causa e efeito da tão propalada decadência. As leis, se bem organizadas, poderiam efetivamente irradiar as luzes "por todas as classes, no menor espaço de tempo". Como podemos constatar, há pressa no processo de regeneração da alma nacional para a qual estava talhada a tarefa da instrução; até porque

“(...) é esta uma circunstância importantíssima a que muito se deve atender quando as existências se abreviam cada vez mais e o estado das nações não comporta largo repouso a ninguém. Primeiro, levar a instrução ( quando não a ilustração ) ao centro das maiorias nacionais; primeiro, fazer homens que não representem somente cifras nas estatísticas da população, mas homens que conheçam por si mesmos as excelências da sociedade civil, e saibam respeitá-las e defendê-las; primeiro criar o homem, para que possa servir tanto na oficina, como na fábrica industrial, como nos cargos da nação. Toda outra casta de organização pública está depois desta. Organizai o indivíduo e dai à alma humana a sublime linguagem com que se conversam a sós todas as obras da criação, e tereis conseguido muita coisa erradamente julgada impossível; tereis achado a milagrosa fórmula de tantas equações, que hoje fatigam a atenção de filósofos e filantropos. O indivíduo é a unidade primária da nação. Constitui o homem como de direito carece para corresponder às excelências de sua natureza; preparai-lhe o espírito com alimento sólido e saudável; educai-lhe e semeai-lhe o coração de moralidade; e tereis desta arte constituído não só a unidade, mas todo um povo, uma nação, um império, o mundo!"433

Posto dessa forma, preparado para a nova civilidade eminentemente urbana, o indivíduo deveria ser habilitado para a familiarização com novos ofícios postos pela modernidade da fábrica industrial e das oficinas. Cabia, por um lado, cumprir com as exigências do Estado para o cumprimento integral da acepção mesma de cidadania; por outro lado, dever-se-ia construir a Pedagogia para novas funções que vinham ainda sendo desenhadas pelo Estado português. Â Pedagogia caberia, então, não apenas acompanhar os tempos, mas fundamentalmente, adiantar-se a eles.

Sugere-se, pelo acima exposto, que o corpo legislativo se encarregasse de multiplicar as escolas de maneira a espraiar a instrução elementar. Para tal tarefa, não haveria, aos olhos do articulista, necessidade de tantos recursos quanto desavisadamente se poderia calcular, dado que, nos termos do texto, "ouro nem sempre é o que mais se carece para

\footnotetext{
${ }^{432}$ José de TORRES, $O$ panorama, volume $\mathrm{X}, 2^{\circ}$ da $3^{\mathrm{a}}$ série, 1853. Como já pudemos observar, para esse autor, nitidamente influenciado por Herculano, da carência da instrução poderiam ser facilmente desmembrados outros perigosos e nocivos males sociais: "Pobre geração é a que agora desponta, se este estado de doce abandono da instrução continuar. Farei lá fiúzas para o futuro nos que agora engatinham.; apregoai alto e bom som que a nossa civilização caminha próspera, que para desmentir-vos cá temos os recenseamentos da população na desfavorabilíssima coluna da classificação literária; cá temos uma e muitas freguesias em que não há dois homens que saibam ler, e se revezem nos cargos paroquiais; cá temos a estatística dos crimes e dos vadios; cá temos a paralítica da indústria; a diminuição da riqueza pública; a universidade e academia sem darem de si novo que as honre e dignifique vida; o catálogo das publicações literárias hidrópico de inutilidades e eivadas sensaborias; a raridade de obras de préstimo e cunho científico; a literatura ainda assim mais filológica do que original e doutrinária, reduzida a meia dúzia de nomes, meia dúzia de cultores salvos como Deucalião do geral cataclismo das letras portuguesas! Oxalá que o zelo nos houvesse enganado nesta apreciação da época; mas ainda mal, que assim não é." (José de TORRES, Id. Ibid. , p. 287)
}

${ }^{433}$ José de TORRES, O panorama, volume X, $2^{\circ}$ da $3^{a}$ série, 1853, p. 266. 
ocorrer as grandes obras. Pensamento bom e amadurecido; meditação repousada e conscienciosa para o alicar; determinações a tempo; vigilância na execução; valem mais do que tesouros. Se queres podes.",434

Tal ensinamento seria extraído do próprio Evangelho, que essencialmente, valorizaria a 'perseverança' e a 'vontade fervorosa', que, por sinal, são também aqui virtudes destacadas. Recomenda José de Torres que o ensino primário viesse a ser assim instaurado na circunscrição de todas as aldeias do reino, explicitando que o decreto legislativo de 20/9/1844 apenas facultava câmaras, juntas, irmandades, confrarias paroquiais a darem subsídios a todos os que ensinassem nos "lugares baldos de escolas". Confessa o autor que

\begin{abstract}
“(...) neste facultar, sem obrigar, reside um dos maiores estorvos ao progresso da instrução elementar. Cumpria determinar, terminantemente, que todos esses corpos concorressem à multiplicação das escolas, que desta arte mais ganhava a humanidade, e ser-lhe-ia este serviço sobre todos relevantíssimo. Em verdade, mui perseguidas de encargos estão as administrações municipais. Não há emprego, não há comissão de novo invento, para que se lhes não mande abonar o ordenado! E as estradas, e as águas a padecer! E tanta obra absolutamente necessária a clamar! E o número de expostos a multiplicar e a absorver quase tudo o que o pobre município liquida, sem que se cuide nos meios por que esse fatal incremento possa porventura parar! E os rendimentos do concelho cada vez menos e mais desfalcados! Cesse todo este abuso. Deixe-se ao município aplicar imediatamente às suas necessidades exclusivas os rendimentos próprios Por que não há de o celibato pagar contribuição direta de captação, com que se dote a junta geral administrativa do distrito, habilitando-a assim a absolver as câmaras da quotização para sustentação de expostos?",435
\end{abstract}

${ }^{434}$ Id. Ibid., p. 274. Na verdade, o projeto de uma escolarização primária estendida à totalidade das crianças do reino estava posto com uma relativa nitidez desde que, na época da Revolução Liberal, os jornais democráticos passaram a falar sobre isso. Lê-se, por exemplo, no Censor provinciano de 25-1-1823 que haveria necessidade coletiva de uma educação nacional que efetivamente fosse comum a todos os cidadãos para configurar, com solidez, o caráter da nação portuguesa. O ensino público abarcaria, de acordo com os articulistas, uma dupla função: se por um lado destinava-se ao indivíduo, por outro, voltava-se para a pátria. O projeto pedagógico que se desejava ver traçado por uma comissão de especialistas, capazes de elencar o rol de matérias necessárias, deveria ser apropriado para confundir os filhos da aristocracia com as crianças oriundas de meios populares. Nos termos do texto: "É porém para esse efeito que aquelas escolas devem ser mais essencialmente estabelecidas, sendo obrigados a ir nelas receber uma educação comum os filhos de todos os cidadãos, o Povo Português. Aí os do pobre, do rico, do artista, do lavrador, do sábio, do cavalheiro, do fidalgo, irão aprender, na entrada para a sociedade, a reconhecer-se iguais entre si; sentando-se indistintamente nos mesmos bancos, ouvindo as mesmas doutrinas, e a ver que só por a diferença dos talentos e dos costumes pôde haver entre os homens diferença. Uns aprenderão a olhar sem desprezo; outros sem prevenção." (CENSOR PROVINCIANO, $\mathrm{n}^{\circ}$ 8, 25-1-1823, p. 114-5). Assim, deveria haver um nível de instrução que fosse deveras comum a todas as crianças do Reino liberal; uma instrução idêntica para todas as classes para todos os talentos da sociedade: a educação nacional, “a das escolas primárias a todos pode dar-se; todos devem ser obrigados a recebê-la” (Id. Ibid., p. 115-6).

${ }^{435}$ Id. Ibid., p.274. Sobre o decreto a que se falou acima, consta do Relatório Anual do Conselho Superior de Instrução Pública referente ao ano letivo de 1856-1857 o seguinte comentário: "O decreto de 20 de setembro de 1844 dispõe (...) que os administradores do concelho, nos primeiros três meses de cada ano letivo avisem, intimidem, repreendam e por fim multem em réis 500 até 1000, a todo pai tutor ou chefe de família que, tendo filho, pupilo ou subordinado seu em idade de aprender, deixar de mandá-lo à escola. Não me consta porém que algum dos administradores deste distrito, exceto o de Ponta do Sol, tenha sido pontual no cumprimento deste dever; e o mais é que, quando se lhes argumenta com a terminante disposição do citado artigo, tomam para desculpa de sua inércia, a doutrina da portaria do Conselho Superior de Instrução Pública, de 22 de março de 1845, cujo sentido torcem e entendem exclusivamente, em harmonia com o sentimento de sua negligência. Esta é, sem dúvida, uma das causas permanentes da pouca frequência das escolas primárias. $O$ desleixo de alguns professores é outra destas causas. Sabem estes funcionários que, quer tenham muitos, quer tenham poucos alunos, sempre hão de ter o mesmo ordenado; porque, lá quanto à gratificação contingente da respectiva municipalidade, não contam com ela. Mas, como ensinar a poucos dá menos incômodo e trabalho, que ensinar a muitos, seu próprio interesse os inibe de terem pela frequência das respectivas escolas, o zelo de que aliás seriam capazes. Professores há que, tomando por pretexto o pequeno número de alunos que lhe frequentam as escolas, encerram a sessão antes da hora prefixa no regulamento, e vão empregar em misteres de conveniência 
Percebe-se que aqui a centralização dos recursos e os privilégios de que ainda desfrutava o clero são compreendidos como vestígios do Antigo Regime, a serem, enquanto tal, derrotados pelos ventos da modernidade em construção. Na trilha de Herculano, o jornalista defende a edificação do moderno cenário urbano à luz da pauta do municipalismo. Sugere-se, nessa direção, que, em prol do investimento na instrução, as administrações municipais repartissem com outras instâncias alguns de seus encargos. Particularmente o amparo dos 'expostos' poderia ficar sob a responsabilidade das 'misericórdias'; o que, por exemplo, aliviaria as câmaras que, nesse caso, passariam verdadeiramente a assumir o encargo da instrução elementar, fundamentalmente onde não houvesse escolas "pagas pelo cofre nacional". O artigo de José de Torres chama a atenção por, na contramão de seu tempo, acenar para a via municipalista como a melhor vertente de desenvolvimento da escolarização primária. Isso contraria a matriz pombalina e a própria acepção da modernidade nacional, dinamizada por uma escola pensada como única e homogênea para todo o território nacional.

\footnotetext{
"O cofre do concelho, proporcionando meios de instruir os seus munícipes, e preparar gerações mais úteis a si e à nação do que o podiam ser até agora, provê a uma das maiores e mais reais necessidades de portas adentro. A junta de paróquia, a irmandade, a confraria suprimiram uma festinha ignorada e inútil, porque nem serve a edificar quando os espíritos não estão convenientemente preparados por uma educação religiosa (...) mas em compensação disso, destiná-las à instrução liberal dos fiéis é um melhor serviço prestado às almas que a pobreza traz condenadas à cegueira, e talvez por isso mesmo à perdição. Sejam todas as escolas primárias da mesma categoria, mas variem de turma na razão dos cofres de que derivam. Multiplique e pague o Estado as escolas ditas nacionais, não tanto aumentando-lhes o número, mas regulando-as normal e adequadamente: obrigue a lei as câmaras a sustentar as escolas municipais; e as juntas, confrarias e irmandades as paroquiais; todas bem gratificadas, e sem diferença de plano, e então veremos desaparecer a grande calamidade, o primeiro estorvo à instrução popular: a tão sentida falta de escolas." 436
}

\section{REERguimento DA VOCAÇÃo DE PORTUgal PELA Generosa Altenativa DA CULTURA}

A escola era então apreendida como algo que não existia. As que existiam não funcionavam: fosse porque as famílias não viam qualquer sentido em sua existência e para lá não enviavam seus filhos, fosse porque ela não cumpria o que dizia fazer - os alunos de lá saíam sem saber ler, nem escrever, nem contar... A escola portuguesa era objeto de indagações pelo que dava a ver e pelo que projetava para o futuro: uma nação inculta, sem tarefa histórica e sem recordação sequer de seu glorioso passado.

Talvez por tal razão era extremamente comum o discurso centrar-se sobre a especificidade necessária de qualquer reforma da educação, que deveria fazer-se à portuguesa, por portugueses e para portugueses, distanciando-se dos modelos e referenciais externos. Ainda que se soubesse o quanto tal prescrição se distanciava da realidade, ela era frequentemente ecoada pelos contemporâneos que dinamizavam com isso o debate sobre a apropriação acrítica de modelos estrangeiros, tão comum...

pessoal o tempo que cerceiam ao serviço do professorado.”(RELATÓRIO ANNUAL [1856-7], O instituto, número $21,1^{\circ}$ fevereiro 1859 , p. 256).

${ }^{436}$ José de TORRES, O panorama, volume X, $2^{\circ}$ da $3^{\mathrm{a}}$ série, 1853, p. 274. 
As nações são encaradas, aliás, a partir de uma índole que lhes seria própria. E esta, por sua vez, desmembrar-se-ia da acepção corrente quanto à idéia que a sociedade tem de vocação. O progresso se deve a vocações não contrariadas, e o modo de existir da teia social revelaria a acepção mais plena desse componente individualizado e coletivo. Enquanto vetor de desenvolvimento individual, a vocação seria, acima de tudo, a adequação entre uma determinada personalidade e uma função social. A descoberta da vocação seria, pois, o segredo para que cada um encontrasse o que, em última instância, de fato procuraria: "pedra filosofal de todos os tempos seria achar para todos e em todos os lugares essa conveniência tão perfeita, tão harmônica, tão fecunda em prodígios, tão assombrosa em seus resultados." Ora, se não foi a vontade humana quem atribuiu a vocação, não compete ao homem desafiar a esse seu natural chamado. Contrariar a vocação seria contrariar o talento e a própria possibilidade de êxito individual. Nas palavras de Luís Filippe Leite $(1828-\ldots)^{437}$, descobrir as propensões com que a natureza dotou de gênio cada um seria a verdadeira e derradeira finalidade da ação educativa.

\begin{abstract}
"O que vulgarmente se chama inclinação nem sempre pode servir de guia. Raro é o menino que não goste de brincar com armas e petrechos militares; mas ninguém concluirá daí que estão destinados todos para Fredericos e Napoleões. A inteligência também não é a melhor guia para decidir da futura aptidão para o exercício de tal ou tal mister. Nem sempre são as inteligências mais precoces que dão os melhores e mais duradouros frutos. Mas então, por onde se deve regular o educador, se inteligência e inclinação enganam tanto na verdadeira apreciação das vocações ? Por aquilo que nem os homens nem os tempos, nem os lugares poderiam jamais destruir, modificar, nem corrigir; numa palavra, pela índole. Com a idade, tudo muda ou se desenvolve no homem; a índole, essa nunca muda. $\mathrm{O}$ atrevimento, a energia, a insinuação, o sangue-frio, a perseverança, a delicadeza, não se adquirem. O gênio, a índole, são de cada indivíduo. Serão os mestres capazes de julgar? Devem sê-lo. Se-lo-ão os pais? Quase nunca infelizmente. Mandam os filhos à escola; julgam ter feito tudo. Era preciso educar primeiro os pais, mas já não é tão fácil. Então os mestres? Esses sim, nesses é que pode residir o observador desapaixonado e livre de preconceitos, caprichos e ambições; é neles que se pode encontrar o juiz imparcial, que estude o coração de seus alunos sem o prisma de loucas pretensões. Ao mestre é que compete este difícil mas valiosíssimo encargo. Ele informará os pais da verdadeira vocação de seus filhos. A vocação não contrariada é meio caminho para a felicidade. E estas duas vice-providências da terra, pais e mestres, decidirão, não já pelo simples acaso dos futuros destinos daquele que um dia tem de ser chamado a contribuir com o seu capital de aptidão em prol da humanidade, da família e de si mesmo."
\end{abstract}

${ }^{437}$ Luis Filipe Leite - vale lembrar - foi professor no Liceu Nacional de Ponta Delgada e depois Diretor da Escola Normal Primária de Lisboa por decreto de 1854. Foi talvez o discípulo dileto de Castilho e escreveu vários livros sobre educação, dos quais destacaríamos Ramalhetinho de puerícia, que foi extremamente utilizado nas escolas de Portugal desde o ano de 1854 e $\mathbf{O}$ engeitado que, segundo nos informa o Diccionario bibliographico portuguez de Innocencio Francisco da Silva, foi publicado a princípio no jornal Archivo universal. Quando D. António da Costa era ministro, Luís Filippe Leite com Castilho foram convidados a participar de uma comissão encarregada de estabelecer bibliotecas populares em todo o país. Leite foi ainda secretário de uma comissão encarregada de organizar programas para o ensino primário - sob a presidência de Pires de Lima - cujos resultados transformaram-se nos regulamentos aprovados em 1881 no Ministério de António Rodrigues Sampaio. Nos termos de Innocencio, Luis Filippe Leite serviu dois anos, 1885 e 1887, como vogal da comissão inspetora das escolas normais, cargo também gratuito e eletivo, recebendo a eleição do Conselho do Liceu Central de Lisboa. No primeiro ano foi relator, mas o seu relatório, mandado para a direção geral da instrução pública, não chegou a imprimir-se." (INNOCENCIO Francisco da Silva, Diccionario bibliographico portuguez, tomo XVI, p. 22) Da biografia de Leite consta ainda a publicação em 1892 de uma memória escrita especialmente para um congresso pedagógico hispano-português-americano que se reuniria em Madrid naquele mesmo ano. Sobre o clássico Do ensino normal em Portugal, remarque-se as palavras de Innocencio que, aliás, é fonte de todas as demais informações desta nota: "Pertence à série de trabalhos impressos de professores portugueses, ali apresentada pelo representante de Portugal ao dito Congresso, sr. Dr. Bernardino Machado (depois ministro das obras públicas, comércio e indústria)" (Id. Ibid.).

${ }^{438}$ Luís Filippe LEITE, O panorama, volume X, $2^{\circ}$ da $3^{\mathrm{a}}$ série, 1853, p. 334-5. Na sequência, o articulista diz acreditar que ao educador público competiria, entre outras, a tarefa de descortinar vocações: "Eduquem-se pois 
O problema do conceito de vocação para a matéria pedagógica reside no facto de que, se por um lado, ele configura uma atualização da acepção de talento, tão cara aos enciclopedistas franceses do século XVIII, por outro, a categoria de vocação retira da Pedagogia parte de suas potencialidades. Se ao nascer, a pessoa traria inscrita consigo uma dada propensão natural para este ou aquele ofício, tornar-se-iam reduzidas as perspectivas de transformação individual pela ação educativa. Ao aplicar a idéia de vocação a uma dimensão coletiva, aí sim, não há volta a dar; cai-se necessariamente na dimensão da fatalidade, do cumprimento de um destino imanente inscrito de maneira teleológica no espírito do povo ou de cada nação em particular: destino esse que viria a se objetivar com o correr dos tempos, mas que permanece e persiste sendo hoje o que fora outrora e sempre. Daí vêm também as noções de caráter nacional e talvez até de identidade de um país construído pela recordação das diferenças perante outros povos, outras culturas. A ilusão de uma feição portuguesa capaz de nacionalizar as idéias emprestadas do estrangeiro é uma tônica bastante presente no discurso pedagógico português do XIX. Cabia, sem dúvida, a inovação. A inovação - sabia-se - envolvia reformas institucionais. Por outro lado, não se aceita dissolver o velho para fundar e estrear o inteiramente novo; nem em política, nem em matéria pedagógica. Pretende-se antes revitalizar alguns aspectos, atualizar outros, para compor um mosaico que verdadeiramente expressasse para os portugueses sua índole própria enquanto nação. ${ }^{439}$

Não adiantaria incorporar, de modo mecânico, conteúdos e metodologias de ensino de outros povos. Não haveria nisso adequação, por faltar aquela correspondência entre índole coletiva e projeto desenhado. Havia que assimilar tais saberes aos usos e aos costumes particulares e específicos de Portugal e então sim eles poderiam ser, de algum modo, aproveitados. Seja como for, reconhecia-se haver um rumo comum para onde se dirigiam inevitavelmente todos os que se pretendessem em consonância com seu tempo; pois acabara a época de nobreza guerreira, quando instrução cabia apenas aos considerados "espíritos fracos". O Estado moderno teria trazido para dentro de suas fronteiras novas posições, novas necessidades, tanto de educação enquanto um requisito social - a envolver inclusive as regras de urbanidade e de cortesia - quanto da instrução, do ponto de vista cognitivo, propriamente intelectual. Os demais países da Europa - e isso era constantemente recordado - já teriam inaugurado aquela desejada modernidade educativa. A propensão civilizatória pressuporia um dado grau de cultivo letrado, ao menos talvez a alfabetização. O próprio modelo escolar firmava-se intencionalmente perante códigos e sinais que dialogavam com uma única acepção

alguns homens nos verdadeiros conhecimentos do espírito e coração, exija-se-lhes como primária condição irrepreensível moralidade, forme-se-lhes a eles também o coração bom e afetuoso, dê-se-lhes a missão de estudar as vocações, isto é, o íntimo da alma e coração da geração nova, nobilitem-se esses pesquisadores das minas do porvir com o honroso título de mestres; não deslizem eles próprios um só ápice do que devem ser, e a felicidade individual e a prosperidade pública terão doravante mais sólidas bases." (Id. Ibid.)

439 "A estas duas ordens de causas, às quais se deve juntar-se o arrojado intento de tudo reconstruir em coisas de instrução com alguns traços de pena, atacando violentamente os hábitos, os costumes, as tradições do passado, poderá talvez com segurança atribuir-se a esterilidade de tantos esforços e tentames empregados em melhorar a sorte da instrução nacional. Por tais razões deve ter-se muito em vista que reformar não é dissolver nem destruir, é melhorar o estado atual das coisas, inovando umas, alterando, modificando e ampliando outras, conciliando o novo com o antigo, respeitando as bases fundamentais d'antes estabelecidas, cobrindo todos os atos do reformador com o escudo da sabedoria a da equidade: que atender até certo ponto aos hábitos contraídos, que se tornam muitas vezes uma segunda natureza; respeitar o caráter nacional e o grau de civilização do país; ter em conta as tendências naturais e as necessidades dos povos; buscar o bem geral com pensamento elevado e desprendido de repugnâncias e interesses pessoais; são tantas condições que devem guiar o espírito reformador, que, se cada povo tem sua vida própria e feições características que o distinguem, as reformas, os regulamentos e as leis, que devem ser a expressão, um como reflexo dos usos, dos costumes e da índole das nações, hão de necessariamente variar segundo os países." (Manoel Francisco de Medeiros BOTELHO, O que é e o que deve ser a instrucção nacional, p. 4-5). Já tivemos a oportunidade de nos referir a outra obra deste autor no capítulo anterior. 
de cultura, que, ao se colocar pelo caminho da instrução, destronaria as pretensas concorrentes de matriz popular. A irradiação da escola, naquele percurso do século XIX, firmaria, de uma vez por todas, a civilização do escrito. Por outro lado, havia de se erigir valores para cuja adesão as crianças e os jovens deveriam ser formados. Evidentemente, nesse rol valorativo vinha muito da memória histórica que se desejava efetivar. A memória coletiva, esta, a escola se encarregaria de ajudar a construir e fundamentalmente de transmitir. Havia signos e indícios perante os quais a escolarização prepararia para o mundo do trabalho as gerações emergentes. A moral e a razão seriam, sob essa dinâmica, as duas âncoras sociais para sedimentar os projetos e as proposições pedagógicas das mais variadas ordens.

\begin{abstract}
"Portanto deixe-se ao professor público ou livre o ensino da constituição do Estado, dos direitos e deveres dos cidadãos, das regras de civilidade ou de boas maneiras, dos princípios de moral, fundada sobre a religião natural, que imprimam nos corações dos alunos os sentimentos de piedade, de respeito pela constituição e leis do país, pela ordem pública, pela verdade e justiça, de dedicação e amor pela pátria, de gosto pelo trabalho e economia, de benevolência para com todos, de temperança, moderação e de muitas outras virtudes, que fazem o bem-estar da sociedade, a prosperidade da nação. (...) Quanto à instrução, ainda que esse ensino não seja consagrado a formar sábios, ele não deve, todavia, limitar-se à simples leitura, escrita e primeiras noções de cálculo: isso é já alguma coisa, mas não é o bastante: saber assinar o seu nome, ler com dificuldade um conto ou lenda popular em qualquer livro de futilidades, distinguir um nome d'entre outros em uma lista eleitoral, não compensa os esforços o encargos do Estado nem os sacrifícios das famílias. Importa pois, ou melhor, é indispensável que os nossos estudos primários obrigatórios abram o espírito e desenvolvam a inteligência a todo o cidadão, lhe ensinem a melhor conhecer seus direitos e a praticar seus deveres; que o tornem mais apto para certa esfera de funções públicas, compatíveis com aquela ordem de estudos; que o coloquem em condições de ir seguindo, quanto possível, o movimento do progresso industrial que se vai realizando em nossos dias, de exercer mais especialmente o trabalho inteligente, único que pode elevar o homem à altura da sua missão, numa época em que a força do vapor e a ação da máquina se vão tornando os únicos fatores do trabalho físico ou puramente material."
\end{abstract}

O papel secular da escola combinaria, pois, ao ensino das habilidades técnicas da leitura, da escrita e do cálculo, o aprendizado das virtudes socialmente recomendáveis, bem como parâmetros de trato interpessoal; enfim, civismo e civilidade, tinham no composto da sociedade a explícita finalidade de formatação do homem português, dentro da perspectiva do que se supunha ser os traços especificamente nacionais. $\mathrm{O}$ traçado da escola era, por assim dizer, um instrumento de combate à decadência. ${ }^{441}$

Sobre o costume dos portugueses que se teriam destacado pela aventura, pela glória e pelas conquistas, Portugal é tido sempre como o primeiro sinalizador de uma época onde teria sido dado enorme impulso ao esforço civilizatório. Nenhuma outra nação poderia ser, sob tal prisma, igualada aos portugueses, que, "se mais mundo houvera, lá teriam chegado". ${ }^{442} \mathrm{O}$ drama é que Portugal é sempre tomado pelo crivo de seu passado, como se

\footnotetext{
${ }^{440}$ Manoel Francisco de Medeiros BOTELHO, O que é e o que deve ser a instrucção nacional, p. 10-12.

${ }^{441} \mathrm{O}$ tema da decadência e do papel da instrução como recordação de gloriosos dias do passado eram muito frequentes em revistas e jornais da época: "O maior serviço que se pode prestar ao país é alimentar o fogo sagrado da instrução; educar um povo dos mais aptos para aprender; falar-lhe à alma e ao coração, lavá-lo pelos instintos nobres que adormecem, mas não morrem; despertá-lo da sonolência pela memória das tradições passadas e pela promessa do melhoramento que o porvir promete à constância e ao trabalho. Quem tomar sobre si esta obra aceitou uma grande missão e pode contar que se não há dever só no meio da estrada." (O PANORAMA, volume IX, $1^{\circ}$ da $3^{\mathrm{a}}$ série, 1852 , p.1)

442 "Portugal, simbolizando uma época de glória, avantajou-se no espírito do valor, não pela idéia de conquista e de domínio, mas pelo impulso da civilização, rasgando o horizonte e abrindo as portas do mundo (...) A pureza de costumes, a virtude e o espírito de união ligam os fenômenos da vida social, animam a vontade até ao
} 
nisso estivesse potencialmente contida a grandeza de um futuro promissor; presente entretanto não há...

\begin{abstract}
"Esforçados e combatentes, sempre valorosos e intrépidos, enristaram eles suas lanças para a conquista e desenrolaram suas velas para a descoberta. Sofredores sem exemplo nas maiores e mais arriscadas fadigas, nunca souberam recuar quando o fim de uma encetada empresa prometesse em definitivo resultado o engrandecimento e glória da pátria. E assim como são constantes nos trabalhos, grandes nas dificuldades, sofredores no infortúnio, do mesmo modo se distinguem em tudo que há demais transcendente e delicado para o espírito." ${ }^{\text {¿43 }}$
\end{abstract}

Distinguindo-se pelo respeito à religião, ao rei e à pátria, o povo português teria na honra seu maior predicado. Cortesia, urbanidade, tolerância e hospitalidade, são caracterizados como atributos pertencentes à índole de uma nação que, por essência, teria na generosidade sua maior grandeza. Ocorre que tais virtudes, ainda que fossem postas como vocação, deveriam ser sempre atualizadas para serem mantidas como características do povo. Isso exigiria a correção de algumas mazelas e dificuldades no plano das condições econômicas do país. Portugal deveria - segundo entendiam os jornais - fomentar a indústria nacional de maneira a desenvolver recursos próprios que o tornasse independente da dinâmica colonial, particularmente em crise desde a independência do Brasil.

A instrução popular, se bem desenvolvida, poderia equipar o povo português para as habilidades que esse mundo moderno e industrial tanto necessitava, preparando, desse modo, uma nova versão da prosperidade nacional. Portugal perdera com a colonização que não soubera efetivar e, por outro lado, teria sido a colonização quem impediu o país de se voltar com maior ênfase para os recursos próprios do seu solo. Havia de se desenvolver um modelo de instrução popular especificamente voltado para regenerar esse erro histórico e recuperar a vocação de grandeza da pátria portuguesa. Formar pela ciência e organizar nessa direção um modelo combinado de instrução popular seria a tarefa máxima do Estado, em

sacrifício no amor da pátria e conservam, pela força da liberdade, a grandeza dos Estados. Se quiséssemos fazer paralelo entre as nações, no seu antigo poder e glória, veríamos que nenhuma outra se mostrou superior, nenhuma ofereceu mais vasto quadro de grandeza e assombro de heroísmo, mais superior estímulo de audácia e grandes virtudes, do que este Pequenino Reino do Ocidente, que se faz conhecer até os mais distantes pontos da Terra, e pelo mundo todo fez espanto. E se mais mundo houvera, lá chegara” (Apolino PINTO, Método intuitivo de leitura, p. 79). Com estas palavras o compêndio apresenta o país e a índole nacional às crianças.

443 José Maria LATINO COELHO, Enciclopédia das escolas, p. 284-5. Na sequência consta a seguinte apreciação sobre a alma portuguesa:"Se Portugal deixou de ser a princesa das nações, como se lhe outrora chamara, face a face com sua decadência, é ainda assim uma nação briosa, tanto quanto lho permite sua importância política. O português ama com excesso sua pátria e apesar da normal placidez de seu caráter, será ainda arrebatado e entusiasta sempre que houver mister de defender a sua independência (...) O português é por índole caritativo para com os seus próprios inimigos e generoso até mesmo da privação da fortuna." (Id. Ibid., p. 285) Os grifos são nossos. Cabe recordar que José Maria Latino Coelho (1825-...) era um importante político e intelectual da época. Foi sócio efetivo da Academia Real das Sciencias de Lisboa, servindo como Secretário Geral da mesma instituição no ano de 1856. Foi também deputado às Cortes por Lisboa em 1855 e deputado pelos Açores em 1856 e 1860. Havia sido ainda diretor do Diário de Lisboa. Como destaca o Diccionario de Innocencio Francisco da Silva, Latino Coelho queixava-se das críticas que recebia por parte de inúmeros intelectuais portugueses, que esperavam talvez dele mais do que de fato seu talento poderia dar, chegando-se a dizer que Coelho era mesmo "um estilo à procura de um assunto". Dentre os trabalhos teóricos que efetuou destacam-se os "Estudos sobre os diferentes métodos de ensino do ler e escrever", que seria publicado no Panorama de 1854, e esta Enciclopédia das escolas que faria em conjunto com Júlio Caldas Aulete. Sobre isso o Diccionario Bibliographico Portuguez comenta o seguinte: "Apesar da indicação do rosto, ainda se ignora ao certo qual é a parte que o Sr. Latino Coelho teve nesta empresa. Uns lhe atribuem a composição de alguns tratados conteúdos no livro, outros afirmam que só a introdução é da sua pena, etc." (INNOCENCIO Francisco da Silva, Diccionario Bibliographico Portuguez, p. 41, tomo V). 
direção a essa específica forma de ver a possibilidade da regeneração de um país que pretendia antes resgatar o que supunha perdido do que transformar as condições objetivas. E a percepção dos contemporâneos sobre si próprios vinha atada à idéia de uma aptidão coletiva que guiaria os destinos do povo português. Atualizar essa tendência parecia ser a tarefa maior:

\begin{abstract}
"Portugal teve seu século glorioso de descobertas e de conquistas, donde, pelos sãos princípios de economia política, se então eles fossem já patentes, teria podido colher mui profícuos resultados. A época das conquistas já passou e oxalá que não volte jamais. Deus não pode querer que umas nações vão fundar fortuna ou grande poderio sobre lágrimas de outros povos. Portugal, hoje pelo seu esvaecimento, procedido de causas de todos sabidas, não pode competir na India e na China, com a imensa indústria e navegação inglesa que domina toda aquela porção do globo. A colonização da nossa África também não poderia dar-nos, realmente, vantagens imediatas. Para onde pois nos deveremos nós tornar mais próxima e vantajosamente, senão para o trabalho produtivo dentro do próprio país? Deve ser o nosso Brasil. Bem constituído, organizado e fortalecido o centro, facilmente se descreve o círculo; facilmente se tiram raios para a circunferência. O resto é o menos difícil. Fomentar toda espécie de indústria, compatível com o nosso solo, deve ser portanto a única mira, assim, do governo como de todos os que deveras amam a pátria: eis o emprego lucrativo, patriótico e honesto, para onde os capitais devem ser encaminhados. Mas, circunscrevendo-me ao assunto principal, direi que é sabido que as artes não podem ser nada, absolutamente nada, sem os princípios da ciência de que elas são mera aplicação. Um ensino fácil e elementar de física aplicada à indústria, de química industrial, geometria aplicada e de agronomia, tudo em locais próprios, em dias e horas oportunas, influiria para logo e poderosamente, sobre toda a indústria, elevando-a à perfeição e prosperidade."444
\end{abstract}

De algum modo, a idéia de regeneração pela via da instrução percorria também um imaginário extremamente preocupado quanto à possibilidade da desordem, da desrazão. As crianças nasceriam todas com pendor para o bem e para o mal, e competiria à ação educativa reforçar ou eliminar tal traço de propensões com que a natureza dota cada um em princípio. No decorrer do desenvolvimento humano, o indivíduo paulatinamente vai deixando o mundo da natureza para ingressar no território da cultura. Nessa trajetória, haveria, entretanto, alguns parâmetros pelos quais a vida da criança em seu desenvolvimento rumo à maturidade poderia ser qualificada como normal. Ser normal é algo posto como um dado; quaisquer desvios da ritualização prescrita poderiam ser compreendidos como vestígios de anormalidade. A educação, enquanto prática, era apontada como tarefa social de controle das paixões e das naturais inclinações. A formação das crianças tinha, pois, que necessariamente ser conduzida perante a completa obediência. E o aprendizado dessa obediência deveria vir ancorado por atitudes de autoridade e não apenas pela ameaça da punição ou do castigo. A rotina da educação deveria ser criada antes pelo hábito do que pelo discurso e, até certo ponto, educar era justamente essa maneira de incutir atitudes socialmente recomendáveis às gerações mais jovens. ${ }^{445}$

Tempos depois, os portugueses continuariam assinalando o fato de que, como se sabia, a instrução jamais fora uma prioridade no rol de políticas públicas em Portugal. Dados de Manoel Francisco de Medeiros Botelho oferecem sobre o ano de 1872 o seguinte quadro: "Na Prússia há uma escola para 633 habitantes; na França, uma para 564; na Holanda, uma para 411; na Suíssa, uma para 349; nos Estados Unidos, uma para 185; em Portugal, uma para 1.156. A desproporção é imensa!" 446 Haveria etapas do desenvolvimento emocional e cognitivo da criança, cuja identificação mostrava-se imprescindível em direção à compreensão dos fatores intervenientes, bem como das distintas fases da desenvolução do

\footnotetext{
${ }^{444}$ F. M. Gouvea PINTO ,Revista universal lisbonense, tomo VII, ano 1847-8, p. 542.

${ }^{445}$ O PANORAMA, volume III, 1839, p. 405-6.

${ }^{446}$ Manoel Francisco de Medeiros BOTELHO, O que é e o que deve ser a instrucção nacional, p. 18-9.
} 
aluno. Sabia-se que as escolas eram insuficientes em termos quantitativos. Sucede que aquelas que existiam quase sempre funcionavam mal, o que induz os educadores e intelectuais da época a refletirem sobre o problema do método e dos procedimentos pedagógicos, bem como sobre as estratégias de aprendizagem. ${ }^{447}$ De algum modo, a tarefa educativa era potencialmente - e paradoxalmente - a radicalização e a contrariedade da acepção de talento, de índole, de vocação e de tudo o que mais pudesse soar como um dom posto pela natureza...

\begin{abstract}
"Quando se fala da vivacidade e esperteza da juventude, não há vocábulo mais ilusório, e até fatal, do que a palavra talento. Dizer a um rapaz que tem talento é as mais das vezes convertê-lo em ignorante e estúpido. Já se sabe que o defeito não está na palavra, mas sim na errada inteligência que ordinariamente se lhe dá. Se nos pedirem a definição de talento diremos que consiste na aptidão dirigida e aperfeiçoada pelo estudo; e estamos intimamente convencidos que a história particular de todos os homens insignes em ciências e artes confirmam a propriedade desta definição."
\end{abstract}

Reconhece-se a necessidade de se estudar a infância, compreender sua especificidade, os passos de sua desenvolução orgânica, emocional e social. A criança era o futuro. De algum modo, a excessiva preocupação com o tema do glorioso passado do país tendia a retirar as imagens mentais da construção do futuro. Supunha-se urgente a canalização da saudade para a projeção de utopias para o futuro. Era como se Portugal vivesse exclusivamente do passado, sem marcar seu lugar nos tempos que corriam. A infância era então elemento estratégico porque - ausência de passado - personificava o potencial de desenvolução futuro. Daí sua relevância social. Essa era a primordial tarefa da escola: encaminhar e fornecer suporte teórico e valorativo para que as gerações mais jovens pudessem trilhar a busca de um destino mais promissor. Assim como Portugal, à infância não é suposto o presente. Bastava o passado e o futuro... Acreditava-se, pois, que seria o ambiente educativo quem proporcionaria a viabilização da utopia contida na própria vocação da nacionalidade portuguesa. É assim que o tema da Pedagogia tem como maior impulso em Portugal do século XIX o diálogo com a tradição, mas sempre tendo em vista a possibilidade de sua superação. Havia que se ultrapassar o passado para se poder libertar o juízo simbólico de uma população que, presa ao que já se foi e fundamentalmente ao que fora ela mesma outrora, não conseguia olhar para diante. Era como se, sob tal aspecto, o julgamento sobre a decadência, qualquer que fosse a vertente interpretativa acerca do facto, eliminasse - pela via do saudosismo - os projetos e as prospecções perante o futuro. $\mathrm{O}$ discurso sobre educação, escola pública e ensino como tarefas básicas e essenciais do Estado nacional virá sem dúvida interpelar esse modo de lidar com a história. E fará isso porque coloca para o povo português a opção: ou se ficava atado às glórias orgulhosas de um passado que jamais regressaria, ou se ingressava na modernidade das nações civilizadas, atentando para aquilo que efetivamente os

\footnotetext{
447 Tirânica para os que ainda não podiam aprender, ilusória para os podiam aplicar-se, a escola assim, composta de elementos inconciliáveis, não foi mais que uma coisa repugnante, absurda, indefinível, estéril; uma casa de detenção temporária para os rapazes malcriados; um foco de mútua corrupção; e (se é permitido o termo) um despejo para onde as famílias lançavam as crianças a quem pretendiam punir das suas travessuras, ou de quem se queriam descartar por algumas horas em cada dia. Para o filho díscolo e refratário, a ameaça suprema era a de ser mandado para a escola; a escola era efetivamente a galé. Faz horror ouvi-lo...mas é uma verdade notória e trivial." (A. F. de CASTILHO, Felicidade pela instrução, p. 54-5)

448 O PANORAMA, volume III, 1839, p. 287-8. O talento enquanto habilidade perder-se-á se não for devidamente cultivado; a aptidão, por sua vez, só poderia ser consolidada pelo esforço. Daí vem o alerta: "Talento natural é ficção da imaginação humana; a aptidão natural é objeto pouco vulgar; e o motivo por que o verdadeiro talento raras vezes se manifesta é porque os que têm aptidão desprezam as faculdades naturais e, presumindo possuir o talento, não curam dos meios porque se pode gloriosamente alcançar.” (Id. Ibid., p. 288)
} 
tempos pareciam exigir: um projeto cultural que habilitasse a um só tempo o trabalhador e o cidadão.

Havia que se educar a pátria até para regenerá-la: assim entendiam Herculano, Castilho, a Geração de $\mathbf{7 0}$ e finalmente os republicanos. Mas assim entendiam também os jornais e as revistas da época que, dissertando sobre a matéria pedagógica, julgavam que o problema da leitura em expansão, de certa maneira, abalaria os próprios alicerces da nacionalidade. Não havia como lutar contra os perigosos e indomáveis efeitos de folhas redigidas que andavam por aí à solta... Havia que orientar, ritmar, socializar e induzir modos e práticas de leitura que pudessem controlar simbolicamente os significados subversivos que o mundo da tipografia arrastara consigo. A leitura, se não viesse acompanhada por práticas educativas efetivamente capazes de dirigir tais efeitos - como advertiam os jornais à época -, não conduziria necessariamente à virtude, mas a um perigoso e indesejável niilismo. Era talvez por isso, mais do que por qualquer outra razão, que a escola era defendida: para eleger e defender conteúdos culturais como se fossem os únicos autorizados e para controlar outros conteúdos que viessem a ser espraiados pela proliferação do material impresso e por eventuais práticas espontâneas de leitura. Era essa a grande ameaça que se desejava combater quando se punha muita ênfase na tarefa civilizatória da escolarização:

\begin{abstract}
"Os absurdos e os paradoxos morais não eram perigosos enquanto andavam só por escolas e disputas de sábios; mas esse alimento corrupto foi oferecido aos engenhos vulgares; e cada vez o será com maior abundância. É assim necessário que aconteça para que a civilização progrida e se derrame: nenhum meio há de instrução popular se não a leitura; porque o homem de vida ativa nem quer nem pode meditar: cumpre que leia. E o que é ler no século atual ? É assistir a uma luta de gladiadores desconhecidos em que ora nos interessamos por um, ora por outro. Por tal modo, se irá derramando o ceticismo entre o povo, com a luz da instrução: este se despirá pouco a pouco de superstições, de erros, de preconceitos, mas a sua vida íntima se tornará pálida, cansada e aborrida. Ele participará também dessas horas eternas de tédio que devoram aqueles a quem por vocação coube o estudo e, por consequência, o duvidar contínuo: ele será mundificado de ignorâncias, mas não será rico de virtudes nem de paixões generosas. Pobre povo, mas sabes tu à custa de quantos gozos interiores, de quantas esperanças, de quantos sonhos formosos, hás-de ir comprando os progressos da civilização! E não haverá meio algum para que esta filha dos séculos se incarne nas multidões, sem que elas para a acolherem nos seu seio arrojem de si a sua crença, as suas virtudes grosseiras, a sua confiança em Deus? Não haverá um bem que nos venha puro e extreme, sem mescla de depravação? Não se poderá nunca aproximar a criatura do criador pelo lado da ciência, sem que dele se afaste pelo lado da bondade e da virtude ? Terrível condição da humanidade fora que a civilização, pulindo a inteligência do homem, lhe corrompesse ao mesmo tempo o coração. Felizmente Deus que inspirou ao gênero humano a sociabilidade e o desejo de aperfeiçoamento, pôs na sociedade o remédio para os males que deviam resultar da imperfeita ciência, única possível no desterro do mundo. Na mesma natureza do nosso espírito está esse remédio contra o ceticismo e contra as suas precisas consequências, o egoísmo e a imoralidade."
\end{abstract}

\footnotetext{
${ }^{449}$ O PANORAMA, volume II, no 62, 7-7-1838, p. 211. A idéia de regeneração da geração futura era a âncora que poderia realinhar as esperanças quanto à correção do que o autor entende por corrupção moral. Essa durante séculos, tinha vingado pela ação perniciosa de uma educação que incutia preconceitos superstições na infância. A ação do clero é assim lastimada e se aponta para a urgência de uma educação capaz de irradiar uma cultura letrada que, atentando contra tais vestígios de credulidade religiosa, pudesse efetivamente lutar contra a corrupção moral da juventude. Ocorre que, quando homem adulto rejeitava os medos, os temores da primeira infância, aí então ele convertia-se a uma decidida incredulidade, a uma completa indiferença à ordem dos valores, ao que muitas vezes se agregava o ódio... Com isso o homem adulto se corrompia, sem que a sociedade fosse capaz de encontrar um substituto àquelas falsas premissas de moralização postas pela ação dos clérigos. Havia que, portanto, acenar para um modelo educativo diferenciado desse, capaz de imprimir nas gerações mais jovens práticas efetivas de uma virtude racional.
} 
A escola se apresentava, dessa forma, como uma estratégia para correção dos excessos da civilização, pela própria via da civilização; ou seja: através da ação escolar, haveria um percurso de aprimoramento na trilha civilizatória. A escola era a possibilidade institucional da mediação entre os valores do passado, as potencialidades do presente e as incertezas e indefinições do sempre indeterminado futuro. Por isso mesmo alguns viam na escolarização a agenda de tempos por vir... A despeito desse fato, a escola era, sem qualquer dúvida, a instituição prioritária para o diálogo com a leitura: dizemos diálogo porque não supomos que toda a leitura estivesse confinada no domínio escolar; não acreditamos tampouco que a escola exercitasse prioritariamente o domínio do ler. Haveria, sim, um intercâmbio, eivado, contudo, de tensões, de contradições, de desconfiança. A leitura é por si uma prática autônoma que, levada ao extremo, pode negar a própria ação escolar. Por essa razão todo o discurso à volta desse tema abarca as vantagens e os perigos do ler: que tanto aproximam como ameaçam a instituição escolar. Nossa tese é a de que a escola se põe na sociedade, pelo menos nesse percurso de século XIX, fundamentalmente para rivalizar com a atitude da leitura espontânea que, em si, é percebida, antes de tudo, como fonte de corrupção dos costumes e transgressão de tradições. Não se pretende que as novas gerações inventem nada; nem ao menos aquilo que foi para elas inventado. Cumpre que se perpetue e se cristalize a herança dos que vieram antes; mesmo que tal herança seja eivada de demarcações postas por hierarquias e desiguais lugares sociais. Subverter a ordem não poderia ser tarefa da pedagogia; esta, por definição, preserva: daí tomar a leitura, o livro e o jornal como suas concorrentes...

\section{A AMBIÊNCIA EDUCATIVA IMPRESSA POR PANORÂMICAS FOLHAS PERIÓDICAS}

O Panorama; jornal litterario e instructivo da Sociedade Propagadora dos Conhecimentos Uteis (1837) pretendia, como o próprio nome assinalava, derramar, através do ato e da criação do hábito da leitura, parâmetros mais adequados de civilização e cultura. Como destaca Catroga, O Panorama teria sido o primeiro instrumento de divulgação das novas idéias, dos novos quadros mentais, da nova concepção de história e de mundo, que se iniciaria em Portugal a partir da efetivação do regime liberal em 1834. Era uma revista que, fundada por Alexandre Herculano, pretendia atingir camadas médias e populares, ou - nas palavras de Catroga - um público interclassista. Para tanto, apresentava um formato inovador para o caso português; tinha uma feição eminentemente enciclopédica e fazia por divulgar, não apenas as conquistas da ciência nas diferentes áreas do conhecimento, mas também os modos de se portar perante elas. Havia nitidamente ali o intuito civilizatório e a revista entendia a si própria com a missão de uma Pedagogia social que pudesse ser formadora de hábitos e criadora de tradições. Era assim que O Panorama falava de educação e do que se fazia nos povos estrangeiros; falava do modo de governar os homens e da Academia Real das Ciências; falava dos indígenas da América e do Marquês de Pombal... Consta que a tiragem da revista alcançaria, em alguns números, uma média de 5000 exemplares. ${ }^{450}$ Muitas outras

\footnotetext{
450 “(...) cifra que, mesmo exagerada, é contudo digna de registro numa época em que a taxa de analfabetismo se aproximava dos 90\%. Seja como for, ela terá chegado aos meios mais alfabetizados, constituindo, como se escreveu nos Anais das Ciências e das Letras, 'um admirável instrumento de iniciação intelectual no atraso relativo em que existíamos por aquele tempo, manifestou os seus efeitos desde logo; e redigido por algumas das capacidades mais distintas do país, concorreu poderosamente para aperfeiçoar a linguagem, desenvolver o
} 
iniciativas teriam o sucesso d'O Panorama por referência. Castilho, com a Revista Universal Lisbonense não denegaria a influência que tivera. A verdade é que o século XIX, desde então, deixou-se registrar em Portugal por tais iniciativas de jornais e de revistas que se pretendiam voltados explicitamente para a educação popular, para a formação de camadas leitoras. ${ }^{451}$ De algum modo, teria havido um papel pedagógico, intencional e planejado nessa leitura de formação, cuja finalidade explícita era, sobretudo, libertar, o leitor de possíveis armadilhas das situações cotidianas, preparando-o e habilitando-o, em uma direção enciclopédica, para temas dos quais se julgava necessário o domínio. Desejava-se pela imprensa formar a cultura geral. Compreender a intersecção entre tais iniciativas e a Pedagogia portuguesa propriamente dita é o que pretendemos fazer neste capítulo. Sobressaíase, como bem destaca Catroga,

\begin{abstract}
“(...) inequivocamente o papel educativo que se pretendia atribuir às narrações do passado (ficcionadas ou investigadas): fosse através de ensaios, ou mediante novelas e romances históricos, O Panorama, carreou informações e gizou quadros cronológicos que os seus leitores 'burgueses' podiam ostentar ou antepor à cultura tradicionalista. De fato, as narrativas históricas, publicadas em folhetins, tinham como receptores ideais uma nova camada de leitores, de estrato burguês, em que não é difícil antever a intenção de sensibilizar a leitora feminina, a mediadora privilegiada da leitura para toda a comunidade familiar. Se, por razões sociológicas, os artigos mais técnicos e utilitários visavam um público profissionalmente ativo, a verdade é que os artigos de cariz mais humanístico, se também procuravam engodar todos os leitores para os assuntos mais áridos, não deixavam de remeter para o 'leitor-tipo' da literatura romântica - a mulher alfabetizada. E foi, sem dúvida, com o fito de alcançar um público mais extenso, capaz de acasalar a formação humanística com a técnica, que Alexandre Herculano atribuía uma função iniciadora à componente literária de O Panorama, dado que, em sua opinião, o nosso povo não beberá 'o remédio, se não lhe pusermos o mel na borda do vaso. A par de um artigo de crítica, de moral, de ciência, deve ir um romance histórico, uma cena dramática, um poema." 452
\end{abstract}

Ainda nos primeiros anos de existência do jornal, particularmente 1837 e 1838, o cenário do prólogo dirigido aos assinantes veicularia, com bastante frequência, a importância social da habilidade coletiva da leitura. O jornal dizia pretender "derramar a instrução, fazendo descer a literatura e a ciência ao nível das inteligências comuns." ${ }^{453}$ Segundo diziam os articulistas, o problema da leitura em Portugal consistia, antes de qualquer coisa, na ausência de interesse das populações sobre esta prática. A disposição de instruir, própria do jornal, deveria ser complementada pela disposição anterior de distrair, na ausência da qual o povo não procuraria instrução. $\mathrm{O}$ mundo da cultura deveria ser apresentado, pois, sob essa

gosto pelas letras, e fazer revocar do esquecimento as tradições gloriosas do nosso passado'." (Fernando CATROGA, Alexandre Herculano e o historicismo romântico, In: A história através da história, p. 42).

${ }^{451}$ Maria Manuela Tavares RIBEIRO já assinalava o seguinte sobre as bases sociais da leitura no século XIX português: "Num complexo e vasto conjunto de fatores estruturais, tendenciais e conjunturais - a alfabetização, a liberalização legislativa da imprensa, os diversos progressos técnicos, a constituição de um mercado editorial do livro, o desenvolvimento concorrencial da imprensa, os problemas suscitados pelo acesso das classes médias aos bens culturais, a necessária educação das classes laboriosas, a reorganização de meios e formas de educação e de cultura, a autonomização dos intelectuais em relação à propriedade literária e às relações do escritor com a sociedade - o livro é veículo importante de circulação de idéias, de comunicação de mensagens e sendo, ao mesmo tempo, um objeto de consumo da sociedade oitocentista portuguesa." (Maria Manuela Tavares RIBEIRO, Livros e leitura no século XIX , In: História da vida privada e do quotidiano em Portugal, p. 2).

${ }^{452}$ Fernando CATROGA, Alexandre Herculano e o historicismo romântico, In: A história através da história, p. 42.

${ }^{453}$ O PANORAMA; jornal litterario e instructivo da Sociedade Propagadora dos Conhecimentos Uteis, volume segundo, 6-1-1837 p. 36. 
dupla perspectiva: aquele que distrai instruindo ${ }^{454}$. Mas para além da instrução, o mundo da cultura deveria perfazer uma atitude formadora dos hábitos e dos valores socialmente prescritos. Desse modo, tratava-se, acima de tudo, de uma tarefa educativa. Como já pudemos observar no tópico anterior, a leitura instrutiva era aquela que, de alguma forma, poderia inclusive exercer a tarefa de controlar a leitura espontânea, sendo que esta última, por sua vez, ocasionaria inevitavelmente a corrupção dos costumes e dos padrões de moralidade.

\begin{abstract}
"Quando desejamos, por exemplo, que os homens destinados para o exercício da lavoura, para as artes fabris, para os vários misteres da sociedade, saibam ler, não queremos que eles se habilitem para ler muitos livros, para gastarem nisto a vida, para virem a ser grandes letrados: não pretendemos encher o mundo de sábios e eruditos. Cumpre ter idéias mais justas da instrução que recomendamos, e dos resultados que dela pretendemos obter. O nosso fim é tão somente que cada indivíduo tenha os meios de empregar, com maior proveito seu e da sociedade, as faculdades que Deus lhe concedeu: que tenha os recursos de que pode precisar em qualquer situação em que a Providência haja de o colocar. Os meninos pobres, que frequentam as escolas elementares, tiram desde logo a grande utilidade de livrar-se da ociosidade, da distração e da dissipação do espírito, dos perigos de uma vida vaga e desocupada, da inclinação ao jogo e aos folguedos tumultuosos daquela idade. Ao mesmo tempo vão contraindo o hábito de aplicação, da ordem, da obediência, do amor do trabalho, da piedade, da recíproca afeição de uns para com os outros, etc. Além disso, a simples instrução do ler, escrever e contar desenvolve, pouco ou muito, nos meninos as suas faculdades, e lhes dá um certo grau de cultura moral. Os homens, que têm aprendido aquelas artes ainda quando, em toda a sua vida, não abram um só livro, sempre serão mais inteligentes, mais dóceis, mais razoáveis, e consequentamente melhores e mais hábeis oficiais dos seus ofícios, do que aqueles cujas faculdades se têm conservado como entorpecidas no meio da grosseira e estúpida ignorância." 455
\end{abstract}

Sugeria-se na sequência que a instrução popular pudesse atuar como uma instituição moralizadora, através do conteúdo dos textos que, por essa atividade leitora, seriam irradiados em profusão. A boa leitura, que principiaria pelo catecismo e pela decorrente tarefa de Pedagogia catequética, adequar-se-ia a todo tipo de situação social. Portanto, esse primeiro degrau da instrução deveria ser universalizado, até pelos efeitos de normatização da vida pública que consigo acarretaria. A leitura do Evangelho e também leituras amenas de "obrinhas populares" eram compreendidas como benéficas por afastarem o indivíduo do ócio que conduz ao vício e por conformarem a pouco e pouco novos costumes, mais apropriados perante o estado atual da civilização. O texto recorda que, se as camadas privilegiadas da população tivessem um ato de generosidade e fundassem efetivamente instituições de ensino

454 "Quando este jornal começou a aparecer, nada mais era, quanto à forma, do que uma imitação do Penny
Magazine, do qual também o são todos os jornais populares publicados na Europa. Persuadidos estávamos
então que nenhum melhor modelo tínhamos para seguir; mas com o tempo nos temos convencido de que as
circunstâncias relativas aos dois países, Portugal e Inglaterra, sendo diversíssimas, deviam influir diversamente
no modo de tratar a literatura popular das duas nações. Em Inglaterra, como em França e na Alemanha, o ler é
uma necessidade intelectual, em Portugal, um prazer, ou antes um desfastio, e é como tal principalmente que a
instrução se deve apresentar entre nós. Em parte nenhuma, portanto, ela deve ter em si os dois caracteres, do
útil e deleitoso, como em nosso país. Na Inglaterra, um jornal que contém quatro ou cinco artigos escritos com
atenção e oferecendo matérias graves, severamente tratadas, louvam-no e lêem-no; em Portugal, louvam-no,
mas poucos o lêem. Entre nós é preciso que o agradável conduza e obrigue o proveitoso aos olhos de grande
número de leitores; é preciso que o escritor não só tenha boa consciência, mas também que esta seja risonha." (O PANORAMA..., 6-1-1837, p. 36).

${ }^{455}$ O PANORAMA; jornal litterario e instructivo da Sociedade Propagadora dos Conhecimentos Uteis, Volume Primeiro, n5, 3-6-1837, p. 37. 
para os setores populares, inequivocamente ambas as partes estariam ganhando. Diz, pois, o contrário dos que temiam o efeito da instrução particularmente sobre os trabalhadores braçais.

\begin{abstract}
“(...) por certo que todos os meninos que a frequentarem receberão aí princípios religiosos, idéias e máximas morais, regras de bons e virtuosos costumes: todos aprenderão a ler, escrever e contar: todos saberão bem o seu catecismo e respeitarão as obrigações religiosas, civis e domésticas: nada os excitará a abandonar, e ainda menos a desprezar, o ofício de seus pais. Nada concorrerá para alterar essa igualdade que se deseja conservada. Enfim não haverá na aldeia senão uma única diferença: que os seus habitantes serão mais inteligentes e menos ociosos: que valerão consequentemente um pouco mais que d'antes."
\end{abstract}

A leitura nos primeiros números d' O Panorama é então apontada como fonte de bons hábitos morais. O costume de ler estruturaria práticas de meditação, desenvolveria a perspicácia do raciocínio, a retidão nos modos de julgamento sobre os homens e sobre os fatos, o abandono de maus modos, ligados, na grande maioria das vezes, a práticas de sociabilidade de setores tidos por menos civilizados. Além de código moral, a leitura veiculava, sobretudo, códigos de urbanidade e estratégias de controle das paixões. Ocorre que, paulatinamente, passa-se a diferenciar a ação da boa escola com a atuação da má escola; do mesmo modo, distingue-se a boa e instrutiva leitura da má e corruptora leitura.. Caberia ao preceptor e ao jornal mostrar que a natureza entendeu que alguns tinham dons que os levariam mais longe que outros; cabia à escola e ao jornal evidenciar que eram eles quem controlavam tal seleção que demarcavam lugares, que estabeleciam distâncias, que ditavam a aceitação e a conformidade.... ${ }^{457}$ Com significativa frequência, o tema do estudo e da leitura são caracterizados por seus riscos e perigos.

\footnotetext{
“(...) a educação moral do povo é mais lenta e descuidada do que a sua educação intelectual; e, seja qual for o motivo por que isso acontece, é certo que se observam e cometem graves erros no ensino e direção da mocidade. Confessamos que o gênero humano nos faz conceber esperanças mui lisonjeiras e que olhamos com uma certa admiração para os progressos de muitos dos nossos compatriotas no caminho da sabedoria. Mas apesar de tudo isso e do muito valor que damos aos dotes intelectuais que tão poderosamente concorrem para o bem-estar dos homens, contrista-nos ver que o progresso moral e religioso é ainda considerado não como o único e verdadeiro fim do estudo, mas como o seu fortuito e insensível resultado. Do gosto pela leitura, que é uma das feições características do presente século, pode fazer-se instrumento do bem perdurável e sólido. A
}

${ }^{456}$ O PANORAMA..., volume primeiro, nº5, 3-6-1837, p. 37.

457 "A escola é um verdadeiro remédio do amor próprio; bem-entendido que falamos da boa escola; a má, além dos frutos detestáveis, que infelizmente produz, tem o inconveniente de não ensinar os meninos a conhecerem-se nem a corrigirem-se. A boa escola também desenvolve os sentimentos de modéstia, de sociabilidade, de ternura, de gratidão, de benevolência, que são todas excelsas virtudes. A má escola exercita uma influência contrária. As superioridades excitam a inveja, o ciúme, o ódio; as distinções mal distribuídas desenvolvem a ambição prematura n'uns, infundem danoso descoroçoamento n'outros. Uns aprendem a sacrificar tudo ao desejo de brilhar; habituam-se a pavonear-se com desmedido amor-próprio; e seu único cuidado é eclipsar até os seus amigos: outros se afazem à preguiça, ao descontentamento, à maledicência, à inveja e ao ódio. Isto é incontestável: mas por tudo isso que na escola se manifestam as paixões, aí as deve combater a educação moral. Tudo está nas mãos do preceptor. Ele deve apontar aos seus alunos as causas do brilhante sucesso de uns e da inferioridade de outros, analisá-las em sua presença, e demonstrar-lhes que todos são dotados da faculdade da atenção e da capacidade para o trabalho; que, na verdade, receberam da natureza dons diversos, este mais memória, aquele mais imaginação, aquel'outro mais juízo, mas que, aplicando-se todos com igual regularidade, podem todos obter, cada um no seu gênero, notáveis vantagens.” (O PANORAMA..., nº35, 30-12-1837, p. 276). 
convicção desta verdade deve inspirar os maiores desejos aos amigos do gênero humano de concorrerem, quanto em si couber, para que a literatura, principalmente periódica, se torne não o veículo das calúnias e imoralidades, mas a fonte perene de ilustração, que doutrine o povo nos seus deveres como católico e como súdito fiel das leis civis." $" 458$

$\mathrm{Na}$ verdade, a instrução é tomada como uma necessidade, como uma inevitabilidade, algo por quem o próprio século clamava. A ambição de saber teria sido dilatada e propagada pelo aperfeiçoamento da ciência e da técnica e o desejo de adentrar o mundo da cultura letrada era uma decorrência natural desse processo. Sentiu-se a necessidade de instrução, que vinha irradiada pelos diversos países, propalada fundamentalmente pelas novas e mais modernas técnicas de dinamização do impresso. Era o livro quem criava a necessidade da escola e do aprendizado da leitura; e não o contrário. Os contemporâneos tinham isso muito claro. ${ }^{459}$ As publicações voltadas para a ilustração popular eram tributárias daquele fervilhar jornalístico. O impresso se firmara no mundo contemporâneo. Mais e mais, o homem do povo faria da leitura um hábito, uma rotina. Era então imprescindível trazer e veicular, até para efeito pedagógico, bons e úteis conhecimentos, a serem irradiados, pela via do livro, do jornal, dos folhetos, que circulavam e que faltavam a quaisquer controles...

\footnotetext{
"Os nossos compatriotas desenvolvem a sua aptidão intelectual; o gosto e o hábito de ler enraizase no povo; e assim com fundamento esperamos que entre nós se derramem os frutos da leitura, deste entretenimento profícuo, que enche o vazio que deixam os maus hábitos e que, expelindo o mau pensamento, dá origem ao bom; falamos da leitura das obras que o povo deve ler, daquelas que enriquecem o espírito com úteis noções, imprimem no coração as doutrinas puras da moral e habilitam para o trato do mundo e conversação cotidiana, mediante notícias interessantes e curiosas. Publicam-se já em nosso país com aplauso merecido jornais especiais dedicados às ciências; cresce progressivamente o número das obras periódicas, destinadas à leitura do máximo número de pessoas. Se o povo não lia, era porque não lhe facilitavam os meios de ler. Sem contarmos volumosas e insípidas novelas, farsas imorais e sátiras indecentes, e outras futilidades e inépcias, com que gemiam os prelos, o que avultava um ou outro livro, que, ou pelo seu preço, ou pela sua especialidade, ou pelo seu estilo e disposição, sobrepujava os meios ou a compreensão do maior número dos leitores?... Mas o povo português hoje também gosta de instruir-se e lê: porque os escritos populares se imprimem e vendem por preços cômodos e portanto se difundem." 460
}

Quanto às escolas propriamente ditas, O Panorama encarregava-se de transmitir preceitos e regras para a conduta do mestre, no sentido de que a ação educativa fosse efetivamente levada a contento. As crianças deveriam ser orientadas para a obediência e quaisquer desvios deveriam ser punidos, seja por uma advertência, uma admoestação ou uma punição. Cabia, porém, ao educador explicitar com distinta clareza o porquê da punição, de modo a garantir a eficácia do eventual castigo. Saber bem recompensar e bem punir eram as

\footnotetext{
${ }^{458}$ O PANORAMA..., volume quarto, 1840, p.119.

459 "Se em tempos remotos as qualidades fisicas, as meramente corpóreas, influíam na valia de um homem; hoje esta se mede pelos dotes da alma, pelos graus de inteligência, da erudição, do saber: todos sentem a necessidade da instrução, todos procuram instruir-se; e por esta única circunstância se explicam as numerosas associações literárias que se organizam, as aulas e bibliotecas que se abrem, a prodigiosa quantidade de livros que se publicam, e mais que tudo os inúmeros jornais literários e de instrução popular que circulam pelo mundo em tão variados idiomas, e sobre tantos e tão diversos assuntos. Como poderia pois, neste movimento geral europeu, a nação portuguesa permanecer imóvel e indiferente ?” (O PANORAMA, n¹40,volume quarto, 1840, p. 1).
}

${ }^{460}$ O PANORAMA, nº 140 , volume quarto, 1840, p. 1 
verdadeiras artes que destacavam a ação do bom educador. Recomendava-se, nesse quesito, que o mestre não se enfurecesse, mas que se mostrasse capaz de manter o equilíbrio, a serenidade, a ponderação do julgamento. Mesmo o ato de castigar deveria ser realizado perante critérios objetivos, sempre mantida a equidade do educador. Por outro lado, consciente de que a juventude é muito propensa à imitação, recomenda-se que o profesor seja capaz de se manter perante códigos irrepreensíveis de conduta moral e civil. As boas ações seriam nessa dimensão postas como o parâmetro a ser seguido, e esse ato complementaria a própria instrução formal.

\begin{abstract}
“Temperai a severidade à medida que vossos discípulos aumentarem em idade; quanto mais cedo os tratardes como entes sensatos, mais depressa a razão se lhes desenvolverá, aperfeiçoando e amadurecendo. E ainda que seja muito importante conduzir as crianças pela senda da razão, nem por isso é conveniente obrigá-las a longos e fastidiosos discursos: falai pouco, mas ponde frequentemente em prática o que for bom e útil. As principais regras que devem acompanhar o desenvolvimento moral das crianças, e que ao hábil educador cumpre saber aplicar e modificar com prudência e tato, conforme a idade, caráter, inclinações e capacidade dos seus discípulos, são as seguintes: poucos preceitos; uma moral prática que faça amar a virtude e incline as crianças a serem compadecidas, generosas e humanas para com os desgraçados; escrupulosa escolha das pessoas que houverem de tratar com elas; conservar na sua presença o procedimento exemplar, afastando-lhe dos olhos o quadro das paixões, fraquezas e defeitos que não devem contrair, evitando ao mesmo tempo o falar-lhes em faltas que ainda não cometeram; achar o meio termo entre a extrema indulgência e a extrema severidade, cedendo aos seus desejos quanto for possível sem inconveniente; pois que desta forma lhes ganharemos amizade, mostrando-nos sempre dispostos a concorrer para seu bem-estar; perseverança inflexível nas coisas que uma vez lhes negarmos quando a negativa se fundar em razão e necessidade; e o talento de nos fazermos igualmente amados e respeitados, governando pela influência dos bons exemplos e familiarizando as crianças com a virtude por meio do hábito" ${ }^{\text {461 }}$
\end{abstract}

A pedagogia d'O Panorama pretendia, sem dúvida, humanizar, modernizar a trazer técnica à escolarização primária portuguesa, esclarecendo os mestres e os pais de família sobre como verdadeiramente compor um mosaico científico de práticas educativas. Entendiam que assim estariam contribuindo para aperfeiçoar uma atividade social que caminhava de maneira tão incipiente, tão refém dos hábitos e das rotinas cristalizadas pelo regime antigo, tão monótona e reticente a quaisquer inovações. A escola renovada e inovadora era já nessa alvorada do liberalismo uma autoproclamada necessidade social. Urgia elevar Portugal à altura de seu século e fundamentalmente à altura que a nação portuguesa sempre mereceu no contexto da Europa. Fazer isso - no entender de Herculano, como vimos - era dever de consciência que deveria mobilizar os esforços intelectuais. Cumpria aos jornais, às revistas, aos professores de instrução primária, abraçarem esta causa. Embora não houvesse correspondência em termos de prioridades de políticas públicas, modernizar Portugal era tarefa que, na compreensão do debate intelectual do período, passava pela leitura e passava pela escola. A proeminência do discurso estava, portanto, posta pelos argumentos...

Como vimos, passa a ser comum, a partir daqueles anos 30, os jornais centraremse sobre a seguinte intriga intelectual: qual era, de facto, a vocação de Portugal? E por que, em seu caminho, pela história da civilização, esse povo obteve tantas glórias durante o tempo das descobertas para imediatamente depois ser relegado a tão profundo esquecimento? Quais eram assim as razões da decadência portuguesa? A questão da escola e da educação popular são tomadas, nessa perspectiva, como fortes hipóteses explicativas do declínio. O país não teria sabido se colocar a par de seu tempo no desenvolvimento de um modelo de civilização

${ }^{461}$ O PANORAMA..., 26-10-1839, volume III, p. 406. 
que o aproximasse dos outros povos europeus naquilo que diz respeito à irradiação e à partilha das conquistas da ciência e da técnica. O tema da escolarização compunha, pois, uma das teses voltadas à superação da decadência...

\begin{abstract}
“(...) e, ao desprezo em que ela se acha entre nós, devem atribuir-se em grande parte as nossas desgraças; os tiranos são ordinariamente obra dos povos, que eles esmagam, e todos os males de uma nação, porém quase sempre dela mesma, quando a educação não tem oposto barreiras à imoralidade. Para fazer um povo feliz é mister primeiro que tudo instruí-lo. O governo no meio das maiores dificuldades tem já melhorado estabelecimentos de educação, e promovido com desvelado empenho todos os meios para organizar um sistema de instrução em todos os ramos: cidadãos altamente conspícuos por suas luzes e patriotismo estão encarregados de tão importantes trabalhos, e nós esperamos que seus nobres esforços serão ajudados em seu complemento por todos os verdadeiros portugueses."
\end{abstract}

A iniciativa editorial de outros inúmeros jornais e revistas editados a partir do final dos anos 30 pretende atender - no modelo d'O Panorama - camadas variadas da população, tendo em vista, como já pudemos observar, essa Pedagogia do homem feito, que tinha, sem sombra de dúvida, na Revolução Francesa seu marco de referência. Tratava-se, entretanto, de reformar a sociedade, para depurá-la de seus elementos de risco, até para prevenir a ocorrência das revoluções. Tendo por meta essa moralização pela leitura, que, ocupando o tempo livre, prepararia os valores do trabalho, havia que tornar atraente o veículo, e, para tanto, costumava-se apresentar para o leitor as vantagens contidas na proposta. Nada como principiar pela evocação do exemplo...

\footnotetext{
"E não é novo isto em Portugal; bem presentes estão a todos os eminentes serviços que à ilustração de nosso país fez o primeiro e o melhor dos nossos jornais populares - O Panorama; e também o acolhimento que ele recebeu em todo o reino provou exuberantemente quanto convinha continuar largamente naquele sistema de publicação, que já agora está provado ser o que mais se conforma com os nossos hábitos, com a nossa índole e com o atual estado de nossa civilização. A Revista Popular não tem nem pode ter as pretensões d'O Panorama - mais modesta; mas há de trabalhar por ser mais útil ainda, se é possível, e mais acessível a todas as circunstâncias (...) Portugal quase que vive só das gloriosas recordações do seu brilhante passado, que o presente esse tem-no desecado e esterilizado as nossas desastrosas dissensões civis. A história nacional, pois, os seus fatos mais memoráveis, ocuparão o primeiro e distinto lugar nas nossas colunas."463
}

\footnotetext{
462 O MOSAICO; jornal d'instrucção e recreio cujo lucro é applicado a favor das Casas d'Aylo da Infancia Desvalida, ${ }^{\circ} 28,1839$, p.218.

${ }^{463}$ REVISTA POPULAR; semanário de literatura e indústria, primeiro volume, 1849, p. 1. O tema muito frequente nesse periódico era a carência de instrumentos intelectuais para construção da prosperidade da indústria nacional. A instrução é assim tomada como alicerce necessário ao reerguimento da nação nas bases da moderna indústria. $\mathrm{Na}$ verdade, mesmo as técnicas agrícolas em Portugal seriam, no parecer dos redatores, completamente defasadas e arcaicas. A ausência de compreensão teórica do próprio ofício tornava portanto os trabalhadores portugueses incapazes de competir com seus colegas de outros países. Nos termos da mesma revista: "O operário cansa-se, consome muito tempo e muito trabalho na execução de uma obra, que poderia levar ao fim, sem fadiga, se a experiência fosse auxiliada por alguns princípios teóricos. Quando se estabeleceu em França o ensino popular da geometria e dos elementos de mecânica industrial, notou-se que os artistas aplicavam, cada um ao seu ramo, os princípios que se lhes ensinavam nas aulas; daqui resultou o aperfeiçoamento de muitos processos, que até então eram imperfeitos e difíceis porque os únicos homens capazes de os melhorar não tinham os conhecimentos para isso necessários. ” (Revista popular..., $\left.\mathrm{n}^{\circ} 10, \mathrm{p} .73\right)$
} 


\title{
REMEMORAR, COMEMORAR, REINAUGURAR UM PAÍS
}

Já pudemos observar o quanto a pedagogia portuguesa do século XIX é tributária da interpretação que os contemporâneos faziam de seu país. Evocava-se a glória passada, o atraso, e a miséria do presente, para propor formas de intervenção que agissem no sentido de atualizar a glória perdida em um futuro que passaria a ser, desde então, criteriosamente palmilhado. Sucede que, como tal perspectiva de futuro é remota, o presente deixa de ser compreendido enquanto uma circunstância, um valor em si, para ser interpretado como um período voltado para o sacrifício da regeneração de um país. Intervalo entre passado e futuro, o presente reduzir-se-ia a um palco de ação redentora dos destinos nacionais. Aos atores efetivos deste ato político - homens, adultos e particularmente crianças - apresentava-se exclusivamente a perspectiva de sacrifício, que seria tanto maior quanto mais importante o papel a se desenvolver depois. O presente é o momento da luta, da abnegação e do sacrifício. O tempo por excelência é o futuro que resgatará o passado.

A história, a quem se diz reservar um 'distinto destaque', era posta, na verdade, como a memória viva da grandeza. O esforço de rememoração parecia, portanto, imprescindível para demarcar a identidade de um país que se sabia em crise... Reconstruir a nacionalidade com olhos voltados para o passado é sem dúvida o máximo intento do romantismo que atinge, com a atuação político-literária de Castilho, seu ponto maior. Foi na direção da Revista Universal Lisbonense, durante os primeiros anos da década de 40, que Castilho teve oportunidade para verdadeiramente evidenciar o tributo que tinha para com a própria biografia de Herculano que, alguns anos antes (1837), fundara - como vimos - O Panorama. ${ }^{464}$. O fato é que justamente nesses anos 40, a Revista priorizava, de fato, o temário ligado à educação, trazendo inclusive inúmeras estatísticas sobre a situação do ensino na época. Na verdade, aqui o tema era trabalhado fundamentalmente na dimensão pública de formação para um dado modelo de cidadania liberal. Era também o problema do voto quem fazia pensar na escola....Atribui-se aquilo que se entendia como crise política, acoplada às dificuldades de ordem material, à carência de instrução; e, sobre isso, dizia-se o seguinte:

\begin{abstract}
"Um cidadão que não sabe ler, escrever e contar, que uso, sinceramente falando, poderá fazer de seu sufrágio eleitoral? Qual é a habilitação que pode a sua consciência adquirir para votar com discernimento sobre o candidato que será de mais proveito na advogação da causa comum? Qual é a discussão pela imprensa que ele por si pode consultar sem induções alheias, para se esclarecer sobre essa mesma e sobre as qualidades do representante que deve eleger para a promover? Como pode haver ou se há de criar essa mesma discussão se ele não concorre para o seu custeio ? E como há de ele concorrer se ela não serve de nada, visto que a não sabe ler?" ${ }^{465}$
\end{abstract}

A instrução era tida como alavanca do governo representativo, aquilo que the trazia solidez, aquilo que o equilibrava. O bem público e o equacionamento das dissensões políticas necessitariam pois da bússola da ilustração popular. Na verdade, o mesmo jornalista

\footnotetext{
${ }^{464}$ Acerca do tema, Saraiva diz o seguinte: “A partir de 1842, a direção da Revista Universal Lisbonense, uma das mais importantes da nossa época romântica, permite-lhe exercer uma influência considerável, que transborda dos meios restritamente literários. Essa influência vai inteiramente ao encontro da reação tradicionalista que então se fazia sentir sob os Cabrais; a revista arvora-se em guardiã dos bons costumes, da sã moralidade e de um temperado ecletismo literário que se arrima aos clássicos eternos.” (A. J. SARAIVA, História da Literatura Portuguesa, p. 761)

${ }^{465}$ Cláudio Adriano da COSTA, Instrucção Pública, In: Revista Universal Lisbonense, tomo II, anno de 1842 3 , p. 15 .
} 
destacava em número posterior que teria sido a monarquia constitucional quem de fato criara a necessidade de escola. Dera-se ao povo um direito que, se ele não soubesse fazer uso, poderia causar complicações... A representação exigia interlocutores preparados, na ausência dos quais todo o sistema poderia repentinamente ir por terra... É fato que, justamente naqueles anos 40, Portugal vivenciava uma situação conturbada em termos da estrutura do poder que, a partir de fevereiro de 1842, voltaria às mãos da direita, através da ação de Costa Cabral. ${ }^{466}$ Como já recordava-nos o texto de Rômulo de Carvalho, foi a Reforma de Ensino empreendida por Costa Cabral quem dividiu formalmente a instrução primária em dois graus sucessivos, tal como já preconizara o próprio Herculano, em consonância com os projetos que haviam sido desenhados pela Revolução Francesa. De qualquer maneira, era com os olhos voltados para o cidadão do dia seguinte e para a provável ampliação dos direitos de cidadania que se desenhava a demarcação, a delimitação, o cronograma e a agenda da instrução das crianças pequenas $^{467}$ :

"Na monarquia pura, era o Rei que fazia todas as leis; boas ou más, não era da nossa conta, lá iam indo, feitas e executadas pelas autoridades a quem ele assim o mandava. O princípio aí é a

${ }^{466}$ Sobre o governo de Costa Cabral, permitimo-nos emprestar a explicação de A. H. De Oliveira Marques: " $O$ Cabralismo adotou a bandeira da ordem e do desenvolvimento econômico. Como tal, estabeleceu no país um regime de repressão e de violência, muitas vezes comparável ao despotismo miguelista. Mas ao contrário de D. Miguel, Costa Cabral não pretendia voltar ao passado nem às suas estruturas obsoletas; o que lhe interessava era o desenvolvimento de Portugal numa via progressiva, sobretudo nos campos das obras públicas e da administração. Muitas das suas reformas iriam por isso durar, mesmo depois de o seu nome se ter convertido em anátema para a maior parte dos cidadãos (...) O despotismo impudente de Costa Cabral, em contraste com o seu respeito teórico pela Carta e pelas liberdades nela consignadas, aliado à sua incapacidade, ou falta de vontade, de levar a violência aos seus últimos limites e se desembaraçar de toda a oposição, resultaram na mais terrivel e mais longa guerra civil que se registrou entre os liberais.” (A. H. OLIVEIRA MARQUES, História de Portugal - volume III, p. 23-4)

${ }^{467}$ A Reforma de Costa Cabral, oito anos após a de Passos Manuel, foi promulgada em 1844. Em linhas gerais, de acordo com a apreciação feita por Rómulo de Carvalho, esta reforma teria mantido os preceitos básicos da que lhe antecedeu, introduzindo, entretanto, algumas novidades, às quais aquele estudioso daria destaque: "Uma delas, de muita relevância, foi a divisão da instrução primária em dois graus. Entendeu-se que a instrução primária tradicional, reduzida ao conhecimento da leitura, da escrita e das quatro operações aritméticas era suficiente como informação mínima de todos aqueles que aí terminassem sua escolaridade. Não correspondiam os dois graus desta instrução aos dois escalões, elementar e superior, que Herculano projetara, pois, para este, o escalão superior equivalia, embora limitadamente, ao ensino secundário ministrado nos Liceus, enquanto Costa Cabral mantinha o ensino liceal de Passos Manuel e ampliava a programação da instrução primária. $O$ primeiro Grau da instrução primária da Reforma de Costa Cabral ocupava-se (artigo $1^{o}$ ) de ler, escrever e contar, exercícios gramaticais, Corografia e História de Portugal, Moral Doutrina Cristã e Civilidade. O segundo grau continuava a desenvolver as matérias anteriores e acrescentava-lhes Gramática, Desenho Linear, Geografia, História Geral, Hitória Sagrada do Antigo e do Novo Testamento, Aritmética e Geometria aplicadas à Indústria e Escrituração." (Rómulo de CARVALHO, História do ensino em Portugal, p.577). Rómulo de Carvalho critica o irrealismo das determinações de Costa Cabral quando o legislador preconizava que os dois graus de ensino se processassem em escolas distintas, devendo as escolas existentes se adequarem ao nível do primeiro grau, e prescrevendo a criação, a partir dali de escolas primárias de segundo grau. Nos termos do mesmo analista: "Também em termos irreais se propôs Costa Cabral combater o analfabetismo decretando que todos os 'pais, tutores e outros quaisquer indivíduos residentes nas povoações em que estiverem colocadas as Escolas de Instrução Primária, ou dentro de um quarto de légua em circunferência dela', mandem à escola 'os seus filhos, pupilos, ou outros subordinados desde os 7 até os 15 anos de idade', ficando sujeitos, se não o fizerem, primeiro a aviso, depois a intimação, depois a repreensão, e por fim a multa. De tal disposição se excetuavam os que provassem que os meninos já possuíam os conhecimentos daquele grau de ensino, ou que poderiam obtê-los de outra forma sem recorrer ao ensino oficial, ou ainda que por sua excessiva pobreza não os pudessem enviar à escola. Aqueles pais que não estivessem em nenhuma destas condições, mas a quem fosse 'penosa a falta de trabalho dos meninos', poderiam mandá-los à escola apenas 'em uma das lições diárias'. Deduzidos todos estes casos, que poderiam abranger uma boa parte da população escolar, a obrigatoriedade para os restantes seria sempre de execução precária, dado o número insuficiente de escolas primárias existentes na época e de todas as demais carências ligadas ao ensino.” (Id. Ibid., p. 578). 
submissão de todos à vontade de um só. Na monarquia constitucional é o povo, porém, a quem toca essas incumbências da legislação; mas como há de ele desempenhá-la sem as prévias disciplinas para esse fim primeiro aprendidas, e como há de depois ele dar à execução os seus próprios arestos privado da necessária instrução para compreender o seu espírito, sem o que, por melhores que eles sejam, eles se desvirtuarão ? Entregar um povo ao seu livre arbítrio sem imediatamente cuidar da sua educação moral e industrial é querer fazer dele péla para ambiciosos jogarem com ela até o jogo acabar na aniquilação de um e de outros, dos pacientes e também dos agentes. Um aborígene dentro de um laboratório químico, que no entanto encerra todos os segredos que nos são preciosos, não podia causar mais dano do que a liberdade das ações entregue a criaturas que não tenham sido doutrinadas na ética, para se haverem com equidade no seu trato para com os outros homens, e a quem se não abram igualmente aulas onde se amestrem em artes, ofícios e ciências, para, pela sua indústria, satisfazerem às necessidades maiores que com essa mesma liberdade se lhe acumulam."

Assim, a instrução popular era tomada como o justo preço a ser pago pelo liberalismo. Os custos da escola primária pública, de acordo com os dados da Revista Universal Lisbonense eram os seguintes:

\begin{tabular}{|l|l||l|l|l|l|l|l||l|}
\hline $\begin{array}{l}\text { Distritos } \\
\text { administra } \\
\text { tivos }\end{array}$ & População & $\begin{array}{l}\text { Custo em } \\
\text { réis da } \\
\text { instrução } \\
\text { primária }\end{array}$ & $\begin{array}{l}\text { Alunos da } \\
\text { instrução } \\
\text { primária }\end{array}$ & $\begin{array}{l}\text { Mestres } \\
\text { ou } \\
\text { cadeiras } \\
\text { providas }\end{array}$ & $\begin{array}{l}\text { Quota dos } \\
\text { alunos } \\
\text { pela } \\
\text { população }\end{array}$ & $\begin{array}{l}\text { Quota dos } \\
\text { Quota } \\
\text { pelo custo }\end{array}$ & $\begin{array}{l}\text { Quota } \\
\text { ordenados } \\
\text { mestres }\end{array}$ & $\begin{array}{l}\text { lunos } \\
\text { pelos } \\
\text { mestres }\end{array}$ \\
\hline \hline Viana & 179.112 & $3.506 \$ 666$ & 2.017 & 44 & 1 em 84 & $3 \$ 506$ & $79 \$ 696$ & 45 \\
\hline Braga & 292.486 & $6.836 \$ 666$ & 4.049 & 74 & 1 em 73 & $1 \$ 709$ & $92 \$ 387$ & 54 \\
\hline Porto & 349.848 & $7.310 \$ 000$ & 2.801 & 72 & 1 em 116 & $2 \$ 611$ & $101 \$ 527$ & 38 \\
\hline Vila Real & 178.144 & $5.216 \$ 666$ & 2.719 & 67 & 1 em 65 & $1 \$ 932$ & $77 \$ 860$ & 40 \\
\hline Bragança & 125.771 & $5.036 \$ 666$ & 1.993 & 56 & 1 em 66 & $2 \$ 518$ & $89 \$ 940$ & 35 \\
\hline Aveiro & 228.710 & $5.846 \$ 666$ & 2.978 & 63 & 1 em 78 & $2 \$ 016$ & $92 \$ 804$ & 47 \\
\hline Coimbra & 239.696 & $6.726 \$ 666$ & 1.857 & 67 & 1 em 133 & $3 \$ 737$ & $100 \$ 398$ & 27 \\
\hline Viseu & 294.703 & $9.636 \$ 666$ & 3.894 & 123 & 1 em 77 & $2 \$ 470$ & $78 \$ 346$ & 31 \\
\hline Guarda & 198.310 & $7.826 \$ 666$ & 2.678 & 86 & 1 em 77 & $3 \$ 010$ & $91 \$ 007$ & 31 \\
\hline Cast. Branco & 130.787 & $4.646 \$ 666$ & 1.238 & 43 & 1 em 108 & $3 \$ 872$ & $108 \$ 063$ & 28 \\
\hline \hline Leiria & 126.862 & $3.776 \$ 666$ & 1.151 & 35 & 1 em 115 & $3 \$ 433$ & $107 \$ 904$ & 32 \\
\hline Santarém & 145.375 & $4.316 \$ 666$ & 935 & 43 & 1 em 155 & $4 \$ 616$ & $100 \$ 387$ & 21 \\
\hline Lisboa & 411.765 & $14.080 \$ 000$ & 2.936 & 108 & 1 em 142 & $4 \$ 855$ & $130 \$ 370$ & 27 \\
\hline Portalegre & 82.398 & $3.776 \$ 666$ & 861 & 36 & 1 em 95 & $4 \$ 385$ & $104 \$ 907$ & 23 \\
\hline Évora & 82.581 & $2.606 \$ 666$ & 784 & 22 & 1 em 105 & $3 \$ 324$ & $118 \$ 484$ & 35 \\
\hline Beja & 105.318 & $3.326 \$ 666$ & 828 & 33 & 1 em 127 & $4 \$ 017$ & $100 \$ 808$ & 25 \\
\hline Faro & 128.224 & $2.576 \$ 666$ & 415 & 16 & 1 em 308 & $6 \$ 207$ & $161 \$ 041$ & 26 \\
\hline & 3.300 .000 & $97049 \$ 990$ & 34.134 & 988 & 1 em 97 & $2 \$ 854$ & $98 \$ 238$ & 34 \\
\hline
\end{tabular}

O artigo em questão, redigido por C.A. Costa revela extrema preocupação quanto às disparidades regionais do investimento em educação. Como demonstravam os dados da tabela, de fato, se havia crise quanto ao oferecimento da instrução primária em todo o Reino, havia verdadeira falência quanto à sua distribuição. Na verdade, como se poderia observar,

${ }^{468}$ Cláudio Adriano da COSTA, Instrucção Pública, In: Revista Universal Lisbonense, tomo VI, anno de 18467, p. 221. 
naquele ano de 1843 - em estando corretos os dados da tabela acima - entre o mais bem dotado distrito (Vila Real) e o menos dotado (Faro) havia uma diferença de 5 para 1. Isso na prática queria dizer que, "enquanto no Algarve há em cada 78 famílias 1 menino que aprende a ler à custa do Estado, há em Vila Real 1 por 15 famílias." 469 Outra questão que frequentemente era destacada pelos artigos sobre a instrução pública naquela Revista residia no tema da escolha, da formação e da habilitação dos professores para o ensino primário. Em artigo publicado no ano de 1846, Silvestre Pinheiro Ferreira destacava a dificuldade que o Estado apresentava quanto à seleção de bons professores, fundamentalmente a partir do péssimo salário que os candidatos ao magistério se disporiam a receber.

\begin{abstract}
"Pois bem: Não há um só país em que os professores de primeiras letras vençam um ordenado igual ao que ganha anualmente qualquer oficial dos ofícios os mais ordinários! Daqui resulta que, salvo mui poucas exceções, só pessoas incapazes para qualquer outro emprego é que se apresentam para dirigir as escolas de instrução primária. De que conceito podem pois gozar no público homens tão insignificantes ? E que respeito lhes podem ter os discípulos testemunhas da nenhuma consideração que se lhes tributa? Fica pois demonstrado que todos os pomposos relatórios que os agentes dos governos e os escritores por eles assalariados apresentam, alardeando os imensos progressos que faz anualmente a instrução primária, não têm mais valor do que aqueles em que eles, na presença de um imenso déficit, blasonam do florescente estado das finanças. Em abono desta triste verdade invocamos o testemunho de todas as pessoas que têm percorrido o interior desses países que se diz estarem à frente da civilização: a Inglaterra e a França. Da Alemanha Setentrional e dos Países Baixos temos a satisfação de poder afirmar, pela nossa própria observação, havermos ali encontrado muito menos ignorância e prejuízo do que nas correspondentes classes inferiores, assim dos campos como das cidades, naqueles dois países; e, pelo testemunho das pessoas fidedignas, sabemos que o mesmo, posto em menor escala, acontece na Suécia e na Dinamarca. Mas aí mesmo, quanto é mesquinha a instrução desses que alguma receberam e quão grande o número de indivíduos que se acham privados dessa mesma ! E não se entenda que falamos de uma instrução científica que seria, não só inútil, mas perigoso pretender vulgarizar naquelas classes; mas da instrução indispensável para se não ser vítima da ignorância, da superstição e dessa imensa variedade de erros e prejuízos que fazem a desgraça dos povos." 470
\end{abstract}

$\mathrm{Na}$ verdade, conclui-se que Portugal estaria aquém de todos os avanços constatados por esses países na divulgação da parcela de conhecimento vista como essencial para todos os indivíduos, independentemente da distinção entre as diferentes vocações e os diversos talentos. Havia, no parecer da maior parte desses formadores da opinião pública que escreviam para os jornais e para as revistas letradas em Portugal daqueles meados de século, um nível fundamental de instrução necessário a todos os homens e que seria o mesmo, invariável e universal, independentemente de proveniências de classe ou de fortuna, não devendo, assim, ser pelas mesmas obstaculizado. ${ }^{471}$ Esse degrau primário corresponderia,

\footnotetext{
${ }^{469}$ Cláudio Adriano da COSTA, Instrucção Pública, In: Revista Universal Lisbonense, tomo II, ano de 1842 1843, p.64. A tabela que acabamos de reproduzir encontra-se neste mesmo artigo, à página 63.

${ }^{470}$ Silvestre Pinheiro FERREIRA, Reflexões sobre o estado actual de instrucção e educação publica, In: Revista Universal Lisbonense, tomo V, anno de 1845-1846, p. 157-8.

${ }^{471}$ Eram inúmeros artigos de jornais e revistas que traziam como anexo ou mesmo como parte do corpo do texto dados sobre a instrução elementar nos grandes países ou nas grandes capitais européias. Tomaríamos como outro exemplo aqui ilustrativo o tomo I do periódico Universo pittoresco; jornal de instrucção e recreio, publicado em Lisboa no ano de 1840. À página 103 do dito tomo I havia uma tabela, sem qualquer indicação de fonte, intitulada "Termo médio dos mancebos que frequentam escolas, em relação à população dos diferentes estados europeus". Pretendia-se obviamente evidenciar o atraso de Portugal que, naquele cômputo, só ganhava da Rússia. Note-se que, na relação indicada, os Estados Unidos da América integravam a lista, como se se tratasse de um país europeu:

"Inglaterra. 1 por cada 11 habitantes
} 
antes de mais nada, à etapa destinada a derrocar as crenças e superstições populares, para gradual instauração daquilo que Catroga caracterizaria como uma mundividência; uma interpretação sobre a própria circunscrição, em sua época, em seu país, mediante uma chave analítica uniforme, através da qual se poderia engendrar uma nova memória e, com ela, ou a partir dela, um novo futuro. Por outro lado, a cultura do escrito - como já pudemos observar nas páginas anteriores - concorria e recusava a dimensão da oralidade, da memória e da cultura oral... Se o livro recusava a fala e a partilha da vida e do relato oral, a imprensa parecia, por seu turno, ultrapassar o livro e apontar para novas dimensões técnicas para a própria cultura do impresso. Se até o livro era visto com reticência, era com extrema desconfiança que se encarava a dimensão do escritor e particularmente o papel que assumia então a imprensa, que nessa medida tornava-se a inimiga número um:

\begin{abstract}
"Se nós temos rendido os maiores cultos, os mais cordiais elogios à imprensa, considerando-a como um dos mais proveitosos mananciais da utilidade pública, quando o escritor sensato e consciencioso, com afã e desvelo, por via dela, emprega seus cuidados e talentos em concorrer à ilustração de seus semelhantes, ensinando-lhes os verdadeiros dogmas de uma pura moral e os legítimos preceitos de uma sociedade política, tendentes à civilização, inspirados pelo ente divino; quando, atendendo-a por outro lado, ela merece todo o nosso desprezo, ódio e indignação, se desviada destes nobres caminhos, deste plausível método, emprega traiçoeiras sugestões, sofismas monstruosos, e muitas vezes o negro e amargo fel da infame sátira, do horrível sarcasmo contra aqueles sagrados objetos ? Zomba então o malvado escritor e mofa dessa preciosa arte que tantos e tão úteis bens, liberal, prodigaliza à humanidade; e constituindo-se réu de enormes crimes, de infernais atentados, arrastado ou por uma cega e delirante paixão, ou pela vil e mesquinha esperança de sórdido ganho; se alguns néscios lhe dão o riso e fingem aplaudi-lo, é abandonado sempre pelo homem probo e justo. Repetimos sempre que todo o escritor, ou nimiamente lisonjeiro ou nimiamente satírico, que não duvida, por interesses particulares, elevar aos céus o crime, calcando sob os pés a virtude, que infame preconiza delírios, e censura ações justas, que não respeita religião, leis, nem autoridades, que em hedionda crítica envolve todos e tudo, sem que a alguém e a alguma coisa respeite, senão ao seu capricho ou ao seu gênio imprudente, perverso e diabólico; é um terrível monstro, tanto mais infesto e venenoso quanto ele, longe de ensinar, mais desmoraliza a sociedade; é um flagelo cruel que dos infernos tem subido, trazendo consigo, para mentor tenebroso, espírito que o inspire e dirija, como representa a nossa estampa." 472
\end{abstract}

De fato, a estampa daquele artigo intitulado "O escritor tenebroso" era o desenho de um soturno e compenetrado intelectual, sentado sobre sua mesa, tendo à sua frente o papel e a pena, e que se punha a escrever... Atrás da mesa, bem atrás dele, entretanto, visualiza-se a figura do demônio que o guiaria por indução de pensamento, talvez de sentimentos, conduzindo pelo mal essa atividade da escrita que, por sua vez, era um perigoso e temido ofício porque facilmente seduzido pelas mãos da tentação. Sob tal perspectiva, é com cuidado

\begin{tabular}{|c|c|}
\hline 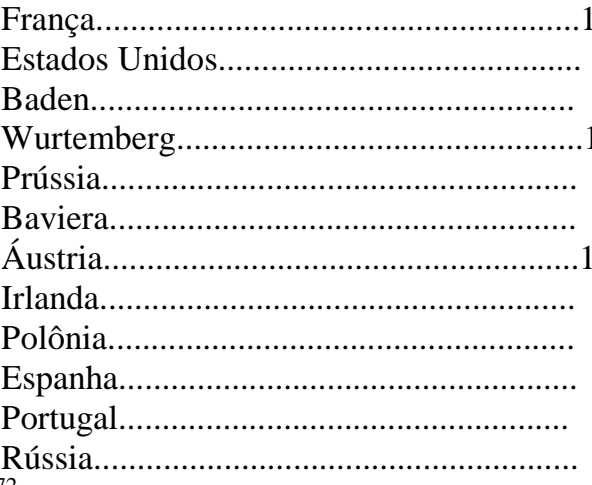 & $\begin{array}{l}1 \text { por cada } 20 \text { habitantes; } \\
1 \text { por cada } 4 \text { habitantes; } \\
1 \text { por cada } 6 \text { habitantes; } \\
1 \text { por cada } 6 \text { habitantes; } \\
1 \text { por cada } 7 \text { habitantes; } \\
1 \text { por cada } 10 \text { habitantes; } \\
1 \text { por cada } 13 \text { habitantes; } \\
1 \text { por cada } 19 \text { habitantes; } \\
1 \text { por cada } 78 \text { habitantes; } \\
1 \text { por cada } 79 \text { habitantes; } \\
1 \text { por cada } 88 \text { habitantes; } \\
1 \text { por cada } 367 \text { habitantes." }\end{array}$ \\
\hline
\end{tabular}

${ }^{472}$ O JARDIM LITTERARIO; semanario de instrucção e recreio, n ${ }^{\circ}$ 24, 1849, p. 189. 
e com alguma reticência que se anuncia a atividade leitora como um bem a ser apreciado. Como se deve ler?

\begin{abstract}
"É de grandíssima importância um sistema judicioso seguido na leitura. Quem quiser aproveitar-se do trabalho mental, deve seguir duas observações: não ler muito e de corrida; prestar atenção ao que lê. Há gente que só lê para matar o tempo: mas engana-se, mata o espírito. Há livros que são como o desenjoativo de uma mesa lauta: mas Deus nos livre destas glozinas e de quem delas se apraz. Só depois do alimento substancial, convém entreter o paladar com as sobremesas." ${ }^{473}$
\end{abstract}

A verdade é que cada vez mais o tema da reforma pela educação ganhava corpo. Em meados do século XIX, o problema da organização social do trabalho, em um mundo que caminhava a passos largos para uma modernidade urbana e industrial - ainda que o caso português não correspondesse por enquanto a isso -, apontava para novas e inusitadas necessidades sociais, dentre elas a necessidade da instrução popular. $O$ trabalho e a instrução eram assim percebidos como tarefas interligadas e interdependentes. Portugal era, com muita freqüência, apresentado - de acordo com o que já foi explicitado anteriormente - como o mais ignorante dos "povos civilizados". O derramamento da instrução vinha, não obstante, associado à tentativa de regeneração moral do povo; fosse pelo caminho da direita, que desejava preservar os tempos da temida revolução social, fosse, por seu turno, pela esquerda, que antevia o tempo do socialismo como um futuro já próximo para o qual se deveria rumar a passos largos... ${ }^{474}$ Supunha-se, na esteira dos ensinamentos de Rousseau, que os progressos da civilização teriam depravado o coração do homem, corrompendo os costumes e produzindo vícios que anteriormente seriam em tese desconhecidos. Era necessário, pela educação popular, remediar esse mal, cuja raiz estaria, entretanto, na própria organização do tecido social, que produzia em grande escala a miséria para atender exclusivamente aos interesses de uma pequena fração da sociedade. Pelo menos, era isso que diziam os primeiros jornais socialistas que tiveram lugar em solo português... O lugar da instrução seria, para eles, o de alterar essa disposição artificial:

\footnotetext{
"Nestes princípios se baseia e neles se resume toda a nossa teoria sobre instrução. Pela igualdade todos têm direito a serem instruídos; pela liberdade cada um pode escolher a instrução que mais lhe convém naturalmente e pela fraternidade todos somos obrigados a concorrer para a instrução de cada um. Mas essa mesma fraternidade, igualdade e liberdade recomendam e exigem que a instrução de cada um seja acomodada às suas forças e propensões porque nem todos podem ser filósofos, nem mesmo dos artistas o bom ferreiro pode sempre, por exemplo, ser bom marceneiro ou vice-versa, posto que até certo ponto o princípio de Fourier seja verdadeiro e possa ser aplicado com proveito. Todo o homem com alguma inteligência e estudo é capaz de picar a pedra e afeiçoar a madeira com arte. Ora, o mesmo trabalho sempre continuado é monótono e desagradável. Quem
}

${ }^{473}$ O JARDIM LITTERARIO; semanario de instrucção e recreio, nº 11,1849 , p. 86-7.

474 “ (...) se verdadeiramente não pode haver instrução popular enquanto o trabalho se não organize, baldados serão também, sem o ensino e a educação comum, todos os esforços tendentes à regeneração social, que, há anos, numa parte da Europa se pressente e já hoje com ansiedade se espera. Damos, é verdade, a precedência à organização do trabalho, mas é porque entendemos que, na ordem dos tempos ou dos fatos, este fenômeno terá e deverá certamente de produzir-se primeiro; é por ele que há de principiar a revolução social, tão necessária quanto inevitável, infalível, que as luzes do século preparam, que as legítimas tendências da humanidade reclamam e que os espíritos mais previdentes não só não temem senão que todos a desejam e aguardam com certa impaciência, como único meio de salvar a sociedade do terrivel flagelo da mais terrivel anarquia." (C. J. VIEIRA, A Península, nº 29, 8-8-1852, p.544). 
por diversão e desenfado, aborrecido de um, pudesse dar-se a outro, seria duplicadamente útil à sociedade. $" 475$

$\mathrm{Na}$ esteira da tradição francesa desde os tempos da Revolução, o pensamento português, e particularmente os primeiros ventos do socialismo, apregoam os requisitos básicos para o contorno da escola pretendida. Sendo assim, tendo por plataforma primeira a ocorrência da "harmonia e concórdia fraternal" através do gesto da irradiação efetiva da educação, pressupunha-se algumas condições: havia que se garantir a todos a instrução gratuita e obrigatória, posto que, se por um lado, todos teriam direito de reclamá-la e exigi-la, todos teriam a contrapartida do dever de enviar suas crianças à escola, na medida em que os benefícios da instrução reverteriam necessariamente em benefício da sociedade. ${ }^{476} \mathrm{~A}$ regeneração da vida social portuguesa principiaria por aí: lentidão quanto ao aumento, à expansão e ao aperfeiçoamento da rede pública de escolas; pequena demanda por instrução primária por parte das comunidades locais; pouca aptidão e ausência de formação profissional dos docentes admitidos; má situação física e material das escolas; e o que era, no contexto, ainda pior - a incúria governamental, que não se sensibilizava perante as candentes necessidades de uma escola que, imóvel persistia sendo a mesma, incapaz de engendrar as sonhadas fraternas mudanças...

\begin{abstract}
“(...) insisto na necessidade urgentíssima de organizar e estabelecer na mais larga escala a instrução profissional teórica e mecânica porque só ela nos pode levantar do abatimento em que jazemos, só ela pode insuflar vida nova neste quase cadáver de Portugal, só ela, enfim, nos pode dar a abundância e a moralidade pelo hábito do trabalho regular e esclarecido. Para isto ninguém pode excusar-se a sacrifícios."477
\end{abstract}

${ }^{475}$ C. J. VIEIRA, A Península, n³2, 31-8-1852, p. 587. Na verdade, entendia-se a instrução como um corolário do próprio desenvolvimento técnico, do maquinismo, necessária, portanto, para engendrar a modernidade institucional da sociedade e para poder florescer efetivamente o governo democrático com que sonhavam naqueles tempos os socialistas: "Para que um povo, compreendendo os seus deveres e direitos, satisfaça aos primeiros, fazendo ao mesmo tempo respeitar os segundos, - que é o que mais importa à ordem, ao bem-estar e saúde da República, porque nisto se resumem todos os interesses vitais - é inegavelmente necessário que esse povo seja primeiro que tudo instruído. Deveres e direitos são para o mundo moral o que os dois pólos para o maravilhoso maquinismo do mundo físico; são, por assim dizer, os eixos sobre que gira toda a sociedade (...) ’'(Id. Ibid., no29, 8-8-1852, p. 545) A educação popular seria pois útil ao bom governo, em proveito dos cidadãos. O monopólio do poder tende a gerar opressão. O "legítimo reinado do proletariado" reclamaria como forma de governo uma república pautada por referenciais de moralidade e de virtude. Essa tarefa estaria colocada ao alcance da instrução, nos seguintes termos: "Um governo ilustrado, justo e digno de dirigir um povo, tendo sobretudo a peito dirigi-lo como deve, esse decerto não poderá deixar de ver na educação geral o seu mais poderoso auxiliar. Para qualquer outro, para o governo que não quer governar, mas só deseja oprimir, para esse é sem dúvida melhor que o povo seja eternamente ignorante, imoral, vicioso e corrupto. Esperais que ele decrete a educação popular ? Esperais pelo seu suicídio; é uma louca esperança. Quem não sabe que só se escraviza o povo embrutecido, que todo o povo civilizado se liberta, se emancipa?” (Id. Ibid., p. 546) Na sequência, o texto discorria sobre a impossibilidade, a seus olhos evidente, de perpetuação da tirania em um Estado onde a instrução houvesse sido efetivamente espraiada. A educação popular era então, no parecer daquela aurora do socialismo em Portugal, evidentemente a primeira inimiga do despotismo.

476 “(...) não só porque o cidadão não se pertence a si exclusivamente, mas a si e à comunidade, como também porque, tendo a sociedade de prestar-lhe os meios para a satisfação de suas necessidades, deve em compensação ter o direito de exigir dele todos os serviços compatíveis com as suas forças físicas e morais. Nem o homem pode esterilizar as suas faculdades porque Deus lh'as não deu para isso, nem a sociedade pode consentir porque isso lhe causaria graves prejuízos. Eis-me aqui, o que a ciência e a filosofia dizem de geral sobre o assunto. A aplicação destes princípios, a realização destas idéias, destas aspirações irão regenerar a sociedade.” (C. J. VIEIRA, A Península, n³2, 31-8-1852, p. 588 )

${ }^{477}$ C. J. VIEIRA, A Península, 8-11-1852, p. 492. Enfatizava-se o fato de tais proposições estarem quase todas elas contidas nas leis sobre educação que já vigoravam em Portugal e que previam no mínimo a gratuidade e a obrigatoriedade do ensino público, sem, entretanto, o país cuidar de fazer cumprir tais dispositivos legais. "Não 


\section{O MODELO ESCOLAR E A PERSISTÊNCIA dO ARCAÍSMO NO CONTEXTO DA PRETENDIDA REGENERAÇÃO}

Os anos 50 presenciaram - como assegura Oliveira Marques - a expansão e a estabilidade da economia e da política em Portugal. Na verdade, a Regeneração teria se constituído em um pacto entre os membros das antigas e arcaicas oligarquias e a burguesia. As rivalidades inter-classistas e as oposições, tão visíveis no decênio anterior iam a pouco e pouco diminuindo e o país entraria em uma época de paz. ${ }^{478}$ Pretendia-se na verdade, recolocar a nação nos trilhos de uma política liberal, efetivando para tanto toda a iniciativa de melhoramentos materiais e tecnológicos que pudessem efetivamente agir no sentido de desenvolução da economia. Rómulo de Carvalho observou que a prosperidade desse período conviveu com o reconhecimento da insuficiência quanto a matrizes teóricas e conhecimentos técnicos, capazes de verdadeiramente alavancar os recursos econômicos, em termos mais competitivos. ${ }^{479} \mathrm{~A}$ escola, dali por diante, viria a ser pensada também como exigência tecnológica, condição para o aprimoramento material das sociedades, pelo fato de capacitar o indivíduo para habilidades exigidas pelo progresso. Os elos que uniam instrução e cidadania continuariam a povoar o discurso e o imaginário sobre a escola. Mas, cada vez com maior intensidade, será destacada a aliança entre a preparação que a escola oferece e a qualificação para o trabalho. Nessa direção, a escola projetada deveria ser uniforme, padronizada, controlada por órgãos nacionais de inspeção. Isso não ocorria. O liberalismo convive, pois, com a persistência de um modelo escolar herdado do Antigo Regime: eram salas de aula esparsas, distantes uma das outras, muitas vezes abrigando crianças de mais de uma aldeia, cada escola com seu respectivo professor; não havia sequer diretrizes conscientemente assumidas. Na indefinição e na incerteza quanto ao método e ao conteúdo, o professor recorria ao compêndio. Estudando, ele - professor - pelo compêndio dirigido aos alunos, procurava, a partir daquilo, ensinar: a ler, a escrever e a contar.

Sem dúvida alguma, o tema da extensão da escola para camadas mais ampliadas da população portuguesa passava também pelo medo da mendicidade e da indigência que ia, de certa maneira, ganhando força nos ambientes citadinos. ${ }^{480} \mathrm{Na}$ verdade, a civilização exigiria

devo passar adiante sem notar que muitos dos princípios que tenho exposto se acham consignados na nossa legislação sobre instrução. Por que é pois que ela está tão atrasada, que não se tem difundido por todo esse país e o povo permanece na mais profunda ignorância ? À parte o incompleto do sistema, de que resultam os mais graves inconvenientes, evidentemente a causa principal do nosso atraso está na falta de execução das leis. " (Id. Ibid., p. 491)

${ }^{478}$ Nos termos de Oliveira Marques, teríamos o seguinte: “O País estava visivelmente cansado de tanta agitação política e desejava a paz. A burguesia, sobretudo, pretendia um governo forte mas maleável, que lhe garantisse tranquilidade e expansão econômica. (...) A expansão industrial, financeira e mercantil do País, em paralelo com a da Europa, harmonizava os interesses de industriais, banqueiros, comerciantes e proprietários rurais aos vários níveis, unificando para objetivos comuns alta, média e pequena burguesias. Entre aristocratas e burgueses, as diferenças foram-se minimizando. De 1851 até ao surto do Partido Republicano, nas décadas de oitenta e noventa, pode dizer-se que não houve, em Portugal, oposição real às instituições, às formas de governar e às políticas ou estruturas econômicas e sociais.(...) Em resumo, poder-se-ia dizer que, com o ano de 1851, se conseguiu a adaptação final do País às novas condições nascidas da perda do Brasil e do ruir do antigo regime.” (A. H. OLIVEIRA MARQUES, História de Portugal - volume III, p. 30-1)

479 "Os melhoramentos conseguidos puseram naturalmente a descoberto a nossa impreparação para as práticas que a sua instalação exigia, relacionada com a ausência de estruturas escolares que habilitassem pessoal para as novas tarefas." (Rómulo de CARVALHO, História do ensino em Portugal, p. 587)

${ }^{480}$ Acerca do tema, o ambiente da Grã-Bretanha é posto como um notório exemplo, particularmente pela ação das paróquias e da ação caritativa dos particulares na educação infantil. A instrução primária estava na Inglaterra quase toda ao encargo das paróquias e isso seria uma vantagem tanto em termos do gerenciamento quanto no que 
a inserção do sujeito no ambiente da palavra, da correção gramatical - em termos tanto da morfologia quanto da sintaxe - exigida pelo convívio social, pela interação do homem com seus conterrâneos. Por outro lado, um ambiente cultural cada vez mais circunscrito sobre o referencial do impresso exigiria o domínio e o manejo do escrito: a leitura e a habilidade de escrever passavam a se situar cada vez mais como imperativos da nova sociabilidade desenhada pela civilização do texto, da técnica; em uma palavra, da modernidade. Talvez haja sido o sentimento e a consciência do tempo quem trouxe a escola. Um tempo que se queria apartado do presente: produzindo a memória escrita para recordar o passado e voltado, substantivamente, para o desejo do futuro. A criança deveria, pela ação escolar, rememorar e apreender o passado que, enquanto descendente, trazia da sociedade que lhe antecedera; a criança era, por sua vez, o templo mais acabado do futuro. Para isso existia a escola. E por causa disso também, a escolarização deveria se constituir não apenas enquanto um veículo eficiente de instrução, mas fundamentalmente como uma agência de moralização; de inculcação de valores e de referências, de transmissão de códigos e de padrões de conduta. A escola era, enfim, um modo de projetar o futuro que o imaginário social predominante julgasse efetivamente adequado. Em certa medida, a escola chegava a ser uma ilusão de escolha do futuro; de intervenção do presente junto às opções desse tempo por vir. A escola pretendia driblar a indeterminação, regrar o acaso... A escola é, igualmente, uma instituição ideologicamente temporal, embora mude com tanta lentidão. Como já pudemos introduzir nos capítulos anteriores, eram inúmeros os intelectuais que redigiam para revistas e jornais da época, destacando o atraso da instrução. Pinheiro Chagas que, nos anos sessenta escrevia para o Archivo pittoresco, remarcava ali a carência de formação de professores - uma única escola normal - e a completa ausência de iniciativa particular na ação educativa. Entendia-se que os progressos da instrução na Inglaterra eram derivados tanto da iniciativa dos particulares no desenvolvimento do ensino quanto da existência de sólidas bibliotecas populares, que eram, por seu turno, o natural complemento da escola. Em Portugal, tudo era deixado, como vimos, sob a iniciativa do governo; e, como este não cumpria, apenas se reclamava...Havia porém quem se comportasse de modo diferente. Havia que se seguir poucos e grandiosos exemplos:

\footnotetext{
"Faleceu na cidade do Porto, domingo, 25 de março do corrente ano de 1866, o sr. Joaquim Ferreira dos Santos, conde de Ferreira. Era um poderoso capitalista que, durante a vida, soube valer a inúmeros infelizes, e que por sua morte distribuiu a grande riqueza que possuía de modo que revelou cristã filosofia e os mais nobres e generosos sentimento. Entre os legados que o sr. Conde de Ferreira deixou inscritos no seu notável testamento, conta-se o de 144:000\$000 réis para a construção de 120 casas para escolas de instrução primária, nas cabeças dos concelhos, dispendendo-se 1:200\$000 réis em cada uma. Parece que este valiosíssimo legado, de tanto alcance para a educação do povo, lhe fora sugerido pela leitura dos artigos do digno comissário dos estudos no distrito de Lisboa, insertos no Archivo Pittoresco. Findando neste número o oitavo volume do nosso semanário temos espaço para esta simples comemoração, mas prometemos desde
}

concerne à fiscalização da rede educativa. "A ignorância e a brutalidade, repelidas dos grandes focos industriais, refugiaram-se nas pequenas indústrias particulares. Ainda aí as foi perseguir a lei, e só parou à porta do domicílio doméstico, inviolável e sagrado para todo inglês. Aí principia a ação da caridade particular, $e$ da influência benéfica das classes ilustradas. Essa lei, altamente justa, é eficazmente auxiliada pelos fabricantes, que não recuam diante de despesa alguma, quando percebem que essa empresa lhes pode ser útil, e eles bem sabem quanto lhes é útil a ilustração de seus operários. Os fabricantes e os negociantes ingleses não são como os nossos que não compreendem senão o ganho imediato, e que não aventuram um capital sem saberem ao certo qual é o juro que lhes compete. Sabem que é necessário semear para colher, às vezes, sete, oito anos depois, e não choram o dinheiro que eles próprios empregam em fundar escolas, porque sabem que dessas árvores de bençãos que plantam, hão de vir a brotar frutos que serão a alegria, o orgulho e a riqueza do cultivador.” (M. Pinheiro CHAGAS, Algumas reflexões sobre instrucção pública III, In: Archivo Pittoresco; semanario illustrado, $8^{\circ}$ anno, 1865, tomo VIII, p. 32) 
já publicar oportunamente o retrato do falecido conde de Ferreira, benemérito da infância e da instrução pública, e acompanharemos o retrato com a competente notícia biográfica." 481

O citado Comissário dos Estudos da cidade de Lisboa, cujos artigos teriam inspirado o testamento do referido Conde de Ferreira era Mariano Guira, que realmente escrevia periodicamente naquele semanário. O referido Comissário dos Estudos, de fato, parecia bastante preocupado quanto a uma organização padronizada das escolas públicas da época, o que permitiria - em seu entendimento - um melhor desenvolvimento da instrução. No ano de 1864, artigo intitulado 'Casas para Escolas' trazia o parecer de Mariano Guira sobre a necessidade de o Estado e os particulares atentarem para os aspectos físicos da vida escolar:

\begin{abstract}
"É por certo importante a consideração que este assunto deve merecer a todos quanto se interessam pelos melhoramentos da instrução primária. As condições materiais da casa escolar não são indiferentes ao professor e aos alunos. O professor, depois das fadigas do magistério, carece de encontrar o modesto conforto de uma habitação, posto que simples, decente e higiênica. A escola deve concorrer para conservar as crianças de bom humor, para lhes incutir o amor pelo estudo, pelo asseio e pela boa ordem. Se a casa de escola não estiver em condições convenientes, se os alunos estiverem constrangidos, apertados, e metidos em uma atmosfera viciada, não pode haver gosto pelo estudo, nem disciplina, nem saúde. O que a tal respeito se observa na grande maioria das escolas deste distrito é muito para lamentar. Se se quiser que a instrução primária seja uma realidade, é indispensável cuidar seriamente da construção de casas apropriadas para escolas. É neste intento que pedimos a atenção das autoridades administrativas, câmaras municipais, juntas de paróquia ou quaisquer outras corporações ou cidadãos que se interessem pelo assunto para os projetos de edificação que apresentamos. A primeira condição que se deve procurar para o estabelecimento de uma escola é um lugar central, de fácil acesso, bem ventilado. A escola deve ficar isolada de qualquer habitação insalubre, e afastada quanto possível dos lugares onde haja ruído ou qualquer outro objeto de distração que possa perturbar os exercícios escolares, ou desviar a atenção dos alunos." 482
\end{abstract}

A sala de aula deveria ainda contar com uma disposição própria, que parecia essencial aos olhos daquele técnico do ensino. Os alunos ficariam em bancadas apropriadamente enfileiradas pelo espaço da sala de aula, defronte ao estrado e à cadeira destinados ao lugar do professor. É toda uma arquitetura que distribui lugares, configura e delimita padrões de espaço e estipula marcas de significados de poder institucional. A escola, já pela disposição física, classificaria e ordenaria os indivíduos, controlando-os ao fazer isso. Há a preocupação quanto à ventilação e à luz necessárias ao funcionamento rotineiro da classe. Parece que, de alguma forma, é a época procurando regrar a dinâmica própria da escolarização, como se fosse possível conferir a ela, por um ato de vontade, uma eficiência padronizada por tal modalidade unívoca de ensino pretensamente simultâneo.

Em outro texto intitulado 'Mobília para Escolas', Mariano Guira discorria sobre o mobiliário de uma escola 'bem organizada'. A instituição, para bem funcionar, precisaria conter os seguintes objetos: estrado; quadro preto; bancadas para os alunos;

\footnotetext{
${ }^{481}$ ARCHIVO PITTORESCO; semanario illustrado, $8^{\circ}$ anno, 1865, p. 411.

${ }^{482}$ Mariano GUIRA, Archivo Pittoresco, $7^{\circ}$ anno, 1864, p. 164-5.
} 
"Além dos objetos mencionados, deve ter a escola: um crucifixo, em frente dos alunos, na parede superior ao estrado; o busto ou o retrato do rei; um contador mecânico com 100 esferas; um relógio; um mapa de Portugal; um quadro do novo sistema legal de pesos e medidas, como o metro, o litro, o quilograma, etc.; um pote com torneira para água e um copo ou um púcaro de metal; um lavatório; cabides numerados à entrada da escola para bonés, capas, etc.; livros para se emprestarem aos alunos mais pobres; exemplares para escrita e cadernos para escrita e para contas." $" 483$

O estrado - de acordo com a recomendação do Comissário - deveria ter uma altura tal que o professor pudesse vigiar todos os alunos. Deveria ter ainda dois ou três degraus. Sobre o estrado, ficaria a mesa do mestre, que teria 2 metros de comprimento por 0,96 metros de largura. $\mathrm{O}$ quadro preto estaria situado à esquerda da mesa do professor, tendo um metro de largura e 0,66 metros de altura. As bancadas que são sugeridas por Guira seriam compostas por duas peças - carteira e banco - ligadas entre si, como se vê na gravura abaixo. Seriam feitas especialmente a partir das medidas médias das crianças e comportariam, cada uma, três alunos. A ligação entre a mesinha e o banco, como já observaram outros estudos, seria importante para estipular a disciplina pretendida, posto que, com mesa e banco ligados, a mobilidade do aluno seria dificultada: ele não seria capaz de deixar sua carteira com tanta facilidade, estando por sua vez devidamente afastado dos colegas e companheiros. Guardavase pelo estrado a distância do professor; pela carteira, assegurava-se o espaço do aluno que deveria, acima de tudo, conhecer o seu lugar; o lugar que os hierarquicamente superiores reservaram para ele. Isso seria o mundo; isso era já a escola... Haveria nas carteiras orifícios para tinteiros. Entende-se, entretanto, que nem todas as escolas poderiam efetivamente ter esse mobiliário ultra-moderno. Pensando nisso, entretanto, o redator esclarece que, nas escolas onde não houvesse aquelas bancadas para os alunos, deveria existir pelo menos o seguinte:

\begin{abstract}
“ $1{ }^{\circ}$ ) Que haja uma banca comprida para a escrita, de modo que um terço dos alunos possam aí escrever, a fim de serem divididos em três classes que ocupam por seu turno a banca. É conveniente que no ato da escrita cada aluno tenha um banco separado (mocho), em vez de estarem sentados uns poucos no mesmo quando escrevem. $2^{\circ}$ ) Que os bancos da aula não deixem de ter costas. É muitíssimo inconveniente e prejudicial à saúde conservar os alunos encostados às paredes úmidas e frias, ou curvados sobre os bancos por não terem onde se encostarem. Na escola de Queluz há uns bancos, mandados fazer há bastantes anos pela casa real ( segundo nos constou ), que reúnem as condições convenientes. Cada banco pode acomodar quatro ou cinco alunos; tem costas de madeira um pouco inclinadas e na parte inferior do assento há uma caixa onde os alunos guardam os livros, barretes, etc."
\end{abstract}

\footnotetext{
${ }^{483}$ Mariano GUIRA, Archivo Pittoresco, $7^{\circ}$ anno, 1864, p. 248.

${ }^{484}$ Mariano GUIRA, Archivo Pittoresco, $7^{\circ}$ anno, 1864, p. 248. O mesmo Mariano Guira, que teria sido também reitor do Liceu Nacional de Lisboa, faria em 1867 a apresentação da da terceira edição da obra didática de Carlos Silva, intitulada $\mathbf{O}$ paleographo em escala calligraphica para aprender a leitura manuscripta, a qual havia já sido aprovada pelo Conselho Superior de Instrucção Publica para uso das escolas. O livro pretendia ser, no parecer de seu autor, "gradualmente litografado do mais fácil caráter de letra à mais dificil caligrafia". Esse compêndio de Carlos Silva - de acordo com as informações prestadas pelo estudo dos relatórios de inspeção - estaria em $13^{\circ}$ lugar entre os compêndios mais utilizados pelas escolas portuguesas, de acordo com os dados de 1867 (com um percentual de $0,8 \%$ em relação ao total da amostra). Entretanto, de acordo com o que nos informa o relatório da inspeção de 1875, o mesmo livro ocuparia o terceiro lugar, com sua utilização correspondendo a um total de $8,1 \%$ de utilização, dentre todos os que seriam utilizados nas escolas primárias públicas portuguesas. Pode-se conferir essa informação pelas tabelas e gráficos dos capítulos 5 e 6 . Aqui porém julgamos interessante reproduzir o prefácio que Marianno Guira (na ocasião, Reitor do Liceu Nacional) faria para O paleographo de Carlos Silva: "Fazia-se sentir nas escolas a falta de uma seleta manuscrita, que viesse substituir as antigas sentenças e uma multidão de escritos mal redigidos e inconvenientes que andavam nas mãos das crianças. Com
} 
Era realmente o tempo de padronização da composição física e simbólica da sala de aula. Havia com frequência notícias sobre a venda de material escolar e fundamentalmente sobre novas descobertas técnicas que eram feitas nesse terreno. Propunham-se novos instrumentos, mais fáceis e mais baratos, novos materiais para fabricação do moderno mobiliário; todo ele voltado para uma boa capitalização comercial da própria idéia da sala de aula... O século XIX desenhava assim sua escola nas revistas. ${ }^{485}$

Talvez a grande temática da educação e da escola no século XIX estivesse contida na nova percepção que os contemporâneos passavam a ter sobre a infância. A criança passaria, ainda na primeira metade do século a ser retratada como um ser específico, dotado de uma complexidade intrinsecamente sua, que pouco teria a ver com as características do adulto. Havia que, nessa medida, instigar os adultos à reflexão sobre a lógica que preside a razão infantil. Supunha-se então que compreender o raciocínio da criança seria a chave para garantir regras para o ato de educar. A meditação sobre o homem, já no século XVIII, falara de perto à infância. O século XIX solicitava o aprofundamento desse estudo. É o que podemos verificar quando jornais e revistas da época, precavendo os contemporâneos, anunciavam o seguinte:

\begin{abstract}
"O homem, sempre objeto de meditação para o homem, dá-lhe lições importantes em todas as idades: é uma escola que se abre no berço e que se fecha no túmulo. Não é nos primeiros dias da existência que o homem nos ensina menos. Se a vida é um livro, a infância é a mais interessante e, sem questão, a mais inocente e sentimental das suas páginas. (...) A infância tem duplicadas vantagens: ao passo que instrui o espírito, interessa o coração. Os risos e as lágrimas do recémnascido mostram o fado de todos os homens. Assim corre depois a vida, da maneira que começa; e em todos os atos e cenas desta representação passageira há prazeres e dissabores. Duma só cor, não é por certo o seu quadro: leva o claro de algumas venturas, e as sombras de muitas desgraças. Vai sempre alternada e entretecida de aflições e de alegrias, de esperanças e desalentos, de desbarates e de vitórias, de fraquezas e de heroísmos, de lágrimas e de risos: num só dia se contam muitas vezes diferentes e opostas cenas da vida." 486
\end{abstract}

a publicação do Paleographo veio V. Prestar um bom serviço à instrução primária, não só porque neste livro se contam gradualmente os diversos caracteres de letra, do mais fácil ao mais difícil, mas também pela cópia de abrviaturas modelos de cartas, de contas e de outros papéis usados nas relações familiares e comerciais. Apreciando o trabalho de V. e agradecendo a delicada oferta do seu livro, sou com estima e consideração (...)", (Mariano GUIRA, Parecer do Exmo. Snr. Reitor do Liceu Nacional acerca da obra..., In: Carlos SILVa, O paleographo em escala calligraphica para aprender a letra manuscripta, terceira edição, 1867).

485 "Desde que, já há anos, começamos a intender no grave e complexíssimo negócio público da instrução elementar, reconhecemos a urgente necessidade de se multiplicarem por baixo preço os aviamentos indispensáveis para as escolas. Quiséramos baratíssimos os livros primários ( e mesmo todos ), os traslados, o papel, as ardósias, etc. Para economizar a verba mui avultada do papel nas escritas de estudo, forcejamos por introduzir os papéis-vidros, que algum dia se hão de generalizar, quando soubermos e pudermos fabricá-los menos imperfeitos e mais em conta. Pelo que pertence às ardósias, forcejamos debalde para que as fizessem de todas as dimensões convenientes com asfalto os que trabalham nessa matéria; como era coisa nova, chamaramlhe impossível, até que o impossível deles o vimos um dia realizado: o senhor Leal, com laboratório químico ao Largo do Carmo, fez para seu uso um quadro de asfalto de vastas dimensões, que aceitava e demitia, tão bem ou melhor que as ardósias ordinárias, a escrita com giz. É um fundo lustroso e dum belo escuro, importa em pouco, e se por acaso se quebra, facilmente concerta com lume e uma colher de pedreiro. Muitas vezes recomendamos aquele exemplo à imitação; não nos consta que mestre algum o aproveitasse. Tornamos hoje a lembrá-lo. (...) As vantagens que esta ardósia bastarda leva à verdadeira são: barateza, leveza, menor fragilidade e poder fabricar-se de qualquer tamanho; no demais escreve-se e risca-se nela como na outra com lápis de qualquer côr, gesso ou giz." (ARDÓSIAS Artificiais, Archivo Pittoresco, $1^{\circ}$ anno, 1857, p. 311).

${ }^{486}$ A INFÂNCIA, In: A distracção instructiva; jornal litterario publicado por uma sociedade d'estudiosos, volume $1, \mathrm{n}^{\circ} 4,1842$, p. 50. Sobre essa trajetória do sentimento de infância, em linhas gerais, o trabalho de P. Ariès permanece como a grande referência. Ali, o historiador afirmará o seguinte: "Uma nova noção moral deveria distinguir a criança, ao menos a criança escolar e separá-la: a noção de criança bem educada. Essa 
$\mathrm{Na}$ verdade, conclamavam-se os leitores para que eles simplesmente passassem a prestar um pouco mais de atenção às suas crianças, aos filhos que eles teriam em casa, ainda que isso fosse feito apenas para que, por tal atitude, os mesmos pais pudessem ter a oportunidade de se reencontrar com a criança que um dia foram. Mostrar que no menino mora o homem era, portanto, estratégia que prometia, pelo conhecimento do outro, um reconhecimento de si. O estímulo para a descoberta da infância não era, pois, desinteressado: passava-se a querer reparar na criança do berço para que ela nos revelasse o que de nós adultos já estaria lá... Desse modo, a tarefa da educação compreenderia uma manifesta intenção civilizatória. Desejava-se educar para ordenar a sociedade em harmonia com padrões de conduta e de distribuição dos bens materiais e simbólicos em vigor pela ordenação social então vigente. Havia nitidamente um intuito de socialização dentre os objetivos explicitados pelos pedagogos que nas revistas abordavam o tema da instrução das crianças. Era preciso, todavia, conhecer a ela - criança - e fazer isso conhecendo também os cuidados que seus pais lhes dispensavam. A partir daí, procurava-se acentuar o rol das obrigações dos pais, obrigações estas que abarcariam a formação moral das gerações emergentes; deveres estes, porém, que, não poucas vezes, eram relegados ao último plano das prioridades familiares. Com cuidado, falava-se do mau pai, daquele que não honra seu dever para com sua prole, atribuindo à má índole os maus tratos e eventualmente a própria falta de amor.

\begin{abstract}
"Que há no mundo maus pais é ponto que infelizmente não admite réplica; sendo-os uns por extravagância, outros por desmazelo, alguns por loucura, e não poucos por má índole. No entanto deve com justiça confessar-se, para a honra da espécie humana, que é muito menor o número dos maus pais do que o dos filhos ingratos e desobedientes. Não faltará quem acoime de paradoxo o acharmos aquela circunstância honrosa à espécie humana; mas os que assim pensam são pessooas que se não entregam ao exame detido das suas opiniões e das alheias. Essas pessoas têm para si, e com muita razão, que entre pais e filhos há deveres recíprocos; que se àqueles cumpre dar a estes o sustento, proteção e uma apurada e virtuosa educação, os filhos, pela sua parte, têm o estrito dever de honrar, obedecer e amar a seus pais. Por maiores que sejam as aflições de um pai à vista dos desvarios e pouco amor de seus filhos, nunca poderão comparar-se às agonias a que a estes, tarde ou cedo, causarão os remorsos da consciência.",487
\end{abstract}

noção prticamente não existia no século XVI e formou-se no século XVIII. Sabemos que se originou das visões reformadoras de uma elite de pensadores e moralistas que ocupavam funções eclesiásticas ou governamentais. A criança bem educada seria preservada das rudezas e da imoralidade, que se tornariam traços específicos das camadas populares e dos moleques.” (P. ARIÈS, História social da criança e da família, p. 185). António Gomes Ferreira, aprofundando as pistas do historiador francês em termos de referência e método, tem estudado o mesmo tema, adequando-o ao caso português.

${ }^{487}$ J. J SALGUES, Deveres dos pais, In: Illustração popular; folha dedicada ao recreio e instrucção, $\mathrm{n}^{\circ} 15$, 1866 , p. 13. Tendo em vista a orientação dos pais e mães de família para o cumprimento da tarefa que lhes competia, a Revista das escolas, na edição do dia 15-2-1895, publicaria um artigo, traduzido de alguma matéria estrangeira, com o título "O decálogo do pai", e que consistia no seguinte: "1". Constituirás uma família com amor, sustenta-la-ás com o teu trabalho e regêela-ás com bondosa energia. $2^{\circ}$. Serás sempre prudente nos negócios, pródigo no ensino, zeloso em manter a autoridade paterna, refletindo antes de resolver, porém, irrevogável nas tuas decisões. $3^{\circ}$. Terás para a tua esposa um inextinguível apoio moral, procurando nela consolação sem nunca deixar de ouvir o seu conselho. $4^{o}$. Destruirás todos os vícios domésticos, toda a preocupação e toda a desordem que possa aparecer no teu lar. $5^{\circ}$. Tratarás de que haja sempre um equilíbrio entre a receita e a despesa. $6^{\circ}$. Procede de maneira que teus filhos vejam em ti quando meninos uma força que ampara; quando adolescentes, uma inteligência que ensina; quando homens, um amigo que aconselha. $7^{\circ}$. Não cometas nunca a torpeza de pôr em oposição ou luta o poder materno com o paterno. 8o. Faze com que teus filhos conheçam o caminho da escola e da desgraça e saibam vencer com virilidade os males e perigos da vida. $9^{\circ}$. Estuda detidamente as aptidões de teu filho. Não lhe faça compreender que pode ser mais que tu. 10 . Faze 
A formação do ambiente doméstico atentaria particularmente para os hábitos consentâneos à acepção de moralidade e de formação para a conduta reta, para os bons costumes. Supunha-se que, paralelamente à escola, cabia ao lar a tarefa civilizatória da educação; educação que, por abarcar a missão de conformar hábitos e extirpar o contato com os vícios, jamais poderia se confundir com a mera instrução intelectual. Ora, mas se a educação era assim compreendida, antes como a formação do coração humano do que dos aspectos concernentes à razão, havia que se atribuir ao mestre de instrução primária um lugar extremamente especial, talvez proveniente do papel que até então era reservado ao pároco, com o qual a partir de meados do século XIX, o mestre de instrução primária passaria a concorrer, como podemos facilmente observar por uma infinidade de fontes didáticas, literárias ou jornalísticas da época. O mestre - como enfaticamente observava António Feliciano de Castilho, em artigo datado de 1855 para o jornal coimbrão intitulado A instrução e o povo - era de fato o instituidor primário e, como tal, deveria ser tratado pela sociedade e particularmente pelos pais de família:

\begin{abstract}
"E o mestre? O mestre, que é o primeiro cultivador dos espíritos e dos corações, o primeiro médico moral do povo, o primeiro, um influentíssimo cura de almas, o piloto que pode encalhar ou perder vossos filhos ainda antes de saírem a barra; o mestre que é sem saber o arquiteto que vai lançando os fundamentos do futuro edifício social; o mestre pode ser a seu salvo a antítese formal de tudo isto. Não só o pode ser; é-o muitas vezes. Todos o sabemos; quase todos o deploramos; poucos invocam remédio para tamanha desgraça; o remédio ninguém lh'o aplica, e os anos passam e o mal invetera-se a perpetua-se." ${ }^{288}$
\end{abstract}

Castilho - admitindo as lacunas da escola primária e particularmente de seus professores no cumprimento da elevada missão social a eles reservada na feitura de uma verdadeira sociedade regenerada e disposta em direção ao aperfeiçoamento incessante destacava no texto a necessidade de implantação de algumas medidas de cunho pedagógico necessárias para a construção de uma escolarização verdadeiramente eficaz, verdadeiramente regeneradora. Sua aposta educativa supunha a criação de modos e métodos de ensinar racionais e apropriados para o ensino, coisa que, a seu ver, não ocorria; a criação de um Ministério exclusivamente dedicado aos assuntos da instrução pública; a criação de folhas periódicas destinadas a instruir, complementando a ação da escola e voltadas também para a formação dos mestres. Esse último objetivo viria a ser consubstanciado - acreditava o educador - pela ação dos jornais voltados para a temática da instrução. A instrução e o povo não era, como temos visto, o único órgão da imprensa que, à época, lidava com a finalidade didática de dirigir ensinamentos aos adultos. Podemos destacar que, na mesma direção, colocavam-se as propostas d'O Panorama, da própria Revista Universal Lisbonense (que o mesmo Castilho fundou em 1840 e foi responsável pela redação dos primeiros quatro tomos) e, em certa medida d' O Instituto, dado que, todos eles traziam inúmeros textos e por vezes até seções reservadas, voltados, quer para o problema da escolarização, quer para a dinâmica da educação doméstica. Seja como for, os intelectuais desejavam à época fazer da imprensa o

com que seja tão robusto como são de inteligência. Faze-o bom antes de o fazer sábio.” (O DECÁLOGO DO PAE, tradução de Mario de Reneville, In: Revista das escolas, anno 1, nº3, 15-2-1895, p. 46)

${ }^{488}$ A. F. DE CASTILHO, Introdução, In: A instrução e o povo; jornal cintífico e literário da sociedade civilizadora, primeiro ano, 1855 , p. 3. Na verdade, Castilho escreve esse texto com sua nova notação ortográfica - a dita 'ortografia fônica' - que, em seu entender, era mais próxima da fala. Não julgamos, entretanto, necessário mantê-la, posto que, como observamos no início deste trabalho, temos atualizado toda a ortografia na transcrição das fontes. 
dispositivo irradiador de suas idéias, muitas vezes buscando através desse recurso a consolidação de novos quadros mentais acerca de temas que julgassem efetivamente relevantes. A escrita em inúmeros veículos de divulgação ampliava o raio de alcance da mensagem. ${ }^{489}$ Por tal razão, conviria falar por muitas vozes e ampliar por tal mecanismo o raio da escuta. Pressionar o governo era também fazer isso: havia de chegar o momento em que os administradores de concelho, as juntas de paróquia, os governadores civis, todas as autoridades enfim se sensibilizariam para a urgência de as prioridades públicas - de uma vez por todas - passarem a abarcar a temática da formação da juventude nas escolas... Entendiam os intelectuais da época que de educação escolar precisava o país; ainda que ninguém acreditasse nisso: nem as autoridades nem mesmo as famílias. Nas palavras de Luiz Filippe Leite - discípulo de Castilho nas idéias e diretor da Escola Normal de Lisboa - a esfera pública da educação era para Portugal a "responsabilidade das responsabilidades":

\begin{abstract}
"Contra a mãe que pode as mais das vezes evitar ao filho uma existência de enfermidades e não faz; contra a mãe que lhe dispõe do coração e lh'o perverte; contra o pai que lhe assenhoreia a inteligência e lh'a deixa perder; contra o mestre, que substitui pai e mãe na medicina preventiva do corpo e do coração, e lhe há de cultivar o entendimento, e que com tudo isto miseravelmente especula; contra o homem em quem o Estado depositou parte de sua autoridade para marcar o rumo da instrução e da educação pública, e dorme a sono solto, pejando os orçamentos; contra o jornalista que entre um tinteiro que dá tudo quando se lhe pede, e um prelo, que recebe tudo quanto se lhe dá [como disse um elegante escritor contemporâneo] contra o jornalista, dizemos, que deixa correr à revelia o máximo interesse do povo, e nada dá do que o interesse do mesmo povo lhe pede; contra o representante da nação que faz do parlamento pátio de comédias; contra os ministros, que não puserem cobro a tantos desconcertos; contra os chefes constitucionais, que, irresponsáveis perante o código, mas altamente responsáveis perante as próprias consciências e
\end{abstract}

\footnotetext{
${ }^{489}$ Luiz Filippe LEITE, que será citado logo abaixo porque escrevia também n'A instrução e o povo, enquanto diretor da Escola Normal de Lisboa, julgava-se no direito e no dever de tomar publicamente a palavra para discorrer sobre a causa da instrução. Com tal convicção, em artigo intitulado 'Dignidade das funções de professor primário', redigido para o volume XII d'O Panorama de 1855, discorria sobre a temática proposta mediante o pressuposto de que o professorado agia como que imbuído de uma elevada missão, A partir disso, o que o redator faz é sobretudo enaltecer a grandeza de propósitos dessa missão. A epígrafe de Leibnitz que enuncia seu texto é já por si reveladora do conteúdo: "Celui-là qui est le maître de l'éducation, peut changer la face du monde". A grandeza do ofício estaria pois aqui resumida. Se domina pela palavra, o mestre deveria ser entretanto guiado pela voz do coração; suas palavras representando a própria pregação viva o 'evangelho social'. Sendo que seu ministério estaria posto antes no domínio da moral do que no campo do intelecto, a retidão de costumes, a conduta absolutamente irrepreensível tornavam-se requisitos imprescindíveis. Tendo em suas mãos o esteio do futuro, e a herança do passado, para que efetivamente pudesse transmitir tradições, o professor primário não poderia - em hipótese alguma - ser um homem vulgar. Na escola, como em um templo, " $a$ profissão do magistério, meio termo entre o sacerdócio e a magistratura, deve representar pelo trabalho as honradas fadigas do operário; pela ciência e pela vocação, o primeiro elemento civilizador deste século." (L.F. LEITE, Dignidade das funções de professor primário, In: O Panorama, volume XII, $4^{\circ}$ da $3^{\text {a }}$ série, 1855 , p. 167). Abnegado, desinteressado, sacrificado, cônscio da grandeza e da rudeza de sua missão - juiz e padre a um só tempo - o professor trabalha pelo esculpir de gerações, trazendo luz onde havia antes escuridão e ignorância. Agente civilizatório por excelência, desconhecido pela história e por vezes desamparado pelas árduas condições de trabalho, ele sabe-se depositário dos destinos da pátria, tornando sempre melhores aqueles filhos que não são seus... A dignidade do magistério estaria, mais do que no reconhecimento público, em uma secreta e inconfessável realização da consciência que, no diálogo consigo própria, julgava estar amparando o futuro da humanidade, mesmo que o custo disso fossem sacrifícios no plano individual. Aí estava o ser professor, sua pessoa, sua dimensão profissional: "Modesto nas falas, singelo no trajar; adorado pelos vizinhos, destemido para as maledicências, galvanizado para as invejas, robusto nas forças; nos contentamentos ainda tão moço, como na primavera da vida; na esperança tão forte como nos dias de mais vigor; com a boca cheia de riso e o coração perfumado de esperança, não vedes um ancião a quem todos cedem o lugar nas festas da aldeia, a quem todos amam como o pai de uma grande família, a quem as criancinhas se achegam como para as carícias maternais ? É o mestre primário. Duas gerações se desentranham em reconhecimento à bondade com que lhes alumiou as escuridões da inteligência. Juram nas suas palavras; e a sua palavra revive e floresce e frutifica também nas boas obras que fez produzir." (Id.Ibid., p. 167)
} 
perante o senso comum, não saberem representar dignamente o seu papel de príncipes, contra todos e contra todas, se porventura os há, se de futuro ainda os houver, contra todos bradam os crimes que ensanguentam as estradas e os patíbulos, as dores que se gemem nos hospitais e no seio das famílias; a ignorância que mata, assassina, rouba, maldiz e morre afrontada; brada a sorte da puerícia quando enfeza e compromete a robustez que devia herdar; brada a adolescência que desfaz no lupanar dezenas de anos que a devassidão precoce lhe abrevia na vida; brada a virilidade que quer trabalho e não o tem; que pede pão e oferece o suor e não vê indústrias que lh'o aceitem, nem sabe ao menos entender as poucas, (onde predomina a concorrência) nem adivinhar outras em que empregue o seu capital de forças; brada a rudeza do povo que toma o fanatismo pela religião, e revolução pela política, a intemperança pela higiene, o vício pelo divertimento, o crime, as vinganças e a crueldade por naturais propensões; brada a mendicidade, que vai degenerando em pauperismo e que veio da turba dos ociosos forçados pela falta de liberdade da terra, e pela crueza em que de propósito lhe deixaram os entendimentos; bradam as colônias que renegam a metrópole; brada a velhice e a decrepitude prematura, que amaldiçoa num epílogo de desespero toda uma existência inútil de fome, de ignorância, de lágrimas, de desprezos; brada a geração nova, que acha tanto que desbravar, que desanima e cruza por fim os braços; contra todos e contra todas que puderam fazer e não fizeram, brada a consciência íntima, que é o mais temível e horroroso de todos os infernos! Responsabilidade das responsabilidades é esta da pública educação."490

De acordo com aquele articulista, competia à instrução primária - como verificamos neste longo excerto - organizar, ordenar, classificar a cidade, preveni-la do crime, da desordem e particularmente das revoluções sociais, que pareciam ser a grande tentação daqueles tempos. A cidade, a vida mercantil, a concorrência de um mercado que, caótico, aparentemente ia se estruturando, esse era o mundo para o qual se deveria dirigir a escolarização pública. A instituição escolar é aqui a agência de prevenção dos desvios e do controle da multidão. Para evitar a marginalidade, a indigência, a mendicidade e o crime, a escola deveria vir. Era a cidade quem a chamava; a cidade que toma aqui a voz daquele diretor da quase única escola de formação de professores que havia em Portugal naqueles meados do século XIX.

\section{A ESCOLA QUE CLASSIFICA, ORDENA, INSTRUI}

Na verdade, conclama-se a escola, como a estratégia de reforma que preveniria o país contra o fantasma da revolução. Desejava-se a mudança, mas a mudança contida, regrada e vigiada, que não rompendo a ordenação do passado, fosse capaz de alterar apenas o necessário, passo a passo, sem violência e sem traumas. Alterar-se-ia assim a ordem aristocrática e arcaica que ainda presidia julgamentos e mentalidades? Quando todos tivessem instrução, não haveria mais o perigo do abalo social, posto que haveria uma regulação natural que equilibraria a disparidade das fortunas através da equalização do direito de cada um

\footnotetext{
${ }^{490}$ Luís Filippe LEITE, Instrução e povo, In: A instrução e o povo; jornal científico e literário da sociedade civilizadora, primeiro ano, 1855, p. 11 . Na verdade, este artigo, como praticamente todos os outros a que pudemos observar neste jornal, estava redigido a partir da ortografia fônica, o que indica que Castilho teria tido singular influência na orientação da linha editorial (Aliás era a Castilho que o texto de L.F. Leite fazia referência quando recordava "um elegante escritor contemporâneo"). A justificativa para tal ensaio de mudança ortográfica era a de que tal modo de escrever, embora não obedecesse a etimologia da língua, era muito mais adequado à escuta e ao modo de falar dos portugueses, facilitando o aprendizado das palavras escritas, e portanto da comunicação linguística. Supunha-se que isso seria estratégico para expandir a língua portuguesa e torná-la mais conhecida, mais viva e mais fluente, inclusive para uso dos países estrangeiros. De acordo com F. G. Lucas que, naqueles anos, escrevia sobre o tema no referido periódico "é eizatamente para obter a facil comunicação entre as linguas vivas qe devemos pugnar por eispurgar de espinhos etimograficos a noça anomala ortografia." (F. G. LUCAS, A ortografia deve ser eitmologica ô fonica, In: A instrução e o povo, 1855, p. 72.
} 
explorar ao máximo suas capacidades intrínsecas, o talento que lhe seria próprio. Nessa medida, cada vez mais, a desigualdade predominante no cômputo geral da sociedade seria essencialmente a desigualdade dos dons individuais: venceriam os melhores, os mais capazes, os mais talentosos. A sociedade estaria finalmente harmonizada com os princípios da justiça social; estando por outro lado garantidas as condições máximas para seu incessante aperfeiçoamento. Cada vez mais, era corrente a idéia de que inteligência bem aproveitada poderia potencializar ao infinito a natureza do homem, conduzindo-o para a civilização, aprimorando essa mesma civilização e trazendo utilidade social ao mundo da propriedade e do trabalho. A inteligência, acrescida pelo estudo, seria, portanto, capaz de alterar por completo a face do globo, subjugando e vencendo a natureza e demarcando a rota de cada nação sobre o território conhecido. Porém, por volta do último quartel do século, o socialismo parecia ser já uma realidade a atormentar os contemporâneos que tendiam a ver naquela doutrina a morte da individualidade e, por conseguinte, a crise da sociabilidade. A educação deveria cada vez mais ser apontada como mecanismo de controle das populações, estratégia de inibição das leituras superficiais, dispositivo de regulação da vida na cidade, estrutura de previsão e produção de uma disciplina social bastante rígida. Desejava-se, por outro lado, impulsionar os portugueses à pesquisa, à investigação, à procura dos conhecimentos e das descobertas que o estudo bem dirigido poderia, com ousadia e tenacidade, permitir. Desejava-se, cada vez mais, concorrer com as demais nações européias em pé de igualdade. A Península Ibérica, que inventara com o 'novo mundo' a modernidade, ficara para trás por se haver atrasado no desenvolvimento técnico. Cabia resgatar essa perda para obter a chave da construção da sociedade do futuro. No decorrer de todo o período que estudamos, verifica-se que, com pouquíssimas e raras exceções, os intelectuais portugueses entendiam que tal empreendimento passava pelas fronteiras da escolarização universal e pelo desenvolvimento técnico e científico $^{491}$. O cultivo da inteligência traria por suposto a ponderação, o equilíbrio, a sensatez para a compreensão das dificuldades cotidianas. Acreditavam os partidários e 'amigos do estudo' que o conhecimento, além de capacitar para a destreza quanto ao enfrentamento de obstáculos do dia-a-dia, habilitaria o indivíduo para a felicidade familiar e para a virtude social. Por tal razão, o conhecimento é assinalado pela imprensa periódica corrente à época como uma obra civilizadora, necessária e preciosa para a desenvolução nacional. Os jornalistas, ao reconhecerem quase unanimemente a utilidade social do saber, aventuram-se a buscar as regras para o bom e eficaz aprendizado. Nessa medida, é comum encontrarmos, desde meados do século, reflexões intrigadas sobre problemas da didática, de como melhor ensinar, dos procedimentos necessários para a obtenção do êxito. Uma das dicas desde logo assinaladas era a urgente necessidade de implementação do ensino paralelo da leitura e da escrita. Acompanhando as polêmicas intelectuais que marcariam a época, o problema do método de fato passaria a ocupar a meditação dos contemporâneos de maneira bastante acentuada desde meados do século, chegando nos anos 70 a ser entendido como a chave de detecção da orientação pedagógica cientificamente refletida.

\footnotetext{
491 “O saber é somente prejudicial quando se lhe junta o orgulho. Que seja acompanhado da humildade e levará o espírito a amar mais profundamente a Deus, a amar mais profundamente o gênero humano. Tudo o que aprenderes, aplica-te a aprendê-lo com a maior profundeza que lhe for possível. Os estudos superficiais produzem mui frequentemente homens mediocres e presumidos, cônscios em secreto da sua inutilidade e por isso tanto mais desejosos de se coligarem com vis importunos, seus semelhantes, para proclamarem ao mundo que são grandes e que os verdadeiros grandes são pequenos. Daí as perpétuas guerras dos pedantes contra as altas inteligências e dos vãos declamadores contra os bons filósofos. Daí o erro em que muitas vezes caem as multidões de venerarem quem mais alto grita e menos sabe. Ao nosso século não faltam homens de egrégio saber, mas os superficiais predominam vergonhosamente." (O AMIGO do estudo: jornal bimensal, $\mathrm{n}^{\circ} 1,1867$, p. 78) Na sequência, o texto sugere ao leitor - contra as tentações da superficialidade, segundo ele, tão comum - a especialização do estudioso em uma área específica do saber, que poderia avançar nesse estudo mais meticuloso. Além da necessária cultura geral, o conhecimento do homem de estudo deveria, pois, ser canalizado para uma área específica qualquer, já que estar em toda a parte - também no campo da ciência - equivaleria a não estar em parte alguma.
} 
Inúmeras experiências pedagógicas que pretendiam implementar novos modelos e referenciais para o ensino das primeiras letras eram postas a prova por educadores que nem sempre passariam para a história. No princípio dos anos $50 \mathrm{~A}$. Forjaz aplicara seu método ao Asilo da Infância de Coimbra, método feito, em parte, por uma nova ordenação do abecedário, com tábuas de palavras e frases que pretendiam - nas palavras do autor - estar em harmonia com a orientação do método que havia sido ainda há pouco tempo desenvolvido por António Feliciano de Castilho. Dizia Forjaz na introdução de sua obra $\mathbf{O}$ amigo dos meninos que, pelas manhãs, o Asilo seguia à risca todos os preceitos do Método Português; à tarde, porém, como parecesse indispensável cuidar das classes mais adiantadas, trazendo-lhes elementos mais aprofundados de escrita, numeração, gramática, etc., os alunos menores ficariam sob o encargo de educadoras de infância que teriam por função recordar-lhes o que deviam ter aprendido pelo curso da manhã. $O$ abecedário escrito por Forjaz viria nessa direção, com o objetivo de tornar-se um roteiro alternativo, mais apropriado do que os tradicionais compêndios, que estariam todos eles atrasados em relação aos procedimentos norteadores da leitura. Resenha crítica, assinada por J. C. Harcourt - no periódico A instrução e o povo - saudaria a publicação da obra de Forjaz, destacando a necessidade de publicações pedagógicas que efetivamente viessem imbuídas por conhecimentos didáticos e metodológicos mais adiantados, em consonância com o próprio avanço da civilização, que, no caso português, se verificava ainda profundamente acanhado.

\footnotetext{
"Mas deste abandono nascia igualmente a falta de homens que dedicassem a sua inteligência à confecção de livros próprios ao ensino. Entendia-se que escrever para crianças era uma missão pouco gloriosa e pouco digna de uma grande inteligência. Erro fatal, que condenava a instrução a nutrir-se de escritores raquíticos, magros de idéias, péssimos de forma, que, em vez de educar, carregavam a inteligência nada virgem de matérias áridas e pouco interessantes. A não ser o Manual Enciclopédico, livro grande em volume, mas, para nós, incompleto e impróprio para escolas primárias, e que só pode dever a sua reputação à falta de outro, nenhum livro tinha ainda aparecido que preenchesse essa lacuna que nos países civilizados havia chamado a atenção dos homens iminentes. Um livro pueril e singelo julgava-se uma puerilidade e a instrução definhava-se lentamente pela influência destas e outras muitas causas, que a índole deste jornal nos obriga a calar. Felizmente, nestes últimos tempos tem-se cuidado deste ponto, o mais capital hoje para este país, e homens superiores se têm entregado a este tarefa verdadeiramente civilizadora. Entre esses homens que a história contemporânea deve apontar com cuidado, figura eminentemente o Sr. Dr. Adrião Forjaz. Professor distinto, ilustração conhecida na ciência econômica, espírito altamente pensador, e conhecendo as necessidades de sua época, não se esquivou a esta nobre missão de ilustrar o povo; o seu espírito, acostumado às meditações profundas da ciência, não recuou perante os prejuízos, sacrificando a sua inteligência eminente às puerilidades de um livro de crianças. Além de muitas obras deste gênero, já conhecidas neste país, acaba de dotar a instrução primária com uma obra preciosa a todos os respeitos e digna de merecer uma séria atenção. É $\mathbf{O}$ amigo dos meninos." 492
}

Em quê Forjaz pretendia inovar? Quais eram substantivamente os pontos que singularizavam sua obra? A introdução dirigida ao leitor já ensaiava tal explicação. O autor dizia pretender na verdade o ensino paralelo das diferentes grafias das letras; ou seja, sugeria que o reconhecimento do texto impresso devesse ser concomitante ao reconhecimento da letra manuscrita, cujo aprendizado na grande maioria das escolas à época ainda antecedia o da letra

492 J. C. HARCOURT, O amigo dos meninos, In: A instrução e o povo; jornal científico e literario da sociedade civilizadora, primeiro ano, 1855 , p. 48. Como poderemos observar nos capítulos posteriores, a referência ao Manual Enciclopédico de Monteverde denotava a intensa utilização desse compêndio pelas escolas à época. 
de imprensa. Supunha-se que a criança teria já à partida a capacidade para decifrar os diversos sinais tipográficos codificados para cada um dos símbolos gráficos. Por outro lado, acreditava-se que se deveria proceder também ao ensino concomitante da leitura e da escrita, posto que ambas as habilidades se entrelaçam em uma única função. Desejava-se com isso aumentar a eficiência e a agilidade do aprendizado das primeiras letras, a partir de novas orientações para a questão do método de ensino. Como assinalava o próprio Forjaz, no relato que propicia aos leitores sobre a experiência já efetuada com as crianças do asilo de Coimbra:

\begin{abstract}
"No mesmo asilo, o ensino da leitura nos dois caracteres, redondo e manuscrito (ou letra inglesa), e igualmente o da escrita e da numeração, principiam a um tempo; com o que ganhamos em adiantamento e maior variedade de exercícios. Conhecidas as vogais nos caracteres redondos, por que não se passar logo aos ingleses, ou vendo-os no livro, ou traçados na tábua do professor? Por que não, por exemplo, lendo os alunos a palavra - a-i-a - nos primeiros, não hão de fazê-lo igualmente nos segundos ? Por que não se há de ir desde logo tentando a escrita dos mesmos caracteres na tábua preta, sem contudo retardar a leitura à espera do aperfeiçoamento que virá para o diante ? (...) Satisfazendo ao desejo que nos tem sido comunicado algumas vezes, damos finalmente um breve diretório da escola deste estabelecimento; no qual os professores encontrarão informações mais importantes acerca do plano total de suas lições" ${ }^{493}$
\end{abstract}

Em relato que, no ano de 1855 fazia a O Instituto o mesmo educador chegaria a descrever a prática de ensino aos meninos do Asilo da Infância de Coimbra que teria dado origem àquele compêndio partidário de se ensinar paralelamente a ler e a escrever. Forjaz pretendia ser um colaborador de Castilho, declarando-se defensor de uma jornada de ensino da leitura capaz de produzir grandes e significativos resultados. Para isso, entretanto, havia que se estruturar o método, organizado e pensado a partir da experiência bem-sucedida do ensino, perante o pioneirismo que, sobretudo, Castilho teria trazido. Sobre os resultados da aplicação daquele modelo de ensino anteriormente descrito para o Asilo da Infância de Coimbra, Forjaz não tem qualquer dúvida no relato. Era uma cruzada que deu certo e que poderia servir de exemplo para um novo modo de se proceder a prática do magistério:

\begin{abstract}
"Meninos que não haviam passado das primeiras tabelas durante meses e talvez anos lêem na escola do asilo, sem grande dificuldade, palavras que se lhes escrevem ou apontam nos livros; e isto em mui poucas lições. Quase todos conhecem o abecedário com os sons racionais e variados de cada vogal e consoantes. E o que não é menos, concorrem com tal prazer que nunca o asilo de infância teve menos faltas de frequência. Cativa-os um contínuo movimento de historietas agradáveis sobre figuras curiosas; de decomposição de palavras a compasso; de canto das regras de leitura (...); de marchas nestes mesmos exercícios; e, fechando tudo com o belíssimo hino ao trabalho do Sr. Castilho, em grande coro de 60 a 70 vozes, infantis sim, mas animadas e harmoniosas." 494
\end{abstract}

\footnotetext{
${ }^{493}$ A apresentação ao leitor continua, com as seguintes palavras: "Os primeiros exercícios de leitura dizem de si. São fórmulas doutrinais, contendo a santa e pura moral do Evangelho; pequenas e delicadas historietas, extraídas de alguns ótimos escritores estrangeiros; e o excelente pequeno catecismo desta Diocese, adotado igualmente nas de Viseu, Lamego, Bragança, e outras; estudo em variados caracteres. O abecedário da numeração, no qual também se contém as primeiras noções do sistema métrico das novas medidas, compreende igualmente o resumo das lições, que desde muito tempo se dão no asilo com bom resultado." (A. FORJAZ, O amigo dos meninos; introdução compreendendo um abecdário de leitura e numeração e uns primeiros exercícios de leitura e nestes o pequeno catecismo de doutrina cristã da diocese de Coimbra em caracteres variados para uso especialmente do Asilo da Infância de Coimbra, p. 4-6 )

${ }^{494}$ A. FORJAZ, Leitura repentina, In: O Instituto; jornal scientifico e literario, volume I, no ${ }^{\circ} 14,1852$, p. 174. Sobre os bons resultados do método português quando aplicado à referida instituição de caridade, artigo anterior do mesmo A. Forjaz já apresentava e anunciava resultados que o teriam impressionado favoravelmente. À página 164 do periódico naquele mesmo ano, lê-se o seguinte: "Quando o público lia aqueles nossos sinceros, mas
} 
Tencionava-se, por assim dizer, que a escola fosse efetivamente desejada pela população. Sabia-se, no entanto, que isso só viria a ocorrer no momento em que os pais julgassem que a frequência à escola era realmente importante para a formação humana, coisa que ainda não acontecia em proporções significativas. A escola desejada é aquela que demonstra rápidos resultados; é aquela que mostra a que veio, transformando pelo conteúdo de seus saberes a alma e o potencial infantil. A escola desejada é aquela que realmente faz o que a família reconhece não saber fazer. A escola socialmente desejada é, finalmente, aquela que aparentemente, pelo trabalho que desempenha, capacita o ser humano para o dia de amanhã. Existiria essa escola em Portugal? Havia n'O Instituto outros artigos que discorriam sobre o ensino paralelo da leitura e da escrita. Entrava na moda a dissertação sobre questões metodológicas. No plano da educação, passava-se a filosofar menos para propor com maior intensidade técnicas e recursos cuja aplicação traria a eficácia almejada. A partir dos anos 50, uma orientação de cunho didático - como já pudemos observar nos capítulos antecedentes passaria a tomar conta dos debates educativos das revistas e jornais especializados. Era como se no método estivesse contido todo o segredo e a alquimia da matéria educativa. Só quando se aperfeiçoasse o método, a importância da escola viria a se fazer sentir. Caminhava-se, neste tempo de transição, para a compreensão da matéria educativa em sua perspectiva eminentemente racional, programada e regrada; enfim, para a acepção científica do problema. A idéia do ensino começava a ser percebida, ainda que preliminarmente, como se de ciência se tratasse...

\footnotetext{
"Visto que o desenvolvimento intelectual de uma criança ainda não lhe permite compreender o alfabeto, nem fazer as abstrações que a soletração pressupõe, quando ela é já capaz de, escrevendo, imitar as figuras que se lhe apresentam aos olhos; ponto essencial para iniciá-la no conhecimento da leitura e da escrita é ensinar-lhe a escrever e ler sílabas antes de lhe ensinar a ler letras. Em obediência a este princípio, a primeira coisa que tem de fazer o aluno, apenas possa pegar numa pena ou lápis de pedra, é aprender a traçar hastes maiúsculas e minúsculas, curvas, ligações singelas e dobradas, círculos elipses e numa palavra quaisquer figuras que mais se assemelhem aos caracteres de letra de mão, única espécie de letra - torno a dizer - de que deverá servir-se enquanto não souber escrever e ler correntemente. Versado que esteja o aluno nestes exercícios, durante os quais se lhe ensinará a assentar bem a mão, pegar na pena e mover os dedos convenientemente, sua principal tarefa deve ser decompor palavras oralmente e reduzi-las aos sons elementares que as formem (...) Logo que o aluno souber decompor e reduzir aos respectivos sons elementares cada um desses vocábulos, ensinar-lhe-á o professor a traduzir aqueles sons nas sílabas naturais que os simbolizem." 495
}

desanimados pensamentos, já alguns discípulos do Sr. Castilho, possuídos de seu espírito, haviam dado princípio, primeiramente na associação dos artistas, e logo depois no asilo da infância, ao ensino da leitura repentina; e um considerável número de pessoas tinha visto, com admiração e louvor, o exercício deste admirável invento. A decomposição das palavras em sílabas, e destas em elementos, em coro e a compasso; a explicação dos diversos sons das letras do alfabeto pelas figuras e contos engraçados que a acompanham; e o canto das regras em verso, que se lêem no livro do Sr. Castilho e nos novos abecedários são executados com entusiasmo. No Asilo da Infância, começa a reabilitar-se o crédito de alguns alunos, reputados por menos suscetiveis de aprenderem até hoje pelos métodos ordinários; e que nos exercícios da leitura repentina avançam na primeira fileira. Observaremos cuidadosamente; e visto que se trata de uma máximo interesse literário, não nos descuidaremos de consignar neste jornal o resultado de nossas observações." (A. FORJAZ, Leitura repentina, In: O Instituto, volume I, $\mathrm{n}^{\circ} 14,1852$, p. 164)

${ }^{495}$ M. R. De MENDONÇA, Methodo do ensino paralello da escripta e leitura - secção III, In: O Instituto; jornal scientifico e litterario, volume IV, $\mathrm{n}^{\circ} 22,1856$. 
Aqui já se esboçava uma preocupação para com a direção analítica do ensino da leitura, posto que, cada vez mais, o desdobramento da palavra parecia a receita mais eficaz para o pleno e ágil aprendizado; até porque é a palavra e não a sílaba, quem representa verdadeiramente a unidade de sentido. No entanto ao contrário do que preconizaria posteriormente João de Deus, para esses pedagogistas, que seguiam as trilhas de Castilho, não se toma a palavra como ponto de partida; há apenas o desdobramento e o reconhecimento dos sons das partes de uma palavra que o alfabetizando não é ainda capaz de ler, dado que a leitura costumeiramente deveria vir por partes...

Procuram-se resultados práticos e isso requeria a explicitação da fórmula adequada para fazer florescer o método projetado. Nenhum passo poderia ser deixado de fora dessas prescrições metodológicas, sob o risco de comprometer todo o projeto de traçar a verdadeira ciência da alfabetização. $O$ conhecimento deveria vir de maneira fácil, quase trivial, amena, sutil, garantindo ao máximo a aplicação das faculdades de observação e as idéias concretas do aluno. Para tanto, porém, a lição deveria vir acompanhada do exercício. $\mathrm{O}$ professor deveria escrever no quadro negro toda a palavra que o aluno já houvesse anteriormente decomposto e reduzido aos respectivos sons elementares. Assim o professor chamaria a atenção de toda a classe para a correspondência entre aquele sinal gráfico e os sons naturais que simbolizavam cada um de seus elementos fônicos. Depois, o mestre escreveria embaixo da palavra a primeira sílaba que a formava, solicitando que os alunos o imitassem com suas respectivas lousinhas.

Depois de copiada pelo aluno cada uma das sílabas deveria ser falada pela classe, que então teriam sua primeira oportunidade de leitura ${ }^{496}$. O professor faria então perguntas aos discípulos que deveriam repetir cada uma das sílabas separadamente, para depois reencontrar o valor de todas elas unidas. Enfatizar-se-ia em todo o processo a voz e a articulação das palavras e das sílabas, posto que elas garantissem o reconhecimento da leitura e o ato da linguagem e da comunicação escrita. Na verdade, buscava-se a construção de um modelo novo de escola, que seria estruturado por meio de uma lógica de sinais e de rituais. A escola como instituição social teria seu êxito assegurado quanto melhor firmados os alicerces dos ritos organizadores do cotidiano institucional. Não havia dúvida, aos olhos da época. Acima de tudo, o bom aprendizado exigia a concentração de esforços em um percurso que tomasse significado aos olhos do estudante; e isso só poderia ocorrer se o aprendizado da escrita viesse concomitante ao da leitura. Conduzir o aprendiz a imitar os sinais gráficos era maximizar os esforços de concentração e de atenção despendidos durante a aula. Começar-seia pelo recurso à imitação, tido por fundamental para esse primeiro aprendizado, para os passos iniciais da leitura. Supunha-se que o ensino paralelo possibilitaria uma maior fixação do aluno na atividade do ler, dado que o exercício da escrita fixaria seu interesse, concentraria

\footnotetext{
496 "Em o discípulo sabendo escrever e ler palavras compostas de sílabas naturais, apresentar-lhe-á o professor uma tábua de todas as sílabas naturais, confeccionada com colunas transversais e verticais por maneira tal, que nestas as vogais sejam as mesmas e variem as consoantes; naquelas, ao contrário, sejam as mesmas as consoantes e variem as vogais. Eis aqui como deverá usar-se desta tábua. Lê o professor a primeira sílaba da primeira coluna transversal; e depois de a ter escrito na tábua, manda ao discípulo que também a leia e copie na lousa. Escrita a primeira, continua o professor a escrever e ler as outras sílabas, e o discípulo a copiá-las e a repetir incessantemente o valor fônico de cada uma. Logo que o discípulo tiver escrito e lido todas as sílabas da primeira linha, far-lhe á notar o professor como naqueles sinais, de par com alguma coisa semelhante, há também uma outra coisa diferente. O primeiro caráter de cada sílaba é o mesmo; o segundo é que difere de uma para outra. Notado issto, escreve o professor a primeira sílaba da segunda linha;e mostra ao discípulo como esta nova sílaba é em parte semelhante e em parte diferente da primeira da linha superior. Assim, em sabendo ele imitar o sinal em que diferem estas duas sílabas, saberá escrever todas as outras da mesma linha; porque, para isso, basta substituir o primeiro sinal da segunda ao primeiro da primeira. E assim a respeito de todas as linhas transversais. Logo que o discípulo tiver lido e trasladado deste modo todas as sílabas da tábua, se entreterá a fazer exercícios para fixar bem na memória a figura e valor fônico de cada uma.” (M. R. de MENDONÇA, Methodo do ensino paralelo da escripta e leitura, In: O Instituto; jornal scientifico e litterario, volume IV, nº22, 1856, p. 269)
} 
sua atenção e consequentemente, permitiria um aprendizado mais eficaz. Mendonça (1856), nas orientações que dava n'O Instituto sobre o ensino paralelo da escrita e da leitura apresentava como requisitos para o ensino bem sucedido o seguinte:

1) Principiar o processo pela letra de mão, até que houvesse leitura corrente; 2) Começar pela decomposição das sílabas naturais; 3) Só depois do reconhecimento de todas as sílabas naturais e artificiais é que o aluno deveria tomar conhecimento do alfabeto manuscrito; 4) Quando enfim soubesse escrever bem o que lhe fosse ditado, lendo com desembaraço tudo o que em letra de mão lhe fosse apresentado, o educando deveria estudar o abecedário da letra impressa, confrontando o valor dos caracteres com aqueles que já conhecia; 5) "Uma vez familiarizado com o abecedário da letra redonda, meta-se-lhe então na mão o primeiro livro impresso, e por ele se exercite na leitura, já lendo, já copiando da letra redonda para a manuscrita, já imitando a letra redonda. Só deste ponto em diante é que devem separar-se, e ser para ele como distintas, individualidades à parte, as disciplinas de ler e escrever."497

O século XIX português seria marcado pela procura do método pelos pedagogos e curiosamente pela ausência de ressonância de tal debate nas práticas rotineiras de sala de aula. Em que medida os professores balizavam sua prática pela interlocução com o discurso pedagógico que então se fazia em Portugal? Em que medida este seria alheio a discussão teórica? Pelo estudo que pudemos efetuar, 'nem tanto ao mar, nem tanto à terra'. Havia, sim, um diálogo entre as inquietações dos políticos, intelectuais e estudiosos de Pedagogia e os mestres de ofício que lidavam com a confecção da escola todos os dias. A correspondência, entretanto, não é certamente aquela que esperavam os arautos da Pedagogia das revistas e dos jornais. Seja como for, do meio para o fim do século - como, aliás, já pudemos observar pela constelação de intelectuais que pretendemos dar a ver nos capítulos anteriores - multiplicamse as orientações de cunho técnico-pedagógico, que passariam, cada vez mais, a tomar o lugar do debate sobre a extensão ou não da escolarização pública. Desejava-se a escola para todos; mas reivindicava-se a possibilidade de indagar e de arbitrar sobre os conteúdos e sobre os métodos dessa escola; sobre o que ela dizia e sobre o que ensinava: acerca do homem; a propósito do mundo; sobre as medidas decimais e sobre o sistema político... Desejava-se criar, cada vez mais ardorosamente, uma nova cosmovisão, capaz de engendrar o homem de amanhã. Este, por sua vez - ao contrário do que um dia propagandearam os revolucionários em França - deveria ser o digno representante dos valores de um Portugal do passado; de uma grandeza perdida na conquista, que não regressara pela colonização e que se esperava ver de volta pelo trabalho pedagógico. Assim julgavam os que acreditavam nos caminhos da instituição escolar; instituição do Estado e para o Estado, mas que deveria estar a todo o instante em estreitas relações com o ambiente doméstico e comunitário de quem dependia e a quem, em última instância, iria servir.

De todo o modo, passava-se a entender o problema da escolarização, cada vez mais, perante uma chave valorativa da leitura. O final do século presencia, como vimos, a intensificação do debate sobre o tema da metodologia prescrita e recomendada para o processo de ensino-aprendizado da leitura e da escrita. Passa-se a compreender que a questão da leitura conformava antes uma habilidade proveniente do desejo do que uma árida atividade cognitiva. A leitura mais fácil é a da fruição; portanto, ensinar pelo e para o prazer poderia significar a recorrência a um novo modelo metodológico e didático, mais preciso, mais ágil, mais eficaz. $\mathrm{O}$ aprendizado também - supunha-se - fruiria com maior espontaneidade. Não era sem algum grau de inquietação que os contemporâneos avaliavam esse problema técnico e ideológico da leitura. Um problema que se confrontava com as orientações da moral vigente: de uma sociedade estamental, pautada pela correspondência entre as desigualdades de fortunas e as distinções de sangue; uma sociedade patriarcal, onde a religião e a família eram autoridades constritivas e inibidoras do novo. Uma sociedade que não parecia, por fim, ter

\footnotetext{
${ }^{497}$ M. R. de MENDONÇA, Methodo do ensino paralelo da escripta e da leitura, In: O Instituto, vol.IV, n²2, p.270.
} 
grandes arroubos para transformar-se, que não parecia sequer ter propensões para a mudança. Mesmo assim, visualiza-se, a conviver com o modelo antigo e arcaico, um inaudito retrato sobre o aprendizado da leitura, pontuado fundamentalmente por aquilo que aquele final de século traria como elemento renovador: o lúdico, a distração, como objetivos que ao educador caberia perseguir. Aprender a ler era, acima de tudo, desejar decifrar a imagem da palavra; decifrar a história, decifrar o mundo da cultura...

“- Eu já sei ler, minha mãe! - gritava o Antonico, entrando aos saltos em casa, de volta da escola. -Já sabes ler ? - perguntou a Maria Rosária, uma honesta camponesa, muito trabalhadeira e que morria pelos filhos.

- É verdade que sim ! - afirmou o Antonico, todo ufano. - O senhor mestre passou-me hoje a ler por cima, e ficou muito contente com a minha lição. Quer ouvir?

- Logo, logo, meu querido filho, vai primeiro comer alguma coisinha, que deves vir com fome. E a desvelada mãe foi buscar à lareira o tachinho de sopas que guardara para o pequenito.

O Antonico comeu com apetite, repartindo com a sua irmãzinha Carlota, que fora para o pé dele. Apenas acabou de engolir o último bocado, disse à mãe:

- Quer ver agora se eu sei ler, minha mãe ?

-Então não vais brincar um bocadinho ?

- Não há melhor brincadeira do que ler uma história bonita. - respondeu o rapazinho.

- Pois sim; então lê alguma coisa da tua lição. - disse Rosária, toda babosa pelo filho.

-Isso é que não. Vossemecê não se lembra que o meu padrinho, o fidalgo, me deu um livro com estampas muito bonitas, dizendo que o guardasse para quando soubesse ler ? Pois olhe que a mim não me esquece. Eu via no livro aquelas figuras tão engraçadas, e ficava muito triste por não saber a história delas. Tomara já saber ler, dizia eu comigo. E foi talvez por isso que aprendi muito depressa. Vamos, minha mãe, dá-me o livro de figuras, que está na sua gaveta.

A mãe satisfez alegremente o justo desejo do filho.

-Queres ouvir uma história, Carlota? - perguntou à irmã o Antonico.

- Queú - respondeu a pequenita, que mal sabia falar.

-Então hás de estar muito quietinha e calada.

- A menina é benita.

E a pequenita Carlota pos-se muito séria e atenta ao lado da mãe, à espera da história. O Antonico abriu o livro em cima dos joelhos da mãe, e começou a leitura, parecendo querer devorar as letras com os olhos.

Que formoso grupo!"498

Da historieta que nos permitimos aqui transcrever, inúmeros são os elementos que mereceriam comentários. Na verdade, tratava-se fundamentalmente de um chamado ao gosto e ao prazer da leitura enquanto atividade espontânea. O Jornal da infância nos anos 80 recordava os leitores da emoção sentida por todos, quando pela primeira vez somos capazes de decifrar o mundo por escrito... Conclamava-se, nessa direção, pais e mães a incentivarem o gosto e a propensão da infância para a leitura como uma distração instrutiva. $\mathrm{O}$ atrativo do livro oferecido pelo padrinho fidalgo remete o menino à vontade de decodificar o texto, até

\footnotetext{
${ }^{498}$ EU JÁ SEI LER!, In: Jornal da Infância, primeiro ano, $\mathrm{n}^{\circ}$ 1, 4-1-1883, p. 81-2. No final da história, o menino, vitorioso de sua nova habilidade, recorre à sua mãe, pedindo aprovação de orgulho: “- Então, minha mãe, sei ou não sei ler? - exclamou o Antonico , terminando a leitura. - Sabes, sim, meu filho! - respondeu a mãe, beijando-o. -E como é bonita esta história ! - acudiu o pequeno, entusiasmado. - Se eu não soubesse ler, não tínhamos passado tão entretidos este bocadinho. -Eu quéu outa história, mano. - disse a pequenita Carlota, que estivera sempre muito atenta e quieta a ouvir o irmão. - Até a Carlota gostou! - exclamou o Antonico. Bendita seja a leitura, e também vossemecê, minha mãe, que me mandou para a escola" (Id. Ibid., p. 83). Percebe-se na verdade o desejo aqui expresso de as famílias também passarem a valorizar o ato da leitura, como uma atividade que se requer para o contato com o mundo da cultura, mas também pelo prazer que se extrai do ato de ler. De algum modo, a pequenina irmã estaria sendo precocemente estimulada ao desejo da leitura, o que eventualmente a ajudaria quando a seu tempo ela também viesse a aprender a ler.
} 
para compreender o significado das estampas, tão bonitas... Na verdade, o menino deseja ler o mundo; o livro de escola seria o instrumento, mas a leitura verdadeira era - sabia-se - a que aproxima da vida cotidiana, ou aquela que mobiliza o aprendizado escolar para o equacionamento e a superação das dificuldades rotineiras. O livro - talvez, quem sabe aproximaria Antonico de seu padrinho fidalgo, trazendo-lhe novas experiências do mundo da cultura, experiências essas tão atraentes quanto as brincadeiras da infância; experiências entretanto que poderiam ser potencializadas para a entrada no universo adulto a partir de um nível mais elevado. A escola prestaria o serviço de facultar a compreensão de uma técnica; técnica que seria transposta imediatamente para a leitura do mundo. Nesse sentido, o papel regulador e orientador da família seria fundamental.

O século XIX, que terminava, percebera finalmente que a escolarização primária universal era uma necessidade, uma fatalidade da história. Portugal havia de seguir a orientação das nações tidas por mais desenvolvidas da Europa. Não se podia mais, definitivamente, lutar contra o espraiar "das luzes". Era necessário, porém, harmonizar esse universo, oferecendo à infância a leitura proveitosa, a mensagem moralizante. Para isso, surgiriam então os jornais e as revistas que se pretendiam destinados não a apenas aos educadores, mas às próprias crianças e jovens. Cabia a esses periódicos a função de pedagogos. No Jornal da infância alguns artigos dirigidos às crianças tinham por narradores supostos alunos de instrução primária. Procurava-se, através desse esforço aproximativo, apresentar o universo da leitura como um território a ser verdadeiramente ocupado pela infância portuguesa. ${ }^{499}$ Enfim, a leitura seria o grande papel da instrução primária e a escola seria o local por excelência do ensino da leitura. Abordar o tema da aquisição de habilidades do mundo escrito significava comentar a tarefa da escolarização. Esta, por sua vez, aproximando a criança dos códigos universalmente aceitos pelo "mundo civilizado", deveria fazer do estudo um substituto da rua. Ir à escola era sair da rua, afastar-se das más influências, precaver-se contra as tentações da marginalidade. Colocar as crianças na escola, na proporção do país, era também impedir os abusos do trabalho infantil; e, nem que fosse só por isso, a escola passa a ser apontada como o salutar contraponto dos abusos da vida produtiva e da vida familiar.

Artigo de Carlos Affonso para o periódico A instrucção portugueza de 6-2-1886, intitulado "O trabalho das creanças na indústria", alerta para os inconvenientes do ingresso prematuro das crianças no mundo do trabalho, fundamentalmente do trabalho industrial. Seria necessário, mediante o cumprimento efetivo da prescrição legal de instrução obrigatória, preservar as crianças do contato precoce com um ambiente operário bastante bruto, no qual ela seria desvirtuada pelas mãos de trabalhadores adultos que exerceriam práticas contrárias a quaisquer princípios de civilidade, atuando por atos de violência física e verbal sobre a criança para proceder ao cumprimento das ordens do patrão. A isso se acrescia a violência que contra a criança era implementada por algumas famílias, tema este sobre o qual pouco se dizia, nada se comentava...

\footnotetext{
"Os perigos a que uma criança se sujeita com a sua entrada nas fábricas podem ser considerados sob o tríplice ponto de vista moral, intelectual e sanitário ou higiênico (...) Todos reconhecem, à exceção dos exploradores da infância, que o trabalho prematuro das crianças não aproveita
}

\footnotetext{
${ }^{499}$ Artigo assinado por alguém que se intitula O pequeno Antoninho, tendo por título As cavalhadas em Vizeu no Jornal da infância publicado em Vizeu, no mês de junho de 1883, traz uma perspectiva elucidativa do que vínhamos dizendo, na medida em que aponta um autor, travestido de personagem, que 'fala' sobre a as leituras das crianças pretensamente do ponto de vista da própria criança: “É pena que eu, um pequeno aluno de instrução primária, não tenha a inteligência precisa para descrever minuciosamente tão curiosas cenas, dando-lhe ao mesmo tempo um certo brilho literário. Mas, como o Jornal da infância é puramente dedicado às crianças, farei por ir exercendo as minhas faculdades intelectuais em trabalhos de pequena monta, certo de que os amáveis leitorzinhos deste semanário me desculparão o atrevimento.” (op. cit., p. 23)
} 
realmente a ninguém, antes produz o vício, a ignorância e a decrepitude, numa palavra, abortos incapazes de trilhar até ao fim o caminho do trabalho, vindo cair fatalmente, ainda na idade em que deveriam trabalhar com mais vigor, nos braços da família ou da sociedade que, nestes casos, como sempre, paga os erros desses e o egoísmo e a avidez d'outros. Sem pretensões a indicar o caminho a seguir para libertar as crianças das mãos de parentes pobres ou ávidos, ou de patrões bárbaros e egoístas, desejamos contudo que se ponha uma barreira aos abusos contra as crianças por parte de patrões e pais. Exista ou não já uma lei sobre o assunto, o certo é que ela carece de ser cumprida. (...) A população das nossas fábricas, especialmente de tabaco e fiação, é, na sua maioria, constituída por crianças dos dois sexos, ordinariamente entregues à direção imediata de operários ou operárias bárbaros e déspotas por índole, ou para comprazer e agradar aos patrões, que desejam ver nos seus estabelecimentos e domínios, continuada a tradição do pontapé e do sopapo, por estarem convencidos de que eles concorrem poderosamente para o ensino e desenvolvimento intelectual, ou pelo menos manual dos seus petits sujets. Haverá exceções do que deixamos dito, mas são tão raras que, esquecendo-as, não cometeríamos graves faltas." "500

Assim a escolarização era, sobretudo, tida por processo e percurso corretor de desvios de outras instâncias corroídas do tecido social. A institucionalização da educação escolar deveria, sob tal perspectiva, compreender a adoção de mecanismos de controle do uso que as famílias faziam de seus filhos, particularmente para abusar do trabalho das crianças. $\mathrm{Na}$ verdade, talvez subrepticiamente, insinuava-se acreditar que a atividade escolar poderia concorrer e assim relativizar no contexto da sociedade o próprio poder da agremiação familiar. Acontece que a criança idealizada pelo universo das revistas não era propriamente a criança real; e, sobretudo, faltava ao professor, mesmo àquele que houvesse se recém-formado em Escola Normal, os métodos, as técnicas, os instrumentos necessários para possibilitar o enfrentamento de uma realidade de analfabetismo e de descaso familiar pela escola, muito mais acentuada do que à época assinalavam os poucos e precários manuais de Pedagogia. Quando o então recém-formado mestre se via em meio a uma turma de rapazes analfabetos de uma escola rural, munido que estaria apenas pelos parcos conhecimentos e pelo rol de definições que sua instrução lhe haveria legado, o que fazia esse jovem docente? Em que medida sua formação lhe seria útil? Como ele equacionaria o contingente enorme de carência das crianças que lhe eram confiadas?

\begin{abstract}
"Esse aluno, esse mestre noviço, toma alegremente posse do cargo e apresenta-se, ainda, cheio de ilusões aos alunos, aos quais faz um discurso cheio de citações, tiradas das notas dos compêndios por onde estudou, e tão cheio de calor e entusiasmo que o faz supor no meio dos seus condiscípulos e mestres na ocasião em que deu a sua última prova, aquela que, porventura, lhe mereceu o louvor que engrinalda o seu diploma e o aponta para auxiliar daqueles de quem bebeu a instrução de que se acha pejada. Mas vendo que o auditório, incluindo também as autoridades da terra, que há de ser o de todos os dias, não manifesta o seu agrado, nem tem uma nota que faça traduzir o seu espanto, mas permanece mudo, cai na realidade, desanima e chega até a esquecer o que lhe havia feito ganhar as esporas de cavaleiro nas lides escolares. Não obstante, começa os seus trabalhos escolares diários, encara os alunos a sangue frio, olha para as paredes da aula, que supõe ser antes um antro do que uma escola, visa os utensílios e fica desapontado. Ainda assim cria forças e ânimo, resigna-se e começa a ensinar as letras a um depois a outro, e assim vai até aqueles que supõe nos casos já de o poderem ouvir e entender. Cria alma nova e então vale-se dos seus recursos e começa a explicar-lhes uma lição ou, se a ocasião se presta, a dar-lhes ou fazer-lhes uma lição de coisas. Os alunos, porque estão familiarizados já com o seu professor, olham para ele atentos, mas com cara de quem não compreende nada; e, se o mestre continua, riem-se com um riso inocente e incrédulo, e da lição nada fica ou ficará. E por quê ? Porque o professor empregou termos e linguagem nunca ouvida, ou lhes falou em objetos e coisas desconhecidos, mas que ainda
\end{abstract}

${ }^{500}$ Carlos AFFONSO, O trabalho das creanças da indústria, In: A instrucção portuguesa, $1^{\circ}$ anno, $\mathrm{n}^{\circ} 6,6-2-$ 1886, p. 68-9. Na verdade o referido artigo estava inserido em uma seção do periódico intitulada "seção industrial”. 
assim admiraram, porque o pai também os admirara já, quando era rapaz. Dumas coisas passa às outras e o professor em cena vê naufragar todas as teorias que constituem seu carregamento mais valioso e prestimoso."501

Havia que se adequar a transmissão dos conhecimentos pedagógicos nas escolas de formação do magistério e a própria orientação mediante a qual eram preparados os professores, tendo em vista a situação acima descrita. A crítica incide sobre a teorização árida acerca da questão do ensino, teorização muitas vezes emprestada de países alheios e que não condizia em hipótese alguma com a realidade portuguesa. A escola assim deixava de cumprir sua tarefa instrumental, a de ser eficaz na transmissão de conteúdos elementares que pudessem, ao ser universalizados para o conjunto das crianças portuguesas, tornar-se úteis para a preparação desses jovens indivíduos para o mundo do trabalho e da vida em sociedade.

\section{LUGAR, FORMAÇÃo E PROFISSÃO DE PROFESSOR: TEMPO DE ESCOLA, ESPAÇO DE CRIANÇAS...}

Havia nas últimas décadas do século XIX português - segundo dados levantados por António Nóvoa - as Escolas de Habilitação para o Magistério Primário que, no ano letivo de 1896-7 eram 45 e em 1899-1900 seriam já 191. No ano seguinte (1900-1), elas passariam a ser 240 e em 1902-3 havia 343 escolas que preparavam o que deveria ser o conjunto do professorado primário em Portugal. ${ }^{502}$ No parecer de Nóvoa, a segunda metade do século XIX seria efetivamente o período 'charneira' no que concerne ao processo de construção de uma profissionalização do corpo de professores. As representações simbólicas sobre o mestreescola do Antigo Regime e que, de alguma forma, persistiam ainda, concorreriam cada vez mais com o novo perfil a ser assumido pelos profissionais da educação, que, a partir de então, seriam dotados de uma nova consciência e de um repertório propriamente profissional cada vez mais tributário de sua formação específica, além de um reconhecimento que vinha se intensificando acerca da identidade própria do magistério enquanto categoria de trabalho. Conforme registra António Nóvoa, tudo isso tornaria mais próximo do modelo científico o professor do novo tempo que vinha se afigurando: "o professor de instrução primária da era científica tomaria definitivamente o lugar do antigo mestre-escola. Essa evolução é fruto de uma ideologia do progresso e de uma fé nas potencialidades da escola, da qual as significações socio-políticas serão doravante claramente depreendidas."503

\footnotetext{
${ }^{501}$ Carlos AFFONSO, Instrucção e trabalho, In: A instrucção portuguesa, $1^{\circ}$ anno, $\mathrm{n}^{\circ}$ 12, 20-3-1886, p. $140-1$.

502 "As Escolas de Habilitação para o Magistério Primário formam em um período muito curto 1160 professores de instrução primária, praticamente $2 / 3$ do número de indivíduos diplomados em relação ao curso elementar nas diferentes escolas normais. É verdade que a qualidade do ensino dispensado nessas escolas deixa muito a desejar, como a imprensa pedagógica lembrava incessantemente no decorrer do século XIX, mas não podemos nos esquecer o papel que elas teriam desempenhado no Boom do ensino normal ocorrido na mesma época. Como nós já sublinhamos, o motivo principal dessa mudança foi a reforma do exame de habilitação para o magistério primário: a partir de 1896 esse exame passava-se diante de um juri composto por professores das escolas normais ou das escolas de habilitação para o magistério primário e era idêntico para os alunos mestres e para os candidatos 'estrangeiros'(ou seja, aqueles que não estavam inscritos em nenhuma dessas escolas)." (António NÓVOA, Le temps des professeurs, volume 1, p. 471-2)

${ }^{503}$ Diz Nóvoa na sequência o seguinte: "O nascimento do professor de instrução primária se faz em interação com a organização e difusão da escola popular e com o desenvolvimento dos grandes sistemas educativos escolares, tal qual nós ainda em nossos dias os conhecemos. A gênese do sistema de ensino de Estado e da
} 
De certo modo, como atesta Nóvoa, o final do século XIX pode ser compreendido como o período de profissionalização do magistério, particularmente pela ação empreendida pela proliferação das Escolas de Habilitação do Magistério e pelas cinco Escolas Normais existentes em Portugal no mesmo período (Marvila, Angra, Calvário, Lisboa, Porto, Évora). A respeito da correlação entre a formação do professor e os saberes com que era estruturado o novo repertório da profissão, Nóvoa dirá o seguinte: "Durante o século XIX a formação dos professores repousa essencialmente, não sobre a aquisição de um corpo de saberes e de saberfazer, mas sobre a aprendizagem de um saber ensinar um certo número de conhecimentos adquiridos antes de entrar nas escolas normais. De acordo com os autores da época, é aí que reside a especificidade da ciência da educação e, portanto, da formação dos professores." ${ }^{\text {,504 }} \mathrm{E}$ fato que, desde o início do último quartel do século XIX, particularmente a partir dos anos 70, começa a haver uma preocupação bastante acentuada na literatura pedagógica produzida em Portugal no tocante ao tema do método de ensino. Supunha-se que o país não acompanhava as nações mais desenvolvidas em certa medida por não ter sido capaz de enfrentar os progressos tecnológicos constatados em outros países e que se faziam tributários do aperfeiçoamento técnico, científico e educacional. Dessa tríplice aliança resultaria o potencial industrial, viário (posto que a construção de ferrovias era, antes de tudo, percebida como sinal dos tempos), e mental. Portugal, por suposto, não acompanhara seu tempo e perdera o lugar de protagonista da História. Havia, como já pudemos comentar anteriormente, a pretensão de se realinhar Portugal à Europa e isso passava pela escola primária e pela erradicação do analfabetismo. Ocorre que, organizadas como estavam, as escolas primárias portuguesas não obtinham êxito no ensino que pretendiam efetuar. Mal estruturadas fisicamente, mal equipadas em termos de mobiliário e de equipamentos, as escolas eram casas frias e pouco atraentes, pela monotonia de seu ofício. Na maioria das vezes sem saber como agir, os professores guiavam-se pela prescrição dos compêndios que, por sua vez, eram também pouco apropriados. A base daquele ensino seria, pois, o medo e o recurso à memória. Não havia nada que estimulasse, portanto, pais e alunos à valorização desse modelo escolar.

Os últimos anos do século contariam com a publicação de inúmeras brochuras sobre o temário pedagógico. Era como se os teóricos e particularmente os editores desejassem socializar a ciência da educação, dirigindo-se, para tanto, aos pais, às famílias e, fundamentalmente, aos professores e técnicos do ensino primário. Apresentavam-se princípios, métodos, e técnicas de ensino intuitivo como prescrição que os novos tempos pareciam exigir. Recomendava-se que os educadores, de modo geral, adotassem, em sua lide cotidiana, aquilo que a investigação científica recomendava como infalível. Julgava-se que o ensino tal como existia era mesmo indefensável. Por isso era preciso modificá-lo, tendo em vista que a necessidade de instrução era já posta como indiscutível. Conviria trazer para Portugal o fruto de pesquisas e investigações científicas que em vários países mostravam que a Pedagogia se tornara já uma ciência regulatória dos métodos e das técnicas para a

profissão de professor remonta ao fim do século XVIII, mas é somente no final do século XIX que a escola e o professor de instrução primária adquirem as características que permanecem sendo as suas atualmente." (António NÓVOA, Le temps des professeurs, volume 1, p. 420).

${ }^{504}$ António NÓVOA, Le temps des professeurs, volume 1, p. 424-5. Sobre a formação do pessoal do magistério classificados pela categoria de gênero, indicamos os quadros às páginas 474 e 475 do mesmo trabalho de Nóvoa. Sobre o mesmo tópico, na conclusão, o mesmo autor destaca o seguinte: "No princípio do século XX, as escolas normais teriam conquistado um lugar sólido no seio do sistema de ensino do Estado. Em 1901, uma etapa decisiva do processo de profissionalização da atividade docente será transposta: daí por diante, ninguém mais poderia ser nomeado professor de instrução primária sem ter seguido uma formação profissional de uma duração mínima de dois anos, no seio de uma escola normal. A adoção desse princípio na Reforma de 1901 satisfaz o corpo docente primário porque essa era uma de suas mais importantes reivindicações, sobretudo na segunda metade do século XIX. Não é aliás por acaso o fato de essa reforma haver sido adotada na sequência de uma série de movimentos coletivos dos professores de instrução primária. Tais movimentos revelam a nascença de um espírito de corpo dos professores e a tomada de consciência de interesses do grupo profissional que eles representam." (António NÓVOA, Le temps des professeurs, volume 1, p. 475) 
viabilização da eficácia do processo da aprendizagem. Havia que dotar os educadores familiares e escolares de um conjunto articulado e classificado de orientações normativas para que a atividade docente pudesse ocorrer perante a aplicação cientificamente calculada de tais requisitos do que se supunha ser o ensino bem-sucedido. Os pedagogos pretendiam, ao apresentarem as bases de aquisição e transmissão no domínio do ensino intuitivo e das lições de coisas, preencher uma lacuna da formação e da prática do professorado português. Ocorre que, nesse caminho para uma perspectiva científica da questão educativa, algumas questões deveriam ser, à partida, equacionadas:

\begin{abstract}
"Na máxima parte das escolas da puerícia entram quotidianamente as criancinhas faltas do indispensável alimento, a ali se conservam largas horas em casas estreitas, sombrias e mal ventiladas, respirando ar infecto, impedidas de fazer os movimentos que a sua idade imperiosamente reclama, sem horizontes extensos e ridentes, que as alegrem, sem nada que as encante ou lhes deleite os sentidos. O mestre, senão carrancudo e severo, é quase sempre suficientemente sério e concentrado, para não lhes incutir a confiança e o amor, que são os mais suaves e ao mesmo tempo os mais fortes laços que prendem o discípulo ao preceptor. Começa a lição. Não há cânticos, nem músicas, nem exercícios ginásticos, nem historiazinhas que alegrem aqueles corações e instruam aquelas mentes nas coisas que com maior facilidade poderiam compreender. Para os mais pequeninos, para aqueles que mais se lembram ainda dos beijos maternais e das doçuras da casa paterna, o triste e monótono a,b,c, as áridas colunas do silabário e a empírica tabuada. Para os mais crescidinhos, a gramática, a história pátria, a corografia, a doutrina cristã. Que percebem os pobres infantes de tudo aquilo que involuntariamente decoram e maquinalmente repetem ? Nada, ou quase nada. Tomai dentre os alunos de uma escola o mais adiantado, o mais estudioso, o que mais talento revele, e interrogai-o. Ouvi-lo-eis repetir o compêndio, mau ou bom, com certa facilidade e elegância; mas se lhe perguntardes o sentido de uma palavra, a razão de um fato, ve-lo-eis corar e emudecer porque a ele, estudante exímio, deixaram sempre em pousio as mais nobres faculdades da alma, excitando-lhe apenas, e ainda assim por um processo defeituoso, a faculdade auxiliar, a memória. Olhar com seriedade para a educação e instrução da infância e reformá-la completamente, adequando-as às idades dos estudantezinhos, e tornando-lh'a facílima, deleitável, e todo o ponto útil, é não só necessidade urgente, senão dever impreterível."
\end{abstract}

De fato, o problema do método e das técnicas pedagógicas conquistava, naquele positivista final de século, seu espaço; e a partir daqui a Pedagogia portuguesa reivindicaria seu papel de ciência da educação. A Pedagogia cada vez mais ia, desse modo, se firmando como um conjunto sistemático de técnicas, métodos, saberes, conteúdos, valores e, sobretudo, linguagem, repertório. A educação passaria, cada vez com maior intensidade, a ser dita por uma língua muito particular, que seria, ao fim e ao cabo, só sua. O vocabulário da pedagogia bem como provavelmente o das outras disciplinas que nesse percurso do século XIX procurariam todas assumir a tonalidade da ciência - estruturar-se-ia pela distinção. Não era mais qualquer um que desde então estaria autorizado a falar o discurso da educação. Nessa perspectiva, do final do século em diante, passa a haver uma profusão prescritiva em termos de normas e regras para orientação do bom aprendizado. Entendia-se - como explicita António Nóvoa - que o firmamento de uma ciência da educação significava tomada de consciência perante valores, uma adesão a princípios, o conhecimento dos modos de ensinar e a identificação dos conteúdos daquilo que se ensinava. A pedagogia se constituía, então, como um corpo de saberes específico, que compreendia em si mesmo um saber-fazer e um referencial valorativo que lhe seria próprio. Ser bom professor teria por requisito conhecer a

\footnotetext{
${ }^{505}$ João José de Souza TELLES, Ensino intuitivo: livro destinado ás mães e paes de família e ás professoras e professores de instrucção primária, p. 23-5. No capítulo intitulado 'Traçado de escola em Portugal: cotidiano e memória' retomaremos esse autor e teremos oportunidade de discorrer sobre o significado dessa sua obra.
} 
didática e o conteúdo das disciplinas ensinadas. A mudança era, nessa dimensão teórica, anunciada. Ocorre que, nas atitudes e atividades rotineiras da sala de aula, lá onde ninguém entra, tudo parecia estar na mesma... A Revista das escolas (1895) anotaria a esse respeito o seguinte:

\begin{abstract}
“A escola primária tem lá a sua geringonça ou jargão, mas que todos entendem, porque todos mais ou menos passaram por ali. Assim, dar lição é um ato mais do discípulo do que do mestre, quando parecia mais lógico ser o mestre quem desse e o discípulo quem tomasse ou recebesse as lições. Pois não, senhor; apesar do velho aforismo: 'ninguém dá o que não tem', é o discípulo quem dá e o mestre quem toma. Sei que isto não é novidade; todavia já bem poucos se recordam dos tormentos a que foram submetidos por estes tristes processos maquinais em que o aluno, de braços cruzados e de pé, tinha de repetir, mastigar e palmear palavra por palavra (a questão era e é mais de palavras que de outra coisa) o texto do compêndio, que se lhe passara na véspera. Passar a lição é arbitrar um certo número de linhas ou de períodos que o desgraçadinho tem de decorar em casa ou ali mesmo na aula para repetir na ponta da língua. Em algumas escolas há mesmo tarifas ou tabelas quantitativas de prêmios, perdões, ou bons-pontos (...) para recompensar o trabalho do estudo (...); tudo regulado, ajustado e contratado entre a memória do discípulo e a pânria do professor, à sombra da mais absurda de todas as rotinas. Deste sistema de aprender a fingir que se ensina é que provém, creio, medir o povo o talento ou penetração dos filhos pela facilidade ou rebeldia da memória. Ter boa memória para o comum da gente compreende todo o encarecimento intelectual que a um estudante se possa fazer."
\end{abstract}

Ocorre que as leituras que já se faziam à época sobre as articulações entre o desenvolvimento intelectual e físico, não permitiam mais que a memória - e ela só continuasse a ser tida como a grande válvula da aprendizagem. Efetivamente, a entrada dos autores positivistas no cenário internacional, além da intensificação do intercâmbio de obras acadêmicas no interior da comunidade européia - e a Geração de 70 tivera nesse processo um papel primordial - fez com que outros teóricos da educação também fossem mais lidos. Passara-se a conviver com Herbart, com Pestalozzi, com Spencer; e os pedagogos do final do século teriam também em Portugal suas idéias irradiadas por veículos jornalísticos que, agora, eram dirigidos primordialmente para a figura do professor. Reconhecia-se no magistério a resistência à mudança. Desejava-se assim que as transformações se seguissem não apenas pela via legislativa, mas substantivamente pela gradual, paulatina e contínua modificação das mentalidades e das atitudes educativas. Intrigava aos educadores o porquê de as crianças, tendo frequentado a escola primária, não serem aprovadas nos exames finais e nos exames dos liceus. Julgava-se que a razão para isso era o uso excessivo da memória nos procedimentos

\footnotetext{
${ }^{506}$ Luiz Filippe LEITE, Excertos d'um livro inédito, In: Revistas das escolas; publicação periodica quinzenal, anno $1, n^{\circ} 4,1-3-1895$, p. 51 . Na sequência do texto, o autor procura evidenciar como eram inócuas as lições da escola a seu tempo. Perante um juri, que se esquecera de seu tempo de estudante, a memória treinada das crianças se apagava; ou, por outras palavras: "Aparece pois um belo dia o nosso escolar diante de um juri enfastiado e massadíssimo de ouvir tolices dias e dias, - d'um juri que, por via de regra, se não lembra de que também foi criança antes de ser juri, e que dispara ao pobre examinando, à queima-roupa e de má catadura, a primeira pergunta vaga e arrevezada que lhe ocorre, na órbita legal d'um programa árido, obscuro, ininteligível as mais das vezes para os próprios examinadores. Que sucede ? É ficar o tal estudantinho que tinha muito boa memória e ganhava muitos bons-pontos na escola, a engolir em seco, de olhos esgaziados e sem atinar com o sentido da pergunta, nem com a razão da insistência de quem lh'a repete duas ou três vezes, sem ao menos sequer lhe encaminhar o espírito para a solução, antes como que triunfando com o enleio $e$ estupefação do mísero ! Sem exageração alguma é este o belo êxito preparado pelo ensino todo à custa da memória. Como a inteligência não entrou ali para coisa alguma, flatam as deixas, e não há ponto oficioso que sirva de espírito santo de orelha, claro está que, feita a pergunta de qualquer forma, a memória falha, as palavras decoradas negam-se à reminiscência assarapantada do examinando, e lá se vai tudo quanto Maria fiou." (Id. Ibid., p. 52)
} 
escolares, a ausência de formação dos professores e a carência de uma sólida rede de inspeção que pudesse verdadeiramente orientar os profissionais do magistério sobre o uso de métodos mais apropriados e de renovadas estratégias de aula. Quando se abria uma escola reconhecia-se - tratava-se de se providenciar um ato político de inauguração, para o qual seriam convidadas as pessoas mais importantes da localidade. Era um cenário limpo, com flores, discursos frequentemente de exaltação aos progressos dos telégrafos e dos caminhos de ferro... A instrução primária, na lógica encadeada do discurso, costumava ser posta também como a evidência mais plena desse progresso a que vinham sendo submetidas as nações mais 'civilizadas' daquele tempo. Enfim, as festas de abertura de escola, bem como seus aniversários comemorativos, costumavam encher de vida aquele território: ocorre que era uma vida artificial, incapaz de ser reproduzida no dia-a-dia, vazia de significado pedagógico; uma vida apenas de aparência...

\begin{abstract}
“Apertam-se as mãos do Snr. Abade e do Snr. Comissário, as visitas saem, os pequenos agarramse às mães, os maiorzinhos marcham diante dos pais, o pároco volta para o seu presbítero, o Snr. comissário vai para sua casa e o Snr. professor lá se fica à espera de ver desfilar dias e dias de insólita fadiga, de tédio, de solidão cruel, porque se acha só entre as crianças, que nunca aprendeu a amar, nem estudou jamais a conhecer; e de fastio incrível porque não há nada que mais aborreça do que não saber fazer aquilo que há obrigação de fazer, nem pior suplício moral do que não ter entusiasmo nem amor pela sua profissão. Visitas, abade, notáveis da terra ou do bairro, o comissário e a sua eloquência de ocasião... viste-los! Nunca aquele mártir duma falsa vocação teve junto a si o conforto do louvor ou do bom conselho, modestamente dados e entre quatro paredes e a sós, ouvidos ! É lidar e mais lidar, barafustar, experimentar processos e expedientes (quando os experimenta) e isso todo o santo dia, e em todo o dobrar de um ano, cujos dias lhe parecem todos iguais no cansaço, na indecisão, na amargura e no desapontamento !",507
\end{abstract}

Ora, pelo fato de a preparação cultural dos professores ser, ainda, incipiente, não havendo suficiente acompanhamento ou orientação da prática docente, as revistas pedagógicas da época - como já pudemos observar anteriormente - pretendiam cumprir essa função $^{508}$. A defesa da escola primária cada vez mais virá acoplada à necessidade de se

507 "A presença de quem pudesse esclarecê-lo falta-lhe; o zelo de quem houvesse de tirar-lhe as dúvidas e encaminhá-lo é apenas mitológico. Entrou às escuras para aquele modo de vida e às escuras ficou. Se alguma vez lhe bate à porta uma visita de inspeção é para lhe exigir um milheiro de respostas a um milheiro de quesitos de que reza um mapa enorme e indigesto, onde o atribulado professor tem de esmiuçar as ocupações dos pais dos seus discípulos e muitas outras curiosidades importunas, ou em que terá de responder a indagações que lhe não competem sobre o regime da aula, porque se constituirá juiz em causa própria." (Luiz Filippe LEITE, Excertos d'um livro inédito, In: Revistas das escolas, anno 1, nº4, 1-3-1895, p.53). No capítulo 5, trabalharemos sobre alguns desses formulários de inspeção às escolas aqui referidos.

508 Jornais diários que circulavam à época também atentavam com uma dada regularidade para a questão das práticas escolares. Artigo escrito por Joaquim Martins de Carvalho - a 5-12-1893 - para o jornal O Conimbricense, sob o título ' $O$ uso da palmatória', discorria sobre a eficácia ou não do uso de castigos físicos na escola primária. Destacando que no século XIX a palmatória entrara em desuso nos colégios jesuíticos, o articulista ressalta o fato de este instrumento haver sido por aquela congregação substituído por técnicas de correção moralizantes, pautadas em geral pelo público vexame. Partindo da premissa de que os jesuítas naquele tempo reprovavam o uso daquele instrumento de físico castigo, o autor procura demonstrar que o uso da palmatória não corrigiria efetivamente estudantes, dado que fora da vigilância do educador, eles andariam muitas vezes aos murros. Havia que se encontrar outros meios de coerção, que efetivamente perdurassem após a saída do aluno da escola...Tratava-se fundamentalmente de questionar a palmatória para a correção dos adolescentes. E para isso o exemplo é convincente: "Num sábado, depois de saírem os estudantes das aulas do Colégio das Artes ou Pátio, alguns deles vieram para o largo do Museu, e andaram a atirar pedras uns aos outros. Esta garotada foi sabida pelos jesuítas. No domingo seguinte, em que todos os estudantes costumavam assistir à missa na capela do Colégio das Artes, ao terminar o ato religioso, foram quatro deles, que mais se haviam distinguido nas pedradas do Largo do Museu, chamados pelo Reitor dos jesuítas e por ele repreendidos. E para 
proceder a mudanças quanto aos processos de ensino ali desenvolvidos. Principia a era em que o tema do método dominaria o discurso. Inúmeras serão as iniciativas que pretenderão engendrar, pelo caminho da leitura dos professores, um novo modelo de conformação escolar; até para que efetivamente se viesse a ensinar aquilo que - todos concordavam - seria o essencial: o ler, o escrever, o contar. Julgava-se que o mundo da indústria exigiria tais habilidades e reforçava-se o fato de que cabia à escola regrar e controlar o perigoso território da leitura. Nos anos 80, uma das grandes revistas destinada aos professores - O Ensino costumava remarcar essa questão da dupla face da escrita:

\begin{abstract}
“É deplorável que se ignore que o ler, escrever e contar são instrumentos tão perigosos como a máquina mais complicada na mão dum operário inábil e ignorante das peças que a constituem e do seu funcionamento. Em breve serão colhidos pela correia que lhe esmagará um braço ou uma perna, se antes não forem despedaçados por enorme explosão; porque não souberam ler o manômetro que lhe indicava a tensão interna do vapor produzido e acumulado na caldeira geradora desse agente. A leitura, a escrita e as contas eram coisas já muito estimáveis nos tempos em que só os frades sabiam isso, um pouco do latim, as regras do Genuense de cor e umas leves tinturas da sagrada teologia. Hoje em nenhuma parte do mundo se admite semelhante absurdo. Antes todos os reformadores mais beneméritos e pedagogistas distintos concordam plenamente em que na escola primária se proporcionem, aos que aprendem, todos os elementos das ciências de mais útil e vulgar aplicação por modo que o homem que se destina ao trabalho ou às carreiras liberais receba aí as noções que o habilitem a ser cidadão do seu século, no conjunto das faculdades físicas, intelectuais e morais."
\end{abstract}

A revista intitulada O Ensino, que possuía durante os anos oitenta uma tiragem bastante considerável, buscava em grande parte de seus artigos clarificar o lugar da Pedagogia como um campo de estudos científico, centralizado pela disciplina Didática, que, por sua vez, seria constituída como a ciência que expõe as leis da educação. A Didática seria, nessa medida, complementada pela Metodologia do ensino, que, enquanto tal, se constituiria na "arte que praticamente tem de dirigir o ensino em conformidade com aquelas leis." ${ }^{, 510}$ Ora, o estado então vigente da civilização não admitiria mais que a missão do professor se reduzisse a obrigar a criança a decorar um conjunto de palavras extraído dos compêndios; e, como já pudemos observar, eles destacavam isso. A idéia de ensinar a ler pelo exercício da repetição monótona, entediante e improfícua daquilo que prescrevia o discurso do compêndio não poderia mais, face aos avanços da discussão da Pedagogia, continuar a ser adotada. Diante disso, a acepção do ensino intuitivo ganhava corpo como suposição básica de um referencial pedagógico que pretendia ser acima de tudo científico. A educação passara a ser tomada como uma ciência de cariz objetivo, de cujas regras poderiam ser desmembradas as orientações da sociedade do futuro $^{511}$. A princípio, compreender o processo de ensino como um caminho que

exemplo ordenou que os quatro estudantes, especialmente acusados, se colocassem por algum tempo nos quatro ângulos do grande Pátio, tendo cada um deles uma pedra na mão e bem à vista de todos. Assim, em lugar da palmatória, tinham o castigo da repreensão e do público vexame perante os seus mestres e condiscípulos. Aqui teria, portanto, o jesuíta Padre José de Araújo, que os jesuítas deste século haviam achado outro meio de corrigir os estudantes que não estudavam, ou andavam aos murros ou pedradas uns aos outros, sem ser o uso da palmatória." (Joaquim Martins de CARVALHO, O uso da palmatória, In: O Conimbricense, 47 ano, 5-121893) Os grifos são nossos.

${ }^{509}$ O ENSINO; revista de instrucção primária, II anno, no 17, volume II, 15-9-1886, p. 259-60.

${ }^{510}$ O ENSINO; revista de instrucção primária, $1^{\circ}$ anno, $2^{\mathrm{a}}$ série, , volume $\mathrm{I}, \mathrm{n}^{\mathrm{o}}$ 7, 31-7-1885, p. 111.

511 António Nóvoa destaca que as décadas finais do século XIX reivindicavam para si o estatuto da cientificidade das ciências da educação. Supunha-se que, do mesmo modo que as ciências físicas, a Pedagogia poderia ser construída pelo exercício da observação sistemática e da experimentação. Entendida como ciência que aplicava outras ciências, particularmente a psicologia, a Pedagogia se estruturaria de um certo modo já questionando a 
passava antes pela intuição do que pela razão exigiria mudança nos processos utilizados para ensinar. Passara-se a valorizar naqueles tempos a faculdade criativa da imaginação, como componente estrutural e necessária ao desenvolvimento infantil. Por outro lado, buscava-se compreender os estágios do desenvolvimento humano e a dinâmica do aprendizado que predominaria em cada um deles. A leitura, por exemplo, era atividade que deveria ser compreendida por ela mesma, enquanto veículo portador de inúmeros e inusitados significados, através dos quais - sabia-se - uma nova leitura da realidade deveria advir. Ora tal constatação exigiria que toda a leitura fosse explicada; tal prática, por seu turno, embora não podendo ser qualificada como inovadora, estaria muitas vezes ausente das salas de aula, onde professores deixavam de tomar a palavra: contentavam-se com a cópia e com a reprodução dos termos do compêndio. Ora, reconhecia-se, contudo, que a tarefa moralizadora da escola era, grande parte das vezes, o que impedia o êxito da instrução. Procurava-se, por ser assim, firmar os alicerces de uma pedagogia coletiva, centrada na palavra, no exemplo e na autoridade do professor, e indubitavelmente referenciada por um corpo teórico que prescrevia como essencial trazer a atividade docente para o centro do processo educativo; como se a educação nova fosse apenas a atualização e a radicalização do que vinha já pressuposto pelo ensino tradicional: os conteúdos enciclopédicos que o 'homem' priorizou, adequados e filtrados para o uso especificamente escolar; vertidos portanto para uma forma específica de organização e distribuídos no espaço e no ritmo da escola. Desejava-se inequivocamente louvar à perfeição aquele modelo, que vinha lá de trás e que agora se julgava tributário do progresso científico.

\begin{abstract}
"Em todo o caso, quer num ou noutro dos sistemas, é preciso sabermo-nos moderar. Não há muito ainda que ouvimos certo professor falar sobre a leitura longo tempo, e explicá-la ainda por cima. Querendo tirar da leitura tudo o que ela pode dar (e já notamos que pode dar muito e muito) sob o ponto de vista da educação moral e intelectual e em proveito desses ensinamentos, tanto fez que, dada a hora de passar a outro ponto, ainda os seus alunos não tinham lido nada. Isto é: ao princípio haviam eles escutado com interesse e respondido com vontade; depois foi-se-lhes esmorecendo a atenção, foi-se-lhes apagando o ardor e as atitudes bem demonstravam a fadiga e o aborrecimento. Aquele nosso caro colega abusa da explicação da leitura; desnatura o exercício; esquece que as crianças, sobretudo as das classes baixas, devem ler por ler e não para aprenderem moral, gramática, etc., a não ser incidentalmente e como por ocasião. Evitaria perfeitamente essa falta se tivesse preparado a sua lição de leitura, anotando o absolutamente necessário e possível de se explicar." 512
\end{abstract}

Faltava, nos termos do redator, a prudência da aula expositiva centrada sobre o que havia de essencial em cada lição. Faltava, sobretudo, a distribuição do tempo, dos horários, na composição harmoniosa de uma grade curricular capaz de ser regrada, uniforme, padronizada. Supunha-se que a escola deveria trazer tudo isso ao estudante; de maneira que

própria forma da escolarização posta como tradicional. Teria sido assim esse final de século que daria origem ao movimento da educação nova, que tanto sucesso faria no começo do século XX. Nas palavras de António Nóvoa, "ao definirem a escola antiga, estes pedagogos traçam uma caricatura que pretende tornar mais nítidos os contornos da novidade de que se sentem portadores. Creio, no entanto, que - apesar de trazerem métodos e formas de trabalho ainda hoje profundamente inovadores, estes homens não põem em causa a gramática da escola, tal como ela se consolidou no término do século passado. Num certo sentido, podemos dizer que eles aprofundam as três lógicas anteriormente mencionadas (estatização, profissionalização e cientificação) no contexto de uma crença total nas potencialidades regeneradoras da escola. É por isso que a Educação Nova me parece mais a tradução no plano educativo de formas de agir e de pensar que estão disponíveis na sociedade da época do que a formulação de modelos educativos (e escolares) radicalmente novos." [António NÓVOA, Uma educação que se diz nova, (texto mimeografado), p. 5]

${ }^{512}$ LEITURA, In: Educação Nacional, $7^{\circ}$ anno, $n^{\circ}$ 41, 7-12-1902, p. 173. 
ela se qualificasse efetivamente como o prefácio da vida adulta. O futuro dos filhos determinaria, para o futuro da família, a capacitação para o trato com o planejamento cotidiano. Sabia-se, todavia, que para a vida da escola e do colégio muitas coisas precisavam ainda ser melhoradas. A despeito, inclusive, do esforço moralizador acima ressaltado, faltava urbanidade àquela população de colegiais:

\begin{abstract}
"Falemos primeiro dos hábitos de urbanidade a que são refratários os colegiais, e depois observaremos, com algum desenvolvimento, o que seria preciso fazer-se para os estudantes ousarem emitir as suas opiniões, fazer uma singela narrativa, ou conversar de um modo culto, diante das pessoas de idade e sexo diferente. Essas duas faltas são uma lástima. O escolar, na intimidade de outros escolares, afoita-se, fala, braceja, mas com tal rusticidade chula, com um plebeísmo tão pitoresco e pronunciado, que fica a gente duvidando se são eles os filhos das pessoas de bem nossas conhecidas que estão falando, ou se os filhos dos seus criados é que se disfarçaram com os trajes desses meninos. Vejamos: será o colégio, tal como ele é, a expressão ótima da educação pública ? Ninguém dirá de boa fé que sim. O colégio substitui a educação em família até onde é possível; mas debaixo de muitos aspectos, supre-a incompletamente. O colégio é uma necessidade, porque o estudo regular poucos o poderiam fazer em suas próprias casas."
\end{abstract}

\title{
CIÊNCIA E MORALIDADE POSTAS À PROVA DA ESCOLA
}

A Pedagogia Nova, na forma pela qual entrava em Portugal, centrava-se, sobretudo, na denúncia do tradicionalismo em educação, na crítica àquele modelo escolar que a modernidade construía e que parecia carecer do reconhecimento do aluno enquanto individualidade, basicamente aos olhos dos educadores que - para usar a expressão de António Nóvoa - se diziam novos. ${ }^{514}$ A Escola Nova pretendia romper com o coletivismo da classe e adentrar pelos mecanismos interiores à aprendizagem de cada educando, individualmente. O coletivismo no ensino, que supostamente confere a equalização das condições do aprendizado, era tomado por tirânico e em desacordo com a dimensão de originalidade posta por cada indivíduo em particular. A nova escola pretenderia, como vimos, mensurar cientificamente as faculdades cognitivas de cada um dos estudantes; ela deveria se comportar, nos termos do que diziam as revistas do princípio do século, como uma "escola por medida", exatamente talvez por fazer da experimentação a chave da nova direção que pretendia agendar para o caminho da educação. ${ }^{515}$ De algum modo, existe aqui a ilusão de conferir à Pedagogia o estatuto de uma ciência exata:

\footnotetext{
${ }^{513}$ Luiz Filippe LEITE, Excertos d’um livro inédito, In: Revistas das escolas; semanário dedicado ás famílias e ao professorado, anno $1, \mathrm{n}^{\circ} 17,7-7-1895$, p. 234.

${ }^{514}$ Sobre os impasses do tema, em texto intitulado "Uma educação que se diz nova", António Nóvoa comenta as dificuldades daquele tão almejado novo modelo: “(...) e depois, há o cansaço de uma escola que se renova, é verdade, mas que resiste a transformar-se, uma escola na qual as linhas de continuidade são bem mais marcantes do que os espaços de ruptura. Como se as práticas escolares tradicionais fossem o natural, que renasce com força logo que os esforços inovadores abrandam por um momento que seja. E houve a Guerra, claro! A Guerra que a Educação Nova quis evitar através da formação de um homem novo, recuperando 'velho mito da regeneração humana pelo sacrificio violento do velho homem' incapaz de perceber que 'a educação nunca fez, e nunca fará, uma mudança revolucionária." ' (António NÓVOA, Uma educação que se diz nova, mimeografado, p. 1).

${ }^{515}$ Sobre esse tema da experimentação no ensino fundamental, dizia Azanha daquilo que caracterizava como contrafação pedagógica: "Experimentar, por assim dizer, identifica-se com observar, ver ouvir, etc. Os alunos são estimulados a realizar experiências que consistem na simples repetição de operações físicas estereotipadas, como se a experiência científica pudesse ser identificada com os procedimentos empíricos necessários à realização da observação de caráter experimental. Trata-se de um equívoco muito grave na interpretação do
} 
"É isto que vem confirmar uma psicologia mais perfeita, propriamente experimental e que pensa ser bem sucedida por processos cada vez mais perfeitos e rigorosos, medindo as faculdades intelectuais ou morais. De modo que se poderão tomar as medidas do espírito como do corpo, e notificá-las em cifras sobre uma ficha psicométrica. Assim precisada, a psicologia reclama uma educação adaptada a cada criança, ou, segundo o termo do Dr. Claparède, a escola por medida. É preciso conceder a maior atenção a este esforço, que tende a constituir uma ciência exata da criança e a renovar ou até a transformar, por uma verdadeira revolução, toda a Pedagogia (...)"516

Cada vez mais se intensificava a crítica a propósito da estrutura da escola primária tradicional portuguesa. Tanto em termos de métodos de ensino quanto no que diz respeito ao próprio conteúdo, que valorizava aspectos abstratos e pouco relevantes dos saberes escolares, a escola falhava naquilo que seria o essencial: o domínio da língua, o raciocínio lógico e a capacidade analítica para lidar com as equações postas pelo cotidiano ${ }^{517}$. Essa tarefa, que seria o dever primeiro da escolarização, a escola deixava para trás; e não cumpria... O problema do livro escolar ganharia vulto a partir dos primeiros anos do século XX. Discutia-se se era apropriada ou não a adoção do livro único; e quem defendia isso em geral alegava como principal razão a carência de formação de professores e os problemas curriculares decorrentes do fato de o mestre não conhecer aquilo que deveria ensinar. Havia uma quantidade considerável de escolas regidas por interinos, na maioria das vezes, despreparados para exercer o magistério. ${ }^{518}$

Havia quem enfatizasse a necessidade de a instrução portuguesa passar a se referenciar mediante as necessidades, as aspirações e as expectativas das populações locais.

papel da experimentação no desenvolvimento do conhecimento científico. Omite-se o fato essencial de que a experimentação - conquanto envolva operações empíricas de observação - serve a um propósito teórico que lhe dá sentido e a conduz. Tudo se passa como se a experiência de sala de aula fosse a reprodução do experimento registrado pela história da ciência. E quase sempre não é, porque resolver um problema não é a mesma coisa que tomar conhecimento da solução encontrada. E, se não se percebe essa diferença fundamental, a reprodução acaba por ser uma contrafação" (José Mário Pires AZANHA, Experimentação educacional: uma contribuição para sua análise, p. 30).

${ }^{516}$ A ESCOLA POR MEDIDA, In: A Federação Escolar, no 86, 3-9-1910. Na verdade, esse artigo, que vinha sem assinatura na seção pedagógica do referido periódico, procurava resumir experiências que, no exterior, já teriam sido efetuadas. O texto sublinha a validade das análises quantitativas para a educação, na medida em que, entrecruzando múltiplas variáveis supostamente científicas e passíveis de serem traduzidas em números, elas possibilitam parâmetros que conduzem à determinação dos perfis individuais.

517 "Que importa que o aluno, ao obter o seu alvará do curso de $1^{\circ}$ grau, fique sabendo que tais e tais palavras se chamam advérbios ou substantivos e que dadas flexões de um verbo são de tal pessoa, de tal tempo e de tal modo, se ele fica ignorando absolutamente qualquer princípio relativo à dignidade humana, aos seus deveres sociais e aos seus direitos, não possuindo a mais leve noção do que seja família e muito menos conhecendo o que seja pátria e o que lhe devemos?! E o trabalho?! (...) Honrar o trabalho e fazêe-lo amar é um elevado princípio de política que desejaríamos ver mais estremecido pelos nossos dirigentes." (EDUCAÇÃO NACIONAL, nº156, 17-9-1899)

518 "É sabido, ninguém ousará negá-lo, que uma grande parte das escolas, dadas como criadas na folha oficial, não passam do papel, e que outra parte, não menos considerável, é entregue à regência de personagens para cujo uso particularíssimo parece ter sido criada a escola, havendo a brilhar no meio dessa formidável plêiade de interinos e de idônios desde o taberneiro alcaiote até a pobre mulherzinha que nem os recibos do vencimento sabe assinar, pela razão simplíssima de nunca ter aprendido a fazer o seu nome. Parece fantástico! Estes casos estupendíssimos, já por nós denunciados, de entregar a escola a analfabetos absolutos ou quase absolutos conduzem-nos a concluir que o analfabetismo não se extinguirá entre nós com a difusão de escolas enquanto tal benefício for assim ministrado ao povo pelo poder central." (DIFUSÃO de escolas, In: Educação Nacional, $24-$ 9-1899, $\mathrm{n}^{\circ}$ 157) O artigo defendia portanto o fim desse controle centralizado que, segundo o articulista, não teria trazido ganho nenhum à educação. 
Isso significava que as localidades, os municípios, as câmaras, as juntas de paróquia, deveriam efetivamente investir no edifício escolar, na mobília, nos utensílios da escola. Deveria haver esse esforço conjugado que resultaria na prática de afastamento dos professores interinos, à medida que se aperfeiçoasse o controle das comunidades sobre a escola. Reconhece-se a inspiração dos ideários de Froebel e de Pestalozzi como precursores do novo modelo de escola que se passaria a defender na esteira daquele movimento da educação nova, de que Portugal desejaria, não apenas figurar como membro, mas efetivamente participar ${ }^{519}$. Remeter Portugal ao plano da inovação educativa era, por seu turno, forçar o país a romper com sua suposta condição de interminável atraso perante outros povos. A esperança no ensino coloca-se aqui mais uma vez voltada para o pensamento sobre a superação da malfadada decadência. A instrução pública era tida por caminho privilegiado para reerguer a perdida vocação nacional:

\begin{abstract}
“Apenas Portugal se conservou estranho ao movimento; não admira. Tudo quanto seja concorrer para o desenvolvimento da instrução, tudo que seja útil neste sentido, os nossos governos o desprezam e lançam ao mais completo desdém. Na lei de 78 e mesmo na atual foi consignado o princípio da criação de escolas infantis, que nunca chegou a ser posto em execução. No artigo $8^{\circ}$ do decreto de 22 de dezembro de 1894 determina-se: 'Nas cidades de Lisboa e Porto e em outras povoações importantes podem ser estabelecidas escolas para educação e ensino das classes infantis, segundo os sistemas mais proveitosamente seguidos'. Pela redação deste artigo vê-se claramente o propósito do legislador em que tal doutrina nunca viesse a ser posta em execução. É o que sucede sempre em casos semelhantes. Nas nossas leis, existem muitas vezes princípios bons e até excelentes; mas é só para o estrangeiro que compulsar a nossa legislação poder asseverar que somos um país adiantadíssimo, que caminhamos na vanguarda do progresso. Belezas exteriores com que pretendem encobrir as pústulas que corroem o âmago do nosso organismo social. As escolas infantis são duma reconhecida vantagem e, numa futura remodelação do ensino, não devem ser esquecidas como até hoje, transformando na prática o que a teoria já há muito aconselha." $" 520$
\end{abstract}

Contrariando o ensino catequético, os educadores desde o princípio do século passarão a preconizar o ensino laico. Acredita-se que é catequético tudo o que recorre exclusivamente à memória, sendo que a acepção de laicismo, mais do que a suspensão de juízos de ordem religiosa, significaria a liberdade de pensamento em sua dimensão de crítica e de criação de referências. O mesmo movimento que propugna a educação nova irá defender a laicidade como parâmetro imprescindível para uma escolarização renovada.

Acerca do tema d' 'A laicização do ensino' Ávila Júnior apontaria - no periódico A Voz do Professor de 1-11-1909 - a impropriedade do argumento religioso para a composição dos saberes escolares. O catecismo seria - no parecer do redator - a pior estratégia para proceder ao ensino das primeiras letras, responsável talvez pelos elevados índices dos

\footnotetext{
519 "No fim do século passado, três vultos importantes estavam predestinados a produzir uma completa revolução na Pedagogia. É do centro da Europa, donde dimanam as mais lidimas idéias, que esses três astros surgem e derramam as primeiras luzes que germinaram as bases em que devia fundamentar-se a Pedagogia moderna. Ao dogmatismo até aí predominante na escola contrapõe-se a intuição, verdadeira ginástica do espírito, base e fundamento de todos os conhecimentos. O nosso século herdou do século XVIII esses três luminares que tanto haviam de concorrer, pela nova feição que imprimiram ao ensino, para, com bastante razão, ser cognominado o século das luzes. A escola primária criaram-na eles, sem dúvida. Essa augusta missão - quem o desconhece ? - coube a Henrique Pestalozzi, nascido em Zurich em 1746; a Gregório Girard, nascido em Friburgo em 1765 e a Frederico Froebel que nasceu em Oberweissbach, na Turíngia em 1782.” (DIFUSÃO de escolas, In: Educação Nacional, no 157, 24-9-1899).

${ }^{520}$ DIFUSÃO de escolas, In: Educação Nacional, no 157, 24-9-1899.
} 
que, não sendo capazes de dominar as habilidades da leitura e da escrita, fatalmente deixavam a escola após as primeiras tentativas. Além de pedagogicamente impróprio, o modelo catequético apresentaria recortes de verdades cristãs calcadas na doutrina, que, curiosamente, apareceriam como reveladores antes da vida profana do que de qualquer dimensão da realidade espiritual. Assim - prossegue o texto - os compêndios utilizados ainda naquela época aconselhavam os alunos a adentrar pelo território do cristianismo mediante leitura pausada de trechos selecionados, em função de cuja leitura os alunos pudessem apreender o "verdadeiro sentido" de cada frase... Entretanto, tais recomendações poderiam facilmente acarretar inóspitas surpresas, e "meter o professor em maus lençóis":

\begin{abstract}
"Imaginemos que o professor manda uma criança recitar, pausadamente a Ave Maria ou a Salve Rainha de maneira que às frases dê o verdadeiro sentido. O que sucede? Sucede que chegando à criança a frase - 'bendito é o fruto do vosso ventre' - frase esta que o professor, a bem da moralidade, pretende passar sem explicação, a criança, muito naturalmente e por ser curiosa, pedelhe que explique o sentido daquela frase. Que faz o professor neste caso? Certamente isto: ou se cala e desobedece à lei ou explica a frase e desmoraliza os seus alunos. Mas temos mais. $\mathrm{O}$ professor chama uma das classes mais adiantadas para lhe lecionar catecismo. Depois de várias perguntas, faz esta a uma das crianças: - O que é pecado original? Responde o aluno com as palavrinhas do compêndio: 'É o pecado cometido no paraíso terreal pelos nossos primeiros pais Adão e Eva e que é comum a todos os seus descendentes." 521
\end{abstract}

Entretanto, antes do professor chegar a formular nova pergunta, uma das crianças lhe interrompe, solicitando uma explicação sobre o quê de fato viria a ser o pecado original, já que não pudera compreender os termos da definição do compêndio. Ora, como o compêndio também recomendava que as crianças explicitassem ao professor todas as suas dúvidas, o menino estaria na verdade apenas a reivindicar o seu virtual direito à explicação. $\mathrm{O}$ professor, hesitante, e como para não se desmoralizar, sai com uma evasiva que transcrevemos na sequência:

“( Ora...pecaram; então já não lhe disse ? (luno) - Disse, sim, senhor; mas eu ouvi dizer que Adão e Eva pecaram porque comeram uma maçã. É verdade, professor ?

(Professor) - É...

(Aluno) - Então, quem come maçã peca ?

(Professor) - Está visto que sim.

(Aluno) sendo assim, nós não podemos comer maçãs ?

(Professor) - Podem... sair, que já deu a hora." 522

Sem se considerar elucidado, o menino chega à casa e pergunta ao pai o que era "pecar originalmente"....

\footnotetext{
521 ÁVILA JUNIOR, A laicização do ensino, In: A Voz do Professor, no 19, ano 1, 1-11-1909.
}

${ }^{522}$ ÁVILA JUNIOR, A lacização do ensino, In: A Voz do Professor, no 19, ano 1, 1-11-1909. 


\begin{abstract}
“As crianças, cheias de admiração e sem saberem a que atribuir tanto mistério, narram os fatos passados na escola e entregam aos pais os seus compêndios de doutrina cristã, oficialmente aprovados, e dizem tristemente: - Foi aqui, papá, que aprendemos o que o fez zangar tanto! O pai abre um deles e vê que é verdade o que lhe dizem os seus queridos filhos. Fica assombrado! Continua a folhear o livro e fica estupefato quando vê em letra redonda o seguinte: $6^{\circ}$ Não ofender a castidade; $9^{\circ}$ Não desejar a mulher do próximo." ${ }^{523}$
\end{abstract}

O articulista com isso revela sua perplexidade, convicto de que a escola portuguesa, ao fundamentar-se sobre o ensinamento catequético, estaria a antecipar para os meninos aquilo que apenas muito mais tarde eles poderiam vir a descobrir. Em virtude disso, indaga-se se efetivamente a moral religiosa que regia até então a vida escolar não seria (ainda que isso representasse uma contradição nos temos) imoral. Mais do que religiosidade, a escola deveria - de acordo com a tendência do mundo contemporâneo - fortalecer conhecimentos verdadeiramente práticos, que habilitassem a mulher a ser mãe e o homem a ser trabalhador e cidadão. Pretende-se formar pela e para a disciplina da vida prática. Essa seria a maior tarefa da escola moderna naquilo que ela diferiria da "escola antiga". ${ }^{524}$ Pretende-se fortalecer, por outro lado, elos de solidariedade inter-societários. Pretende-se, ao fim e ao cabo, maior produtividade profissional e prosperidade para o país. A educação deveria, ao invés de preparar seres catequizados, formar para a utilidade social do conhecimento; a escola deveria capacitar o indivíduo, enfim, para a resolução de seus afazeres cotidianos. Nessa direção, postula-se com frequência o que se caracterizava por "aprendizado ativo da obediência". Contraposta aos inconvenientes do mimo excessivo, tão frequente na vida familiar, a escolarização não daria asas a caprichos ou fantasias, mas se direcionaria fundamentalmente para a formação de hábitos, dos quais as crianças posteriomente deveriam se valer na vida do trabalho: hábitos de regularidade, de exatidão, de doçura e de "benevolência nas relações exteriores". A nova pedagogia não abdicaria da autoridade do professor; pelo contrário, deveria torná-la mais eficaz, mais ágil o processo do que agora se passaria a intitular ensinoaprendizado. Ainda tomada como obra de aperfeiçoamento do gênero, a educação deveria ser norteada por três referências, como constava do texto da Educação Nacional já nos idos 1899:

\footnotetext{
“1”. Natural, simultânea e propensiva, isto é, deve seguir a marcha da natureza sem a violentar e sem a retardar; ter em vista o natural da criança, desenvolvendo simultaneamente e numa mesma proporção as faculdades do seu espírito. $2^{\circ}$ Liberal, isto é, respeito à pessoa da criança, que é por si mesma um fim, como afirmou Kant, e nunca servir-se dela como um meio; e, sob o ponto de vista da instrução, fazer-lhe adquirir o maior número de conhecimentos gerais que for possível, sem a limitar ou encerrar na especialização. $3^{\circ}$ Moral, isto é, deve ter por ideal não só o fazer concorrer à instrução e à moralização, mas ainda dirigir finalmente a vontade da criança para o bem que lhe
}

\footnotetext{
523 ÁVILA JUNIOR, A laicização do ensino, In: A Voz do Professor, no 19, ano 1, 1-11-1909.

${ }^{524} \mathrm{O}$ mesmo Ávila Junior, em artigo intitulado 'A escola primária portuguesa", destacaria o seguinte, alguns meses antes de se pronunciar sobre o tema da questão religiosa naquele já referido periódico: "A pobre criança só decora palavras, não aprende fatos porque não vê coisas. Eis o que é a escola primária portuguesa - a escola antiga. Não é assim a escola moderna, a escola imaginária de Rabelais, de Comenius, de Rousseau, de Pestalozzi e de tantos outros ilustres pedagogistas. Nesta encontra o professor todos os elementos indispensáveis ao ensino e, por isso, o vastíssimo campo que se estende sob suas vistas é de fácil cultura e muito ubérrimo. Na escola antiga só há treva porque nela o todo ensino é prático. Para a criança e para o professor nada há mais difícil, penoso e improfícuo do que o ensino teórico. A criança não se satisfaz com palavras: quer ver, quer tocar. Além disso, como sua atenção é pouco duradoura, é preciso prendê-la sem a cansar, - o que só se pode conseguir com o ensino prático." (ÁVILA JUNIOR, A escola primária portuguesa, In: A Voz do Professor, ${ }^{\circ} 1$, ano1, 1-2-1909)
} 
tiver feito reconhecer e amar. (...) A educação como obra de aperfeiçomento dura toda a vida. Porque, quando somos novos, o saber e a experiência dos outros são os fatores que nos orientam; quando homens, a nossa própria experiência ensina-nos muitas coisas e permite-nos tornar-nos melhores. Ao passo que nos melhoramos pela educação, influímos também sobre os nossos semelhantes e até sobre os nossos descendentes, pois que, pelas leis da hereditariedade psicológica, é sabido que, em certa medida, as tendências e hábitos contraídos por um indivíduo se transmitem à descendência.",525

\section{ESCOLA, DISCIPLINA, CORREÇÃO, CASTIGO E GINÁSTICA}

Supunha-se realmente que a obediência a normas, regras e preceitos escolares habituaria o caráter da juventude ao cumprimento da própria ordenação social; particularmente ao necessário respeito pelas leis do Estado. Em função disso, acreditava-se que o hábito da vida disciplinada poderia contribuir para a recusa de quaisquer procedimentos de insubordinação ou tentativas subversivas de supressão da autoridade. Havia uma forma liberal de ser sociedade portuguesa. Tal formato implicava mecanismos de seleção, adaptação, ajustes e exclusão. Tencionava-se preparar a identidade do homem português para que, em contato com as diretrizes que presidem a vida política e econômica, ele simplesmente acatasse seus pressupostos. Essa era talvez a dimensão oculta do currículo praticado pela escola... Por um lado, parecia-se acreditar que isso viesse a ocorrer; por outro, duvidava-se e temia-se, como efeito imediatamente contrário, que a educação fortalecesse a capacidade crítica, o potencial inovador e transgressor da ordem instituída. Na verdade, havia já a exemplificação histórica de que os setores dominantes da sociedade, as autoridades consolidadas não pareceram durante tantos séculos estar convictas da necessidade de escolas para impedir a subversão. Talvez, assim como o mito da regeneração é convenientemente criado para defender a atividade escolar, o questionamento e a crítica da instituição também se pautem nesse outro mito, que agiria na direção oposta. A sociedade portuguesa nunca recorrera à escola para conter eventuais rebeliões. Seria a escola agora necessária para essa finalidade? Estaria a escola disponível para cumprir essa finalidade? Ainda na incerteza, havia nos arautos ou precursores da Educação Nova o desejo explícito de inovar perante a primazia da educação sobre os limites da mera instrução. Para conter a desordem e inculcar o acatamento dos valores, pretendia-se advogar a alardeada formação integral:

\footnotetext{
“Assim é que, ao passo que a instrução iluminará a inteligência, a educação compreendida assim, como uma disciplina firme, sem dureza, há de fazer ainda uma obra muito mais útil; há de preparar para a pátria cidadãos dedicados, soldados escravos do dever; homens dignos deste nome, que se não deixarão seduzir pelos vãos discursos dos utopistas que querem destruir o edifício social na sua base, abolindo a lei. Numa palavra, o que não é menos necessário, esta educação formará mulheres, enérgicas e instruídas, que nem se deixarão arrastar pelos preconceitos, nem pelas superstições, que hão de saber disciplinar os seus filhos e serão capazes de completar a educação pública, auxiliando os educadores nesta parte tão importante da sua tarefa, em que eles dificilmente conseguiriam sozinhos triunfar., 526
}

\footnotetext{
${ }^{525}$ PEDAGOGIA, In: Educação Nacional, no 171, 31-12-1899.

${ }^{526}$ EDUCAÇÃ O Nacional, anno $6^{\circ}$ (1902), nº 292. No mesmo periódico, artigo intitulado 'Castigos Escolares', publicado a 17-8-1902, defenderia que o professor devia ter autonomia para decretar os castigos que julgasse convenientes. Entretanto, o texto se coloca frontalmente contrário à expulsão do aluno da escola, posto que isso significaria, por parte da própria instituição, a confissão de que há alunos incorrigíveis. Entretanto, os castigos
} 
Acerca do tema, a grande questão colocada para os contemporâneos era a dos castigos. Deveriam ser padronizados? Deveriam ficar sob o encargo e responsabilidade de cada professor? Na confiança quanto a seu discernimento? Deveriam compreender a possibilidade da expulsão e o castigo físico? Ou não? Os pioneiros da Educação Nova em Portugal não pareciam - ao menos no que diz respeito ao debate transposto nas revistas chegar a um acordo quanto a esses polêmicos aspectos da disciplina que, em última análise, eram elementos essenciais para a obtenção da desejada forma escolar ${ }^{527}$.

Artigo publicado na Educação Nacional com data de 25-1-1903 - sob o título "Insuficiência das reações naturais na manutenção da disciplina escolar; necessidades das reações artificiais: castigos e recompensas" - destacava, já à partida, a importância de se proceder ao que se caracterizava aqui como "medicina escolar", imprescindível enquanto estratégia de firmamento de um modelo de ensino verdadeiramente eficaz. Acerca dos fatores intervenientes naquilo que se compreendia por disciplina escolar, julgava-se urgente o reconhecimento de detalhes que, de origem extremamente variada, nem sempre eram valorizados nos debates acerca do tema.

\begin{abstract}
"Todos os meios conducentes a estabelecer a boa ordem dentro da escola, os destinados ao incitamento ao estudo, e ainda aqueles que visam a reprimir faltas cometidas, constituem o objeto da disciplina escolar (...) Com a disciplina, tudo se prende, absolutamente tudo, desde a parte material do edifício até a organização interna da escola. Se a casa escolar não satisfizer a todas as condições higiênicas e pedagógicas; se se notar carência absoluta de material de ensino indispensável, pelo menos, para se poder ministrar o ensino real, o ensino pela intuição; se o mobiliário for de molde a que as crianças estejam contrafeitas ou ainda dispostos de tal maneira que o professor não possa exercer uma vigilância ativa e contínua sobre os seus alunos; se, finalmente, a escola, considerada no seu conjunto material e moral, se não apresentar como um templo cheio de atrações, agradável, risonho e alegre, certamente que a tarefa do educador restará
\end{abstract}

corporais não teriam efeito ruim, devendo estar apenas na alçada e na dependência do professor. Atribuindo ao profissionalismo do professor a delimitação dos critérios adotados para a "correção disciplinar", ressaltava-se como um valor esse discernimento do profissional do magistério. Acerca dos tipos de criança que haveria para serem corrigidas, não se considera nenhuma delas incorrigível, embora fossem preconizados castigos diferenciados para camadas sociais economicamente inferiores: “(...) umas são tão sensíveis que ficam enormemente castigadas só com o fato do professor lhe retirar aparentemente a sua amizade; outras só se comportam bem e têm boa aplicação com a mira dum pequeno prêmio; mas também há algumas, especialmente saídas de camadas sociais muito baixas, que só se domam por meio de castigos corporais, aplicados em oportunidades muito escolhidas e com criteriosa prudência. Só não é desta opinião um e outro filósofo que nunca foi pai nem educador. Mas dentre tantos processos de incitamento e correção, quase um para cada criança, só o professor pode eficazmente escolher o mais próprio para a ocasião. Não pode nem deve existir na lei o que deve sair do critério e experiência dum bom professor." (CASTIGOS escolares, In: Educação Nacional, anno 6, nº 308, 17-8-1902) Os grifos são nossos.

527 "Há dois partidos - o dos que julgam a férula indispensável na escola e o dos que a rejeitam em absoluto. Eu sou dos que se enfileiram no último partido, bem que isso pese aos meus amigos da 'Educação'. E não se poderá dizer que faço doutrina, ou antes, voto de doutrina inconscientemente, visto que hei atravessado, nestas lides do ensino primário, já um longo estádio, desde a escola de aldeia a 90 mil réis por ano até a escola da capital. O castigo corporal que o nosso regulamento autoriza não é um elemento de disciplina, não é um excitante para o ensino, não corrige, não moraliza; insubordina, causa horror à escola, bestializa, tira à criança a dignidade e apouca extraordinariamente o valor do mestre. Eu faço uma pergunta simples, mas que pode ter (bem o sei) muitas complicadas respostas: - Em que casos o professor pode usar dos castigos corporais? Queira alguém indicar-me o primeiro, a ver se me convence da sua necessidade. Geralmente o mestre (e que vítima eu fui do sistema) bate nos meninos porque não sabem a lição; bate-lhes porque não entendem o que se lhes explica; bate-lhes porque não estão com atenção; bate-lhes porque são inquietos; batelhes por tudo e por nada!” (TÚLIO, De Lisboa, Educação Nacional, anno 7, nº 317, 19-10-1902, p. 10). 
cheia de espinhos, e será muito mais difícil enfim, porquanto não pode observar à risca estas duas condições essenciais: boa divisão do trabalho e justa aplicação do tempo." 528

$\mathrm{Na}$ verdade, o problema da organização interna da escola parecia vir ajustado a uma nova racionalidade, em consonância com os padrões e os valores da modernidade. $\mathrm{O}$ século XIX parecia pelos atos e pelas representações entender a si mesmo como o ápice, o aprogeu, a radicalização última da modernidade. Por ser assim, inventava novas necessidades sempre e as justificava com frequência em nome da técnica. Em que medida há verdadeiramente uma relação intrínseca entre o currículo escolar e a história da fábrica? Não teriam sido os próprios contemporâneos que, para justificar a necessidade e a propriedade da escola diziam isso? Controlar a precisão do fator tempo era uma bandeira da época; o que não significa, em hipótese alguma, que a escolarização tenha tomado de empréstimo padrões que antes teriam pertencido à fábrica. Pelo contrário: como já indica alguma bibliografia de História da Educação, talvez tenha ocorrido um processo concomitante, ditado talvez pelo espírito que norteava aquele período em especial. ${ }^{529}$ Reconhecendo, em qualquer dos casos, a variedade dos meios passíveis de serem utilizados pelo professor com o objetivo de manter a disciplina das classes, destaca-se que quaisquer procedimentos deveriam ser observados em função do meio específico de proveniência e, por outro lado, da própria índole interna à criança. Teoricamente, haveria sustentação tanto para os que julgavam ser possível a formação do aluno exclusivamente pelas ditas reações naturais, recusando, nessa medida, quaisquer estímulos internos, quanto para os que - na outra margem, e em maior número ainda advogavam o emprego de maneiras artificiais de obtenção do aprendizado: recompensas e castigos. De qualquer modo - sugere o autor - o ensino coletivo dificultaria a adoção de medidas disciplinares uniformes, posto que as crianças provinham de meios familiares diferenciados, recebendo portanto formação sempre distinta. Mais uma vez, percebe-se a clara oposição entre a escola e a família enquanto instituições concorrentes que na sociedade travavam disputa de representações no território educacional. A idéia aqui é a de que o meio familiar é viciado; menos ou mais viciado, mas sempre viciado e, por decorrência, corruptor de costumes. ${ }^{530}$ A oposição entre a família e a escola torna-se escancarada quando os autores

528 INSUFICIÊNCIA das reações naturais na manutenção da disciplina escolar. Necessidade das reações artificiais: castigos e recompensas, In: Educação Nacional, $7^{\circ}$ anno, nº 331, 25-1-1903, p. 175.

${ }^{529}$ Sobre a correlação entre os níveis de industrialização dos países europeus e a irradiação que cada um deles faria da instrução elementar, Petitat, por exemplo, questiona qualquer aproximação automática; que, segundo ele, seria, no mínimo, apressada: "Fatores como a industrialização e a urbanização não podem ser totalmente responsabilizados por estas variações. Em 1851, 84\% da população ativa da Inglaterra e do País de Gales encontram-se nas indústrias e nos serviços, $50 \%$ nas cidades enquanto que um terço dos adultos ainda não sabe nem ler nem escrever! A Suécia parece uma imagem invertida desta realidade: é um país pouco urbanizado, pouco industrializado, onde os analfabetos desapareceram quase completamente. A relação entre industrialização e alfabetização se decompõe em diversos elementos. Pode-se sustentar que a tecnologia industrial implica conhecimentos dificilmente transmissíveis e aplicáveis sem o recurso da escrita. Mas de toda forma, no século XIX este raciocínio só é real para uma fração limitada dos novos proletários: na maior parte das vezes, um aprendizado sumário na prática é amplamente suficiente para a realização de tarefas mecânicas e repetitivas. A Inglaterra é exemplo disso: entre 1800 e 1840, enquanto a industrialização se desenvolve consideravelmente, as taxas de analfabetismo permanecem praticamente estáveis. Além disto, em certos setores industriais, o trabalho infantil atua como freio da instrução elementar." (André PETITAT, Produção da escola: produção da sociedade, p. 151).

530 "A maioria da população que frequenta as nossas escolas vive num meio moral por demais viciado, e essas crianças quase abandonadas a si, saem do seio da família sem a mais leve noção de dever, e, o que mais é, eivadas de vícios, repletas de maus hábitos. Mas há mais: a ação modificadora, destinada a transformar, pela ação educativa, o caráter do educando, será duma diminuta potência, de quase nenhuma eficácia, visto que sobre ele a intervenção direta do professor se exerce apenas durante algumas horas do dia e isso não basta para o disciplinar." (INSUFICIÊNCIA das reações naturais..., In: Educação Nacional, $7^{\circ}$ anno, nº 331, 25-11903). 
preconizam a utilização mais frequente dos castigos físicos para crianças cujas famílias tivessem origem popular. Na verdade, nesse momento, a constelação das classes e das ordens que dividiam o tecido social tornava-se mais explícita e o discurso escolar revelava, no contexto dos castigos, sua face mais perversa e até então talvez oculta. Ao discorrer sobre o tema dos castigos e das punições, mais do que em qualquer outro momento, a escola se revelava... E ao se revelar, revelava também a estrutura da sociedade a quem servia; suas hierarquias, suas distinções, suas fronteiras, seus interditos.

Era muito comum, naquelas revistas do princípio do século, matérias voltadas para a prevenção pedagógica de alguns dos males com os quais a sociedade se defrontava, particularmente a embriaguez dos povos das aldeias. Acreditava-se que a instrução e os benefícios dela decorrentes poderiam ser antídotos eficazes do alcoolismo, já que a ignorância e a carência de meios materiais e de perspectivas de cultivo espiritual seriam fatores que provocavam esse sucedâneo com que se conflagravam os povos. Isso conduziria o aldeão com significativa frequência - a ter doenças depressivas, não dispondo nesse sentido da vida saudável que tantas vezes a literatura desejara atribuir ao povo camponês. Educar o povo trabalhador era, sob tal perspectiva, conferir a ele hábitos de moderação, capazes de extirparlhe a tentação do vício: ${ }^{531}$

\begin{abstract}
"Em geral resignado, não tendo das injustiças sociais uma bem definida visão, vivendo de pouco, aspirando a pouco, alheio às inquietações das lutas complexas, sempre no vivificador contato da natureza, o aldeão tem para o álcool um irresistível pendor (...) E um perigo real a ponderar-se é que o aldeão, na sua ignorância, faz das crianças que gerou uns pequenos alcoólicos. Onde o vinho é a principal cultura, os rapazes habituam-se de cedo a largas porções do excitante líquido - 'É para ganhar forças', dizem os pais sorridentes, na triste significação da sua cegueira mental. E muitas dessas crianças amarelecem ."532
\end{abstract}

A recomendação de exercícios ginásticos nas escolas ia exatamente por aí. $\mathrm{O}$ condicionamento corporal teria analogia ao condicionamento da alma; quer no tocante à propensão para o vício, quer no cultivo de bons e saudáveis costumes - de acordo com as respectivas opções. A constituição do indivíduo, impregnada por esses dois aspectos

${ }^{531}$ Artigo de E. C. Pereira, intitulado "A vida das crianças: palestras maternais" - publicado no periódico A mulher e a criança de maio de 1910 - recomendava, na direção do que já vínhamos anotando, o estímulo familiar à leitura como um preceito fundamental para orientar a educação da criança nos aspectos que dizem respeito à evolução de seu caráter. Considerava-se aqui que haveria um ensino conjugado do qual se encarregariam família e escola, cujos conteúdos deveriam ser voltados para o aprendizado intermitente de regras de urbanidade, afastando as crianças da "habitual lenga lenga de carochinhas sem sentido algum" e buscando, pela leitura de biografias, de romances históricos e de tudo o que pudesse ser qualificado como acontecimento verdadeiro, o conhecimento que os contos de fadas não estariam aptos a dar. Além de tais recomendações sobre a leitura, propugnava-se que a cura de males comportamentais ocorresse, como se de doenças físicas se tratassem: "Suponde que a Mariasinha teve sarampo e depois alguma recaída. A mãe não hesita em tratá-la meigamente, noite e dia, e já em convalescença a vigia com solicitude. Mas suponde agora que a pequena Maria tem sarampo moral e é colérica, vingativa ou mentirosa, ou, na falta de pecados cardeais, é negligente, carrancuda e obstinada, - que acontece? A mãe, ou fecha os olhos ao fato de que a sua pequenita filha não é o que devia ser, ou se apoquenta, censurando e castigando uma ou duas vezes dizendo por fim com um suspiro 'eu era provavelmente tão má ou ainda pior do que a Maria quando era da sua idade; em crescendo, muda'. Pobre pequenita Maria! Tratai os seus defeitos e manias como vós trataríeis os seus males físicos. Está provado por aqueles que disso fizeram um estudo especial, que um mês ou seis semanas persistentemente empregadas a curar um defeito, curam-no." (E. C. PEREIRA, A vida das crianças: palestras maternais, In: A mulher e a criança, maio 19010, $\mathrm{n}^{\circ}$ 12, p. 7) Relaciona-se, por fim uma lista de qualidades para as quais deveria estar voltada a educação da criança: diligência, reverência, gentileza, verdade, prontidão, asseio, cortesia, lealdade, observação metódica, exatidão. De qualquer maneira, formar a criança era precaver o vício do adulto...

${ }^{532}$ A EDUCAÇÃO e o alcoolismo, In: Educação Nacional, $7^{\circ}$ anno, n³27, 28-12-1902, p. 91. 
entrelaçados, deveria se firmar com maior vigor quando a prática regular de exercícios ginásticos fizesse parte do movimento rotineiro do currículo das escolas primárias. Existe nitidamente, na preocupação com a prescrição de exercícios físicos, um intuito subreptício de purificação do corpo frente a tudo o que pudesse corroê-lo ou, por contágio, vir a debilitá-lo. A 21-6-1905, o periódico A Escola trazia um artigo assinado por Sanches de Moraes - "A ginástica nas escolas primárias" - destacando o papel precursor desempenhado por Alves dos Santos que, enquanto inspetor da circunscrição de Coimbra, conseguira efetivamente programar ali a prática regular dos exercícios ginásticos na escola:

\begin{abstract}
“Os movimentos passivos e algumas máquinas podem desenvolver os músculos, produzindo um certo efeito higiênico, mas não tornam o homem destro e animoso. Os jogos entretêm e provocam a iniciativa; os exercícios metódicos provocam a perseverança no esforço, dão a certeza no resultado, disciplinam portanto. Os exercícios ginásticos provocam a audácia e temperam os caracteres; e se o seu fim é aperfeiçoar, e se com eles se procura tirar um resultado útil e socialmente útil, como consequência, elevam a alma, desenvolvem o espírito de sacrifício e fazem abandonar os prazeres que debilitam e arruínam a saúde."
\end{abstract} SEGREDOS PARA O DOMÍNIO DA ALQUIMIA DO MAGISTÉRIO: VOCAÇÃO, CRIATIVIDADE,
ENTUSIASMO, CONTEÚDO, DISCIPLINA

Entendia-se à época que os requisitos necessários para o bom desempenho da tarefa do magistério pautavam-se no domínio de algumas habilidades e na posse de alguns atributos, que vêm assim arrolados: 1). Capacidade de captar a admiração de seus discípulos; 2). Domínio completo da relação com o discípulo, mediante autoridade construída sobre três bases, assim estruturadas: moralidade; conhecimento do conteúdo da aula; preocupação quanto a atualização constante do conhecimento a ser transmitido; 3). Capacidade de despertar a inteligência do aluno, levando-o a apaixonar-se pelo conhecimento a ser adquirido; 4). Entusiasmo, criatividade e habilidade de inovação perante a rotina e as ingratidões com as quais o trabalho do magistério é atingido. Aí estariam, pois, arrolados os requisitos para se criar um bom professor. ${ }^{534}$

\footnotetext{
${ }^{533}$ Sanches de MORAES, A ginástica nas escolas primárias, A Escola, III ano, no 178, 21-6-1905, p. 1.

534 Tais requisitos constavam do editorial intitulado "Faculdades Pedagógicas" publicado no periódico A Escola, na edição datada de 1-7-1905. Um ano antes, naquele mesmo jornal, texto de autoria de Agostinho Campos, sob o título "Mandamentos do bom educador", indicava para os pais como eles deveriam se comportar para educar corretamente seus filhos. "1.Educa tu próprio os teus filhos. 2. Disciplina e corrige desde o berço. 3. Nunca elogies nem repreendas teus filhos na presença de estranhos. 4. Exige deles obediência completa; mas facilitalhe o encargo de obedecer e dá o máximo prestígio aos teus mandatos por meio de uma sensata parcimônia de proibir e ordenar. Sê escrupulosamente justo, verdadeiro e lógico; aconselha, adverte com paciência antes de punir; respeita como um contrato sagrado a promessa feita, seja de prêmio ou castigo. 5. Subtrai quanto possível as crianças às conversas dos adultos, se as quiser conservar moralmente saudáveis e puras (...) É à noite que em geral se faz em casa a crônica das torpezas da vida. E os pequeninos cérebros trabalham sem cessar e adivinham facilmente a meia linguagem das reticências e dos olhares. 6. Não faças dos teus filhos brinquedos, expondo-os como prodígios à admiração de estranhos ou amolecendo-os com carícias excessivas filhas mais do egoísmo que do amor. 7. Evita a ociosidade das crianças para que elas não se tornem preguiçosas, irritantes ou precocemente contemplativas. 8. Cultiva na alma de teus filhos a tenacidade. 9. Não sufoques o instinto infantil de perguntar, que é o mais precioso auxiliar da educação. Satisfaz em todas as ocasiões e o melhor que possas, essa fecunda curiosidade; sê verdadeiro, sério e paciente em suas respostas, para que a criança, ao mesmo tempo que aprende, se acostume a respeitar-te e a amar-te como um guia leal e bom. Não festejes os seus erros, reproduzindo-os embevecido, em vez de o corrigir, porque perderás assim uma
} 
O ensino científico e a valorização dos conteúdos da ciência são, como vimos, uma constante nesse tempo. Desejava-se entender a própria Pedagogia como uma ciência da educação. Havia editoriais de jornais pedagógicos que acenavam para a necessidade de introdução da matéria de ciências naturais na escola primária, o que contribuiria para acentuar o progresso da civilização. Apontava-se nessa direção, com muita frequência, para a matriz positivista, declarando o intuito do "saber para prever". Com isso, os contemporâneos julgavam prover o futuro de instrumentos técnicos e mentais mais apropriados. A intuição previdente que se reconhecia existir no cotidiano do homem comum deveria ser acrescida de parâmetros de cultura científica, capaz de libertá-lo de explicações supersticiosas e, nessa condição, absurdas. Parte-se do suposto de que a natureza seria regida por leis que nos são reveladas por manifestações as mais variadas. Sendo incognoscível o território das causas primeiras e inglória a busca do desvendamento absoluto do universo físico, competiria, ainda assim, ao homem, a observação e a decodificação das leis reguladoras do universo.

\footnotetext{
"Saber para prever, como disse um filósofo. O homem não pode perfeitamente ajustar a sua vida às leis naturais que o vitalizam, que o fazem feliz, fecundo e nobre, com uma ignorância completa de quanto o cerca, da causa imediata dos fenômenos que são o modo de existir da matéria. É verdade que, de muitos desses fenômenos, pela observação cotidiana, tem todo o homem uma intuição, que é, em certa maneira, previdente. Mas é um conhecimento incompleto, mesclado de absurdos quase sempre, e de que ainda certas superstições e uma falsa concepção da ordem natural das coisas prejudicam a boa lógica." 535
}

Mas nem todos viam a marca civilizatória da escola como uma virtude. Em 1899, artigo de Bethencourt-Ferreira para a Revista de Educação e Ensino destacava - sob o título "A Pedagogia no ponto de vista médico" - que as reformas da instrução pública sobrecarregavam os programas de ensino com disciplinas que, entulhadas em reduzido tempo, em nada contribuiriam para o progresso e divulgação das conquistas do conhecimento, estando, na maior parte das vezes, em desacordo com a marcha de aperfeiçoamento do espírito das sociedades. A crença na ciência amparava a crítica que se fazia à situação das escolas. Na verdade, em consonância com o parecer deste referido autor, nenhuma das reformas até então realizadas,

excelente ocasião de ensino; mas também o não ofendas, recebendo esses erros com gargalhadas de troça; porque a inocência de uma criança deve ser para nós tão venerável como os cabelos brancos de um velho. 10. Expulsa a mentira do teu lar, como vírus terrível. Habitua a criança a confessar sem medo seu delito; castiga severamente a dissimulação; sê leal sem requinte, para teres o direito de exigir uma lealdade igual, semente e flor do caráter." (Agostinho de CAMPOS, Mandamentos do bom educador, In: A Escola, nº147, 10-8-1904, p. 1-2). Os grifos são nossos.

${ }^{535}$ SCIENCIAS naturais nas escolas primárias, In: Educação Nacional, 7º anno, nº337, 8-3-1903, p. 187. "Noções de ciências naturais ao povo, sim, é preciso dar-lhas devotamente. Isto o há de melhorar no físico, no intelectual e no moral. Isto o levará para a higiene, que é pela maior parte dos homens completamente desprezada. Há de despertar nesse maior número dos componentes sociais o amor da verdade, que é a condição primária da elevação intelectual, e ela trar-lhe-á como lógica e bem produtiva consequência deste amor um mais fundo apego à sinceridade, à virtude, à solidariedade, ao bem. Porque a ciência não é, como muitos dizem, a esterilização do sentimento. Ela pode perfeitamente coexistir com as tendências levantadas duma alma profundamente mística. O homem que sabe ler no grande livro da natureza parece que adora esta com mais alto fervor. Não há alma superior que não aspire à verdade, por conseguinte, à ciência e nenhuma alma de poeta sem uma vibração sublime. O saber fortifica a razão alta que sabe da imaginação e do sentimento e que é a que produz os argumentos fortes dos grandes lutadores por um mundo melhor, de mais felicidade e de mais calma." (Id. Ibid., p. 169-70). 
“ (...) executadas, revogadas, esquecidas, relembradas, sucedidas de incerto êxito, condenadas todas, nenhuma houve na qual se possa gabar o particular cuidado na saúde dos jovens escolares, de nenhuma lei que apoiasse o seu fundamento em princípios de fisiologia, de psicologia, de higiene, desta última ciência ao menos, de tão imediata dependência médica, para que a reforma assim concebida lograsse ter por fim ou como resultado o aperfeiçoamento físico, a regeneração moral, o equilíbrio das funções cerebrais."

Havia quem - temendo os efeitos desconhecidos do potencial que a escolarização poderia carrear escondido - recusava a alternativa da escola e recordava, para aqueles que se diziam partidários da instrução em nome do progresso, os efeitos perniciosos que o mundo da cultura letrada vinha particularmente trazendo para as terras portuguesas desde que o século anterior irradiara à quase totalidade dos indivíduos o acesso ao impresso, o contato com o texto. Sugere-se que teria havido uma via editorial da corrupção dos costumes e que essa deveria ser sustada, de maneira a impedir que aquelas populações ignorantes, muitas vezes miseráveis, fugissem do controle dos que, além de possuidores do capital monetário, pretendiam ter o monopólio do capital simbólico que circulava por aquela sociedade. Logo depois da proclamação da República, havia ainda quem temesse a instrução como um valor popular... Jornais críticos do republicanismo - como era o caso de $\mathbf{O}$ Ensino - costumavam denunciar a exaltação das virtudes do progresso; dentre elas, a que agigantava o papel da instrução para o suposto aprimoramento da ordem que há pouco se instituíra. Naquele referido semanário - que convivia com a pecha de jornal reacionário por defender arduamente desde os tempos da monarquia a religião de Estado - sob o título "Instrução e civilização", texto redigido por João Manuel d'Abreu apresenta como tese o fato de o desenvolvimento do ensino ter sido acompanhado, não pelo avanço, mas pelo retrocesso da civilização. Na verdade, a acepção pela qual se compreende aqui o trajeto da civilização parece bastante esclarecedora, ao delimitar as fronteiras do objeto que pretende anunciar.

\begin{abstract}
"Civilizar quer dizer polir os costumes; dando lições práticas de urbanidade, observando os preceitos da boa cortesia, do decoro e do respeito, tanto nas ações como nas palavras. A civilização não consiste, como muitas pessoas julgam erradamente, na difusão da imprensa periódica, se tal imprensa não é essencialmente educativa, nem na sujeição ao império da moda, na adoção mensal dos figurinos, na arvorização das ruas e avenidas, no ajardinamento das praças, nos progressos do bom gosto arquitetônico: não. A civilização consiste em educar e policiar, ainda mais do que instruir.",537
\end{abstract}

536 BETHENCOURT-FERREIRA, Sobre a Pedagogia no ponto de vista médico, In: Revista de Educação e
Ensino, volume XIV, 1899, p. 146 .
537 João Manoel d'ABREU, Instrução e civilização, In: O Ensino, 24-12-1910. Dá-se o exemplo de senhoras que
eram molestadas na rua por indivíduos instruídos, porém destituídos das mais rudimentares noções de
urbanidade. Recorda-se, com saudosismo, que há meio século, quando não havia instrução para os "deserdados
da fortuna", existia entre os homens do povo, melhores hábitos, expressos no seguinte: "O espirito de obediência
era o distintivo dos humildes, como a polidez, a cortesia eram o adorno do homem instruído." Evoca-se,
inclusive, maior atuação da polícia para conter as manifestações públicas consideradas abusivas, seja como
ameaça à ordem, seja como desacato à autoridade. Imersos pelos efeitos daquilo que nos teríamos habituado a
chamar de civilização, os habitantes de centros urbanos estariam reféns de tais distorções: "Pois não se vem
fazendo, há um quarto de século, a mais intensa propaganda de imoralidade pelo jornal, pelo romance suspeito,
pelas ilustrações pornográficas, pela cena cômica recheada de ditos chulos, de esgares impudicos e tudo com
grande aplauso do pai de família? Uma sociedade civilizada por semelhantes processos, um povo que ouve e
aplaude a piada fresca, o dito picante, capaz de fazer corar uma tábua; uma sociedade, enfim, que alimenta tais
fatores de degenerescência moral e social será o que quiserem menos povo civilizado." Considera-se que estaria
então a haver nas nações européias de modo geral uma "degringolada" moral dos povos, com um padrão 
A escola era exaltada como templo do presente para redenção do passado de grandeza e construção de um futuro de elevadas expectativas. Desde o princípio do século, eram intensificadas as campanhas em prol da sensibilização dos órgãos administrativos e dos governantes para com o tema do ensino. O outono da monarquia anunciava a instrução como fonte de revigoramento nacional; e apontava para a encruzilhada do século como uma solene transição rumo ao firmamento e o cumprimento de promessas emancipatórias. Nessa direção, o periódico republicano Educação Nacional, que explicitamente rivalizava com O Ensino (tanto no regime de governo propugnado quanto nos métodos e procedimentos sócio-políticos sugeridos), procurava referendar a necessidade da instrução para o progresso do país. O Ministro do Reino, naquele limiar de século, teria afirmado que da causa da instrução pública dependia a evolução civilizatória da nação portuguesa. $\mathrm{O}$ rei - no discurso da coroa - teria também dedicado algumas palavras para o tema da educação. O editorial datado de 7-1-1900, no número 172 da Educação Nacional apresentava júbilo, esperança e expectativa em relação aos rumos futuros da instrução e do ensino. Principiavam os últimos cem anos do milênio; e

\begin{abstract}
"Portugal vai enfim entrar na comunhão dos povos cultos. Vai retomar o lugar que lhe pertence na grandiosa história dum passado fúlgido. As almas amantes da pátria, os corações que ainda não estavam empedernidos para os impulsos do bem, os cérebros que ainda não se encontravam amolentados para as altas inspirações do progresso, devem, neste momento, sentir uma viva impressão de alegria. É que temos promessas solenes, é porque os que dirigiram a nau do Estado despertaram, enfim, da sua comatosa indiferença para acudir ao problema capital da atualidade." 538
\end{abstract}

A escola primária é tida como alavanca de reconstrução nacional e deveria, sob essa égide, alçar-se como prioridade inarredável da monarquia. Extinguir o analfabetismo era plataforma que contaria com a militância da imprensa periódica, a qual, por sua vez, teria na Educação Nacional papel de destaque. O discurso frisava o lugar de resistência que aquela tribuna desempenhara na interpretação diária do sentimento coletivo dos educadores, de sua missão, de sua tarefa de classe. Criticando impiedosamente a indiferença dos poderes públicos para com a causa educacional, o jornal perfilhara intensa campanha pela arquitetura de uma sólida escolarização primária. Na verdade, entendia-se aqui que o progresso viria na esteira da

civilizatório mais próximo do "estúpido paganismo romano" do que de quaisquer metas traçadas pela orientação social. O exemplo do desnorteamento evidenciado seria sintomático na idolatria com que se passara a julgar a idéia de República: "Então como traduzir o culto prestado à figura da República, na Horta, por sete marinheiros que, em plena calçada, se descobriram e dobraram o joelho ante uma mulher que simbolizava o atual regime? Não consentimos que ninguém mais do que nós acate o atual regime; mas o culto de adoração só pertence a Deus. A idolatria está bem para os selvagens, mas de modo nenhum para os homens que se dizem civilizados. Não confundamos o culto do Deus vivo, aliás tão combatido pelos espíritos fortes, com os sinais de respeito por uma idéia e por um sistema. Oh! Não retrocedamos aos tempos em que predominou a superstição na Babilônia, no Egito, na Grécia e Roma! Não precipitemos a sociedade no princípio ... do fim ! As ruínas de Tiro, Babilônia e Jerusalém estão aí patentes a quem as quer examinar, mostrando que, quando a majestade do Onipotente é ofendida, quando os mentores da sociedade a paganizam, ao contrário de a civilizar, perto está o 'Flagelo de Deus'. Eduquemos, pois, e civilizemos.” (Id. Ibid.)

538 “(...) trabalhem todos os que podem concorrer a fim de ser levantado o nosso país pela escola primária, porque a glória chega para todos (...) Nem deve haver partidos nem vaidades ofendidas. A causa é de todos nós, a causa é nacional (...) O governo há de desejar a extinção desse enorme exército de analfabetos, que ao raiar o século XX obumbram as brilhantes manifestações do progresso moderno. Há de envidar toda a sinergia dos seus esforços para pôr o termo mais rápido às desgraças que oprimem a malfadada escola primária portuguesa." (AURORA da Esperança, In: Educação Nacional, 7-1-1900, nº 172) 
civilização: "Já examinamos qual é o poder da educação. Vimos que a sua reflexão não se estende apenas a uma geração isolada, mas que os homens e as gerações vindouras são beneficiados pela herança que os avoengos legaram. Para obter esse desidrato o professor deve exercer a sua ação por três meios: $1^{\circ}$ ) pela educação propriamente dita; $2^{\circ}$ ) pela instrução; $3^{\circ}$ ) pela disciplina." ${ }^{\text {"539 }}$

No que concerne aos objetos próprios a cada um desses três fatores acima arrolados, entende-se por educação o desenvolvimento das faculdades da criança, de sua inteligência para torná-la capaz de aprender aquilo que é necessário que conheça. Já a instrução seria voltada para o enriquecimento da memória, trazendo para o espírito a substância anteriormente preparada pela ação educativa. Unidas por laços estreitos, instrução e educação teriam, por ser assim, inegáveis elos de complementaridade. ${ }^{540}$ Uma não existiria sem a outra e, através dessa conjugação, o homem se faria conhecedor da "origem de seus direitos" e do "valor de seus deveres". O domínio humano sobre a natureza e o hábito do convívio social exigiriam, por seu turno, conhecimentos específicos de elementos introdutórios a todas as ciências, particularmente a Geografia e as ciências do solo. A escola capacitaria o indivíduo para o trabalho; para a conquista, para o domínio. Portugal permanecia aquém do restante da Europa por não ter sido capaz de construir metodicamente estratégias apropriadas para lidar com o solo, com a agricultura, com a indústria, de modo a alavancar a economia. Portugal atrasara-se por não haver coroado as conquistas pelo imprescindível desenvolvimento técnico. Portugal distanciara-se assim de sua vocação original de grandeza. Ora, cabia recuperar o lugar perdido voltando-se antes para o universo da metrópole do que para a vida colonial. Compreender cientificamente aquele território e aquele povo, esses eram, sim, os verdadeiros e contemporâneos desafios ${ }^{541}$ :

539 AURORA da Esperança, In: Educação Nacional, 7-1-1900, no 172.
540 "São como duas espécies do mesmo gênero, ou como uma idéia comum, distinta por matizes. Uma forma o
caráter, os hábitos; a outra eleva e alimenta a inteligência; uma dirige-se à alma, ao coração, às paixões; a
outra, à imaginação, ao entendimento, ao espírito. Enfim, poderia-se quase dizer que a educação sem instrução
seria impossível porque é esta última que traz os materiais de que a educação deverá servir-se para elevar a sua
obra. Compreende-se agora porque uma nação que quer fazer homens, na mais alta e larga acepção do termo, exija instrução obrigatória. ” (AURORA da Esperança, In: Educação Nacional, 7-1-1900, n 172)

${ }^{541}$ Editorial da Educação Nacional, datado de 15-5-1900, sob o título "Ainda não..." reporta-se à defasagem de Portugal perante os outros países como fruto de errôneas opções históricas: "O nosso país, que na sua pequenez já foi grande, que dormitou durante séculos enquanto as outras nações compreendiam o progresso, começa agora a despertar e a fazer tentativas para recuperar o tempo perdido. Enquanto Portugal gastou um tempo precioso olhando sua alma mórbida, lá fora, outros povos, que de nós receberam lições, entendendo melhor a vida e vendo de que lado sopravam os ventos, foram construindo, à nossa custa, o edifício da sua grandeza. Nós, como acima dizemos, também parecemos acordar. Mas este despertar dum sono que durou séculos não é a valer. As tentativas da nossa indústria, tentativas que nem merecem simpatia porque nascem do estímulo do interesse e não podem produzir um grande bem humano, terão de chegar em breve ao seu termo. A nossa indústria só pode viver à custa dos pretos e é certo que, para uma data mais ou menos próxima, nem com os pretos poderemos contar. Pretos há de havê-los ainda por muitos séculos, mas é que os pretos, dentro em pouco, já não poderão ser nossos. Não lhes poderemos vender nada. Conseguintemente é fictícia a vida da nossa indústria. Por quê ? Por muitos motivos, entre os quais avulta o de chegarmos tarde à luta da concorrência (...) Um outro motivo, talvez secundário, é o nosso atraso intelectual (...) A ciência é a rainha do tempo e ai de quem não lhe presta vassalagem. Lá fora assim se compreendeu e ninguém há que não veja na sua supremacia uma condição infalível e indispensável de progresso. Entre nós, não. Vivemos no culto da santa ignorância, sem ao mesmo tempo termos aquela fé firme e robusta que leva a desprezar as coisas da terra para só pensar nas coisas do céu. Neste ponto, somos um povo único, cujas desgraças e cuja miséria ainda não foram postas em toda a evidência porque há nos portugueses uma tal vivacidade intelectual que encobre a monstruosidade da ignorância em que vivemos. Não temos industriais inteligentes nem operários educados.” Considera-se que, diante de tal situação, os políticos desprezariam aquela que seria, ao fim e ao cabo, a única tábua de salvação da pátria a degenerar-se: a instrução primária. Nos termos do mesmo editorial: "Reconhece-se que a nossa instrução vai mal. A primária, que é o fundamento e a base de todas as outras, arrasta-se numa vida mesquinha, sem escolas, sem material de ensino, sem mestres suficientemente remunerados, com imposições odiosas e jugos legais impossíveis a pesarem sobre eles.” (AINDA Não..., In: Educação Nacional, 15-5-1900, n 190). Por 
"Podemos resumir nossa opinião sobre a utilidade e valor do saber nesta fórmula da filosofia contemporânea: saber, a fim de prever e prover. Objeta-se, é verdade, a estas diversas considerações, que os maiores criminosos eram os mais instruídos e deduz-se daí que a instrução não pode ter nenhuma influência moralizadora. A isso responderemos que realmente a instrução mal dada, isto é, sem o concurso da alta inspiração moral, pode oferecer tristes e deploráveis resultados. Não é dessa instrução que se trata aqui. A instrução verdadeira não pode passar sem o concurso da educação, e da mesma forma que é facilitar a obra desta última exercer e esclarecer o espírito pela instrução, da mesma maneira também é preparar para a instrução uma base sólida e cultivar a alma pela educação."

Seja como for, as estreitas relações entre educação, instrução e disciplina constituiriam os pilares norteadores da "preparação das faculdades da inteligência", da "aquisição de conhecimentos úteis e indispensáveis", e do "hábito de submissão, de obediência, de respeito". Não se louva aqui quaisquer méritos da imaginação ou da faculdade criativa. Pelo contrário: o que possibilita o amadurecimento intelectual é - na visão do texto a tenacidade, a persistência, a perseverança; que, no conjunto, conformariam as atitudes e os hábitos que permitiriam florescer no indivíduo o salutar convívio com os códigos e as regras impressas no mundo da cultura letrada. Na mesma direção, passam a ser frequentes os artigos que salientam o valor da educação física na orientação pedagógica das gerações mais jovens. A sensibilidade dos nervos, amenizada pela prática regular dos exercícios físicos, passava a ser tomada por matéria pedagógica, na mesma proporção que se reconhecia o equívoco da recorrência exclusiva ao recurso da memória. Educar pelos sentidos, pelo físico e pelo psíquico seria na verdade complementar a tarefa do exercício intelectual. Ou, mais precisamente, nos termos da Revista Pedagógica de 17-9-1907:

\begin{abstract}
"O povo português encontra-se num estado aflitivo porque, para viver, um povo precisa também de ar e de luz; a atmosfera que deve respirar é a liberdade, e a luz é a instrução que o coloca em igual latitude à dos outros povos civilizados. $\mathrm{O}$ povo português sente-se infeliz porque vê que não pode avançar; porque é analfabeto. Um mal estar a todos inquieta e desassossega, porque, lavrando o indiferentismo, atrofia-se o cérebro da nação; a decadência originada da falta de instrução deprime. O espírito nacional congestiona-se pois a tão decantada normalidade parece mais um prenúncio de bancarrota moral e cívica; e o professor primário, apesar das palavras bombásticas com que o qualificam, como - alavanca... do progresso, archote... da civilização; continua abandonado. Oxalá que as gerações que nós educamos não se esqueçam de quem as ensina a ler., 543
\end{abstract}

quaisquer motivos, a discussão sobre as escolas seria entretanto adiada pelo parlamento, e os legisladores, de maneira geral, passavam alegremente a discussões estéreis sobre a caça.

${ }^{542}$ AURORA da Esperança, In: Educação Nacional, 7-1-1900, $\mathrm{n}^{\mathbf{0}}$ 172. A obra educativa exigiria porém o recurso à disciplina como parte constitutiva da ciência da educação. Sobre ela, continua o texto: "Mas para que esta influência moralizadora e recíproca possa estabelecer-se, é preciso que o educador tenha o recurso de certos meios, fundados sobre a própria natureza da criança para a qual são escolhidos. O conjunto destes meios constitui a disciplina, terceira parte da ciência da educação. Se a instrução é necessária para completar a educação e para a auxiliar na sua obra, não é menos indispensável para permitir à educação que produza seus frutos. Todo o sistema disciplinar varia segundo a opinião que se faz do homem. Se o acreditarmos nascido mau, como os teólogos, temos de lançar mão de grande aparato de severidades. Se o julgarmos bom, como Rousseau, deveremos falar à natureza e ela se encarregará da repressão, do castigo ou da recompensa. Devemos usar da 'severa doçura' de que fala Montaigne, ou da paciência que reclama Fenelon. Mas, em todos os casos, e seja qual for o ideal a que o educador se proponha, deverá ter sempre ao lado uma certa soma de meios disciplinares, que serão como os guardas e conservadores das vantagens adquiridas pela educação." (Id. Ibid.)

${ }^{543}$ Eusébio de QUEIROZ, Divagando, In: Revista Pedagógica, ano 2, no 36, 17-9-1907 
Naquela época, o reconhecimento - por parte dos educadores e simpatizantes da causa do ensino - quanto à inefícácia da ação governamental revestira-se já por uma tonalidade corporativa cuja grande marca vinha sendo firmada pela ação dos Congressos e das Conferências Pedagógicas, além da atividade tenaz e persistente da Liga Nacional da Instrução, sobre a qual costumeiramente discorria a imprensa especializada. ${ }^{544} \mathrm{O}$ professor primário passava a ser tomado pelo profissionalismo e pela força política que sua tarefa específica já por si continha. O professorado reconhecia, coletivamente, a força simbólica que poderia desempenhar e passa a agir em nome dela. Por sua vez a imprensa especializada assumiria, de uma vez por todas, sua voz, pretendendo já agora falar pela boca da própria criança. Havia jornais e revistas que eram destinados diretamente aos alunos. Neles também, e com significativa frequência, insistia-se em denunciar o descaso dos poderes públicos para com os assuntos do mundo da cultura. Como consequência, invariavelmente era pontuado o atraso de um país que não caminhava no ritmo intensificado de desenvolvimento e prosperidade que aparentemente dirigia o resto da Europa. No campo da cultura e da educação, o ritmo era seguramente insuficiente, aos olhos dos conterrâneos. A 9-1-1909, artigo que se seguia às férias de final de ano - sob o título "Bem Vindos" - revelava, acerca do assunto, o parecer do periódico $O$ Gorro: jornal dos alunos do liceu de Coimbra, dizendo o seguinte:

\begin{abstract}
"Os livros, companheiros inseparáveis, sim, mas porque a isso nos obriga a força das circunstâncias. Perdoai-me, queridos colegas, mas a verdade é esta: nós, estudantes, na maioria, em grande maioria, odiamos os livros. E por quê? Porque nós, portugueses, somos indolentes por educação e contágio, não temos amor pelo trabalho e conseguintemente nós, estudantes, carecemos de amor pelo estudo; é esta a regra geral. Não absolvo aqui ninguém, nem o próprio mestre que bastas vezes enferma do mesmo mal. É certo que hoje se estuda algum tanto mais que noutros tempos mas o que não merece dúvida é que se estuda pouco, e esse pouco apenas com o fim de satisfazer os mestres mais ou menos exigentes, outras vezes estuda-se por vaidade e orgulho e nunca com o desejo de estudar para saber."
\end{abstract}

\footnotetext{
${ }^{544}$ Segundo dados fornecidos pelo trabalho de Catroga, a Liga Nacional de Instrução teria sido fundada em 1908, possuía tendências republicanas e laicizantes, defendendo como eixos de sua intervenção social a questão da gratuidade e da obrigatoriedade da escola primária. O programa da Liga abarcaria os Congressos Pedagógicos realizados nos anos de 1908 e 1909. A fundação daquela agremiação político-educativa tinha como objetivo como remarca o próprio Catroga - "combater o analfabetismo e dar à sociedade portuguesa uma alma nova, através do lançamento das 'bases da educação nacional na sua completa integração, sob os aspectos fundamentais, - físico, intelectual e moral, criando o verdadeiro ensino superior, transformando radicalmente o secundário, difundindo o primário e aperfeiçoando o técnico - tudo isto em relação íntima com as nossas necessidades e com o espírito da civilização moderna'. Perante este programa, não é de espantar que encontremos destacados republicanos nos núcleos fundadores e dirigentes da Liga." (Fernando CATROGA, O republicanismo em Portugal: da formação ao 5 de outubro, segunda parte, p. 395-6)

${ }^{545}$ M. MIGUENS, Bem Vindos, In: O Gorro: jornal dos alumnos do lyceu de Coimbra, $1^{\circ}$ anno, $5^{\circ}$ número, 9-1-1909. Alguns dias depois, o mesmo periódico publicaria sobre o tema artigo de Maurício S. Monteiro intitulado "Educação". Dizia este o seguinte: "A ignorância é muitas vezes um mal tão prejudicial como uma epidemia devastadora, porque enerva os espíritos daqueles que podiam produzir alguma coisa, envolvidos como estão naquele ambiente anti-progressivo. O nosso meio social ressente-se um pouco deste mal. Enquanto o francês, o inglês, o alemão, estuda, investiga e inventa, o português dorme descansado e esperançoso à espera de melhores tempos, relembrando os feitos passados, descurando as ciências, letras e artes. Todo o cidadão deve ter uma idéia definida sobre o papel a desempenhar na sociedade e para isso é necessário ter certas noções dos deveres cívicos. Ora é isso que infelizmente não temos em Portugal, mercê da assustadora percentagem de analfabetos! E daqui vem o principal motivo e talvez o único porque nós em vez de progredirmos temos ficado quase indiferentes à grande marcha progressiva de toda a Europa. Onde buscar remédio para tão grande mal? Grande parte em vós, colegas, esperançosos obreiros da civilização. A Pátria alberga em vós a esperança de seu alevantamento intelectual e artístico de maneira a poder nivelar-se com as
} 
O princípio do século traria um novo estatuto para o professor primário, que agora passaria a ser efetivamente reconhecido pelos intelectuais como o primeiro grande e insubstituível apóstolo da causa da civilização. Nem sempre, porém, os intelectuais conseguiam convencer as populações; e aqui não se tratava de uma exceção. Artigo de Cesário Tavares publicado na Educação Nacional de 23-11-1902, sob o título "Mestre-escola e professor primário" identificava as dificuldades quanto ao reconhecimento efetivo do valor social de uma profissão que efetivamente carecia de prestígio ${ }^{546}$. A própria utilização ainda em voga da expressão "mestre-escola" parecia suficiente para evidenciar o menosprezo, a zombaria, e principalmente o não reconhecimento do estatuto profissional daqueles "funcionários da primeira instrução". Na verdade, supunha-se que o "escárnio das multidões" pelo mestre-escola decorria de sua tarefa de apóstolo da civilização, ainda que, muitas vezes, se dedicasse a ela sem dedicação e sem entusiasmo. Séculos de ignorância - recorda o referido articulista - fizeram por induzir o descaso e o desprezo justamente pelas mais elevadas das profissões, dado que, em coro com os professores, os médicos e os escritores eram também reputados em baixa consideração na escala social. Na verdade, o desprezo pela escola e muito particularmente pelas letras era identificado como um dos mais perniciosos males da sociedade portuguesa. A mesma sociedade que desdenhava os mestres repudiava as letras...

\footnotetext{
“(...) ninguém como o mestre de primeiras letras atentava mais diretamente contra a bestialidade contumaz dos que compunham as multidões. A ignorância é ousada e o mal é pertinaz. A revolta é o que se depara logo a quem se propõe suprimir estas coisas irritantes. Mas abstraindo de toda a idéia de mal, que com a ignorância melhor se casa, o saber devia de ser qualquer coisa de diabólico que podia subverter o mundo e por isso os sábios eram estranhos seres que pactuavam com o demônio. Vencida, ao fim, essa noção falsa, ainda ficava a rebeldia aos hábitos de polidez, de higiene e de disciplina que a educação traz consigo. As paixões pressentem vivamente o que as há de contrariar e os hábitos de infância ficam verdadeiras paixões. No típico mestre-escola, sem ciência, sem orientação, anteviam as multidões a revolução pedagógica que havia de atingi-las. E reagiam, irritavam-se, vingavam-se com fúria no pobre ser faminto, miserável e bufão que em tristonhos pardieiros ensinava a ler meia dúzia de crianças, filhos de pais corajosos e já de ambições mais altas, ou porventura de idéias fundamentalmente progressivas. Passaram-se os
}

\footnotetext{
nações modelos e dizer orgulhosa: ainda somos os mesmos portugueses.” (S. MONTEIRO, Educação, In: O Gorro: jornal dos alumnos do lyceu de Coimbra, $6^{\circ}$ número, 23-1-1910)

546 "Até a entidade professor primário, mestre-escola, no citado dizer expressivo, serve ainda às vezes a romancistas, contistas, escritores de teatro, jornalistas e gazetilheiros, ou de tipo irrisório de caricatura grotesca, ou de inspiração de prosas trocistas, de versos hilariantes. Assim nisto se nivelam muitos trabalhadores do pensamento, ou às vezes pretendidos tais, com a baixa canalha que nas sociedades ainda vegeta, sem criação e sem letras, sem outra lei que a da necessidade, sem outro respeito que o da força da autoridade constituída, rebelde à civilização, invejosa do justo bem que os dignos desfrutam, e na qual em verdade o professor primário ainda suscita certa mofa, algo de revoltante grosseria. Restos da tradição do mestre-escola ignaro, sem saber e sem caráter, a lembrar na aversão geral com que o tratavam, nas vaias, nos apuros com que era sempre saudado da gente grosseira, sem ideais, aquele desprezível escravo que os espartanos embriagavam para servir de asco aos que deviam ser os futuros cidadãos da república valorosa. Na verdade, o mestre-escola era uma criatura limitada, sem boas noções profissionais, cheio de baixezas e servilismos, quase mendigo, quase palhaço, com vivos traços de charlatão, um todo de ser nauseante $e$ profundamente lastimável. Entretanto quantos deles talvez não possuíram almas superiores, de exceção, com altas e legítimas ambições e aos quais a sorte afligiu com requintes de tortura nessa posição deprimente, a imginação a mostrar-lhes distante, malogrado, nas horas de mais profunda melancolia, um destino sonhado de venturas e bem merecidas glórias. Fado talvez!" (Cesário TAVARES, Mestre-escola e professor primário, In: Educação Nacional, $7^{\circ}$ anno, $n^{\circ} 322,23-11-1902$, p. 53).
} 
tempos. Generalizou-se mais a vontade de aprender, exceção de aldeias sertanejas, onde o abandonamento é a lei, e onde a civilização provoca protestos e risos de rude violência."547

No entanto - destaca o redator - a população procurava na escola meios para poder ter acesso a carreiras lucrativas. Nessa inflexão dos tempos é que o mestre-escola teria sido substituído pelo professor primário. A mudança de expressão traria em sua carga semântica notável conteúdo simbólico, à medida que o professor primário pretende ser um profissional consciente, pautado pelo rigor de uma assumida ciência pedagógica: “(...) se a escola faz a ele, é ele quem faz a escola.” Tendo por carreira o perfil de uma nova profissionalização, ele deveria ter já uma formação específica, um curso profissional que lhe preparasse para o exercício pleno do magistério. Nesse curso, o aspirante a professor travaria contato com as conquistas da então considerada ciência da educação. Com a prática, seu ofício tornar-se-ia mais metódico, os processos e as formas de atuação mais disciplinados e seu estatuto profissional parecia já inconteste.

Frequentemente apontado como a grande alavanca da instrução pública, reconhece-se no professor primário a verdadeira possibilidade de motivação das populações ao estudo. Tendo herdado do mestre-escola atributos como modéstia, escrúpulo, caráter, decoro, lisura e decência, o professor primário é tomado como arauto das virtudes cívicas e sociais e talvez nessa qualidade residisse grande parte do segredo do poder que desempenhava. Ressalta-se ainda seu veio estudioso, dado que, a despeito da baixa remuneração, gastava vultosas quantias para a aquisição de livros e assinatura de jornais. Cerrando fileiras pela causa da instrução, sendo dela o primeiro apóstolo, o professor primário seria, acima de tudo, um militante convicto, que, entusiasmado, convenceria os relutantes sobre os benefícios da escola, sobre a validade do aprendizado escolar. Caberia, pois, a ele o futuro de regeneração de um Portugal decadente. ${ }^{548}$ A educação para o professor da escola primária deveria, portanto, ser primeiramente uma aposta; aposta global de modelagem de um futuro em nome do qual ele empenharia a própria vida... ${ }^{549}$

\footnotetext{
"Porque o seu zelo não se exerce só no penoso trabalho que lhe cabe. Faz sua a grande causa da instrução do povo e por todos os modos a serve e por todos os seus aspectos a fortalece. Escolas há que não teriam frequência sem a sua tenacidade de propaganda. Enfim, está bem no domínio da verdade a afirmativa de que todo o moderno progresso da escola popular, de Portugal se fala somente, compreende-se, deve-se ao professor primário principalmente. Está-se bem longe, pois, do mestre-escola, de desopilante tradição. (...) E quem há de regenerar Portugal há de ser o professor primário; ele á quem há de restituir à nossa velha tradição o seu bom nome d'outrora, esse nome pungente em todo o largo mundo conquistado por feitos famosos de vantagens para a civilização. Que o modesto servidor da escola popular cada vez melhor preencherá, principalmente impelida dessa sua devoção própria tão relevante e tão nobre, a missão levantada a que foi
}

\footnotetext{
${ }^{547}$ Cesário TAVARES, Mestre-escola e professor primário, In: Educação Nacional, $7^{\circ}$ anno, $n^{\circ}$ 322, 23-111902, p. 53.

${ }^{548}$ A metáfora da luz atribui a sacralidade a este funcionário da civilização, como explicita o próprio texto a que temos nos referido: "Trabalhador, não há no país funcionário mais diligente, mais escravizado ao dever. Ninguém sabe quanto é rude, quantas vezes escuramente desonsoladora essa tarefa larga do ensino de crianças, senão a criatura que a exerce. Mas ativo e resignado, como preceitua a melhor filosofia, é assim que o professor primário vai com a luz de sua alma iluminando muitas almas, com a sua vontade, preparando outras vontades, com o seu amor, aliciando corações e sempre à sua fé robusta atraindo novos crentes." (Cesário TAVARES, Mestre-escola e professor primário, In: Educação Nacional, $7^{\circ}$ anno, n³22, 23-11-1902, p. 54)

549 A idéia da educação como uma aposta social é retomada com muita frequência na história das idéias pedagógicas. A respeito do tema, teríamos na atualidade a referência do texto de Hubert HANNOUN, Le paris de l' éducation.
} 
chamado, e que é com efeito a de fazer entrar o seu país no caminho do progresso justo e extensamente libertador."550

\section{O ASSOCIATIVISMO DOCENTE E A CRÍTICA AO MÉTODO JOÃO DE DEUS}

Muito do que dizia sobre o reforço do laço associativo entre os professores tinha a ver com as reivindicações específicas da questão do magistério público e de suas condições de trabalho, tendo em vista inclusive a proximidade de reformas do ensino público que, desde o final do século vinham sendo pelos jornais anunciadas. Nessa medida, também a imprensa especializada cumpriu indubitavelmente um papel singular, por irradiar informações sobre o estado e as perspectivas da escolarização no país naquele momento. Essa imprensa especializada seria dividida entre os jornais reconhecidamente adeptos da causa republicana como A Federação Escolar e A Educação Nacional - e aqueles que dela se distanciavam como $O$ Ensino. No primeiro caso, tratava-se de incentivar a agremiação do magistério, reforçar a idéia de associativismo e lançar as sementes para que os professores fossem efetivamente os grandes divulgadores da causa da República na agenda da sociedade civil. No segundo caso, tratava-se de deter o movimento e evidenciar que o tema da educação nova nada teria a ver com a acepção mais literal da política e que as imprescindíveis reformas da instrução poderiam ser acopladas a uma perspectiva religiosa e tradicional, não implicando as complexas transformações políticas que os republicanos, ligados à Liga Nacional de Instrução, pareciam exigir.

Ora, havia, contudo, outras questões, aparentemente menores, mas que na época tiveram significativa expressão, merecendo, pois, tratamento extensivo dos jornais e revistas pedagógicas. Uma das discussões que com maior frequência apareceria nos jornais ligava-se ao debate sobre o método João de Deus e particularmente sobre a ação que vinha sendo desenvolvida pelas Escolas Móveis. Paralelamente aos aplausos que inegavelmente a iniciativa angariara - como já pudemos observar no capítulo anterior deste trabalho - houve resistências, críticas e mesmo certo repúdio, expresso em inúmeros e constantes artigos publicados em jornais, quer da direita, quer da esquerda. Era natural - diga-se de passagem que essa polêmica ocorresse. Os jornais e associação, de algum modo, ligados à categoria dos professores, explicitamente rivalizavam-se para disputar quem representaria o papel de vanguarda política daquela "classe" profissional que vinha, a passos largos, descobrindo e utilizando seu papel de formação da opinião pública. Quem seriam as lideranças? Quem enfim responderia pelo coletivo? Quais vozes ressoariam com maior intensidade? Quem portanto obteria a representatividade para falar em nome do professorado? João de Deus Ramos era um dos mais fortes pretendentes ao posto de vanguarda. João de Deus Ramos era filho de João de Deus e aproveitava-se do prestígio e do nome que a memória do pai lhe deixara. Em função disso - particularmente nos anos que imediatamente antecederam à proclamação da República - Ramos proferia inúmeras conferências por todo o país insinuando aos professores do ensino público a necessidade histórica de se adotar a cartilha de seu pai que, segundo ele, além de ser incomparavelmente melhor, era também mais barata do que as outras. O fanatismo com que o método de João de Deus era tratado contribuiria para que a imprensa mais reacionária sobre isso se mostrasse ao lado do que supostamente havia de mais progressista. Eram muito comuns os artigos que vinham criticar a atuação fanática dos adeptos de João de Deus naquele princípio do século. Tanto A Federação Escolar, quanto $\mathbf{O}$ Ensino teciam críticas extremamente frequentes e ácidas às comparações que se costumava

\footnotetext{
${ }^{550}$ Cesário TAVARES, op. cit., p. 54. Os grifos são nossos.
} 
fazer à época entre João de Deus e alguns dos mais renomados nomes da pedagogia mundial, como Comenius, Rousseau, Pestalozzi e Froebel ${ }^{551}$. João de Deus era apresentado como o grande educador português de todos os tempos. Havia quem sublinhasse o despropósito.

Artigo de Augusto Lessa - publicado n’A Federação Escolar de 27-11-1909 discorre a propósito de indagações relativas ao método João de Deus. O autor tentava ali ponderar que, apesar do respeito que o professorado primário teria pela memória e pela obra educacional do poeta, o método dito "maternal" não poderia - em virtude dos crescentes progressos da nova pedagogia - ser aceite de maneira inequívoca. Na verdade, naquela ocasião, a Associação das Escolas Móveis teria alardeado em uma circular que a adoção oficial do método facultaria para as escolas de estado uma significativa economia, além de incontestável melhoria nos padrões e nas práticas do ensino da primeira leitura. A crítica aqui coincide com a tônica do editorial datado de 6-11-1909 quanto ao questionamento dos procedimentos adotados para a elaboração das estatísticas. Na sequência, a controvérsia acerca da adoção do livro único:

\begin{abstract}
"O método João de Deus estacionou no seu autor e foi-se com ele. Como princípio inicial do ensino da leitura deixa hoje muitíssimo a desejar. O avanço da ciência e a moderna pedagogia têm hoje meios mais que suficientes ao seu alcance para poderem conseguir mais e melhor, duma maneira real e positiva sem auxílio do tão apregoado método de João de Deus. Não queira a associação impor o método como livro único. Combata, discuta, que da discussão nasce a luz. Agora, pretendendo metê-lo à cara, como sendo uma coisa única, um verdadeiro maná, isto às escuras e nas encruzilhadas sob a ameaça do punhal, envenenando a mentira, brandido por qualquer celerado, assim... adeuzinho., ${ }^{, 552}$
\end{abstract}

Tratava-se de uma questão eminentemente política. Não se atacava propriamente os deméritos da cartilha em si, embora se destacasse sua inadequação em face dos atuais progressos da pedagogia. Não se questionava mais a validade didática do método global que

\footnotetext{
${ }^{551}$ Artigo publicado n’ A Federação Escolar sob o título “João de Deus Ramos e a Cartilha Maternal criticava o educador pela obsessão deste em oficializar o método de seu pai. Atacando aqueles a quem chama de fanáticos, o autor diz o seguinte: “A Cartilha Maternal, todos os nossos camaradas de trabalho o sabem, é uma obra péssima, sob o ponto de vista pedagógico, e é um perigo, sob o ponto de vista higiênico. É certo que João de Deus teve prosélitos fanáticos pela sua obra e não é menos certo que ainda hoje existem criaturas que apontam a Cartilha Maternal como maravilha. Dentre estes, destacam-se alguns jornalistas, cuja incompetência em questões de pedagogia papenteiam claramente na impropriedade dos termos. É ver: nos jornais diários, tudo se reduz ao...método. Um sistema de leitura, como a Cartilha Maternal é um método, os processos, as formas, os modos e o método de ensino, tudo isto é o método! E o fanatismo pelo nome de João de Deus, numa inconsciência que punge quem sinceramente se interessa pelas coisas da instrução, vai até ao ponto de comparar o poeta a Comenius, Pestalozzi e Froebel! Fê-lo ainda há dias em Lisboa, num discurso primoroso na forma, o ilustre parlamentar e lente da Universidade sr. Dr. Egas Moniz! Comenius, Pestalozzi e Froebel ao lado do autor da Cartilha Maternal. Que heresia!” (JOÃO DE DEUS RAMOS e a Cartilha Maternal, In: A Federação Escolar, nº 12, 7-4-1909).

${ }^{552}$ Augusto LESSA, Pau de Laranjeira, In: A Federação Escolar, no 46, 27-11-1909. A 18-12-1909, o mesmo articulista escreve outra vez - agora valendo-se da variação sobre o mesmo título: Pau de... Laranjeira -, com a pretensão de oferecer aos leitores uma réplica aos argumentos tecidos pelo tal Laranjeira, que teria dito que os professores primários produzem dez vezes menos o valor de seu ordenado. Indignado, Augusto Lessa replica: "Com a existência matemática e insofismável dos números, pretende arrastar, para sobre o professor primário, a grande responsabilidade do estado de miséria mental em que se encontra o povo português. Que responsabilidade poderá caber ao atual professor primário pelo estado de analfabetismo em que se encontram os indivíduos maiores de 30 anos, que são os que maior contingente fornecem para essa enorme porcentagem de $70 \%$ d'analfabetos na população portuguesa? Que responsabilidade caberá ao professor primário pelo estado decadente da instrução primária, quando o Estado se furta a proporcionar-lhe os requisitos indispensáveis para a extinção desse mal, privando-o por consequência de contribuir poderosamente para a grande regeneração social?” (Augusto LESSA, Pau de... Laranjeira, A Federação Escolar, 18-12-1909, nº 49).
} 
em Portugal João de Deus inventara. Tratava-se, antes, de desqualificar a autoridade do filho e do uso mercadológico que este fazia da descoberta do pai. Ramos era acusado por inúmeros veículos de imprensa - republicanos e monárquicos - quanto ao uso que se fazia dos recursos angariados pela ação das Escolas Móveis. Por outro lado, tornava-se cada vez mais evidente aos olhos dos educadores que a divulgação da Cartilha Maternal tornava-se, cada vez com maior intensidade, uma questão de dinheiro. Era o momento onde ficara claro que - de uma vez por todas - o mercado editorial controlaria grande parte dos debates pedagógicos do mundo capitalista. Muitos eram os artigos - como o de Oliveira Mendonça publicado n' A Federação Escolar de 18-12-1909 - que acusavam a cizânia sobre a Cartilha Maternal, declarando que se tratava fundamentalmente da preocupação de João de Deus Ramos com a venda da obra de seu pai. Tendo em vista o parecer daquele educador quanto aos índices de fracasso escolar recentemente publicados, Mendonça chamava-lhe de "patriota de algibeira, que vive da venda da Cartilha". No mesmo acorde, o movimento das Escolas Móveis era também acusado de se alicerçar na clara tentativa de desprestigiar o ensino oficial. A venda da "paternal" cartilha era irredutivelmente o objetivo último de Ramos e seus partidários:

\begin{abstract}
"Eles dizem a miúdo que os professores oficiais lhe não entendem o método, o que para eles é o menos - desde que lhe comprem a cartilha. O célebre Dr. Sem Clientes Laranjeira - o tal da Pátria já levou até a sua incoerência, para não lhe chamarmos coisa pior, ao ponto de no último congresso promovido pela Liga Nacional de Instrução afirmar que o professorado oficial não sabia ensinar pelo método, ao mesmo tempo que advogava a idéia de pedir ao governo para impor a adoção desse método nas escolas oficiais. Ora o que, certamente, o homem queria era isto: que o professorado oficial fosse compelido a fazer-lhe gasto na cartilha. Que importava não conhecer o método? - bastava conhecer o livreiro..."
\end{abstract}

Os católicos que, na outra margem, se agremiavam ao redor do semanário $\mathbf{O}$ Ensino também revelavam bastante inquietação quanto ao êxito que as Escolas Móveis pareciam obter na época. Julgava-se que ali estava um poder concorrente, diferenciado e, acima de tudo, desleal. Destacava-se o fato de ter ocorrido uma verdadeira sacralização da Cartilha Maternal exaltava as paixões e dificultava o predomínio da serenidade no exame da questão. Remarcava-se que, embora tendo representado inovação a seu tempo, João de Deus estaria ultrapassado na história da pedagogia, o que - sabemos - não era verdade, posto que

\footnotetext{
${ }^{553}$ Oliveira MENDONÇA, Os da 'Cartilha', In: A Federação Escolar, 18-12-1909, n’ 49. Carlos da Costa, em texto intitulado "Naufrágio em perspectiva" também discorria em número posterior do mesmo jornal sobre a falta de ética posta nos escritos de João de Deus Ramos, os quais - diga-se de passagem -, ao contrário de seu pai, primavam pela descortesia. $\mathrm{O}$ articulista questionava ainda o papel desempenhado pela imprensa, que não parecia se pautar pela tentativa de levar os oponentes a superarem a discórdia: "infelizmente é desse canudo que os homenzinhos se servem, para vazar sobre nós a baboseira de suas sandices. É que, afora uma honrosa exceção, uma grande parte enferma do mesmo mal (...) Assim, corrompe em vez de educar. Meios de depravação, infelizmente, não faltam à sociedade portuguesa. O que era necessário era oporem-se-lhe outros, de efeitos mais benéficos e educativos. A escola e a imprensa conseguiriam esses fins se fossem bem orientadas. Porém o mal tenta contaminar esta, a ponto de ir atacar desalmadamente e injustamente os obreiros daquela. Oxalá que ele possa ser debelado, se não estamos todos arranjadinhos... somos atirados todos - os que não lemos a Cartilha Maternal - a um charco (...). Eduquem-se; aprendam a ser leais e dignos; a dizerem só o que devem para não ofenderem uma classe laboriosa e honrada com as suas baboseiras; prestem culto à verdade, ainda que esta vé ferir os interesses das suas algibeiras, representadas nas Escolas Móveis João de Deus; sejam parriotas e educados porque, do contrário, teremos de lamentar, num prazo mais ou menos curto, um terrível naufrágio, em que o náufrago será este pobre Portugal." (Carlos da SILVA, Naufrágio em perspectiva, In: A Federação Escolar, 1-1-1910, nº51).
} 
Decroly só divulgaria seus princípios analíticos semelhantes aos de João de Deus anos mais tarde. ${ }^{554}$ Mas como não se pode julgar a história por ela desconhecer o futuro, ouçamos mais uma vez os contemporâneos tradicionalistas, quando estes criticavam as Escolas Móveis particularmente por elas representarem novas idéias, de um republicanismo latente, prestes a explodir:

\begin{abstract}
"Sejamos francos. A Associação das Escolas Móveis pelo Método João de Deus longe, muito longe de concorrer para o bom nome e lustre da pátria pelo derramamento da instrução, estabelece uma desorientação pasmosa e assustadora no espírito das gerações infantis pela guerra sistemática e insistente que faz às belas e sublimes virtudes cívicas e religiosas (...) A adoção dum método dum grande poeta português, que a moderna pedagogia mandou pôr de parte e que se tenta, por uma tática, tão hábil como interesseira, torná-lo exclusivo? Há coisa melhor. Ou antes, há métodos mais recentes, em conformidade com a pedagogia moderna. Mas deixemos o método para outra vez. Ensinar a ler, escrever e contar vinte ou trinta analfabetos de duas freguesias em cada ano? Ora... adeus! Ler, escrever e contar!... Que deficiência! Eram analfabetos os alunos ? Analfabetos ficaram. São analfabetos. Eram cegos de espírito? Cegos ficaram. Meio curados de tão terrível enfermidade. Que diríamos de um médico que tratasse um indivíduo e o abandonasse a certa altura da doença, deixando-o em meio da cura?",555
\end{abstract}

Seria isso que, no parecer de seus opositores, faziam as Escolas Móveis, agências de aparente efeito instrutivo, que o articulista define como "dissolventes em se tratando de educação". A ligeireza do método possibilitaria apenas uma alfabetização incipiente, duvidosa e talvez doutrinária. Realmente os professores republicanos quiseram atar seu nome e sua atuação à causa da regeneração nacional, à idéia da superação da decadência. Entendiam os profissionais de ensino daqueles primeiros anos do século - anos esses que imediatamente antecederam a república - que só a ação educativa poderia erradicar a miséria das camadas indigentes da população. Como conquista humana, o progresso é tido por pressuposto necessário para a trajetória dos povos. Mas a evolução deveria, no entanto, principiar pela elevação moral e racional de uma pátria que, na tradição e no rastro legados pelo positivismo, era tida por ser coletivo. Há aqui a idéia segundo a qual a "classe" dos professores era portadora natural de um futuro, onde lhe fora reservada a missão de desencadear a revolução moral, a regeneração que reporia Portugal nos trilhos de vitória que estariam já para a nação traçados, possibilitando aquilo que se entendia ser a ressurreição nacional. Pareceu isso o que aconteceu a 5-10-1910: viera, de uma vez por todas, a tão aclamada República!

\footnotetext{
${ }^{554}$ A idéia analítica teria, entretanto, predecessores, pois - como consta da História Mundial da Educação -, o método Regimbeau, em Paris de 1845 partia, como João de Deus, de palavras formadas por apenas uma sílaba. As palavras também eram postas na Cartilha em duas cores para diferenciar os 'pedaços'. Julgando que não havia leitura fora do pensamento ou sílabas fora das palavras, Regimbeau principia o percurso previsto para a alfabetização unindo ao mesmo tempo "uma unidade fonética e uma unidade semântica, num conteúdo visual e gráfico suscetível de ser facilmente apanhado e escrito.” (AS TÉCNICAS das aprendizagens rudimentares no século XIX, In: Jean VIAL e Gaston MIALARET História mundial da educação, volume III, p. 206). Naquela época eram muito frequentes as experiências comparativas entre os métodos da educação, tal como ocorreria com todas as polêmicas ao redor dos métodos de Castilho e João de Deus. Inclusive os dois métodos que os portugueses são ambos acusados de plagiar - Lemare e Regimbeau - teriam sido submetidos a inúmeras experiências, sempre calcando-se no pressuposto segundo o qual "o bom livro elementar é antes o fruto de uma longa experiência do que de um longo saber.” (Id. Ibid., p. 201)

555 Joaquim de VASCONCELLOS, Um projecto: 522 missões!, In: O Ensino, 18-6-1910, nº7.
} 